(3)

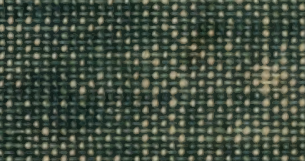





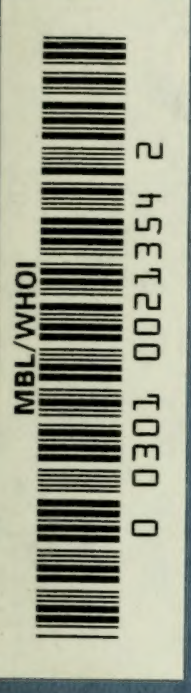




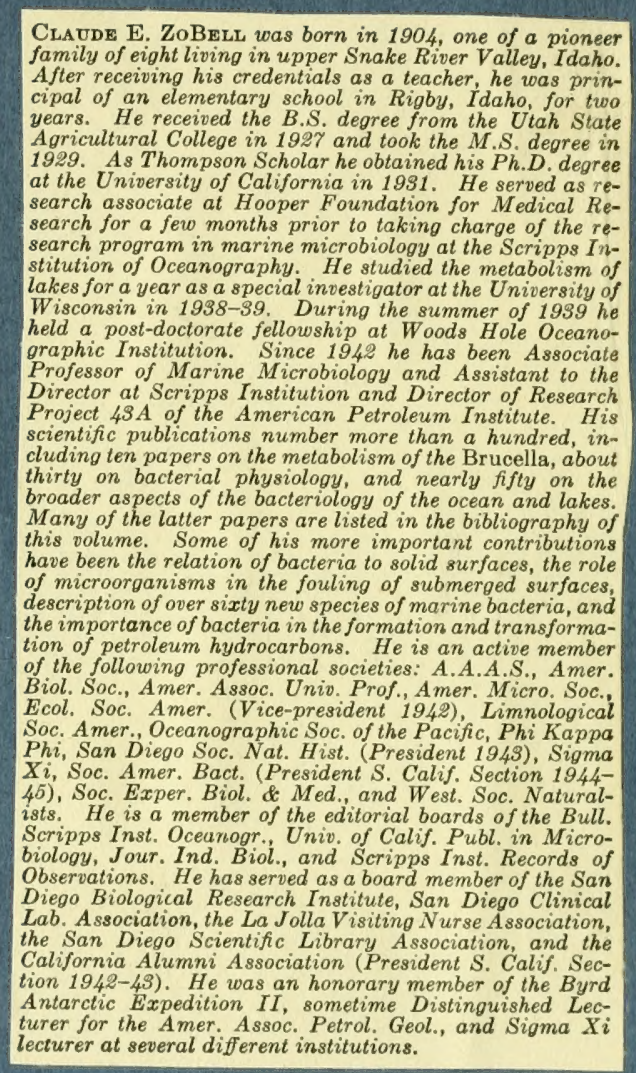




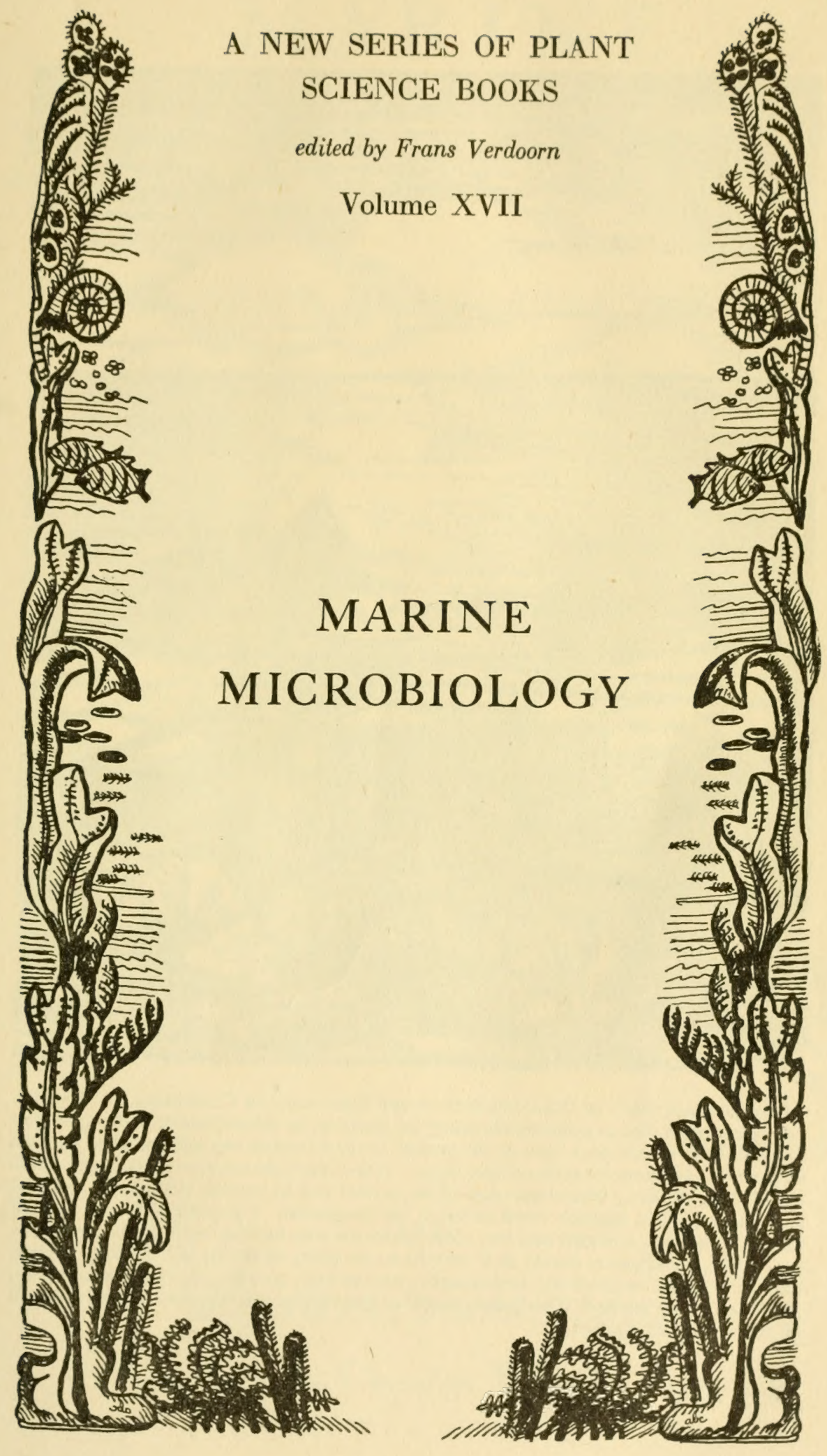




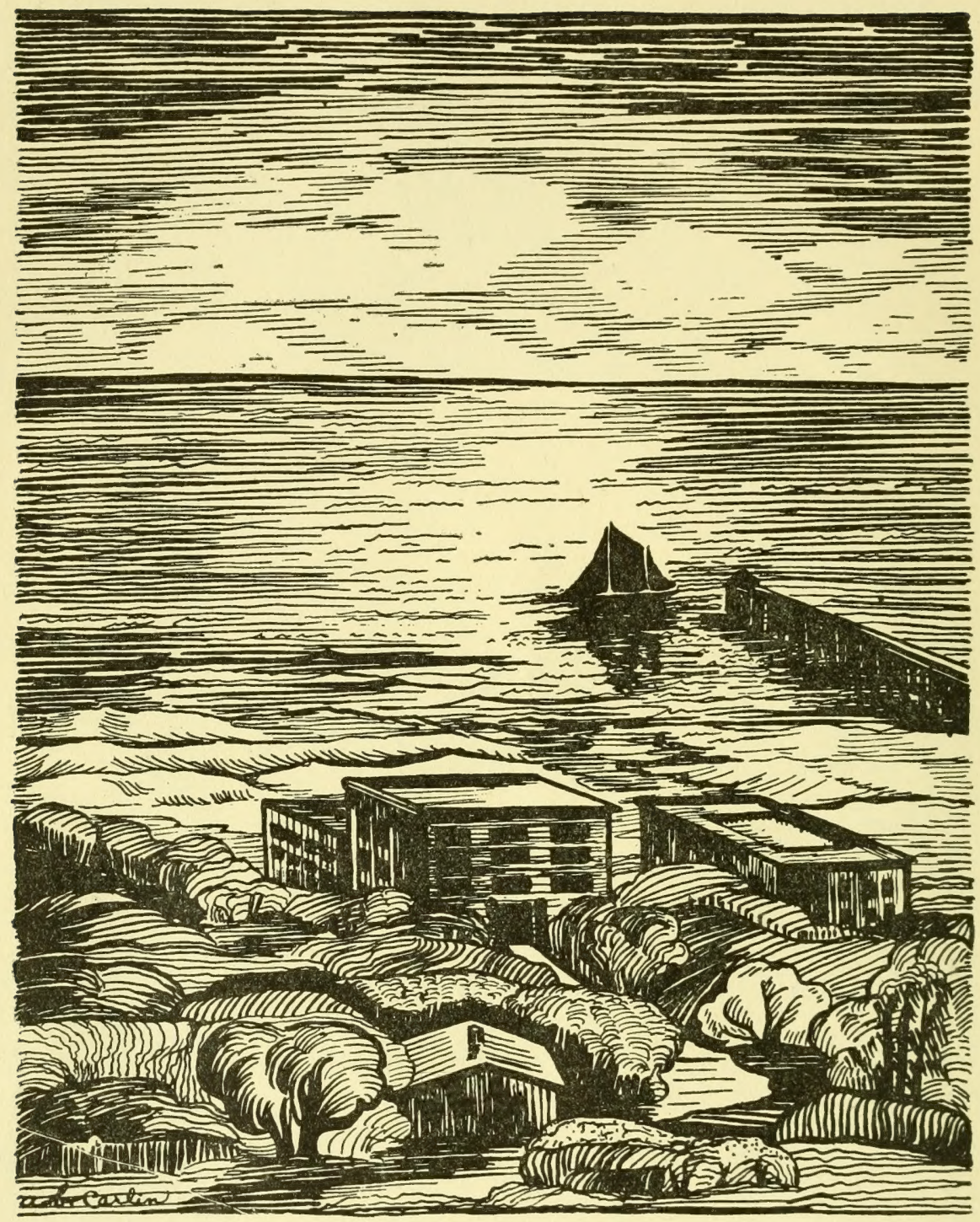

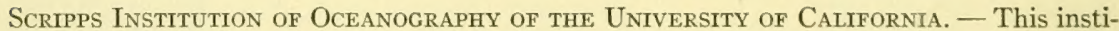
tution, started in 1892 as a seaside laboratory for studying the natural history of marine organisms, has been located since I9Io on the present I77-acre campus two miles north of La Jolla and sixteen miles from the center of San Diego. It now has three modern well-equipped buildings divided into forty laboratories and offices, several smaller service buildings, a rooo-foot pier, and a 104 -foot research vessel shown in the foreground. The permanent resident staff consists of a dozen scientists and two dozen assistants who together with graduate students and visiting investigators devote their energies to the study of marine microbiology, botany, zoology, ecology, biochemistry, hydrography, meteorology, geology, physical oceanography, and other marine sciences. This sketch as well as the vignettes in this volume were prepared by Alma Broulik Carlin. 


\title{
MARIN E
}

\section{I C R O B I O LO G Y}

\section{A MONOGRAPH ON HYDROBACTERIOLOGY}

\author{
$B Y$ \\ Claude E. ZoBell, Ph.D. \\ Associate Professor of Marine Microbiology, \\ $S_{\text {cripps Institution of Oceanography, }}$ \\ University of California, La Jolla \\ Foreword by SELMaN A. WAKSMaN \\ Professor of Microbiology, Rutgers University, etc.
}

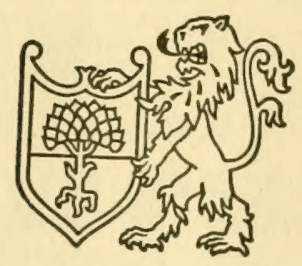

1946

WALTHAM, MASS., U.S.A.

Published by the Chronica Botanica Company 


\section{First published MCMXLVI \\ By the Chronica Botanica Company \\ of Waltham, Mass., U. S. A.}

COPYRIGHT, 1946, BY THE CHRONICA BOTANICA CO. All rights reserved, including the right to reproduce this book or parts thereof in any form

New York, N. Y.: G. E. Stechert and Co., 31 East 10th Street.

San Francisco, Cal.: J. W. Stacey, Inc., 244 Flood Building.

Ottawa, Ont.: Thorburn AND Aвbott, LtD., 115 Sparks Street.

México, D. F.: Axel Moriel Sucrs., San Juan de Letran 24-116; Ap. 2762.

Bogotá, and Medellín: Libreria Central.

Lima: Libreria Internacional Del Peru, Casa Matriz. Boza 879; Casilla 1417.

Santiago de Chile: Libreria Zamorano y CAPERAN, Compañía 1015 y 1019; Casilla 362.

Rio de Janeiro: Livraria Kosmos, Rua do Rosario, 135-137; Caixa Postal 3481.

São Paulo: Livraria Civilização Brasileira, Rua 15 de Novembro, 144.

Buenos Aires: Acme Agency, Soc. De Resp. Ltda., Bartolomé Mitre 552.

London, W. 1: WM. Dawson AND Sons, LTD., 43, Weymouth Street.

London, W. C. 1: H. K. Lewis AND Co., LtD., 136, Gower Street.

Groningen: N. V. Erven P. NOORDHOFF.

Paris, VI: Librairie H. Le SOUdIER, 174 , Bvd. St. Germain.

Torino: Rosenberg \& Sellier, Via Andrea Doria 14.

Lisbon: Livraria SÁ DA Costa, 100-102, R. Garrett \& 24, Poço Novo.

Moscow: Mezhdunarodnaja Kniga, Kuznetski Most 18.

Calcutta, Bombay, and Madras: MaCMILlaN AND Co., LTD.

Johannesburg: Central News AgenCy, Ltd.,

Commissioner \& Rissik Sts.; P. O. Box 1033.

Melbourne, C. 1: N. H. Seward, Pty., Ltd. 457 , Bourke Street.

Made and printed in the U.S.A. 


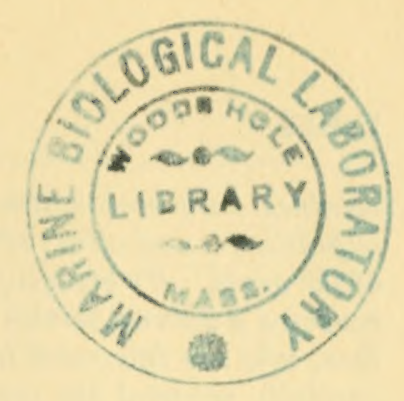

\section{FOREWORD}

It has long been recognized that the sea contains an extensive microbiological population. The microorganisms comprising this population are frequently separated, on the basis of their specific habitats, into planktonic, nectonic, benthonic, and periphytic forms. The corresponding bacterial populations and this book deals largely with marine bacteria, the diatoms and the protozoa not falling within its scope - vary greatly in nature and in relative abundance, depending upon the geographical, climatic, and other conditions, as well as upon the depth of the water, distance from shore, nature of sea bottom, abundance of plankton, water movement, and a number of other factors.

Bacteria take part in a number of processes in the sea, including the decomposition of complex plant and animal residues, and the liberation of carbon, nitrogen, phosphorus, and certain other essential elements in available forms. Since the concentration in sea water of nutrients necessary for the continuation of marine plant and animal life is very limited, such life would soon come to a standstill were it not for the bacteria that keep these mutrients in continuous circulation. Other processes in the sea for which bacteria are responsible are the oxidation of ammonia to nitrate, denitrification, the oxidation of sulfur, the reduction of sulfate, and many others. Bacteria have thus come to be recognized as playing an essential role in the organic production of the sea. However, certain marine processes, in which bacteria appear to take an active part, still remain unsolved. It is sufficient to mention, for example, the significance of the processes of nitrogen fixation and denitrification in the nitrogen metabolism of the sea, the part played by bacterial cells as food for protozoa and other invertebrates, the symbiotic relationships of bacteria with other forms of life, and the role of bacterial slime in the formation and nature of the ocean floor.

Marine bacteriology has become as much an essential branch of oceanography as have marine zoology, marine geology, and physical and chemical oceanography. The marine bacteriologist has much in common, however, with the soil bacteriologist. Both deal with mixed populations of microorganisms rather than with pure cultures; both study the effect of these organisms upon the activities of others. But the marine bacteriologist uses special equipment for obtaining his samples; he deals with a much greater vertical range of depth of natural substrate and with totally different types of interaction between the bacteria and the higher forms of plant and animal life. The physicochemical nature of the soil environment is markedly different from that of the aquatic environment, thus resulting in a different type of microbiological population. Because of this, the marine bacteriologist is not concerned to the same extent with the numerous fungi and actinomycetes that play such important parts in soil processes. In dealing with a somewhat more homogeneous medium, he encounters less variation in the nature of chemical reactions carried on by the bacteria.

Although much work has been done and considerable information has been accumulated on the nature and activities of the marine bacteria, the results 
obtained have been scattered in numerous journals, monographs, reports of expeditions, and other, often quite inaccessible, publications in various parts of the world. By bringing together this scattered information, Dr. ZoBell has rendered a distinct service to the bacteriologist, to the oceanographer, and to all those who are interested in the cycle of life in natural water basins. He has carefully reported the essential information concerning the abundance and activities of bacteria in the sea and has laid a path for others to follow. This book should prove a useful forerunner of many future investigations in the field of marine bacteriology, or as the author prefers to designate the subject, marine microbiology.

Selman A. WAKSMAN 


\section{$P R E F A C E$}

There are many problems in the general economy of the ocean and lakes the solution of which requires the aid of the microbiologist. In fact, there are very few questions regarding the science of the sea which can be satisfactorily answered without due consideration of bacteria, yeasts, molds, and related organisms, and of the chemical and geological processes in which such organisms are involved.

The role of microorganisms in the carbon, nitrogen, sulfur, and phosphorus cycles in the sea as well as in the general circulation of organic compounds by processes analogous to those in the soil is usually taken for granted. By virtue of their effects upon plant nutrients, the microorganisms with which the microbiologist is concerned influence the productivity of the sea. Many marine microbes associated with aquatic plants and animals are parasitic while others are beneficial in various ways. The distribution of oxygen and carbon dioxide in water is influenced by microbial activity. Microorganisms are the principal dynamic agencies which influence the hydrogen-ion concentration and oxidation-reduction potential of natural bodies of water and of the underlying bottom deposits. There are several ways in which microbial activities affect the diagenesis of sedimentary materials, including protopetroleum. There are doubtless questions of variations in the interfacial and surface tension of water, colloidal state, or conditions affecting the penetration of sunlight for which microorganisms must be held in part responsible.

Microbiology thus occupies a logical and prominent position as an integral marine science. Besides contributing to a fundamental study of the sea, its inhabitants, its constituents, its boundaries, and its relation to man, the marine microbiologist is confronted by several practical problems such as the role of microorganisms in the spoilage of fish and other marine products, the fouling of ships' bottoms, and the deterioration of fish nets, cork floats, ropes, and wooden structures exposed to water. Likewise the marine microbiologist is in a position to contribute to sanitary science and to the pure science of bacteriology.

The hydrobacteriological investigations of the pioneers, including B. FISCHER, FrankLand, Houston, and Jordan, were concerned primarily with the distribution and behavior of bacteria in water. Since the turn of the century more and more attention has been focussed upon a study of the factors which influence the survival of coliform or other adventitious organisms of hygienic interest. However, a handful of scientists bave continued to accumulate information on the distribution, characteristics, biochemical activities, and hydrobiological importance of microorganisms indigenous to aquatic environments. Special methodology has progressed apace. As a result, marine microbiology has become a specialized field of research which is world-wide in scope.

In this volume an attempt has been made to summarize and correlate the extensive literature on the subject, with particular reference to the importance of bacteria and allied microorganisms as biochemical, geological, and hydrobiological agents. Although conditions in the sea serve as the central theme, frequent reference is made to observations in inland bodies of water, both fresh and saline. It is possible that common elements in the evolutionary histories 
have contributed to lakes and oceans alike the kindred microbiological conditions shared in each general type of environment.

Though more directive than comprehensive, the bibliography provides a key to the relevant literature. For the most part the citations have been restricted to papers dealing with aquatic phenomena, the purpose of this volume being to give a condensed account of what is known regarding the effects of microorganisms upon the marine environment and the effect of environmental conditions upon marine microorganisms. While some of the generalizations may prove to be premature, it is hoped that the volume will serve as a useful source of information, scant though it may be, and that it will stimulate the interest of more students of microbiology, oceanography, limnology, and ecology in studying the importance of bacteria and allied microorganisms in aquatic environments.

Methods of collecting and analyzing water and mud samples have received special attention. Space limitations prohibit giving complete descriptions of the numerous microbial species reported to be indigenous to aquatic environments, but an effort has been made to name and to give references to all known marine bacteria, yeasts, and molds in the text in connection with their principal physiological activities. The author will appreciate receiving information on species which have escaped his attention for inclusion in supplemental or revised publications.

Much valuable aid and stimulation have been received from my colleagues, associates, and graduate students at the S.I.O. as well as from certain staff members of the University of Wisconsin and the Woods Hole Oceanographic Institution. The unpublished final report of Dr. HALDANE GEE, formerly in charge of marine microbiological research at the S.I.O., has been consulted freely in the preparation of this manuscript, and credit is given to him for his concept of the scope and function of microbiology in the science of the sea. Special acknowledgment is also due to Dr. H. U. Sverdrup, Director of the S.I.O., who contributed to the chapter on the Marine Environment, to Dr. F. K. SPARRow, Professor of Botany at the University of Michigan, who criticized the chapter on Aquatic Yeasts and Molds, to Dr. Robert S. BREed, New York Agricultural Experiment Station, for counsel on taxonomic problems, and to Dr. D. L. Fox, Associate Professor of Marine Biochemistry at the S.I.O., for his generous help in reading and criticizing the whole of the manuscript. The author is also indebted to Miss Harriet Dunn for typing the manuscript, to Dr. William D. ROSENFELD for proof reading, to Miss JEAN E. SwITZER for proof reading and help in preparing the indices, and to Miss BARBARA FAY BROwN for preparing the figures and checking the bibliography.

SCRIPPS Institution OF OCEANOGRAPHy University of CaLIFornia

La Jolla, California 
"There is hardly an aspect of oceanography but affects one or another phase of modern civilization; and naturally so, for this science is concerned with the physical and biological economy of some seventy-one per cent of the earth's surface... The problems of marine bacteriology center around the roles that bacteria play in keeping in motion the cycle of matter through its organic and inorganic stages in the sea... Such glimpses as have been gained of their activities there are enough to show that these must be assayed before we can hope to understand the maintenance of organic fertility in the oceans." Henry B. Bigelow, "Oceanography," Houghton Mifflin Co., Boston, Mass., pages 167 and 185, I93

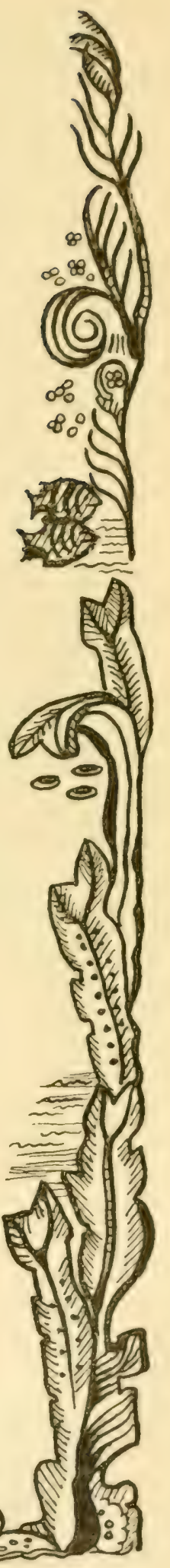


A New Series of Plant Science Books:-

1, MacDougal: Tree Growth (out of print)

2, GRant: Wood Pulp (out of print)

3, DARRAH: Principles of Paleobotany (out of print)

4, Pfeiffer: Experimentelle Cytologie (out of print)

5, Ed. 1 out of print, see sub 13 for ed. 2.

6, Guilliermond-Atkinson: The Cytoplasm of the Plant Cell (pp. 247, $\$ 4.75)$

7, REED: A Short History of the Plant Sciences (pp. 323, \$5.00)

8, BaLdwIN: Forest Tree Seed (pp. 240, $\$ 4.75)$

9, Lloyd: Carnivorous Plants (pp. 352, $\$ 6.00$ )
10, WulfF: Historical Plant Geography (pp. 223, \$4.75)

11, SchOPFER-NOECKER: Plants and Vitamins (pp. 300, \$4.75)

12, Erdtman: Pollen Analysis (pp. 239, $\$ 5.00)$

13, BAwDEN: Plant Viruses and Virus Diseases, Second entirely revised edition (pp. 294, \$4.75)

14, Hoagland: Inorganic Plant Nutrition (pp. 226, \$4.00)

15, Wodehouse: Hayfever Plants (pp. $245, \$ 4.75)$

16, VERDOORN (ed.): Plants and Plant Science in Latin America (pp. xl + $384, \$ 6.00$ )

17, ZoBell: Marine Microbiology (pp. $240, \$ 5.00)$

Volumes in press or in preparation include: WILDE, Forest Soils and Forest Growth; JoHANSEN, Plant Embryology; Dachnowski-Stokes, Peat; Kelley, Mycorrhiza in Plants; Condit, The Fig; UphoF, Dictionary of Economic Botany; Crocker \& BARton, Seed Physiology, and G. M. Smith (ed.), Manual of Phycology.

CHRONICA BOTANICA, an international collection of studies in the method, philosophy, and history of biology and agriculture, founded and edited by FRANS VERDOORN, is published bimonthly. It aims primarily at the promotion of (1) international relations in the plant sciences, (2) studies in the method, philosophy and history of pure and applied biology, (3) a better understanding between specialists in various branches and their relations with the outside world. An annual volume contains about 600 pages of memoirs, directories and census of current activities, articles and discussions, annotated reprints of important and rare classical papers, news, reviews and notices, etc., at $\$ 7.50$ to regular subscribers (post free, foreign and domestic). - Back volumes are available at $\$ 7.50$ (paper) or $\$ 8.75$ (buckram), postage extra. - Binding cases may be obtained for recent volumes at $\$ 0.75$, prepaid (post free, foreign and domestic).

The following recent and forthcoming issues of CHRONICA BOTANICA are available to non-subscribers:Browne, A Source Book of Agricultural Chemistry (pp, 290, \$5.00). - RAFinesoue, A Life of Travels (pp. 72, \$2.50). - Browne, Thomas Jefferson and the Scientific Trends of his Time (pp. 64, \$1.25). - JAck, Biological Field Stations of the World (pp. 80, $\$ 2.50)$. — DE SAINT-HiLAIRE, Voyages au Brésil et Paraguay $(\$ 2.50)$. - HowARD, Luther Burbank, A Factual Study (ca. \$3.75), - ARBER, Goethe's Botany (ca. $\$ 2.50)$. - Cooper, Arboretums, their Aims and Scope (ca. \$2.50). - E. D. MERrill, Merrilleana - Selected General Writings (ca. \$3.75). - STEHLÉ, Histoire de la Botanique et de l'Agronomie aux Antilles Françaises (ca. $\$ 5.00)$,

Annales Cryptogamici et Phy topathologici, our new serial, consists of memoirs (each forming a separate volume), devoted to general and systematic cryptogamy and to phytopathology. It continues Annales Bryologici. - Vols. 1, GarRetr, Root Disease Fungi (pp. 177, \$4.50) and 2, Horsfall, Fungicides (pp. 240, $\$ 5.00$ ) have recently been issued. - The following vols, are in press: 3, FULFORD, The Genus Bazzania in C. and S. America (ca. $\$ 5.00) ; 4$, Chester, Cereal Rusts (ca. \$5.00); 5, Copeland, Genera Filicum (ca. \$5.00).

Annales Bryologici, a journal devoted to the study of mosses and hepatics, of which we published (in the beginning in cooperation with Messrs. Nijhoff) 12 volumes and 4 supplementary volumes between 1927 and 1939, is now being continued by the Annales Cryptogamici et Phytopathologici (see above). Complete sets and single vols. of ANNALES BRYoLOGICI are still available at $\$ 4.00$ a volume. The bryological exsiccati formerly issued by Dr. FranS VERDOORN: Bryophyta Arduennae Exsiccata (dec. 1-5. 1927/29), Hepaticae Selectae et Criticae (11 series, 1930/39) and Musci Selecti et Critici (7 series, 1934/40) are no longer available.

Orders may be sent directly to the Chronica Botanica Co., to any bookseller or to their authorized agents, as listed on $p$. vi, in New York City; San Francisco, Cal.; Ottawa, Ont. (Canada); México City; Bogotá and Medellín (Colombia); Lima (Peru); Santiago (Chile); Rio de Janeiro and São Paulo (Brazil); Buenos Aires (Argentina); London; Groningen (the Netherlands); Paris; Torino (Italy); Lisbon (Portugal); Moscow; Calcutta, Bombay and Madras (India); Johannesburg (South Africa); and Melbourne (Australia).

The Chronica Botanica Co., Waltham 54, Massachusetts, U.S.A.

- Established in Leiden, Zuid Holland, in 1939-Cables: Flora, Wallham, Mass., U.S.A.- 


\section{CONTENTS}

\section{Chapter $I$}

GENERAL INTRODUCTION:- THE IMPORTANCE OF BACTERIA IN THE SEA - THE PERIOD OF EXPLORATION - INTENSIFICATION OF HYDROBACTERIOLOGICAL INVESTIGATIONS

Chapter 2

THE MARINE ENVIRONMENT:-EXTENT AND DEPTH OF THE SEA - TOPOGRAPHY OF THE SEA FLOOR - BIOTIC ZONES - Penetration of sunlight - Temperature of the maRINE ENVIRONMENT - THE MOVEMENTS OF SEA WATER SALINITY, CHLORINITY, AND DENSITY - OSMOTIC AND HYDROSTATIC PRESSURE - CHEMICAL COMPOSITION OF SEA WATER Dissolved Gases AND THE PH OF SEA WATER - ARTificial OR SYNTHETIC SEA WATER - MARINE BOTTOM DEPOSITS Plant and animal population

\section{Chapter 3}

\section{COLLECTION AND EXAMINATION OF SAMPLES AT}

SEA:- ThE COLLECTION OF WATER SAMPLES - Metal CYLINDERS FOR COLLECTING SAMPLES - SAMPLERS HAVING A CAPILLARY TUBE INLET - METAL BOTTLES ARE BACTERICIDAL - EFFECT OF PRESSURE DURING SAMPLING - THE COLLECTION OF MUD SAMPLES - StORAgE OF SAMPLES - TEMPERATURE CHANGES DURING COLLECTION OF SAMPLES - THE EXAMINATION OF SAMPLES AT SEA

\section{Chapter 4}

METHODS OF ENUMERATING MARINE BACTERIA:MEdia For PLATE COUNTS - SOLIDIFYing AGENTS FOR PLATING MEDIA - INCUBATION TEMPERATURE FOR PLATE COUNTS DILUTION WATER BLANKS FOR MARINE BACTERIA - THE SUCCESSIVE DILUTION METHOD FOR ENUMERATING BACTERIA The enumeration of Marine ANAERobes - Direct MicroSCOPIC COUNTS - THE CONCENTRATION OF ORGANISMS FOR DIRECT COUNTS - DIRECT COUNTS ON BACTERIA IN MUD SUbMERGED SLIDE TECHNIC FOR STUDYING BACTERIA IN WATER - Aged sea water

\section{Chapter 5}

FACTORS INFLUENCING THE DISTRIBUTION OF BACTERIA IN THE SEA:- FLUCTUATIONS IN NUMBERS OF MICROORGANISMS - DistANCE FROM LAND - EFFECT OF THE TIDE - DIURNAL FluCtuAtions IN THE BACTERIAL POPUlaTION - VERTICAL DISTRIBUTION OF MARINE BACTERIA - EFFECT OF HYDROSTATIC PRESSURE - EFFECT OF SOLAR RADIATIONS - TeMPeRATURE AS AN ECOLOGICAL FACTOR-SEA- 
SONAL DISTRIBUTION OF MARINE BACTERIA - EFFECT OF OTHER ORGANISMS - THE ANTAGONISTIC EFFECTS OF MICROORGANISMS - BACTERIOPHAGE IN SEA WATER - EFFECT OF SOLID SURFACES - EFFECT OF SEDIMENTATION - EFFECT OF ORGANIC MATTER . . . . . . . . . . . . . . .

\section{Chapter 6}

MICROORGANISMS IN BOTTOM DEPOSITS:- NUMBERS OF BACTERIA IN SEDIMENTS - VERTICAL DISTRIBUTION OF BACTERIA IN MUD - LOWER LIMITS OF THE BIOSPHERE - FACTORS INFLUENCING ABUNDANCE OF BACTERIA IN MUD - BIOCOENOSIS AND BACTERIA IN BOTTOM DEPOSITS - KINDS OF MICROORGANISMS OCCURRING IN BOTTOM DEPOSITS . . . . . .

\section{Chapter 7}

ACTIVITIES OF MICROORGANISMS IN BOTTOM DEPOSITS:- CALCIUM CARBONATE PRECIPITATION - DEPOSITION OF IRON AND MANGANESE - EFFECT ON HYDROGEN-ION CONCENTRATION - EFFECT ON OXIDATION-REDUCTION POTENTIAL - FACTORS INFLUENCING OXYGEN CONSUMPTION GASES IN BOTTOM DEPOSITS - EFFECT ON ORGANIC CONTENT OF BOTTOM DEPOSITS - THE PETROLEUM PROBLEM - SUlFuR DEPOSITION - PARTICLE-BINDING ACTION OF MICROORGANISMS - ENZYMES IN BOTTOM DEPOSITS . . . . . . . . . .

\section{Chapter 8}

CHARACTERISTICS OF MARINE BACTERIA:- CELL MORPhology - Cultural CHARACTERistics - Physiological CHARACTERISTICS - SALINITY REQUIREMENTS - TEMPERATURE TOLERANCE - ATtA CHMENT PROPENSITIES - BACTERIAL GENERA REPRESENTED IN THE SEA . . . . . . . . . . .

Chapter 9

AQUATIC YEASTS AND MOLDS:-OCCURRENCE OF YEASTS IN THE SEA - MARINE MOLDS - SigNIFICANCE OF YEASTS AND MOLDS IN THE SEA - IMPORTANCE OF FUNGI IN LAKES . . .

Chapter IO

TRANSFORMATION OF ORGANIC MATTER:-QUANTITY OF ORGANIC MATTER DECOMPOSED - DECOMPOSITION OF CARBOHydRATES - Lignin DECOMPOSITION - Proteina CEOUS COMPOUNDS - ChITIN DECOMPOSITION - LiPOLYTIC BACTERIA BACTERIAL OXIDATION OF HYDROCARBONS - MARINE HUMUS

\section{Chapter II}

THE NITROGEN CYCLE IN THE SEA:- AMMONIA PRODUCTION - BACTERIAL OXIDATION OF AMMONIA - OXIDATION OF NITRITE TO NITRATE - REDUCTION OF NITRATE AND NITRITE - NITROGEN FIXATION 


\section{Chapter 12}

BACTERIA WHICH TRANSFORM SULFUR COMPOUNDS: - LiBERATION OF SULFUR FROM ORGANIC COMPOUNDS - SULFATE REDUCTION - THE OXIDATION OF SULFUR COMPOUNDS ACHROMIC SULFUR BACTERIA - PURPLE SULFUR BACTERIA TRANSFORMATION OF SELENIUM COMPOUNDS.

\section{Chapter I3}

THE PHOSPHORUS CYCLE:- AsSIMILATION OF PHOSPIATE BY MICROORGANISMS - REgENERATION OF PHOSPHATE - EFFECT OF BACTERIA ON SOLUBILITY OF PHOSPHATE

\section{Chapter I4}

RELATION OF MARINE BACTERIA TO FLORA AND FAUNA: - RECIPROCAL RELATIONS OF BACTERIA AND PLANTS - Marine plant pathogens - Reciprocal Relations of BACTERIA AND ANIMALS - BACTERIA AS FOOD FOR ANIMALS Marine animal Pathogens - Antibiotic Conditions CaUsed BY BACTERIA

Chapter 15

MICROORGANISMS IN MARINE AIR:- BACTERIA IN MARINE AIR - YEASTS AND MOLD SPORES IN AIR - MICROBIAL CONTENT OF PRECIPITATION - POLLENS IN MARINE AIR AERIAL TRANSPORT OF MARINE BACTERIA

Chapter I6

SANITARY ASPECTS OF MARINE MICROBIOLOGY:HuMAN PATHOGENS IN SEA WATER - COLIFORM BACTERIA SURVEYS - BACTERIOLOGY OF SHELLFISH - BACTERIOLOGY OF MARINE FISH - SANITATION OF SEA-WATER BATHS - BACTERIOLOGY OF ICE

\section{Chapter I7}

ECONOMIC IMPORTANCE OF MARINE MICROORGANISMS:- FOULING OF SUBMERGED SURFACES - BACTERIA ASSOCIATED WITH WOOD-BORERS - DESTRUCTION OF CORDAGE AND FISH NETS - BACTERIAL DETERIORATION OF CORK AND RUBBER - HaLOPHILIC BACTERIA IN SOLAR SALT - SPOILAGE OF MARINE FOOD PRODUCTS

Chapter 18

MICROBIOLOGY OF INLAND WATERS: - THE Black SEA - Bacteriology of Russian limans - Great Salt Lake The Dead Sea - Fresh-water lakes . . . . . . . . 200

BIBLIOGRAPHY . . . . . . . . . . . . 209

AUTHOR INDEX .............. . . . 23I

GENERAL INDEX . . . . . . . . . . . . 234 


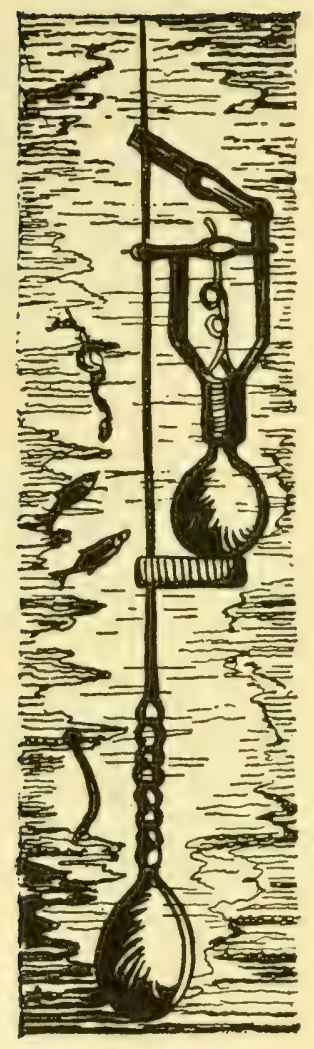




\section{Chapter I}

\section{GENERAL INTRODUCTION}

The ocean, which covers nearly three-fourths of the earth's surface, is the home of a vastly diversified plant and animal population. Exclusive of insects, about four-fifths of all animal species known to man dwell in the sea, and more than 8000 species of marine plants have been described.

Although the ocean has been described as the "world's largest and most efficient septic tank," there are some land-locked biologists who question the existence of bacteria in the sea beyond the littoral zones influenced by contamination from the land. The high salinity of sea water, the paucity of organic matter, the abundance of natural enemies, the processes of sedimentation, the germicidal effect of ultraviolet radiations near the surface, high hydrostatic pressures at great depths, and unfavorable temperatures have been credited by some with making the marine environment virtually uninhabitable by bacteria and allied microorganisms. However, it is now known that such microorganisms are widely distributed in sea water and on the ocean floor where they influence chemical, physicochemical, geological, and biological conditions.

The importance of bacteria in the sea:- The critical examination of water samples from the euphotic zone and of mud from the ocean floor reveals the presence of a biochemically versatile microflora. Some of these microorganisms mineralize organic matter. Others oxidize ammonia to nitrite or nitrate, transform sulfur compounds, liberate phosphate, or otherwise affect the chemical composition of sea water and bottom deposits. Marine bacteria play an indispensable role as producers of plant nutrients, and the bacteria themselves may be ingested by certain animals as a source of food.

There are several ways in which marine microorganisms tend either to decrease or increase the hydrogen-ion concentration of sea water or mud, and their activities influence the oxidation-reduction potential. The distribution of oxygen, nitrogen, hydrogen, and probably other gases in the sea is influenced by microbial activity.

As geological agents, marine microorganisms influence the diagenesis of sedimentary materials in many ways. By their effect on the hydrogenion concentration and carbon dioxide tension of sea water, bacteria influence calcium carbonate precipitation. They are believed to be responsible for the deposition of iron under certain conditions, and they affect the state of oxidation or reduction of many mineral constituents of marine sediments. Accumulating evidence suggests that marine microorganisms play an important role in the formation, migration, and accumulation of petroleum.

Besides being essential for a complete understanding of chemical, geological, and biological phenomena in the sea, a knowledge of marine microbiology has numerous utilitarian applications. Bacteria are very troublesome in the spoilage of foods and other marine products of commerce. As primary film formers, they influence the attachment of seden- 
tary organisms on submerged surfaces such as ships' bottoms, pilings, and aqueducts. Bacteria and allied microorganisms are primarily responsible for the deterioration of fish nets, cork floats, and ropes, and they may aid boring animals in the destruction of wooden structures in the sea.

These and numerous other ways in which marine microorganisms are of academic or economic interest will be elaborated in the succeeding chapters. The characteristics, methods of studying, and distribution of bacteria and allied microorganisms in the sea will also be discussed.

Although marine microbiology is regarded as being a new and relatively undeveloped science, one of the first accurately described species of bacteria, Spirochaeta plicatilis, was isolated from sea water more than a hundred years ago by EHrenberg (1838). CoHN (1865) isolated and described the marine-dwelling Beggiatoa mirabilis in 1865 , and WARMING (I875) described Beggiatoa minima in I875. A year later WARMING (I876) described Thiospirillum violaceum, Thiospirillum rosenbergii, and Achromatium mulleri.

However, only 86 of the species of bacteria out of the 1335 species listed in BERGEY'S (I939) Manual of Determinative Bacteriology were isolated from the sea, and most of these have been only incompletely studied. Even less is known concerning marine yeasts and molds. This is symptomatic of the fact that the study of marine microbiology has been sadly neglected. There are perhaps as many, and probably more, different species of bacteria in the sea than there are on land, and future studies may reveal that marine bacteria are as important as those which live on land or in fresh-water environments.

There are several reasons why the study of marine microbiology has been neglected. Relatively few scientists have had ready access to the sea as compared with the number who have had access to the soil, fresh water, or other sources of microorganisms. Even those who have the necessary laboratory facilities close to the sea may find that estuarine or coastal waters are not typical of oceanic conditions. This is particularly true in regions where there is much fresh-water or terrigenous pollution.

Ordinarily it is necessary to collect samples at considerable distances from the mainland in order to insure their freedom from terrigenous contamination, and the samples must be analyzed soon after collection if the results are to have any quantitative significance. The aseptic collection and bacteriological analysis of samples of water, bottom deposits, and other marine materials has required the development of special equipment and techniques. Very few ocean-going research vessels have been available for the study of the sea, and only rarely has the scientific staff included a trained microbiologist.

In spite of the difficulties which have curtailed the study of marine microbiology, considerable progress has been made since bacteria were first found in the sea. The pioneer work of CERTES (I884a), FISCHER (I886), Russell (I89I), and their contemporaries established that living bacteria are widely distributed throughout the ocean.

The period of exploration:- While on the Talisman Expedition, Certes (I884a) collected ioo samples of water and bottom deposits, some from depths as great as 5000 meters. Bacteria which multiplied under aerobic conditions of cultivation were found in all except four of the samples, thereby indicating a widespread distribution of bacteria. He was unable to demonstrate any anaerobes. Although his results have no 
quantitative significance, because his samples were analyzed only after prolonged storage, his work is instructive.

CERTES believed that he had surmounted the special difficulties attending the collection of a rigorous sample from any desired depth. The occurrence of viable bacteria in samples collected from great depths showed that they could survive high hydrostatic pressures and that they were not killed by the decrease in pressure as the samples were hauled to the surface. CERTES found some sporeformers in both water and bottom deposits. The latter yielded a variety of microorganisms. A predominating species which was tested for pathogenicity gave negative results.

During a decade of service as ship's physician, BERnHard Fischer made many important observations on the distribution and characteristics of marine microorganisms. On the expedition of the S.M.S. Moltke from the Baltic Sea to the West Indies and return, Fischer (I886) found that under ordinary circumstances ocean air contains few or no germs carried there from land, but that large numbers of terrigenous bacteria occur in the air near land masses. From West Indies waters Fischer (I887) isolated and described a photogenic bacterium, Photobaclerium indicum. PFlÜGer ( $S_{75}$ ) was probably the first to recognize photogenic bacteria as such on fish, but he described no species. BANCEL and Husson (1879) found photogenic bacteria on lobsters.

Later FISCHER (I888a) found Photobacterium indicum in the Baltic Sea along with a closely related photogenic species, Pseudomonas phosphorescens. In Kiel Harbor, Fischer (I $888 b$ ) isolated I4 different species of marine bacteria which grew at $0^{\circ} \mathrm{C}$. After experimenting with various methods of aseptically collecting water samples from any desired depth, Fischer (I893) described a bacteriological water sampler (see page 27).

Some of Fischer's best work was done during the Plankton Expedition of the Humboldt Foundation, the first expedition of its kind to make provisions for studying the role of bacteria in the biology of the sea. On this cruise across the Atlantic Ocean from July to November I889, living bacteria were found in nearly all I-ml. samples of water. FISCHER (I894a) reports finding an average of 1,083 bacteria per $\mathrm{ml}$. in 175 samples examined, the highest count being 29,400 bacteria per $\mathrm{ml}$. While much higher counts have been obtained with the use of more modern media (see page $4 \mathrm{I}$ ), interesting ecological relationships were noted. FISCHER used nutrient gelatin or fish gelatin prepared with sea water for the cultivation of marine microorganisms. In tropical waters it was necessary to use agar as a solidifying agent.

In general, FISCHER found the largest bacterial populations in coastal waters. More than twice as many bacteria were found in inland seas, such as the Baltic or North Sea, as in waters from similar depths in the open ocean. More bacteria were found at 200 to 400 meters than in surface waters, which FiscHer ( $1894 \mathrm{~b}$ ) attributed (probably erroneously) to the lethal or inhibitory effect of sunlight near the surface (see page 69). At depths exceeding 200 to 400 meters the bacterial population decreased with depth. Very few bacteria were found in the water at depths exceeding I 100 meters.

The great variation in the number of bacteria was attributed to the belief that bacteria do not normally live in the water itself but grow primarily on the dead bodies or excretions of marine plants and animals. However, Fischer did establish that bacteria can multiply in pure sea water incubated in flasks. Significantly he noted that the greatest abun- 
dance of bacteria was associated with plankton organisms either in coastal waters or far from land at the borders of two convergent ocean currents. The prevalence of bacteria in such places is now attributed to larger quantities of organic matter from the remains of dead organisms or to upwelling which brings nutrient-rich water to the surface.

On the Humboldt Plankton Expedition, Fischer (1894a) isolated nine new species of photogenic bacteria including Photobacterium annulare, $P h$. caraibicum, Ph. coronatum, Ph. degenerans, Ph. delagadense, Ph. glutinosum, Ph. hirsutum, Ph. papillare, and Ph.tuberosum. He also described seven other new species of heterotrophic bacteria to which he assigned the generic name, Halibacterium, the prefix hali denoting salt or sea. Halibacterium aurantiacum, $H$. liquefaciens, H. pellucidum, H. polymorphum, $H$. purpureum, H. roseum, and $H$. rubrofuscum were isolated from sea water or other marine materials.

Most of the marine bacteria grew only, or preferentially, in nutrient media prepared with sea water or water rendered isotonic with sea water by the addition of sodium chloride. Helicoidal-shaped spirilla or vibrio and pleomorphic rods predominated. Fischer failed to find any streptococci or sarcinae. Most of the bacteria were actively motile and gramnegative. When stained with aniline dyes, some of the bacteria showed polar bodies. Sporeformers were not observed but no exhaustive search was made for them. Mold fungi were often found, particularly near land, and yeasts were regularly encountered.

A full account of his observations and conclusions together with a review of the early literature has been summarized by Fischer (I894a) in an 82-page monograph entitled "Die Bakterien des Meeres."

During the time that FrScHER's classical studies were in progress, FORSTER (I887) isolated from plaice, flounder, and other marine fish photogenic bacteria which would grow on fish gelatin prepared with as much as 6 to 7 per cent sodium chloride. They failed to grow in distilled water media. The cultures were physiologically active at temperatures ranging from $0^{\circ}$ to $20^{\circ} \mathrm{C}$. ForSTER (1892) also demonstrated the occurrence throughout the year of bacteria in the North Sea and the Zuider Zee. The bacteria were able to multiply at $0^{\circ} \mathrm{C}$.

In the Gulf of Naples, Russell (I89I) collected samples of sea water and bottom deposits from depths as great as I 100 meters and at distances up to about ten miles from land. Bacteria were found in all samples. Bottom slime contained 25,000 to 300,000 bacteria per $\mathrm{ml}$. while the bacterial population of the overlying water rarely exceeded roo per $\mathrm{ml}$. Slime from shallow bottoms generally contained more bacteria than that from greater depths, but there was little difference in the bacterial content of water with depth.

Although a few soil forms belonging to the Bacillus subtilis-mesentericus group were found in the Gulf of Naples, Russell believed most of the bacteria which live in the sea to be autochthonous marine species. Certain typical bacteria inhabiting the mud were never found in the overlying water. This, together with the fact that the bacteria can multiply in the mud, indicated to RUSSELL that the mud was their native habitat, thereby discounting the view held by some that the bacteria find their way there merely by sedimentation. He expressed the opinion that the low temperatures characteristic of great depths might inhibit the growth of bacteria, but those which he observed grew best at temperatures lower than $25^{\circ} \mathrm{C}$. Very few of the bacteria tolerated temperatures as high as $37^{\circ} \mathrm{C}$. 
From water and mud RUssel (I89r) isolated six organisms which he believed to be new species. Unfortunately they were only incompletely described, and cultures were not maintained for further study. His Bacillus litoralis is now listed in the BERGEy (I939) Manual as Achromobacter litorale, and Spirillum marinum is listed as Vibrio marinu. His Bacilluss thalassophilus is probably synonymous with Bacillus sphacricus, his Cladothrix intricata is believed to be the same as Bacillus mycoides, his Bacillus limosus is the same as Bacillus cercus, and his Bacillus granulosis is claimed to be synonymous with Bacillus tumescens (see ZoBELL and UPIAM, 1944). The four organisms in this latter group will be recognized as soil species which may be only adventitious or transitory inhabitants of the sea. RusSELL described Bacillus halophilus as a non-spore-former, so it probably should be listed as Bacterium halophilum. It, as well as Achromobacter litorale and Vibrio marina, was characterized as requiring either sea water or 3 per cent $\mathrm{NaCl}$ solution for growth. As far as is known the last three named organisms live exclusively in the sea.

At Woods Hole, Massachusetts, Russell (I892) examined samples from depths as great as I40 meters collected at distances as far as I00 miles from land. The water was found to contain from five to I 20 bacteria per ml., with little difference in abundance at different depths. An average of $\mathrm{I} 7,000$ bacteria per $\mathrm{ml}$. was found in bottom deposits. Several physiological types of bacteria were demonstrated. Most of the bacteria were aerobes or microaerophiles which liquefied gelatin and digested casein. Many of them reduced nitrate. Pigment production and pleomorphism were common. No pathogens were found.

Several of the organisms found at Woods Hole were recognized as being the same as species in the Gulf of Naples, although a few distinctive species were observed. RUSSELL (1893) described three new species of marine bacteria at Woods Hole, including Bacillus limicola, B. maritimus, and $B$. pelagicus.

While on the solar eclipse expedition to Vadsö on the vessel Neptun, FRANKLAND and BURGESS (I897) made some interesting though rather fragmentary observations on the occurrence of bacteria in the North Atlantic Ocean. In sea water having a temperature of $7.8^{\circ} \mathrm{C}$. a few miles from the North Cape of Europe ( $70^{\circ}$ I I $^{\prime}$ N. Lat.), they demonstrated an average of $5 \mathrm{I}$ bacteria per $\mathrm{ml}$. The samples were collected from a depth of about 2 feet. The plates were incubated for five days at $20^{\circ} \mathrm{C}$.

As a member of the Nathorst Expedition to Spitzbergen, LEvin (I899) bacteriologically analyzed sea water in the vicinity of Spitzbergen, Bear Island, and King Charles Land. Using questionable cultural procedures, he found fewer than one per $\mathrm{ml}$. in all samples examined in water ranging in temperature from $-1.5^{\circ}$ to $3^{\circ} \mathrm{C}$. Near the surface he found one bacterium in II ml. of Arctic water from melting ice, one in $4 \mathrm{ml}$. of water from a depth of 25 meters and one in $\mathrm{I} .3 \mathrm{ml}$. of water from a depth of 2700 meters. Spirilla were the most numerous, followed by rods and cocci. No anaerobes were found. He was unable to demonstrate any microorganisms in Arctic air, contrary to the findings of more recent investigators.

The inadequacy of LEviN's cultural procedures is indicated by the fact that he found no bacteria in the intestinal tracts and feces of marine animals which he examined. With the exception of sea gulls, the viscera of sea birds were also reported to be sterile. A bacterium resembling Escherichia coli was demonstrated in the intestines of polar bears and 
seals. Careful studies by more modern workers have established that the excrement of animals like those examined by LEVIN usually contains an abundance of microorganisms.

Observations on the Rückreise, while crossing the Atlantic Ocean from Gibraltar to New York, were made by Minervini (igoo). He found a constant small population in surface waters with little difference between coastal water and that from the high sea. In the North Atlantic Ocean he found 8 to I 40 bacteria per $\mathrm{ml}$. in water from a depth of 5 to Io meters. Vibrio species predominated. In appraising his results it should be noted that he collected samples through a sea cock in the engine room while the vessel was traveling and he often stored his samples on ice for a few hours before examining them. The significance of sampling technique and of storing samples is discussed in Chapter III.

In Dröbak Sound, an arm of Oslo Fjord, Schmidt-Nielsen (I90i) found from 40 to 420 bacteria per $\mathrm{ml}$. at a depth of 25 meters and an average of only 26 per $\mathrm{ml}$. at the surface. However, this vertical distribution of bacteria even in sheltered areas was obliterated during periods of rough weather. He pointed out that the term "surface water" is relative, suggesting that during periods of extreme calm it may make a difference whether one examines the topmost layer of water or layers only a few $\mathrm{mm}$. below the surface. Many of the bacteria were chromogenic.

GAZERT (I906a) had charge of the bacteriological investigations of the German South Polar Expedition on the ship Gauss. He was only moderately successful in demonstrating bacteria by the methods used by Fischer. On a trip from Kiel to Capetown, Gazert (rgo6b) found an average of fewer than one bacterium per ml. of surface water from the open Atlantic Ocean. Growth occurred in all roo-ml. tubes of meat infusion broth inoculated with $20 \mathrm{ml}$. of sea water. On one occasion he recovered 6 bacteria per $\mathrm{ml}$. by plating water collected from a depth of $\mathrm{I} 800$ meters where the temperature was $2.5^{\circ} \mathrm{C}$. Surface water samples collected while cruising from Kerguelen Island in the Indian Ocean into South Polar waters and back to Capetown contained relatively few bacteria except where there was much seaweed. In water around seaweeds only io to 30 bacteria per $\mathrm{ml}$. were found.

In the deepest water from South Polar seas GAzERT (I906b) found relatively few bacteria, but appreciable numbers of bacteria were found in the bottom ooze or sediment even from depths as great as 5320 meters where the temperature ranged from $-0.2^{\circ}$ to $-2.0^{\circ} \mathrm{C}$. He found bacteria in the intestinal contents of seals, fishes, and albatrosses but not in penguins. Most of the bacteria isolated by GAzERT grew at $\circ^{\circ} \mathrm{C}$. but the optimum temperature was around $20^{\circ} \mathrm{C}$.

GAZERT attributed the paucity of bacteria in the open ocean to the low content of organic matter. Like his predecessors, he found many more bacteria near shore, and especially in harbors, than in the open sea. It must be emphasized, however, that the actual numbers of bacteria reported by various workers are by no means comparable because different procedures were employed in the analysis of the samples. It may be significant that GAZERT used a metal cylinder for the collection of water samples (see page 33 ).

GAZERT (I906b) gives an excellent description of the ship's laboratory. He stressed the difficulties with which the bacteriologist has to contend while examining water or mud on a small rolling ship.

As a member of the Swedish South Polar Expedition, EkElöF (I907) 
analyzed samples of surface sea water near Snow Hill Island in the vicinity of Ross Island. He found 4 to 5 bacteria per $\mathrm{ml}$. of water, the temperature of which was $-1.0^{\circ}$ to $-2.0^{\circ} \mathrm{C}$. Most of the bacteria were curved or rod-shaped cells. He found bacteria in the intestinal tract of gulls but not in other animals. Growth was obtained on about half of the petri dishes which were exposed to the air for two hours.

As a member of the Scottish Antarctic Expedition on the Scotia in I $902-4$, PIRIE (I II 2) found bacteria in most samples of surface water near the Orkney Islands. The water temperature was about $-\mathrm{I}^{\circ} \mathrm{C}$. Most of the bacteria were spirilla or rods. Bacteria were also demonstrated in samples collected from depths of 4000 to 5000 meters. Bacteria were found in most of the marine animals which were examined, but the intestinal contents of certain birds appeared to be sterile. Nitrifying bacteria were not found in either surface or bottom water, but denitrifiers were common. Plates of nutrient media exposed to the air on the crow's nest were sterile.

Otтo and NeumanN (I904) examined several samples of water while crossing the Atlantic Ocean from Europe to South America on a passenger ship. They perfected a technique for collecting surface samples while the vessel was moving, but subsurface samples could be collected only when the forward progress of the vessel was stopped. The largest bacterial populations were found in coastal waters near Boulogne, Lisbon, Cape Verde, and Pernambuco. An average of 60 bacteria per $\mathrm{ml}$. were found in the open ocean 5 meters below the surface. Somewhat more were found at 50 to Ioo meters, below which the bacterial population decreased sharply with depth. Bottom deposits harbored a rich microflora. Vibrios and rod-shaped bacteria resembling Proteus vulgaris, Escherichia coli, and Pseudomonas fuorescens predominated.

GRÄF (I909) analyzed water samples from 32 stations on the Planet Expedition in the Atlantic Ocean. Using methods similar to those prescribed by FISCHER, GRÄF found an average of 42 bacteria per $\mathrm{ml}$. of surface water from stations exceeding I 20 miles from land and an average of 2000 per $\mathrm{ml}$. near shore. In the harbor of Lisbon, Portugal, he found 54,000 bacteria per $\mathrm{ml}$.

DREW (I9I3) demonstrated the occurrence of large numbers of bacteria in tropical water off Andros Island in the Bahamas. They were most abundant in the surface water where several thousand bacteria were found per $\mathrm{ml}$. At 400 meters he found $\mathrm{I}_{7} 60$ bacteria per $\mathrm{ml}$., I 5 in water from depths of 800 to I 200 meters, and only 2 in water from a depth of 1600 meters. He noted the heat sensitivity of marine bacteria and the bacteriostatic action of metal sampling apparatus, two factors which may account for the low counts obtained by earlier workers. Many of the bacteria were denitrifiers which DREw believed tended to induce the precipitation of calcium carbonate in sea water. His later contributions on this subject are discussed in Chapter VII.

In the Mediterranean Sea near the coast of Monaco, Bertel (I9I2) noted a progressive decrease in the bacterial population with distance from land in surface water. He found more bacteria in deeper water than at the surface and more bacteria in surface water at night than in the afternoon hours. He attributed the vertical and diurnal distribution of bacteria to the lethal effect of sunlight, a conclusion which has not been confirmed by more recent observations (see page 69). BERTEL found a high bacterial count in the Atlantic Ocean between the Azores and Portu- 
gal, which he attributed to the existence of a submarine ridge with rich fauna.

During a trip to Scotland, Iceland, and Spitzbergen on the passenger liner Grosser Kurfïrst, Hesse (I9I4) found from 45 to Io,000 bacteria per $\mathrm{ml}$. of surface water which was collected in a sterile sail-cloth sampler. Except near land, the largest bacterial populations were found where the warmer water from the Atlantic Ocean meets the colder water from the Arctic. In this region many marine organisms die due to the sudden change in temperature, thereby providing a plentiful food supply for bacteria.

Most of the bacteria isolated by Hesse (I9I4) were motile rods or vibrios. The majority were denitrifiers. They grew better at refrigeration temperatures than at $37^{\circ} \mathrm{C}$. Room temperature was optimum for their growth. The organisms would grow in either sea-water or freshwater nutrient media.

Intensification of hydrobacteriological investigations :- In a 300-page Russian monograph which includes 420 references to the relevant literature, Issatchenko (I9I4) reviewed his own and others' observations on the occurrence and importance of bacteria in the sea. Whereas most earlier workers had been concerned primarily with establishing the presence of bacteria in the sea and studying some of the factors which influence their distribution, Issatchenko placed the emphasis upon the importance of bacteria in the sea as biochemical agents. He found a physiologically versatile microflora including nitrifiers, denitrifiers, nitrogenfixers, sulfate-reducers, ammonifiers, and other types of organisms in the water of Arctic seas to depths of $6_{5}$ to roo meters and in the bottom mud. He also reported the presence of yeasts. Most of the organisms were functional at $\mathrm{I}^{\circ}$ to $3^{\circ} \mathrm{C}$.

From the White Sea, Barents Sea, and Arctic Ocean along the Murman coast of northern Russia, IssATCHENKo (I9I4) isolated the following organisms which were described as new species: Bacillus kildini, Bacterium amforeti, Bact. arcticum, Bact. barentsianum, Bact. beijerincki, Bact. breitfussi, Bact. fausseki, Bact. flavum, Bact. knipowitchi, Bact. linkoe, Bact. marimum, Bact. papillare, Bact. septentrionale, Bact. siccum, Bact. spirale, Micrococcus boreus, $M$. catharinensis, $M$. centropunctatus, M. gelatinosus, M. marinus, M. minutissimus, Microspira murmanensis, Chromatium gobii, and Thiodictyon mimus.

The period of preliminary exploration terminated in I9I4, probably as a result of World War I which restricted research activities at sea and along the coasts of belligerent nations. There followed a period of relative quiescence for a decade, after which the modern era of quantitative and applied hydrobacteriology began. As pointed out by GEE (I932d), "Many of the early workers, prompted possibly by curiosity, attacked the problem in a sweeping way and did succeed in establishing the widespread occurrence of bacteria in the ocean. Later, as they sought to unravel the skein of complicating factors, their efforts have been directed more towards an ecological understanding of geographically limited areas, of restricted bacterial groups, or of one or two chemical processes influenced by bacteria. There has been a growing tendency in favor of an intense attack on some definite phase of the problem as most productive of useful results."

During the last two decades the emphasis has been increasingly upon 
the function of aquatic bacteria and allied microorganisms as biochemical, geological, and hydrobiological agrents. Methods of studying such organisms have been perfected, and considerable quantitative data on their distribution and activities have been accumulated by microbiologists at some of the leading oceanographic and biological stations of the world. Although our knowledge of hydrobacteriology is still woefully scant, enough progress has been made to indicate that such knowledge is prerequisite to a complete understanding of the economy of the sea, the cycle of matter, the composition of bottom deposits, and other oceanic as well as limnologic problems.

In appraising the scope, problems, and economic importance of the study of the oceans, BIGELow (I93I) says of bacteria, "Such glimpses as have been gained of their activities are enough to show that these must be assayed before we can hope to understand the maintenance of organic fertility in the oceans." His contention is substantiated by frequent references to bacteria as geological, bionomical, and chemical agents in WELCH's (I935) monograph on Limnology, the symposium of Recent Marine Sediments edited by TRASK (I939), and the comprehensive volume on "The Oceans" by Sverdrup, et al. (I942). Considerable space is also devoted to bacteria and allied microorganisms in the 405-page Symposium on Hydrobiology published by the University of Wisconsin Press in I94I.

For nearly two decades marine microbiology has been established as an integral part of the oceanographic program at the Scripps Institution of Oceanography at La Jolla, California (see publications by GEe, ZoBELL, and associates listed in the bibliography), and at the Woods Hole Oceanographic Institution at Woods Hole, Massachusetts (see papers by WaKsman, Carey, Hotchisiss, RenN, Reuszer, von Brand, et al.). Contributions have also been appearing regularly from the Marine Biological Association at Plymouth, England (see CoOper), the Marine Biological Station at Millport, Scotland (see Llovd), and other biological stations throughout the world. Several technical papers on the relation of bacteria to fisheries problems have been written by BEDFORD, GibBons, HARRISON, HESS, TARR, and associates under the auspices of the Canadian Fisheries Experimental Stations and by WooD of the Australian Division of Fisheries at Melbourne. Bacteriologists at the University of Wisconsin (Fred, MCCoy, Wrlimams, and others) together with HeNrici at the University of Minnesota have assumed the leadership in the study of freshwater lakes in this country. TAYLOR and associates at the Freshwater Biological Association, Westmorland, England, have been making a series of important contributions in recent years. BAIER's ambitious hydrobacteriological investigations at Kiel, Germany, have probably been temporarily interrupted by World War II. Extensive studies on bacteria in water and mud have been made by Butkevich, Issatchenko, KusNETZOw, RuBENTSCHI, and fellow Russian investigators. Attention is also directed to the unique studies of ELAZARI-VoLCANI on the bacteriology of the Dead Sea, and to BENECKE's (r 933) review of the literature on marine bacteriology which includes a good statement of many of the problems. Further reference will be made to the contributions of the aforementioned students of hydrobacteriology and their contemporaries in the following chapters. References to the key literature are given in the bibliography. 


\section{Chapter II}

\section{THE MARINE ENVIRONMENT}

The distribution, characteristics, and activities of microorganisms in the sea are influenced by the marine environment. In turn, certain environmental conditions in the sea are influenced by the activities of microorganisms. Therefore a knowledge of the essential features of the environment is prerequisite to the study of marine microbiology.

Extent and depth of the sea:- The oceans and seas cover $143,000,000$ square miles, or about $7 \mathrm{I}$ per cent of the earth's surface. The average depth of this water is nearly I 2,500 feet as compared with a mean elevation of the land above sea level of 2,300 feet. Whereas the greatest land elevation, Mount Everest in the Himalayas, is 29,000 feet above sea level, the greatest known depression on the earth's surface, the Mindanao Deep off the Philippine Islands, is 35,400 feet below sea level.

According to data compiled from Kossinna by SVERDRUP et al. (I942), 92.4 per cent of the ocean area, including adjacent seas, exceeds 656 feet or 200 meters in depth. The percentage area of depth zones is recorded in Table I.

TABLE I.- Percentage area of depth zones in the oceans, including adjacent seas, from SVERDRUP et al. (I942):-

\begin{tabular}{|c|c|c|c|c|}
\hline WATER DEPTH & AtLANTiC & Pacific & INDIAN & ALL OCEANS \\
\hline$>200$ meters & 86.7 & $94 \cdot 3$ & 95.8 & 92.4 \\
\hline$>1000$ & 79.6 & 91.2 & 92.7 & 88.1 \\
\hline$>2000$ & $74 \cdot 3$ & 87.3 & $89 \cdot 3$ & 83.9 \\
\hline$>3000$ & $65 \cdot 5$ & $82 . I$ & $8 \mathrm{I} .9$ & 77.1 \\
\hline$>4000$ & 47.0 & 63.6 & 57.9 & $57 \cdot 5$ \\
\hline$>5000$ & 21.2 & 28.4 & I9. 8 & $24 \cdot 5$ \\
\hline$>6000$ & 0.6 & I. 8 & 0.4 & I. 2 \\
\hline$>7000$ & $\ldots$ & 0.2 & ... & $0 . I$ \\
\hline
\end{tabular}

Topography of the sea floor:- The topography or profile of the ocean bottom is very irregular. There are submerged mountain-like structures of various dimensions which are termed ridges or rises, some of which rise precipitously for several thousand feet. Some, whose tops extend above the water, form islands. The term sill is applied to a submerged elevation separating two basins. Ridges, rises, and sills influence the movement of water masses and thereby exert a pronounced effect upon the physical, chemical, and biological properties of the water. Certain elevations restrict the migrations of marine animals. For these and related reasons the topography of the sea floor must be taken into account in the study of the ecology and activities of marine organisms.

Large scale depressions are called troughs, trenches, or basins. A deep is the lowest part of a depression, being the antithesis of a mountain peak. Canyons are relatively long narrow depressions or furrows in the continental shelf. Submarine canyons range in size from small gullies to vast depressions equalling the Grand Canyon of the Colorado River in all 
dimensions. The walls of submerged valleys are usually not nearly as steep as those of canyons.

A shelf is a gently sloping seaward extension of the land around continents and continental islands from lowest tide level to the con tour where the angle of descent increases rather sharply toward great depths. The water depth at the outer margin of the continental shelf ranges from 100 to 300 meters. Although there is considerable overlapping, the continental shelf marks the boundaries of a fairly distinctive biotic zone.

The continental slope is beyond the outer edge of the shelf where the inclination downward is greater than $I^{\circ}$, or more than one meter in 60 meters. The declivity of the slope is usually much greater than $I^{\circ}$. The lower limit of the slope is even more arbitrarily defined than its upper limit but, in general, it is marked by the termination of the steep gradient. An abyss is the bottom of the deep sea.

A bank is a fairly extensive, relatively flat-topped, submarine elevation approaching the surface. The water over it is usually sufficiently deep for navigation. The ecological significance of banks is indicated by the fact that some of the world's best fishing grounds are over banks. A reef is a coral or rocky, elongated elevation, part of which may actually extend above the water level

Biotic zones:- The marine environment is divided into biotic zones according to the nature of the plant and animal life inhabiting each. This is a function of such environmental factors as water temperature, salinity or osmotic pressure, depth, proximity to shore, etc. Marine organisms may be classified according to habitat into the categories of benthic or pelagic. Benthic or benthonic organisms, also called benthos, inhabit the sea floor. Those which live in the water and are not confined to the bottom are pelagic.

The distinction between the neritic and oceanic zones is less sharply defined than that between the benthic and pelagic zones. Literally neritic denotes the zone of shallow water which is relatively near land, and oceanic refers to organisms which live in the open ocean. However, marine ecologists usually employ the term neritic to include the zone outlined by the continental shelf, the oceanic zone embracing the open ocean beyond these boundaries. According to EKMAN (I935), the 200 meter depth contour roughly separates the neritic from the oceanic zone, this approximating the mean depth of water at the edge of the continental shelf. It is also the depth to which little or no sunlight penetrates.

Some workers define the littoral zone as that near the coast. Others define it as being synonymous with the intertidal zone or the area between high- and low-tide water marks, but EkMaN (I935) considers the littoral zone as the floor of the continental shelf.

The euphotic zone receives enough sunlight for the photosynthetic processes of plants. It is the zone of primary productivity in the sea. The depth of the euphotic zone varies with the factors which influence the penetration of light, but on the average it extends from the surface to a depth of around Ioo meters. Below the euphotic zone is the aphotic zone, a lightless region in which photosynthetic plants cannot grow. The animal life in this zone, which comprises about 95 per cent of the sea, consists almost exclusively of carnivores and detritus feeders. Bacterial life abounds in the aphotic zone, particularly on the sea floor where organic matter, raining down from the euphotic zone, accumulates. Some work- 
ers recognize a dysphotic zone in the ocean between the euphotic and aphotic zones as a region 80 to 200 meters below the surface which receives some light but not enough for effective plant production.

Penetration of sunlight:- There are several factors which influence the depth to which sunlight penetrates sea water. These include surface reflection, transparency of the water, the angle of incidence of light, and the intensity of the incident light. The latter two factors are largely functions of atmospheric conditions, the time of day, and latitude. Ordinarily, light penetrates tropical water to greater depths than water at higher latitudes. where the angle of incidence is greater.

Data recorded by SVERDRUP et al. (I942) indicate that an average of 65 per cent of the incident light (energy) in fairly transparent oceanic water is absorbed in one meter. Only I 7 per cent of the incident light penetrates to a depth of 5 meters, 9.5 per cent penetrates to a depth of Io meters, 3.7 per cent to a depth of 20 meters, 0.3 I per cent to a depth of 50 meters, and 0.0057 per cent penetrates to a depth of Ioo meters. In less transparent coastal waters only 0.5 per cent of the incident light penetrates to a depth of Io meters. Pure sea water, free of all suspended and coloring matter, permits the penetration of 22 per cent of the incident light to a depth of ro meters, but only 3 per cent of the light penetrates pure sea water to a depth of Ioo meters.

Considerable difference is found in the transparency of water from different parts of the ocean. According to CLARKE (I936), the water in the Sargasso Sea is more transparent than sea water in any other part of the world. It is 2 to 4 times more transparent than water in the Gulf of Maine which is characteristic of water on the continental shelf, and the latter is 3 to 4 times more transparent than water in Woods Hole Harbor.

There is a marked difference in transparency of water for different wave lengths of light. For example, CLARKE (I936) reports that the transparency of the Sargasso Sea is greater than that at Woods Hole Harbor by the following factors: 6-fold for green light, 7 -fold for red, I I-fold for violet, and 16 -fold for blue.

In general, green light, or that having a wave length ranging from 4920 to $535^{\circ} \AA$, penetrates sea water to greater depths than the shorter or longer wave lengths of the visible spectrum. Blue (4220 to $4920 \AA$ ) and yellow ( 5350 to $5860 \AA)$ are more penetrative than orange $(5860$ to $6470 \mathrm{~A})$ or violet ( 3900 to $4220 \AA)$. Red $(6470$ to $8100 \AA)$ is the least penetrative part of visible light. Sea water is relatively opaque to ultraviolet radiations. The decreasing intensity of orange, green, and blue light with increase in depth is given in Table II.

TABLE II.-Per cent of transmitted light of three spectral bands in water at Dixon Entrance, Southern Alaska, taken from data by UTTERBACK (I936):-

\begin{tabular}{|c|c|c|c|}
\hline $\begin{array}{l}\text { DEPTH OF } \\
\text { WATER }\end{array}$ & $\begin{array}{c}\text { ORANGE } \\
6000 \mathrm{~A}\end{array}$ & $\begin{array}{l}\text { GREEN } \\
5300 \AA\end{array}$ & $\begin{array}{c}\text { BLUE } \\
4800 \AA\end{array}$ \\
\hline meters & per cent & per cent & per cent \\
\hline 0 & 100 & 100 & 100 \\
\hline 5 & I8 & 35 & 26 \\
\hline IO & 1. 8 & 16 & 7.8 \\
\hline I5 & 0.53 & 7.6 & 3.9 \\
\hline 20 & 0.27 & 5.7 & 2.3 \\
\hline 30 & 0.012 & 0.12 & 0.082 \\
\hline
\end{tabular}


The amount of photosynthetic activity which occurs at different depths as indicated by oxygen production and carbon dioxide consumption, or other means, is one criterion of the penetration of light. At depths where there is much photosynthetic activity during the hours of daylight, more oxygen is liberated than the amount which is consumed by the respiration of organisms. With decreasing depth a point is reached where the amount of oxygen liberated is just equal to the amount consumed. It is termed the compensation point.

ClARKE (1936) found the compensation point in the Sargasso Sea at a depth of 80 meters. In the Gulf of Maine the compensation point was at a depth of 24 to 30 meters and in Woods Hole Harbor it was only 7 meters. He observed measurable amounts of photosynthesis at i 8 meters in Woods Hole Harbor, 40 meters in the Gulf of Maine, and I 40 meters in the Sargasso Sea.

Besides the effect of light on photosynthetic organisms which are the primary producers of the sea (CLARKE and OSTER, I934), light is the most important factor controlling the diurnal migrations of plankton (CLARKE, 1936). Not only does light influence the migrations, vertical distribution, production, and physiology of zooplankton, but the attachment and rate of growth of sedentary animals are also influenced directly or indirectly by light (RUSSELL, I936). The specific effect of radiations on the activities and distribution of marine microorganisms is outlined in Chapter V.

The literature on the penetration of light through water has been reviewed by ATKINs (1932). The reader is also referred to the symposium volume on the measurement of submarine light and its relation to biological phenomena by Clarke (I936), Russell (I936), UtTERBACK (I936), and others.

Temperature of the marine environment:- Closely related to the penetration of light is the temperature of sea water, which is primarily a function of the intensity of solar radiation. The effects of volcanic disturbances and adiabatic heating or cooling are far less than the direct or indirect effects of solar radiation.

The surface temperatures of sea water vary with season and latitude. Tropical waters in the open sea may have surface temperatures as high as $28^{\circ}$ to $30^{\circ} \mathrm{C}$, or $38^{\circ}$ to $40^{\circ} \mathrm{C}$. in localized regions near shore, while in polar seas water temperatures approximate the freezing point of the water. The freezing point is a function of the salinity. Water having a salinity of $35^{\circ} / 0$ begins to freeze at $-\mathbf{I} .9 \mathrm{I}^{\circ} \mathrm{C}$. Because the salinity is never suffciently high, except in localized regions, to depress the freezing point lower than $-2.0^{\circ} \mathrm{C}$., this approximates the lowest temperature found in the sea. The temperature range of the marine environment, $-2^{\circ}$ to $40^{\circ} \mathrm{C}$. is small contrasted with the range of air temperatures, $-65^{\circ}$ to $65^{\circ} \mathrm{C}$.

The temperature of surface water usually fluctuates less than $\mathrm{I}^{\circ} \mathrm{C}$. throughout the day. Diurnal changes are barely perceptible below a depth of to meters and are probably too small to be of biological importance. Annual changes may affect the temperature of sea water to a depth of 10 to 200 meters. Below this depth the water temperatures are fairly constant throughout the year, although fluctuations may be caused by the movements of water masses. The temperature of sea water usually decreases with depth except in shallow turbulent seas or during the winter at high latitudes.

The temperature of the water in the uppermost layers, which are 
mixed by the action of wind and waves, is fairly homogeneous. Below this homogeneous layer, which is ro to roo meters deep, the temperature decreases rapidly with depth to about $5^{\circ} \mathrm{C}$. or less at a depth of 200 to Iooo meters, depending upon the latitude. The zone of maximum temperature gradient is called the thermocline. Below the thermocline the temperature continues uniformly low to the bottom of the sea. Minor irregularities in the temperature curve may be caused by the intrusion of layers or tongues of colder or warmer water.

The temperature range of water exceeding rooo meters in depth is $5^{\circ}$ to $-\mathrm{I} .5^{\circ} \mathrm{C}$. Thus, about 90 per cent of the marine environment is perpetually colder than $5^{\circ} \mathrm{C}$. However, SмiтH (I940) points out that more than half of the ocean's surface ranges from I $5^{\circ}$ to $30^{\circ} \mathrm{C}$, and only 27 per cent of the surface water of the ocean has a mean annual temperature below $10^{\circ} \mathrm{C}$.

The effects of water temperatures on the activities and distribution of marine organisms have been summarized by HARVEY (I928), EKMAN (I935), SVERDRUP et al. (I942), and others. The temperature of the water also influences the density and movement of water masses.

The movements of sea water:- Although the marine environment is fairly stable in most respects, in many places the water is in a state of continuous movement. In virtue of the mobility of its waters, the sea responds readily to all forces acting upon it. The principal movements are waves, tides, tidal streams, and currents.

A wave is a ridge or swell of water normally having a forward motion. Waves may be propagated for long distances. Upon reaching shallow water, the wave steepness increases causing the waves to curl over and form breakers. In deep water the water particles within progressive as well as standing waves move in circles (SVERDRUP; et al., I942). Over deep water, surface waves sometimes attain a maximum height of nearly roo feet, the height of a wave being the vertical distance from the bottom of the trough to the top of the crest. Besides tending to mix water, wind waves produce considerable agitation of bodies in the water, particularly at the surface and sometimes on the sea bottom. The action of waves and breakers along the coast and in shallow water is an important ecological factor.

The attraction of the moon and sun causes tides, the alternate rising and falling of the surface of the ocean and of gulfs, bays, and other bodies of water connected with the ocean. The biological effects of tides are most noticeable along the coast, especially in the intertidal zone. The latter is alternately inundated and then left exposed to the air. In different parts of the world the vertical distance between the highest spring tide and the lowest neap tide ranges from less than one foot to 42 feet or more. According to MARMER (I932), the largest observed tidal ranges occur in the Bay of Fundy near Nova Scotia, Port Gallegos at the southern end of Argentina, and Frobisher Bay on Baffin Island where the maximum tidal ranges are 42,36 , and 35 feet respectively. Depending upon the bottom gradient, the intertidal zone may extend from a few feet to several miles from land.

For further information on tides, tidal streams, ocean currents, and other movements of sea water, the reader is referred to JoHNSTONE (I928), Marmer (I932), Patton and Marmer (I932), and Sverdrup et al. (I942).

The movements of sea water affect marine organisms in several ways 
either directly or indirectly. In the latter category may be mentioned the effect of water movements upon the temperature of the marine environment in various regions and upon the chemical composition of sea water. Vertical mixing or upwelling tends to bring nutrients to the euphotic zone. The greater abundance of microorganisms found in regions where warm and cold water meet or in regions of upwelling has already been mentioned.

Salinity, chlorinity, and density:- The concentration of total solids dissolved in sea water is usually expressed as salinity in terms of parts per thousand, per mille, or grams of solids per kilogram of sea water, for which the symbol $\%$ is used. For biological purposes it usually suffices to state the salinity as the nearest whole number or to the first decimal place, but because minute differences in salinity materially influence the dynamic stability of water masses, oceanographers give the salinity to the second decimal place.

Unless diluted by heavy rainfall, melting ice, or rivers, the salinity of surface sea water generally ranges from 33 to $37 \%$. However, in regions of considerable fresh-water dilution, as in the Gulf of Bothnia, for example, the salinity may approach zero. In isolated regions where surface water evaporates rapidly, as in the Red Sea or in tide pools, the salinity may exceed $40 \%$ for short periods of time. The salinity of the Dead Sea, like that of Great Salt Lake, sometimes reaches $320 \%$ while that in the Black Sea is only I6 to $23 \%$, but these inland bodies of water are far removed from the great oceans of the world. The salinity of deep or bottom water of the oceans varies within narrow limits, approximately 34.6 to $35 \%$ (SVERDRUP et al., I942).

The chlorinity is the number of grams of halogens, calculated as chlorine, precipitable by silver nitrate, contained in a kilogram of sea water. Since analytical procedures for determining the chlorinity of sea water are simpler and more precise than those for determining salinity directly, and since there is a constant relationship between salinity and chlorinity, the salinity of sea water is generally calculated from its chlorinity: Salinity = $0.03+1.805 \times$ chlorinity.

The density or specific gravity of sea water can be calculated from the chlorinity if the temperature is known. At $0^{\circ} \mathrm{C}$. the density equals $0.999,93 \mathrm{I}+0.00 \mathrm{I}, 470,8 \mathrm{Cl}-0.000,00 \mathrm{I}, 57 \mathrm{Cl}^{2}+0.000,000,039,8 \mathrm{Cl}^{3}$. The density may also be obtained by reference to KNUDSEN's (Igor) Hydrographical Tables. Roughly the density of sea water ranges from I.024 to I.030.

For hydrographical purposes the density of sea water may be determined accurately to the fifth place. Since the first two figures are always the same, it is practical to express the density by omitting the first two figures and shifting the decimal point three places to the right so that a density of I.028I4, for example, is expressed simply as 28 . I4.

Osmotic and hydrostatic pressure:- The osmotic pressure of sea water at any given temperature may be calculated from its salinity or chlorinity. According to THOMPsoN (I932), the freezing point of sea water, $\triangle$, equals $-0.0966 \mathrm{Cl}-0.000005_{2} \mathrm{Cl}^{3}$. From the colligative properties of dilute solutions it is known that when $\triangle$ is $-1.86^{\circ} \mathrm{C}$., the osmotic pressure is 22.4 atmospheres. Thus the osmotic pressure of sea water at $0^{\circ} \mathrm{C}$. approximates $\frac{22.4}{\mathrm{I} .86} \times \triangle$ or $12.04 \times \triangle$. ThOMPson (I932) 
points out that a small correction must be introduced for changes in sea water resulting from the heat of fusion and the heat of dilution, the corrected factor being $\mathrm{I} 2.08$. Therefore the osmotic pressure of sea water at $0^{\circ} \mathrm{C}$. equals $\mathrm{I} 2.08 \times \triangle$. If the osmotic pressure at $0^{\circ} \mathrm{C}$., $\mathrm{OP}_{0}$, is known, the osmotic pressure at any other temperature, $\mathrm{OP}_{t}$, can be calculated from the following formula:

$$
\mathrm{OP}_{\mathrm{t}}=\mathrm{OP}_{\mathrm{o}} \times \frac{273+\mathrm{t}}{273}
$$

The osmotic pressure, density, and salinity of sea water of different chlorinities are summarized in Table III. The osmotic pressure of sea water of average salinity, $35.00^{\%}$, is 23.07 atmospheres at $0^{\circ} \mathrm{C}$. or 24.69 atmospheres at $20^{\circ} \mathrm{C}$.

TABLE III.- The salinity, density, freezing point, and osmotic pressure of sea water of different chlorinities at $0^{\circ} \mathrm{C}$., calculated from KNUDSEN's (IgOI) Hydrographical Tables:-

\begin{tabular}{|c|c|c|c|c|}
\hline ChLoRinity $(0 / 00)$ & I7.00 & I9.00 & 19.38 & 21.00 \\
\hline SALINITY $(\% / \infty)$ & 30.72 & $34 \cdot 33$ & 35.01 & 37.94 \\
\hline FREEZING POINT $\left({ }^{\circ} \mathrm{C}.\right)$ & $-\mathrm{x} .67$ & $-\mathrm{I} .87$ & $-I .9 I$ & -2.08 \\
\hline $\begin{array}{l}\text { OSMOTIC PRESSURE (ATMOSPHERES) } \\
\text { DENSITY (AT O } 0^{\circ} \text { C. REFERRED TO }\end{array}$ & 20.17 & 22.59 & 23.07 & 25.13 \\
\hline DIST. WATER AT $4^{\circ} \mathrm{C}$.) & I. 02468 & I. 02758 & 1.02814 & I. 03049 \\
\hline
\end{tabular}

Most marine organisms are stenohaline, or adaptable to only slight changes in salinity or osmotic pressure. Those which are able to live in water having a wide range of salinity or osmotic pressure are termed euryhaline. Certain crustaceans and the salmon are outstanding examples of euryhaline organisms. Some bacteria thrive in fresh water and others live in the most concentrated brines, but most of the bacteria and allied microorganisms found in the sea at places which are remote from possibilities of terrigenous contamination tend to be stenohaline (see Chapter VIII). Contrary to popular conception, marine microorganisms tolerate hypertonic solutions no better than they tolerate hypotonic solutions.

The hydrostatic pressure of sea water is primarily a function of depth and secondarily of temperature, chlorinity, compressibility, and latitude. For practical purposes the effect of atmospheric pressure on the hydrostatic pressure is not generally considered. In fact, for biological purposes only the depth need be considered.

Roughly, the hydrostatic pressure increases one atmosphere for each ten meters, an atmosphere being ${ }_{5} 5$ lbs. per square inch or the weight of a $760 \mathrm{~mm}$. column of mercury. At a depth of one mile the pressure approximates one ton per square inch. There are few land-dwelling organisms which can tolerate such pressures. Very little is known concerning the effect of pressure on marine organisms but certainly it does not exclude life from the abyssal regions of the sea. Living organisms have been recovered from the greatest depths dredged. Bacteria appear to be more abundant in bottom deposits than elsewhere in the sea, regardless of the depth of overlying water or the pressure.

The pressure influences the solubility of substances although the effect of pressure on the chemical or physical properties of sea water is considerably less than that of temperature or salinity. The effect of pressure on sampling apparatus must be taken into consideration because unless adequately protected, thermometers and other instruments will be broken by the pressure at great depths. 
Chemical composition of sea water:- Sea water is a physiologically balanced salt solution containing more than half of the known elements. It is a dilute solution of several salts with some dissolved gases and traces of a vast number of organic compounds.

Except for a few constituents which are produced or consumed by biological agencies, the composition of sea water is relatively constant. The concentration of the principal inorganic solutes in sea water having a salinity of $34.325^{\circ} / 00$ is given in Table IV.

TABLE IV. - Concentration of elements, exclusive of gases, in sea water having a salinity of $34.325 \%$ (from data recorded by SVERDRUP et al., 1942):-

\begin{tabular}{|c|c|c|c|c|}
\hline EleMENT & $\begin{array}{l}\text { GM./KG. } \\
\text { OR } \% / 00\end{array}$ & $\begin{array}{l}\text { PER CENT OF } \\
\text { TOTAL SOLIDS }\end{array}$ & $\begin{array}{l}\text { ELEMENT } \\
\text { (CONT.) }\end{array}$ & $\begin{array}{c}\text { GM. /KG. } \\
\text { OR } \% 00\end{array}$ \\
\hline Chlorine & I8. 980 & 55.29 & $\operatorname{Iron}^{*}$ & $0.000,02$ \\
\hline Sodium & IO. $56 \mathrm{I}$ & 30.77 & Manganese* & $0.000,01$ \\
\hline Oxygen & I. 733 & 5.05 & Copper & $0.000,01$ \\
\hline Magnesium & I. 272 & $3.7 \mathrm{I}$ & Zinc & $0.000,005$ \\
\hline Sulfur & 0.884 & 2. 57 & Lead & $0.000,004$ \\
\hline Calcium & 0.400 & I. 16 & Selenium & $0.000,004$ \\
\hline Polassium & 0.380 & I. II & Cesium & $0.000,002$ \\
\hline Bromine & 0.065 & 0.189 & Uranium & $0.000,00 \mathrm{I}, 5$ \\
\hline Carbon & 0.028 & $0.08 \mathrm{I}$ & Molybdenum & $0.000,000,5$ \\
\hline Strontium & 0.013 & 0.038 & Thorium & $<0.000,000,5$ \\
\hline Boron & $0.004,6$ & 0.013 & Cerium & $0.000,000,4$ \\
\hline Silicon* & $0.004,0$ & 0.012 & Silver & $0.000,000,3$ \\
\hline Fluorine & $0.001,4$ & 0.004 & Vanadium & $0.000,000,3$ \\
\hline Nitrogen* & $0.000,7$ & 0.002 & Lanthanum & $0.000,000,3$ \\
\hline Aluminum & $0.000,5$ & - & Ytrium & $0.000,000,3$ \\
\hline Rubidium & $0.000,2$ & - & Nickel & $0.000,000,1$ \\
\hline Litlium & $0.000, \mathrm{I}$ & - & Scandium & $0.000,000,04$ \\
\hline Phosphorus* & $0.000, \mathrm{I}$ & - & Mercury & $0.000,000,03$ \\
\hline Barium & $0.000,05$ & - & Gold & $0.000,000,006$ \\
\hline Iodine & $0.000,05$ & - & Radium* & $3 \times 10^{-13}$ \\
\hline Arsenic* & $0.000,02$ & - & & \\
\hline
\end{tabular}

- The quantity of the elements marked with an asterisk is highly variable in sea water primarily due to biological activity. The concentration given is the maximum ordinarily found.

The chlorine and bromine occur almost exclusively as chloride and bromide anions. Similarly sodium, magnesium, calcium, potassium, and strontium occur as cations. The oxygen reported in Table IV occurs mostly in sulfate ions, with smaller quantities in bicarbonate, borate, phosphate, nitrite, and nitrate ions. The nitrogen occurs as ammonium, nitrite, or nitrate ions and to a lesser extent in organic compounds. The ratios of the three principal anions of sea water, i.e., carbonates, sulfates, and chlorides in sea water are the reverse of the ratios of these anions in river water:

$\begin{array}{lc}\text { River water } & \% \text { CARBONATE } \\ \text { Seq water } & 80 \\ & <\mathrm{I}\end{array}$

\% SUlFate
I 3
II

$\%$ CHLORIDE 7 88

Similarly the ratios of cations, particularly sodium and calcium, are different in sea water and in river water:

$\begin{array}{lcccc} & \text { \% CALCIUM } & \text { \% SODIUM } & \text { \% MAGNESIUM } & \% \text { POTASSIUM } \\ \text { River water } & 57.7 & 26.8 & 9.5 & 6.0 \\ \text { Sea waler } & 3.2 & 83.7 & 10.1 & 3.0\end{array}$

The ratios are calculated from data given by CLARKE (I924) on the analyses of river water and sea water. 
Although compounds of nitrogen occur in sea water only in very low concentrations, they have received much attention because they are essential for plant growth. Moreover, the nitrogen content of sea water is a useful indicator of the past history of the water.

The nitrate- $\mathrm{N}$ content of sea water ranges from near zero to about one milligram per liter. Since the concentration of nitrate like that of nitrite, ammonium, and phosphate is relatively low, it is usually expressed as milligrams per cubic meter $\left(\mathrm{mgm} . / \mathrm{M}^{3}{ }^{3}\right)$ or as micrograms per liter $\left(\mu \mathrm{gm} . / \mathrm{L}\right.$.). One milligram per liter is equal to $1000 \mathrm{mgm} . / \mathrm{M}^{3}$ or 1000 $\mu \mathrm{gm} . / \mathrm{L}$.

The nitrate content of sea water varies with season, depth, latitude, distance from land, and other factors. As a rule water in the euphotic zones contains less nitrate than that at greater depths. THомpson and RoBINSON (1932) report that at a certain station in the Pacific Ocean $5 \mathrm{mgm} . / \mathrm{M}^{3}{ }^{3}$ of nitrate $\mathrm{N}$ was found in surface waters, $384 \mathrm{mgm} . / \mathrm{M}^{3}{ }^{3}$ at 400 meters and $500 \mathrm{mgm} . / \mathrm{M}^{3}$ at 800 meters. In the euphotic zone the nitrate- $\mathrm{N}$ content is generally less than roo mgm./M. ${ }^{3}$ and often less than Io $\mathrm{mgm} . / \mathrm{M} .^{3}$

The fact that deep water usually contains more nitrate than surface waters is cited by certain workers as evidence that nitrate is formed in deep water, but more likely this vertical distribution merely shows that nitrate is being utilized by photosynthetic organisms. The effect of microorganisms on the nitrate, nitrite, ammonium, and phosphate content of sea water is discussed in Chapters XI and XIII. Additional information on the nitrate content of sea water is given by HARVEY (1926) and by THOMPSON and RoBINSON (I932).

The nitrite- $\mathrm{N}$ content of sea water ranges from near zero to $50 \mathrm{mgm} . / \mathrm{M}^{3}$ It is usually less than Io mgm./M. ${ }^{3}$ and often less than 1.0 mgm./M. ${ }^{3}$ ORR (I926) and RAKESTRAW (I936) have summarized the factors which influence the occurrence of nitrite in the sea.

There is nearly always some detectable ammonia- $\mathrm{N}$ in sea water. The concentration ranges from I to $350 \mathrm{mgm} . / \mathrm{M}^{3}$, usually 5 to $50 \mathrm{mgm} . / \mathrm{M}^{3}$ The distribution of ammonia in the sea is somewhat irregular but the ammonia content of water deeper than 500 meters is relatively uniform and low (RAKEstraw, I936; REDField and Keys, I938), nearly always being less than Io mgm./M. ${ }^{3}$ The highest concentrations of ammonia are found near shore particularly where there is much terrigenous pollution or near the sea floor in shallow water. SEIwell (I93I) found as much as $350 \mathrm{mgm} . / \mathrm{M}^{3}$ of ammonia in a bottom sample where the water depth was around 50 meters, compared with $\circ$ to $50 \mathrm{mgm} . / \mathrm{M}^{3}$ found in surface waters.

Ammonia is produced and consumed by microorganisms. The evidence that ammonia is assimilated by marine plants, perhaps preferentially, is reviewed by ZoBELL (I935).

There is a marked parallelism between the concentration of phosphate and that of nitrate in the sea (REDFIELD, I934; RAKESTRAW, I936). Because it is an essential plant nutrient which sometimes becomes a limiting factor in the productivity of the sea, the occurrence of phosphate has received much attention by oceanographers and marine biologists.

The concentration of phosphate in the sea generally increases with depth. During the photosynthetic season, surface water in tropical and temperate zones may contain from $\circ$ to $\mathrm{I} \mathrm{mgm} . / \mathrm{M}^{3}$ of phosphate- $\mathrm{P}$, whereas water at depths exceeding 500 meters contains 5 to $200 \mathrm{mgm} . / \mathrm{M}^{3}{ }^{3}$ 
of phosphate-P (Arkins, 1923). Surface water at high latitudes usually contains more phosphate than surface water in tropical seas. The cycle of phosphorus in the sea has been reviewed by SEIwELL (1935) and RENN (I937a), the latter emphasizing the role of bacteria.

Organic matter is quite evenly distributed throughout the sea, the content being uniformly small except in the vicinity of land or in bottom deposits. KroGH (I93 I), found an average of only $2.36 \mathrm{gm}$. of organic carbon per cubic meter of sea water or 2.36 parts per million.

One might expect to find appreciably more organic matter in the euphotic zone than at greater depths in the sea due to the preponderance of plant and animal life in this zone, but actually only a small proportion of the organic content occurs as organized protoplasm. GRAN and RUUD (I926) estimated that the ratio of particulate to dissolved organic matter in the sea is I:7. KROGH (I934) placed the ratio at I:300. BIGELOW and SEARS (I939) report I:I00 to I:4000. The demarcation between dissolved and particulate organic matter is poorly defined, the separation usually being made upon a basis of the ability of the organic fraction to pass through filters of various dimensions or to be removed by centrifuging. In spite of the experimental difficulties in obtaining quantitative results, however, there is unquestionably considerably more unorganized organic matter (dissolved, colloidal, or minute particles) than that which occurs in organized protoplasm.

An average of $5^{6}$ per cent of the organic matter in sea water consists of carbon and about a tenth as much is nitrogen. The ratio of carbon to nitrogen in marine organic matter ranges from about 8:I to I2:x. Much of the organic matter is fairly refractory to decomposition by biological agencies (WAKSMAN and CAREY, I935a).

Bottom deposits and the juxtaposed water contain much more organic matter than the overlying water. According to TRASK (I939), oceanic deposits contain an average of 1.0 per cent organic matter while near shore deposits contain an average of 2.5 per cent organic matter.

Dissolved gases and the $\mathrm{pH}$ of sea water:- The $\mathrm{pH}$ encountered in the sea ranges from 7.5 to 8.5 . When in equilibrium with the $\mathrm{CO}_{2}$ of the atmosphere, the $p \mathrm{H}$ of sea water ranges from 8.I to 8.3. In the euphotic zone photosynthetic plants may reduce the $\mathrm{CO}_{2}$ content of the water until the $p \mathrm{H}$ reaches 8.3 to 8.5 during the hours of intense sunlight. Below the cuphotic zone the $p \mathrm{H}$ decreases with depth to a minimum of 7.5 at depths exceeding rooo meters.

In marine bottom deposits, tide pools, bays, and estuaries, the $p \mathrm{H}$ may exceed 8.5 or fall below $p H$ 7.0. There are several ways in which the activities of microorganisms-influence the $p \mathrm{H}$ of sea water by producing or destroying organic acids, nitrates, nitrites, ammonium, sulfates, hydrogen sulfide, etc. Some of the biological effects of the $p \mathrm{H}$ of sea water are discussed by HARVEY (I928).

Bicarbonates constitute the principal buffer system of sea water. Borates play a minor role. Phosphates and proteinaceous materials are far too dilute to exert a detectable influence on the $p \mathrm{H}$ of sea water.

The $\mathrm{CO}_{2}$ content of sea water decreases as the $p \mathrm{H}$ increases. In sea water more alkaline than $p \mathrm{H} 7 \cdot 5$, there is virtually no free $\mathrm{CO}_{2}$ in solution, most of it occurring in combination as bicarbonates or carbonates. The effect of $p \mathrm{H}$ on the relative concentrations of free $\mathrm{CO}_{2}$, bicarbonate, and carbonate in sea water is shown by Figure I which is prepared from data given by MOBERG et al. (I934). 
$\mathrm{CO}_{2}$ is produced by the respiration of all organisms and is utilized by photosynthetic and chemosynthetic organisms. The $\mathrm{CO}_{2}$ in the atmosphere is in equilibrium with that in the ocean. Minute changes in the $p H$ of the oceans of the world would materially alter the $\mathrm{CO}_{2}$ content of the atmosphere.

The dissolved oxygen content of sea water is a function of temperature, pressure, salinity, and biological activity. When in equilibrium with the atmosphere at $760 \mathrm{~mm}$. pressure at $15^{\circ} \mathrm{C}$., sea water having a salinity of $34.325 \%$ contains $5.86 \mathrm{ml}$. or $8.40 \mathrm{mgm}$. of oxygen per liter. The solubility of oxygen increases with decreasing temperature and it increases with decreasing salinity. Oxygen is consumed by respiring organisms including bacteria. In sea water and bottom deposits bacteria probably consume more oxygen than all other organisms combined, depleting the oxygen in certain localized regions. Photosynthetic organisms produce oxygen, sometimes in sufficient amounts to supersaturate the water in the euphotic zone.

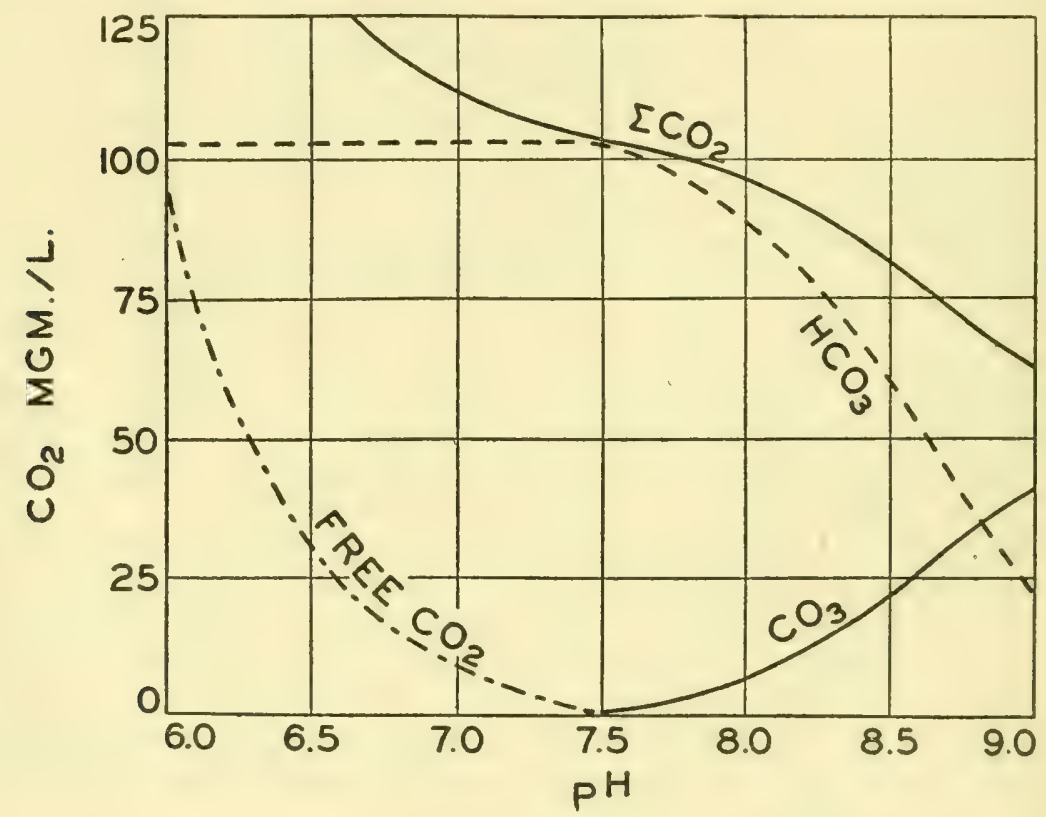

FIG. I. - Effect of $p \mathrm{H}$ on the relative concentrations of free $\mathrm{CO}_{2}, \mathrm{HCO}_{3}{ }^{-}, \mathrm{CO}_{3}{ }^{--}$, and total $\mathrm{CO}_{2}$ in sea water (adapted from MoBERG et al., I934).

Below the euphotic zone the oxygen content of sea water usually decreases vertically to a depth of 600 to 900 meters, the so-called oxygen minimum layer, and then increases again towards the bottom. The oxygen content of sea water at depths exceeding 1000 meters is determined primarily by its past history, origin, or movements, because there are not enough organisms present at such depths to have much effect until the sea floor is reached. Little or no dissolved oxygen is found in bottom deposits and the juxtaposed water.

Dissolved nitrogen is of little biological importance in the sea. Small quantities may be utilized by nitrogen-fixing bacteria and some is liberated by the activities of denitrifying bacteria, but it has not been demon- 
strated that the activities of such microorganisms perceptibly influence the dissolved nitrogen content of sea water (see Chapter XI).

In surface water the dissolved nitrogen is in equilibrium with the atmosphere. The amount found at greater depths is believed to indicate the temperature of the water when it occupied a position at the surface, the solubility of nitrogen varying inversely with temperature.

Artificial or synthetic sea water:- In experimental work it is often desirable to work with artificial or synthetic sea water. Since a solution like sea water probably does not contain all the ingredients arbitrarily combined, it is not surprising to find that several different formulae have been proposed by different workers (FowLER and ALLEN, I 928; SVERDRUP et al., I942). The formulae differ primarily in the form in which the constituent ions are added and in inclusiveness.

\begin{tabular}{|c|c|c|}
\hline Distilled water $\left(\mathrm{H}_{2} \mathrm{O}\right)$ & \multicolumn{2}{|c|}{1000.00 grams } \\
\hline Sodium chloride $(\mathrm{NaCl})$ & $24 \cdot 32$ & \\
\hline Magnesium chloride $\left(\mathrm{MgCl}_{2} \cdot 6 \mathrm{H}_{2} \mathrm{O}\right)$ & 10.99 & " \\
\hline Sodium sulfate $\left(\mathrm{Na}_{2} \mathrm{SO}_{4}\right)$ & 4.06 & "6 \\
\hline Calcium chloride $\left(\mathrm{CaCl}_{2} \cdot 6 \mathrm{H}_{2} \mathrm{O}\right)$ & 2.25 & “ \\
\hline Potassium chloride ( $\mathrm{KCl})$ & 0.69 & “ \\
\hline Sodium bicarbonate $\left(\mathrm{NaHCO}_{3}\right)$ & 0.20 & “ \\
\hline Potassium bromide (KBr) & 0.10 & “ \\
\hline Strontium chloride $\left(\mathrm{SrCl}_{2} \cdot 6 \mathrm{H}_{2} \mathrm{O}\right)$ & 0.042 & “ \\
\hline Boric acid $\left(\mathrm{H}_{3} \mathrm{BO}_{3}\right)$ & 0.027 & " \\
\hline Sodium silicate $\left(\mathrm{Na}_{2} \mathrm{SiO}_{3} \cdot 9 \mathrm{H}_{2} \mathrm{O}\right)$ & 0.005 & “6 \\
\hline Sodium fluoride $(\mathrm{NaF})$ & 0.003 & “ \\
\hline Ammonium nitrate $\left(\mathrm{NH}_{4} \mathrm{NO}_{3}\right)$ & 0.002 & " \\
\hline Ferric phosphate $\left(\mathrm{FePO}_{4} \cdot 4 \mathrm{H}_{2} \mathrm{O}\right)$ & 0.001 & " \\
\hline
\end{tabular}

The formula for synthetic sea water given in Table $\mathrm{V}$ is based upon the work of LYMAN and FLEMING (I940). It differs from their formula in that it contains traces of certain additional constituents known to occur in sea water which are' essential for the growth of organisms. For convenience in its preparation the amount of each ingredient is given on a weight to volume basis. Synthetic sea water prepared according to this formula has a chlorinity of about $19 \%$. After reaching equilibrium with the $\mathrm{CO}_{2}$ of the atmosphere the reaction is $p \mathrm{H}$ 8.o. With an appropriate source of food or energy it provides for the growth of most marine diatoms, bluegreen algae, yeasts, molds, and bacteria which have been studied.

Marine bottom deposits:- Environmental conditions on and in the sea floor are of importance to the extensive benthic population. The latter consists of plants and animals to the depth penetrated by sunlight, below which the benthos consists of animals, bacteria, and certain fungi.

Animal and bacterial life has been recovered from bottom deposits at all depths of water from which samples have been examined, but due to technical difficulties of probing deep into the bottom deposits for suitable samples, it is not known to what depths within the bottom deposits animals occur. Certain animals are known to penetrate near-shore bottom deposits to a depth of two or three feet. However, penetrations to such depths are usually temporary. It is doubtful if many animals live in mud below the topmost few inches owing to the lack of oxygen. While a few ciliates and other simple forms of animal life can live in an anaerobic environment, most animals require oxygen. The lack of oxygen does not 
limit the depth to which bacteria are found in bottom deposits because many species thrive in the complete absence of free or dissolved oxygen. Living anaerobic bacteria have been recovered from the greatest depths sampled, namely about 25 feet (see Chapter VI).

In general, neritic bottom deposits, or those in water adjacent to land to the 200 meter depth contour, consist primarily of sand and other coarse material. Oceanic bottoms, or those beyond the 200 meter line, consist largely of muds and oozes. The oceanic or deep-sea deposits consist of terrigenous or pelagic material.

Terrigenous deposits come from the land or are formed close to land. They consist of disintegrated rock fragments and the remains of certain littoral organisms. Therefore the constituents may be classified as either inorganic or organic. Terrigenous deposits are also classified according to texture which is a function of their content of sand, silt, or clay. The International Society of Soil Science gives the following mean dimensions for sand, silt, and clay:

PARTICLE OR FRACTION

Rocks or pebbles
Coarse sand
Fine sand
Silt
Clay

DiAMETER IN MM.

$$
\begin{aligned}
& >2.0 \\
& 2.0 \text { to } 0.2 \\
& 0.2 \text { to } 0.02 \\
& 0.02 \text { to } 0.002 \\
& <0.002
\end{aligned}
$$

SETTLING VeloctTy IN WATER CM./SECOND

347.6

3.476

0.03476

0.00034

Terrigenous deposits can be characterized according to color which may be black, white, blue, red, yellow, green, or brown.

Pelagic deposits consist of the remains of calcareous and siliceous organisms from the overlying water and the hydrous silicates of iron and aluminum from the disintegration of materials from submarine volcanic action.

If the sediment consists primarily of the tests of pelagic foraminifera, it is termed globigerina ooze. In coccolith ooze the calcareous remains of Coccolithophoridae, minute flagellates, predominate. Pteropod ooze is characterized by a predominance of the calcareous shells of pteropods, small gastropod mollusks. Diatom ooze and radiolarian ooze contain a large proportion of the siliceous skeletal material from diatoms or Radiolaria respectively. Pelagic deposits which contain less than 30 per cent of the calcareous or siliceous remains of organisms are known as red clay.

For further information on the properties of marine bottom deposits the reader is referred to MurRay and HJort (I9I2), TraSk (I939), and SVERDRUP et al. (I942).

Plant and animal population:- Over 8000 species of marine plants have been described, with species of red algae, diatoms, brown algae, dinoflagellates, green algae, and blue-green algae predominating in the order listed. The red and brown algae, which are known collectively as seaweeds, are the most conspicuous plants along the coast and in shoal waters, but it is the microscopic diatoms and dinoflagellates that are most important in the economy of the sea. Diatoms and dinoflagellates are more or less universally and generally abundantly distributed throughout the photosynthetic zone. Though microscopic in size, their mass greatly exceeds the combined mass of all other primary producers including the more conspicuous seaweeds and higher plants. The siliceous shells, or frustules, of diatoms are of considerable importance in sediments 
and have formed extensive fossil deposits known as diatomaceous earth. Several hundred species of marine plankton diatoms have been described by Cupp (I943) who lists much of the relevant literature.

Outstanding in importance among the higher plants is eel grass, Zostera marina, an angiosperm which is widely distributed along the protected coasts of Asia Minor, eastern Asia, Europe, and North America. Phyllospadix, a related genus, is confined to the open, wave-washed coasts of the Pacific. Six genera of Potamogetonaceae closely related to freshwater Potamogeton species also inhabit the sea. In all there are only around 30 species of marine Spermatophytes (seed plants) and no known Pteridophytes (ferns) or Bryophytes (mosses). Besides providing food for animals and saprophytic microorganisms, aquatic Spermatophytes, algae, and certain diatoms provide anchorage for sessile microorganisms of various kinds including bacteria. The interrelationships of bacteria and plants are outlined in Chapter XIV.

Vegetation is described by CoKER (1938) as "the broad base of the pyramid of life in the sea. The contrast to conditions on land is marked. None of the higher plants occur in the ocean remote from the shores. The great group of blue-green algae, abundant in lakes and rivers, are prominent in the ocean only in the waters near the mouths of large rivers or in tropical regions. The green algae, predominant in fresh waters, are sparsely represented in salt water and then chiefly where there is some admixture of fresh water. The off-shore plant life, barring the floating Sargassum, is of extreme simplicity of form. Even the relatively simple filamentous forms, so characteristic of all sorts of fresh water, are missing. Conditions in the sea have not favored cell aggregations and the associated specialization in form and development of larger bodies. ... The basis of all the life in the modern ocean is to be sought in the microorganisms of the surface."

In comparing animal life in the sea with terrestrial and fresh-water faunas, Coker (I938) points out that "the diversity in basic types of living animals is much greater in the ocean than in fresh water or on land.... There is in the ocean a predominance of the more primitive types of animals and of those types that constitute the possible links between the several phyla. In a way we may look upon the seas as representing a living museum of biological antiquities, or it might better be said, as comprising the chief repository of the early archives of our family history." This may also be said of the bacterial kingdom which is represented in the sea by a great diversity of species, including many primitive forms.

The animal population of the sea has far-reaching effects on the marine environment and the microbial population. Some of the factors influencing the distribution of animals in the sea are discussed by Ekran (I935). The sea is the home of over 60,000 species of mollusks, about half as many crustaceans, I5,000 fishes, and enough representatives of other classes to make a total of around 150,000 species of marine animals which have been described. Of the 48 major classes of animals only insects, reptiles, birds, myriopods, amphibia, and mammals are predominantly non-marine. Most of the other classes are predominantly or almost exclusively marine. In the latter category are coelenterates, ctenophores, echinoderms, sponges, tunicates, and bryozoans, all of which are largely confined to the sea.

Of special microbiologic and oceanographic interest are the Protozoa, of which there are many thigmotropic and planktonic types. In the 
Woods Hole area, LAckey ( I 936) found from 27,000 to I35,000 protozoans per liter of sea water. He observed I 83 different species attached to surfaces, 146 planktonic species, and 79 different species in bottom samples. Numerous representatives of all of the major groups as listed by CALKINS (1926) were observed in marine materials. LACKEY stressed the importance of Protozoa as food for copepods and similar grazing animals (see also Clarke and Gellis, I935). Protozoa also have an important function in the turnover of organic matter. They ingest bacteria (LuCK et al., I93 I) and otherwise influence the bacterial population.

More than a thousand species of Foraminifera, rhizopod Protozoa having calcareous shells, occur in the sea. ElLIs and MEssina (I940) catalog some 18,000 living and extinct species of Foraminifera. Species of the genera Globigerina and Biloculina are extraordinarily abundant, their dead shells making up a large part of the soft mud on many parts of the ocean floor. Similarly, the siliceous skeletons of Radiolaria give rise to radiolarian ooze.

Tintinnids are protozoans belonging to the Class Ciliata, which occur in vast numbers, especially in coastal waters. At times tintinnids along with copepods and euphausiids make up a major part of the zooplankton. Copepods and euphausiids belong to the Class Crustacea. Copepods usually constitute about 70 per cent of the zooplankton. Besides the aforementioned organisms, marine zooplankton also consists of ostracods, amphipods, jellyfishes, siphonophores, worms, heteropods, pteropods, and the sperm, eggs, and larval stages of many animals.

The term plankton is applied to the vast assemblage of feebly swimming or floating organisms, both plant (phytoplankton) and animal (zooplankton), which drift with the motion of the water. The chief components of phytoplankton are diatoms and dinoflagellates, with smaller numbers of coccolithophores, silicoflagellates, blue-green algae, green algae, and the reproductive products of seaweeds. Being dependent upon radiant energy, active phytoplankton are confined to the euphotic zone. Zooplankton, like other animals, depend either directly or indirectly upon photosynthetic organisms for food. As is elaborated in Chapter V, the abundance of bacteria and allied microorganisms is closely linked with the abundance and activities of zooplankton and phytoplankton.

Plankton are often classified on a basis of size as macroplankton, which are large enough to be seen with the naked eye or to be taken with a coarse net of No, $\infty$ to $\infty 00$ bolting cloth; net plankton, which are smaller than I mm. yet large enough to be retained by a No. 20 or 25 silk bolting cloth net having a mesh of 0.06 to $0.08 \mathrm{~mm}$.; and nannoplankton, minute organisms which are too small to be retained by a No. 25 net. Because nannoplankton (from Greek nanos meaning dwarf), which range in size from I to $5 \circ \mu$, are often removed from water by centrifuging (LOHMANN, I922; WULFF, I926), such organisms are sometimes termed centrifuge plankton. Nannoplankton can also be removed by filtering the water through hard filter paper (LEBOUR, I9I 7). Some workers apply the term microplankton to all planktonic organisms which are smaller than macroplankton as defined above, while others use the term microplankton as being synonymous with nannoplankton as defined above. Free-floating or swimming organisms ranging in size roughly from 0.2 to $5 \mu$ have been designated ultraplankton. The bacteria and yeasts which lead a planktonic existence belong to the ultraplankton, but most bacteria are associated with larger organisms or other particulate material where they lead a sessile existence. 
Sessile organisms are termed epiplanklon by HuBER-PESTALOzzI (I938) in his treatise on phytoplankton. Many epiplankton are parasitic. The teim neuston is applied to plants, animals, and bacteria which are associated with the surface film of water. Under certain conditions the surface film of water serves as a mechanical support for neuston (W ELCII, I 935).

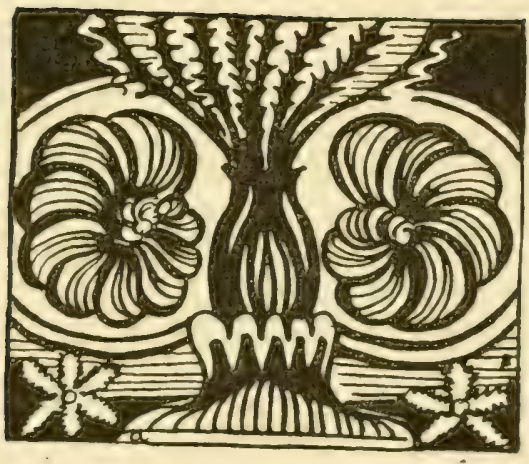




\section{Chapter III}

\section{COLLECTION AND EXAMINATION OF SAMPLES AT SEA}

One of the most difficult of the peculiar problems of technic confronting the marine bacteriologist is the collection of samples of sea water or bottom deposits for analysis from any desired location or depth. There are very few places in the world where samples uncontaminated by land drainage can be obtained without the use of a boat, and it is often necessary to travel considerable distance from land. A small boat necessitates the special preservation and rapid transport of samples, while bacteriological work at sea even on a boat large enough to provide laboratory facilities is vicissitous to say the least.

The collection of water samples:- Most of the hundred or more bacteriological water samplers which have been described are suitable only for collecting surface samples or samples from shallow depths. In the latter category are bottles from which the stopper can be removed by a string, spring, or messenger at the desired depth. JoHNston (I892) devised such an instrument with a glass-stoppered bottle fastened in a weighted metal frame which was lowered to the desired depth with a rope. A second line was attached to the stopper in such a way that pulling the line removed the stopper, thereby permitting the previously sterilized bottle to fill with water. When the tension on the line is released, the stopper drops back into position.

Several modifications of this type of apparatus for removing the stopper from a water bottle have been devised. Heydenreich (I899) attached the operating string in a different way. Esmarch's bottle for collecting samples with a rope and wire line is described by EYRE (I930).

ZILLIG (I929) avoided the use of the troublesome second string, which has a tendency to become entangled with the supporting rope, by a messenger arrangement for activating the removal of the stopper. The rope was attached to both the bottle and the stopper in such a way that the messenger releases the rope from the bottle so that the bottle is suspended by the stopper which pulls the stopper from the bottle. A string connecting the stopper to the bottle provides for hauling the bottle to the surface.

Аввотт (I92I) described a sampler in which a single line is connected directly to the stopper. Springs hold the stopper in the bottle until a sudden jerk on the line by the operator removes the stopper long enough to permit the bottle to fill with water. A simplified version of such a mechanism is described by WHIPPLE (I927), who pictures several other types of bacteriological sampling bottles which have been used by various workers.

Although some most ingenious devices have been designed for removing the stopper from bottles, all such bacteriological samplers have two inherent defects: They are useless at depths exceeding 5 to 40 meters where the hydrostatic pressure makes it impossible to remove the stopper, and the sample may be contaminated by bacteria from the outside of the sampler.

MinerVINI (I900) took samples through a sea cock in the boiler room 
of a steamer. This procedure is open to question because some of the sedentary organisms which grow in and around the external orifice of the sea cock will probably enter the sample. Most submerged surfaces, including ships' bottoms and water conduits, are covered with a profuse growth of plant and animal life along with large numbers of bacteria.

Metal cylinders for collecting samples:- Some of the pioneer work has been done on water samples collected with water bottles designed by hydrographers for collecting water for chemical analyses. Essentially Ekman, Nansen-Knudsen, Green-Bigelow, Sigsbee, and similar water bottles (Committee on Oceanography, I932) are open metal cylinders through which the water flows while the device is being lowered to the desired depth. When a messenger is dropped down the hydrographic wire by which the bottles are lowered, the ends of the cylinders are closed by various kinds of valves thus entrapping a sample of water.

In general, bacteriological results obtained with samples collected with such apparatus are of questionable validity. In the first place, they may contain contaminating organisms. Secondly, most of the metals used in the construction of hydrographic samplers have a bacteriostatic or bactericidal effect in sea water (page $3 \mathrm{I}$ ). Although glass bottles were used for collecting some of their surface samples, FISCHER (I894a), GAZERT (I906b), and many other workers used metal cylinders for sub-surface samples. This must be taken into consideration in the appraisal of their quantitative results.

OtTo and NEUMANN (I904) collected samples for bacteriological analysis in a metal cylinder, the ends of which could be closed with rubber gaskets by dropping a messenger at the desired depth. A nickel-plated cylinder with cocks operated by a messenger was used by BERTEL (I III).

None of the cylinders which go down open can be relied upon to bring up samples which are uncontaminated by adventitious bacteria. Even if the cylinders are first sterilized, which is not always practical, they may be contaminated by the water passing through them while being lowered.

Mathews (I9I3) sought to obviate this difficulty by filling a glasslined cylinder with 95 per cent alcohol to provide for the sterility of the apparatus as well as for the equalization of pressure inside and outside of the closed cylinder. One messenger was dropped to open the ends of the cylinder, which permitted the disinfectant to be flushed out by the water. Then, after allowing sufficient time for the disinfectant to diffuse away, a second messenger was dropped to entrap a water sample at the desired depth. DREW (I9I4) used this apparatus with expressed confidence for collecting samples for bacteriological analysis to depths of 800 meters. Others have used it or modifications with the cylinder filled with phenol solution or other disinfectants.

Besides being somewhat complicated and inconvenient to use, there is always the possibility of the disinfectant diffusing out prematurely through a faulty valve. With a slightly compressible disinfectant such as 95 per cent alcohol, sea water would be forced into the cylinder through nearly any kind of valve feasible for use on such an apparatus. On the other hand, all of the disinfectant may not be washed out of the cylinder during the time the valves are opened and closed.

Young et al. (I93I) fitted a phosphor-bronze cylinder with a brass piston which aspirates a water sample when the piston is pulled out by a messenger-activated mechanism. A similar device made of a roo-ml. 
glass hypodermic syringe has been used by Dr. C. E. RenN at the Woods Hole Oceanographic Institution. It is difficult to exclude water from a cylinder fitted with a piston or plunger, especially at great depths, unless equipped with a valve near the orifice. If such a cylinder could be made absolutely leak-proof, the pressure of the water at great depths against the walls of the cylinder may bind the plunger unless the walls are very thick.

REYNIERS (I932) used a glass cylinder fitted on each end with smallbore flexible rubber tubing to which cords are attached. When suspended by the rubber tubing, the latter is bent at a sharp angle thereby sealing the ends of the cylinder. After lowering the apparatus to the desired depth, a second line is used to take the tension off the rubber tubing, which permits the rubber tubing to straighten out, allowing the cylinder to fill with water. This ingenious sampler has the disadvantage of requiring two lines for its operation, and no provisions are made for excluding water from the ends of the inlet tubes, a possible source of contamination from the overlying water.

The glass cylinder sampler described by ButKevich (I932a) has rubber connections which are operated by a messenger-activated mechanism.

Samplers having a capillary tube inlet:- RUSSELL (I892) perfected the evacuated glass bulb sampler of MAsseA (Fig. 2A) by fitting a small flask with a glass tube, the end of which could be hermetically sealed. Provisions were made for breaking the end of the tube by dropping a messenger at the desired depth, thus permitting the flask to fill with water. It is not necessary to close such a sampling bottle because when left down until the water pressure on the inside is in equilibrium with that on the outside, the tendency will be for water to be forced out of the bottle as it is drawn toward the surface. Therefore there is no possibility of adventitious organisms entering the sample while being hauled to the surface. The glass flasks are easy to clean, sterilize, and manipulate. Various modifications of this device have been used by PORTIER and RICHARD

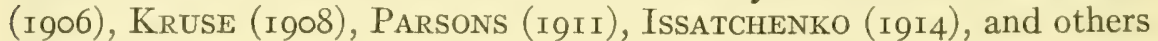
(see Fig. 2).

WILSON (I920) simplified the apparatus by using a large test tube fitted by means of a rubber stopper with a capillary glass tube, the end of which could be sheared off by a messenger-activated lever. GeE (I932a) attached it to an Ekman bottle. To provide for collecting samples at greater depths, he used a thick-walled test tube with the neck constricted to prevent the rubber stopper from being pushed into the tube by the hydrostatic pressure which increases with depth (Fig. 2D). Although GEE recommended it for "critical work at great depths," ordinary Ioo-ml. thick-walled test tubes are broken by pressures encountered at a depth of 600 to rooo meters.

ZoBELL and FELTHAM (I934) perfected a mechanism for breaking the capillary tube. Correcting a fault inherent in the construction of earlier models, the capillary tube was bent in such a way that the broken end of the tube through which the water enters the sampler was a few inches away from any part of the apparatus which might carry contaminating organisms (Fig. 2E).

After nearly ten years of experimentation with various kinds of devices, ZoBELL (I94IC) described the J-Z bacteriological water sampling bottle. It consists of a universal metal frame carrying the messenger- 
activated breaking mechanism which can be used for either citrate of magnesia bottles or collapsible rubber bottles. The former can be used to a depth of 200 meters without danger of breakage by the water pressure. Rubber bottles can be used to any depth in the sea. Both types of bottles are fitted with a short piece of heavy-wall rubber tubing which is closed by a piece of small-bore glass tubing hermetically sealed at the end (see Fig. 3 ).

The assembled $\mathrm{J}-\mathrm{Z}$ bottles are sterilized by steam pressure. 'They are sealed as soon as they are removed from the autoclave so that upon cooling they shall remain partly evacuated. The resulting reduced pressure facilitates the collection of samples. The rubber bottles are completely collapsed prior to sealing.

An important innovation in the $\mathrm{J}-\mathrm{Z}$ sampler is the piece of rubber tubing, suggested by SсHACH (I938), which facilitates the construction and adjustment of the capillary inlet tube. An assembled bottle is con-

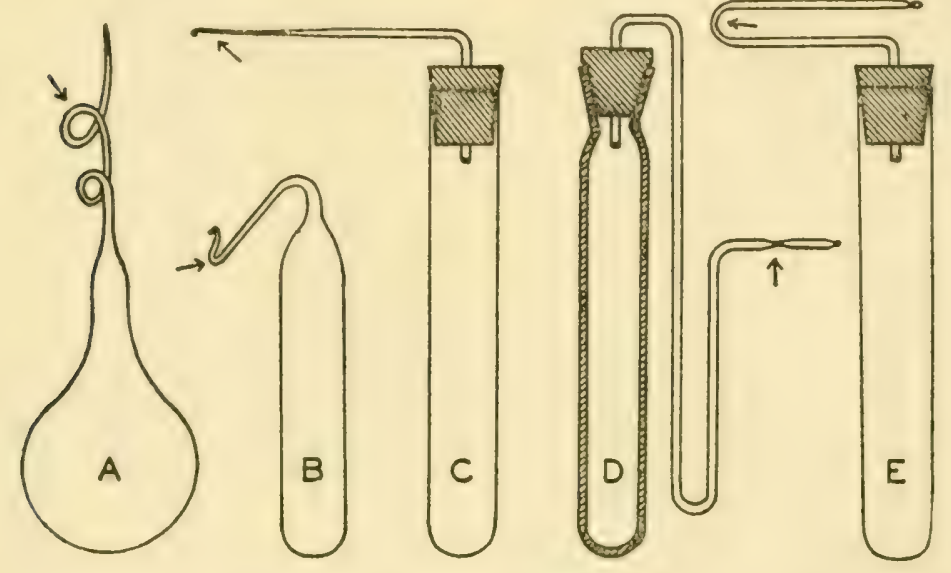

FIG. 2. - Types of capillary-tube water samplers used by Russell (A), Issatchenko (B), Wilson (C), Gee (D), and ZoBell (E). The arrows indicate the points where the tubes are broken by the breaking mechanisms to permit the entrance of water.

nected to the carrier as illustrated by Figure 3. When the messenger engages the lever, the latter strikes the glass tube, causing it to break at a point of strain, FM, a file mark. When the glass tube is broken, the rubber tube straightens out so that the sample is taken from a position several inches away from any point of contamination on the carrier or cable to which it is attached.

The carrier is adapted for ready connection to a standard hydrographic wire or cable. Several of the J-Z bacteriological water samplers can be connected seriatim on the cable as it descends into the water, thereby making it possible to collect samples concurrently from several different depths at the same station. When the messenger activates the uppermost sampler on the line, it releases a second messenger which activates a second sampler farther down the line. This releases the third messenger, the third releases the fourth, and so on. The J-Z samplers can be used on the same line with Nansen bottles, Allen bottles, reversing thermometers, and other standard hydrographic apparatus. 


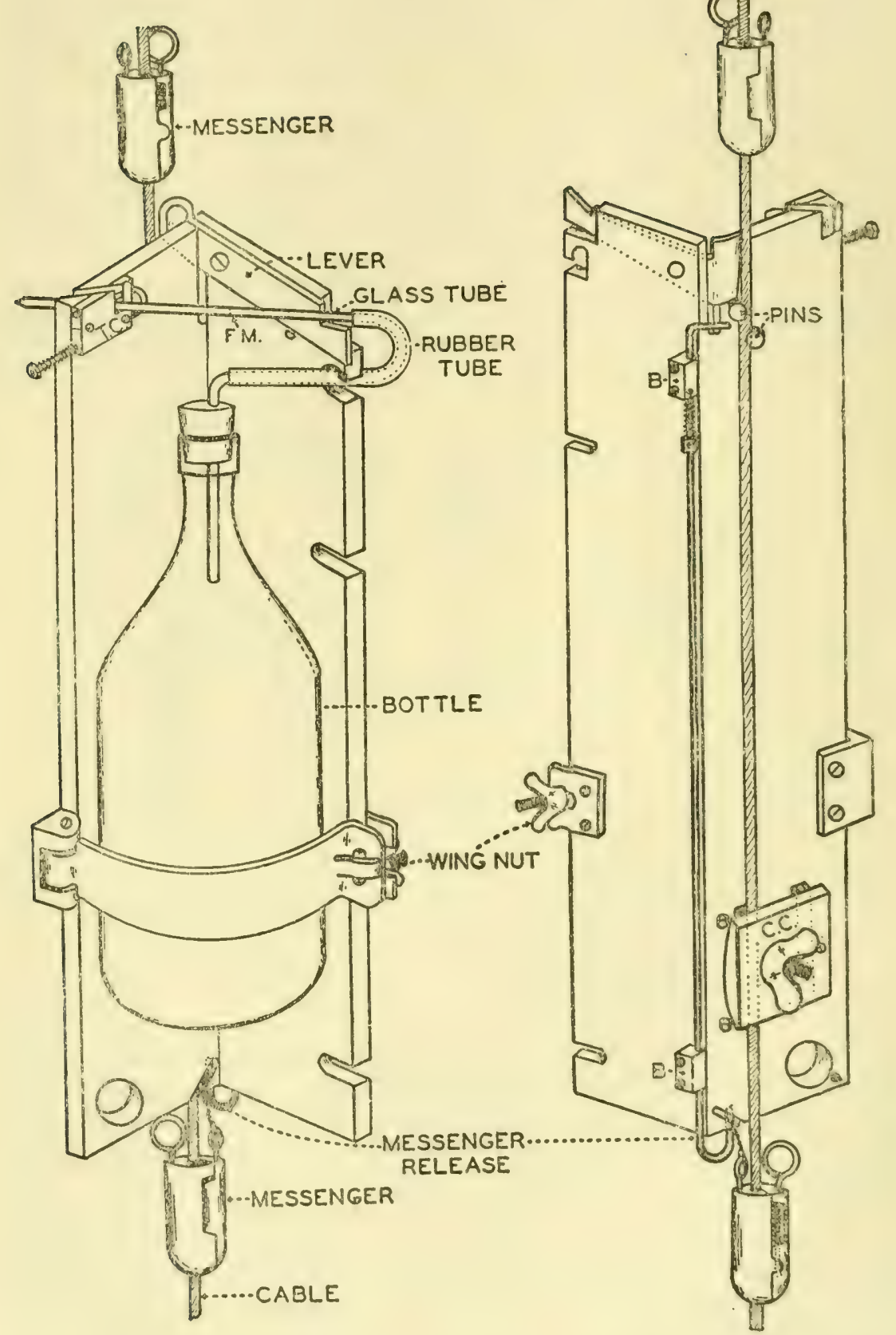

FIG. 3. - Front and back view of the J-Z bacteriological water sampler (from ZoBELL, I94I $c$ ). 
In practice, several dozen glass or collapsible rubber bottles are assembled and sterilized in the autoclave for use at sea. After collecting the sample, the water is analyzed or transferred aseptically to other containers. The sample bottles are then sterilized in a pressure cooker in the ship's galley and refitted with new capillary tubes. In an emergency they may be sterilized with 70 per cent alcohol or by boiling for an hour, but neither procedure is recommended for critical work.

Metal bottles are bactericidal:- It has been noted that in many of the early observations on the occurrence of bacteria in the sea, water samples were collected in metal containers. The very low counts obtained with unsterilized metal cylinders led such workers as FISCHER (i894a), Otto and Neumann (ig04), Bertel (igi i), Gazert (igo6b), and others to believe that adventitious organisms were effectively flushed out of the open-end cylinders as the latter dropped through the water. Actually some of the low or anomalous counts reported by these workers may be attributable to the bacteriostatic or bactericidal effect of the metal (mostly brass) containers or to contamination.

After finding a reduction of 97 to roo per cent in the bacterial population in $100 \mathrm{ml}$. of sea water exposed for six hours to 2 square inches of bright bronze, nickel, brass, silver coins, or copper foil, DREW (I9I4) concluded that platinum is the only metal suitable for the interior of bacteriological sampling apparatus. BEDFORD (I93I) noted little bactericidal effect of the Prince Rupert brass and phosphor-bronze sampling bottle of Young et al. (I93I) in sixty minutes, but in ninety minutes there was an appreciable diminution in the bacterial count of sea water stored in the metal bottle. Bacteriologists working in the Oceanographic Laboratories of the University of Washington sought to obviate the bactericidal effect of the Prince Rupert water bottle by having its interior plated with platinum for collecting samples of sea water for bacteriological analysis.

ZoBELL (I94IC) noted a marked decrease in the bacterial population in sea water stored in brass Nansen bottles as compared with that stored in glass bottles. This is shown by the data in Table VI which gives the average of four experiments. Characteristic of stored sea water, there was a slight decrease in the bacterial population in the glass bottles during the first few hours, followed by an increase later.

TABLE VI.- Number of viable bacteria in sea water after different periods of storage in brass $N a n s e n$ bottles and in glass bottles for different periods of time at $22^{\circ} \mathrm{C}$. The number of bacteria is expressed as per cent of the number present at the beginning of the experiment:-

\begin{tabular}{|c|c|c|c|c|}
\hline $\begin{array}{l}\text { STORAGE TIME } \\
\text { IN MINUTES }\end{array}$ & $\begin{array}{c}\text { NaNSEN BOTTLE } \\
\text { No. I } 3\end{array}$ & $\begin{array}{l}\text { Nansen bottle } \\
\text { No. I } 8\end{array}$ & $\begin{array}{l}\text { NANSEN BOTTLE } \\
\text { No. I9 }\end{array}$ & $\begin{array}{l}\text { GLASS } \\
\text { BotTLES }\end{array}$ \\
\hline o & 100 & 100 & I00 & 100 \\
\hline 5 & 94 & 85 & 69 & 103 \\
\hline 10 & 82 & 74 & 62 & 95 \\
\hline 30 & 78 & $5^{6}$ & 40 & 96 \\
\hline 60 & 70 & $5 \mathrm{I}$ & 36 & 92 \\
\hline 120 & 52 & 37 & 29 & $9 r$ \\
\hline 300 & 28 & I4 & 7 & 93 \\
\hline I 440 & I9 & 3 & 6 & 543 \\
\hline
\end{tabular}

Some of the Nansen bottles were found to have a greater bacteriostatic effect than others, probably due to differences in the metallic sur- 
faces which were exposed to the water. Brightly polished metals are known to be more bacteriostatic than those which are coated with oxides or other film-forming substances.

Not only does contact with brass and similar copper-containing alloys tend to decrease the viable bacterial population in sea water; the sea water itself is rendered less growth-supporting by contact with copper, lead, nickel, silver, tin, or zinc. Sea water is affected more than fresh water by such metals. It is recommended that sea water which is to be used for the cultivation of microorganisms be collected and stored in glass, ceramic, or other non-metallic containers. Diatoms are more sensitive to traces of heavy metals than are some of the bacteria.

Effect of pressure during sampling:- The hydrostatic pressure of sea water increases with depth by approximately I 5 pounds per square inch for each to meters. This is enough to force the rubber stopper into a test tube at a depth of 20 to 30 meters. If the test tube is not broken at Ioo meters, the rubber stopper will be pushed half way to the bottom of the tube. This difficulty can be obviated by using test tubes or bottles with constricted necks to prevent the descent of the rubber stopper. Constricting the neck to half the diameter of the bottom end of the stopper provided for a perfectly water-tight seal at all depths tolerated by ordinary laboratory glassware. The same result can be achieved by placing a piece of thick-walled glass tubing in citrate of magnesia bottles so that the upper end of the vertical tube contacts the inserted end of the rubber stopper.

Citrate of magnesia bottles, which are commonly used by hydrographers for storing water samples, were found to be pressure-resistant to a depth of 100 meters. In one series of experiments, I 20 rubber-stoppered citrate of magnesia bottles fitted with thick-walled glass tubes to prevent the descent of the stoppers were immersed by tying them to the weighted hydrographic cable. They all came up intact and empty after being lowered to Ioo meters. When lowered to 200 meters, 8 of the bottles were broken by the pressure. Eighty-four of the bottles came up intact after being lowered to 300 meters. Only 32 of the original 120 bottles tolerated the pressure encountered by being lowered to 400 meters and none of them survived pressures at 600 meters.

Little is known concerning the effect of hydrostatic pressure on the viability and physiological activities of microorganisms. The fact that large numbers of viable bacteria have been found in bottom deposits collected from depths exceeding 5000 meters shows that these bacteria can live at high pressures and that many of them are not injured by the release of the pressure effected by bringing the mud samples to the surface.

It is still questionable whether some bacteria are injured by the sudden change of pressure when samples are collected with an evacuated glass bulb. When the capillary tube on such a sampler is broken in water one mile deep, the pressure of the inflowing water changes almost instantaneously from nearly a ton per square inch to near zero. GeE (I932a) made provisions for minimizing the deleterious effect this might have on the microbes in the water by extending the capillary tube to a length of 20 inches. He explains that the long capillary tube "acts as a spring, preventing hammering action of the inrushing water."

Although one might expect the sudden release of pressure to be injurious to microorganisms in the water, there is no evidence to prove it. 
On the contrary, as many viable bacteria have been found in water samples collected with an evacuated glass bottle as in the $\mathrm{J}-\mathrm{Z}$ collapsible rubber bottle in which the pressure inside and outside is virtually the same at all times. Experimental evidence that hydrostatic pressures considerably higher than any that occur in the sea are not inimical to microbial life is summarized on page 69 .

The alleged injurious effects of releasing the pressure can be largely discounted because it requires an hour or two to haul a sample from the deep sea to the surface. This would be regarded as a gradual decrease in pressure to which the microorganisms in the sample are subjected. In the experiments of LARSEN et al. (I9I8), bacteria subjected to pressures of 6000 atmospheres were not injured when decompressed in five or ten minutes, although decompressing the bacteria within a few seconds killed some of them.

KROGH (I934) points out that only marine animals with swim bladders are injured by sudden changes of pressure because they consist largely of water. According to SVERDRup et al. (I942), "pressure in itself does not exclude life from the abyssal regions of the sea, for water is but little compressed and equilibrium exists between the inner and outer pressure affecting body tissue." Some marine animals are known to migrate daily 400 meters vertically, corresponding to a pressure change of 40 atmospheres.

The collection of mud samples:- Samples of bottom deposits are collected by various kinds of buckets, spuds, grabs, snappers, dredges, and coring devices, several types of which are described by NAUMANN (I930) and TRASK (I939). With the exception of the Renn sampler, none of them makes provisions for aseptic technic. The Renn sampler, which uses the evacuated glass tube principle, is suitable for collecting only the uppermost layer of poorly compacted, fine-grained sediments in relatively shallow water.

The Renn sampler consists of an evacuated bottle with a projecting glass tube about one inch in diameter mounted in a metal frame. The latter is attached to the dredging or hydrographic wire by which it is lowered to the sea floor. The end of the glass tube is broken off by a mechanism activated by a spring, which is released when a trigger makes contact with the bottom. A sample of the bottom material is sucked into the previously sterilized glass tube.

While a sampler which reaches the bottom in a sterile condition may be desirable for the collection of mud samples, for bacteriological analysis, such a sampler is not prerequisite. There is little likelihood that either quantitative or qualitative results will be influenced by contaminating organisms from the overlying water, because wherever samples have been carefully examined, hundreds to thousands of times as many bacteria have been found per unit volume of bottom deposits as in the overlying water, and any bacterial species found in the water may be carried to the bottom by the processes of sedimentation or otherwise. By taking certain precautions to minimize the possibilities of contamination, samples of bottom deposits, which are satisfactory for bacteriological analysis, can be collected with coring tubes which of necessity go down open.

A coring tube is a thin-walled pipe which can be driven into the mud in such a way that a core of mud enters the tube or pipe and remains there when the apparatus is pulled to the surface. Mechanisms have been described for driving the core barrel into the bottom deposits mechan- 
ically, by suction or differences in hydrostatic pressure, gravity, and explosives (TRASK, I939). In water only a few meters deep a rigid pipe can be hammered into the bottom deposits, and a pile-driver form of apparatus can be used in water two or three hundred feet deep, but neither mechanism can be used for collecting samples at great depths.

The gravity-activated coring device described by EMERY and DIETZ (I94I) can be used for collecting fairly well stratified bottom deposits from any depth of water unless the bottom material is semifluid or rocky. The sampler of HJORT and RUUD (I938) provides for collecting samples of mud together with the water immediately above the bottom. Biologically this is a significant zone, it being the transitional layer between the overlying water and the solid bottom.

The EMERY-DIETZ (I94I) coring device illustrated in Figure 4 consists of a steel-pipe core barrel 2 to $2 \mathrm{I} / 2$ inches in diameter and 5 to 25 feet long with a sharpened cutting nose on the bottom end and with the operating mechanism attached to the top. The core nose contains a valve or core retainer which is made of a short cylindrical piece of flexible celluloid cut in strips in such a manner that these are pushed back against the tube wall while the core is entering, but, if the core starts to slip out, the celluloid strips close the opening as does a multiple flap valve. A large rubber stopper serves as an auxiliary check valve above the core barrel. A second 8- to 2o-foot length of pipe fastened to the top of the corer serves as a shaft which has two essential functions. One is to provide a resting place for enough lead disks to give a weight of 300 to 600 pounds for forcing the apparatus into the bottom material. The second function of the rigid shaft is to lower the center of mass of the sampler thereby increasing the tendency of the core barrel to be forced into the mud in a vertical position. The corer is attached to a wire cable by which the ship's winch lowers it into the water. When the readings on the fathometer indicate that the corer is about 300 feet from the bottom, it is allowed to fall rapidly until it hits the bottom. With the EMERY-DIETz corer, stratified mud cores exceeding I 5 feet in length have been obtained from the sea floor.

The use of a removable core-barrel liner facilitates the removal of undisturbed uncontaminated samples. Snugly fitting lucite cylinders have been used as core-barrel liners. Varves and other interesting geological structures can be observed through the transparent lucite liner after the latter is withdrawn from the core barrel. Then, using aseptic technic, samples can be removed by sawing off the tube and dissecting out radially central portions for bacteriological analyses.

Core-barrel liners consisting of I 5 gauge celluloid, which is about 0.02 inches in thickness, have also been used. A strip of celluloid, about 8 inches wide and as long as the core barrel, is rolled into a cylinder and inserted into the core barrel. After removal from the core barrel, the celluloid liner surrounding the mud straightens out, thereby permitting the observation of the material and the collection of sub-samples. When washed free of adherent mud, the celluloid core-barrel liner can be used again. If desirable, it can be sterilized with chemical disinfectants.

Typical deep-sea cores collected with the apparatus described above are cylinders of mud about 2 inches in diameter and 2 to I 5 feet long. Sub-samples for bacteriological analysis are selected from different core depths by cutting through sections with previously sterilized spatulas or wooden tongue blades. Using a second sterile blade, the freshly cut surface of the core is scraped free of material which might have been intro- 
duced while cutting the sections. Then, using another sterile instrument resembling a cork borer, radially central sections are dissected out and transferred either to sterile sample bottles for future reference or directly to enrichment media.

The principal innovation of the mud sampler designed by HENRICr and

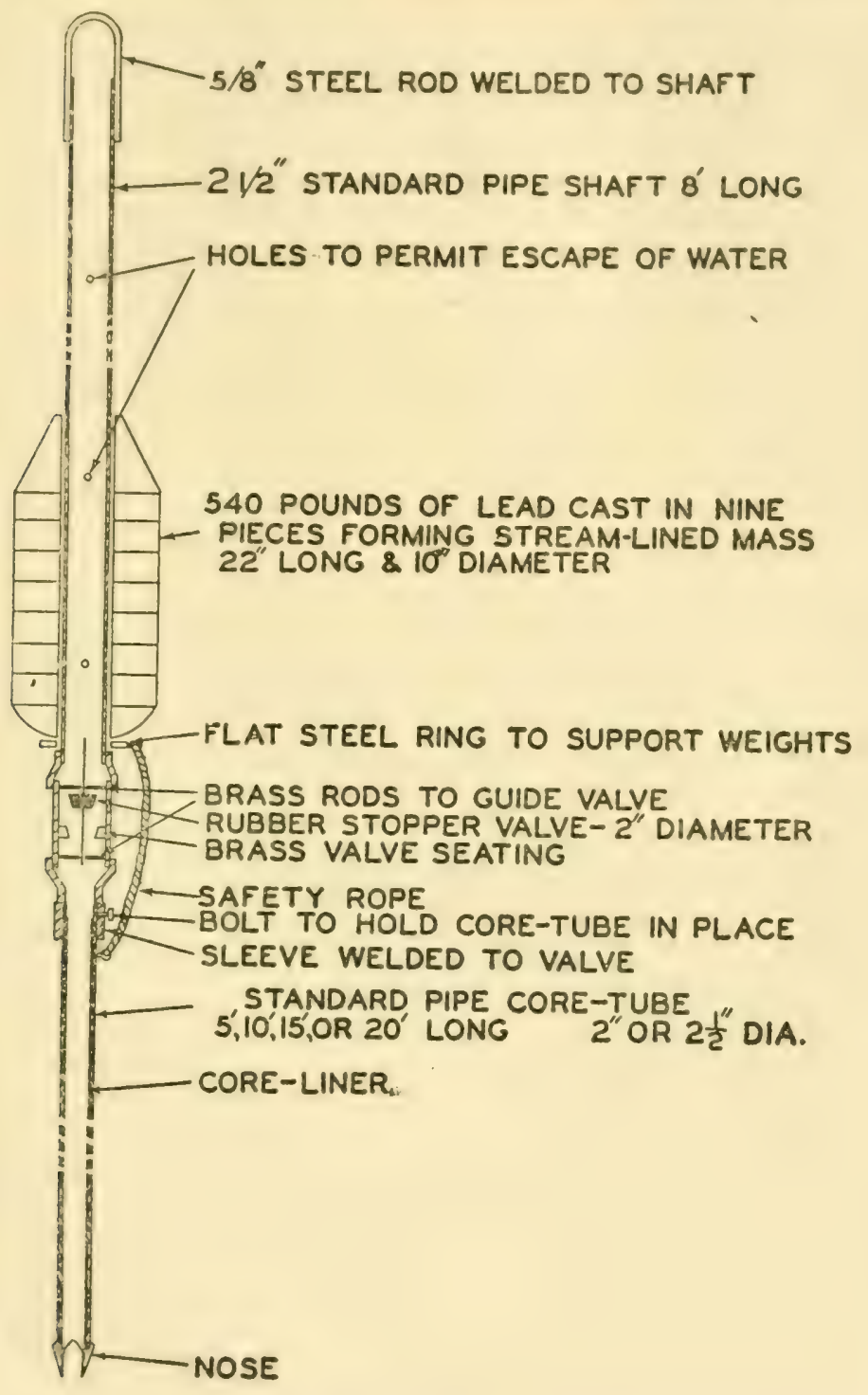

Fig. 4. - Coring device described by EMERy and DIETz (194I) for collecting long mud cores from the deep sea bottom.

MICOy (1938), for collecting profile samples of mud of semifluid consistency for bacteriological analysis, is a series of small threaded holes drilled at intervals along the side of the sampler tube. These holes are fitted with slotted, threaded plugs which may be removed to provide for the aseptic removal of mud samples with a pipette at different levels. The holes can also be closed with paraffin plugs or covered with a strip of adhesive tape. 
After plugging the ends of the sampler tubes with cotton, a number of them can be sterilized in the laboratory ready for field use. Since the tube is made of brass, the mud samples should be removed shortly after collection, and the sub-samples should be taken from near the center of the core.

Storage of samples:- The storage of samples of water or mud is usually accompanied by a slight decrease followed by a rapid increase in the microbial population and a continuous decrease in the detectable number of species. These changes become apparent within an hour or two after the collection of the samples and may continue for several days. The magnitude of the changes is a function of the original composition of the sample, the temperature, size of sample, availability of oxygen, exposure to light, and other factors.

WHIPPLE (I9OI) found that the bacterial population of water, which initially contained 77 bacteria per ml., decreased for a few hours and then increased to as many as 4r,400 per ml. after 24 hours' storage. He attributed the initial decrease in the bacterial population to a dying off of the less resistant species, since there was an actual decrease in the number of species with time of storage. Agitation or continual shaking of the stored samples was found to retard the multiplication of bacteria only slightly if at all.

Whipple (I90I) noted that about io per cent of the bacteria in the water were tenaciously attached to the walls of the glass receptacle after 24 hours' storage. After observing a far greater increase in the bacterial population in water stored in small bottles than in large bottles, WHIPPLE attributed the increase to the more ready availability of oxygen, because relatively more water was exposed to the air when stored in small receptacles than in large receptacles. However, ZoBell and Stadler (r940b) found that the multiplication of bacteria in stored lake water was independent of the oxygen tension over a wide range, 0.30 to $36 \mathrm{mgm}$. $/ \mathrm{L}$. More recently ZoBELL ( $1943 b$ ) has summarized the evidence which indicates that the more rapid multiplication of bacteria in small samples of water is associated with the area of solid surface, small receptacles presenting considerably more solid surface per unit volume of water than larger receptacles (see page 83 ). Similar conclusions were reached by LLOYD (1937).

The concentration and composition of organic matter in sea water are also important factors which influence the changes in the bacterial population during storage (WAKSMAN and CAREy, I935 $a$, ZOBELL and GRANT, I943).

FRED et al. (I924) attributed an observed increase in the bacterial population of stored lake water from I 26 per $\mathrm{ml}$. to $7,400,000$ per $\mathrm{ml}$. partly to the death and decomposition of bacteria-feeding protozoans which were unable to tolerate confinement. HEUKELEKIAN (I933) doubts whether there are enough protozoans in diluted sewage to play an important role on the number of bacteria during the storage of samples.

After considering the influence of agitation, size of receptacle, temperature, and other factors which influence the bacterial population of stored samples, Butterfield (I933a) concluded that "the more interference with normal conditions, the greater the increase in bacterial numbers." He observed more rapid changes in samples stored at $37^{\circ}$ and $20^{\circ} \mathrm{C}$. than in those stored at $10^{\circ} \mathrm{C}$. 
It is the concensus of most workers that the storage of samples at low temperatures tends to minimize the changes in the quantity and quality of the microbial population, but not even temperatures as low as $0^{\circ} \mathrm{C}$. will prevent gross changes. Most investigators emphasize the importance of analyzing water samples as soon as possible, since chilling samples with ice has only slight advantages. According to TANNER and SCHNEIDER (I935), the behavior of bacteria during storage varies greatly with different strains. Little difference was noted in the number of viable organisms in water samples stored at $0^{\circ}$ to $7^{\circ} \mathrm{C}$. for 24 hours, but the quality of the flora may have changed considerably.

In its Standard Methods for the Examination of Water and Sewage, the American Public Health Association (1936) specifies that "During the period of storage, the temperature shall be kept between $6^{\circ}$ and $10^{\circ} \mathrm{C}$." It warns that "Because of the rapid and often extensive changes which may take place in the bacterial flora of bottled samples when stored even at temperatures as low as $10^{\circ} \mathrm{C}$., it is urged, as of importance, that all samples be examined as promptly as possible after collection."

This precaution applies equally to samples of sea water and marine mud. The matter is emphasized because, owing to the difficulties of analyzing samples of marine materials in the field, many of the results reported in the literature are based upon the bacteriological analysis of samples which have been stored for several days or, in some cases, a few weeks. Oftentimes there is no alternative except to store samples until adequate laboratory facilities are available, under which conditions the time and temperature of storage should be stated along with the analytical results. Preferably the temperature of storage should be near $0^{\circ} \mathrm{C}$. Many bacteria from the sea are injured by being subjected to temperatures exceeding $25^{\circ} \mathrm{C}$.

ZoBell and Feltham (I934) noted as much as 50 per cent decrease in 12 hours in the total numbers of bacteria found in water samples, followed by a many-fold increase during storage at $20^{\circ} \mathrm{C}$. When plated shortly after collection, 4I8 colonies representing 26 different types developed from $\mathrm{I} .0 \mathrm{ml}$. of water. After storage for one day at room temperature there were 1500 bacteria per $\mathrm{ml}$. with only four types present.

As pointed out by ZoBELL and ANDERSON (I936a), the bacterial population of samples of stored sea water may increase from initial counts of hundreds per $\mathrm{ml}$. to millions per $\mathrm{ml}$. after a few days. Then the counts may decrease to thousands or hundreds per ml., with only one or two predominating species remaining in water which initially contained 20 to 30 types of bacteria. The magnitude of the changes is primarily a function of the organic content of the water. The rate of the change is primarily a function of temperature, being very slow at $0^{\circ} \mathrm{C}$.

GEE (1932b) found an increase of 65 -fold in the bacterial population of sea water from Tortugas, Florida, after eight days' storage and an 8 -fold increase in the bacterial content of marine mud. The data in Table VII are illustrative of the magnitude of the quantitative and qualitative changes in the bacterial flora of mud samples from the Pacific Ocean after different periods of storage at $0^{\circ}$ to $4^{\circ} \mathrm{C}$.

Neither the magnitude nor the rate of change in the bacterial flora of mud samples is nearly as great as in samples of sea water. This is because environmental conditions affecting the microbial population are not altered as much with the storage of mud as with the storage of water samples. 
TABLE VII. - Plate count of mud samples collected at Scripps Station $36 E_{I}\left(32^{\circ} 42.5^{\prime} N\right.$. and $\mathrm{II} 7^{\circ} 27^{\prime}$ W.) from a water depth of 608 meters after different periods of storage at $0^{\circ}$ to $4^{\circ} \mathrm{C}$. The number of different types of colonies recognized on the plates is also given (from data of ZOBELL, I938a):-

\begin{tabular}{|c|c|c|c|c|}
\hline \multirow{2}{*}{$\begin{array}{l}\text { STORAGE TIME } \\
\text { SAMPLE No. }\end{array}$} & \multicolumn{3}{|c|}{ BACTERIA PER GRAM (WET BASIS) } & \multirow{2}{*}{$\begin{array}{c}\text { NUMBER OF DIFFERENT } \\
\text { COLONY TYPES }\end{array}$} \\
\hline & 9829 & 9830 & 9849 & \\
\hline$<$ I hour & $2,910,000$ & I, 680,000 & $3,000,000$ & 47 \\
\hline 24 hours & $3,300,000$ & $3,500,000$ & $5,200,000$ & 44 \\
\hline 48 hours & $4,000,000$ & $6,700,000$ & $8,100,000$ & 40 \\
\hline 7 days & I 2, 500,000 & $25,000,000$ & I $5,700,000$ & I 8 \\
\hline I2 days & $38,200,000$ & $30,000,000$ & I 2, $, 000,000$ & I6 \\
\hline 24 days & $59,300,000$ & I9,000,000 & $22,300,000$ & 9 \\
\hline 44 days & I6,400,000 & I $2,000,000$ & $7,300,000$ & 7 \\
\hline 90 days & I $7,400,000$ & I I , 700, ,00 & $6,150,000$ & 3 \\
\hline
\end{tabular}

Temperature changes during collection of samples:- GAZERT (I9o6b) expressed concern over the harmful effects that may result from the change in temperature which occurs while hauling water samples from the depths of the ocean where the temperature is near $0^{\circ} \mathrm{C}$. to the surface through water which is considerably warmer. Since it requires several minutes for the best electrically operated winches to haul up two or three miles of wire rope, the temperature of deep-sea samples collected in tropical and temperate zones may be increased several degrees before the samples reach the surface. The extent of the temperature change is primarily a function of the temperature gradient of the water, the time required to haul the sample to the surface, and the volume of the water sample.

Unless the temperature gradient is great and several hours are required to haul the sample to the surface, there is little likelihood that increased bacterial activity will influence the number of bacteria in the sample while it is being hauled to the surface. The extent to which heatsensitive species may be injured by the increased temperature during the collection of samples from great depths is problematical. Since the maximum range of the surface temperature of deep water is around $25^{\circ} \mathrm{C}$, samples from great depths usually are surfaced before their temperature reaches $20^{\circ} \mathrm{C}$. Assuming that provisions can be made for preventing further increases in temperature after the sample is surfaced, it is a question of whether any marine bacteria are injured by such temperatures.

ZoBELL and ConN (I940) found that about 20 per cent of the bacteria occurring in sea water and 30 per cent of those in deep sea mud are rendered incapable of multiplication after being held for ten minutes at $30^{\circ} \mathrm{C}$. There was no evidence that any of the bacteria were injured by heating to $25^{\circ} \mathrm{C}$. for ten minutes, but as shown by the data in Table IX on page 45 , somewhat more bacteria developed on plates incubated at $18^{\circ}$ than at $25^{\circ} \mathrm{C}$. The optimum temperature for the multiplication of most marine bacteria, including those from cold bottom deposits, is $18^{\circ}$ to $22^{\circ} \mathrm{C}$.

While all of the available data suggest that marine bacteria from the deep sea are not injured by exposure to temperatures up to $20^{\circ}$ or $25^{\circ} \mathrm{C}$, the data are not conclusive because most of the observations have been made on samples which have been subjected to temperatures nearly this high prior to or during the analysis of the samples. Only by the critical examination of samples from the deep sea which have been kept cold will 
the conclusion be warranted that there are no bacterial species in the sea which are injured by the temperature changes which occur during the collection of samples. If there are such supersensitive bacteria in the sea, certainly they are in the minority because as many bacteria are demonstrable in deep sea deposits subjected to temperatures of $20^{\circ} \mathrm{C}$. as in warmer shallow water deposits similarly treated.

The examination of samples at sea:- The preparation of materials for bacteriological work at sea requires careful planning. For obvious reasons it is necessary to take everything aboard the boat that will be needed for the examination of samples while on the cruise, and even the largest and best equipped research vessels provide only limited space for laboratory supplies. The microbiologist who has ten square feet of laboratory space and twenty cubic feet of storage space on a research vessel may feel relatively fortunate.

Due to the pitch, roll, vibration, and other movements of the vessel, the microbiologist will find it convenient to have a stationary stool upon which he can steady himself with his legs or with a strap so that both hands can be free to work. The stool should be so located that everything needed for the examination of samples is within arm's reach. Ledges around the edges of the laboratory desk and shelves will help to prevent equipment from rolling or sliding off. Special flat-bottomed holders must be provided for pipettes, test tubes, reagent bottles, and other equipment in order to prevent spillage and breakage. For this purpose holes of the correct diameter drilled into blocks of wood two inches thick are useful. The blocks can be secured to the laboratory table in the most convenient location. Wooden boxes designed to fit the available space in the vessel and to accommodate snugly the glassware provide for the storage and transport of equipment.

An alcohol burner can be used to sterilize inoculating needles and to flame the mouths of culture receptacles. While it is recommended that as much glassware and media be sterilized as possible before embarking, the galley oven and a pressure cooker can be used for the sterilization of glassware and media while at sea. Even on poorly equipped boats, materials can be sterilized in a pressure cooker over a primus or other burner.

Experiencing difficulty pouring Petri dishes in rough weather at sea and finding that a platform hung on gimbals failed to provide the necessary stability, GEE ( $1932 \mathrm{C}$ ) recommended the use of a mechanical spinner for preparing Esmarch cultures. Melted nutrient agar cooled to $42^{\circ}$ to $45^{\circ} \mathrm{C}$. in large test tubes was inoculated with $1.0 \mathrm{ml}$. of appropriately diluted material, after which the tube was rapidly rotated mechanically until the agar solidified in a thin layer on the walls of the tube. After a few days of incubation the colonies which develop can be counted and picked for further study. While this ingenious device achieves its intended purpose, it greatly complicates the preparation of cultures for counting.

Flat-sided six-ounce medicine or prescription bottles have proved to be superior to either Petri dishes or Gee-Esmarch tubes for plating samples at sea for colony counts. After introducing 20 to $25 \mathrm{ml}$. of nutrient agar, the prescription bottles can be stored in quantity with the screw-top caps tightly closed until they are needed. Then after melting the agar, they are cooled to $42^{\circ}$ to $45^{\circ} \mathrm{C}$. in a water bath and inoculated with appropriately diluted sea water or mud. Immediately after receiving the inoculum the bottles must be plunged up to the neck into cold water for an instant 
in order to cool them to $20^{\circ}$ or $25^{\circ} \mathrm{C}$. because many marine microorganisms are injured by being exposed to higher temperatures for a few minutes. Before the agar has congealed, the prescription bottle is placed on its side. In most cases the agar congeals in a smooth layer which permits colonies to be counted. With an inoculating needle having one end bent at right angles, colonies can be transferred to other media for further study.

Counts obtained on prescription bottles under controlled conditions in the laboratory compare favorably with Petri dish counts. For work at sea the prescription bottles have the advantage of being economical and easy to pack. With them it is not necessary to transfer the media as it is when pouring Petri dishes. This saves time and minimizes the possibilities of contamination. The screw-top caps prevent the dehydration of the media. Prescription bottles have been used by the author for plating bacteria in a row boat as well as on sea-going research vessels. Their use for plating water bacteria was first observed by the author in the laboratory of Dr. Elizabeth MCCoy at the University of Wisconsin. HeNRICI and $\mathrm{McCoy}$ (1938) used prescription bottles for plating bacteria from lakes.

The six-ounce prescription bottles can also be used for 9o-ml. and 99-ml. dilution water blanks as well as for enrichment media receptacles. For example, when looking for nitrifying bacteria, it is very simple to introduce I-, IO-, and Ioo-ml. quantities of sea water into prescription bottles containing a suitable ammoniacal saline solution. After they are inoculated, they can be compactly stored or incubated in either an upright or horizontal position until ready for examination.

Further details concerning the use of enrichment media for the detection of various physiological types of bacteria and other analytical procedures will be given in the following chapters.

The rowboat crane for hauling limnological apparatus, described by BRown and BALL (I940), has proved to be very useful for collecting samples from a small boat. 
After sterilization at $120^{\circ} \mathrm{C}$. for 20 minutes, Medium $22 \mathrm{I} 6$ has a reaction of $p \mathrm{H} 7.5$ to 7.6 when in equilibrium with atmospheric $\mathrm{CO}_{2}$.

Medium 2216 differs very little in composition from the medium recommended by Fischer (I894a), which contained I.O per cent peptone and 0.5 per cent fish extract in sea water. Fischer used either Io per cent gelatin or 2 per cent agar as the solidifying agent. Although in his earlier work FISCHER used KOCH's nutritive gelatin prepared with fresh water, he soon discovered that sea water was far superior for the cultivation of marine microorganisms. He relates that many bacteria found in the sea failed to grow unless the media were prepared with sea water. Neither mussel, shrimp, copepod, diatom, nor beef extract gave results as good as fish extract.

Although several workers have used fish extract media for the cultivation of marine bacteria, we have failed to note any increase in plate counts by fortifying Medium 22I6 with various fish extracts. Similarly, after trying extracts of various marine organisms including fish, LLOYD (I930) concluded that they are not essential for the growth of marine bacteria in spite of the claims of many earlier workers. Of course, it should be pointed out that the commercial peptones available today are much more growth-promoting for most bacteria than are the peptones which Fischer and others used during the last century. Not nearly as many colonies or kinds of bacteria developed on a fish-extract peptone agar prepared according to the directions of Fischer as on Medium 22I6.

After experimenting with various media, bacteriologists (REUszER, I933) at the Woods Hole Oceanographic Institution adopted the following one which consistently gave them the highest counts of bacteria:

Peptone
Glucose
$\mathrm{K}_{2} \mathrm{HPO}_{4}$
Agar
Sea water

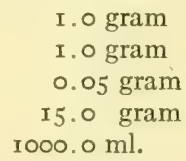

Except for the presence of glucose, this medium is similar to the one employed by Drew (I9I3) and in which LIPMAN (I929) found higher counts than in any other medium with which it was compared. REUSzER's formula differs from Medium 2216 in that it contains glucose and a lower concentration of peptone. In many comparisons with marine materials from the Atlantic Ocean as well as from the Pacific Ocean, ZoBell (I94Ia) found only 53 to 78 per cent as many colonies on REUSzER's medium as on Medium 22I6. The addition of glucose to Medium 22 I6 failed to increase either the numbers or kinds of bacteria which developed.

The addition of 0.0 I per cent ferric phosphate to REuszer's formula resulted in counts which were nearly as high as those obtained on Medium 22 I6. It has been found that the addition of o.or per cent of either ferric citrate, ferric phosphate, or ferrous sulfate to nutrient sea-water agar increased the plate count by i 8 to 76 per cent, the iron being more beneficial in slightly alkaline than in acidic media.

Maximum plate counts were obtained on media having a reaction of from $p \mathrm{H} \mathrm{7.5}$ to 7.8 . The results were nearly comparable throughout the range of $p \mathrm{H} 7.0$ to 8.0. Very few colonies develop on media more alkaline than $p \mathrm{H} 8.5$ or more acid than $p \mathrm{H}_{5.5}$. The influence of the hydrogen-ion concentration upon the development of colonies is illustrated by the data summarized in Figure 5 .

The media employed by Berkeley (I9r9), LIPMAN (1926), BAVEN- 
DAMM (I932), GEE (I932b), and many others for the cultivation of marine bacteria contain nitrate. Using concentrations of potassium nitrate ranging from 0.005 to 0.Io per cent, ZoBELL (I94Ia) was unable to demonstrate that nitrate had any effect, either beneficial or detrimental, on the number or kinds of bacteria which developed in nutrient media.

Following the methods of soil bacteriologists, DüGGELI (I924), SNOw and FRED (I926), HENRICI and MCCOY (I938), and others have featured the use of sodium caseinate in media designed for the cultivation of freshwater bacteria. Sodium caseinate or Nährstoff Heyden has also been recommended for the cultivation of marine bacteria by GAZERT (Igo6b) and others. ZoBELL ( $194 \mathrm{I} a$ ) found, however, that caseinate tends to make sea-water agar opaque, and there is no evidence that it promotes the growth of any bacteria when used in combination with Bacto-peptone.

Medium 2216 is recommended for general plate counts of aerobic heterotrophs occurring in the sea. Selective or differential media must

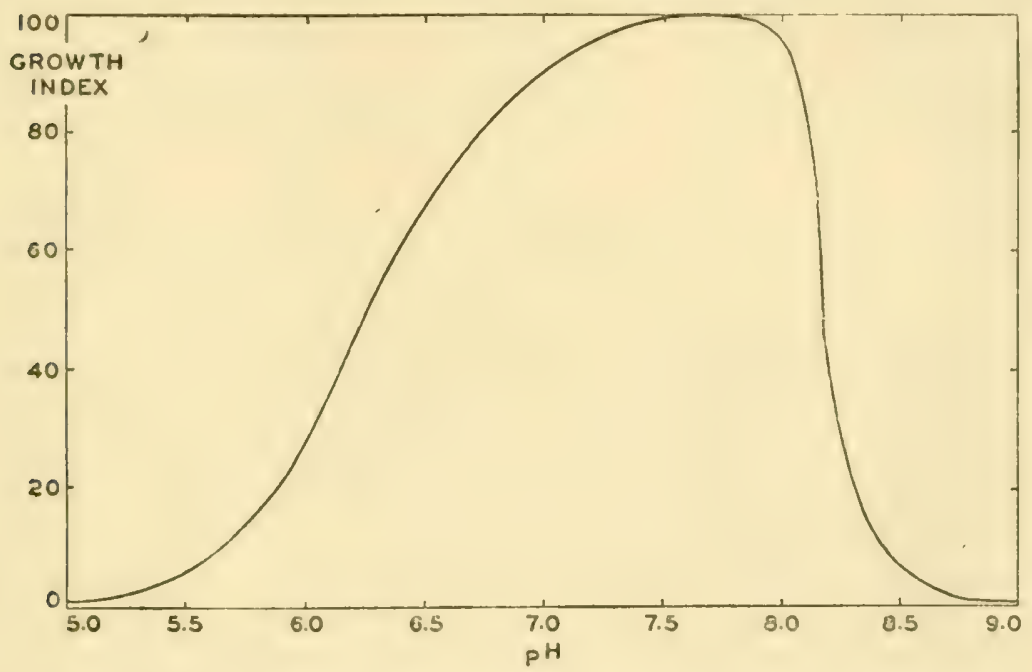

FIG. 5. - Curve showing the effect of $p \mathrm{H}$ of nutrient sea-water agar on the number of colonies of marine bacteria which develop (from ZoBELL, I94Ia).

be used when looking for special kinds or types of microorganisms. Parallel direct microscopic counts and successive dilution methods of estimating bacterial populations indicate that the best general-purpose plating medium detects only one to ten per cent of the bacteria present in marine materials, but Medium 22 I 6 does give maximum and reproducible counts. The small number of bacteria detected by plate counts is largely attributable to the occurrence of many bacteria in clumps, chains, zooglea, or attached to particles of detritus which give rise to single colonies. Direct microscopic studies show that marine bacteria rarely occur as solitary individuals.

An amazingly large number of workers have used distilled water or tap water, sometimes with and sometimes without the addition of salts, for the preparation of nutrient media for marine microorganisms, thereby following standard methods recommended for the cultivation of freshwater bacteria. Some workers justified their use of fresh-water media for the cultivation of marine bacteria by finding nearly as many bacteria 
from "marine" materials developing on fresh-water media as on parallel sea-water media. However, most if not all of the workers in this category were plating material from bays, estuaries, and near-shore bodies of brackish or salt water which probably contained large numbers of bacteria from the land. Workers who have plated samples of sea water or marine mud collected at places remote from possibilities of terrigenous contamination have found many more bacteria developing on sea-water media than on fresh-water media. The relative numbers of bacterial colonies developing on media similar in all respects except salt content when inoculated with material from different sources are summarized in Table VIII. Similar results have been obtained by BERKELEY (I9I9), KorINEK (I926), and LIPMAN (I926), who recommend sea water for the growth of marine microorganisms.

TABLE VIII.- Relative numbers of bacteria from marine and terrestrial sources which de veloped on mutrient agar prepared with various salt solutions:-

\begin{tabular}{|c|c|c|c|c|}
\hline $\begin{array}{c}\text { MEDIA } \\
\text { INOCULATED } \\
\text { WITH }\end{array}$ & $\begin{array}{l}\text { NUMBER } \\
\text { OF } \\
\text { SAMPLES }\end{array}$ & $\begin{array}{c}\text { Natural } \\
\text { SEA } \\
\text { WATER }\end{array}$ & $\begin{array}{c}3 \text { PER CENT } \\
\mathrm{NaCl} \\
\text { SOLUTION }\end{array}$ & $\begin{array}{c}\text { TAP } \\
\text { WATER }\end{array}$ \\
\hline $\begin{array}{l}\text { Raw sea water } \\
\text { Marine mud } \\
\text { Brackish water } \\
\text { Sewage } \\
\text { Soil }\end{array}$ & $\begin{array}{r}31 \\
18 \\
7 \\
14 \\
10\end{array}$ & $\begin{array}{r}100 \\
100 \\
100 \\
13 \\
15\end{array}$ & $\begin{array}{r}56 \\
6 I \\
I I 4 \\
4 I \\
52\end{array}$ & $\begin{array}{r}\text { I3 } \\
\text { I9 } \\
\text { I56 } \\
\text { I00 } \\
\text { I00 }\end{array}$ \\
\hline
\end{tabular}

There is not enough difference in the salinity of sea water collected from different parts of the ocean to influence plate counts materially, but there are detectable differences in the growth-promoting properties of sea water collected at different seasons, stations, and depths (MATUDAIRA, 1939). These differences in the growth-promoting property of sea water disappear when the sea water has been stored or aged at room temperature for a few weeks. Presumably the organic fractions which are responsible for the differences are oxidized by bacteria during storage.

Special media must be employed when examining water or mud samples for the presence of yeasts, molds, autotrophic bacteria, and other physiological types of microorganisms.

Solidifying agents for plating media:- Gelatin has only a limited usefulness as a solidifying agent in media for marine microorganisms. It may not congeal in the tropics or in the hot hold of a research vessel lacking adequate facilities for refrigeration. If it escapes these rigors, plates of gelatin will be liquefied by the actively proteolytic marine microflora, causing colonies to merge before many of the more slowly growing bacteria have had time to develop into macroscopically visible colonies.

An appreciable number of the bacteria found in the sea digest agar, but rarely do they liquefy plates of nutrient agar sufficiently to invalidate plate counts. The principal disadvantage of agar is the relatively high temperature at which it commences to congeal, i.e. about $42^{\circ} \mathrm{C}$. Many marine bacteria are injured by exposure to this temperature, although the injurious effects can be largely minimized if precautions are taken to cool the agar rapidly immediately after inoculation.

Being cognizant of the limitations of gelatin and agar, BERTEL (I936) has recommended the use of organic skeletal material of sponges. While 
this material has certain applications, it is not suitable for plate count procedures.

When prepared with fresh water by the method outlined by Hanks and Weintraub (1936), silica gel contains about 3.5 per cent of sodium chloride, which is formed when the sodium silicate is neutralized with hydrochloric acid, thereby giving without dialysis a solid medium which is isotonic with sea water. Using a procedure similar to that described by Moore (I940), it has been possible to prepare and sterilize a solution of sodium silicate which sets slowly into a suitable gel when mixed with a dilute solution of hydrochloric acid containing peptone and other nutrients. About half as many colonies developed on this silica gel medium as on Medium 2216 solidified with agar. Although its use is not advocated for general plate-count purposes, silica gel prepared in this way has proved to be useful for plating autotrophs and other special physiological types of bacteria.

The threatened shortage of agar, imported from Japan prior to the War, has encouraged an extensive search for agar substitutes. To date neither Irish moss extract (WALKER and DAY, I943), fibrous sodium pectate (McCREADY et al., I943), nor alginates have proved to be satisfactory agar substitutes for the cultivation of marine microorganisms.

Incubation temperature for plate counts:- The numbers and kinds of bacteria which develop into countable colonies on plates of nutrient agar are influenced by the time and temperature of incubation. This is illustrated by the data in Table IX compiled by ZoBELL and ConN (1940) who counted the number of colonies on replicate plates incubated at different temperatures and for different periods of time. The media were inoculated with identical quantities of appropriately diluted sea water or marine mud. Results with water and mud samples were almost the same regardless of whether collected from great depth where the ocean temperature was less than $5^{\circ} \mathrm{C}$. or from shallow water of higher temperatures.

TABLE IX. - Relative number of bacterial colonies appearing on mitrient sea-water agar after different periods of incubation at different temperatures, the average plate counts being expressed as percentages of the plate count at 18 days at $18^{\circ} \mathrm{C} .:-$

\begin{tabular}{|c|c|c|c|c|c|c|c|}
\hline \multirow{2}{*}{$\begin{array}{c}\text { INCUBATION } \\
\text { TIME }\end{array}$} & \multicolumn{7}{|c|}{ INCUBATION TEMPERATURE } \\
\hline & $4^{\circ} \mathrm{C}$ & I $2{ }^{\circ} \mathrm{C}$ & $18^{\circ} \mathrm{C}$ & $22^{\circ} \mathrm{C}$. & $25^{\circ} \mathrm{C}$. & $30^{\circ} \mathrm{C}$. & $37^{\circ} \mathrm{C}$. \\
\hline days & per cent & per cent & per cent & per cent & per cent & per cent & per cent \\
\hline 2 & $\circ$ & I 8 & 30 & 36 & $4 I$ & 44 & 8 \\
\hline 4 & ० & 28 & $4 I$ & 60 & 65 & $6 I$ & 12 \\
\hline 7 & 4 & 46 & 67 & 82 & 78 & 69 & 12 \\
\hline Io & 9 & 67 & $9 \mathrm{I}$ & 96 & 84 & 71 & $I_{3}$ \\
\hline 14 & I 7 & 90 & 98 & 97 & 85 & 70 & \\
\hline 18 & 26 & 97 & 100 & 95 & 82 & 63 & \\
\hline $2 I$ & 33 & 98 & 96 & 87 & 74 & 53 & \\
\hline
\end{tabular}

During the first few days of incubation the most colonies appear on plates incubated at $25^{\circ}$ or $30^{\circ} \mathrm{C}$., but after seven to ten days greater numbers of colonies appear on the plates incubated at $12^{\circ}$ to $22^{\circ} \mathrm{C}$. The bacteria which multiply at the higher temperatures develop into visible colonies more rapidly than those incubated at lower temperatures, but there are relatively few bacteria in the sea which grow at temperatures higher than $25^{\circ} \mathrm{C}$. Most of the colonies which develop on plates incu- 
bated at the higher temperatures are larger than those found on plates incubated at lower temperatures, thereby giving the former plates the superficial appearance of having more colonies.

The decrease in the counts recorded for plates after prolonged incubation is due to the merging of colonies and the liquefaction of the agar by some of the bacteria which obliterate surrounding colonies.

Very few colonies develop on plates incubated at $37^{\circ} \mathrm{C}$. In fact, many marine bacteria are killed by ten minutes' exposure to temperatures no higher than $30^{\circ} \mathrm{C}$. The thermal sensitivity of marine bacteria is indicated by the fact that some perish by being exposed for a few seconds to the temperature of agar near its congealing point, as is shown by the data in Table X. While too few bacteria are killed when the medium is cooled to near $42^{\circ} \mathrm{C}$. to invalidate the use of agar plates for enumerating bacterial populations, it is emphasized that prolonged exposure at $42^{\circ} \mathrm{C}$., or short exposure at temperatures a few degrees higher, is lethal for an appreciable number of bacteria occurring in marine materials.

TABLE X.- Relative numbers of colonies developing on mutrient agar inoculated with sea water or marine mud when the agar was poured at different temperatures, the plate counts being expressed as percentages of the average plate count on media poured at $42^{\circ} \mathrm{C}$. (from data of ZoBELL and ConN, I940):-

\begin{tabular}{|c|c|c|c|c|c|c|}
\hline INOCULA & $\begin{array}{c}\text { NUMBER OF } \\
\text { SAMPLES }\end{array}$ & $42^{\circ} \mathrm{C}$ & $45^{\circ} \mathrm{C}$ & $50^{\circ} \mathrm{C}$ & $55^{\circ} \mathrm{C}$ & $60^{\circ} \mathrm{C}$ \\
\hline $\begin{array}{l}\text { Sea water } \\
\text { Marine mud }\end{array}$ & $\begin{array}{r}14 \\
9\end{array}$ & $\begin{array}{c}\text { per cent } \\
\text { I00 } \\
\text { I00 }\end{array}$ & $\begin{array}{c}\text { per cent } \\
95.8 \\
93.4\end{array}$ & $\begin{array}{c}\text { per cent } \\
89.4 \\
82.1\end{array}$ & $\begin{array}{c}\text { per cent } \\
34.2 \\
26.9\end{array}$ & $\begin{array}{c}\text { per cent } \\
\text { I } 7.5 \\
\text { I I. } 4\end{array}$ \\
\hline
\end{tabular}

Dilution water blanks for marine bacteria:- It is always necessary to dilute mud samples before they can be used to inoculate plating or extinction-dilution method media, and it is often necessary to dilute sea water or other marine materials such as surface slime, the intestinal contents of organisms, etc. A dilution water used for this purpose should provide for the suspension and prolonged survival of the microorganisms in the samples being analyzed.

Sterilized sea water might be considered to be the best dilution water for marine microorganisms but it is surprising to note the number of workers who have employed distilled water, tap water, physiological saline solution, or other solutions for dilution purposes. Some workers merely specify that "sterile water" was employed and others fail to mention the dilution water at all. The effect of the composition of the dilution water blank upon the plate count of marine mud is illustrated by the data summarized in Table XI on page 47.

In this experiment, samples of marine mud were diluted with raw sea water until it was estimated that $\mathrm{I} .0 \mathrm{ml}$. of the mixture should contain around 20,000 bacteria which would develop into colonies on Medium 22I6. Then with two people working together, I.O-ml. quantities of the mixture were transferred to $99-\mathrm{ml}$. sterile dilution water blanks. The latter were shaken uniformly for one minute, after which I.o-ml. quantities in duplicate were used to inoculate plates to which Medium 2216, cooled to $42^{\circ} \mathrm{C}$., was added. The data in Table XI summarizes the average of five such experiments, the plate counts from the different dilution water blanks being expressed as percentages of the number of colonies 
which developed from autoclaved sea-water dilution water blanks after one minute exposure. After 55 minutes the inoculated blanks were again shaken and I.o-ml. quantities were transferred to Petri dishes. The procedure was repeated after a total elapsed time of 30 minutes and 60 minutes. "Aged" or "rotted" sea water (see page 58) was used.

TABLE XI. - Relative numbers of bacteria demonstraled by plate counts in identical samples of marine mud after different periods of time in different kinds of dilution water blanks, expressed as perentages of the number of bacleria found in autoclaved sea water after one minule:-

\begin{tabular}{|c|c|c|c|c|}
\hline \multirow{2}{*}{$\begin{array}{c}\text { DESCRIPTION OF DILUTION } \\
\text { WATER BLANK }\end{array}$} & \multicolumn{4}{|c|}{ PERIOD OF EXPOSURE IN MINUTES } \\
\hline & I & 15 & 30 & 60 \\
\hline Autoclaved sea water & I0O & 98 & 97 & 92 \\
\hline Synthelic sea water & 96 & 95 & 91 & 84 \\
\hline Tap waler & $4 I$ & 35 & 28 & 21 \\
\hline $0.5_{5} \% \mathrm{NaCl}$ & 77 & 82 & 63 & 60 \\
\hline Distilled water & 33 & 28 & I4 & II \\
\hline Berkefeld fillered sea water & IO3 & 97 & 62 & 58 \\
\hline $10 \%$ sea water & 79 & 64 & 56 & 42 \\
\hline $25 \%$ sea water & 92 & 76 & 67 & 62 \\
\hline $50 \%$ sea water & 98 & 104 & 95 & 99 \\
\hline $75 \%$ sea water & 107 & 96 & II 3 & 102 \\
\hline $3 \% \mathrm{NaCl}$ & 90 & 83 & 87 & 79 \\
\hline Sea water plus $3 \% \mathrm{NaCl}$ & 76 & 71 & 60 & 53 \\
\hline "Formula C" (see below) & $6 \mathrm{I}$ & 34 & 26 & 18 \\
\hline "Formula C" with $3 \% \mathrm{NaCl}$ & 93 & 90 & 87 & 74 \\
\hline
\end{tabular}

All of the dilution water blanks except one which was passed through a Berkefeld- $\mathrm{N}$ filter were sterilized by heating in the autoclave for $20 \mathrm{~min}$ utes at $\mathrm{I} 2 \mathrm{I}^{\circ}$. C. Since KIRIBAyashi and AIDA (I934) have reported that certain bacteria survive longer in boiled than in raw sea water, it seemed desirable to compare boiled or autoclaved sea water with Berkefeldfiltered sea water. Actually the latter was not as good as autoclaved sea water. Apparently in passing through Berkefeld or Mandler filters, contact with the brass and nickel-plated connections renders sea water slightly bactericidal. This conclusion was reached after experimenting with Berkefeld-filtered sea water which had been autoclaved and placing sterile Berkefeld filters in autoclaved sea water. However, part of the bactericidal effect of sea water sterilized by filtration is ascribable to a thermolabile, filter-passing, toxic agent which occurs in raw sea water, as has been demonstrated by the use of Coors and Chamberland all-porcelain filters and sintered glass filters having no metal parts.

From the data in Table XI it will be observed that marine bacteria rapidly perish when suspended in tap water, 0.85 per cent sodium chloride solution, distilled water, or Formula C. The latter is a balanced salt solution having the following composition:

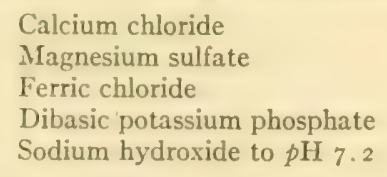

$$
\begin{aligned}
& 0.250 \text { millimols } \\
& 0.100 \text { millimols } \\
& 0.0005 \text { millimols } \\
& 0.312 \text { millimols }
\end{aligned}
$$

Formula $\mathrm{C}$, which is based upon the average composition of river water, has been recommended by BUTTERFIELD (I932) and others as a dilution water for "water" bacteria. However, even when rendered isotonic with sea water by the addition of 3 per cent sodium chloride, Formula $\mathrm{C}$ is not satisfactory for marine bacteria. 
Within the limits of the experimental error, synthetic sea water or sea water diluted with an equal volume of distilled water gave results which were comparable with results obtained by using natural sea water. For routine work sea water diluted $3: 1$ with distilled water is recommended for dilution water blanks. This so-called 75 per cent sea water provides for the prolonged survival of marine bacteria, and unlike undiluted sea water, no precipitate develops in it after sterilization and standing in soft glass receptacles.

It is noteworthy that marine bacteria are equally sensitive to both hypertonicity and to hypotonicity as indicated by the results with sea water to which 3 per cent sodium chloride had been added. Working with "fresh-water" organisms, TANNER and Houston (I940) concluded that bacteria are quite resistant to changes in osmotic pressure. Our observations confirm those of KORINEK (1926) that "fresh-water" bacteria are more resistant to changes in osmotic pressure than are marine bacteria. Additional information on this subject is given in Chapter VIII.

The successive dilution method for enumerating bacteria:- The successive dilution method, also called the extinction or minimum dilution method, consists of diluting the material to be examined usually by powers of 10 , and inoculating equal volumes of the diluted material into liquid media (HALVORSON and ZIEGLER, I933a). The reciprocal of the highest dilution which yields positive results is regarded as the most probable number of bacteria present. Thus the occurrence of growth from the inoculation of $1.0 \mathrm{ml}$. of a $\mathrm{I}: \mathrm{I00}$ dilution but not of a I:I0,000 dilution indicates that the original material contained at least nooo viable bacteria per $\mathrm{ml}$.

As pointed out by HaLvorson and ZiEgLER (I933b), the accuracy of the dilution method depends primarily upon the uniform distribution of cells in the solution, the number of dilutions used, the number of tubes inoculated with each dilution, and the fitness of the media to support the growth of the bacteria. Inoculating each of ten tubes with three effective dilutions, ZoBELL (I94I $a$ ) analyzed 38 samples of marine mud and sea water by the successive dilution method and also by duplicate plate counts. Representative results are given in Table XII. The nutrient composition of the media was identical.

TABLE XII.- Most probable number of bacteria in samples of marine materials indicated by the successive dilution method and plate counts:-

\begin{tabular}{|c|c|c|c|c|c|}
\hline \multirow{2}{*}{$\begin{array}{c}\text { SAMPLE } \\
\text { No. }\end{array}$} & \multicolumn{3}{|c|}{ Positive tUBES IN DILUTION } & \multirow{2}{*}{$\begin{array}{l}\text { DILUTION } \\
\text { METHOD } \\
\text { COUNT }\end{array}$} & \multirow{2}{*}{$\begin{array}{c}\text { AVERAGE } \\
\text { PLATE } \\
\text { COUNT }\end{array}$} \\
\hline & $10^{-2}$ & $10^{-3}$ & $10^{-4}$ & & \\
\hline I 235 & Io & Io & 2 & 3490 & 2120 \\
\hline I 238 & IO & 8 & ○ & 1300 & $\mathbf{I} 740$ \\
\hline I3I 4 & xo & 7 & 0 & Ioro & 820 \\
\hline I3I 5 & Io & 4 & 2 & 700 & 370 \\
\hline 1413 & 7 & 4 & 3 & 208 & 320 \\
\hline 1444 & Io & 8 & $\mathbf{I}$ & 1500 & 830 \\
\hline
\end{tabular}

There was a fair agreement between the results obtained by the successive dilution method and plating procedures, the former being an average of I 2 per cent higher than plate counts. Similarly, ButTerfield $\left({ }^{9} 933^{b}\right)$ found that if enough tubes were used under standardized condi- 
tions, plate counts differ very little from dilution method counts of water bacteria. BuTKEVICI $(1932 b)$ reported that the inoculation of tubes of liquid media with successive dilutions of material from the Barents Sea demonstrated the presence of from ten to a hundred times as many bacteria as plate counts on solid media. It is possible that his solid media were poured too hot, or the plates may not have been incubated sufficiently long.

Since it requires much more time and material for dilution method counts in order to approach the accuracy of plate counts, the use of the former for estimating the general bacterial population is not recommended. However, if one lacks the facilities for plating samples of marine materials in the field, valuable information can often be obtained by inoculating a few tubes of nutrient media with various dilutions. It is far better to know the order of magnitude of the bacterial population than to have no information at all, and from the tubes in which growth occurs, cultures for further study can be isolated after returning to the shore laboratory.

The successive dilution method finds its widest application for estimating the abundance of different physiological types of bacteria by the use of selective or differential media. For example, the number of bacteria in samples which reduce nitrate can best be estimated by inoculating nitrate broth with different dilutions of the sample and then determining the highest dilution which caused the reduction of nitrate.

The enumeration of marine anaerobes:- Anaerobic bacteria are found in nearly all samples of marine bottom deposits and in most samples of sea water. Many of them prove to have the faculty of growing either in the absence or in the presence of free oxygen although some are strict anaerobes.

There is no sharp demarcation between aerobes and anaerobes. For purposes of discussion, bacteria which grow in the absence of free oxygen or in media having an oxidation-reduction potential of $E_{\mathrm{h}}$ o to -0.4 volt or lower are regarded as anaerobes while those which grow in the presence of free oxygen or in media having an oxidation-reduction potential of $\mathrm{E}_{\mathrm{h}} \circ$ to +0.4 volt are regarded as aerobes. Fifteen species of strict anaerobes studied by REED and ORR (I943) were found to grow best at $\mathrm{E}_{\mathrm{h}}-0.2$ volt. Microaerophilic bacteria are those which grow best in the presence of traces of free oxygen or at $\mathrm{E}_{\mathrm{h}}+$ o. I to - O.I volt.

There is no relationship between the oxidation-reduction potential of the medium and the oxygen tension except in so far as the oxygen tends to influence the $\mathrm{E}_{\mathrm{h}}$. According to KLIGLER and Guggenherm (I938), anaerobes require a low $\mathrm{E}_{\mathrm{h}}$ only if oxygen is present. It has been amply demonstrated that certain so-called strict or obligate anaerobes will grow in the presence of free oxygen if the $\mathrm{E}_{\mathrm{h}}$ is sufficiently low (HEwitr, I936).

Considerable difficulty has been experienced in estimating the abundance of marine anaerobes. Most of the conventional procedures (HaLl, 1929) have failed to yield reproducible results, and they require the use of complicated, bulky and time-consuming apparatus which is impractical for field studies at sea. No one nutrient medium has proved to be satisfactory for estimating the general anaerobic population, although good results have been obtained with Medium 2216 enriched with 1.0 per cent glucose, 0. I per cent sodium thioglycollate and 0.0002 per cent methylene blue. If protected from atmospheric oxygen following autoclave steriliza- 
tion, the oxidation-reduction potential of this medium is generally lower than $\mathrm{E}_{\mathrm{h}}-\mathrm{O}$.I volt. The reduced methylene blue helps to maintain a low $\mathrm{E}_{\mathrm{h}}$ and it serves as an indicator of the $\mathrm{E}_{\mathrm{h}}$, the $\mathrm{E}_{\mathrm{o}}$ of methylene blue being +o.oII volt at $p H$ 7.0. $\left(\mathrm{E}_{\mathrm{o}}=\mathrm{E}_{\mathrm{h}}\right.$ when the oxidant is 50 per cent reduced). For certain purposes, such as the cultivation of sulfate-reducing bacteria, O.I per cent ascorbic acid is better than sodium thioglycollate. The influence of ascorbic acid on the growth of anaerobes has been studied by Kligler and Guggenheim (I938). Reed and OrR (I943) found ascorbic acid to give about the same results as sodium thioglycollate.

Alkaline pyrogallol cannot be relied upon to remove enough oxygen from anaerobe jars to prevent the growth of microaerophiles and certain aerobes. STONE (I936) has found chromous sulfate to be more than forty times as efficient as pryogallate as an oxygen absorbent. Both chromous sulfate and yellow phosphorus have been employed for depleting the oxygen from anaerobe jars at sea. Burning phosphorus leaves an undesirable film on the culture receptacles. Though useful in the shore laboratory, McIntosh-Fildes jars requiring hydrogen are somewhat cumbersome on a research vessel. Moreover, the maritime underwriters look with disfavor upon the use of potentially explosive mixtures such as hydrogen and oxygen.

A 20-quart pressure cooker has proved to be a good anaerobe jar. It is sturdy and has a capacity of 80 to roo Petri dishes. A glass receptacle must be used in the pressure cooker to contain the mixture of chromous sulfate and sulfuric acid or other oxygen-absorbing agents in order to prevent the corrosion of the metal. A pressure cooker has also been wired with a McIntosh-Fildes palladinized asbestos heating element to provide for the ignition of hydrogen. The principal disadvantage of these improvised anaerobe jars is their lack of transparency; it is necessary to open them in order to observe the cultures.

For field work, extensive use has been made of circular glass disks, slightly smaller in diameter than Petri plates, for maintaining anaerobic conditions in single dishes. After inoculating and pouring the plate in the conventional manner, a sterile glass disk is placed on top of the medium to exclude atmospheric oxygen. The failure of the blue color of methylene blue to return to the medium except around the periphery of the plate indicates reducing conditions under the glass disk. Colonies can be observed and counted as they develop. After carefully removing the glass disk, colonies can be transferred to other media for further study. When employing this method of anaerobiosis, the glucose content of the medium should be reduced to o. I per cent or less. Otherwise gas production from the fermentation of glucose by anaerobes often causes fragmentation of solid media.

Rittenberg et al. (I937) employed oval tubes about $380 \mathrm{~mm}$. long and 6 by $\mathrm{I} 4 \mathrm{~mm}$. in cross-section for the enumeration of marine anaerobic bacteria. One end of the tube is closed and the other end is flared to facilitate the introduction of the medium. It is easier to observe colonies in the flat-walled oval tubes than in ordinary round glass tubes.

The oval tubes are sterilized in a pipette can. Then ro ml. of nutrient agar, recently heated to $100^{\circ} \mathrm{C}$. to expel oxygen and cooled to $42^{\circ} \mathrm{C}$., is inoculated with $\mathrm{I} .0 \mathrm{ml}$. of the appropriately diluted sample, and without undue agitation, the inoculated medium is poured into the oval tube. The medium is covered with a $40 \mathrm{~mm}$. layer of reduced methylene-blue agar to serve as a seal or plug for excluding oxygen. When colonies de- 
velop, they can be readily counted in reflected light against a dark background.

The oval tube technic is applicable not only to the enumeration of anaerobes in general, but by employing appropriate differential media, the abundance of various physiological types can be estimated. If, however, the anaerobes produce gas, the medium in the oval tubes will be shattered, thereby rendering it useless for counts.

Colonies of anaerobes can be removed from the medium for further study either by breaking the oval tube (after scoring it with a file) near the colony and then aseptically dissecting out the colony with a sterile inoculating needle; or the entire plug of agar can be expelled from the oval tube into a sterile Petri dish. Then, by dissecting away the surrounding agar with a hot needle, the desired colony can be isolated. To remove the agar, the oval tube is immersed for a second in boiling water to loosen the agar from the walls of the tube, after which heat from boiling water or a Bunsen flame is applied to the bottom of the tube until the increasing vapor pressure expels the intact plug of agar.

When using the successive dilution method to enumerate marine anaerobes, oxygen must be excluded from the differential media to prevent the multiplication of aerobes. Wide-mouth Mason jars, which are inexpensive and rugged, have proved to be useful for this purpose in the field. One-quart bottles accommodate I 5 /8-inch test tubes or $2 \mathrm{I}$ I/2-inch tubes. Immediately before placing the inoculated tubes of media in the jar, 5 grams of powdered chromium metal and $100 \mathrm{ml}$. of I 5 per cent sulfuric acid are introduced (RosentHaL, I937). After the initial vigorous evolution of hydrogen has subsided, the jar is sealed.

If it will not interfere with the specific functions of the medium, the enrichment of differential media with o.I per cent of either ascorbic acid or sodium thioglycollate is recommended to maintain reducing conditions, and 0.0002 per cent methylene blue helps to poise the medium while serving as an indicator of anaerobiosis.

Media which are rendered semi-solid by the addition of 0 .I to 0.3 per cent agar are better than either solid or liquid media for the cultivation of anaerobes. Semi-solid media for the cultivation of anaerobes have been recommended by SPRAY (I936), REED and ORR (I943), and many others. Hitchens (I92I) has reviewed the literature on the advantages of semisolid media for the cultivation of microorganisms.

Direct microscopic counts:- Wherever careful comparisons have been made, direct microscopic counts have detected the presence of many more bacteria in water and mud than have plate counts. According to WAKSMIAN et al. (I933c), direct counts on sea water are Iooo times as large as plate counts. Direct counts made by BERE (I933) on water from Lake Mendota were from 20 to 335 times as high as plate counts, while water in Lake Wingra gave direct counts which were from 8 to 125 times as high as plate counts.

Direct counts are higher partly because of the failure of any one nutrient medium to satisfy the cultural requirements of all bacteria and primarily because of the tendency of bacteria to occur associated together either as zoogleal masses, chains, sheets, or clumps, or tenaciously attached to particulate material. The studies of ZoBELL ( $1943^{b}$ ) show that most bacteria appear to be associated with particulate material, both living and inanimate. This is in agreement with the observations of 
LLOYD (I930) that marine bacteria are not free-floating but usually occur attached to solid particles. According to Waksman et al. (I933c), most marine bacteria are found attached to larger plankton organisms, existing "only to a very limited extent in the free water of the sea." Similarly, most of the bacteria in mud occur attached to or adsorbed on solid particles. When plated, each particle, mass, clump, or group of bacteria will give rise to only one colony, whereas many individual cells associated with such particles or groups may be distinguished microscopically. However, direct counts are attended by many technical difficulties and have limitations which restrict their usefulness. At best, direct counts give data which only supplement and aid in the interpretation of results obtained by cultural procedures.

If the material to be examined contains more than a million bacteria per ml., a modified BREED and BREW (IgI6) method can be employed for their enumeration. After treating the material with 0.02 per cent gelatin to serve as a fixative, $0.0 \mathrm{I} \mathrm{ml}$. is transferred to a clean glass slide with a capillary pipette or a platinum loop calibrated to deliver o.or ml. This material is spread evenly over exactly $1.0 \mathrm{sq} . \mathrm{cm}$. of the glass slide by using guide plates designed for this purpose or by marking off a square centimeter with a grease pencil. After drying and staining, the smear is examined microscopically using the oil immersion objective of a compound microscope equipped with a mechanical stage. If the field of vision of such a microscope is I/ $5000 \mathrm{sq}$. $\mathrm{cm}$., the average number of bacteria seen in a microscope field multiplied by 500,000 represents the number of bacteria per ml. of the original material. The area of the field of vision of each microscope must be determined from the diameter of the field.

Either carbol-erythrosin or rose bengal consisting of 1.0 per cent of the dye and 0.02 per cent anhydrous calcium chloride in 5 per cent aqueous phenol solution, as recommended by ConN (I9I8) for the direct microscopic study of soil microorganisms, has given good results for staining smears of marine microorganisms.

TARR (I94I) has described a modification of the BREED and BREW direct microscopic method for counting bacteria in fish flesh.

Employing a shallow haemocytometer resembling the Petroff-Hausser counter described below and a dark-field microscope, AmanN (I9I I) found nearly 80,000 bacteria per $\mathrm{ml}$. of spring water and only 600 by plating procedures. However, AMANN emphasized that accurate or reproducible counts require the examination of numerous samples.

After investigating various direct and cultural methods for enumerating bacteria, Wilson and Kullmann (I93I) stated that "The direct count with the Petroff-Hausser or similar bacteria counting chambers proved to be the most accurate of all the methods investigated and its use whenever possible is advised." The Petroff-Hausser counter is a modified haemocytometer having a chamber only $0.02 \mathrm{~mm}$. deep which minimizes the necessity of extensive focussing in order to locate bacteria in different levels. The bacteria can be stained for light-field observation or they can be observed unstained with the dark-field microscope. The disadvantage of this method is that each bacterium per square on the Petroff-Hausser counter represents $20,000,000$ organisms per $\mathrm{ml}$. of sample. Therefore it can be used to advantage only when numbers of organisms are high.

The concentration of organisms for direct counts:- If the material to be examined contains fewer than a million bacteria per ml. (sea water 
rarely contains this many), it must be concentrated before the bacteria can be counted by the direct microscopic method. It is not practical to concentrate sea water by evaporation at reduced pressures, as advocated by BERE (I933) and others for fresh water, because of the high salt content of sea water. With very little concentration, certain salts commence to precipitate from sea water, carrying many bacteria with the crystals. Moreover, the higher osmotic pressure of the concentrated sea water has undesirable effects on the morphology of microorganisms. By evaporating lake water at a reduced pressure at $35^{\circ} \mathrm{C}$. to concentrate the bacteria, KUSNETZOW and KARZINKIN (I93I) microscopically counted 2000 to 4000 times as many bacteria in water from Lake Glubokoje as were demonstrated by plate counts. They preserved the water with formalin, used agar as a fixative, and stained the smears with carbol-erythrosin.

Centrifugation is not a feasible method of concentrating the bacteria in sea water because the specific gravity of most of the bacteria is near that of the sea water, I.024 to I.030. The force of a high-speed angle centrifuge precipitates some of the bacteria with the sediment while others are concentrated at the top of the liquid, but the majority remain suspended in the sea water or become attached to the glass. Some of the problems of concentrating marine microplankton and nannoplankton by centrifuging are discussed by LEBOUR (I9I7), LOHMANN (I922), and others. Most of these methods detect only clumps of bacteria, zooglea, bacteria which are attached to larger organisms, and bacteria which exceed Io $\mu$ in diameter.

SNOw and FRED (I926) treated water with aluminum hydroxide to facilitate the flocculation of bacteria. They reported the recovery of 95 per cent of the known number of suspended bacteria in the stained sediment after centrifuging. The direct microscopic examination of water samples from Lake Mendota treated in this way revealed the presence of from 7 to 14 times as many bacteria as did plate counts.

MÜlLER (I9I 2a) concentrated bacteria by centrifuging IoO-ml. samples of water treated with ferric perchlorate. A measured quantity of the sediment was transferred to a known area of glass slide and stained with gentian violet for microscopic examination. He believed that the direct counts, which were 25 times higher than plate counts, detected 97 to 99 per cent of the bacteria in water.

Various modifications of the centrifuge-flocculation method used by SNOw and FRED (I926) have been applied to sea water with inconclusive results. The principal difficulty has been in the precipitation by the flocculating agents of various salts from sea water, thereby obliterating some of the bacteria from view. From to to 200 times more bacteria were found in sea water by its direct microscopic examination than by plate counts. The statistical treatment of the data from the examination of I00 samples shows that whereas the deviation of duplicate plate counts was 2.3 to $2 \mathrm{I} .7$ per cent, the duplicate successive dilution method counts (using ten tubes for each effective dilution) deviated from the mean by I9.4 to ro6.7 per cent and duplicate direct microscopic counts deviated from the mean by 32.8 to 790 per cent. In other words, plate counts are much more reproducible than direct microscopic counts on samples of sea water, although the latter detect more microorganisms.

Provisions are made for the direct microscopic observation of chemically flocculated ultraplankton by UTERsöIIL (I93I) who observed the stained organisms from below by inverting the microscope. His inverted 
microscope method makes it possible to observe the organisms which settle out of rather deep counting chambers, provided the latter have thin bottoms made of optical glass. UTERMöHL (I93I) gives detailed directions for staining microorganisms with complimentary colors, and the use of light filters in order to provide contrast for the microorganisms.

Like most of the direct microscopic methods, UTERMÖHL's inverted microscope method cannot be recommended for counting bacteria at sea due to the effect of vibration of the boat on the focus when using the necessary high magnifications. However, the samples can be preserved with formalin or otherwise for observation in the shore laboratory.

BENECKE (I933) has proposed filtration methods for concentrating the bacteria in sea water prior to making direct counts, as suggested by the work of KoLKWITZ who concentrated microplankton with membrane filters. However, such filters do not retain the free bacteria which are smaller than $5 \mu$ in diameter.

After treating samples of fresh water with formalin in preservative concentrations, CHOLODNy (I929) filtered Ioo $\mathrm{ml}$. through a membrane filter having a porosity of only $2 \mu$. When all except 4 or $5 \mathrm{ml}$. had passed through the membrane, the exact volume was determined and $0.05 \mathrm{ml}$. was transferred to a measured area of glass slide. This smear was air dried, fixed, and stained with erythrosin preparatory to making microscopic counts from which the bacterial population of the original material could be estimated. CHOLODNy found from a hundred to a thousand times as many bacteria in water samples by this direct method as by plate counts although his fine filter membrane may not have retained all of the bacteria. Cholodny recognized that one big disadvantage of the direct method is its failure to differentiate between dead and living cells. The filters employed by CHOLODNy were manufactured by P. AltmanN, Berlin. Such membranes may be dissolved in acetone to facilitate the separation of bacteria.

GEE (I932d) reported indifferent success in his attempts to enumerate marine bacteria, employing the aluminum hydroxide adsorption method of SNOW and FRED (I926) and CHOLODNY's ultrafiltration procedure. The primary difficulty was caused by agglutination of the organisms, giving a preparation in which the bacteria were collected in bunches. GEE proposed a method of concentrating bacteria in sea water by their adsorption to $\mathrm{CaCO}_{3}$ precipitated by the addition of ammonia. He believed that the bacteria entrained with the precipitated $\mathrm{CaCO}_{3}$ could be concentrated by filtration. Then weak acids or carbon dioxide could be used to dissolve the carbonate, thus releasing the entrained bacteria. We have not found the method to be promising.

It is difficult to recover all of the bacteria from filters of very fine porosity. Furthermore water passes very slowly through such filters, thus limiting the volume that can be filtered. Certain workers have undertaken to obviate the former difficulty by the use of filter membranes which may be dissolved with chemical reagents. For example, collodion membranes are soluble in ether, and filters made of powdered $\mathrm{CaCO}_{3}$ or $\mathrm{MgCO}_{3}$ dissolve readily in dilute $\mathrm{HCl}$. Carbonate filters have yielded the best results for concentrating bacteria in sea water, but many technical difficulties must be overcome before this method of enumerating bacteria can be recommended for general use. 
Direct counts on bacteria in mud:- Bacteria are usually sufficiently abundant in marine bottom deposits so that it is not necessary to concentrate them preparatory to estimating their abundance by the direct microscopic method, although there are other difficulties. CoNN (1918), Winogradsky (I928), Cirolodny (I930), Rossi (I936), and others have described methods for the direct microscopic study of soil microorganisms. Some of these methods are applicable to the enumeration of microorganisms in marine sediments.

ConN's (I9I8) method calls for mixing one part of soil with ten times its weight of 0.015 per cent gelatin solution. Exactly $0.01 \mathrm{ml}$. of this is transferred with a calibrated capillary pipette or platinum loop to a clean glass slide and smeared evenly over exactly $1.0 \mathrm{sq} . \mathrm{cm}$. The smear is air dried, stained with carbol-erythrosin or rose bengal, and subsequently the bacteria which appear in each of Io to roo fields are counted, using the oil immersion lens. The average number of bacteria per field, multiplied by a factor which must be determined from the area of the microscope field, represents the number of bacteria per gram of soil sample.

WINOGRADSKX (1928) recommended centrifuging the diluted soil sample and the examination of $0.0 \mathrm{I} \mathrm{ml}$. of the resulting sediment as well as o.or $\mathrm{ml}$. of the supernatant fluid. This gives additional information on the spatial distribution of the bacteria in the soil. When applied to marine sediments it is found that virtually all of the bacteria occur intimately associated with particulate matter. The adsorption of marine bacteria by particulate materials has been discussed by WAKSMAN and VARTIOVAARA (1938) and by ZoBELL ( 1943 b).

Cholodny (I930) recommended the insertion of sterile glass slides directly in the soil in slits prepared with a knife or spatula. The slides are left there for one to three weeks during which time many bacteria become attached. Then the slides are carefully removed by excavation. After washing free of adherent dirt and fixing over a flame, each slide is stained with erythrosin, carbol-fuchsin, or rose bengal. Obviously this method can be applied to studies of marine bacteria only in mud flats and in the intertidal zone, but there it has given much information on the ecology and morphology of microorganisms. Often Cholodny slides bear microorganisms which never appear in cultural material. The number of microorganisms which attach suggests that a large proportion of bottomdwelling microorganisms are sessile, stereotropic, or thigmotactic. Microcolony development gives some idea concerning the rate of growth of bottom-dwelling microorganisms in situ.

Rossi (I936) prepared impression smears by pressing sterile slides against a freshly prepared soil surface and examining them at once after fixing and staining. This method has contributed information on the spatial relationships of microorganisms in mud flats studied by ZoBELL and Feltham (I942). It is also useful for investigating the distribution of microorganisms in mud cores by making impression smears against freshly cut surfaces of the cores. Such impression smears can be prepared in the field for subsequent examination in the shore laboratory.

Soil microorganisms are counted by the ratio method of THORNTON and GRAY (I934) by diluting $5 \mathrm{gm}$. of soil with $25 \mathrm{ml}$. of indigotin suspension which contains about 200 million indigotin particles per $\mathrm{ml}$. This mixture of soil and indigotin suspension is diluted with $25 \mathrm{ml}$. of sterile o.or per cent agar solution and shaken for three minutes. A drop smeared on a glass slide is permitted to dry, after which it may be stained with 
carbol-fuchsin or rose bengal. The bacteria and indigotin particles in ro to 50 fields are counted under the oil immersion lens. By knowing the number of indigotin particles present per gram of soil, one can calculate the number of bacteria per gram of soil from the ratio of bacteria to indigotin particles counted microscopically.

The direct microscopic study of microorganisms in marine mud is attended by numerous obstacles. Many of the microorganisms are submicroscopic in size or barely within the range of the resolving power of an ordinary microscope. In many cases it is impossible to distinguish bacteria from particles of clay and organic detritus, and some of the bacteria are obliterated by larger particles. At their best, direct counts on marine mud are useful primarily for giving information ancillary to counts obtained by cultural procedures. The latter are indispensable for evaluating the physiological activities of microorganisms.

The significance of counting the number of microorganisms in a given environment is often over-estimated. The population is merely an expression of the dynamic balance between the rate of production and the rate of destruction of microorganisms. In appraising the role of microorganisms in chemical, geological, and biological conditions, the rate of reproduction and activity of the microorganisms is a more important consideration than is the number of microorganisms which may be present at a given time.

BENECKE (I933) suggested adapting the method of Koffmann to the study of bacteria in marine sediments or to those which are attached to plankton organisms. After elutriating the soil with reagents selected to separate the bacteria from particulate material and to disintegrate clumps, the supernatant fluid in which the bacteria are suspended is decanted and passed through an ultra-filter having a porosity of O.I $\mu$. The residue is stained with alcohol-soluble cyanosin for direct microscopic examination. The success of such a method will depend upon the efficiency of the elutriants in suspending bacteria and upon finding a satisfactory means of distinguishing bacteria from small particles of organic detritus.

Submerged slide technic for studying bacteria in water :- Glass slides and other solid surfaces which are submerged in the sea soon become covered with microorganisms. While studying the factors which influence the fouling of ships' bottoms, HiLEN (I923) observed that the slime which forms on surfaces submerged in the ocean is composed of a variety of bacteria as well as yeasts and molds. NAUMANN (1925) reported that, due to their tenacious attachment, excellent preparations of iron bacteria may be prepared by the submergence of glass slides in iron-bearing waters. Several other workers mentioned by ZOBELL and ALLEN (I935) have submerged slides and later examined them microscopically to follow the distribution of sessile algae, diatoms, and other minute aquatic organisms without attempting to detect bacteria.

HENRICI (I933) observed the attachment and growth of fresh-water bacteria on submerged glass slides. Although HENRICI recognized the limitations of the submerged slide technic, he concluded that "the method does offer a short cut towards an ecological survey of water bacteria." Later HENRICI (I936) observed a limited positive correlation between plate counts and the number of bacteria found on slides submerged in lakes. He recommended suspending slides $50 \times 75 \mathrm{~mm}$. in size in the water for a few hours to a few days, depending upon the habitat.

The attachment of bacteria, diatoms, actinomyces, and other micro- 
organisms on glass slides submerged in sea water was observed by ZoB BeLL and Allen (I933) who noted the appearance of dividing cells, chains of bacteria, and micro-colonies. The microorganisms are so tenaciously attached that it is necessary only to stain the slides without fixation for microscopic examination. ZoBELL and ALLEN (I935) made continuous studies for several months on microorganisms found attached to standard $25 \times 75 \mathrm{~mm}$. glass slides submerged in the sea by means of a special car-

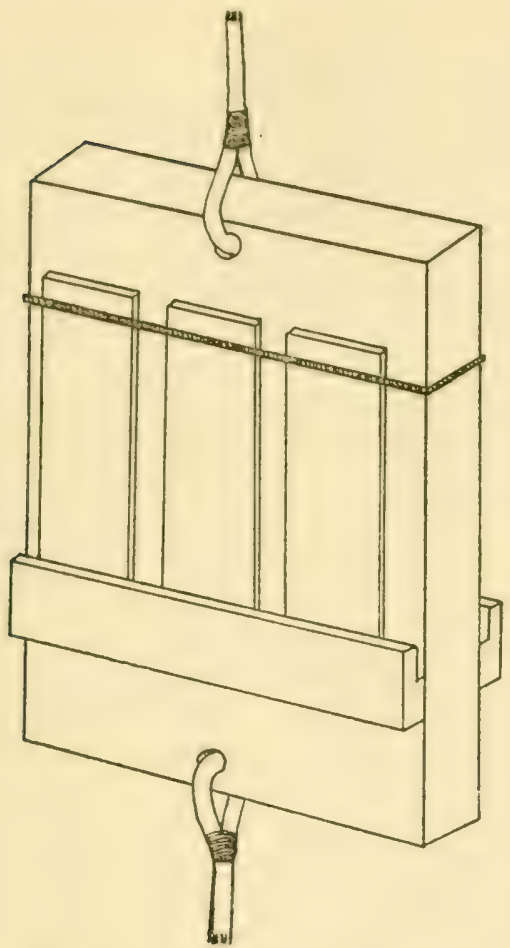

FIG. 6. - Carrier for submerging in water glass slides to be examined by the direct microscopic method. Several such carriers may be submerged in tandem to provide for the simultaneous collection of attachment microorganisms from different depth. A weight or anchor must be fastened to the bottom cord. The carriers may be constructed of wood, plastics, or other materials. Glass slides are secured by slipping them under the cord which encircles the carrier and into the slot near the bottom of the carrier.

According to HoTchKiss and WAKSMAN (1936), the submerged slide technic, in contrast to other direct microscopic methods, can be used in the case of waters containing small numbers of bacteria. A direct correlation was found between plate counts and attachment counts in sea water samples at different temperatures, in sea water samples to which carbon and nitrogen compounds were added, in sea water inoculated with pure cultures, and in filtered sea water. These workers reported that "Not only were high values for the plate counts associated with high values for the attachment counts, but constants could be determined from experi- 
mental data which permitted the calculation of the numbers to be expected from the attachment count, if the plate counts were known."

SMith and ZoBeLL (I937) used the submerged slide technic to demonstrate the occurrence and growth of bacteria and allied microorganisms in Great Salt Lake. Controlled experiments proved that neither dead nor senescent bacteria adhere to submerged slides. The development of micro-colonies on slides submerged in the lake indicated that the bacteria were multiplying.

While it is unquestionably a useful and practical method for making qualitative and quantitative studies on microorganisms in relatively shallow water, the submerged slide technic has its limitations. HENRICI (1936) emphasized that it selects only those bacteria in water which are capable of growing attached to a submerged surface. ZoBelL (I943b) carefully examined the attachment propensities of 96 different species of marine bacteria, finding that only 29 of them attached in appreciable numbers to glass slides submerged in sea water, 47 of them showed some tendency to attach, and 20 of them failed to attach to glass slides. Moreover, not all individual cells of the attachment species attached themselves to glass slides. ZoBELL ( $1943 b)$ discusses several factors including the attachment propensity of the species, the growth phase (bacteria attaching more readily during the logarithmic phase of growth than later), interfacial tension, organic content of the water, the associative or synergistic effects of other sessile organisms, and other factors which influence the attachment of bacteria to solid surfaces.

Slides must be submerged in sea water for a few hours to several days before appreciable numbers of bacteria appear. If they are not left submerged long enough, there will be too few bacteria to give significant counts and if they are left too long, the bacterial film may be too dense to make an attachment count, or the bacteria may be obliterated by the attachment of larger sedentary plants and animals. Therefore the submerged slide technic is most useful at places where continuous observations can be made rather than in the open ocean or in deep water where it is difficult to anchor boats or buoys.

Aged sea water: - In order to obtain reproducible results, it is recommended that "aged" or "rotted" sea water be employed in the preparation of dilution water blanks or nutrient media for marine bacteria. Such water is prepared by storing raw sea water in glass bottles in the dark for a few weeks or longer. The water should be collected from places that are reasonably free of fresh-water or terrigenous pollution. Because contact with certain heavy meta!s renders sea water bacteriostatic, glass receptacles should be used for the collection and storage of the water. Passing the water through a sintered glass filter of medium porosity serves to remove particulate material, thereby providing for greater uniformity in composition. If germ-proof filters are used for this purpose, the water should be inoculated with a little raw sea water to insure the presence of a bacterial flora which will decompose the organic matter in the water. During storage or incubation in the laboratory at room temperature for a few weeks the organic content of the water may be reduced from an initial 4 or $5 \mathrm{mgm}$. $/ \mathrm{L}$. to one-tenth this amount. Of greater importance than the reduction or stabilization of the organic content of the water, the slightly bacteriostatic principle referred to on pages 44,47 , and $8 \mathrm{I}$ gradually disappears with prolonged storage. The water must be stored in the dark to prevent the growth of photosynthetic organisms. 


\section{Chapter V}

\section{FACTORS INFLUENCING THE DISTRIBUTION OF BACTERIA IN THE SEA}

A multiplicity of interrelated factors are known to be responsible for the number and variety of microorganisms found in an environment as complex as the sea. Therefore it is difficult to appraise quantitatively any one factor. The dynamic character of the marine environment further complicates the problem. Water masses are moving continuously. A water mass which is here today may be ten miles away tomorrow.

Cognizance must be taken of the fact that the number of microorganisms found in a given environment at any particular time is the resultant of the forces which influence the reproduction and those which cause the death of microorganisms. In spite of the existence of optimal conditions for the reproduction of bacteria in a given environment, the bacterial population may be very low if conditions for survival are unfavorable. On the other hand, where certain environmental conditions are optimal for the prolonged survival of bacteria, large populations may occur, notwithstanding exceedingly slow rates of reproduction, growth, and activity.

It is reiterated that, due to the widely divergent analytical procedures which have been employed in studies of the distribution and activities of marine bacteria, the quantitative results reported by different workers in different parts of the world are not directly comparable.

Fluctuations in numbers of microorganisms:- Although, compared with land, the marine environment has a relatively high uniformity in chemical composition and other properties, bacteria are not evenly distributed in the ocean. Besides variations in the diurnal, seasonal, vertical, and geographical distribution of bacteria in the sea, detectable differences occur in the bacterial population of samples collected at the same time and place. If, however, enough samples of sufficient size are analyzed, these local differences in the abundance of bacteria may be greatly minimized.

By carefully analyzing a large number of samples of sea water collected at one locality, ZoBELL and FELTHAMr (I934) found that the average deviation of duplicate plate counts on the same well-shaken water sample was 7.8 per cent, the range being o to 26.6 per cent. The analysis of ten Io-ml. samples collected at one place within a few seconds of each other showed an average deviation of 85.3 per cent from the average plate count on all of the samples, the range being I 2 .I to I 55.8 per cent. When only I.o-ml. samples collected directly from the ocean were plated, the counts on individual samples deviated by as much as 900 per cent from the mean, or in other words from I 8 to 20 times as many bacteria were found in some r.o-ml. samples as in others collected at the same place. The average deviation from the mean of roo-ml. samples was only 29.4 per cent, the range being $\mathrm{I} 2.7$ to 74.9 per cent.

After finding from 2 to 83 bacteria per ml. of sea water in ten different samples collected seriatim from the same depth at a single station, REUSZER (I933) concluded that "considerable variation may be expected 
in the number of bacteria in samples of sea water taken from the same spot." RusSELL (I893) also observed that an occasional sample of sea water yielded unexpectedly high numbers of bacteria.

This unevenness in the distribution of bacteria in water is due partly to the occurrence of relatively large numbers of bacteria aggregated in clumps or associated with particulate matter. Vigorous shaking preparatory to analyzing the samples separates some of the bacteria in such clumps, thereby increasing the number detected by plating procedures. The number of bacteria constituting clumps and their separability by shaking are both variables which contribute to the unevenness in the distribution of bacteria. The decomposing remains of a small organism such as a copepod or a dinoflagellate may harbor scores of living bacteria. Also the presence of a school of fish or the defecation of some marine animal may cause large, though temporary, increases in the bacterial population in localized areas.

TAYLOR (1940) has observed in lakes marked fluctuations in the numbers of bacteria which bore no relation to fluctuations in the concentration of dissolved substances or other factors. He noted a semblance of correlation between high bacterial counts and periods of rainfall, and some relation existed between the total numbers of phytoplankton and the bacterial populations of water samples.

The distribution of other planktonic organisms with which bacteria are intimately associated is also uneven. After observing the uneven distribution of diatoms and dinoflagellates in sea water in his studies on the range of error in microenumeration, ALLEN (I92I) stressed the need of many samples and the importance of the continuity of collections. From evidence accumulated over a period of thirty years, ALLEN (I94I) concluded that the uniformity of distribution of plankton in sea water is practically nonexistent at any time. The reasons for the occurrence of plankton organisms in swarms or sporadically are not well understood. The relations between bacterial and other plankton populations are discussed elsewhere in this volume.

Distance from land:- - The largest bacterial populations usually occur in sea water near land regardless of the depth or temperature of the water. According to Fischer (I894a), harbor water often contains more than a million bacteria per ml. Inland seas generally contain more than 500 bacteria per ml., and waters from the open ocean, four or more kilometers from land, generally contain fewer than 250 bacteria per $\mathrm{ml}$. Larger bacterial populations were observed by Fischer in the open ocean beyond the direct influence of the coast where there was a convergence of cold nutrient-rich water and warmer water. Also he noted bacterial populations exceeding 1000 per $\mathrm{ml}$. associated with seaweeds in the Sargasso Sea. 4. In the Gulf of Naples, SANFELICE (I889) noted a marked decrease in the bacterial population at greater distances from land. This observation led him to conclude that bacteria are not indigenous to the marine environment but rather passive inhabitants from the land.

CASSEDĖBAT (I894) found thousands of bacteria per ml. in harbor water of Oran, Algeria, compared with only 33 per ml. two kilometers from land.

Gazert (I906b) made similar observations in the South Atlantic and Antarctic Ocean where the largest bacterial populations were found either in the vicinity of land or seaweeds. Seaweeds are usually most abun- 
dant near land although some varieties such as sargassum, for example, are not restricted to shallow waters. Also great rafts of sessile seaweeds are sometimes dislodged and carried far to sea by storms and ocean currents. GAZERT noted that the bacterial content of harbor water, which was nearly always higher than that of the open ocean, was related to the amount of terrigenous pollution in the region and was independent of the water temperature. Not nearly as many bacteria were found in harbor water at Simonstown, South Africa, as in Capetown harbor which receives much more land drainage.

Otтo and NeumanN (I904) observed the presence of thousands of bacteria per ml. of water near land and usually less than a hundred per $\mathrm{ml}$. in the Atlantic Ocean between Europe and Brazil. During a storm which stirred up the bottom material, over 10,000 bacteria per $\mathrm{ml}$. were found in sea water. It is to be expected that turbulence which suspends bottom deposits will increase the bacterial population of water because the bacterial population of bottom deposits is generally of the order of magnitude of millions per $\mathrm{ml}$. compared with hundreds per $\mathrm{ml}$. for the overlying water.

At 20 stations in the open Atlantic I 20 or more miles from land, GRÄF (I 909 ) found an average of 42 bacteria per $\mathrm{ml}$. as compared with an average of 2000 bacteria per ml. at I 2 stations less than I 20 miles from land. Using comparable procedures he found 54,000 bacteria per $\mathrm{ml}$. of water in the harbor of Lisbon, Portugal, and 15,000 per $\mathrm{ml}$. in that of nearby St. Vincent.

In the South Seas, LIPMAN (I920) found only ro bacteria per ml. of water from stations exceeding four miles from shore whereas there were as many as 400,000 bacteria per $\mathrm{ml}$. in samples near the strand. In the vicinity of Tutuila, Samoa Islands, LIPMAN found 1000 to 2000 bacteria per $\mathrm{ml}$. two or three miles from shore and 70,000 to 100,000 per $\mathrm{ml}$. in shallower water over Aua Reef.

From his studies on the bacterial populations of the ocean in the vicinity of Cape Cod, Massachusetts, REuszer (I933) concluded that on open, exposed shores receiving little land drainage, the effect of land on the bacterial content of sea water appears to be negligible. Along open shores, receiving considerable land drainage, any effect of the proximity of land does not extend beyond about a mile from the open shore, but in harbors receiving land drainage the number of bacteria may rise to very high levels.

Although more bacteria are nearly always found in coastal waters than in the open ocean, the proximity to land per se is not responsible for the larger bacterial populations. This is illustrated by the observations of ZoBell and Feltham (I934) at the Scripps Institution of Oceanography, which is strategically located beside the sea where there is virtually no land drainage except during the short rainy season, and the water depth increases rapidly with distance from land. The chemical composition, including the organic content of the water near shore, is virtually the same as that in the open ocean. During the dry season when the sea is calm there is little difference in the bacterial population of the water with distance from land, as illustrated by the data in Table XIII.

Water samples have been collected almost daily for twelve years from the Scripps Institution pier which extends rooo feet from shore. Plating procedures detect an average of a few hundred bacteria per ml., or about the same number as is found in surface waters of the Pacific Ocean at sta- 
tions up to several hundred miles from land. However, the bacterial population of the water collected from the pier and at other near-shore stations increases during and following periods of land drainage. Also when strong currents or turbulent seas stir up bottom deposits or carry in seaweed, many more bacteria are found in the water. GEE (I929) has commented on the more or less oceanic conditions near the Scripps Institution as indicated by the bacterial flora. The average annual rainfall in this region is only about I inches.

TABLE XIII.- Average number of bacteria per $m l$. of sea water collected at different distances from land in the vicinity of the Scripps Institution of Oceanography, La Jolla, California (from ZoBell and FelthaM, 1934):-

\begin{tabular}{c|c|c|c}
\hline \multirow{2}{*}{ DistancE From LAND } & \multicolumn{3}{|c}{ DAte OF EXPERIMENT } \\
\cline { 2 - 4 } & 23 Aug. I932 & 7 Sept. 1932 & I4 Sept. I932 \\
\hline I000 feet & 340 & $\mathbf{1 4 3}$ & 287 \\
3 miles & 470 & 157 & I9I \\
5 miles & 750 & 75 & 238 \\
7 miles & 330 & 65 & 332 \\
Io miles & 410 & 43 & 213
\end{tabular}

Entirely different conditions occur in the water of nearby Mission Bay and San Diego Bay. Water in these arms of the ocean contains from thousands to millions of bacteria per ml., and the microflora differs qualitatively as well as quantitatively from the oceanic microflora. Going seaward from San Diego Bay, the bacterial content of the water decreases with distance from land as shown by the data in Table XIV.

TABLE XIV.- Average number of bacteria per ml. of sea water collected while traveling sea. ward from San Diego Bay at low tide:-

\begin{tabular}{l|l|r}
\hline \multicolumn{1}{c|}{ Station } & \multicolumn{1}{c}{ Location } & Bacteria PER ML. \\
\cline { 1 - 2 } Yacht Club Harbor & About a mile inside the Bay & 480,000 \\
Whistling Buoy & Near entrance to Bay & 67,000 \\
$5 M_{34}$ & About 5 miles west of Bay entrance & 430 \\
IOM $_{34}$ & About Io miles west of Bay entrance & 5I0
\end{tabular}

The distance from land to which land drainage influences the bacterial population of sea water is primarily a function of the volume of drainage, oceanic circulation in the region, and the depth of the water. The terrestrial influence is noticeable far from the mouths of large rivers like the Columbia or the Amazon. The influence of the latter extends nearly 200 miles from land at certain times. Warm fresh water of low density mixes very slowly with non-turbulent sea water.

The wind often carries large numbers of soil microorganisms and other materials into the sea (ZoBELL, I942c), but the effect of wind-borne material on the bacterial population of sea water is negligible as compared with that of land drainage.

The decreasing abundance of bacteria with distance from land is not peculiar to the marine environment. A similar horizontal distribution of bacteria has been noted in fresh-water lakes, which indicates that factors besides salinity are responsible for the death of bacteria carried into large bodies of standing water.

Bacterial counts were about 200 times as great at the mouth of the main river flowing into Lake Windermere, England, as in samples of water 
which TAYLOR (I940) collected from the lake at a distance 200 meters offshore from the point of entry of the river. In his studies on the fate of bacteria washed into Lake Zürich by inflowing rivers, KLEIBER (I894) noted that the bacterial population dropped of sharply with increasing distance from land, the zone of rich flora extending only about 20 meters from the mouth of the river.

Similar observations on the horizontal distribution of bacteria were made in Lake Mendota by FreD el al. (I924). They found 400 to 600 times as many bacteria in samples taken at the mouth of a storm-water sewer as in samples of water collected roo meters offshore. The bacterial population of Lake Mendota, Wisconsin, was not influenced by the inflowing water after heavy rainfall or at times of melting snow for a distance of more than 1000 to 2000 meters from shore. These investigators concluded that, although land drainage is a continual source of contamination in the lake, the adventitious organisms introduced from the land do not remain long in large numbers, and except under unusual conditions, they do not occur very far from shore.

Effect of the tide:- The number of bacteria found in the entrance of San Diego Bay is influenced by the tide, which moves in and out twice a day. After the tide has been flowing in for five or six hours, the water may contain no more than a few thousand bacteria per ml. as compared with hundreds of thousands per ml. after the tide has been ebbing out of the Bay for similar periods. The bacterial content of the water a mile or two from the entrance to San Diego Bay is also influenced by the ebb and flow of the tide. The larger bacterial population of the Bay water is attributed to an increased content of organic matter and suspended solids, both of which promote the growth of marine bacteria.

Movements of the water caused by tides have no effect on bacterial populations except in very shallow water where bottom deposits are suspended or in regions where large quantities of organic matter may be carried seaward by tidal currents. ZoBELL and FELTHAM (I934) collected samples from the end of the Scripps Institution pier at high and low tide over a period of 14 weeks, finding an average of 348 bacteria per ml. at low tide and 294 per ml. at high tide. On I 5 days the low tide samples had a larger bacterial population, on I 2 days the high tide samples showed the larger counts and on 26 days the results of high and low tide samples were virtually the same. No other diurnal variations were noted during this time.

In those parts of the world where the tidal range is much greater than it is in the San Diego region, one might expect the influence of tidal currents on the composition of water to extend farther from land than it does here.

According to LLOYD (I930), the influence of tidal movements is more marked when there is a slightly shelving coast-line with a comparatively broad intertidal zone which supports much plant and animal life. In the lochs which she investigated in the Clyde Sea area off Scotland, "the steeply sloping sides afforded only a narrow intertidal zone, and the tidal variations do not appear to have much effect on the bacterial content of the water."

The bacterial population of sea water collected from the mouth of Mission Bay fluctuates with the tide as shown by the data in Table XV. Mission Bay is a shallow inlet of the ocean located midway between San Diego 
TABLE XV.-Bacterial population of inflowing and outflowing water collected at the mouth of Mission Bay (from ZoBell and FELTHAM, 1942):-

\begin{tabular}{l|r|r} 
DATE & $\begin{array}{c}\text { INFLOWING } \\
\text { WATER }\end{array}$ & $\begin{array}{c}\text { OUTFLOWING } \\
\text { WATER }\end{array}$ \\
\hline & Bacteria per ml. & Bacteria per ml. \\
$3 / 23 / 35$ & 2, I00 & 67,000 \\
$3 / 24 / 35$ & 870 & 102,000 \\
$3 / 25 / 35$ & 2,900 & 143,000 \\
$7 / 22 / 35$ & 1,360 & 380,000 \\
$7 / 23 / 35$ & 430 & 96,000 \\
$2 / 16 / 36$ & 7,200 & $2,060,000$ \\
$2 / 27 / 36$ & 1,740 & $1,850,000$ \\
Average for 34 days & 1,472 & 294,800 \\
Minimum & 194 & 31,000 \\
Maximum & 9,600 & $4,400,000$
\end{tabular}

and La Jolla, California. At high tide the water covers an area of four square miles and at low tide it is reduced to channels and lagoons aggregating less than half this area. The average depth of Mission Bay is only one meter, so a considerable portion of water is exchanged at each tidal cycle. Therefore an analysis of the outflowing water gives information on the bacterial population of the Bay water while the inflowing water is more representative of marine conditions. The rapid movement of the water tends to suspend much material.

Diurnal fluctuations in the bacterial population:- FISCHER (I894a) reported finding somewhat more bacteria in surface waters of the North Atlantic during the hours of darkness than during periods of intense sunlight. Similar diurnal fluctuations in the bacterial population of surface water were noted by BERTEL (I9I2) in the Mediterranean Sea and by Lloyd (I930) in the Clyde Sea. However, only a limited number of observations were made by these workers. BERTEL's conclusions were based upon only three series of samples.

Bacteriologists at the Scripps Institution of Oceanography have plated water samples periodically throughout the day and night at the end of the pier as well as at several stations in the Pacific Ocean off the coast of southern California and in the Gulf of California. The results from nearly a hundred series of samples failed to show any regular diurnal fluctuations in the bacterial population of water collected from depths of from one to five meters. In 26 series, more bacteria were found at night than during the day-time, but in 21 series the reverse condition was found. In 47 series the night and day counts were the same within the limits of accuracy of the plate count procedures; namely, \pm Io per cent. In those series where there was a significant difference in the abundance of bacteria found during different times of the day, the difference was no greater than what might be expected from the sporadic distribution of microorganisms in sea water.

As will be discussed below, it is doubtful whether the penetration of the ultraviolet radiations of sunlight is sufficient to cause any perceptible diurnal fluctuation in the bacterial content of sea water, particularly in view of the fact that the topmost few meters of water are fairly well mixed by wave action. The diurnal vertical migrations of zooplankton or nekton may influence the diurnal distribution of bacteria in the euphotic zone 
(CLARKE, I933). Likewise it is conceivable, although not demonstrated by field data, that the growth of bacteria may be influenced by diurnal fluctuations in the activity of photosynthetic organisms in the euphotic zone. In fact, there are several indirect ways in which sunlight could influence the abundance of bacteria in sea water throughout the day, but there is no experimental evidence to prove that sunlight has a direct effect upon the bacterial population of sea water (see section on the Effects of Solar Radiations on page 69).

Vertical distribution of marine bacteria:- In the mid-Atlantic Ocean, Fischer (I894a) usually found more bacteria at depths of 200 to 400 meters than in water near the surface. Hardly any bacteria were found at depths exceeding 1000 meters. Fiscuer examined samples from depths as great as 5250 meters, but his quantitative results are of questionable validity because he used a brass cylinder with open ends for collecting many of his samples. He reported that BASSENGE found bacteria to be most abundant a few meters below the surface in the North Atlantic Ocean and Caribbean Sea. Details concerning the technic used by BASSENGE are not available.

Using an evacuated glass bulb for the collection of samples in the Gulf of Naples, Russell (I89I) found about as many bacteria at a depth of I 100 meters as in surface water. Likewise no variation in the vertical distribution was noted in the shallow water in the Cape Cod region where RUSSELL (I893) analyzed samples from depths up to I40 meters at stations up to I 20 miles from land. Water movements in this region tend to prevent stratification.

Just off the coast near Oran, Algeria, Cassedebat (1894) noted an abrupt decrease in the bacterial content of water with increasing depth.

The number of bacteria found at different depths in the open Atlantic Ocean between Portugal and Brazil by OTTo and NEumanN (1904) is given in Table XVI. It is unfortunate that these workers failed to collect samples from depths intermediate between 5 and 50 meters. More recent work suggests that it is in these intermediate depths where the maximum bacterial population might have been found.

TABLE XVI.-Bacteria per ml. of water from different depths and stations in the Allantic Ocean (from Otto and NeumanN, I904):-

\begin{tabular}{l|r|r|r|r}
\hline \multirow{2}{*}{ Nearest LaNd } & \multicolumn{3}{|c}{ DEPTH OF WATER IN METERS } \\
\cline { 2 - 4 } & 5 & 50 & 100 & 200 \\
\hline Canary Islands & 120 & 76 & 20 & 1 \\
Cape Verde Islands & 58 & 16 & 64 & 6 \\
St. Paul Island & 20 & 480 & 54 & 4 \\
Pcrnambuco, Brazil & 48 & 168 & 83 & 14
\end{tabular}

During prolonged periods of calm weather, SCHMUDT-NIELSEN (I9OI) often noted the presence of twice as many bacteria in water at a depth of 25 meters as in surface waters of the North Sea between Oslo and Stavanger. He found bacterial stratification to be more marked in fjords than in unprotected water. Stratification is obliterated when the sea is rough. Although SCHMIDT-NIELSEN presented no data to prove his contention, he believed that when the sea was absolutely calm, differences might be found in the bacterial content of the very topmost layer and strata a few millimeters below the surface. 
As a matter of fact, a large number of microorganisms are usually associated with the surface film of water. The surface film serves as a mechanical support for organisms and miscellaneous particulate materials. Organisms which are associated with the surface film of water are termed neuston. WELCH (I935) describes various kinds of neuston found in freshwater lakes. In perfectly calm water the present author has often found two to four times as many bacteria concentrated in the surface film of water as in that collected a few centimeters below the surface, but more often no such relationships can be demonstrated.

The bacterial neuston is believed to have an influence on the surface tension of water. Occasionally during mild sea breezes, slicks have been observed at considerable distance from land in which the surface tension of the water was found to be only $6_{5}$ to 68 dynes $/ \mathrm{cm}$. as compared with 74 to 75 dynes/cm. for normal sea water. The topmost layer of water from these slicks usually contains many more bacteria than the surrounding water which is more readily ruffled by the wind. The cause of the increased bacterial populations in these slicks is still undetermined, but they are believed to be responsible for the depressed surface tension.

As a rule, there are no differences with depth in the abundance of bacteria in the topmost 5 or ro meters of sea water from the open ocean at any time of day or at any season of the year. The data recorded in Table XVII are typical of several investigations made at the Scripps Institution on the vertical distribution of bacteria in calm sea water.

TABLE XVII. - Average number of bacteria per $m l$. of sea water collected at various depths at La Jolla, California (from data by ZoBell and MCEwen, 1935):-

\begin{tabular}{c|c|c|c}
\hline \multirow{2}{*}{$\begin{array}{c}\text { WATER DEPTH } \\
\text { IN METERS }\end{array}$} & \multicolumn{3}{|c}{ DATE OF EXPERIMENT } \\
\cline { 2 - 3 } & 5 June I934 & 2 July I934 & 3 Aug. I934 \\
\hline 0 & 87 & 206 & 48 \\
O. I & 62 & 249 & 78 \\
O.5 & 38 & I64 & 35 \\
I.0 & 80 & 9 I & 73 \\
2.5 & 94 & I34 & 42 \\
5.0 & 63 & 282 & 27
\end{tabular}

Below the topmost 5 to Io meters (or more in turbulent seas) the bacterial population generally increases with depth to 25 or 50 meters and then decreases in water at stations off the coast of southern California. Below depths of 200 meters the bacterial population is rather sparse, plate counts rarely revealing the presence of more than io bacteria per $\mathrm{ml}$. In many samples rigorously collected from depths exceeding 200 meters, populations of fewer than one bacterium per $\mathrm{ml}$. have been detected by cultural procedures at stations where hundreds to thousands of bacteria per $\mathrm{ml}$. have been demonstrated in the euphotic zone. Thousands to millions of bacteria have been demonstrated per ml. of water taken at the bottom regardless of the depth of the overlying water. The curve in Fig. 7 depicts the general vertical distribution of bacteria based upon the average results obtained at more than a score of deep-water stations off the coast of southern California. Curves for individual stations differ markedly.

Schmidt-Nielsen (igor), Bertel (I9I2), and Föyn and Gran (I928) have observed that the bacterial population of sea water collected at different stations in the Atlantic Ocean increased from the surface 
downwards to depths of 40 to 50 meters and then decreased with depth until the bottom was reached. OTTO and NEumanN (I904) found somewhat more bacteria in the Atlantic Ocean between Europe and Brazil at depths of 50 to 100 meters than in surface waters and virtually no bacteria at depths exceeding 200 meters. DREW (I9I2) reported the number of

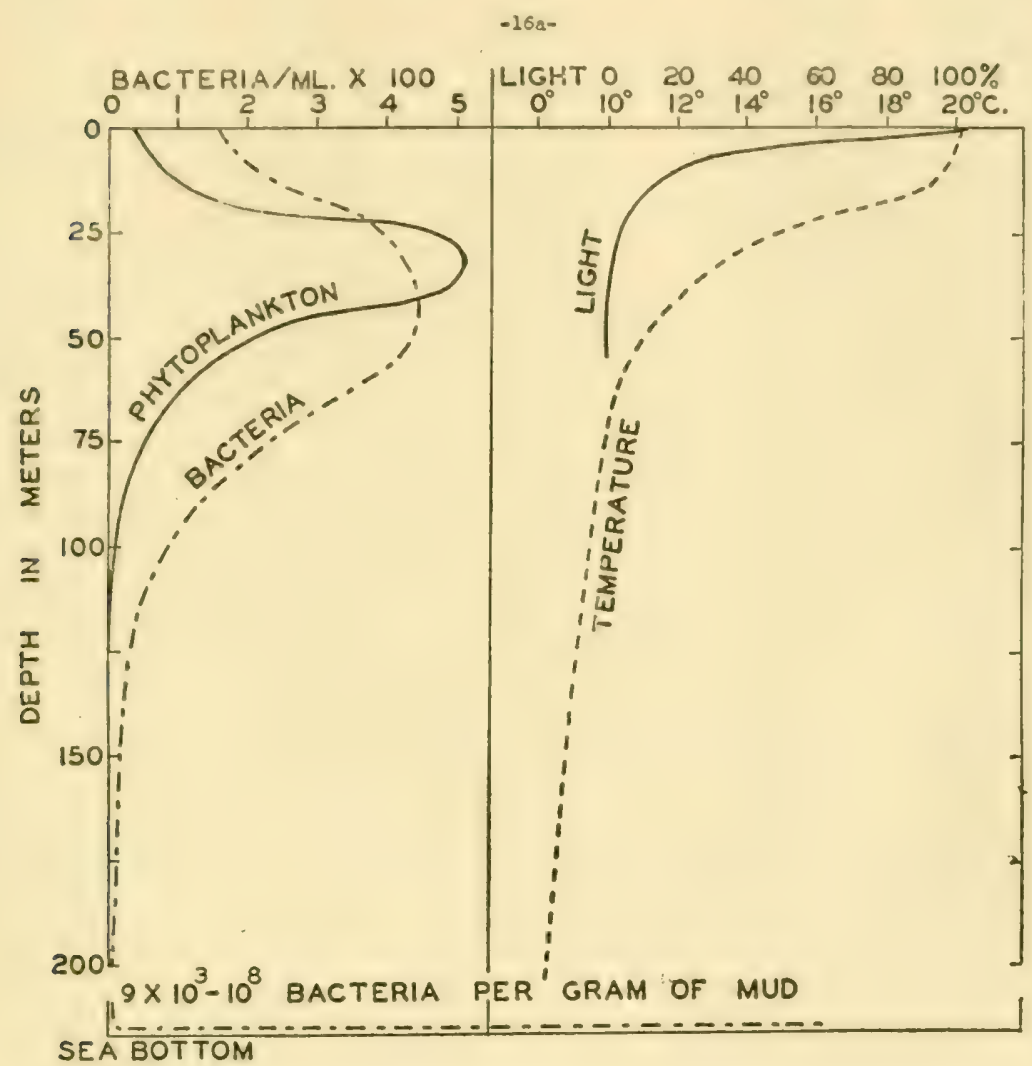

FIG. 7. - Vertical distribution of phytoplankton, bacteria, sunlight, and temperature in the Pacific Ocean, based upon the average results at several different stations off the coast of Southern California. The bacterial population is given in terms of numbers per ml. as indicated by plate counts, and the phytoplankton population is given as the numbers of diatoms per liter of water (ZoBELL, 1942a).

bacteria found at different depths of sea water off Andros Island, West Indies, as follows:

to 50 fathoms
200 fathoms
400 fathoms
600 fathoms
800 fathoms
Bottom deposits

Too numerous to count I60 bacteria per ml. I6 bacteria per $\mathrm{ml}$. I 7 bacteria per $\mathrm{ml}$. $\circ$ to 2 bacteria per $\mathrm{ml}$. $160,000,000$ bacteria per $\mathrm{ml}$.

Table XVIII summarizes the average number of bacteria found at different depths by LLOYD (I930) at certain representative stations in the Clyde Sea. The water samples from the "bottom" in Table XVIII were probably taken a meter or two off the bottom, because LLOxD (I93Ia) reported the presence of many thousand bacteria per ml. of bottom depos- 
TABLE XVIII.- Average number of bacteria per ml. of water found at different depths in the Clyde Sea by Lloyd (I930):-

\begin{tabular}{|c|c|c|c|c|}
\hline DEPTH & Loch Striven & Loch LoNG & GREENOCK & Cumbrae Deep \\
\hline Surface & 80 & 39 & 240 & 100 \\
\hline ro fathoms & I5 & 27 & $7 x$ & 9 \\
\hline 20 fathoms & 8 & 6 & - & 23 \\
\hline 30 fathoms & 7 & 一 & 一 & 9 \\
\hline Bottom & 8 & Io & $7 \mathrm{I}$ & 16 \\
\hline
\end{tabular}

its in the Clyde Sea. Lloxd (I930) found that the number of bacteria in surface water fluctuated widely, "apparently in relation to factors which are not seasonal but irregular.'

Due to differences in the depth, size, water movements, inflowing streams, seasonal changes, stratification, and other conditions in different lakes, it is difficult to generalize on the vertical distribution of bacteria in lakes. Moreover, the annual turnover tends to minimize differences in the vertical distribution of bacteria. According to HENRICI (I939), there is no sharp differentiation between the numbers of bacteria in the epilimnion and the hypolimnion even during periods of stratification, although he and most other workers have found somewhat more bacteria in the epilimnion than in the hypolimnion. The epilimnion is the upper stratum of sea or lake water in which the temperature is essentially uniform. In the stratum next below, known as the thermocline, there is a sharp drop in temperature per unit of depth. The hypolimnion is the lowermost region or stratum in which the temperature is nearly uniform.

KLEIBER (I894) failed to find any differences in the abundance of bacteria at various depths in Lake Zürich, but he examined water from only a few levels. At first, Minder (I920) made similar observations on the vertical distribution of bacteria in Lake Zürich, but later, when he examined samples from depth intervals of 5 meters, MINDER (1927) found the largest bacterial populations at a depth of 15 meters:

$\begin{aligned} \text { Surface } & 623 \text { bacteria per } \mathrm{ml} . \\ 5 \text { meters } & 700 \text { bacteria per } \mathrm{ml} . \\ \mathrm{r} 5 \text { meters } & 826 \text { bacteria per } \mathrm{ml} . \\ 30 \text { meters } & 503 \text { bacteria per } \mathrm{ml} . \\ 50 \text { meters } & 57 \mathrm{I} \text { bacteria per } \mathrm{ml} .\end{aligned}$

In Lake Ritom in Switzerland whose high salt content in the hypolimnion prevents an overturn of water, DüGGELI (I924) found marked differences in the types and numbers of bacteria at different depths. There were numerous heterotrophic aerobes in the surface layers and virtually none in the deeper water. Sulfate-reducing bacteria were abundant in the more saline bottom layers which had a high content of $\mathrm{H}_{2} \mathrm{~S}$. Purple sulfur bacteria thrived in an intermediate zone where the $\mathrm{H}_{2} \mathrm{~S}$-containing water approached the overlying oxygenated water. A similar bacterial stratification occurs in the Caspian Sea in which there is little or no dissolved oxygen below 300 meters. The Caspian Sea is a salt lake having a salinity ranging from ro to $20 \%$, the average being around I $2.8 \%$.

Bacterial stratification is even more marked in the Black Sea. Heterotrophic aerobes are abundant in the upper layers where the salinity is I 5 to $18 \%$ and virtually absent in the $\mathrm{H}_{2}$ S-rich water at depths exceeding I 50 meters where the salinity is 22 to $25 \%$. Only sulfate reducers and a few other anaerobic types of bacteria occur in the Black Sea at depths exceeding 150 meters. 
Effect of hydrostatic pressure:- After demonstrating the ability of bacteria to tolerate a pressure of 600 atmospheres of nitrogen, CERTES (1884b) concluded that the hydrostatic pressure of sea water does not influence the vertical distribution of microorganisms. CHLOPIN and TAMMANN (I903) found that bacteria, yeasts, and molds were not injured by pressures as high as 2900 atmospheres. This is approximately three times the greatest pressure found in the deepest part of the ocean.

HrTE ct al. (I9I4) subjected bacteria and yeasts to pressures exceeding I0,000 atmospheres. All of the organisms tolerated 2000 atmospheres for an hour. Many were not injured by a pressure of 6000 atmospheres.

None of the bacteria which LARSEN et al. (I9I8) subjected to a hydrostatic pressure of 3000 atmospheres were killed in I4 hours. Spore formers survived at 6000 atmospheres for 14 hours, but most asporogenous bacteria were killed by 6000 atmospheres. When compressed to 50 atmospheres, carbon dioxide killed some of the organisms. They tolerated I 20 atmospheres of nitrogen. The sudden release of the pressure was more harmful than continuous subjection to high gas or hydrostatic pressure.

Basset and Macheboeuf (1932) found that all bacteria tested withstood a pressure of 3000 to 4000 atmospheres. Some were killed at 6000 atmospheres. Spores of Bacillus subtilis tolerated pressures up to i 7,600 atmospheres. Some of the bacteria examined by BASSET et al. (I938) resisted pressures exceeding 20,000 atmospheres, although asporogenous bacteria were killed at 5000 atmospheres after 45 minutes. A pressure of I3,000 atmospheres was required to inactivate enzymes.

According to the literature reviewed by CATTELL (I936), single-celled microorganisms tolerate pressures of 3000 to 6000 atmospheres under ordinary conditions. Since the highest pressure in the sea approximates only I 000 atmospheres, it seems safe to conclude that the hydrostatic pressures encountered at great depths do not restrict marine bacterial life.

In all of the experiments upon which these conclusions are based, microorganisms which normally live at a pressure of one atmosphere were subjected to increased pressures. The reverse process, or a decrease in hydrostatic pressure, occurs when bacteria from the deep sea are brought to the surface. Finding large numbers of viable bacteria in samples of bottom deposits from great depths is ample evidence that these bacteria are not killed by being subjected to decreasing pressures. However, just what effects hydrostatic pressure may have on the metabolism of the bacteria is problematical.

In interpreting experiments on the effects of hydrostatic pressure on bacteria, cognizance must be taken of the fact that the results are influenced by the temperature and the composition of the medium. In some of the experiments reported in the literature, the temperature of the compressed material has approached the threshold of thermal tolerance of the organisms being tested. In other experiments the products of metabolism, including high concentrations of endogenous carbon dioxide, may have contributed to the observed lethal effects. The rates of compression and release of the pressure are likewise important factors.

Effect of solar radiations:- The curves in Figure 7 (p. 67) seem to suggest that the abundance of bacteria in the topmost 25 to 50 meters of water is more or less proportional to the intensity of sunlight at different depths. A similar relationship between the abundance of bacteria and the 
intensity of light noted by various workers has led some of them to conclude that bactericidal radiations restrict the bacterial population in surface waters (PFEnNIGer, I902; Minder, I920; DỦGgeli, I924).

Half a century ago FRANKLAND and FrANKLAND (I894) recorded the following observations: $(r)$ There is no question that bacteria are injured by sunlight, particularly ultraviolet radiations. (2) A complicating factor in the study of the effect of light on bacteria is the influence of the surrounding medium. (3) Most divergent results have been obtained by different workers as regards the precise duration of exposure to sunlight. (4) Although the exact time that bacteria will endure insolation in water varies greatly, the balance of evidence tends to show that they are less rapidly destroyed in water than when exposed in culture media, probably due to peroxide formation in the latter. (5) Evidence on the depth of water to which the sun's rays take effect is very contradictory, but it seems to be the concensus of most workers that solar rays are largely, if not entirely, deprived of their bactericidal effect by passing through from 5 to $60 \mathrm{~cm}$. of water. "In its special connection with the bacteriology of water we must, therefore, recognize in sunshine a powerful bactericidal agency, but one the importance of which there has been a considerable tendency to magnify and exaggerate."

FISCHER (I894a) found more bacteria in surface water from the North Atlantic at sunrise than in the afternoon. Schmidt-Nielson (I90I) attributed to the lethal action of sunlight the difference between 26 bacteria per $\mathrm{ml}$. of surface sea water and 420 per $\mathrm{ml}$. found at a depth of 25 meters. Similarly GAARDER and SPÄRCK (I93I) ascribed to the bactericidal effect of sunlight the paucity of bacteria in Norwegian oyster pools in the summer as compared with their greater abundance in winter. MiNder (I920) sought to explain the summer minima and low bacterial counts in surface water in Lake Zürich on a basis of the lethal action of sunlight. ZIH (I932) offered the same explanation to account for the greater abundance of bacteria in winter than in summer in Lake Lunz, Switzerland.

While it has been amply confirmed in nearly all parts of the world that there is often an apparent negative correlation between the abundance of bacteria in water and the intensity of light, there are no data which prove that the bactericidal action of sunlight is directly responsible for the diurnal, seasonal, or vertical distribution of bacteria in either the ocean or large lakes. FRED et al. (I924) found no evidence that light influences the bacteria in surface water of Lake Mendota, Wisconsin. Although the number of bacteria observed by LLOYD (I930) in the surface layers of water in the Clyde Sea, Scotland, increased slightly during the hours of darkness, even on sunny summer days there were more bacteria at the surface than in the underlying strata, leading her to deduce that the bactericidal effect of sunlight is negligible. REuszer (I933) found no correlation between the number of bacteria in surface sea water and exposure to sunlight during the summer months near Cape Cod, Massachusetts. From their studies on the California coast, ZoBeLL and Feltham (I934) concluded that if there is any direct harmful effect of sunlight on bacteria in sea water, it is obscured by other factors.

Failing to find any evidence for the lethal effect of sunlight upon the diurnal, seasonal, or vertical distribution of bacteria in the sea, ZoBELL and MCEwEN (I935) exposed shallow layers of sea water in glass vessels to direct mid-summer sunlight at La Jolla, California. The results, which 
are summarized in Table XIX, demonstrate that sunlight does have a lethal effect on bacteria suspended in shallow layers of sea water, but the effect does not extend to depths exceeding $20 \mathrm{~cm}$. In their experiments the temperature of the water was maintained at $25^{\circ}$ to $26^{\circ} \mathrm{C}$. in a bath of running water. Controls were kept in the dark.

TABLE XIX. - Average number of bacteria per ml. of sea water of different depths in ballery jars after being exposed to sunlight for two hours from I1:00 A.MI. to I:00 P.M.:-

\begin{tabular}{|c|c|c|c|c|}
\hline \multirow{2}{*}{$\begin{array}{c}\text { DEPTI OF WATER } \\
\text { IN MM. }\end{array}$} & \multicolumn{3}{|c|}{ NuMBER OF Bacteria PER ML. OF WATER } & \multirow{2}{*}{$\begin{array}{l}\text { PERCENTAGE } \\
\text { DECREASE } \\
\text { ATTIUUTABLE } \\
\text { TO EFFECT OF } \\
\text { SUNLIGHT }\end{array}$} \\
\hline & $\begin{array}{l}\text { AT BEGINNING } \\
\text { OF EXPERIMENT }\end{array}$ & $\begin{array}{l}\text { AFTER } 2 \text { HOURS } \\
\text { IN THE DARK }\end{array}$ & $\begin{array}{c}\text { AFTER } 2 \text { HOURS' } \\
\text { EXPOSURE }\end{array}$ & \\
\hline 2 & I 71 & 164 & 76 & 48.7 \\
\hline 5 & I69 & I 59 & 108 & 32.0 \\
\hline 10 & 168 & 163 & I 26 & 22.7 \\
\hline 10 & 240 & 228 & 184 & $19 \cdot 3$ \\
\hline 20 & 203 & I 88 & 165 & 12.2 \\
\hline 35 & $24 \mathrm{I}$ & 216 & 198 & 8.7 \\
\hline
\end{tabular}

It has already been pointed out on page $\mathbf{2}$ that the penetration of sunlight decreases rapidly with depth. Ultraviolet radiations are far less penetrative than visible radiations, the penetration of the former decreasing with wave length. This is graphically illustrated by Figure 8 which

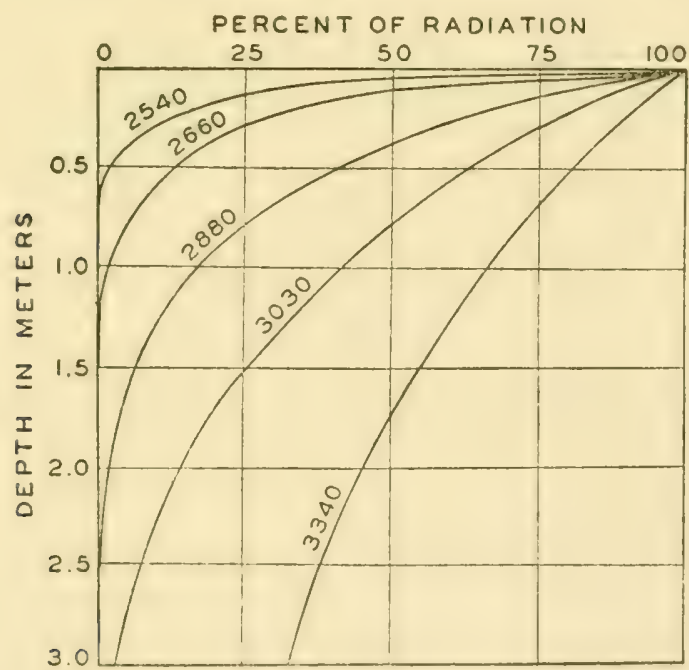

FIG. 8. - Percentage of incident radiations of different wave lengths (expressed as Angstrom units) which penetrate clear sea to different depths (adapled from HulbuRT, 1928).

gives the absorption curves for ultraviolet radiations of different wave lengths in the abiotic range in clear sea water. According to the literature reviewed by Ellis et al. (I925) and by Buchanan and Fularer (I930), the bactericidal range of solar radiations is from 2100 to $2960 \AA$, the maximum being between 2500 and $2800 \AA$. Wave leng ths from 3000 to $3660 \AA$ are only feebly abiotic.

From Figure 8 it will be observed that the penetrative power of wave 
lengths shorter than $2800 \AA$ is very small. Virtually all of the radiations which are most bactericidal are absorbed by the first meter of sea water. The intensity of the most lethal radiations is reduced nearly 50 per cent by passage through only $10 \mathrm{~cm}$. of sea water. The lethal action of ultraviolet radiations decreases exponentially with decreasing intensity. If the intensity of sunlight is sufficiently intense at the surface of the water to kill a given bacterium in ten seconds, it would require more than Ioo seconds to kill such a bacterium protected by a layer of sea water $40 \mathrm{~cm}$. thick, and rooo seconds to kill it in $70 \mathrm{~cm}$. of water.

The absorption curves in Figure 8 are based upon observations by Hulburt (I928) in which the angle of incidence of the radiations is $90^{\circ}$ and in perfectly quiet, clear sea water free of suspended matter. The transmission of radiations is reduced proportionately as the angle of incidence decreases. The transmission is also reduced when the surface of the water is ruffled and by the presence of particulate matter. So few as roo bacteria per $\mathrm{ml}$. of water greatly decrease the transmission of ultraviolet radiations.

HULBURT (I928) found that sea water is much less transparent to ultraviolet radiations than is pure distilled water, the absorption coefficient for the wave length of $3030 \AA$ being 0.017 in sea water as compared with 0.005 in distilled water. The transmission of ultraviolet radiations by fresh water in lakes or rivers is primarily a function of its content of electrolytes and suspended materials, its turbulence, the angle of incidence, and the intensity of the incident radiations.

In natural fresh water, BUCHNER (I893) noted only a feeble lethal action of sunlight on bacteria, the bactericidal power penetrating less than 3 meters. JORDAN (I900) found that in river water, sunlight is virtually without bactericidal action. Even in clear calm water it is doubtful whether abiotic radiations are active more than 5 feet from the surface, and due to the turbidity and constant movement of most bodies of water in nature, it is improbable that bacteria are subjected to radiations for sufficient time or in sufficient intensity to be killed.

From his data on the seasonal and vertical distribution of bacteria in Lake Windermere, England, TAYLOR (I940) detected no bacteriostatic effect of the sun's rays. During an eleven-week period he found almost as many bacteria in samples collected from the immediate surface as in samples from a depth of I meter, and there were generally more bacteria in surface water than in samples from a depth of ro meters.

It has been pointed out by PREscott and WinsLow (I93I) that the tendency of bacteria to settle in standing water has been misinterpreted as a lethal action of sunlight. This criticism is applied to the work of Clemesha who attributed very great importance to the action of light in the self-purification of lakes and rivers in India after observing more bacteria in bottom water than in the superficial layers of water.

The increasing abundance of bacteria from the surface downward as shown by the curve in Figure 7 on page 67 may appear at first sight to indicate a direct inhibitory effect of sunlight in surface waters, but there are other more cogent factors which account for the vertical distribution of bacteria. Unquestionably light does have an indirect effect upon the diurnal, seasonal, horizontal, and vertical distribution of bacteria in sea water or lake water through the intermediary of photosynthetic organisms and to a lesser extent of phototropic organisms. In the latter category are certain zooplankton which migrate towards the surface during 
hours of darkness and sink to deeper water as the intensity of sunlight increases (SPOONER, I933; ClARKE, I933; Russell, 1936). The abundance of diatoms, dinoflagellates, and other phytoplankton in water is directly associated with light intensities (STANBuRY, I93 I I'ETTERSSON et al., 1934).

Temperature as an ecological factor:- In a stable environment like the sea where the lack of organic matter or solid surfaces are known to limit the bacterial population, it is doubtful whether the temperature has much influence on the number of bacteria found there, although the temperature unquestionably influences the kinds of bacteria and their activities. The total bacterial population is merely the dynamic balance between the rate of reproduction and the death rate of bacteria in a given environment. Increasing the temperature may increase the rate of multiplication of bacteria within certain limits, but it may also increase their rate of death.

In all except surface waters, the temperature of the marine environment is practically constant throughout the year. In surface waters the annual temperature range is usually only a few degrees Centigrade. If organic nutrients and other conditions essential for growth are present, minor increases in temperature may materially accelerate the rate of bacterial multiplication and metabolic activity - but only temporarily. At the increased rate of assimilation of organic nutrients, a lack of the latter soon restricts further multiplication, in spite of the increased temperature, until more organic matter becomes available from some source. In the meantime, the increased temperature may have accelerated the death rate of the bacteria so that the increased temperature merely causes a temporary fluctuation in the bacterial population.

Evidence for these views is forthcoming from data on the abundance of bacteria in sea water having different temperatures. The largest bacterial populations in the sea occur on the sea floor which, in general, is the coldest part of the ocean. However, little difference has been found in the numbers of bacteria in shallow bottoms in tropical seas where temperatures of from $20^{\circ}$ to $25^{\circ} \mathrm{C}$. prevail and in deep sea bottoms where the temperature is perpetually lower than $5^{\circ} \mathrm{C}$. In warm shallow bottoms, bacteria multiply more rapidly, partly because the temperature is higher and partly because more organic matter is settling from the overlying water, but they are also dying off more rapidly. In cold deep bottoms which receive only a limited amount of organic matter, bacteria multiply more slowly but they live longer. When a dynamic balance is struck, it appears that the total bacterial population is independent of temperature except in so far as the temperature influences the availability of organic matter, the principal limiting factor.

It has already been mentioned that an annual temperature change of about $8^{\circ} \mathrm{C}$. in the surface water temperature at La Jolla has not caused any detectable fluctuations in the seasonal distribution of bacteria over a period of ten years. Similarly there are no differences in the number of bacteria in surface waters at different latitudes which can be correlated directly with temperature over a range of near $0^{\circ} \mathrm{C}$. in arctic waters to $25^{\circ} \mathrm{C}$. in tropical waters. However, the temperature does influence the metabolic rate of bacteria and the kinds which are present. As will be elaborated elsewhere, there are marine bacteria which multiply at temperatures considerably lower than any temperature found in the sea and 
others which multiply at temperatures several degrees higher than those encountered in any marine environment.

In environments less stable than the ocean or in regions where there are no other limiting factors, temperature is one of the most important ecological factors. In lakes and reservoirs, for example, there is often an indirect correlation between the vertical and seasonal distribution of bacteria with temperature. Moreover, seasonal changes in temperature are responsible for the annual overturn of the water which is characteristic of lakes in the temperate zones (WELCH, I935). TAYLOR (I940) found no direct effect of temperature on the number of bacteria in water in English lakes, the annual temperature of which ranges from $2^{\circ}$ to $20^{\circ} \mathrm{C}$.

The bacterial population of sea water stored in glass receptacles is largely a function of the temperature of incubation until a state of equilibrium is reached. Thereafter the bacterial population is independent of temperature within the range of from $0^{\circ}$ to $25^{\circ} \mathrm{C}$.

The temperature range of growth of marine bacteria and the influence of temperature on their activities are discussed elsewhere in this volume.

Seasonal distribution of marine bacteria:- Very few workers have been in a position to make sufficiently extensive or continuous observations on the bacterial populations of oceans or lakes to show definite seasonal cycles of abundance. In Lake Zürich, PFENNIGER (I9O2) observed a summer minimum, with spring and autumn maxima. He attributed the autumn maximum to the food supplied by dead plankton organisms. After making similar observations in Lake Zürich, MiNDER (I920) ascribed the summer minimum to the lethal action of sunlight, but he failed to consider several other concomitant factors which are known to influence the abundance of bacteria in bodies of natural water. RUTTNER (I932) correlated the spring and autumn maxima observed in Lake Lunz with the semiannual turnover of the lake. The highest counts occurred in the spring following the runoff of melted snow.

Conversely FRED et al. (I924) failed to find any definite seasonal cycles. These workers, who recognized the complexity of factors which influence the seasonal distribution of bacteria, observed the abundance of bacteria in Lake Mendota for three consecutive years. In I920 the highest plate counts were observed during the summer, in I92 I the maximum occurred in the autumn, and during 1922 in the spring.

In Lake Alexander in Minnesota, HENRICI (1938) found a gradual increase in the bacterial population as indicated by plate counts as well as by the submerged slide technic from the time that the ice went out in April until August when the maximum count was obtained. The bacterial population decreased throughout September and October, at which time the survey was discontinued. Only minor fluctuations were noted. The fluctuations were probably less than could be accounted for by the sporadic distribution of microorganisms in water and variations directly attributable to sampling and counting errors. Significantly, the curve for the abundance of bacteria in Lake Alexander followed that for the abundance of plankton during the months when observations were made.

LLOYD (I930) found the number of bacteria in the Clyde Sea to be remarkably constant throughout the year for all layers except the surface. The bacterial content of surface waters fluctuated widely, but there was no evidence of rhythmic seasonal variation. In interpreting her data, Lloyd says, "Any variations outside the limits of the accuracy of the 
experimental methods adopted appear to be erratic and therefore camnot be correlated with any factor varying seasonally." Drainage from land was one factor which operated intermittently at irregular intervals to increase materially the bacterial population of surface water. The number of bacteria in surface water was also observed to be unusually high during the time that herring fishing was in progress in the Clyde Sea. The range of temperature variation was not sufficiently wide during the year to affect the bacterial content of sea water.

Samples of sea water have been collected from the end of the Scripps Institution pier five or six times a week for bacteriological analysis, using comparable procedures since January 1932. The only break in this series was during 1938. Besides giving information on the seasonal distribution of bacteria in sea water, the plates provided a source of cultures which have been used for studies on bacterial physiology and for other purposes. The monthly averages for the years are recorded in Table XX.

TABLE XX.- Average plate counts on surface sea water at La Jolla, Califormia, based upon about 24 daily plate counts for each month during a ten year period:-

\begin{tabular}{l|r|r|r|r|r|r|r|r|r|r|r}
\hline & & & & & & & & & & & \\
AGE \\
AG- \\
FOR \\
TEN \\
YEARS
\end{tabular}

The most striking feature of the monthly averages is their remarkable constancy throughout the year. From Table XX it will be observed that during only four months in ten years was the average plate count for the month less than Ioo bacteria per $\mathrm{ml}$. of sea water. The monthly average exceeded 1000 bacteria per $\mathrm{ml}$. only eight times. The lowest plate count obtained for any one day during the ten year period was on a sample collected October 4, I932, which contained only 7 bacteria per ml. of water. The count remained quite low during the first week in October I 932 to bring the average for the entire month down to Io8 bacteria per $\mathrm{ml}$. The highest count during the ten year period was on a sample of water collected on November I6, I94I. This high count of 30,700 viable bacteria per $\mathrm{ml}$. and other high counts on two or three following days are directly attributable to a storm which stirred up the bottom and brought in large quantities of seaweed from the kelp beds a few miles away.

Many of the high counts obtained during the winter months are attributable to the turbulence of water caused by storms. If it were permissible to disregard the plate counts obtained on the days during and immediately following such oceanic disturbances, the resulting averages for relatively calm days would show that the abundance of bacteria in the water parallels the abundance of phytoplankton more closely than any 
other observed property of the water. AlLEN's (1937) data on the seasonal distribution of phytoplankton off the La Jolla pier from I920 through 1939 show that phytoplankton organisms vary in abundance throughout the year much more than do bacteria.

There is a definitely rhythmic seasonal cycle in the temperature of the surface water at this latitude. Year after year the water temperature has been observed to increase from a minimum of about $12^{\circ} \mathrm{C}$. in the winter months to a maximum of about $23^{\circ} \mathrm{C}$. reached during the summer months, but the abundance of bacteria in the surface water fails to parallel this seasonal periodicity, except for short periods of time.

Likewise the annual distribution of bacteria in surface sea water cannot be correlated with the intensity of solar radiations. The latter has

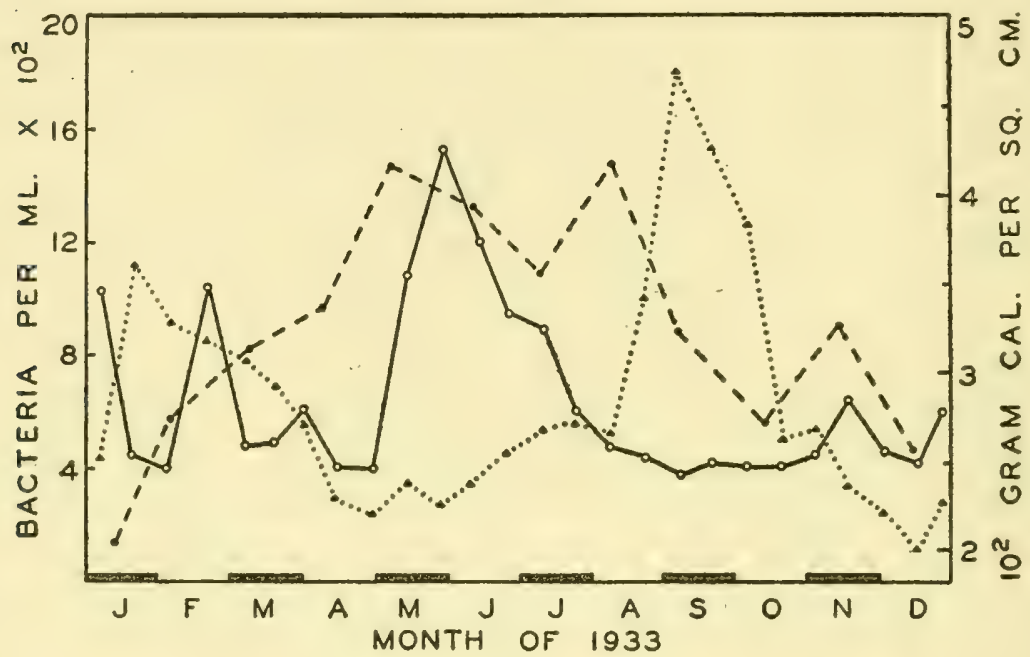

FIG. 9. - Seasonal distribution of bacteria (dotted line) in surface sea water at La Jolla, California, based upon the average of daily plate counts from January through December, I933. The relative number of phytoplankton organisms per liter of sea water (solid line) and the intensity of solar radiation (dashed line) are also given. The latter was measured by the recording pyrheliometer at the Scripps Institution.

been measured continuously by an automatic recording pyrheliometer which shows a definite seasonal cycle, the period of maximum insolation at this latitude being from May through July. Minimal plate counts are often observed during this period of maximum insolation as shown by the curves in Figure 9, but during other years there is no semblance of correlation between the abundance of bacteria in surface sea water and the intensity of sunlight.

The studies stress the importance of continuous and extensive observations preliminary to evaluating any single ecological factor. The complexity of the factors influencing the marine environment is also illustrated by these studies on the seasonal distribution of bacteria. The complexity of the marine environment is emphasized by ALLEN (I94I) in his "Twenty years' statistical studies of marine plankton dinoflagellates of southern California."

Below the euphotic zone the marine environment appears to be highly uniform throughout the year. One would not expect to find seasonal 
microbiological variations in such a constant environment. The fragmentary observations which have been made show nothing to the contrary.

Effect of other organisms:- Prof. W. E. AlLEN of the Scripps Institution has kept a daily record of the abundance of diatoms and dinoflagellates in samples of local sea water during the last 25 years. A comparison of these phytoplankton records with the bacterial plate counts during the last ten years shows that, in general, the largest bacterial populations are found in water containing the most phytoplankton. This is shown better from an inspection of the daily or weekly averages than from the monthly averages, because the abundance of phytoplankton fluctuates within rather wide limits from day to day as does the bacterial population of sea water. It is for this reason that ALLEN (I94I) stresses the necessity of continuous observations over a long period of time.

Curves for the vertical distribution of bacteria follow very closely the curves for the vertical distribution of diatoms and other phytoplankton, as is illustrated by Figure 7 on page 67 .

Since phytoplankton constitute the principal source of food of bacteria in the sea, as well as providing solid surfaces for attachment, it is not surprising that the abundance of bacteria is closely related to the abundance of phytoplankton. The total quantity of organic matter in sea water varies very little with depth until the bottom of the sea is reached. Actually there is often somewhat more organic matter in water below than in the euphotic zone in spite of the activities of photosynthetic organisms. Nevertheless, bacteria are usually most abundant where there is particulate organic matter.

In studying the relation of marine bacteria to plankton diatoms in which bottles filled with sea water were suspended in the sea, GraN (I 933) observed that the abundance of bacteria increased and decreased with the diatoms. While there is nothing in GRAN's experiments to indicate whether the bacteria were attached to the diatoms or whether the diatoms provided the saprophytic bacteria with organic matter for growth, the observation provides supplementary evidence of the close relationship between bacteria and diatoms in the sea.

WAKSMAN et al. (I933c) analyzed sea water and plankton tows from the same water for the presence of bacteria. A number 20 silk net was used, which until the pores become clogged would not collect many nannoplankton or bacteria. However, large numbers of bacteria were found in the plankton tows, presumably because the bacteria were attached to the plankton. From 500 to 2,270 times as many bacteria were found per unit volume of diatom plankton as were found in the unstrained water. These workers concluded that this indicates that a definite parallelism exists between the bacteria and the plankton content of the sea. The actual existence of such a relationship is substantiated by the fact that the bacteria from the diatom tow showed a considerable abundance of agarliquefying organisms. While one encounters only infrequently such organisms in the free water, they were found to make up 5.7 to 6.7 per cent of the total bacterial flora in plankton tows, as determined by the plate method.

According to WAKSMAN et al. (1933c) bacteria occur only to a very limited extent floating free in water, most of them being attached to plankton organisms. Bacteria may live upon dead plankton or upon the 
excretion products of the cells, upon the cell membranes, and especially upon the mucilaginous substances which are excreted by certain algae. Since dead or decomposing plankton organisms serve as well or better for the attachment or food requirements of bacteria, the abundance of bacteria may not always parallel the abundance of living plankton. The maximum bacterial counts may occur after the diatoms start to die. The data from an experiment conducted by WAKSMAN et al. (I933c) are summarized in Table XXI to illustrate this point. Not only do dead and decomposing plankton organisms furnish saprophytic bacteria with a ready source of food, thereby providing for the multiplication of bacteria, but when the particulate organic matter is decomposed, attached bacteria are liberated, thereby making it possible to detect more of them by plating procedures.

TABLE XXI.- Comparative numbers of diatoms and bacteria per ml. of sea water afte different periods of incubation at $25^{\circ} \mathrm{C}$.:-

\begin{tabular}{l|c|c|c|r}
\hline & \multicolumn{4}{|c}{ PERIOD OF INCUBATION } \\
\cline { 2 - 4 } & 0 & 3 DAYS & 7 DAYS & \multicolumn{1}{|c}{ I2 DAYS } \\
\hline Diatomi & $\mathrm{I} 77$ & $\mathrm{I}, 026$ & $\mathrm{I} 78$ & I65 \\
Bacteria & 346 & 20,600 & 22,800 & I3,900
\end{tabular}

HENRICI ( I938) observed a distinct parallelism between the abundance of bacteria and the abundance of phytoplankton in Lake Alexander.

The view is expressed by PÜTTER (I926) that the secretion of dissolved substances by phytoplankton is the most important process by which heterotrophic bacteria in the euphotic zone are nourished. According to BRAARUD and FöYN (I93I), not less than 30 per cent of the anabolites of certain phytoplankton are secreted by the living cells. From their experience with diatoms, MARSHALL and ORR (I930) doubt that phytoplankton secrete dissolved organic matter. GRAN and RUUD (I926) and GAARDER and GRAN (I927) believe that certain phytoplankton secrete organic substances copiously. Various aspects of this controversial problem are discussed by ROBERG (I930) and KROGH (I93I).

WAKSMAN et al. (I937) found no evidence that living diatoms nourish saprophytic bacteria, although dead diatoms are rapidly decomposed by bacteria and large bacterial populations are found associated with living diatoms. Quite likely the bacteria associated with living diatoms serve a useful purpose by producing ammonia, phosphate, carbon dioxide, and possibly other plant nutrients from the decomposition of dead organic matter.

WAKSMAN et al. (I937) believe that amoebae, ciliates, copepods, and other grazing animals may be largely responsible for the destruction of living diatoms.

Bacteria are also found associated with zooplankton and other animals in the sea. However, in the euphotic zone, animals do not appear to exert as great an influence on the abundance of bacteria as do phytoplankton and other plants. This is because phytoplankton organisms greatly outnumber zooplankton and nektonic animals in total numbers as well as in total weight. Apparently zooplankton have fewer bacteria associated with them than phytoplankton, the ratio of bacterial numbers per unit volume of zooplankton tow to numbers of bacteria in the unstrained water being $225: \mathrm{I}$ as compared with ratios of from 500:I to 
2,270:I for bacteria in phytoplankton tows (WAKSMAN et al., I933c).

On the sea floor the direct influence of animals is more pronounced than that of plants. Dead animals, like dead plants, provide food for saprophytic bacteria. Large numbers of bacteria are also often associated with living marine animals, but it is doubtful whether this association materially influences the distribution of bacteria in the sea except in localized regions. Many kinds of marine animals ingest and digest bacteria as a source of food (page I73). Such animals may tend to restrict the bacterial population of the sea within certain limits. The interrelations of bottom fauna and bacteria have been investigated by MARE (I942).

Animals which promote the precipitation and sedimentation of bacteria probably play an important role in restricting the bacterial population. Lamellibranch mollusks, certain tunicates, sponges, coelenterates, and other ciliated mucus feeders filter large quantities of water, removing from it suspended material including bacteria. Sea mussels of average size studied by Fox et al. (I937) propelled from 2.2 to 2.9 liters of water per hour through their gill chambers removing all suspended matter. Some of the material removed from the water is swallowed by the mussel and the rest is rejected as strands of pseudofeces. Fox and CoE (I943) have demonstrated the ability of the California mussel to remove from sea water very fine, uncentrifugable, colloidal material such as Congo Red or boiled "soluble starch" particles which are considerably smaller than bacteria. In experiments conducted by ZoBELL and LANDON (I937), the California mussel reduced the bacterial population from 200 million bacteria per $\mathrm{ml}$. of sea water to less than ro,000 per $\mathrm{ml}$. in two hours. DodGSON (I928) has reviewed the earlier literature on the importance of mussels, oysters, and other animals in the purification of water.

The early literature on the role of predatory protozoans and other bacteria-feeders upon the self-purification of natural water has been reviewed by Müller (I9I2b), Prescott and Winslow (I93I), and by BAIER (I935). There is clear-cut evidence that in polluted water which may contain millions to billions of bacteria per $\mathrm{ml}$, protozoans and micro-crustaceans thrive at the expense of the bacterial population. This is illustrated by the experiments of PURDy and ButTerfield (I9I8) in which the bacterial population of polluted water containing no Paramoecia remained fairly constant, but when Paramoecia were present the bacterial population decreased while the Paramoecia increased.

A stage is reached when there are no longer enough bacteria present to provide a livelihood for the predatory animals. A survey of the literature fails to reveal any instance in which protozoans or other bacterivorous organisms have reduced the bacterial population below several thousand per ml. as determined by plating procedures. Since the bacterial population of sea water is generally in the order of magnitude of hundreds per $\mathrm{ml}$, it is reasonable to conclude that bacterivorous animals are not a major factor in restricting the number of bacteria found in the open sea. In polluted water or bottom deposits, however, which support large bacterial populations, bacteria may constitute an important part of the dietary of small animals, and the predatory activities of such animals may be an important ecological factor.

WAKSMAN (I937) relates that the significance attached to protozoans as a factor controlling the microbial population of the soil has been considerably modified in recent years. In many cases the protozoans are actually beneficial, as shown by the observations of CUTLER and CRUMP ( I 929), 
MeIKLEJohn (I930), and others. Although protozoans consume appreciable numbers of bacteria, CUTLER and CRUMP (I935) believe that the activities of protozoans in the soil keep the bacteria at a level of maximum efficiency.

The significance of the relationship between the fauna of lakes and the bacterial population is emphasized by BAIER (I935) who has reviewed the rather extensive literature on the importance of bacteria as food for animals. BAIER's appraisal of the relative role played by bacteria as food for different classes of animals in different types of lakes is summarized in Table XXII.

TABLE XXII.- Relative importance of bacteria as food for different classes of predacious animals in different kinds of lakes (from BATER, 1935):-

\begin{tabular}{|c|c|c|c|}
\hline \multirow{2}{*}{$\begin{array}{c}\text { TYPE OF LAKE OR } \\
\text { NUTRIENT PROPERTIES }\end{array}$} & \multicolumn{3}{|c|}{ CLASS OF PREDACIOUS ANIMALS } \\
\hline & Protozoans & Filterers & SEDIMENTATERS \\
\hline $\begin{array}{l}\text { Eutrophic, rich in } \\
\text { nutrients }\end{array}$ & $\begin{array}{l}\text { Predominant } \\
\text { importance }\end{array}$ & $\begin{array}{l}\text { Predominant } \\
\text { importance }\end{array}$ & $\begin{array}{l}\text { Considerable } \\
\text { importance }\end{array}$ \\
\hline $\begin{array}{l}\text { Dystrophic, rich in } \\
\text { humus }\end{array}$ & $\begin{array}{l}\text { Slight } \\
\text { importance }\end{array}$ & $\begin{array}{l}\text { Moderate } \\
\text { importance }\end{array}$ & $\begin{array}{l}\text { Slight } \\
\text { importance }\end{array}$ \\
\hline $\begin{array}{l}\text { Oligotrophic, poor } \\
\text { in nutrients }\end{array}$ & $\begin{array}{l}\text { Considerable } \\
\text { importance }\end{array}$ & $\begin{array}{l}\text { Moderate } \\
\text { importance }\end{array}$ & $\begin{array}{l}\text { Slight } \\
\text { importance }\end{array}$ \\
\hline
\end{tabular}

Further details on the relationship of marine bacteria to flora and fauna are given in Chapter XIV.

The antagonistic effects of microorganisms:- Bacteria and allied microorganisms indigenous to the marine environment help to make the sea uninhabitable to exotic or adventitious species, and the indigenous species may have some antagonistic effect on each other. The chief way in which this may occur is by alteration of the food supply or by reduction of its concentration to levels below the minimal requirements of other organisms. Certain microorganisms produce specific toxic substances which inhibit the growth of other organisms in the immediate vicinity or destroy them. There are several other ways in which microorganisms are mutually antagonistic, a relationship which is designated as antibiosis in contradistinction to symbiosis.

WAKSMAN (I937) writes: "When two organisms are capable of utilizing the same nutrients, but are differently affected by environmental conditions (reaction, air supply, temperature), the one organism that finds conditions more suitable develops more rapidly and thus depresses the other." This, together with the production of toxic substances, explains why certain fungi and bacteria are capable of growing in practically pure culture even in a non-sterile environment. Some workers regard the toxic or growth-inhibiting substances as "protective metabolic products produced by microorganisms in their struggle for existence."

A classical example of a toxic or antagonistic substance is penicillin which is produced by a soil fungus, Penicillium notatum. Penicillin in extremely dilute concentrations inhibits the growth of bacteria. The production by actinomycetes of toxic substances which limit the development of soil bacteria has been reported. A strain of Pseudomonas fuorescens isolated from water by LEWIS (I929) produced in nutrient media a toxin 
which inhibited the growth of bacteria, yeasts, and molds. Additional examples of specific and indirect antagonistic effects of microorganisms are given by WAKSMLAN (194I $b$ ).

There are no quantitative data on the extent to which microbial antagonism may limit the bacterial population of the sea, but the presence of organic bacteriostatic substances in sea water has been definitely established. It has been known since the work of DE GiAXA (I889) that the profuse growth of bacteria in raw sea water eventually renders it unfit as a medium for the cultivation of bacteria, presumably due to the formation of toxic products. According to DE GIAXA (I889), Vibrio comma rapidly disappeared from raw sea water, the rate of disappearance being directly proportional to the abundance of other bacteria in the water, but in boiled or autoclaved sea water Vibrio comma survived for a long time. Similarly, Kiribayashi and Aida (I934) and Krassilnikov (1938) observed that bacteria survived much longer in sterile than in raw sea water. PRescott and Winslow (I93I) give references to observations on the greater longevity of the typhoid bacillus in sterile sewage as contrasted with its rapid disappearance from raw sewage, which is attributed to bacterial antagonism.

In raw water freshly collected from the Black Sea, only I, 500 Staphylococcus aureus developed per ml. in experiments conducted by KRASSILNIKOV (I938). Similar water previously sterilized by passage through a Seitz filter or by boiling supported the growth of 860,000 and $86,000,000$ Staph. aureus respectively.

Sea water is rendered more growth-promoting by boiling or autoclaving, not only because the heat treatment frees it from antagonistic microorganisms, but because it also destroys certain thermolabile toxic products. ZOBELL (1936) found that sea water sterilized by filtration was approximately three times as toxic for coliform bacteria as was sea water sterilized by heating. When coliform bacteria, confined in all-porcelain Coors filter candles impregnated with collodion, were immersed directly in the sea they died approximately ten times as fast as when they were thus immersed in autoclaved sea water or in Berkefeld-filtered water. The average results from several such experiments are recorded in Table XXIII. These experiments prove that the toxic principle is thermolabile, water-soluble, and tends to be adsorbed by untreated Berkefeld bougies.

TABLE XXIII.- Relative numbers of coliform bacteria which survived in stoppered, collodiontreated, Coors porous filter tubes when immersed in different kinds of water at $16^{\circ} \mathrm{C}$. (from ZoBELL, I936):-

\begin{tabular}{l|r|r|r|r}
\hline \multicolumn{1}{c|}{ IMMERSED IN } & \multicolumn{3}{|c}{ TrMe IN MINUTES } \\
\cline { 2 - 3 } & 30 & 60 & 90 & I20 \\
\hline "Formula C" control (see page 47) & I00 & $9 \mathrm{I}$ & 82 & 97 \\
Natural sea water & 47 & $3 \mathrm{I}$ & I5 & 3 \\
Autoclaved sea water & 56 & 38 & 27 & 36 \\
Berkefeld-filtered sea water & 39 & 20 & 23 & I9
\end{tabular}

Further experiments have shown the toxic principle to be adsorbed by activated charcoal, diatomaceous earth, bentonite, and other surfaceactive substances. Also, it is precipitated from solution by iron and aluminum salts in a slightly alkaline medium. There is a higher concentration of the toxic principle in polluted sea water than in sea water collected from the open ocean. 
After noting that bacteria survived longer and were more active in heat-sterilized sea water or in artificial sea water, WAKsMAN and НотснKISS (I937) concluded that the antagonistic effects of microorganisms including nannoplankton help to explain the low numbers of bacteria usually found in natural sea water.

Another manifestation of microbial antagonism is the progressive decrease in the number of species of bacteria found in sea water during its incubation in the laboratory (ZOBELL and ANDERSON, I936a). As a rule, the larger the bacterial population which develops in stored sea water, the fewer the species which survive. After several months storage, only two or three species of bacteria were found in samples of sea water which contained thirty to forty species when collected from the sea.

TAYLOR (I940) directs attention to the commonly observed fact that the denser the bacterial population in natural waters, the smaller the number of species. In Lake Windermere, which normally contains only a few thousand bacteria per ml., TAYLOR (I942) found scores of bacterial types, contrasted with only a few types found in polluted river water entering the lake.

Besides contributing to the rapid destruction of adventitious species, the accumulation of hetero-antagonistic substances in the sea may help to explain the specificity of marine bacteria. In spite of the interchange of bacteria between the land and sea through the intermediaries of wind and water, most of the bacteria occurring in the sea at places remote from possibilities of recent terrigenous contamination are quite unlike bacterial species occurring in soil or fresh-water environments.

Bacteriophage in sea water:- Bacteriophage is a lytic, filter-passing, self-propagating principle which causes the destruction of susceptible bacteria. It has been credited with contributing to the self-purification of polluted water. According to D'Hérelle (I926), the first record of bacteriophage action was the observation of HANkIN in I896 that unsterilized waters of certain rivers in India have a tendency to destroy bacteria. For example, just below Agra more than I00,000 bacteria per $\mathrm{ml}$. were found in the Jumna River, while 5 kilometers farther down the river fewer than Ioo bacteria were found in the water. The antiseptic property of the water was destroyed by boiling.

Our knowledge of the occurrence and activity of bacteriophage in sea water is rather fragmentary. Bacteriophage is relatively resistant to adverse chemical and physical conditions, occupying a position in this respect intermediate between vegetative forms and spores of Bacillus subtilis (D'HERELLE, I926). A high concentration of salt is not injurious to bacteriophage, BRUTSAERT (I924) having shown that the bacteriophage for Staphylococcus aureus and Staph. albus is active in broth containing as much as $\mathrm{I} 4.5$ per cent $\mathrm{NaCl}$.

After noting the occurrence of bacteriophage in rivers, soil, sewage, and in nearly all environments harboring large bacterial populations, D'HéRELle (I926) remarked, "It is everywhere present, one might say." D'HéRELLE found bacteriophage active against dysentery bacilli in sea water at the mouths of rivers. He found the bacteriophage for Escherichia coli in the estuary of Mekong, French Indo-China. Although bacteriophage is often present in sea water along the coast and particularly near the mouths of rivers, D'HÉRELLE was unable to find it in water collected from the Indian Ocean at approximately $60^{\circ} \mathrm{E}$. Long. and $10^{\circ} \mathrm{N}$. Lat. 
The presence of bacteriophage active against various bacteria has been reported by Hauduroy (I923), Fernand el al. (i925), Fejgin (I926), Fortunato (ig28), Gildeneister and Watanabe (193i), and others who have examined coastal waters. FERnAND $\mathrm{el} \mathrm{al}$. (1925) believed that the rapid disappearance of fresh-water bacteria observed in the sea is due primarily to the action of bacteriophage rather than to the unfavorable salt content of sea water or to other adverse physical conditions. GILDEMEISTER and WATANABE (I93I) concluded that while bacteriophage may occur in sea water, the content is very small. GEE (I932d) wrote that, although the activity of bacteriophage in reducing the bacterial population of water has not been determined, it certainly may be expected in the intestinal contents of marine fishes. DAVIS (I933) was unable to demonstrate any bacteriophage in either sea water or in polluted sea-bath waters.

Observations at the Scripps Institution indicate that bacteriophage for several different bacteria occurs in sea water along the coast, but it is rather difficult to demonstrate its presence. The infrequency with which positive results are obtained indicates that bacteriophage is not present in high concentrations or that it occurs only sporadically. The lytic principle has never been demonstrated in water collected beyond the littoral zone.

Since bacteriophage is generally found associated with large numbers of rapidly multiplying bacteria, it is very doubtful if the sparse bacterial population characteristic of the open ocean is conducive to the development or activity of bacteriophage. The activity of bacteriophage may contribute to the destruction of bacteria in polluted water along the coast, but there are no experimental data or theoretical considerations to suggest that bacteriophage is a factor which limits the bacterial population of the open ocean.

Effect of solid surfaces:- Unlike polluted waters, the bacterial population of which decreases from billions per $\mathrm{ml}$. to millions per $\mathrm{ml}$. during storage in small receptacles, the bacterial population of sea water which normally contains only a few hundred bacteria per ml. increases to thousands or millions of bacteria per $\mathrm{ml}$. after being stored for a few days in glass receptacles. WAKSMAN and CAREY (I935a) attributed the increase in the bacterial population of stored sea water to the dying out of protozoans and other animals which devour bacteria and to the modification of "certain controlling factors (in situ) injurious to free bacterial development." KEys et al. (I935), who observed similar changes in stored sea water, expressed the belief that the activity of bacteria in the sea is limited by the "extreme stability of the ocean as a chemical and physical factor." This may be another way of saying that there are not more bacteria in the sea because they die off as fast as they multiply, but it fails to explain why the bacteria multiply faster than they die for a few days following storage of the water in glass receptacles.

Temperature cannot be regarded as responsible for the increased bacterial activity in stored sea water, because the bacterial population increases regardless of the temperature within the range of from $0^{\circ}$ to $30^{\circ} \mathrm{C}$. In fact, there is increased bacterial activity in sea water which is stored in bottles submerged in the sea under conditions which otherwise simulate very closely natural environmental conditions. Likewise the bacterial population increased a hundred- to a thousand-fold when the water was stored in the sea retained in glass bottles with open mouths which per- 
mitted the entrance of small predatory animals. When introduced from plankton tows into such bottles, protozoans and copepods survived without having any noticeable effect upon the bacterial population within the limits of hundreds to hundreds of thousands of bacteria per ml. of water.

After observing that bacteria multiply proportionately faster in small receptacles than in larger ones, WHIPPLE (I9OI) concluded that the availability of oxygen was the responsible factor. When the receptacles are only partly filled with water, proportionately more of the water is exposed to the atmosphere when it is stored in small receptacles than when it is stored in larger receptacles of similar shape. However, ZoBELL and STADLER (I940b) have shown that the multiplication and respiration of aquatic bacteria are independent of the oxygen tension throughout the range of from 0.30 to $36 \mathrm{mgm}$./liter.

ZOBELL and ANDERSON (I936a) confirmed WHIPPLE's observation that bacteria multiply in water stored in small receptacles appreciably faster than in identical water stored in larger receptacles of similar shape. After proving that neither temperature nor oxygen tension is responsible for the observed phenomenon, the increased bacterial activity was attributed to the beneficial effect of solid surfaces of the receptacles in which the water was stored. The beneficial effect of added glass beads, ignited sand, and other inert particulate materials substantiated this conclusion, which has also been confirmed by the observations of LLOYD (I937).

In dilute nutrient solutions such as sea water which contain less than Io mgm. of organic matter per liter, solid surfaces promote the multiplication of bacteria. This is illustrated by the data in Table XXIV obtained by storing sea water in glass-stoppered Pyrex bottles for two weeks at I $6^{\circ} \mathrm{C}$., after which bacterial populations and oxygen consumption were measured.

TABLE XXIV. - Number of bacteria found in sea water, which initially contained 276 bacteria per $m l$., after two weeks storage in the dark at ${ }_{1} 6^{\circ} \mathrm{C}$. in glass-stoppered bollles of different capacities. The area of glass exposed to the water and the ratio of volnme in ml. of water to the area of glass surface are also given (from ZoBELL and ANDERSON, 1936a):-

\begin{tabular}{|c|c|c|c|c|}
\hline $\begin{array}{l}\text { VOLUME OF SEA } \\
\text { WATER IN ML. }\end{array}$ & $\begin{array}{l}\text { SOLID SURFACE } \\
\text { IN } \mathrm{CM}^{2}\end{array}$ & $\begin{array}{l}\text { RATIO OF } \\
\text { ML.: CM. }{ }^{2}\end{array}$ & $\begin{array}{l}\text { AVERAGE NUMBER OF } \\
\text { BACTERIA PER ML. }\end{array}$ & $\begin{array}{c}\text { OXYGEN CONSUMED } \\
\text { MGM. } / \mathrm{L} .\end{array}$ \\
\hline I4 & 37 & $I: 2.64$ & $r, 86_{3}, \infty 00$ & $3 \cdot 42$ \\
\hline I 20 & I 48 & I:I.23 & $1,070,000$ & 2.53 \\
\hline I, 225 & 640 & $I: 0.52$ & 553,000 & I. 3 I \\
\hline I 3,220 & 3174 & I:O. 24 & 261,000 & 0.97 \\
\hline
\end{tabular}

Solid surfaces promote activities of bacteria in dilute nutrient solutions primarily by adsorbing organic matter, thereby making it more available to bacteria. ZoBELL ( $943 b$ ) has presented chemical and biological evidence that glass and other inert solids adsorb measurable quantities ( 2 to 27 per cent) of the organic matter in sea water.

After observing the accumulation of organic matter on chemically cleaned glass slides, STARK el al. (I938) expressed the belief that adsorbed organic nutrients favor bacterial growth. Corroborative evidence is given by the studies of HeUkelekian and Heller (I940) on the relation between food concentration and solid surfaces. In their experiments, Escherichia coli failed to multiply when the concentration of food was less than 0.5 p.p.m. unless glass beads were added to provide adsorbing surfaces. The beneficial effect of glass beads was noticed in solutions containing up to 25 p.p.m. of nutrients, above which concentration solid 
surfaces were not particularly beneficial. By adsorptive concentration of nutrients, solid surfaces enable bacteria to develop in substrates otherwise too dilute for growth.

Besides concentrating nutrients, solid surfaces in sea water provide surfaces for the attachment of sessile bacteria. The sessile habit of aquatic bacteria is the basis of the submerged slide technic employed by HENRICI (I933, I936), ZoBell and Allen (I933, I 935), Hotchkiss and WAKsMaN (I936), Surth and ZoBell (1937), and others for the direct microscopic enumeration of bacteria. KusNetzowa (I937) believes that all water bacteria are capable of attaching themselves to glass, and that many of them grow only when attached to solid surfaces. Several species of bacteria which grow only when attached to firm substrates have been described by Henrici and Johnson (I935), ZoBell (1943b), and ZoBell and UphaM (I944). Most of the bacteria in bottom deposits appear to be adsorbed on or attached to particles of sediment (WAKSMIAN and VARTIOVAARA, I938).

Solid surfaces retard the diffusion of exoenzymes and partially digested food away from bacteria. Large molecules of organic matter must be converted into soluble substances by bacterial exoenzymes before the food can be assimilated by bacteria. Consequently in a dilute nutrient solution such as sea water, free-floating bacterial cells may not be able to digest and absorb enough nutrient to provide for their organic requirements. However, when the bacterial cells and organic nutrients are juxtaposed on solid surfaces, the bacteria may more effectively absorb the food which has been rendered soluble by their exoenzymes. Bacteria in an anchored position are less influenced by molecular bombardment (with the resultant Brownian movement and diffusion) which would tend to separate them from their exoenzymes and hydrolyzates. Also, solid surfaces probably facilitate the orientation of exoenzymes in the most advantageous position, thereby increasing their stability and activity.

The beneficial effects of solid surfaces in dilute nutrient solutions help to explain why marine bacteria generally occur intimately associated with solid particles, as has been shown by the work of LLOYD (I930), WAKSMIAN et al. (I933C), and others. In considering the factors which influence the distribution of bacteria in natural waters, PRESCOTT and WINSLOW (I93I) emphasized that in natural waters bacteria are to a great extent attached to large solid particles. Inert particles appreciably smaller than bacteria are not beneficial to bacteria; they may even be injurious to bacterial activity (ZoBELL, I943b). Other evidence for the attachment propensities of aquatic bacteria is reviewed on pages $5^{6}$ and 193 .

Effect of sedimentation:- After stressing the importance of the low concentration of organic nutrients in sea water as a factor which limits the marine bacterial population, RENN (I937b) declared that, "Particulate substrates, necessary for the favorable development of large attached populations, tend to settle and carry large numbers of bacteria into the mud during sedimentation." Thus, while the affinity of solids for bacteria tends to promote bacterial multiplication in dilute nutrient solutions, solid particles whose density exceeds that of sea water also tend to reduce the bacterial population.

FRANKLAND and FRANKLAND (I894) concluded that sedimentation is of the utmost importance in the purification of water. JORDAN (I900) regarded it as noteworthy that in all the instances recorded in the literature 
where a marked purification has been observed, the conditions are precisely those which are most favorable for sedimentation. GAINEy (I939) emphasized the importance of sedimentation in the purification of water by declaring that "The decrease in bacterial numbers in water stored in reservoirs, while not entirely due to sedimentation, should probably be attributed largely to this factor." He gives substantiating laboratory and field data. Applying Stokes' law of falling bodies, SpITta (I903) estimated that 20 to 50 per cent of the bacteria in canal water settle out due to their attachment to gross particles.

RUSSELL (I89I) recognized the importance of sedimentation in the distribution of bacteria in the Gulf of Naples where many more bacteria were found in the bottom deposits than in the superficial strata of water. However, the occurrence in bottom deposits of bacterial species never found in the overlying water convinced him that bacteria multiply in the bottom deposits and are not merely passive transients from the overlying water. HENRICI (I939) ascribed the great preponderance of bacteria in lake bottom deposits as compared with the number found in the overlying water to several different factors, "the most important being the tendency of bacteria to be adsorbed by or otherwise attached to solid particles in the water, and to be carried by these particles to the bottom."

Sedimentation is most important in removing bacteria from sea water along the coast, particularly in localities where there is much land drainage. In such places the precipitation and sedimentation of suspended matter are accelerated by flocculation which occurs when fresh water is mixed with sea water. Sedimentation is believed to be primarily responsible for the localization of the pollution of sea water by land drainage as manifested by the rapidity with which bacterial populations decrease with distance from sewage outfalls and from the mouths of rivers. In such places the bacterial population decreases much more rapidly than can be accounted for by dilution alone.

From the average bacterial content of river water and that of sewage entering the Pacific Ocean, it is estimated that no fewer than $5 \times 10^{23}$ bacterial cells enter the sea from the land along the coast of the North Pacific Ocean each day. Yet rarely does one find terrigenous bacteria in the sea at distances greater than a few miles from the mouths of rivers or sewage outfalls, in spite of water movements which are favorable for the widespread distribution of such organisms. The majority of the bacteria are carried to the sea bottom very near the point of entrance to the sea. The principal exceptions to this rule are caused by small quantities of floating solids and by fresh water flowing over the non-turbulent surface of sea water for considerable distances.

Sedimentation also has a marked influence on the distribution of bacteria in lakes, as shown by the quantitative studies of KLEIBER (I894) in Lake Zürich. Bacteria introduced into the lake in large numbers by inflowing streams are detectable only for short distances in the lake. The decrease in the bacterial population parallels the rapidly diminishing turbidity or cloudiness in the lake induced by the streams. An average of ro bacteria per $\mathrm{ml}$. was demonstrated in lake water a few meters from shore as compared with plate counts exceeding 10,000 per $\mathrm{ml}$. of water in the mouth of the river. Since calculations indicated that this observation could not be attributed solely to dilution, KLEIBER considered sedimentation to be the chief cause of the rapid diminution of bacteria where streams enter the lake. 
In their "Elements of Water Bacteriology," Prescott and Winslow (I93I) state that chief among the factors influencing the diminution of bacteria in surface waters appear to be sedimentation, the activity of other microorganisms, light, temperature, food supply, and perhaps more obscure conditions such as osmotic pressure.

Baier (i 935), Rubentschik el al. (I936), TAylor (I940), and others stress the importance of sedimentation as a factor which limits the microbial population of lakes, reservoirs, and bays.

Sedimentation is not the prime cause of the paucity of bacteria in the open ocean, but it helps to explain the vertical distribution of bacteria. Here sedimentation occurs more slowly due to a dearth of suspended particles. Most of the suspended particles in the open ocean are diatoms, dinoflagellates, and other plankton organisms equipped with special flotation adaptations which retard or prevent sinking. It is with such solid particles that the bacteria in the open ocean are associated. Following the death of the supporting plankton organisms, the organic tissues of the latter are gradually decomposed, leaving skeletal remains of greater density. As the density increases and the flotation mechanisms disintegrate, the skeletal remains sink faster and faster towards the bottom. The rate of sinking of such organisms or their remains at different depths probably approximates the reciprocal of the curves which represent their abundance at different depths (see Figure 7 on page 67 ), assuming that the organisms are not completely decomposed.

Of course, large numbers of plankton organisms are devoured by predatory animals and some may be completely decomposed by bacteria. However, the remains of numerous plankton organisms sink to the sea bottom, carrying with them attached bacteria. The numbers of bacteria found in the sea at different depths are directly proportional to the quantity of particulate material, regardless of whether the latter is living or dead. The paucity of particulate matter at depths exceeding 200 meters is believed to be ascribable primarily to the accelerated rate of sedimentation when the remains of organisms reach this depth. A similar view is expressed by LLOYD (I930) who observed a progressive decrease in the bacterial population with depth in the Clyde Sea, paralleling the sinking of suspended matter.

Effect of organic matter:- The concentration of organic nutrients in sea water is very low, being near or below the threshold of the requirements for many kinds of bacteria. According to KROGH (I934), sea water contains from 4 to $5 \mathrm{mgm}$. of total organic matter per liter, or about I/5000 as much as ordinary garden soil. An appreciable portion of the organic content of sea water is highly refractory to attack by bacteria. KEYS et al. (I935) estimated that only ro to I 5 per cent of the total organic content of sea water is utilized by bacteria after storage for several days at $2 I^{\circ} \mathrm{C}$. WAKsMLAN and CAREY $\left(1935^{b}\right)$ found that $5^{\circ}$ per cent of the total organic content of sea water is readily subject to decomposition by bacteria, the rest being very resistant to bacterial attack. About 60 per cent of the organic matter decomposed by bacteria is completely oxidized to carbon dioxide and water, and 40 per cent is converted into bacterial cell substance or intermediate products of metabolism. Simlar results have been reported by WAKSMAN and RENN (I936).

That organic matter is a factor which limits the multiplication of bacteria in sea water has been established by the experiments of WAKSMAN 
and CAREy (I935). When they added $2.5 \mathrm{mgm}$. of glucose to a liter of natural sea water, they found $2,005,000$ bacteria per $\mathrm{ml}$. of water after 24 hours incubation as compared with only 625,000 in the control. This quantity of glucose increased the plate count to $3,850,000$ when the sea water was also enriched with a little ammonium sulfate. During the same period the addition of $15 \mathrm{mgm}$. of glucose per liter of sea water increased the plate count to $24,050,000$ bacteria per $\mathrm{ml}$. These observations were confirmed by WAKSMAN and RENN (I936) who concluded that organic carbon is the principal factor which limits the bacterial population of sea water.

When I. 5 mgm. or more of glucose is added per liter of sea water, combined nitrogen also becomes a limiting factor for the multiplication of bacteria. The nitrogen requirements of most marine bacteria are satisfied by either ammonium salts or amino acids. All of the ${ }_{5}$ "representative aerobic bacteria of marine origin" studied by OsTrofF and HENRY (I939) were found to utilize organic nitrogen compounds, but only 5 were able to utilize inorganic ammonium compounds as a source of nitrogen in a mineral medium enriched with glucose. Most cultures grew luxuriantly on amino acids, which, as a class of compounds, were the best source of nitrogen and carbon. The number of cultures which grew in glucose media utilizing different nitrogen compounds is shown in Table XXV.

TABLE XXV.- Number of cultures of marine bacteria out of 15 tested which utilized different nitrogen compounds in glucose media (from OSTROFF and HENRY, 1939):-

\begin{tabular}{|c|c|c|c|}
\hline COMPOUND & $\begin{array}{c}\text { NUMBER OF CULTURES } \\
\text { WHICH GREW WELL }\end{array}$ & $\begin{array}{l}\text { COMPOUND } \\
\text { CONT. }\end{array}$ & $\begin{array}{l}\text { NUMBER OF CULTURES } \\
\text { WHICH GREW WELL }\end{array}$ \\
\hline $\begin{array}{l}\text { Glutamic acid } \\
\text { Aspartic acid } \\
\text { Asparagine } \\
\text { Propionamide } \\
\text { Urea } \\
\text { Creatinine } \\
\text { Acetamide } \\
\text { Sodium hippurate } \\
\text { Di-ammonium phosphate } \\
\text { dl-Alanine } \\
\text { Cystine }\end{array}$ & $\begin{array}{l}9 \\
8 \\
8 \\
8 \\
7 \\
7 \\
6 \\
6 \\
5 \\
5 \\
5\end{array}$ & $\begin{array}{l}\text { Ammonium oxalate } \\
\text { Pyridine } \\
\text { Betaine } \\
\text { Uric acid } \\
\text { Tyrosine } \\
\text { Ammonium chloride } \\
\text { Ammonium formate } \\
\text { Ethylamine } \\
\text { Aniline } \\
\text { Guanidine } \\
\text { Peptone }\end{array}$ & $\begin{array}{r}4 \\
3 \\
2 \\
2 \\
\text { I } \\
\text { I } \\
0 \\
0 \\
0 \\
0 \\
\text { I5 }\end{array}$ \\
\hline
\end{tabular}

It is generally claimed that the minimum concentration of organic nutrients required for the multiplication of heterotrophs ranges from $0.00 \mathrm{I}$ to o.or per cent or ro to Ioo mgm. per liter. CURRAN (I93I) reported that $250 \mathrm{mgm}$. of peptone per liter was the minimum quantity that supported the germination of bacterial spores. Bacteria which live in the ocean or in oligotrophic lakes must be peculiarly adapted to live in extremely dilute media because the organic content of sea water and many fresh-water lakes is less than $5 \mathrm{mgm}$. per liter. ZoBELL and Grant (I943) found that most marine bacteria multiplied in mineral media containing only o.I mgm. of peptone or glucose per liter. However, the bacteria multiplied very slowly in the presence of such low concentrations of organic nutrients. Probably the solid surfaces of the walls of the culture receptacles made it possible for the bacteria to utilize the small quantities of organic nutrients. Supplementing the solid surface by the addition of glass beads, glass tubes, or other inert solids promotes the growth of marine bacteria in media containing less than Io mgm. of organic nutrients per liter.

The optimum concentration of readily utilizable organic matter such 
as peptone or glucose for the multiplication of marine bacteria is between 1000 and $10,000 \mathrm{mgm}$. per liter of sea water. This is 200 to 2000 times the concentration of organic matter in sea water, and only a small fraction of the latter is readily utilizable. This emphasizes that the concentration of organic matter in the sea is decidedly sub-minimal for bacterial activity. The addition of as little as o.I mgm. of utilizable organic matter to sea water results in increased bacterial activity. Up to $100 \mathrm{mgm}$. per liter, doubling the concentration of organic nutrients approximately doubles the rate of bacterial multiplication.

Although it is difficult to appraise quantitatively each of the numerous interrelated factors which influence the distribution of bacteria in the sea, the organic content of water is certainly one of the most important factors. Increases in the availability of organic nutrients in sea water are almost invariably accompanied by increased bacterial populations. The low concentration of organic nutrients and the lack of solid surfaces for concentrating organic nutrients are believed to be the principal factors which account for the small number of bacteria found in the sea. Wherever there is an influx of organic matter or an increase in the amount of suspended particles caused by land drainage, stirring up of the bottom, the activity of photosynthetic organisms, the appearance of seaweeds, fisheries activities in localized areas, upwelling, or convergence of cold and warm water which kills many organisms, bacteria are found in greater numbers than in surrounding water.

While the numbers of bacteria which may develop in sea water stored in the laboratory are directly proportional to content of utilizable organic matter, the bacterial population of sea water in situ is not necessarily indicative of the organic content of the water. A large bacterial population may more effectively utilize the organic content of sea water and reduce it to a lower level than a few bacteria, in which case there would be relatively little organic matter in the presence of large numbers of bacteria until the latter perish. The bacteria themselves contain very little organic matter, it requiring a bacterial population of about 10,000,000 per $\mathrm{ml}$. to be equivalent to $1.0 \mathrm{mgm}$. of organic matter per liter. On the other hand, in certain regions there may be enough organic matter to provide for the rapid multiplication of bacteria, but the population may never exceed more than a few thousand per $\mathrm{ml}$. due to the activities of predators or other factors inimical to the prolonged survival of bacteria.

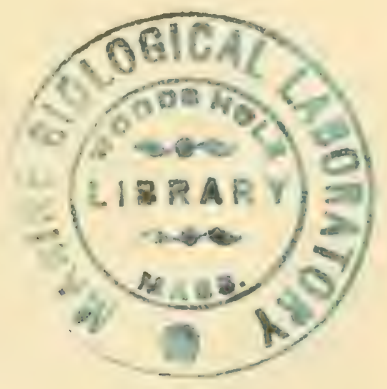




\section{Chapter VI}

\section{MICROORGANISMS IN BOTTOM DEPOSITS}

It is in the sedimentary materials on the floor of the sea that the microbial population is most extensive and physiologically versatile. Large numbers of microorganisms of various kinds live in the mud or sand where they influence the activities of sedentary or burrowing animals, the diagenesis of bottom deposits, and certain properties of the overlying water. Viable microorganisms have been demonstrated in most samples of bottom deposits examined for their presence regardless of the depth of the overlying water, distance from land, latitude, or the composition of the bottom deposits.

Numbers of bacteria in sediments:- CERTES (I884a) found appreciable numbers of bacteria in all except four of roo sediment samples, some of which were collected from water depths as great as 5, I00 meters on the Talisman expedition, but his results have no quantitative significance because he analyzed the samples only after prolonged storage. Employing plating methods, RUSSELL (1892) found from 25,000 to 300,000 bacteria per ml. of mud from the Bay of Naples as compared with I0,000 to 30,000 bacteria per $\mathrm{ml}$. of mud in the vicinity of Woods Hole, Massachusetts. The bacteria from the Bay of Naples were generally different from the species isolated at Woods Hole, and at both stations the bottom flora differed somewhat from the flora in the overlying water.

DREW (I9I2) demonstrated an average of $160,000,000$ bacteria per $\mathrm{ml}$. of mud from the sea floor near Andros Island in the West Indies. Predominating in the lime-rich mud was an organism which DREw described as Bacterium calcis. GEE (I932b) estimated that the order of magnitude of the bacterial population of mud from the Florida Keys was hundreds of thousands per gram (wet basis). LLOXD (I93I $a$ ) found up to 300,000 bac teria per gram (dry basis) of mud from the Clyde Sea.

Incidentally, the water content of recent marine sediments ranges roughly from 30 to 99 per cent, a factor which should be taken into account in expressing quantitative results. Most mud quantities are expressed on a wet or natural weight basis because this is more representative of the spatial relations of the microorganisms. Unlike soil, in which there may be marked seasonal fluctuations in the water content, the water content of marine bottom deposits varies but little from time to time.

In the calcareous deposits around the Bahama Islands, BAVENDAMM (I932) counted up to I6,800,000 bacteria per gram of wet mud. The bacterial population decreased sharply with core depth. In this same region Sмітн (I926) found an average of 565,000 bacteria per gram of calcareous mud. Unless otherwise stated all counts refer to aerobes.

Sediments from the Channel Island region off the coast of southern California were found by ZoBELL and ANDERSON (I936b) to contain up to several million viable bacteria per gram (wet basis). Like other workers who have made such studies, they found that the topmost layers of marine sediments generally contained many more bacteria per unit volume than did surface sea water. The bacterial content of the water of the mud- 
water interface is comparable with that of the underlying mud. The bacterial content of the water decreases sharply above this mud-water transitional zone.

In bottom deposits of fresh-water lakes, HenRICI and McCoy (1938) found from a few thousand to $500,000,000$ bacteria per ml. Direct counts were even higher. RUBENTSCHIK et al. (I936) demonstrated 3 billion bacteria per gram of mud from limans near Odessa. IsSATCHENKo (I 937) found a maximum of I I billion bacteria per gram of mud from the Kara Sea. These Russian workers employed the direct microscopic technic. Most of the bacteria were adsorbed upon sediment particles, a condition which tends to make plate counts lower than direct microscopic counts because large numbers of bacteria may be adsorbed to a single particle which may give rise to only one colony on a plate. The tendency for bacteria to be adsorbed by marine bottom deposits has been emphasized by the studies of WAKSLAN and VARTIOVAARA (I938).

Other general observations on the bacterial content of bottom deposits have been made by WILLIAMS and MCCOY (I935), DÜGGELI (I936), Butkevich (i938), Hartulari (i939), and Elazari-Volcani (i943).

Vertical distribution of bacteria in mud:- Wherever profile series have been examined, a progressive decrease in the bacterial population of bottom deposits from the surface downward has been observed (LLOYD, i93ia; Reuszer, i933; ZoBell and Anderson, i936b; ZoBell and FelthaM, 1942). The decrease is most rapid in the topmost few centimeters of sediment, below which the decrease is more gradual or even sporadic. This is illustrated by the data in Table XXVI.

TABLE XXVI. - Number of bacteria per gram of mud (wet basis) in different core sirata (from ZoBELL, I942b):-

\begin{tabular}{|c|c|c|c|}
\hline CORE NUMBER & $\mathrm{XIV}-37$ & $\mathrm{XIV}-45$ & $\mathrm{XIV}-53$ \\
\hline StaTION LOCATION & $\begin{array}{l}32^{\circ} 26.4^{\prime} \mathrm{N} . \\
\operatorname{II} 7^{\circ} 4 \mathrm{I} \cdot 3^{\prime} \mathrm{W}\end{array}$ & $\begin{array}{r}32^{\circ} 36.4^{\prime} \mathrm{N} \\
1 \pm 7^{\circ} 27.8^{\prime} \mathrm{W}\end{array}$ & $\begin{array}{r}33^{\circ} \circ 3 \cdot 3^{\prime} \mathrm{N} \\
\mathrm{I}^{\circ} 7^{\circ} 25 \cdot 5^{\prime} \mathrm{W}\end{array}$ \\
\hline ATER DEPTH & 3120 feet & 3570 feet & I $4 I_{5}$ feet \\
\hline
\end{tabular}

\begin{tabular}{c|r|r|r}
\hline $\begin{array}{c}\text { CORE DEPTH } \\
\text { IN INCHES }\end{array}$ & $\begin{array}{r}\text { BACTERIA } \\
\text { PER GRAM }\end{array}$ & $\begin{array}{r}\text { BACTERIA } \\
\text { PER GRAM }\end{array}$ & $\begin{array}{r}\text { BACTERIA } \\
\text { PER GRAM }\end{array}$ \\
\hline $0-1$ & $38,000,000$ & $7,500,000$ & 840,000 \\
I-2 & 940,000 & 250,000 & 102,000 \\
$4-5$ & 88,000 & 160,000 & 63,000 \\
$9-10$ & 36,000 & 23,000 & 19,000 \\
$14-15$ & 2,400 & 8,700 & 1,500 \\
$19-20$ & 400 & 2,100 & 2,200 \\
$29-30$ & 180 & 600 & 370 \\
$39-40$ & 330 & 200 & 190 \\
$59-60$ & 250 & 300 & 210 \\
$79-80$ & 130 & 100 & 140 \\
$99-100$ & 290 & 150 & 140
\end{tabular}

Significant numbers of viable bacteria have been found in marine sediments at all depths sampled. WAKSMAN et al. (I933C) reported the occurrence of bacteria down to a depth of $90 \mathrm{~cm}$. RiTTENBERG (I940) demonstrated the presence of numerous bacteria throughout the length of several cores, some of which were longer than $350 \mathrm{~cm}$. The numbers of bacteria found varied greatly from core to core. The abundance of bacteria decreased from the surface downward, although in certain sediments, zones or strata of high bacterial population were found beneath strata of 
lower population. These discontinuous zones corresponded exactly with the loci of abrupt changes in the physical and chemical properties of the sediments, a striking example of the relation between bacterial population and environment.

Representative data on the vertical distribution of bacteria in Minnesota and Wisconsin lake bottoms are summarized in Table XXVII. CARPENTER (I939) found a progressive decrease with depth in the bacterial population of mud from Crystal Lake, an oligotrophic lake in northern Wisconsin. Most of the organisms below the topmost layer of mud appeared to be either anaerobes or facultative aerobes.

TABLE XXVII. - Bacteria per ml. of lake mud from different depths as determined from plate counts by HENRICi and MCCOY (1938):

\begin{tabular}{|c|c|c|c|}
\hline $\begin{array}{l}\text { CORE DEPTH } \\
\text { IN CMI. }\end{array}$ & $\begin{array}{c}\text { Station } 7 \text { IN } \\
\text { LAKE AlEXANDER }\end{array}$ & $\begin{array}{c}\text { Station I IN } \\
\text { LAKE MENDOTA }\end{array}$ & $\begin{array}{c}\text { STATION I IN } \\
\text { BrazELLE LAKE }\end{array}$ \\
\hline $\begin{array}{l}\text { o (surface) } \\
2 \text { to } 4 \\
5 \text { to } 8 \\
9 \text { to I } 2 \\
\text { I3 to } 20 \\
2 \text { I to } 30 \\
3 \text { I to } 40\end{array}$ & $\begin{array}{r}123,400 \\
51,060 \\
\ldots \\
14,980 \\
8,425 \\
1,860 \\
260\end{array}$ & $\begin{array}{r}\text { I48,000 } \\
\text { I I } 7,000 \\
\text { I } 6,400 \\
\text { I } 9,400 \\
\text { I } 2,400 \\
\text { I } 2,800 \\
\text { I,670 }\end{array}$ & $\begin{array}{r}147,000 \\
66,000 \\
36,000 \\
22,900 \\
2,750 \\
710\end{array}$ \\
\hline
\end{tabular}

One of the longest cores on record was collected from the Gulf of California by EMERY and DIETZ (r94I), it being nearly I 7 feet in length. To obtain this core, the core barrel penetrated the bottom sediment to a depth exceeding 25 feet. Plate counts made by microbiologists showed that the bottom-most part of the core, as well as many other cores representing penetrations ranging from so to 20 feet, contained a minimum of several hundred viable bacteria per gram (wet basis).

Lower limits of the biosphere:- Finding significant numbers of living bacteria at such great depths, which represent geological ages of many centuries, provokes the question: what is the lower limit of the biosphere? From the extrapolation of the curves showing the abundance of bacteria in sediments with depth, one might expect to find some bacteria at depths of several hundred feet.

In highmoor peat, which is a type of bottom deposit especially rich in organic matter, WAKSMAN and STEVENS (1929) found bacteria in almost undiminished numbers throughout the entire profile to the bottom of the greatest depth examined, $5 \mathrm{IO} \mathrm{cm}$. In ancient sediments which are now above sea level, voN WOLZOGEN KÜHR (I922) found sulfate-reducing bacteria at depths of Io to 37 meters by rigorously collecting samples for bacteriological analysis from the walls of recent excavations. Sulfate reducers have also been recovered from oil-well brines, which are presumably from ancient marine sediments, from depths exceeding a thousand feet by Bastin (I926), Gahl and Anderson (I928), Bastin and Greer (I930), Ginter (I930), Ginsburg-Karagitscheva (I933), and others. Of course, it is questionable whether the sulfate reducers are indigenous to the oilwell brines or were adventitiously introduced in the process of drilling the wells.

In their investigations to determine at what depths in the earth's crust bacteria can live, LIESKE and HOFMANN (I929) found bacteria in coal at a depth of 1089 meters. LIPMAN (I93I) reported the presence of living 
bacteria in Pennsylvania anthracite at a depth of I 800 feet, but FARreLL and TURNer (1932) have questioned the significance of bacteria found in anthracite coal. ISSATCHENKO (I940) avers that bacteria, which he found in oil to a depth of 2000 meters, are indigenous species from near the lower limits of the biosphere. If his contention is substantiated, then we might expect temperature, organic matter, and water to be the chief factors which limit the depth to which living microorganisms may occur in sediments. While there is no reason to believe that living bacteria are widely distributed in ancient sediments at great depths, accumulating field and laboratory data indicate that bacteria are alive and active in certain deeply buried deposits containing organic matter.

The occurrence of viable bacteria at great depths in sediments leads one to wonder whether they have been reproducing throughout the thousands of years that they have been buried or if they are passively resting cells in a state of suspended animation. ZoBELL and ANDERSON (I936b) have pointed out that conditions in the bottom deposits of the sea, namely low temperature and absence of free oxygen, have proven most conducive to great longevity of bacteria in a dormant state. Anaerobic bacteria may be physiologically active in such an environment, but some of the strict aerobes which have been found at a depth of several feet either have been carried there by burrowing organisms or other agencies or else they have been buried in a dormant state for many centuries. Since we have no reasons for believing that strict aerobes have been carried deep into the bottom deposits and since the aerobes in question are mostly sporogenous Bacillus species, these bacteria may have survived in a dormant state for many centuries. Of course, there is a possibility that the so-called "strict aerobes" are capable of reproducing in a highly reducing environment by physiological mechanisms still unknown to microbiologists.

While a few strict aerobes are found in bottom deposits at appreciable depths, their abundance decreases sharply from the surface downward (ZOBELL, I938a). Curves depicting the vertical distribution of aerobes are reminiscent of logarithmic curves for the order of death of bacteria when the survivors are plotted against time. HENRICI and MCCox (I938) found that profile series of bacteria from lake bottom deposits give typical logarithmic death curves, suggesting that aerobes are slowly dying off. However, that many of the bacteria (probably anaerobes) in bottom deposits are physiologically active to great depths is indicated by the changes which they cause in the chemical composition and physicochemical properties of the bottom deposits, as is elaborated in Chapter VII.

Factors influencing abundance of bacteria in mud:- Neither distance from the mainland nor depth of the overlying water seems to have any direct influence upon the bacterial population of bottom deposits. This conclusion is based upon a study of several hundred mud samples, the bacterial content of which has been reported by various workers. In the Gulf of Naples, Russell (1892) observed a decreasing abundance of bacteria in mud samples with distance from shore, but in light of recent information this horizontal distribution appears to be more closely related to the organic content of the mud than to its distance from land or to the depth of the overlying water. This also applies to REuszer's (I933) observation that the bacterial numbers on the continental shelf in the vicinity of Woods Hole decrease regularly with distance from land. 
There is no evidence that either numbers or kinds of bacteria in bottom deposits are influenced by seasonal cycles except near shore or in very shallow water where bottom conditions are influenced by turbulence, storms, run-off, insolation, etc. In deep water, where environmental conditions are monotonously constant, one might expect no detectable seasonal fluctuations in the microbial population, but in shallow water, which is subject to cyclic changes caused by meteorological conditions and seasonal cycles in organic productivity, one might anticipate and does find seasonal changes in the bottom flora. This is especially true of lakes in the temperate zone which undergo a seasonal overturn. Even here, though, seasonal changes in the bottom flora are not as pronounced as are changes in the microbial population of the overlying water.

Relatively small numbers of bacteria are found in coarse sand which occurs along the coast and in shallow water. However, the bacterial popuJation is more closely related to the character of the sediments than to their distance from land, because, as a rule, sand contains fewer bacteria than sediments consisting chiefly of smaller particles regardless of their topographical location. Table XXVIII shows the average number of bacteria found in different types of bottom deposits. The particle size and nitrogen content of the sediments is adapted from data by TRASK (I932). The water content was determined by drying the samples for 24 hours at $105^{\circ} \mathrm{C}$.

TABLE XXVIII.- Average nitrogen, water, and bacteria content of sediment samples from the Channel Island region (from ZOBELL, I938a):-

\begin{tabular}{|c|c|c|c|c|}
\hline DEPOSIT & $\begin{array}{c}\text { MEDIAN DIAMETER } \\
\text { OF PARTICLES IN } \\
\text { MICRONS }\end{array}$ & $\begin{array}{c}\text { NITROGEN CONTENT } \\
\text { IN PER CENT }\end{array}$ & $\begin{array}{l}\text { WATER CONTENT } \\
\text { IN PER CENT }\end{array}$ & $\begin{array}{c}\text { BACTERIA PER } \\
\text { GRAM } \\
\text { (WET BASIS) }\end{array}$ \\
\hline $\begin{array}{l}\text { Sand } \\
\text { Silt } \\
\text { Clay } \\
\text { Colloid }\end{array}$ & $\begin{array}{l}50 \text { to } I, 000 \\
5 \text { to } 50 \\
I \text { to } 5 \\
<\mathrm{I}\end{array}$ & $\begin{array}{l}0.09 \\
0.19 \\
0.37 \\
1.00\end{array}$ & $\begin{array}{l}33 \\
56 \\
82 \\
98\end{array}$ & $\begin{array}{r}22,000 \\
78,000 \\
390,000 \\
I, 510,000\end{array}$ \\
\hline
\end{tabular}

The greater abundance of bacteria found in finer sediments is attributed primarily to the higher organic content, although a multiplicity of other interrelated factors are involved. At the mud-water interface, the sorting action in sedimentation tends to segregate particles of similar size, so the tendency is for any free-floating bacteria to be deposited with other particles of colloidal dimensions. Likewise bottom-dwelling animals which ingest bacteria are more abundant in coarse sediments, such as sand or silt, than in clay. Finally, small particles offer much more surface area than larger particles, and solid surfaces enhance the multiplication and survival of bacteria (ZOBELL, I943b).

According to REUSzer (I933), the distribution of bacteria in marine mud is directly correlated with the organic content. In the topmost layers at the mud-water interface it was found that the bacterial population was more dependent upon the degree of decomposition of the organic matter than upon the total quantity of organic matter present. Much of the organic content of bottom deposits consists of material which is fairly refractory to bacterial decomposition, being designated as "marine humus" by WAKSMAN (I933). Marine humus is more resistant to attack than freshly deposited plant and animal residues (WAKSMAN and НотсHKISS, I937), but in the presence of free oxygen it is slowly decomposed, as shown experimentally by the liberation of carbon dioxide and ammonia. 
ANDERSON (I940) has studied some factors which influence the bacterial oxidation of the organic matter in marine sediments.

In emphasizing the importance of organic matter raining down from above, the presence of autotrophic bacteria in well aerated bottoms is not being overlooked, but in most marine bottoms, autotrophs occur only in insignificant numbers as compared with heterotrophic organisms.

The dissolved oxygen content of the overlying water influences the rate and kind of bacterial activity in bottom deposits, but there is no evidence that oxygen tension has a marked effect on the total numbers of bacteria found in mud. An abundance of free oxygen favors the rapid multiplication of aerobes and, consequently, a rapid destruction of organic matter. In the absence of free oxygen, bacteria may reproduce more slowly, under which conditions the organic content is not rapidly depleted. This, together with the reducing conditions characteristic of anaerobic sediments, favors the prolonged survival of bacteria. Therefore, when equilibrium is established, it is found that the replenishment of organic matter from the overlying water is a more important factor than oxygen tension in controlling the numbers of bacteria in bottom deposits.

The oxygen tension influences the kinds of microorganisms present. With very few exceptions, anaerobic bacteria are the only organisms which are capable of normal activity in the absence of free oxygen. A few anaerobic protozoans have been described, and some animals are able to make temporary excursions into anaerobic environments. Most marine yeasts, molds, actinomycetes, and chemo-autotropic bacteria require free oxygen.

Due to the rapidity with which oxygen is consumed by bacteria (ZoBELL, I $940 a, b)$ in bottom deposits and the slowness with which it is replaced by diffusion or oceanic circulation, there is little or no free oxygen in many bottom deposits. As far as is known, conditions are completely anaerobic below the topmost few inches of sedimentary material. In the mud at the bottom of stagnant bodies of water including land-locked fjords, isolated ocean basins, and certain inland seas such as the Black Sea, for example, bacteria appear to be the only forms of life (STRoM, I939). According to Allgeier et al. (I932), the organic matter in lake deposits is subject to anaerobic fermentation. These workers demonstrated by plating procedures the presence of as many as 450,000 bacteria per $\mathrm{ml}$. of anaerobic material.

Biocoenosis and bacteria in bottom deposits:- Due to the effects of bacteria upon environmental conditions in bottom deposits, ecologists (MacGinitie, r935; Mare, I942; ZoBell and Feltham, i 942; Pearse et al., I942) recognize that bacterial activities must be taken into account in explaining the distribution of plants and animals. Similarly plants and animals in bottom deposits have a pronounced effect upon the bacterial population.

Photosynthetic plants provide the principal source of organic matter. In deep water, phytoplankton organisms or their remains settle to the sea floor where they are buried or decomposed by microorganisms. In shallow waters penetrated to the floor by sunlight, both planktonic and benthonic plants may be found growing at the bottom. Besides providing food for bacteria and animals, such plants produce or consume oxygen and carbon dioxide and otherwise influence the chemical composition of the mud and water. 
HeNRICI and McCoy (I938) found that bacterial counts from littoral stations occupied by aquatic plants are much higher than profundal ones where there is little or no vegetation. In general, a correspondence was observed between the abundance of bacteria in lake bottoms and the primary productivity of lakes. Primary productivity is principally due to photosynthetic organisms, most of which are phytoplankton. The most intense bacterial activity in the sea observed by ZOBELL and FELTHAM (I942) was in surface layers of sediments in mud flats where photosynthetic organisms are active.

The effect of vegetation on the abundance of bacteria in bottom deposits is shown by the investigations of HENRICI (I939) in Lake Alexander in Minnesota. He found the following numbers of bacteria per ml. at different stations described according to the predominating vegetation:

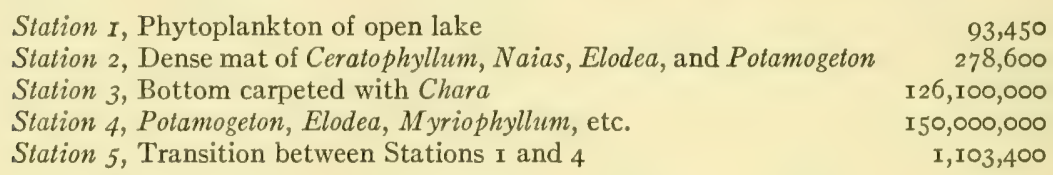

From these and similar observations, HENRICI (I939) concluded that "probably the most important factor determining the shoreward distribution of bacteria is the occurrence of aquatic plants. Where these are abundant, bacteria are numerous. Mere shallowness of the water is not an important factor. It is probable that the increase in bacteria in the vicinity of aquatic plants is due to larger amounts of organic matter derived from these plants."

Large numbers of bacteria are ingested by mud-dwelling animals, but it is difficult to estimate what effects predatory animals may have on the bacterial population of bottom deposits. Although bacteria may constitute an appreciable proportion of the food of mud-eating animals (MACGINITIE, I935; BAIER, I935), the presence of such animals may in turn enhance the multiplication of bacteria. As a rule the largest bacterial populations are found in bottom deposits richest in fauna. It is problematical whether this is a cause or an effect, or whether environments which promote the growth of animals are also beneficial to bacteria. But it is clearly indicated that in spite of their ingestion of bacteria, bacterivorous animals do not restrict the bacterial population of bottom deposits.

In seeking to appraise quantitatively the importance of bacteria as an ecological factor, MARE (I 942) estimated from plate counts that there are from 0.3 to $2 \mathrm{mgm}$. of living bacteria per gram of marine mud (dry basis). All other organisms, both plant and animal, amounted to about I $7 \mathrm{mgm}$. per gram of mud. In a square meter of mud to the stated depth she estimated the relative weights of organisms as follows:

\footnotetext{
Large macrobenthos in topmost $10 \mathrm{~cm}$.

Small macrobenthos in topmost $5 \mathrm{~cm}$.

Meiobenthos in topmost $0.5 \mathrm{~cm}$.

Microbenthic fauna in topmost $0.5 \mathrm{~cm}$.

Bottom diatoms in topmost $0.5 \mathrm{~cm}$.

Bacteria in topmost $0.5 \mathrm{~cm}$.
}

$$
\begin{array}{r}
75.00 \text { grams } \\
33.00 \text { grams } \\
1.15 \text { grams } \\
0.02 \text { grams } \\
0.05 \text { grams } \\
0.36 \text { grams }
\end{array}
$$

All groups of organisms except the bacteria were enumerated by direct counts. The bacteria were enumerated by plate counts employing REUsZER'S (I933) medium. Since plate counts detect only I to ro per cent of living bacteria, the estimated weight of bacteria should probably be multiplied by a factor of between ro and Ioo in order to give comparable data. 
Furthermore, any viable population of a given environment at any particular time is merely an expression of the dynamic balance between the rate of death and the rate of multiplication of the organisms. Since the generation time of bacteria is considerably shorter than that of the other organisms tabulated above, bacteria may be a more important component of mud than indicated by the tabulated values. Thus, in spite of the fact that large numbers of bacteria are ingested by animals, they are rapidly replaced by reproduction.

MARE (1942) defines macrobenthos as the large animals living in the mud. Meiobenthos consists of bottom-dwelling copepods, small polychaetes, lamellibranchs, nematodes, Foraminifera, and other fauna of intermediate size. Microbenthos consists of protozoans, exclusive of the Foraminifera, and other unicellular organisms in the mud. She found the macrobenthos to be confined largely to the topmost Io $\mathrm{cm}$. of mud. The meiobenthos, microbenthonic fauna, and diatoms were largely confined to the topmost $0.5 \mathrm{~cm}$. of mud. Bacteria were more abundant at the surface than at a depth of $3 \mathrm{~cm}$., but large numbers of bacteria were found at all depths examined for their presence. Since with few exceptions animals are dependent upon free oxygen, they are restricted to the surface layers of mud. Relatively few animals occur in bottom deposits at depths exceeding $10 \mathrm{~cm}$.

Using the direct microscopic technic for estimating the abundance of bacteria, ButKevich (I938) estimated that the biomass, or total weight, of bacteria per unit volume of mud was about the same as the biomass of plankton algae in the Caspian Sea near the mouth of the Volga River. In bottom desposits the biomass of bacteria exceeded that of plants.

Kinds of microorganisms occurring in bottom deposits:- In the uppermost layers of mud, aerobic bacteria appear to be more abundant than anaerobes. This may be due to limitations of the anaerobic media used for estimating the abundance of anaerobes, since the examination of colonies isolated from plates which have been incubated in the presence of oxygen reveals that a majority of them are facultative aerobes. Actually over 90 per cent of the colonies which have been isolated from either aerobic or anaerobic plates have proved to be facultative aerobes. Most of them grow much better in the presence of oxygen than in its absence. As a matter of fact, relatively few strict anaerobes have been isolated from marine mud. It should be pointed out, though, that in spite of the fact that anaerobic conditions predominate in bottom deposits, most workers have used aerobic procedures exclusively in studying the microflora of mud.

The predominant bacteria which Lloyd (I93Ia) isolated from Clyde Sea mud were small, Gram-negative, asporogenous rods resembling the genera Achromobacter and Chromobacterium. In lesser abundance she found Gram-negative diplococci and sarcinae, relatively large spore-forming bacilli, and a few slow-growing spirilla. LLOYD characterized the bottom flora as being "true water bacteria." Conversely, Russell (I89I) reported that most bottom-dwelling bacteria differed from those in the overlying water, although many were common to the water as well as to the mud in the Bay of Naples.

It has been our experience that the colonies developing in plates inoculated with marine mud differ grossly from those inoculated with sea water. While many of the bacteria are common to both habitats, some mud-dwell- 
ing bacteria have never been observed in water, and others isolated from water have not been found in mud. Unfortunately there are not enough data on this point to be statistically significant. In general, the colonies developing from marine mud are smaller, grow more slowly, and are less likely to be pigmented than those developing from sea water.

Butkevich (1932b), who demonstrated from I00 to I000 times as many bacteria in mud from the Barents Sea by direct microscopic counts as by plate counts, expressed the opinion that most bacteria in bottom deposits are spore formers. He detected numerous nitrate reducers and sulfate reducers to depths of 30 to $40 \mathrm{~cm}$. Most of the bottom-dwelling bacteria were able to reproduce at $-3^{\circ}$ to $-7^{\circ} \mathrm{C}$. RUBENTSCHIK and CHAIT (I937) estimated that from 6.2 to 13.3 per cent of the bacteria in mud occur as spores. The bacteria observed by BuTkevich (I938) in muds of the Caspian Sea were almost exclusively spores below a mud depth of $20 \mathrm{~cm}$.

The physiological versatility of microorganisms occurring in bottom deposits is indicated by the large variety of substrates which are attacked. The relative numbers of different physiological types of bacteria given in Table XXIX were determined by the minimum dilution method, the number being expressed as the reciprocal of the highest dilution in which there was activity in the differential media. A plus sign $(+)$ indicates that the bacteria were demonstrated in the sample but that their numbers were not determined.

TABLE XXIX.- Relative numbers of different physiological types of bacteria demonstrated in the topmost 3 to $5 \mathrm{~cm}$. of three mud samples from the Pacific Ocean (ZoBELL, I938a):-

Sediment Sample No.

Station LOCATION

DEPTH OF OVERLYING WATER

Total aerobes - Plate count

Total anaerobes - Oval tube count Ammonification - Peptone $\rightarrow \mathrm{NH}_{4}$

Ammonification - Nutrose $\rightarrow \mathrm{NH}_{4}$

Urea fermentation - Urea $\rightarrow \mathrm{NH}_{4}$

Proteolysis - Gelatin liquefaction

Proteolysis - Peptone $\rightarrow \mathrm{H}_{2} \mathrm{~S}$

Denitrification - $\mathrm{NO}_{3} \rightarrow \mathrm{N}_{2}$

Nitrate reduction $-\mathrm{NO}_{3} \rightarrow \mathrm{NO}_{2}$

Nitrogen fixation

Nitrification - $\mathrm{NH}_{4} \rightarrow \mathrm{NO}_{2}$

Sulfate reduction $-\mathrm{SO}_{4} \rightarrow \mathrm{H}_{2} \mathrm{~S}$

Dextrose fermentation

Xylose fermentation

Starch hydrolysis

Cellulose decomposition

Fat hydrolysis (lipoclastic)

Chitin digestion

\begin{tabular}{c|c|c}
$8 \mathrm{I} 60$ & 8330 & 9309 \\
$32^{\circ} 5 \mathrm{I} .2^{\prime} \mathrm{N}$. & $33^{\circ} 25.9^{\prime} \mathrm{N}$. & $33^{\circ} 44.2^{\prime} \mathrm{N}$. \\
II $7^{\circ} 28.3^{\prime} \mathrm{W}$. & II $8^{\circ} 06.5^{\prime} \mathrm{W}$. & II $8^{\circ} 46 . \mathrm{I}^{\prime} \mathrm{W}$. \\
780 meters & 505 meters & I 322 meters
\end{tabular}

\begin{tabular}{l|l|l}
930,000 & $31,000,000$ & $8,800,000$
\end{tabular}

\begin{tabular}{l|l|l}
190,000 & $2,600,000$ & $I, 070,000$
\end{tabular}

\begin{tabular}{l|l|l}
100,000 & $I, 000,000$ & $I, 000,000$
\end{tabular}

\begin{tabular}{l|l|l}
10,000 & $x, 000,000$ & 100,000
\end{tabular}

$100+1,000$

\begin{tabular}{l|l|l}
100,000 & $10,000,000$ & $I, 000,000$
\end{tabular}

$\begin{array}{lll}10,000 & 1,000,000 & 100,000\end{array}$

$\begin{array}{lll}100 & 10,000 & 10,000\end{array}$

\begin{tabular}{l|l|l}
100,000 & $10,000,000$ & 10,000
\end{tabular}

\begin{tabular}{l|l}
0 & 0 \\
0 & 0
\end{tabular}

\begin{tabular}{r|r|r}
1,000 & 1,000 & 10,000
\end{tabular}

$\begin{array}{lll}10,000 & 100,000 & 1,000\end{array}$

$10,000+10,000$

$\begin{array}{lll}10,000 & 100,000 & 10,000\end{array}$

$\begin{array}{ll}1,000+ & 1,000\end{array}$

I,, 000

100

Although their presence was not demonstrated in the analyses summarized in Table XXIX, nitrogen-fixing and nitrifying bacteria have been reported in marine bottom deposits (COOPER, I937b). Their significance is discussed in Chapter XI. CAREY and WAKSMAN (I934) reported the presence of nitrifying bacteria in mud samples collected from a water depth of 4,742 meters in the Atlantic Ocean just north of Bermuda.

Microorganisms which decompose lignin and hemicellulose were 
demonstrated in marine mud by Benson and Partansky (1934). ZoBELL and STADLER (I940a) found bacteria in lake deposits which slowly oxidize various kinds of natural and purified lignin.

According to ZoBELL and UPHAM (1944), agar-digesting colonies appear on most plates of nutrient agar inoculated with marine mud, although they are relatively more abundant in sea water than in bottom deposits. BAVENDAMn (I932) was intrigued by the abundance of agar digesters found in marine mud. He also observed various kinds of cellulose fermenters, urea bacteria, nitrogen fixers, sulfur bacteria, and sulfate reducers in the mud.

Species of Nocardia, Actinomyces, Pseudomonas, Micromonospora, and Mycobacterium which oxidize various kinds of petroleum hydrocarbons have been demonstrated in marine bottom deposits by ZOBELL et al. (I943). ElazARI-VolCANI (I943) found microorganisms in bottom sediments of the Dead Sea which utilized kerosene and petroleum. Several species of Micromonospora which attacked paraffin wax, paraffin oil, and aromatic hydrocarbons as well as chitin, cellulose, and lignin were isolated from lake mud by ERIKSON (I94I).

Besides finding significant numbers of most of the physiological types of bacteria listed in Table XXIX, WiLliaMis and McCoy (I935) found both aerobic and anaerobic nitrogen fixers, thiosulfate oxidizers, and sulfur oxidizers in the bottom deposits of Wisconsin lakes.

BAVENDAMM (I932) and BENECKE (I933) mention several kinds of sulfur bacteria which have been found in marine mud. From marine mud near Kiel, BrenNer (IgI6) isolated Micrococcus selenicus, an anaerobe which allegedly reduces selenate and selenite. BuTKEVICH (I928) found certain iron-oxidizing bacteria in ferromanganese deposits on the sea bottom. Thiel (1925) noted the presence of bacteria and molds in marine muds and peat bogs which precipitate manganese.

CARPENTER (I939) studied the relative abundance of urea fermenters, denitrifiers, cellulose decomposers, and pectin fermenters in lake mud. Proteolytic, pectin-fermenting, aerobic and anaerobic cellulose-decomposing, denitrifying, anaerobic nitrogen-fixing, and fat-splitting bacteria were found in lake mud by OMelansky (I9I 7). Allgeier et al. (I932) demonstrated in lake deposits the presence of bacteria which liberated methane, hydrogen, nitrogen, and carbon dioxide from the anaerobic fermentation of organic matter. From the mud of Red Lake (Rotsee) in Switzerland, DÜGGELI (1936) isolated 72 species of bacteria including some which produce hydrogen and methane. Proteolytic organisms predominated in the 530 samples of mud examined by DüGGELI.

In reviewing the literature on the microbiology of muds, ISSATCHENKO (I938) gives I7I references, most of which deal with the physiological types, distribution, and activity of microorganisms in Russian limans and lake deposits.

Besides numerous representatives of the orders Eubacteriales, Actinomycetales, Chlamydobacteriales, Myxobacteriales and Spirochaetales, which are generally regarded as bacteria, other microorganisms found in bottom deposits include yeasts, molds, and algae. From the Dovey salt marshes which are soaked with tidal sea water, EцLIOTT (I930) isolated 48 fungi, most of them being common soil forms. Algae and diatoms are restricted to mud and water depths penetrated by sunlight. Protozoans and minute metazoan organisms are widely distributed in marine bottoms. 


\section{ACTIVITIES OF MICROORGANISMS IN BOTTOM DEPOSITS}

Bacteria are important chemical and geological agents in bottom deposits, not so much because they are indispensable to any one process, but rather because they help to accelerate many processes. The vast numbers, physiological versatility, and almost universal distribution of bacteria in recent marine sediments help to account for the long-range effectiveness of their work.

In general, the geological activities of bacteria are neither specific nor confined to a limited number of species. The metabolic products of practically all bacteria have some effect upon their geological environment. Evidence of their early creation (bacteria probably being one of the first forms of life on the earth) indicates that they have had an enormous span of time in which to exert their profound influences. Controlled laboratory experiments with samples of bottom deposits under environmental conditions simulating those on the sea floor demonstrate that bacteria could be functional in situ, or in the environment in which they occur. This, together with the correlation of the numbers and kinds of microorganisms with chemical, physico-chemical, and geological conditions found in sediments, clearly shows that microorganisms are instrumental in the modification and diagenesis of the sediments.

Calcium carbonate precipitation:- According to estimates by VAUGHAN (1924), marine sediments contain an average of 20 per cent of calcium carbonate in the form of limestone, while the entire earth's crust contains only about 6 per cent. Almost pure $\mathrm{CaCO}_{3}$ is being deposited in certain parts of the sea, and in most bottom deposits precipitated $\mathrm{CaCO}_{3}$ serves as an important conglomerating or cementing material. While large quantities of $\mathrm{CaCO}_{3}$ are deposited in the skeletal remains of animals and by calcareous algae (GLOCK, I923), the activities of heterotrophic bacteria contribute to the process in various ways.

MURRAY and IRvine (I889) attributed the precipitation of $\mathrm{CaCO}_{3}$ to the reaction of ammonium carbonate with calcium sulfate:

$$
\left(\mathrm{NH}_{4}\right)_{2} \mathrm{CO}_{3}+\mathrm{CaSO}_{4}=\mathrm{CaCO}_{3}+\left(\mathrm{NH}_{4}\right)_{2} \mathrm{SO}_{4}
$$

Ammonium carbonate originates from ammonia and $\mathrm{CO}_{2}$ resulting from the microbiological disintegration of nitrogenous organic substances.

In an obscure Russian publication which escaped attention until his observations were published in German (NADson, I928), NADSON (I903) showed that the bacterial production of ammonia from proteinaceous materials promotes the precipitation of $\mathrm{CaCO}_{3}$ in Lake Weissowo. Proteus vulgaris, Bacillus mycoides, Actinomyces albus, Bacterium albo-luteum, and Bacillus salinus were the principal organisms involved. Ammonia production tends to increase the $p \mathrm{H}$ of water and thus promotes the precipitation of $\mathrm{CaCO}_{3}$ (MoBerg et al., I934). Besides liberating ammonia from proteinaceous materials, certain organisms observed by NADSON re- 
duced nitrate to free nitrogen or ammonia, thereby creating conditions sufficiently alkaline for the precipitation of both $\mathrm{CaCO}_{3}$ and $\left.\mathrm{MgCC}\right)_{3}$ with the formation of limestone and dolomite. Oolithic formations were also observed.

NADSON (I928) believed that the bacterial reduction of sulfate also contributes to the precipitation of carbonates:

$$
\mathrm{CaSO}_{4}+\mathrm{CH}_{3} \mathrm{COOH}=\mathrm{CaCO}_{3}+\mathrm{H}_{2} \mathrm{~S}+\mathrm{H}_{2} \mathrm{O}+\mathrm{CO}_{2}
$$

Whether $\mathrm{CaCO}_{3}$ will be precipitated depends primarily upon the $p \mathrm{H}$. The destruction of the strongly acidic sulfate radicle tends to make conditions more alkaline, but the effect of sulfate-reducing bacteria on the hydrogenion concentration depends upon the nature of the organic matter used as a source of energy, as well as upon the concentration and form of calcium sulfate. RitTENBERG (I94I) and others have found that under certain conditions the media in which sulfate reducers are growing become progressively more acidic because the organic matter which is being utilized as a source of energy is oxidized to organic acids in sufficient concentrations to offset the effect of the sulfate which is reduced.

DrEw (I9II, I9I3) attributed the precipitation of $\mathrm{CaCO}_{3}$ in the sea largely to the action of denitrifying bacteria according to the following reaction in which hydrogen and carbon are derived from the anaerobic oxidation of organic matter:

$$
\mathrm{Ca}\left(\mathrm{NO}_{3}\right)_{2}+{ }_{3} \mathrm{H}_{2}+\mathrm{C}=\mathrm{CaCO}_{3}+{ }_{3} \mathrm{H}_{2} \mathrm{O}+\mathrm{N}_{2}
$$

His conclusion was based primarily upon experiments in artificial media and the observation of large numbers of denitrifying bacteria in tropical seas where there was evidence of limestone formation. Believing that the process was fairly specific, DREW (I9I2) named the organism involved Bacterium calcis. This organism was more thoroughly described by KELLERMAN and SMIth (I9I4) who classified it as Pseudomonas calcis. It is closely related or identical to marine denitrifiers described by GRAN (IgOi), Baur (I902), Feitel (I903), and Parlandt (I9I I).

Kellerman and SMith (I9I4) confirmed Drew's observations on the precipitation of $\mathrm{CaCO}_{3}$ in nitrate media by Pseudomonas calcis. They found further that ammonia production either from protein or nitrate decomposition resulted in $\mathrm{CaCO}_{3}$ precipitation:

$$
\mathrm{Ca}\left(\mathrm{HCO}_{3}\right)_{2}+2 \mathrm{NH}_{4} \mathrm{OH}=\mathrm{CaCO}_{3}+2 \mathrm{H}_{2} \mathrm{O}+\left(\mathrm{NH}_{4}\right)_{2} \mathrm{CO}_{3}
$$

Other microorganisms may be instrumental in the process by oxidizing the calcium salts of organic acids, leaving calcium and $\mathrm{CO}_{2}$ which, in the presence of water, unite to form $\mathrm{CaCO}_{3}$. These observations were confirmed and extended by Kellerman (I9I5a). Kellerman and Smith (I9I6) found halophilic lime-precipitating bacteria in Great Salt Lake which resembled those isolated from the sea.

BERKELEY (19I9) failed to find any evidence of denitrification (liberation of free nitrogen from nitrate) by bacteria in sea water collected off Vancouver Island. In artificial media, however, the bacterial reduction of nitrate resulted in the precipitation of $\mathrm{CaCO}_{3}$. BERKELEY attributed the precipitation of $\mathrm{CaCO}_{3}$ in sea water primarily to the bacterial oxidation of organic calcium salts:

$$
\mathrm{Ca}\left(\mathrm{COOCH}_{3}\right)_{2}+{ }_{4} \mathrm{O}_{2}=\mathrm{CaCO}_{3}+{ }_{3} \mathrm{CO}_{2}+3 \mathrm{H}_{2} \mathrm{O}
$$

LIPMAN (I924) has questioned the ability of Pseudomonas calcis or other denitrifying bacteria to precipitate $\mathrm{CaCO}_{3}$ from pure sea water 
which has not been enriched with either calcium salts, organic matter, or nitrate. He regarded ammonia production from organic matter to be the most important factor. The utilization of $\mathrm{CO}_{2}$ by plants, thereby increasing the $p \mathrm{H}$ of sea water, was also recognized as an important factor. In a later publication, LIPMAN (I929) averred that under ordinary conditions bacteria do not possess the ability to precipitate $\mathrm{CaCO}_{3}$ from sea water, a conclusion which was predicated primarily upon the paucity of bacteria in the open sea. This conclusion has been rendered untenable by the large numbers of bacteria found in marine bottom deposits, particularly calcareous deposits (BAVENDAMM, I932).

Being guided by the work of $\mathrm{DREw}$, who regarded $\mathrm{CaCO}_{3}$ precipitation as being due to specific "calcium bacteria," MoLISCH (I925) reported the discovery of aquatic bacteria which precipitate $\mathrm{CaCO}_{3}$ by the formation of ammonia. He isolated Pseudomonas calcipraecipitans from sea water and Pseudomonas calciphilia from fresh water. MoLIsch also described an Actinomyces sp. and a pink yeast, Saccharomyces olexudans, both of which allegedly precipitate $\mathrm{CaCO}_{3}$.

Sмгтн ( 1926 ) grouped bacteria from "chalky mud" from the Bahama Banks into six categories according to their physiological activities and morphology. Only two groups, denitrifiers of the Pseudomonas calcis type and strong ammonifiers, formed calcite from calcium sulfate in sea water. Sterilized bottom mud was employed as a source of nutrients. The addition of peptone and nitrate increased calcite formation. The production of calcite aggregations was enhanced by the presence of 0.2 per cent agar.

From a review of the rather extensive literature on the subject and his own investigations, BAVENDAMM (I93I, I932) concluded that calcium precipitation in tropical seas is primarily a microbiological process but that there are no specific "calcium bacteria." He correctly emphasized that microbiological precipitation can be ascribed only to certain marine sections. In other regions of the ocean, microorganisms may be dissolving calcareous deposits. Soil bacteria studied by MUrRay and Love (I929) produced enough acids, including carbonic acid, from organic matter to make them much more effective than atmospheric carbon dioxide in dissolving limestone.

Whether the combined activities of microorganisms will tend to precipitate or dissolve $\mathrm{CaCO}_{3}$ depends upon the sum total of their effects on chemical and physico-chemical conditions, their effect on the $p \mathrm{H}$ of the environment being one of the most important considerations. While autotrophic organisms are instrumental in the process, microbiological $\mathrm{CaCO}_{3}$ precipitation is confined largely to sections where there is an abundance of organic matter. This condition is not fulfilled over most of the sea bottom, but it is certainly met in shallow, swampy areas where there is much $\mathrm{CaCO}_{3}$ deposition.

Although their preliminary experiments failed to prove the connection of the activity of microorganisms and the precipitation of $\mathrm{CaCO}_{3}$ within the deposits of Lake Mendota, Williams and MCCoy (I934) isolated from the lake deposits many aerobic organisms which were capable of precipitating $\mathrm{CaCO}_{3}$ under artificial conditions. They also examined several commonly known bacterial species which were endowed with this ability. Some of the bacteria precipitated $\mathrm{CaCO}_{3}$ from solutions carrying the same amount of calcium as does lake water. Believing that nitrate reduction, the oxidation of organic calcium salts, or ammonia production from nitrogenous material accounted for the microbiological precipitation of $\mathrm{CaCO}_{3}$, 
WrLliams and MCCoy employed media which contained either peptone, calcium lactate, or potassium nitrate besides various other ingredients.

Kalantarian and Petrossian (1932) isolated Bacterium sewanense from Lake Sewan, Transcaucasia, Russia. This organism was believed to induce the precipitation of $\mathrm{CaCO}_{3}$ by reducing nitrate and producing ammonia.

From his extensive review of the literature, BAIER (I937a) lists the following ways in which microorganisms may influence $\mathrm{CaCO}_{3}$ equilibrium: (a) by their effect on the $p \mathrm{H},(b)$ by producing or consuming $\mathrm{CO}_{2},(c)$ by oxidizing organic calcium salts and $(d)$ by assimilating calcium. The direction and extent of the reactions depends upon the types of microorganisms present, the chemical composition of their surroundings, and other environmental conditions.

- Deposition of iron and manganese:- There are several ways in which microorganisms are instrumental in the deposition and transformation of iron and manganese. Autotrophic species such as Leplothrix ochracea and Gallionella ferruginea, which allegedly obtain their energy requirements by oxidizing ferrous iron, are generally associated with ironbearing waters and bog-iron deposits. Similarly, species of Siderocapsa, Crenothrix, Cladothrix, and Clonothrix are often found in iron-bearing surface waters as revealed by the literature reviewed by HARDER (I9I9), Ellis (I9I9), Cholodny (I926), Dorff (I935), and Baier (I937b). The taxonomic position and metabolism of many of the so-called "ironbacteria" are highly problematical but such organisms do promote the deposition of iron either directly or indirectly.

HARDER (I9I9) reports that, "iron-depositing thread-bacteria have never been found in sea water and probably do not occur there on account of the high percentage of certain inorganic salts." However, CHOLODNY (I926) has shown that iron bacteria can develop in chalybeate waters, the salt content of which is greater than that of sea water. THIEL (I925) reports finding in marine mud numerous heterotrophic bacteria and molds which precipitate iron and manganese, but he names no species.

Butkevich (I928) isolated Gallionella turtuosa from the Petschora Sea and Gallionella reticulosa from the White Sea. The organisms were found in ferromanganese concretions in bottom deposits. Leptothrix longissima was isolated from the sea by MoLISCH (I9I0).

In the black mud of the Sea of Azov and the Black Sea, IssATchenko (I9I2) found Spirillum levocolelaenum, an organism which precipitates iron sulfide in the bacterial cell. Issatchenko (I929) believed that bacteria are the chief agents in the formation of pyrite. While ferrous sulfide is formed intracellularly by some bacteria and deposited as pyrite following their death, any bacteria which produce $\mathrm{H}_{2} \mathrm{~S}$ may contribute to the deposition of iron as pyrite.

Besides the autotrophic bacteria which oxidize iron or manganese to the corresponding hydroxides and the heterotrophs which precipitate the metals as sulfides by producing $\mathrm{H}_{2} \mathrm{~S}$, there are other ways in which microbiological activities contribute to the deposition or transformation of iron. STARKEY and HALVORSON (I927) believe that heterotrophic organisms play a more important role in the deposition of iron than do autotrophs. This the heterotrophs do by decomposing organic compounds of iron, by changing the $p \mathrm{H}$ of the water or mud, and by altering the oxygen tension or $\mathrm{E}_{\mathrm{h}}$. Both the $\mathrm{E}_{\mathrm{h}}$ and $p \mathrm{H}$ of a system influence the state of iron. By 
producing oxygen, algae and diatoms may cause the precipitation of ferric iron. STARKEY and HALVORSON question the widespread occurrence and activity of autotrophic iron bacteria.

ThIEL (I928) is also of the opinion that the importance of true autotrophic iron bacteria as geological agents has been overemphasized, while the effects of heterotrophs on the deposition and transformation of iron have been neglected. He reports that manganese as well as iron compounds are precipitated by heterotrophic bacteria and by certain fungi found in peat.

HARDMAN and HENRICI (I939) believe that Siderocapsa treubii, which has been regarded as an autotroph, probably is a heterotrophic organism, utilizing the organic radicle of organic iron compounds and merely depositing the iron as a waste product upon the cell capsules. This organism, together with the closely related Siderocapsa major, was found abundantly in alkaline, hard-water lakes of the drainage type and in certain rapidly flowing streams. Species of Siderocapsa were not found in neutral or acidic soft-water lakes of the seepage type. Leptothrix crassa and related iron-depositing bacteria were found in certain lakes having a high content of iron.

Microbiological deposition of manganese is believed to occur in about the same way as iron deposition (DORFF, I935; BAIER, I937 $b$; ZAPFFE, I93 I). In many environments iron and manganese are deposited together, and most of the bacteria which precipitate iron likewise precipitate manganese. According to JACKSON (I9O2), Crenothrix polyspora, Cr.manganifera, and $\mathrm{Cr}$. ochracea are able to precipitate either iron, manganese, or aluminum from water.

The precipitation of copper (as sulfide) in mud by bacterial activity has been reported by LovERING (I927). Copper precipitation is due not to specific bacteria but rather to the action of reducing substances produced during bacterial metabolism. LOVERING believed that the precipitation of vanadium as vanadite and cornotite may be accounted for upon a basis of bacterial activity. In discussing the role of bacteria in halloysite formation, Bucher (I92I) stated that sulfate-reducing bacteria promote the precipitation of aluminum silicate.

Effect on hydrogen-ion concentration:- As has been stated before, microorganisms are probably the principal dynamic agencies which alter the hydrogen-ion concentration, oxidation-reduction potential, gas tension, and other physico-chemical conditions in bottom deposits. Depending primarily upon the numbers and kinds of microorganisms present, the chemical composition of the substrate, and various environmental conditions, they may tend to increase or to decrease the hydrogen-ion concentration or $p \mathrm{H}$. The following microbiologically activated processes tend to increase the hydrogen-ion concentration or to decrease the $p \mathrm{H}$ : (I) Production of $\mathrm{CO}_{2}$ by respiring cells, (2) production of organic acids such as lactic, butyric, acetic, and formic acids, for example, from the decomposition of carbohydrates, lipids, proteins, etc., (3) oxidation of $\mathrm{H}_{2} \mathrm{~S}$ or sulfur to sulfuric acid or other acid sulfates, (4) reduction of sulfur to $\mathrm{H}_{2} \mathrm{~S}$, (5) formation of nitrite or nitrate, (6) assimilation of ammonium as a source of nitrogen or its oxidation as a source of energy, and $(7)$ the liberation of phosphate from organic compounds. The extent to which these reactions may occur in the marine environment is discussed elsewhere in this volume. 
The hydrogen-ion concentration may be decreased or the $p \mathrm{H}$ increased by the following microbiological reactions: $(I)$ Utilization of $\mathrm{CO}_{2}$ by either chemosynthetic or photosynthetic autotrophs, chiefly diatoms and algae, (2) oxidation or decarboxylation of the salts of organic acids such as formate, acetate, propionate, lactate, etc., (3) reduction of sulfate to sulfur or $\mathrm{H}_{2} \mathrm{~S}$, (4) reduction of nitrate or nitrite, and (5) the formation of ammonia from nitrogenous compounds such as amino acids, proteins, urea, purine bases, etc.

Microorganisms capable of activating the aforementioned reactions have been demonstrated in sedimentary materials. The hydrogen-ion concentration of bottom deposits at depths to which $\mathrm{CO}_{2}$ does not diffuse from the atmosphere is probably largely a function of the interrelated factors which influence the abundance, kinds, and activity of bacteria. An appraisal of these factors will require much additional quantitative information. According to MIYADI (I934), bacterial activity has a pronounced effect upon the hydrogen-ion concentration of lake mud. KusNetzow (I935a) reports that bacterial activity may affect the hydrogen-ion concentration as well as the oxidation-reduction potential of an entire water basin. The influence of bacterial activities on the $p \mathrm{H}$ of water is discussed by ENEVOLDSEN (1927).

Besides influencing the solubility and reactivity of calcium, magnesium, iron, manganese, and other sedimentary constituents, the hydrogenion concentration also influences the oxidation-reduction potential of the sediments. Its effects on base exchange and on the properties of clay are discussed in the symposium volume edited by TrASK (I939).

ZOBELL $(1942 b)$ records that the hydrogen-ion concentration of the topmost layers of bottom deposits is usually nearly the same as that of immediately overlying water. The hydrogen-ion concentration of sea water ranges from $p H$ 7.6 to 8.3, depending primarily upon the depth of the overlying water and its origin. In some cores from the Gulf of California and the Channel Island region off the coast of southern California it increases to as much as $p \mathrm{H} \mathrm{8.9,} \mathrm{and} \mathrm{in} \mathrm{other} \mathrm{cores} \mathrm{it} \mathrm{decreases} \mathrm{with}$ depth to as low as $p \mathrm{H}_{7.2}$. In fresh-water lakes the range is much greater, varying considerably from lake to lake (AlLGEIER el al., I94I).

Effect on oxidation-reduction potential:- The oxidation-reduction $(\mathrm{O} / \mathrm{R}$ or redox $)$ potential of a system may be defined as its relative oxidizing or reducing power or its electron-escaping tendency. The higher the concentration of free electrons in a solution the greater is its reducing power (or the lower its $\mathrm{E}_{\mathrm{h}}$ ), and the lower the concentration of free electrons the greater its oxidizing power (or the higher its $\mathrm{E}_{\mathrm{h}}$ ). The reducing power, oxidizing power, or redox potential of a solution containing a reversible oxidation-reduction system can be expressed conveniently in terms of $\mathrm{E}_{\mathrm{h}}$ measured in volts as E.M.F. compared with the E.M.F. of a normal solution of hydrogen ions (HEwitT, I936). BuCHANAN and FuLMER ( 1928 ) point out that, in general, any system having an $\mathrm{E}_{\mathrm{h}}$ value less than another system will tend to reduce it, and the system having the higher value will tend to oxidize the lower.

Most bacteria tend to create reducing conditions or to lower the $\mathrm{E}_{\mathrm{h}}$ of culture media from an initial $E_{h}$ of +0.2 or +0.3 volt to $E_{h}-0.1$ or -0.2 volt at $p \mathrm{H} 7.0$ (HEwiTT, I936). Anaerobes generally require a lower $\mathrm{E}_{\mathrm{h}}$ for the initiation of growth, and they create more reducing conditions or a lower $\mathrm{E}_{\mathrm{h}}$ than do aerobes (REED and ORR, r943). Not only do bac- 
teria influence the $\mathrm{E}_{\mathrm{h}}$ of the medium in which they are growing; the $\mathrm{E}_{\mathrm{h}}$ of the medium has a pronounced effect on the multiplication and metabolism of bacteria (see extensive reviews of literature by ELEMA, I932; HEwITT, I936; and KANEL, I94I). For example, sulfate reduction, denitrification (Elema et al., I934; Korochkina, I936), and the reductive deaminization of amino acids are enhanced by a relatively low $\mathrm{E}_{\mathrm{h}}$, whereas the oxidation of carbohydrates to $\mathrm{CO}_{2}$ and water is favored by positive $\mathrm{E}_{\mathrm{h}}$ values. Whether acids, alcohols, or other products result from the fermentation of carbohydrates has been shown by KusNeTzow (I93I) to be partly a function of the $E_{h}$ of the medium.

The redox potential of sea water is primarily a function of its oxygen content. CoOper (I937a) found the redox potential of normal surface sea water to be near $\mathrm{E}_{\mathrm{h}}+0.4 \mathrm{~B}$ volt, increasing as the $p \mathrm{H}$ decreases. This value compares favorably with $\mathrm{E}_{\mathrm{h}}+0.46$ to 0.50 volt found by HutchiNSON et al. (I939) in oxygenated lake water. Somewhat lower values were found in shallow inland seas by KUSNETzow (I935a).

The redox potential of lake muds examined by Kusnetzow (I935 $b$ ) ranged from $\mathrm{E}_{\mathrm{h}}+0.145$ to -0.142 volt. In Wisconsin lakes AlLGEIER et al. (I94I) found $E_{h}$ values ranging from +0.5 I 2 volt in upper oxygenated water to -0.140 volt in bottom deposits. Finding marked differences in the redox potentials on different dates led them to conclude that the potentials are controlled by dynamic factors that are in a state of flux, and not by static agents. Bacteria or their metabolic products are probably the responsible agents in the hypolimnion and in bottom deposits.

In brown bottom deposits from the Barents and Kara Sea which contained appreciable quantities of iron and manganese, BRUJEVICZ (I937, I938) found the $\mathrm{E}_{\mathrm{h}}$ to range from +0.105 to 0.250 volt. In black mud rich in $\mathrm{H}_{2} \mathrm{~S}$, one might expect the conditions to be reducing.

Several hundred potentiometric measurements made on profile samples of bottom deposits from the Pacific Ocean show that, as a rule, the redox potential decreases with depth. Except under water containing $\mathrm{H}_{2} \mathrm{~S}$, the redox potential of the sediments at the mud-water interface ranges from $E_{h}$ o or slightly positive values to $E_{h}-0.2$ volt. The redox potential decreases more or less regularly with depth to a depth of 25 to $50 \mathrm{~cm}$. where the $\mathrm{E}_{\mathrm{h}}$ is -0.2 to -0.4 volt. At greater depths the results have been somewhat erratic, fluctuating from $\mathrm{E}_{\mathrm{h}}-0.2$ to -0.5 volt at $p \mathrm{H}$ 7.0. One sample gave a reading of $\mathrm{E}_{\mathrm{h}}-0.58$ volt, this being the most reducing sediment examined. Bacterial cultures observed in the laboratory are able to create such reducing conditions, and unquestionably are at least partly responsible for the reducing conditions found in bottom deposits (ZoBelL, I939a).

The erratic results obtained at core depths exceeding 25 to $50 \mathrm{~cm}$. are attributed partly to technical difficulties involved in making the measurements on freshly collected samples and partly to the decrease in the content of reversibly oxidizable or reducing constituents. The poising capacity, as indicated by the quantity of reducing substances in the sediments, usually decreases with core depth. This is shown by the data in Table XXX which gives the oxygen-absorbing capacity (spontaneous or abiogenic) of samples from different core depths.

The redox potential has a marked influence upon the direction, velocity, and magnitude of chemical reactions which involve the exchange of electrons, or the oxidation or reduction of reactants. Consequently, the redox potential probably influences the diagenesis of bottom deposits in many 
TABLE XXX. - Numbers of bacteria which developed acrobically and anacrobically in marine mud strata from differcut depths. The redox capacity in terms of spontancous or abiogenic oxygen absorption and the redox potential (intensity) in terms of E corrected to pH 7.0 are also given (from ZOBELL and ANDERSON, 19366):-

\begin{tabular}{|c|c|c|c|c|c|}
\hline $\begin{array}{l}\text { CORE DEPTH } \\
\text { IN CM. }\end{array}$ & $\begin{array}{l}\text { ANAEROBES } \\
\text { PER GRAM }\end{array}$ & $\begin{array}{l}\text { AEROBES } \\
\text { PER GRAM }\end{array}$ & $\begin{array}{c}\text { MGM. OXYGEN } \\
\text { ABSORBED/GRAM }\end{array}$ & $\begin{array}{l}E_{h} \text { IN } \\
\text { vOLTS }\end{array}$ & $\begin{array}{l}p \mathrm{H} \text { or } \\
\text { MUDD }\end{array}$ \\
\hline$\circ$ to 3 & $1,160,000$ & $74,000,000$ & 2.8 & -0.12 & 8.2 \\
\hline 4 to 6 & 14,000 & 314,000 & I. 3 & -0.29 & $7 \cdot 9$ \\
\hline 14 to 16 & 8,900 & 56,000 & 0.6 & -0.37 & 7.8 \\
\hline 24 to 26 & 3,100 & 10,400 & 0.7 & $-0.3^{2}$ & 8.0 \\
\hline 44 to 46 & 5,700 & 28,100 & 0.3 & -0.37 & $7 \cdot 9$ \\
\hline 66 to 68 & 2,300 & 4,200 & 0.4 & -0.34 & 7.8 \\
\hline
\end{tabular}

ways. Pearsall and Mortimer (1939) find that the states of iron, sulfur, and certain nitrogen compounds are functions of the redox potential of mud. Reducing conditions created by bacterial processes are believed by LOVERING (I927) to promote the precipitation of copper, vanadium, and other minerals.

Factors influencing oxygen consumption:- Most bacteria consume oxygen. The marine bacteria studied by JoHnson (I936) consumed from 2.8 to $185 \times 10^{-12} \mathrm{mgm}$. of oxygen per cell per hour as "resting cells" suspended in sea water at $25^{\circ} \mathrm{C}$. About one-fifth this quantity of oxygen was consumed at $5^{\circ} \mathrm{C}$., the $\mathrm{Q}_{10}$ being 2.3 between $5^{\circ}$ and $15^{\circ} \mathrm{C}$. and 2.18 between $15^{\circ}$ and $25^{\circ} \mathrm{C}$. The addition of 0.04 per cent alginate increased the oxygen uptake by from 7.9 to I ro per cent, while the addition of 0.04 per cent glucose effected an increase of from to to $37^{8}$ per cent.

By determining the amount of oxygen consumed by bacteria in sea water and the number of bacteria present at any given time, ZoBELL ( $1940 b$ ) estimated that marine bacteria multiplying in sea water consume an average of $20.9 \times 10^{-12} \mathrm{mgm}$. of oxygen per cell per hour at $22^{\circ} \mathrm{C}$. The rate of oxygen consumption was increased nearly four times when the sea water was enriched with 0.05 per cent of asparagine or glucose. The rate of oxygen consumption was found to be independent of the oxygen tension within the examined range of between 0.43 and $17.84 \mathrm{mgm}$. of oxygen per liter.

The oxygen consumption of microorganisms in Lake Glubokoje, Russia, studied by LIAGINA and KUSNETZOw (I937) ranged from I2.5 to $30.3 \times 10^{-12} \mathrm{mgm}$. per cell per hour for bacilli to $\mathrm{I} 28$ to $\mathrm{I} 84 \times 10^{-12} \mathrm{mgm}$. per cell per hour for torulae at $I 5^{\circ}$ to $25^{\circ} \mathrm{C}$. Their calculations clearly show that the respiration of bacteria could account for the depletion of oxygen from the bottoms of the lakes studied.

Multiplying bacteria from Lake Mendota, Wisconsin, were found by ZOBELL and STADLER (I94Ob) to consume from 5 I to $93 \times 10^{-12} \mathrm{mgm}$. of oxygen per cell per hour in freshly collected lake water at $25^{\circ} \mathrm{C}$. The rate decreased as oxidizable organic matter became a limiting factor, but the rate of oxygen consumption was independent of the oxygen tension within the examined ranges of 0.30 to $36 \mathrm{mgm}$. per liter. The rate of respiration is a function of temperature, the $Q_{10}$ being 2.I between $8^{\circ}$ and $25^{\circ} \mathrm{C}$. (ZoBelL, I940a). The effect of the quality and quantity of organic matter upon the respiration of marine bacteria has been studied by ZOBELL and GRANT (I943) who found that concentrations of organic matter as low as 0.Io mgm. per liter are quantitatively utilized. 
The foregoing data on the rate of oxygen consumption by aquatic bacteria should suffice to indicate that the abundant bacterial flora of bottom deposits may play an important role in depleting dissolved oxygen in lake bottoms. Not only is all of the oxygen consumed in most bottom deposits faster than it can be replaced by diffusion from the atmosphere or photosynthetic processes, but there is generally an oxygen deficit in bottom deposits as shown by the spontaneous oxygen-absorbing capacity (see Table XXX). ZoBell and Feltham (I942) estimated that there are enough bacteria in the topmost $1.0 \mathrm{~cm}$. of each square meter of Mission Bay mud to consume from 8.4 to $25.2 \mathrm{mgm}$. of oxygen per day at $20^{\circ} \mathrm{C}$.

Bacteria in various lake deposits examined by Mryadi (I934) consumed from 0.42 to $1.26 \mathrm{mgm}$. of oxygen per gram of mud in 60 hours at $15^{\circ} \mathrm{C}$. In general, muds having the highest organic-carbon content and those under water containing the least dissolved oxygen exhibited the largest biochemical oxygen demand. WAKsMaN and Hotchkiss (I938) likewise found the oxygen consuming capacity of bottom deposits to be a function of the organic content. The biochemical oxygen demand of bottom deposits from the Woods Hole region was found to be from 0.08 to $2.83 \mathrm{mgm}$. of oxygen per gram in I4 days at $25^{\circ} \mathrm{C}$.

KusNetzow and KaRzinkin (I93I) attributed the zones of diminished oxygen tension in Lake Glubokoje to bacterial activity, after observing that the disappearance of oxygen corresponded with large bacterial populations. This conclusion has been substantiated by more recent observations of KusNETzOW ( $1935 b$ ) who found that heterotrophic bacteria are the chief agents responsible for the depletion of oxygen from lake bottoms. Methane- and hydrogen-oxidizing bacteria were regarded by KusNetzow as also being very important.

Gases in bottom deposits:- Because of the relatively large bacterial populations and high content of organic matter in bottom deposits, it is primarily in or immediately above bottom deposits that the most oxygen is consumed. Likewise it is primarily in or near bottom deposits that other gases are produced or transformed by bacteria.

Under anaerobic conditions appreciable quantities of methane and hydrogen may be produced from the decomposition of organic matter. According to WAKSMAN ( $194 \mathrm{I} a$ ), the anaerobic oxidation of organic matter by aquatic bacteria results in the formation of methane, hydrogen, $\mathrm{H}_{2} \mathrm{~S}$, and organic acids besides $\mathrm{CO}_{2}$, phosphate, and ammonia, whereas under aerobic conditions organic matter is decomposed with the formation of $\mathrm{CO}_{2}$, phosphate, ammonia, and sulfate.

The gaseous products resulting from the anaerobic decomposition of lake muds observed by AlLGEIER et al. (I932) consisted of from 65 to 85 per cent methane, 3 to 30 per cent $\mathrm{CO}_{2}$, I to 3 per cent $\mathrm{H}_{2}$ and from 3 to 22 per cent $\mathrm{N}_{2}$. The catabolic $\mathrm{H}_{2} \mathrm{~S}$ had probably combined with mineral constituents to give metallic sulfides.

DÜGGELI (1936) reported that the gas produced in deep muds from Red Lake in Switzerland consisted largely of methane and $\mathrm{N}_{2}$ with lesser quantities of $\mathrm{H}_{2}, \mathrm{CO}_{2}$, and $\mathrm{H}_{2} \mathrm{~S}$.

Very little work has been done on methane production in marine muds but there is voluminous literature on the factors which influence the bacterial production of methane in industrial wastes, soil, and under laboratory conditions (BARKER, I936a, b; Buswell, I936). The general occurrence of methane in natural gas which is usually associated with an- 
cient marine sediments, and the almost universal formation of methane in recent marine sediments rich in organic matter, suggest the importance of this gas as an end product of decomposing organic matter.

The evolution of methane and hydrogen from Lake Glubokoje has been described by KusNetzow (I935b) who discusses the importance of these so-called "mud gases." He believes that the oxidation of methane and hydrogen by autotrophic bacteria in the overlying oxygenated water plays an important role in depleting the oxygen content of lakes. The bacterial production of methane, hydrogen, $\mathrm{CO}_{2}$, and $\mathrm{H}_{2} \mathrm{~S}$ has been observed by ButKevich (1938) in mud from the Caspian Sea.

The anaerobic fermentation of organic matter usually results in the formation of a certain amount of hydrogen (BuswelL, I936). Several species of bacteria are endowed with this ability. Due to the chemical reactivity of nascent hydrogen and the tendency of various bacteria to activate molecular hydrogen, it is difficult to estimate how much hydrogen may be produced in bottom deposits. However, the fact that free hydrogen is often detectable is evidence that it is formed, probably in very significant quantities. Sugawara el al. (I937) noted the presence of hydrogen, along with methane and nitrogen, in lake deposits of high organic content.

Large quantities of hydrogen may be consumed in the production of methane in mud. SöHNGEN (I9IO) postulated that methane is formed by the bacterial reduction of $\mathrm{CO}_{2}$ in the presence of hydrogen:

$$
{ }_{4} \mathrm{H}_{2}+\mathrm{CO}_{2}=\mathrm{CH}_{4}+{ }_{2} \mathrm{H}_{2} \mathrm{O}
$$

This mechanism of methane formation has been amply confirmed (BARKER, I936a), but it is still problematical whether free hydrogen is always involved as an intermediate reactant in methane formation.

STEPHENSON and Stickland (I93I) observed that certain anaerobes use molecular hydrogen to reduce sulfate to $\mathrm{H}_{2} \mathrm{~S}$ in the proportions indicated by the following equation:

$$
\mathrm{H}_{2} \mathrm{SO}_{4}+{ }_{4} \mathrm{H}_{2}=\mathrm{H}_{2} \mathrm{~S}+{ }_{4} \mathrm{H}_{2} \mathrm{O}
$$

This observation has been confirmed by the work of STARKEY and WIGHT (I943) and others. Hydrogen may play a role also in the hydrogenation of organic matter with the formation of petroleum hydrocarbons.

Nitrogen may be liberated from nitrogenous organic matter undergoing anaerobic decomposition, although the mechanism of the reaction is not well understood. Ammonia ordinarily is liberated from decomposing proteins but it will appear as a gas only when present in high concentrations or in an alkaline environment. Nitrogen may be liberated from nitrates or nitrites by the process of denitrification, but since neither nitrates nor nitrites occur in bottom deposits having a low $\mathrm{E}_{\mathrm{h}}$, they are not likely sources of nitrogen.

Often appreciable quantities of $\mathrm{H}_{2} \mathrm{~S}$ are formed during the decomposition of proteins and from the reduction of sulfate. The $\mathrm{H}_{2} \mathrm{~S}$ may be either fixed in the sediments as metallic sulfides or may escape in to the overlying water. Most black muds are rich in ferrous sulfide. If enough $\mathrm{H}_{2} \mathrm{~S}$ is produced to escape into the water, it tends to deplete the dissolved oxygen either abiogenically or through the activities of sulfur bacteria. $\mathrm{H}_{2} \mathrm{~S}$ produced on the bottom of the Black Sea and in other stagnant bodies of water is primarily responsible for the prevailing anaerobic conditions in the overlying water. COPENHAGEN (I 934) records that $\mathrm{H}_{2} \mathrm{~S}$ generated in 
the bottom of Walvis Bay on the South African Coast depleted the oxygen from the overlying water, and at times has been lethal to the fauna and flora. MEARS (I943) relates that in certain polluted harbors (notably Calloa, Peru) so much $\mathrm{H}_{2} \mathrm{~S}$ is produced that metallic surfaces and surfaces coated with lead-base paints are blackened by the formation of metallic sulfides, giving rise to the phenomenon known in nautical parlance as the "Calloa Painter."

From his investigations on the "stinking putrefaction" in the Little Kiel, Germany, during summer, BAIER (I935) concluded, that while the production of appreciable quantities of $\mathrm{H}_{2} \mathrm{~S}$ corresponded with periods during which there was much organic matter undergoing decomposition, the $\mathrm{H}_{2} \mathrm{~S}$ was derived primarily from the bacterial reduction of sulfate and only to a slight extent from proteins. Most if not all of the $\mathrm{H}_{2} \mathrm{~S}$ was generated in the bottom mud.

Autotrophic bacteria may be instrumental in the oxidation of $\mathrm{H}_{2} \mathrm{~S}$, methane, carbon monoxide, and hydrogen at the mud-water interface or in the overlying water, provided that there is an adequate supply of dissolved oxygen.

Effect on organic content of bottom deposits:- Bacteria influence the quality and quantity of organic matter, both during the time that it is settling to the bottom and after it has been deposited and buried. The organic compounds which are most susceptible to attack, such as simple proteins and carbohydrates, are utilized first, leaving the more refractory compounds such as lignins, complex proteins, chitins, lipids, polyuronides, and other complexes known collectively as humus. This occurs in marine bottom deposits (WAKSMAN, I933; TrASK, I939) as well as in lakes (WAKsMAN, I94I $a$ ).

Illustrative data are provided by WAKSMAN and Hotchkiss (I937) who found the biochemical oxygen demand (B.O.D.) of mud from different depths as follows:

$\begin{array}{cc}\text { DePth OF } & \text { Nitrogen CONTENT } \\ \text { LAYER } & \text { OF DRY MUD } \\ \text { O to I cm. } & 0.095 \% \\ \text { I to } 5 \mathrm{~cm} . & 0.087 \% \\ 5 \text { to } 20 \mathrm{~cm} . & 0.070 \%\end{array}$

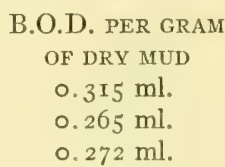

The B.O.D. is the amount of oxygen consumed by bacteria in oxidizing organic matter in a given period of time. Thus the B.O.D. is partly a measure of the quantity of organic matter and partly a measure of its biological oxidizability.

ANDERSON (I940) determined the organic content of a large number of marine muds and also their B.O.D. In general, the largest organic content, as well as the highest I 5-day B.O.D. per gram of organic carbon, was found in the topmost sections of the cores, although many unexplainable irregularities are reported. As a rule, the surface layers of mud contain the most organic matter, and that which is present is more readily decomposed by bacteria than the organic matter at greater depths in the cores. In representative experiments conducted by ANDERSON (I940), the B.O.D. of samples was $1.39 \mathrm{ml}$. during the first 5 days, $0.27 \mathrm{ml}$. during the second five days, and $0.24 \mathrm{ml}$. during the third 5 days, thereby showing a progressive decrease in the oxidizability of the organic matter.

Detailed analyses of cores from the southern California region by Moberg et al. (I937) showed that the highest organic content is at the 
surface of the cores. Within core samples $50 \mathrm{~cm}$. long, the organic content near the lower end of the core fell to about two-thirds of that found near the surface. The amount of organic matter in the lower portion of the core was relatively constant. The vertical distribution of organic matter corresponded with the abundance of bacteria.

From his extensive studies of the organic content of marine sediments, TrASK (I939) concluded that by the time the sediments have been buried to a depth of $30 \mathrm{~cm}$., the quantity of organic matter seems to have decreased about I 5 per cent, and by the time that they have been lithified, some tens of millions of years after they have been deposited, the average decrease in organic content is about 40 per cent. He points out that these figures of 15 and 40 per cent are only rough approximations because the loss of organic matter differs greatly in different sediments. TRASK (1932) believes that anaerobic bacteria are the only living things which can alter organic matter after it has been buried to considerable depths.

Further details on the transformation of organic matter are given in Chapter X.

The petroleum problem:- Since the majority of the known petroleum deposits occur in ancient marine sediments, one is led to wonder whether organic matter is being converted into petroleum or protopetroleum in recent sediments. Assuming that petroleum is formed from plant or animal organic matter, there are many ways in which the activities of bacteria may contribute to the process.

Field observations and laboratory experiments show that bacteria tend to convert organic matter into substances which are more petroleumlike. This they do by reducing the oxygen, nitrogen, phosphorus, and sulfur content of organic matter. The average proximate analyses of samples of organic matter representing different geological ages as compiled from various sources is as follows:

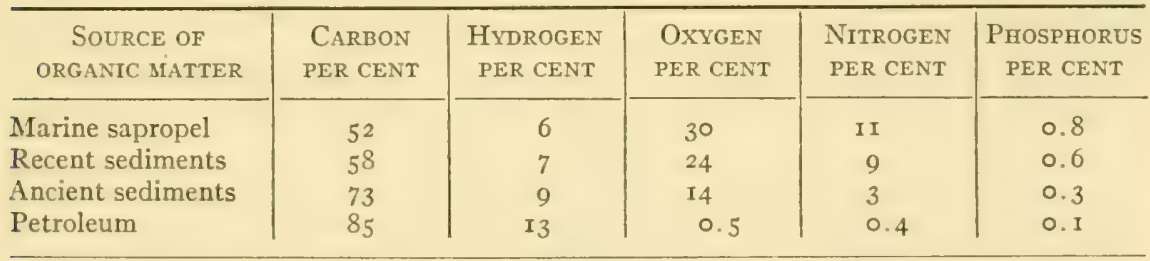

Microbiologically produced hydrogen may be instrumental in the hydrogenation of certain kinds of organic matter, thereby converting it into substances which are more petroleum-like. Methane is known to be produced by the bacterially-activated hydrogenation of $\mathrm{CO}_{2}$ (BARKER, I936a), and it is not impossible that higher hydrocarbons may be formed by the hydrogenation of certain kinds of organic matter such as cellulose, for example. $\mathrm{H}_{2} \mathrm{~S}$, which is a good reducing agent, may likewise contribute to the hydrogenation or reduction of organic matter.

JANKowskI and ZoBELL (I944) have found that certain sulfate-reducing bacteria are able to produce paraffin hydrocarbons ranging from $C_{10}$ to $\mathrm{C}_{35}$ from various fatty acids and carbohydrates. The common occurrence of sulfate-reducing bacteria in oil-well brines (BASTIN and GREER, I930; GAHL and ANDERSON, I928) and the low content of sulfate in oil-well brines is very suggestive of the significance of sulfate reducers in petroleum formation. 
Besides their ability to produce and transform petroleum hydrocarbons (TAUSSON and ALIOSCHINA, I932), sulfate-reducing bacteria may help to liberate adsorbed oil by producing $\mathrm{CO}_{2}$ which decreases the viscosity of oil. Likewise, sulfate reducers may dissolve limestone or dolomite, thereby liberating the adsorbed oil, or the latter may be set free by microbially produced surface-active or detergent substances. Other anaerobes besides sulfate reducers may also contribute to these processes.

The low $\mathrm{E}_{\mathrm{h}}$, or highly reducing conditions, created by bacteria in bottom deposits tend to favor the formation and preservation of petroleum hydrocarbons. TRASK and PATNODE (I942) point out that source beds of petroleum are usually highly reducing. In so far as is known, bacteria are the principal agents responsible for these reducing conditions.

While there are several ways in which bacterial activities may contribute to petroleum formation, under certain conditions hydrocarbonoxidizing bacteria may prevent the accumulation of oil. The literature on this subject has been reviewed by ZoBell et al. (1943). Further information on the relation of bacteria to petroleum formation is given by ZoBell (1943a).

Sulfur deposition:- There are two main types of elementary sulfur occurring in nature. The solfataric or volcanic type is formed from $\mathrm{H}_{2} \mathrm{~S}$ and $\mathrm{SO}_{2}$ in volcanic gases. The gypsum type is believed to result from the reduction of calcium sulfate. The gypsum type of sulfur deposits are associated with marine sediments. There is evidence that gypsum or calcium sulfate is being reduced to sulfur at the expense of the buried organic matter which serves as a source of energy for the reaction. Although conclusive proof is still lacking, it is generally believed by geologists and microbiologists that anaerobic bacteria are responsible for sulfur deposits of the gypsum type. Some of these sulfur deposits in Louisiana and Texas are a hundred or more feet thick. Unique sulfate-reducing bacteria, which appear to be indigenous species, have been isolated from sulfur-limestoneanhydrite formations from a depth of I $55^{\circ}$ feet. HUNT (I9I 5) attributed the origin of the sulfur deposits of Sicily to the bacterial reduction of sulfates in ancient shallow marine seas resembling present conditions in the Black Sea.

Sulfur is also deposited either intracellularly or extracellularly by various autotrophic bacteria. The activities of autotrophic sulfur bacteria as well as those of heterotrophic sulfate-reducing bacteria are discussed in Chapter XII. As geological agents which deposit sulfur, the sulfate reducers are probably by far the more important of the two categories of microorganisms.

Particle-binding action of microorganisms:- Besides their effects on the chemical and physico-chemical conditions of bottom deposits, there are several ways in which microorganisms may promote mechanically the diagenesis, lithification, or consolidation of particles of sand, silt, clay, and colloids which constitute marine sediments.

The calcareous materials which are precipitated either directly or indirectly by bacteria in recent sediments tend to cement together solid particles such as clay, silt, or sand. $\mathrm{CaCO}_{3}$ is one of the commonest cementing materials in sedimentary rocks. $\mathrm{MgCO}_{3}$ is also important.

Certain bacteria produce mucilaginous exudates or capsular materials which adhere to particles of sediments or which cause the particles to 
adhere to the bacteria. The aggregation of particles of clay, silt, and sand hastens the rate of sedimentation and influences the structures of the resultant bottom deposits. The work of WAKSMLAN and VARTIOVAara (1938), RuBENTSCHK et al. (1936), and others has demonstrated that bacteria have a marked affinity for solids. Filamentous cells may weave particles together into intricate meshworks. The extent of the binding action depends primarily upon the types of microorganisms present and the quality of the organic matter (PEELE, I936). The influence of microorganisms on soil aggregations has been investigated by MARTIN and WAKSMAN (I940).

Enzymes in bottom deposits:- In considering the evidence for various types of biochemical processes which occur in bottom deposits, KrEPS (I934) points out that the absence of specific microorganisms does not prove the absence of the corresponding biochemical process because the latter may be effected by organic catalysts or enzymes. He believes that bacterial enzymes are concentrated upon the sea bottom where they continue to function long after the bacteria have disappeared. There are no data available for appraising the part played by buried enzymes or the enzymes of resting cells in the transformation of bottom deposits, but it is possible that such enzymes may be very important catalytic agents.

Seitz-filtered, germ-free sea water from Murman coast fjords was observed by Bokova et al. (I936) to calalyze changes in the oxygen, phosphate, nitrate, and ammonia content of water samples. Bacterial enzymes, including both oxidases and reductases, were found in greatest concentration in water collected just off the bottom. The observations suggest that marine bottom deposits may be especially rich in various enzymes from the remains of bacteria and other organisms. Certain bacterial oxidases, in concentrations greater than can be accounted for by the presence of living bacteria, have been observed in bottom deposits by ZoBell (I939a).

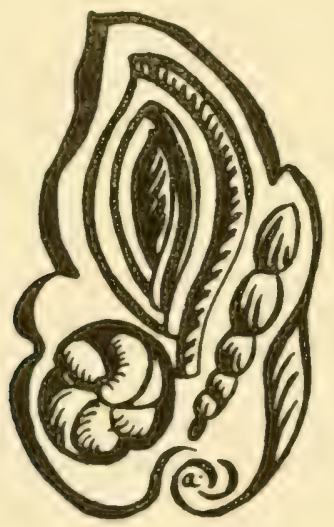




\section{CHARACTERISTICS OF MARINE BACTERIA}

Near shore the movements of water, wind, migratory birds, and other agencies provide for a continuous interchange of microorganisms between the land and the sea. Since many fresh-water and soil bacteria can survive for prolonged periods of time in a salt concentration equal to or greater than that occurring in the sea, and since bays and estuaries provide a gradual transition from fresh to salt water, one might expect to find soil and fresh-water bacteria in the sea freely intermingled with marine forms. Such a condition does prevail along the littoral zone, but only to a very limited extent in the open ocean.

Although there are no infallible criteria for the differentiation of marine from non-marine bacteria, most of the bacteria which occur in the open ocean differ in certain respects from those found in non-marine habitats. This is probably because adventitious organisms either fail to perpetuate themselves in the marine environment or else lose their identity in becoming acclimatized thereto.

Unfortunately there have been no comprehensive studies of the general characteristics of marine bacteria as a group, although the observations of Russell (I89i), Fischer (i894a), Issatchenko (i9i4), BaVendaMm (I932), BeNeCKE (I933), WAKSMAN and coworkers (I932-36), and BEDFORD $($ I $933 a, b)$ are informative. The generalizations recorded below are based upon the published reports of these and other workers together with our own observations.

Cell morphology:- About 80 per cent of the marine bacterial species catalogued by ZoBELL and UPHAM (I944) are Gram-negative rods. From the random examination of colonies which developed on plates as well as from the direct microscopic examination of marine materials stained by the method of Gram, it is estimated that approximately 95 per cent of the bacteria occurring in the sea are Gram-negative. This compares favorably with the percentage of Gram-negative bacteria found in bodies of fresh water by TAYLOR (I942), and is more than twice as many as TAYLOR and LOCHHEAD (1938) found in soil (see Table XXXI).

Apparently there are proportionately more cocci in soil than in

TABLE XXXI.-Comparison of main morphological groups of bacteria in soil, lake water, and marine materials:-

\begin{tabular}{|c|c|c|c|c|}
\hline MORPHOLOGICAL GROUP & SoIL ${ }^{1}$ & Sorr $^{2}$ & LAKE WWATER ${ }^{3}$ & MARINE MATERIALS \\
\hline & per cent & per cent & per cent & per cent \\
\hline Gram-negative rods & 36.1 & 26.7 & $95 \cdot 5$ & 94.6 \\
\hline Gram-positive rods & 46.5 & $73 . I$ & 3.8 & I. 2 \\
\hline Gram-variable rods & 9.4 & & & 0.9 \\
\hline Cocci & 3.8 & & 0.7 & 2.8 \\
\hline Others & $4 \cdot 2$ & 0.2 & & 0.5 \\
\hline
\end{tabular}

1625 soil cultures examined by TAYLoR and Locmead (x938).

2209 soil cultures examined by Topping (1937).

8671 cultures from fresh-water lakes examined by TAYLOR (I942).

750 cultures from sea water and marine mud examined by ZoBell el al. 
aquatic environments, but any generalizations must be preceded by more extensive investigations. Pleomorphism appears to be more common among marine bacteria than among the microflora of rivers, lakes, or soil. About one-fifth of the Gram-negative "rods" occurring in the sea are helicoidal, being properly classified as vibrio or spirilla. For the sake of simplicity, both straight and helicoidal rods are grouped together in Table XXXI since the investigators failed to mention vibrio or spirilla. This may have been an oversight, although there are perhaps more vibrio and spirilla in the sea than in soil or lakes.

The majority of the bacteria found in the sea are actively motile. Flagella have been demonstrated on between 75 and 85 per cent of the pure cultures which have been examined, and a somewhat higher percentage have been reported as "motile." It is interesting to speculate upon the preponderance of motile forms as a possible aquatic adaptation.

Spore-forming bacteria do not appear to be particularly abundant in the sea, although NEwTON (I924) has described the characteristics of 80 different pure cultures of heat-tolerant bacteria which she isolated from the alimentary tracts of marine animals and from sea water. The ability of the organisms to tolerate a temperature of $80^{\circ} \mathrm{C}$. for ten minutes was used as a criterion of spore formation. Twelve of her cultures survived boiling for three hours. Most marine bacteria are notoriously heat sensitive, as is discussed below.

Marine spore-forming bacteria described by ZoBELL and UPHAM (1944) include Bacillus abysseus, B. borborokoites, B. cirroflagellosus, B. filicolonicus, B. imomarinus, B. submarimus, B. thalassokoites, and B. epiphyticus. All of these were isolated from mud except $B$. epiphyticus. It was found associated with algae.

On the average, marine bacteria are smaller than those which occur in milk, sewage, fresh water, or soil. Fresh-water bacteria are smaller on the average than soil forms. This generalization applies to representatives of the sub-order Eubacteriineae. Sulfur bacteria and representatives of the Chlamydobacteriales and Spirochaetales present many exceptions.

Species of Pseudomonas, Vibrio, Flavobacterium, Achromobacter, and Bacterium predominate in the sea in the order named. Representatives of several other genera occur in smaller numbers (see Table XXXIV on p. I24). This may be contrasted with the preponderance of species of Bacillus and Actinomyces ordinarily found in soil. Due to their sanitary significance in fresh-water bodies, the importance of the enteric bacteria has been stressed by many investigators, but numerically they are outnumbered by species of the aforementioned genera.

WAKSMAN (I934) writes, "The bacterial population of the sea is quite characteristic. It is distinct in nature from the population usually found on land, as shown by the more limited number of bacterial types found in the sea. Spore-forming bacteria, which comprise an important part of the bacterial population in soil, are practically absent in sea water, although they may be present in considerable abundance in the sea bottom. Cocci are also of limited occurrence in the sea. Motile rods and various types of vibrios, or comma-shaped organisms, usually make up the major part of the bacterial population thus far studied. The poverty of bacterial species in the sea depends largely upon the specific nature of sea water as a medium for the growth of these organisms."

For further information concerning the morphology of marine bacteria the reader is referred to the literature summarized by ZoBELL and 
UPHAM (I944) who have prepared a list of marine bacteria and have described 60 new species. Of these, 49 are flagellated, 45 are Gramnegative, and 54 are rod-shaped. The average cell is 2 to $3 \mu$ in length by 0.4 to $0.6 \mu$ in width.

Cultural characteristics:- In general, marine bacteria grow more slowly and the colonies are smaller than most microorganisms from soil, sewage, and milk. Whereas plates inoculated with terrestrial bacteria may be counted with good results after incubation from two to seven days at optimal temperatures, the numbers of macroscopically visible colonies of marine bacteria are still increasing significantly after ten days' incubation (see Table IX on page 45). Diffuse, spreading colonies are encountered less frequently on plates inoculated with marine materials than on plates inoculated with soil or fresh water.

Depressed colonies occur on nearly all agar plates inoculated with sea water or marine mud, and occasionally an appreciable portion of the medium will be liquefied by agar digesters. Agar digesters are also found in fresh water and soil, but not nearly as frequently as in the sea. Because they are so conspicuous on agar plates, one may get the impression that agar digesters constitute a sizeable percentage of the marine microflora, but actually an average of only about one to two per cent of the colonies prove to be agar digesters. Over ten per cent of the pure cultures of marine bacteria described in the literature digest agar, but this is because agar digesters have been selected for special studies.

Typical of water bacteria, more than half of those occurring in the sea are chromogenic. An examination by ZoBeLL and FELTHAM (I934) of several thousand colonies developing on nutrient agar inoculated with sea water or marine mud showed that 69.4 per cent of them produced pigments. The distribution of colors was as follows: 3 I.3 per cent yellow, I 5.2 per cent orange, 9.9 per cent brownish, 7.4 per cent fluorescent, 5.4 per cent red or pink, and 0.2 per cent green. The commonest type of fluorescence exhibited is greenish. Indigo, black, and silvery-sheen colonies have been observed on special media. Twenty species of yellow chromogens were described by ZoBeLL and UPHAM (I944), including Flavobacterium marinotypicum, $\mathrm{Fl}$. marinovirosum, $\mathrm{Fl}$. okeanokoites, $P$ seudomonas neritica, Ps. obscura, Ps. oceanica, Ps. vadosa, Ps. xanthochrus, $V$ ibrio adaptatus, V. marinoflavus, and V. marinovulgaris.

In order to accentuate pigment production, the bacteria were grown in sea-water media enriched with Bacto-tryptone, neopeptone, and beef extract. The plates were incubated at $4^{\circ} \mathrm{C}$. for three weeks following a preliminary incubation of 4 days at $25^{\circ} \mathrm{C}$. Lower temperatures tend to favor pigment production. The unpublished observations of HARVEY UPHAM working in the Scripps Institution laboratories indicate that infusions of fish, octopus, mussel, and other tissues promote the production of pigments by marine bacteria. Many marine bacteria gradually fail to produce pigment during prolonged laboratory cultivations.

Yellow colonies predominated among those observed by GEE (I932b) in sea water and mud around the Florida Keys. Of 855 colonies examined, 593 were yellow and 135 were red. According to PEIRCE (I9I4), the red color of brine around marine salterns may be due to the abundant growth of chromogenic bacteria, although other organisms including Protococcus salinus and Dunaliella salina may be partly responsible. The discoloration of halibut has been shown by BEDFORD (I933a) to be due to the 
growth of marine chromogenic bacteria which develop at $\circ^{\circ} \mathrm{C}$. From the skin of the discolored halibut he isolated various yellow, orange, red, and pink bacteria, some of which grew at temperatures as low as $-5^{\circ} \mathrm{C}$. Further reference is made to the extensive literature on chromogenic bacteria which discolor marine fish on page I90.

SNOw and FRED (1926) found that, except during the period of gross contamination, chromogenic bacteria constitute a high percentage of the microflora indigenous to Lake Mendota. An average of 52 per cent of the bacterial colonies were white or cream-colored, 35 per cent were yellow or orange, and I I per cent were pink or red. Blue, violet, green, and black colonies were noted only infrequently. SNOw and FRED contrast these findings with the percentage of chromogens of all of the Eubacteriales from various habitats described in the I923 edition of BERGEY's Manual of Determinative Bacteriology: 18 per cent white or cream, I8 per cent yellow or orange, and 9 per cent pink or red. Only 3 per cent of the soil bacteria listed in the Bergey Manual produced red or pink pigments as compared with I9 per cent of the salt-water bacteria and 23 per cent of the fresh-water bacteria which were described as red or pink pigment producers.

Considerably more work should be done on the factors which influence pigment production and the ecological significance of chromogenesis. However, the attractiveness of the more perspicuous chromogens should not influence one to overlook the less distinctive achromic varieties.

Nearly all of the bacteria isolated from sea water or marine mud have proved to be facultative aerobes. They grow better in the presence than in the absence of atmospheric oxygen under ordinary conditions of laboratory cultivation. Neither strict aerobes nor strict anaerobes are common in the sea, whereas both are fairly common in soil. The facultative aerobes tend to lose their ability to grow anaerobically after prolonged laboratory cultivation. These are provisional generalizations concerning the relationship of marine bacteria to oxygen, and may be subject to modification when more information is available.

Physiological characteristics:- Reference has already been made to the physiological versatility of marine bacteria. It is believed that there are bacteria in the sea which are capable of attacking nearly any kind of organic substrate, and many inorganic compounds are altered by the activities of marine microorganisms. The same may be said of soil and fresh-water microorganisms, although there are certain gross dissimilarities.

As a group, marine bacteria are more weakly saccharolytic and probably more strongly proteolytic than are either soil or fresh-water bacteria. Whether these properties are influenced by the salinity of the medium or whether they are peculiar adaptations of certain autochthonous species is problematical. Certainly the dissimilarities do not apply to individual species.

Although ZoBELL and Grant (I943) present evidence which suggests that all heterotrophic marine bacteria are able to assimilate glucose, only 46 of the 60 cultures studied by ZoBELL and UPHAM (I944) fermented glucose with the formation of acid, and none of them produced "gas" from glucose. This may be due to a general lack of fermentative ability, but more likely it is due to the efficiency of the organisms in assimilating utilizable organic matter. When cultivated in dilute solutions, the marine 
bacteria studied by ZOBELL and GRANT ( I 943) converted 30 to 35 per cent of the glucose into bacterial protoplasm or intermediate products of metabolism, the rest being oxidized to carbon dioxide and water as a source of energy. WAKSMAN and CAREY (1935 $b$ ) reported that around 60 per cent of the organic matter assimilated by marine bacteria is oxidized and 40 per cent is converted into bacterial protoplasm or intermediate products. It will be interesting to ascertain whether this economy of utilization is peculiar to marine bacteria which have become adapted to living in the extremely dilute organic nutrient concentrations existing in the sea.

Rarely in the open ocean are bacteria encountered which produce acid from lactose. Gas producers are found only in contaminated water. Lactose fermenters are common in soil and most fresh-water bodies. Their sanitary significance is discussed in Chapter XVI. Very few marine bacteria produce acid from sucrose, maltose, xylose, glycerol, mannite, or salicin, and gas producers have not been reported from the high seas. However, like glucose and lactose, most of these carbon compounds can be assimilated by marine bacteria. About one-third of the described species of marine bacteria metabolize starch, but little, if any, acid and no gas is produced from starch. The weak fermentative power of marine bacteria has been mentioned by Coupin (I9I 5 ).

As a group, marine bacteria are actively proteolytic, rapidly attacking most kinds of proteinaceous materials. Nearly all of them liberate ammonia from peptone, and approximately three-fourths of them liquefy gelatin. So many marine bacteria liquefy gelatin that it is not a satisfactory solidifying agent for plate-count media. Only a few marine bacteria liberate detectable quantities of indol from tryptophane. Among the sixty new species described by ZoBELL and UPHAM (I944), only Vibrio adaptatus and Vibrio marinofulvus formed indol in tryptophane broth.

The observations of Gran (I902), Drew (I9I2), KELlerman and Smith (I9I4), Molisch (I925), and others on the abundance of denitrifiers in the sea has focussed attention upon this group of bacteria. Some workers have concluded that most marine bacteria require nitrate, and that many reduce nitrate to nitrogen. The media employed by BERKELEY (I9I9), Lipman (I926), Bavendamm (I93I), GeE (I932b), and other marine microbiologists all contain nitrate. However, ZoBELL (I94Ia) failed to find that nitrate enhanced the growth of marine bacteria. A good many marine bacteria reduce nitrate to nitrite in appropriate media and a few liberate nitrogen from nitrate, but marine bacteria are not distinctive in this respect.

Luminescence is not necessarily a physiological property of marine bacteria, although most described species of photogenic bacteria have been isolated from marine materials. When provisions are made for their detection, photogenic bacteria are found in most samples of sea water, and they are often associated with certain marine animals in considerable abundance.

Several species of photogenic bacteria, some of which may prove to be identical, have been isolated from the sea and described. Besides the nine species of Fischer (I894a) listed on page 3-4, Fischer (I886) described Photobacterium indicum and $P h$. phosphorescens (FIscher, I887). BEIJERINCK (I889) described Ph. luminosum for the first time and gave additional information on Ph. phosphorescens, Ph. indicum, and Ph. fischeri. The latter organism has been described by JoHnson and SHunK (1936) 
as Achromobacter fischeri. JoHnSON and SiIUNK also described Achromobacter harveyi, which they isolated from marine materials. KATz (I89I) isolated marine photogenic bacteria now known as Bacillus argenteo-phosphorescens, Bacillus cy'aneo-phosphorescens, Baclerium smaragdinophosphorescens, Achromobacter phosphoricum, A. phosphoreum, and A. luminosum. Most of these are characterized by BERGEY et al. (I939) who also list Pseudomonas pierantonii, Vibrio pierantonii, Bacterium giardi, Micrococcus phosphoreus, $M I$. pfliigeri, and Photobacterium pfliigeri. In a comprehensive résumé of the literature and compilation of species, DAHLGREN (I915) adds the following: Photobacterium ballicum, Ph. cyaneum, Ph. javanense, $P h$. plymouthii, and $B$. phosphorescens gelidus, all of which were found in sea water or associated with marine fish. DAHLGREN regards many of the afore-mentioned species as being synonymous. Bioluminescence is preponderantly a property of marine organisms (HARVEY, I940).

The luminous marine bacteria studied by Jornson and HARVEY (I938) required sea water for maximum efficiency. Luminescence, as well as respiration, fell off when sea water was diluted by more than 50 per cent with fresh water. Below a concentration of Io per cent sea water, both respiration and luminescence were irreversibly destroyed, and only a small fraction of the cells remained viable. Doubling the salinity of sea water by the addition of salts did not markedly affect luminescence, but further increases in salinity were inimical to the respiration, luminescence, and viability of marine photogenic bacteria. Isotonic salt or sugar solutions were not so favorable as was natural sea water for the activity of the bacteria.

The physiological characteristics of various groups of marine bacteria are discussed elsewhere in this volume. In the foregoing paragraphs only a few of the distinctive physiological characteristics of marine bacteria, as a class, have been compared with bacteria from other habitats.

Salinity requirements:- The preference of marine bacteria for sea water over either tap water or $\mathrm{NaCl}$ solution isotonic with sea water is illustrated by the data in Table VIII on page 44. Plate counts of either raw sea water or marine mud collected beyond the zone of land contamination are invariably higher when the nutrient media are prepared with sea water rather than with fresh water. Conversely, samples of sewage, soil, fresh water, human excreta, etc., show many more colonies when

TABLE XXXII.- Relative numbers of bacteria from marine and terrestrial sources which developed on nutrient media prepared with different concentrations of sea water (from ZoBELL, I941a):-

\begin{tabular}{|c|c|c|c|c|c|c|c|}
\hline \multirow{2}{*}{$\begin{array}{c}\text { MEDIA } \\
\text { INOCULATED } \\
\text { WITH }\end{array}$} & \multirow{2}{*}{$\begin{array}{l}\text { NUMBER } \\
\text { OF } \\
\text { SAATPLES }\end{array}$} & \multicolumn{6}{|c|}{ PER CENT OF SEA WATER IN MEDIUM } \\
\hline & & 100 & 75 & 50 & 25 & Io & ० \\
\hline & & & \multicolumn{5}{|c|}{ average grouth index } \\
\hline Raw sea water & $3 I$ & I00 & 93 & 65 & 38 & I7 & 9 \\
\hline Marine mud & I8 & IOO & 89 & 61 & 46 & 28 & I9 \\
\hline San Diego Bay mud & 3 & IOO & I08 & I3I & 142 & I39 & I I4 \\
\hline Mission Bay mud & 4 & IOO & 107 & II 7 & I 42 & I 56 & 106 \\
\hline Mission Bay water & 5 & 100 & 103 & II5 & 108 & II 8 & 97 \\
\hline Sewage & I3 & I3 & 27 & 51 & 79 & 106 & 100 \\
\hline Tap water & 8 & 4 & IO & 28 & 58 & 105 & 100 \\
\hline Inland soil & 6 & I5 & 23 & 40 & 66 & 89 & IOO \\
\hline Mfouth microflora & 5 & 9 & I5 & $4 I$ & 78 & 93 & I00 \\
\hline
\end{tabular}


plated on media prepared with fresh water rather than with sea water. Diluting sea water by 50 per cent reduces both its growth-promoting properties for marine microflora and its toxicity for terrestrial bacteria, as shown by the data in Table XXXII on page II9.

Similar results have been reported by BERKELEy (I9I9), KorINEK (I926), LIPMAN (1926), and others. KORINEK (I927) believes that marine bacteria can be distinguished from non-marine forms upon a basis of their salt tolerance. While this may not be true of every individual culture, it is statistically true of marine bacteria as a group. The effect of the dilution of sea water is shown by the following data which LIPMAN (I926) obtained by plating sea water collected one mile from land on sea-water media diluted with distilled water:

$\begin{array}{ccc}\text { Per cent SEA WATER } & \text { Per cent DIST. WATER } & \text { Bacteria PER ML. } \\ \text { IOO } & 0 & 270 \\ 70 & 30 & 200 \\ 50 & 50 & 150 \\ 30 & 70 & 0 \\ \text { IO } & 90 & 0\end{array}$

As shown below, LIPMAN obtained somewhat different results when he plated sea water collected from the wharf at the Tortugas Laboratory where there was much shore contamination:

$\begin{array}{ccc}\text { Per Cent SEA Water } & \text { Per Cent Dist. Water } & \text { Bacteria PeR ML. } \\ \text { IOO } & 0 & 960,000 \\ 75 & 25 & 730,000 \\ 50 & 50 & 640,000 \\ 25 & 75 & 680,000\end{array}$

The beneficial effects of sea water on marine bacteria and its inhibitory effects on non-marine bacteria are most conspicuous when appropriately diluted samples of marine or non-marine materials are plated on media containing different concentrations of sea water. This is illustrated by the experiments described above. Following laboratory cultivation, many bacteria seem to develop a tolerance for certain types of adverse conditions. As a matter of fact, most old stock cultures of either marine or non-marine bacteria will grow almost equally well on either sea-water or fresh-water media when the media receive large inoculations. However, marked differences are noted in the salt tolerance of individual cells constituting the respective cultures if they are properly diluted and then plated on the two kinds of media. Under these conditions there emerge statistically determined preferences of marine bacteria for sea water and of the non-marine bacteria for fresh water. Within old stock cultures, though, some individual cells are found to be euryhaline over a wide range and others are relatively stenohaline. The salt requirements of the latter may be high, low, or intermediate, depending upon the origin and cultural history of the organism.

According to KORINEK (I927), after a year's cultivation original differences in the salinity requirements between fresh-water and marine bacteria were not eliminated. Conversely, 9 of $\mathrm{I} 2$ cultures isolated from the sea and maintained in the laboratory for five months by ZOBELL and Michener ( 1938 ) were able to grow in fresh-water media, although upon initial isolation they required sea-water media. The conditions under which the organisms are cultivated unquestionably influence the results.

After laboratory cultivation on sea-water media for periods of from two to twelve years, 56 of the 60 new species of marine bacteria described 
by ZoBeLL and UPHAM (I944) have developed the ability to grow in fresh-water media. Upon initial isolation, all of them required sea water or isosmotic salt solution. Interestingly, the Bacillus and Micrococcus species isolated from the sea have proved to be much more euryhaline than Pseudomonas or Vibrio species. Only six out of I8 species of marine Pseudomonas and three out of II species of Vibrio became acclimatized to fresh water (and these only poorly), while all of the 8 species of Bucillus and all of the 6 species of Micrococcus became tolerant of fresh water. Micrococcus euryhalis, $M$. aquivivus, $M$. infimus, and $M$. maripuniceus grew equally well in either sea-water or fresh-water media after cultivation for a few months in the laboratory. This was also true of Sarcina pelagia and Serratia marinorubra, both of which required sea water upon initial isolation from the sea.

Neither isotonic salt solution nor artificial sea water is as good as is natural sea water for the cultivation of recently isolated marine bacteria. Moreover, marine bacteria are as sensitive to increases in salinity as they are to decreases. Our observations substantiate those of KORINEK (I926) that marine bacteria are even less resistant than are fresh-water bacteria to changes in osmotic pressure.

Doubling the salinity of sea water either by the addition of $\mathrm{NaCl}$ or sea salt may reduce by 25 to 50 per cent the number of marine bacteria which will grow in it. Very few marine bacteria have been observed to grow in sea-water media to which 12 per cent $\mathrm{NaCl}$ has been added. Thus, while marine bacteria are often characterized as being halophilic or salt-requiring, they are far less so than are bacteria found in salted fish, salt-cured furs, pickle brines, salt lakes, and limans (see Chapter XVIII). Virtually no marine bacteria, exclusive of those found in salterns or associated with salted fish or similar marine products, grow in sea water to which 24 per cent $\mathrm{NaCl}$ has been added. Numerous bacteria which occur in strong brines flourish in media containing from 18 to 30 per cent $\mathrm{NaCl}$ (HoF, I935).

Studies on their salinity requirements indicate that, while bacteria from different environments differ in salt tolerance and in their ability to become acclimatized to changes in osmotic pressure, most of the bacteria found in the sea, exclusive of adventitious contaminants, are specifically marine. This conclusion is substantiated by the fact that very few commonly known species of terrestrial bacteria such as members of the coliform, subtilis-mesentericus, or Gram-positive cocci groups have been found in the sea except relatively near land.

Temperature tolerance:- ForSTER (I892), Drew (I9I4), ANGST (I929), and others have emphasized the extreme thermal sensitivity of marine bacteria. BERKELEY (I9I9) believed that low plate counts obtained with sea water collected from depths of 20 to Ioo fathoms may be due to the failure of some of the bacteria to tolerate the plating temperature of nutrient agar, i.e., about $42^{\circ} \mathrm{C}$. LLOYD (I930) suggested using plating temperatures ranging from $25^{\circ}$ to $35^{\circ} \mathrm{C}$. to avoid killing "ordinary microorganisms" indigenous to the sea.

The data in Table $\mathrm{X}$ on page 46 show that if plating temperatures of the medium exceed $42^{\circ} \mathrm{C}$. by a few degrees, plate counts on samples of sea water and marine mud are noticeably decreased. These studies were extended by ZoBell and CONN (I940) with the use of nutrient gelatin, which solidifies at lower temperatures than does agar. The data in Table 
XXXIII show that some marine bacteria are quickly injured at $35^{\circ} \mathrm{C}$. However, it appears doubtful whether enough bacteria may be injured by the plating temperature of agar $\left(40^{\circ}\right.$ to $45^{\circ} \mathrm{C}$.) to contra-indicate the use of agar plates for estimating the abundance of viable bacteria.

TABLE XXXIII. - Relative numbers of colonies developing from sea water and marine mud plated with nutrient sea-water gelatin at different temperatures and cooled immediately to $12^{\circ} \mathrm{C} .:-$

\begin{tabular}{|c|c|c|c|c|c|c|}
\hline \multirow{2}{*}{ INOCULA } & \multirow{2}{*}{$\begin{array}{l}\text { NUMBER OF } \\
\text { SAMPLES }\end{array}$} & \multicolumn{5}{|c|}{ POURING TEMPERATURE OF GELATIN } \\
\hline & & $30^{\circ} \mathrm{C}$. & $35^{\circ} \mathrm{C}$. & $40^{\circ} \mathrm{C}$. & $45^{\circ} \mathrm{C}$. & $50^{\circ} \mathrm{C}$. \\
\hline $\begin{array}{l}\text { Sea water } \\
\text { Marine mud }\end{array}$ & $\begin{array}{l}\mathbf{1} 2 \\
\mathbf{1} 6\end{array}$ & $\begin{array}{l}\% \\
100 \\
100\end{array}$ & $\begin{array}{c}\% \\
98.6 \\
97.9\end{array}$ & $\begin{array}{c}\% \\
96.5 \\
91.3\end{array}$ & $\begin{array}{c}\% \\
87.5 \\
83.4\end{array}$ & $\begin{array}{c}\% \\
76.2 \\
67.8\end{array}$ \\
\hline
\end{tabular}

While brief warming during plating at temperatures ranging from $30^{\circ}$ to $40^{\circ} \mathrm{C}$. does not destroy the viability of large numbers of marine bacteria, the majority of them are killed by exposure to this temperature for ten minutes, as shown by the following results obtained by ZoBELL and Conn (r940) who plated in duplicate ten samples of sea water and ten samples of marine mud:

$\begin{array}{lcccccc}\text { Samples held ro minutes at } & 20^{\circ} \mathrm{C} . & 30^{\circ} \mathrm{C} . & 40^{\circ} \mathrm{C} . & 50^{\circ} \mathrm{C} . & 80^{\circ} \mathrm{C} . & 100^{\circ} \mathrm{C} \text {. } \\ \text { Per cent survival in sea water } & 100 & 8 \mathrm{r} .3 & 2 \mathrm{I} .9 & 6.8 & 3.0 & <\mathrm{I} \\ \text { Per cent survival in mud } & 100 & 68.5 & 18.3 & 10.3 & 5.2 & <\mathrm{I}\end{array}$

Comparing these results with those reported by FRANKLAND and FRANKLAND (1894) for the percentage survival of bacteria in river water reveals that, whereas the majority of marine bacteria succumb when held for Io minutes at $30^{\circ}$ to $40^{\circ} \mathrm{C}$., the average thermal death point of freshwater bacteria is about ro degrees higher:

Samples held ${ }_{5}$ minutes at

Per cent survival in Seine River water

$$
\begin{array}{ccccc}
20^{\circ} \mathrm{C} . & 43^{\circ} \mathrm{C} . & 50^{\circ} \mathrm{C} . & 60^{\circ} \mathrm{C} . & 80^{\circ} \mathrm{C} . \\
100 & 75.6 & 15.6 & 4.7 & 3.1
\end{array}
$$

There is no evidence to suggest that any of the bacteria are killed by prolonged maintenance at $20^{\circ}$ to $25^{\circ} \mathrm{C}$., although some marine bacteria are killed in ten minutes at $28^{\circ} \mathrm{C}$. The following number of pure cultures of marine bacteria survived ten minutes in broth at the stated temperatures:

Cultures held ro minutes at 25 cultures from sea water 25 cultures from marine mud 78 marine stock cultures

$\begin{array}{ccccccc}20^{\circ} \mathrm{C} . & 30^{\circ} \mathrm{C} . & 40^{\circ} \mathrm{C} . & 50^{\circ} \mathrm{C} . & 60^{\circ} \mathrm{C} . & 80^{\circ} \mathrm{C} . & 100^{\circ} \mathrm{C} . \\ 25 & 24 & 9 & 3 & 0 & 0 & 0 \\ 25 & 2 \mathrm{I} & \text { II } & 5 & \mathrm{I} & \mathrm{I} & 0 \\ 78 & 78 & 36 & \mathbf{I} 4 & 8 & 6 & 2\end{array}$

BEDFORD ( $1933 b)$ found that $37^{\circ} \mathrm{C}$. was lethal for 40 of the $7 \mathrm{I}$ cultures of marine bacteria with which he was working. These thermal death points are considerably lower than those of most terrestrial or fresh-water bacteria.

Thermotolerant spore-formers are in the minority, although large numbers of them occur in the sea as attested by the isolation of 80 such cultures from marine materials by NEwTON (I924).

Optimum temperatures for the growth of the $7 \mathrm{r}$ cultures of marine bacteria studied by BEDFORD (I933 $b$ ) ranged from $20^{\circ}$ to $25^{\circ} \mathrm{C}$. The maximum temperatures at which they grew were as follows: 5 at $25^{\circ} \mathrm{C}, 36$ at $30^{\circ} \mathrm{C}$, I3 at $37^{\circ} \mathrm{C}$, 5 at $40^{\circ} \mathrm{C}, 2$ at $42.5^{\circ} \mathrm{C}$., and 4 at $45^{\circ} \mathrm{C}$. All of BEDFORD's cultures grew at $15^{\circ} \mathrm{C}$., 67 of them grew at $10^{\circ} \mathrm{C}$, 53 at $0^{\circ} \mathrm{C}, 22$ at $-5^{\circ} \mathrm{C}$., and ro at $-7.5^{\circ} \mathrm{C}$. 
The optimum temperature for maximum plate counts on marine materials was found by ZOBELL and CoNN (I940) to be $18^{\circ}$ to $22^{\circ} \mathrm{C}$. (see Table IX on page 45). Unlike soil and fresh-water bacteria, very few marine bacteria ordinarily grow at $30^{\circ}$ to $37^{\circ} \mathrm{C}$, and plate counts at $25^{\circ} \mathrm{C}$. are significantly lower than those at $18^{\circ} \mathrm{C}$. As many colonies of marine bacteria may develop on plates of nutrient media incubated at $12^{\circ} \mathrm{C}$. as at $22^{\circ} \mathrm{C}$., but longer periods of incubation are required at the lower temperature.

While marine bacteria cannot be described as psychrophiles because their optimum temperatures lie between $18^{\circ}$ and $22^{\circ} \mathrm{C}$., most of them multiply slowly and are otherwise physiologically active at $0^{\circ}$ to $4^{\circ} \mathrm{C}$. Their ability to grow at near zero or sub-zero temperatures is not a unique property of marine bacteria, since microorganisms from other habitats are endowed with this ability, but it seems to be more common among marine bacteria. Forster (I887) isolated from marine fish photogenic species which reproduced at $0^{\circ} \mathrm{C}$. Later FonsTeR (1892) found that bacteria capable of growing at low temperatures are quite widely distributed in water and soil. Most of the photogenic bacteria isolated from the sea by Fischer (I894a) grew at $0^{\circ} \mathrm{C}$. From the water at Kiel, Fischer (I888b) isolated i4 species of bacteria which were capable of growing at $0^{\circ} \mathrm{C}$.

According to HEss (I932), autolysis of haddock muscle is almost negligible at $2.2^{\circ} \mathrm{C}$. Bacterial decomposition was considerable at this temperature and about half as rapid at - I.I ${ }^{\circ} \mathrm{C}$.

Marine bacteria studied by Hess ( $1934 a$ ) grew readily at $-3^{\circ} \mathrm{C}$., at which temperature they were physiologically active and most intensely pigmented. Some of them grew at $-6.5^{\circ} \mathrm{C}$. It is difficult to study the activities of organisms at temperatures lower than $-5^{\circ} \mathrm{C}$. because, unless solutes are added to the media to depress the freezing point, the water crystallizes as ice. If a high concentration of solutes is added to the media, the osmotic pressure is increased proportionately as the freezing point is depressed, under which conditions it is indeterminate whether the low temperature, the high osmotic pressure, or the specific effect of the solute is the limiting factor.

Hess $(1934 b)$. reports that the optimum temperature for obtaining a large crop of marine bacteria approaches $5^{\circ} \mathrm{C}$. Larger crops were obtained at $0^{\circ}$ and $-3^{\circ} \mathrm{C}$. than at $20^{\circ} \mathrm{C}$. The bacteria multiplied more rapidly at $20^{\circ} \mathrm{C}$. than at $5^{\circ} \mathrm{C}$. but they also died more rapidly at the higher temperature. The bacteria were rapidly destroyed at $37^{\circ} \mathrm{C}$. They lived almost indefinitely in sea water at $-3^{\circ}$ to $5^{\circ} \mathrm{C}$.

SANBORN (I930) described several species of marine bacteria which cause the decomposition of fish fillets stored at $-5^{\circ} \mathrm{C}$. Gribons (I934C) observed the bacterial decomposition of iced fillets at $-5^{\circ} \mathrm{C}$. but not at $-18^{\circ} \mathrm{C}$. At the lower temperature most of the water is probably solidified as ice causing the arrest of bacterial activities. STEwart (I934) decided that a refrigeration temperature of $-\mathrm{I} 2{ }^{\circ} \mathrm{C}$. was necessary to inhibit the growth of bacteria in fish muscle. She noted a rapid multiplication of bacteria at $-3^{\circ} \mathrm{C}$., and certain chromogens grew at $-6^{\circ} \mathrm{C}$. Included in her study were 9 species of Achromobacter, I3 species of Flavobacterimm, 4 species of Micrococcus, and 3 yeasts.

Eighty per cent of the cultures isolated from mackerel were found by KISER (I944) to produce macroscopically visible growth in six days at $0^{\circ} \mathrm{C}$. From the growth curves of an Achromobacter species it was calculated that the minimum generation times were 0.98 hours at $25^{\circ} \mathrm{C}$., 4.84 
hours at $7^{\circ} \mathrm{C}$., and 30.7 hours at $-4{ }^{\circ} \mathrm{C}$. These generation times indicate a much more rapid rate of growth at the two lower temperatures than has been reported for most non-marine bacteria.

Additional literature on the temperature relations of marine bacteria is given by Horowitz-Wlassowa and Grinberg (I933), ZoBeLL (I934), and KISER and BECKWITH (I942).

Attachment propensities:- The tendency of marine bacteria to grow associated with solid surfaces is discussed on pages 56 and 83 . This is not a peculiarity of marine bacteria, since many microorganisms from other habitats grow exclusively or preferentially attached to solid surfaces. However, bacteria which live in extremely dilute nutrient solutions such as sea water or the water of oligotrophic lakes appear to depend more upon solid surfaces than do those which inhabit regions where there is more nutrient material. It appears that a relatively large proportion of marine bacteria have become adapted to the sessile manner of growth, due to the paucity of nutrients in the liquid system and the greater concentration of adsorbed food materials upon solid surfaces.

Fifty of the 96 different cultures of marine bacteria examined by ZoBELL $\left(I 943^{b}\right)$ exhibited marked attachment propensities, and all of them exhibited some tendency to attach to glass slides submerged in sea water. Thirty of the cultures developed more rapidly on submerged slides than in a free-floating condition in dilutely nutrient media. Many species formed micro-colonies on submerged surfaces. Pseudomonas coenobios, Ps. marinoglutinosus, Ps. membranula, Ps. membranoformis, Ps. periphyta, Ps. sessilis, Ps. stereotropis, Vibrio phytoplanktis, V. haloplanktis, Bacillus epiphyticus, Flavobacterium amocontactum, Micrococcus sedentarius, $M$. sedimenteus, Achromobacter stationis, A. aquamarinus, Bacterium sociovivum, and Bact. immotum are outstanding examples of attachment bacteria listed by ZoBeLL and UpHAM (I944). Species of Gallionella, Sideromonas, Siderocapsa, and Caulobacter grow almost exclusively on submerged surfaces. This also applies to many genera of sulfur bacteria and most representatives of the order Myxobacteriales.

Bacterial genera represented in the sea:- Further details regarding the characteristics of marine bacteria can be conveniently summarized by listing all of the recognized genera of bacteria and indicating whether species of each have been found in the sea. The genera are described in BERGEY's (1946) Manual of Determinative Bacteriology. The relative frequency with which representatives of each genus have been observed in the sea is indicated by plus $(+)$ or minus $(-)$ signs in Table XXXIV.

TABLE XXXIV. - Reported and/or observed occurrence of genera of Schizomycetes represented in the sea. (An "A" indicates that quite likely the observed species are adventitious):-

FAMILY

Order I. Eubacteriales

GENUS

OCCURRENCE IN THE SEA

Nitrobacteriaceae

Sub-Order I. Eubacteriineae

Nitrosomonas

Nitrosococcus

Nitrosospira

Nitrosocystis

Nitrosogloea

Nitrobacler

Nitrocystis

Hydrogenomonas

Thiobacillus

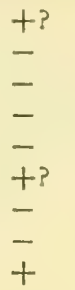


FAMIILY

Pseudomonadaceae

Azotobacteriaceae

Rhizobiaceae

Micrococcaceae

Neisseriaceae

Lactobacteriaceae

Corynebacteriaceae

Parvobacteriaceae

Enterobacteriaceae

Achromobacteriaceae
Table XXXIV cont.

\section{Genus}

- Pseudomonas

Xanthomonas

Methanomonas

Acetobacter

Prolaminobacter

Mycoplana

- Vibrio

Desulfovibrio

Cellvibrio

Cellfalcicula

Thiospira

Spirillum

Azotobacter

Rhizobium

Agrobacterium

Chromobacterium

Micrococcus

Gaffkya

Sarcina

Neisseria

Veillonella

Diplococcus

Streptococcus

Leuconostoc

Lactobacillus

Microbacterium

Propionibacterium

Butyribacterium

Corynebacterium

Listeria

Erysipelothrix

Pasteurella

Malleomyces

Brucella

Hemophilus

Moraxella

- Noguchia

Dialister

Bacteroides

Escherichia

Aerobacter

Klebsiella

Erwinia

Serratia

Proteus

Salmonella

Shigella

Achromobacter

Flavobacterium

Alkaligenes
OCCURRF.NCE IN THE SEA

$+t+$

$+$

-

$-$

$+t+$

$+t$

$+$

$+$

$+$

$+t+$

+ ?

$-$

$+$

$+$

-

-

$+?$

$+$

$+$

$+$

A

A

-

$+$

$+t$

A

-

$++t$
$+++t$ A 
FAMILY

\section{Bacteriaceae}

Bacillaceae

Nevskiaceae

Gallionellaceae

Siderocapsaceae

Caulobacteriaceae

Chromotioidaceae

Rhodobacteriaceae

\section{Mycobacteriaceae \\ Actinomycetaceae}

Streptomycetaceae

Chlamydobacteriaceae
Table XXXIV cont.

\section{Genus}

OCCURRENCE

\section{Kurthia}

Actinobacillus

Leptotrichia

Fusobacterium

Bacterium

\section{Bacillus \\ Clostridium}

IN THE SEA

$$
\begin{gathered}
+ \\
- \\
+
\end{gathered}
$$$$
\begin{gathered}
+++ \\
++
\end{gathered}
$$

Sub-Order II. Caulobacteriineae

$$
\text { Nevskia }
$$

Gallionella

Siderocapsa

Sideromonas

Caulobacter

Sub-Order III. Rhodobacteriineae
Thiocystis
Thiosphaera
Thiosphaerion
Thiocapsa
Thiosarcina
Lamprocystis
Thiopedia
Thioderma
Lampropedia
A moebobacter
Thiodictyon
Thiothece
Thiopolycoccus
Chromatium
Rhabdomonas
Thiospirillum
Rhodacapsa
Rhodothece

$$
\begin{aligned}
& - \\
& + \\
& + \\
& + \\
& +?
\end{aligned}
$$

$+$

-

$\overline{+}$

$+$

$+$

$\pm$

-

$+$

Rhodocystis

Rhodonostoc

Rhodorrhagus

Rhodobacterium

Rhodobacillus

Rhodovibrio

Rhodospirillum

Order II. Actinomycetales

Mycobacterium

$++$

Actinomyces

Nocardia

$+$

Streptomyces

Micromonospora

$+$

Order III. Chlamydobacteriales

Sphaerotilus

Clonothrix

Leptothrix 
Family

Crenothricaceae

Beggiatoaceae

Achromatiaceae

Cytophagaceae

Archangiaceae

Sorangiaceae

Polyangiaceae

Myxococcaceae

Spirochaetaceae

Treponemaceae
Table XXXIV cont.

GeNus

OCCURRENCE IN THE SEA

$+$

$+$

$+$

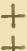

Achromatium

Thiophysa

Hillhousia

Order IV. Myxobacteriales

Cytophaga

$++$

Archangium

Stelangium

Sorangium

Polyangium

Synangium

Melittangium

Podangium

Chondromyces

Myxococcus

Chondrococcus

Angiococcus

Sporocylophaga

$+$

-

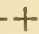

$-$
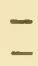

$\overline{-1}$

$-$

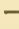

$-$

$\overline{+}$

Order V. Spirochaetales

Spirochaeta

Saprospira

Cristospira

+
+
+
-
+
+

Treponema

Leplospira

Through the courtesy of the Board of Editors of BERGEY'S Manual of Determinative Bacteriology, this Outline Classification follows that used in the new (Sixth) Edition of this book now in press (see BrEED et al., r944, I945).

The symbol A indicates that representatives of the genus have been found as adventitious organisms in the sea, i.e., in polluted water only or under other circumstances which strongly suggest that they are not indigenous species.

It has been necessary to rely largely upon personal judgment in recording the frequency of occurrence of bacterial genera in the sea. The descriptions of many marine bacteria are so fragmentary that it is difficult or impossible to ascertain the genus to which they belong. Early workers in the field indiscriminantly applied the generic name Bacillus or Bacterium to most rod-shaped organisms, many of which properly should be classified as Pseudomonas, Flavobacterium, Proteus, Achromobacter, Serratia, etc., in light of more recent developments in taxonomic bacteriology. This is true of the numerous species of Photobacterium and Halibacterium described by Fischer ( $1804 a$ ) and the Agarbactcrium species described by ANGST (I929), although certain species of these obsolete genera actually are Bacterium or Bacillus as defined by BERGEY et al. (I946). 
The number of plus signs in the table indicates the relative abundance of the genus as judged from reports in the literature and our own observations. The plus signs do not indicate the relative numbers of species of each genus, since in many cases the species are not known. There may be only one marine species of Desulfovibrio, for example, but since it appears to be widely and abundantly distributed in the sea, particularly in bottom deposits, it is scored two-plus $(++)$. On the other hand, there may be several marine species of Staphylococci or Actinomyces but since the presence of representatives of these genera have been only infrequently reported, they are scored one-plus $(+)$. Representatives of all orders have been found living in the sea.

Attention is directed to the actinomycetes, which, because of the moldlike appearance of certain genera, are often not regarded as bacteria. Though not true bacteria, the actinomycetes belong to an order of Schizomycetes, the Actinomycetales. Species of Actinomyces have been found growing on dead marine algae, on submerged surfaces where organic matter has accumulated, and in bottom deposits. ZoBeLL and UPHAM (r944) described two new species, Actinomyces marinolimosus and Act. halotrichis. Species of Mycobacterium, Nocardia (Proactinomyces), and Micromonospora have been observed in sea-water enrichment cultures growing on petroleum hydrocarbons (ZoBeLL et al., 1943) and rubber products (ZoBELL and BECKWITH, I944). They appear to be widely distributed in the sea.

There are nearly as many known marine species of the order Spirochaetales as those reported from non-marine habitats, notwithstanding the fact that the sea has not been extensively explored by bacteriologists. Spirochaeta plicatilis, which EHRENBERG (1838) found in sea water, has the distinction of being the first accurately described bacterium. Spirochaeta marina and probably $S p$. eurystrepta live in the sea. Species of Saprospira and Cristospira have been found almost exclusively in shellfish (see p. I87). The observations of ZUELZER (I928) suggest that Leptospira biflexa occurs in the sea.

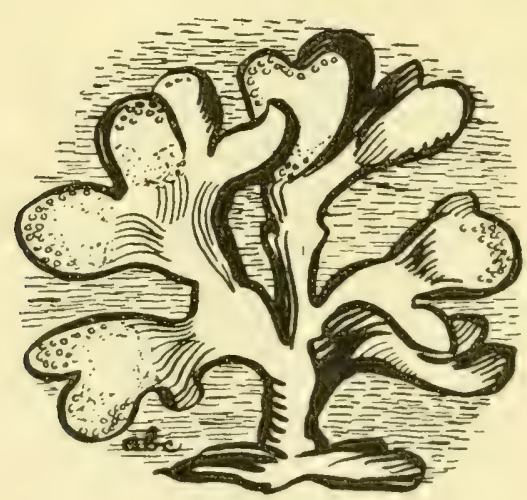




\section{AQUATIC YEASTS AND MOLDS}

Technically speaking, yeasts and molds as well as bacteria are Fungi. Fungi may be defined as achlorophyllous plants constituting a primary division of the phylum Thallophyta, co-ordinate with the Algae which contain chlorophyll. The division Fungi comprises the classes Myxomycetes (slime molds), Eumycetes (true fungi), and Schizomycetes (fission fungi or bacteria). The class Eumycetes consists of the sub-classes Phycomycetes, Ascomycetes, Fungi Imperfecti, and Basidiomycetes. Though primarily terrestrial, all sub-classes of Eumycetes except the Basidiomycetes have a number of aquatic representatives. No species of Basidiomycetes have been found living normally in bodies of water. Several hundred representatives of the Phycomycetes and smaller numbers of Ascomycetes and Fungi Imperfecti live in aquatic environments.

Organisms which in popular parlance are known as molds or mold fungi embrace certain orders of Phycomycetes, Fungi Imperfecti, and Ascomycetes. The latter also includes, besides other orders, the Saccharomycetales or yeasts. The true yeasts multiply by budding or by the formation of ascospores, hence the sub-class name, Ascomycetes, to which they belong. The so-called wild yeasts or torulae belong to a family of Fungi Imperfecti, namely the Dematiaceae. Torulae, or wild yeasts, differ from the true yeasts in that they do not form spores. The asporogenous Mycoderma are also called wild yeasts.

Occurrence of yeasts in the sea:- Yeasts are widely and commonly distributed in nature. Though probably not as well adapted, as a class, as bacteria to growing throughout a wide range of environmental conditions, there are yeasts which are capable of tolerating nearly any extremes of osmotic pressure, hydrostatic pressure, temperature, $p \mathrm{H}$, or oxygen tension found in the sea. Yeasts may be cultivated by the same methods as are used for bacteria, and they are more readily enumerated by direct microscopic counts than bacteria because, on the average, yeasts are larger than bacteria and have a more distinctive morphology.

In spite of the fact that, for the most part, special nutrient media rich in carbohydrates or other utilizable organic matter have not been employed, many bacteriologists report finding yeasts in the sea. Colonies of yeasts often appear along with bacteria on nutrient media designed primarily to detect bacteria. Most of the reports fail to describe the yeasts, so it is not known whether the organisms were true yeasts, torulae, or other yeast-like organisms. FISCHER and BREBECK (I894) reported the presence of many Torula and Mycoderma and a few true yeasts in sea water. They found Blastoderma salmonicolor in a sample of sea water taken near the Azores Islands. It is problematical whether certain of these organisms are indigenous to the sea because they occur so commonly in the air.

From the North Sea, NADson and Burgwitz (I93I) isolated 22 varieties of yeast-like organisms including I 5 varieties of white Torula, 7 of 
red Torula, and one variety each of Dematium, Oidium, and Endomyces. The yeast-like organisms were found associated with Laminaria saccharina, Alaria esculenta, Fucus vesiculosus, and other seaweeds. The white Torula species ranged from I.25 to $5.2 \mu$ in width and from 2.5 to $9.4 \mu$ in length. The red Torula species were somewhat larger, being from I. 75 to $5.0 \mu$ in width and from 3.75 to $x_{5} .0 \mu$ in length. The yeast-like cultures developed readily in sea-water media enriched with mannite, sugars, or with Laminaria extract. They grew at temperatures as low as $2^{\circ} \mathrm{C}$. Much better growth was observed at $12{ }^{\circ} \mathrm{C}$. Salt-tolerant varieties of the so-called "fat yeast," Endomyces vernalis, along with Saccharomyces cerevisiae and Saccharomyces ellipsoideus, were also found. Endomyces vernalis as well as the Torula species were believed by NADSON and BuRGwITZ to be autochthonous marine species.

FISCHER ( $1894 a$ ) noted the appearance of numerous yeast colonies along with molds and bacteria in sea water collected on the cruise of the S.M.S. Moltke. For example, his logbook records that in Sample ro collected 330 miles from the nearest land, the Azores, 242 colonies developed on nutrient gelatin inoculated with $0.25 \mathrm{ml}$. of sea water. Halibacterium pellucidum predominated, with nearly as many yeasts, most of which were believed to be Torula. Two of the latter were pink. Three colonies of mold fungi were noted. Of the 666 colonies which developed from $0.5 \mathrm{ml}$. of sea water in Sample 26 collected one mile off Plymouth, England, only I3 were molds, but many were yeasts including 8 pink Torula. There were almost as many yeasts and molds as bacteria among the 262 colonies which developed from O.I ml. of Sample 29 collected in Wilhelmshaven Roads off the north coast of Germany. One Mycoderma species and 20 pink yeast were identified in this sample. Samples collected farther from land generally yielded fewer microorganisms of all types, particularly molds, but yeasts were generally found in all samples regardless of the distance from land. In some samples collected in the open ocean, actually more colonies of yeasts than bacteria developed on the gelatin plates.

The nutrient composition, together with the relatively low $p \mathrm{H}$ (near 7.0) of the medium employed by Fischer, may account for the preponderance of yeasts observed in some of the samples. Be this as it may, his extensive survey instructs us that yeasts are widely distributed in the sea. Besides the species of Torula which appeared to be fairly common in the sea, particularly in higher latitudes, FISCHER found species of Mycoderma and Saccharomyces at considerable distances from land. The widespread occurrence of yeasts in the sea, together with the fact that some of them grew better in nutrient sea-water media than in corresponding fresh-water media, led him to conclude that there are autochthonous species of marine yeasts.

ISSATCHENKo (I9I4) reported the general occurrence of yeasts in the Arctic Ocean. Although ZoBelt and Feltham (I934) made no special efforts to estimate their abundance, yeasts were observed on most plates of sea-water agar inoculated with samples of marine materials collected near land as well as in the open ocean.

A pink yeast, probably a Torula, was found by HuNTER (I920b) to be responsible for the spoilage of oysters. The yeast, which grows readily at low temperatures, produces a pink or reddish pigment. While excessive contamination of oysters with the yeast was attributed to careless handling, examinations of samples of surface and bottom water from the 
oyster-growing areas revealed the presence of the pink yeast. It could also be recovered from healthy oysters.

There are frequent references in the literature to the occurrence of yeasts in lakes. Many of the numerous species of true yeasts, torulae, and yeast-like organisms found in the soil have been reported in lakes. Generally they are most abundant near shore or associated with higher aquatic plants such as Sagittaria, Myriophyllum, Naias, Zostcra, Lemna, Elodea, Vallisneria, Potamogeton, Chara, Cladophora, etc.

Marine molds:- Disregarding those obviously originating from air contamination, Fischer (I894a) found molds in the sea far less frequently than either bacteria or yeasts. With very few exceptions, he found numerous molds in sea water only fairly close to land. The molds which FISCHER observed were common species of terrestrial fungi, primarily Penicillium and Aspergillus. WAKSMAN (I934) also observed that common dust and wind-borne species of Penicillium and Aspergillus occupy a prominent place among the fungi reported in marine materials.

In marine muds from the Woods Hole region, SPARROw (1937) found species of Penicillium, Aspergillus, Rhisopus, Altemaria, Cephalosporium, Trichoderma, Chaetomium, and Cladosporium associated with decaying phytoplankton. He doubts, however, that these are true marine fungi. Though definitely able to live in the sea, most of them were well-known terrestrial species.

Owing to their small size and the difficulty of observing them under anything like natural conditions, the search for fungi associated with marine algae has been disappointing. The additions made by most mycologists have been few and accidental. SPARROW (I934) remarked regarding marine Phycomycetes that "one is at once confronted with a very real problem in endeavoring, first, to find sporangia which have not already discharged their zoospores in the interval between collection and examination, and, secondly, to produce conditions in the laboratory favorable for the development and discharge of these sporangia. This, together with the very small size of zoospores produced by these fungi, has greatly retarded our knowledge."

Petersen (1905) made a systematic search for fungi along the coast of Denmark where he found several species of chytridiaceous Phycomycetes growing either parasitically or saprophytically on marine algae. He described the fungi now known as Petersenia lobata, $P$. pollagaster, Sirolpidium bryopsidis, Olpidium laguncula, Ectrogella perforans, Rhizophydium discinctum, Pleotrachehus inhabilis, $\mathrm{Pl}$. mimutus, $\mathrm{Pl}$. paradoxus, $\mathrm{Pl}$. rosenvingii, and Pontisma lagenidioides.

SUTHERLAND (I9I $5 a$ ) described five new species of Fungi Imperfecti, Mycosphaerella pelietiae, Stigmatea pelvetiae, Pharcidia pelietiue, Pleospora pelvetiae, and Macrosporium pelvetiae, which were found associated with species of the rockweed Pelvetia along the coast of Britain. He (I9I5b) also described Orcadia pelvetiana, Didymosphaeria pelvetiana, Didymosphaeria fucicola, and Hypoderma laminariae. These Pyrenomycetes were parasitic on Pelvetia, Fucus, and Laminaria respectively.

From the green alga, Codium mucronatum, growing in the Puget Sound region, ZeLLer (IgI8) isolated and described Chytridium codicola, Rhizophydium codicola, and Stemphylium codii.

Twelve species of marine Phycomycetes were collected by SparRow (I934) in the Kattegat near Frederikshavn, Jutland, including Pythium 
marinum, Eurychasma dicksonii, Sirolpidium bryopsidis, Pontisma lagenidioides, Petersenia lobata, Petersenia pollagaster, Pleotrachelus olpidium, Pleotrachelus rosenvingii, Ectrogella perforans, Chytridium megastomum, and Chytridium polysiphoniae. They were growing on either living or moribund marine algae.

Near Woods Hole, Massachusetts, Sparrow (I936) isolated and described I5 marine species of Phycomycetes, two Myxomycetes, and a Protomyxa-like protozoan. SPARRow pointed out that marine fungi have been only very incompletely studied. Some of the fungi observed by him are true parasites which attacked healthy host plants unassisted by other organisms. Included in this category were Ectrogella perforans, Eurychasmidium tumefaciens, Olpidium sphacellarum, Rozella marina, and Chytridium magastomum, none of which was observed living saprophytically. Rhizophydium discinctum and Petersenia andreei were only doubtfully parasitic. Labyrinthula chattoni and Thraustochytrium proliferum were saprophytes found only on dead algal cells. Rhizophydium globosum, Pontisma lagenidioides, Sirolpidium bryopsidis, and Chytridium polysiphoniae were true parasites on certain host plants and saprophytic on others.

Besides noting the apparent obligate association of fungi with marine plants which strongly suggests that the fungi are true marine species, SPARROw noted the abundance in the sea of so-called chytridiaceous fungi which possess biciliate zoospores. Most of the true chytrids inhabiting fresh-water algae are uniciliate, while in the sea the biciliate forms predominate.

BARGHOORN and LINDER (I944), who observed along the coast of Maine, Massachusetts, and Connecticut many marine fungi which were quite unlike any known terrestrial organisms, were impressed by the diversity of fungi found in the sea. The following Fungi Imperfecti were isolated and described: Phialophorophoma litoralis, Diplodia orae-maris, Botryophialophora marina, Orbimyces spectabilis, Alternaria maritima, Helicoma maritimum, $H$. salinum, and Speira pelagica. Marine Pyrenomycetes as follows were also described: Samarosporella pelagica, Ceriosporopsis halima, Remispora maritima, Amphisphaeria maritima, Lentescospora submarina, Halosphaeria appendiculata, Leptosphaeria orae-maris, Sphaerulina orae-maris, Peritrichospora integra, P. lacera, Halophiobolus cylindricus, $H$. opacus, $H$. longirostris, $H$. maritimus, $H$. medusa, $H$. halimus, and $H$. salimus. Most of these will be recognized as not only new species, but as new genera, since, with few exceptions, the organisms have no counterpart in terrestrial species or genera.

The fungi described by BARGHOORN and LINDER (I944) were found in both brackish water and sea water of normal salinity. Most of them grew better in nutrient sea water than in corresponding fresh-water media, as illustrated by data on radial growth of mycelia, expressed in millimeters per day:

\footnotetext{
Halophiobolus opacus Halophiobolus salinus Ceriosporopsis halima Peritrichospora integra Helicoma salinum
}

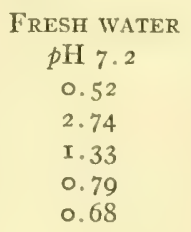

SeA WateR
pH 7.4
3.10
3.16
I. I7
0.96
I. 14

Tolerance of relatively high salt concentrations was demonstrated by growth of the fungi in media containing three times as much salt as nor- 
mal sea water. With one exception the entire group developed best in media with an initial $p H$ above 7.6, and, unlike most terrestrial molds, growth was definitely unfavorable in acid media. Their response to salinity and hydrogen-ion concentration was interpreted as a physiological modification to marine conditions. All species cultured made an appreciable growth at $5^{\circ} \mathrm{C}$, although the most favorable temperature for growth on complex synthetic media was between $22.5^{\circ}$ and $27.5^{\circ} \mathrm{C}$.

Special attention is directed to the slime mold Labyrinthula, a genus of Myxomycetes. According to WHrpple (I927), no aquatic species of Myxomycetes had been reported as late as I927. This may be because labyrinthulae are regarded by some as rhizopods, since they possess pseudopodia and exhibit remarkable powers of amoeboid movement. SPARROW (I936) described two species of marine Labyrinthula, one of which is parasitic and the other saprophytic. The latter is not unlike $L$. macrocystis which Cienkowsky isolated from marine algae in 1867 . It also resembles the Labyrinthula species which RENN (I936) found associated with diseased eel grass. JEPPs (I93I) observed, in debris which collects in the bottom of aquaria containing marine algae, species of Labyrinthula, which infect and eventually destroy diatom cultures. Injured Laminaria are also infected, but Miss JEPps found no evidence that uninjured Laminaria were parasitized by Labyrinthula. Two or more fungi may be involved. SPARROw (I943) relates that a Labyrinthula, along with Pyrrhosorus marimus and a Woronina-like fungus, has often been found in decaying marine algae.

In his monograph on aquatic Phycomycetes, SPARrow (I943) states that most of the Phycomycetes discovered thus far in marine environments are members of the orders Saprolegniales, the so-called water molds, and Lagenidiales. The Chytridiales, Plasmodiophorales, and Peronosporales also have marine representatives. Most of these are chytrid-like forms living in or on algae. SPARROw points out that in many cases there are no hard and fast distinctions between aquatic, amphibious, and terrestrial fungi. Representatives of all groups occur in both salt and fresh water.

Significance of yeasts and molds in the sea:- Exclusive of parasitic varieties, the importance of yeasts and molds in modifying the marine environment is strictly secondary to that of the ubiquitous and more versatile bacteria. Most yeasts and molds require a medium rich in organic nutrients, particularly the simple carbohydrates, and the sea is notoriously poor in organic matter. However, when associated with plants or animals or their products, aquatic fungi may be very active in the sea.

As the causative agents of diseases of marine plants and animals, fungi may be extremely important. Fresh-water animals including fish are extensively parasitized by Saprolegnia and other aquatic fungi, and it may develop that many marine animals are also the victims of parasitic fungi. SPARRow (1936) described a fungus, Petersenia sp., which parasitizes rotifer eggs.

Malformed sardine eggs collected and preserved for us by the California Fish and Game Commission were found to be filled with fungi. This research project was interrupted by the War before it could be established whether the fungi were responsible for the malformation of the sardine eggs or if the fungi attacked only moribund eggs. The preliminary observations suggest the possibility of fungus infections accounting for extensive failure of sardine crops. 
Parasitic and epiphytic fungi may occur on marine algae much more extensively than indicated by the fragmentary literature on the subject Such organisms are difficult to detect and identify even in properly collected specimens. The distinguishing morphological structures of the fungi are so minute and so intimately associated with the host tissue that they may escape detection. In some cases they have been mistaken for the fruit bodies of certain marine algae. For example, KIBBE (I9I6) described Chytridium alarium as a fungus parasitic on Alaria fistulosa, but SPARROw (1943) records that KIBBE mistook the cystidia of the alga for a fungus.

According to the literature summarized by KIBBE (I9I6), LEMMERMAN named a marine fungus, Dothidella laminariae, which is parasitic on Laminaria. ESTEE described Guignardia irritans, parasitic on Cystoseira and Halidrys. PATOuIllard described Zignoella calospora, parasitic on Castagnea. PATOUILlARd and HARIot found Zignoella enormis on Stypocaulon. REED described two ascomycetes, Guignardia ulvae on Ulva, and Guignardia alaskana on Prasiola. CoHN described Chytridium polysiphoniae on Polysiphonia, Olpidium plumulae on Antithamnion, and Olpidium entosphaericum on Hormiscia. FiscHer mentions Rhizophydium dicksonii on Ectocarpus, Olpidium sphacellarum on Sphacelaria, Olpidium tumefaciens on Ceramium, Olpidium bryopsidis on Bryopsis, and Olpidium aggregatum on Cladophora. Besides these parasitic marine fungi to which references are given by KIBBE (I9I6), SPARRow (I943) lists Rhizophydium gelatinosum, and Achlyogeton salinum, both of which are parasitic on Cladophora, Olpidium lauderiae parasitic on Lauderia, Rhizophydium marinum parasitic on Melosira, and Rozella marina parasitic in the sporangia of Chytridium polysiphoniae.

SPARROW (I936) suggests that the peculiar rhythms of blooming periods and distribution of pelagic diatoms which cannot be attributed to hydrographic factors may sometimes be due to the activities of parasitic fungi. There is accumulating evidence, but no conclusive proof, that many of the diatoms and dinoflagellates which observers report are found in "poor condition" may have been parasitized. Diatoms parasitized by Ectrogella perforans were observed by SPARRow (I934) to distort the frustules sometimes so much as to suggest that the fungus had dissolved the siliceous material and produced hypertrophy of the diatom cell. The possibilities of parasitism, coupled with the importance of diatoms and dinoflagellates as primary producers, invite early attention to this problem.

The wasting disease of Zostera marina which has depleted the eel grass from hundreds of miles of coast in Europe and America may be due to a fungus infection. TUTIN (1934) believed Ophiobolus halimus to be the causative agent. RENN (I936) failed to find any Ophiobolus-like fungi associated with the rhizomes or leaves of diseased plants, but he did find a species of Labyrinthula in all of the diseased plants which he examined. The association of Ophiobolus (Halophiobolus) salimus, H. halimus, and $H$. maritimus with eel grass has been reported by BARGHOORN and LINDER (I944), who state that further research is required to ascertain whether these species are causative agents of the wasting disease, secondary invaders, or merely saprophytic.

The brown alga, Macrocystis pyrifera, which is of considerable economic importance, may be subject to epidemics of fungus infections. Similarly, other commercially valuable marine algae may be affected by 
parasitic or saprophytic fungi, another problem which invites attention.

Most of the fungi described by BARGIIOORN and LINDER (I944) were isolated from wood or rope which had been submerged in the sea. Histological examination of their natural substrata showed that the fungi penetrate and ramify the cell walls of wood and cordage fibers, inducing decay by enzymatic hydrolysis of the cellulose and other cell wall constituents. The fungi readily utilized cellulose, pectin, and starch under experimental conditions. Maltose, galactose, xylose, and asparagine were also utilized. Growth was vigorous and fairly rapid on wood flour agar. Many of the fungi attacked lignin. The evidence is convincing that fungi cause the deterioration of cordage fibers and wood under marine conditions.

Importance of fungi in lakes:- In reviewing the literature on the subject, Weston (I94I) states that there are between 700 and 800 species of Phycomycetes which are definitely aquatic, besides many others which, though normally terrestrial, are capable of living in water. In this latter category are several species of Penicillium and Fusarium. Relatively few species of Ascomycetes are adapted to aquatic life.

Aquatic fungi are capable of activity and survival over a wide range of environmental conditions, being found in inland waters throughout the world. They grow equally well in direct sunlight or darkness. Certain ones are active at temperatures ranging from $\mathrm{I}^{\circ}$ to $33^{\circ} \mathrm{C}$., and in water as acidic as $p \mathrm{H}_{3.2}$ or as alkaline as $p \mathrm{H}_{9.6}$. Most fungi require free oxygen.

Aquatic fungi are both saprophytic and parasitic. Their ability to break down pectins, hemicelluloses, and cellulose is widespread. In attacking organic matter, fungi may influence the $p \mathrm{H}$, oxygen content, and other chemical properties of the water. Most plants and animals living in lakes are susceptible to parasitism by aquatic fungi. Serious fungal epidemics among diatoms and desmids have been reported. The eggs of some animals are destroyed by fungi, and such organisms may also cause extensive infections of fresh-water fish. Fungi may be a limiting factor in aquatic biology.

Many aquatic animals such as protozoans, rotifers, coelenterates, arthropods, etc., devour fungi spores from which they derive nourishment.

According to WESTON (I94I), water fungi are "ubiquitous, abundant, versatile, hardy, and efficient, playing a significant part in the complexly interwoven pattern of biologic interaction in inland waters; as saprophytes in manifold capacities unceasingly active in the essential degradation of complex materials; and as parasites ever preying inconspicuously on the major groups of plants and animals important in hydrobiology, and occasionally so severely destructive as to reduce productivity."

Numerous species of Phycomycetes, which parasitize the eggs, embryos, and adult forms of various aquatic animals, are described by SPARROW (I943). Fresh-water algae, diatoms, and other aquatic plants are likewise infected. Some of the Phycomycetes are responsible for infections of epidemic proportions. For example, Rhiwophydium agile has been reported to destroy up to 75 per cent of the Chroococcus turgidus cells in the field and in gross cultures. Attention is directed to the extensive bibliography on aquatic Phycomycetes compiled by Sparrow (I943). 


\section{Chapter X}

\section{TRANSFORMATION OF ORGANIC MATTER}

The chief function of bacteria in the carbon cycle is the decomposition of organic matter to $\mathrm{CO}_{2}$, water, ammonia, and certain minerals. The efficiency with which they perform this function is indicated by the low content of organic matter in sea water, which averages less than $5 \mathrm{mgm}$. per liter. It is because bacteria are able to mineralize virtually all kinds of organic matter that the sea has aptly been characterized as the world's largest and most efficient septic tank.

A second function of bacteria in the carbon cycle is that of converting waste and dissolved organic matter into bacterial cell substance which can be assimilated by filter-feeding and mud-eating animals (see page I $_{73}$ ). The bacteria may convert as much as 30 to 40 per cent of the organic matter into bacterial cell substance while oxidizing the rest to $\mathrm{CO}_{2}$ and water as a source of energy.

Third, certain bacteria living symbiotically in the intestinal tracts of animals may aid the latter in the digestion of food. There is ample evidence that such bacteria are widely distributed, but there are no data for apraising quantitatively their importance in the carbon cycle.

A fourth function is the primary production of organic matter by chemosynthetic and photosynthetic autotrophs. Below the photosynthetic zone, chemosynthetic bacteria are the only primary producers which can synthesize organic matter from $\mathrm{CO}_{2}$ and water. However, in spite of the academic interest centering around chemosynthetic and photosynthetic bacteria, they appear, when compared with green plants, to play a very minor role as primary producers in the sea.

Quantity of organic matter decomposed:- Different workers, using various methods of approach, estimate that the primary production of organic matter in the sea ranges from 5 to rooo grams of organic matter per square meter per year (see literature summarized by RILEY, I94I). Taking Io gm. $/ \mathrm{M}^{2} /$ year as a conservative production figure, there is produced in the oceans of the world a minimum of $3.7 \times \mathrm{IO}^{12}$ kilograms of organic carbon per year. Only a small fraction of this organic matter is

TABLE XXXV.- Summer standing crop in Wisconsin lakes given as kilograms per hectare of lake surface on a wet-weight, ash-free basis (from JUDAY, 1942):-

\begin{tabular}{|c|c|c|c|c|}
\hline & $\begin{array}{c}\text { LAKE } \\
\text { MENDOTA }\end{array}$ & $\begin{array}{l}\text { GREEN } \\
\text { LAKE }\end{array}$ & $\begin{array}{c}\text { Nebish } \\
\text { LAKE }\end{array}$ & $\begin{array}{c}\text { WeBER } \\
\text { LAKE }\end{array}$ \\
\hline Phytoplankton & $\mathbf{I}, 875$ & 2,767 & 608 & 1,069 \\
\hline Botlom flora & 4,600 & 4,218 & 590 & 553 \\
\hline Total weight of plants & 6,475 & 6,985 & I, I9 8 & 1,622 \\
\hline Zooplankton & $\mathrm{I} 20$ & 177 & 42 & 74 \\
\hline Bottom fauna & 414 & r 38 & 122 & 147 \\
\hline Fish & & & 35 & 23 \\
\hline Total weight of animals & $534^{*}$ & $315^{*}$ & I99 & 244 \\
\hline Dissolved organic matter & I5,20I & 27,901 & 3,829 & 2,866 \\
\hline
\end{tabular}

* Excluding fish, the standing crop of which is not given. 
removed from the oceans per year in the form of fish, whales, commercial algae, and other products, and a similarly negligible amount is buried in bottom deposits. This means that more than 99.9 per cent of the total organic production in the sea must be decomposed.

Plants oxidize some organic matter which they themselves have synthesized, but most of the plant tissue is ingested by animals or decomposed by bacteria and allied microorganisms (see ligure ro). Grazing animals ingest a proportion of the diatoms, dinoflagellates, and other primary producers, converting some of the organic carbon into animal

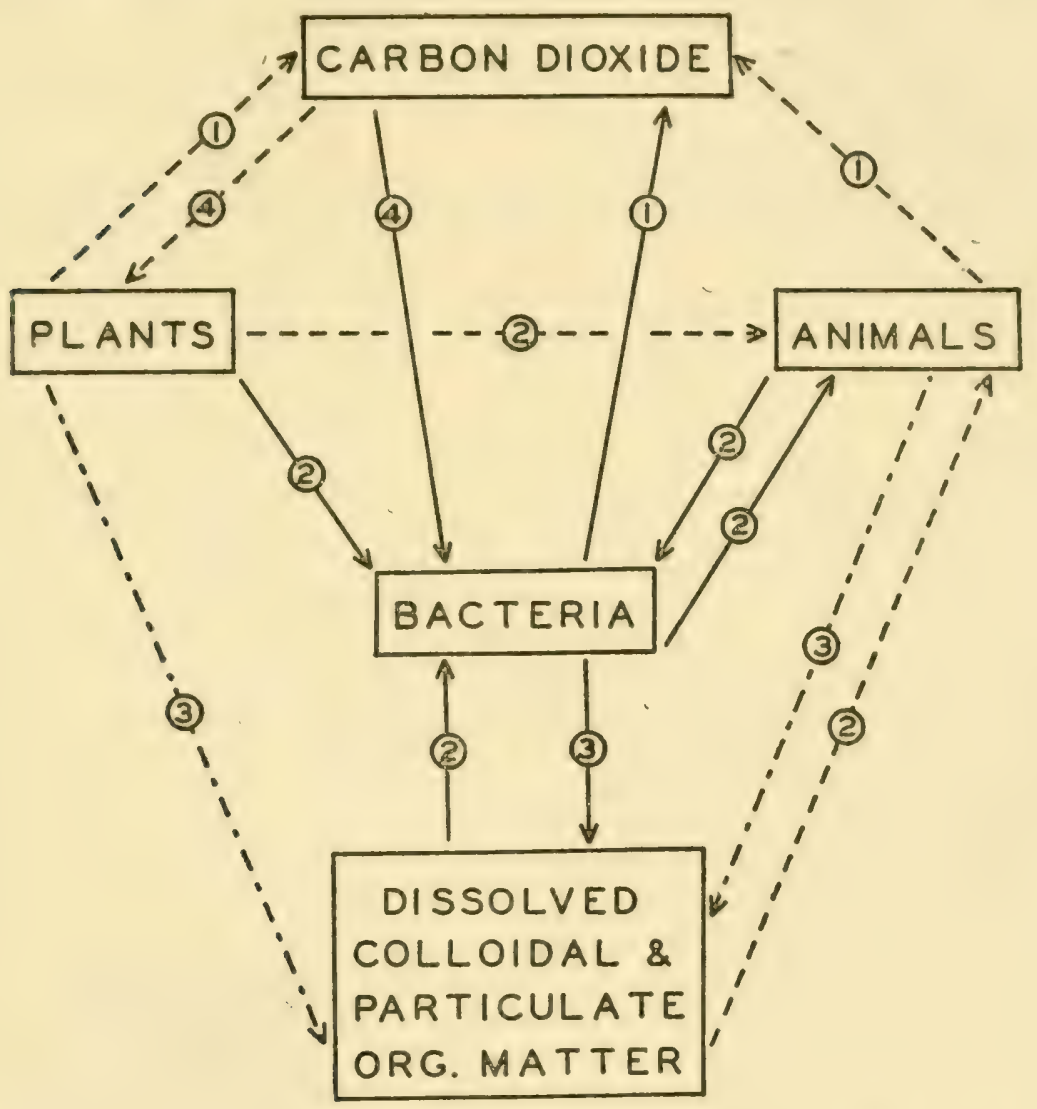

Fig, xo. - Carbon cycle in the sea. Solid lines represent processes in which bacteria exclusively participate, dot-dashed lines represent processes in which bacteria may participate, and dashed lines represent processes in which bacteria do not participate. Respiration ( 1 ), nutrition (2), decomposition (3), and $\mathrm{CO}_{2}$ fixation (4).

tissue, excreting varying quantities, and oxidizing most of it as a source of energy. Grazing animals in turn may be ingested by predatory animals.

In small inland lakes where such problems are more susceptible to quantitative solution, JUDAY (I942) estimated that the total weight of plants produced is about six to twenty times as great as the total weight of animals (see Table XXXV on opposite page). Insufficient data are available to compare these estimates for lakes with conditions in the ocean. Certainly the production of bottom flora is far less in the ocean than in lakes because most of the ocean bottom lies beneath the levels that are 
penetrated by light. In oceans as well as in lakes there is much more "dissolved" organic matter than particulate (including plants and animals).

The so-called "dissolved" organic matter represents that which is not removed with a high speed centrifuge. It includes minute particles of decomposing organic material, some bacteria, colloids, and organic matter in true solution. Although some of the colloidal and minutely particulate organic matter can be assimilated by certain filter-feeding and mudeating animals, most of it and all of that in true solution can be utilized only by bacteria and allied microorganisms. JúdAY (I942) points out that "the dissolved organic matter is in a constant state of flux; it is continually receiving both decomposing and excretory materials from the biota on the one hand and losing organic substances that change over to inorganic compounds on the other."

After noting marked increases in the bacterial population and oxygen consumption in filtered sea water incubated in the laboratory, WAKSMAN and CAREY (I935a) concluded that sea water contains sufficient organic matter in true solution to support an extensive bacterial population under favorable conditions. In the decomposition of the organic matter in sea water by bacteria, a definite parallelism was obtained between bacterial multiplication, oxygen consumption, and liberation of nitrogen as ammonia.

When sea water was placed in glass containers and kept under favorable conditions, WAKSMAN and CAREY (I935b) found that from 25 to 50 per cent of the organic matter was decomposed within Io or 12 days, as measured by the amount of oxygen consumed and ammonia liberated. About 60 per cent of the organic matter decomposed was completely oxidized, as shown by the amount of oxygen consumed, and about 40 per cent of it was converted into bacterial cell substance and other products of bacterial metabolism. The rapidity of the process was found to be influenced by the temperature, oxygen tension, abundance of organic matter, and the chemical nature of the organic substrate itself.

After five or six months storage in the dark the organic content of filtered sea water was found by ZOBELL and GRANT (I943) to be reduced to around $0.2 \mathrm{mgm}$./L. from an original 3 to $4 \mathrm{mgm}$./L. Glucose, glycerol, ethanol, lactate, succinate, starch, and asparagine in concentrations ranging from 0.25 to $5 \mathrm{mgm}$./L. were quantitatively utilized by bacteria in sea water in from 16 to 30 days at $22^{\circ} \mathrm{C}$. From 60 to 70 per cent of the organic substrate is oxidized and 30 to 40 per cent is converted into bacterial protoplasm and intermediate products. Cultures attack concentrations of glucose as low as O.I mgm./L.

While the chief function of bacteria in the transformation of organic matter appears to be the utilization of "dissolved" organic matter, there is an extensive bacterial flora in the sea which is uniquely adapted to decompose chitin, lignin, waxes, cellulose, and other complex organic substances which are assimilated poorly, if at all, by other types of organisms.

Decomposition of carbohydrates:- Simple sugars ranging from trioses to hexoses are readily assimilated by many species of marine bacteria. In a balanced mineral solution containing an available source of nitrogen, simple sugars are quantitatively utilized. Part of the carbon is oxidized to $\mathrm{CO}_{2}$ as a source of energy and part is converted into bacterial protoplasm. The quantitative oxidation of glucose by bacteria in sea water 
requires the addition of available nitrogen. This observation of WAKsMAN and CAREY (19356) suggests that the bacterial population of the sea and the decomposition of carbohydrates may be limited by the amount of available nitrogen present.

Although widely and abundantly distributed in the sea, splitters of disaccharides such as sucrose, lactose, and maltose are fewer in numbers of species than are the bacteria which decompose simple sugars. About a third of the bacterial species isolated from marine materials hydrolyze starch. Achromobacter thalassius, Actinomyces halotrichis, Act. marinolimosus, Flavobacterium halohydrium, Fl. neptunium, Pseudomonas pleomorpha, Vibrio marinopraesens, and $V$. ponticus are examples of amylolytic organisms described by ZoBell and UpIIAM (I944). Most of their Bacillus species from the sea, none of their Micrococcus species, and very few of their Pseudomonas or Vibrio species attacked starch. Fox (I934) demonstrated the ability of 69 different species of marine bacteria, 3 molds, and 2 yeasts to hydrolyze amygdalin with the gradual production of $\mathrm{HCN}$.

Several species of marine fungi studied by BARGHOORN and LINDER (I944) utilized maltose, galactose, xylose, starch, cellulose, and pectin. Growth of the fungi was most rapid in sea water agar enriched with either cellulose, pectin, or starch.

Mannite was attacked by many species of marine bacteria observed by Enevoldsen (I927). While on the steamer Dana, he noted an increased acidity in sea water samples treated with mannite, a carbohydrate-like hexatomic alcohol which occurs in certain marine algae. ENEVOLDSEN believed that mannite could serve as a carbon source for marine bacteria in their natural habitats.

Only a specialized few marine microorganisms are endowed with the ability to utilize cellulose, although such organisms may be demonstrated in most Io- to Ioo-ml. samples of sea water and in nearly all one-gram samples of bottom deposits. Using the minimum dilution method, ZOBELL (I938a) demonstrated rooo cellulose digesters per gram of mud, as compared with 100,000 glucose fermenters and 10,000 starch hydrolyzers.

Cellulose-decomposing bacteria were found to be generally present in sea water, and particularly abundant in bottom deposits and diatom tows, by WAKSMAN et al. (1933a) in the Gulf of Maine and George's Bank. Species of Cytophaga, Cellvibrio, and Cellfalcicula were identified. In crude cultures, the cellulose-decomposing bacteria were invariably accompanied by numerous protozoans, including flagellates, ciliates, and amoebae, all of which feed upon bacteria. Most of the cellulose decomposers were aerobic, but anaerobic forms were also demonstrated. Some of the latter produced gas. A variety of sugars were utilized by the cellulose decomposers. Some of them decomposed agar and other hemicelluloses.

BAVEndam (1932) found aerobic cellulose digesters in all marine mud samples, and anaerobic cellulose digesters in many samples which he examined. Many other workers refer to the occurrence of cellulosesplitting bacteria in the sea, but no noteworthy quantitative studies have been made on marine cellulose digesters.

RUBENTSCHIK (I928b) reported that aerobic cellulose digesters are active in salt limans. He isolated Actinomyces melanogenes which decomposed paper. Later he (I933) found that anaerobic cellulose digesters are 
also widely distributed in aquatic environments. The decomposition of cellulose by these organisms was unimpaired by a salt concentration as high as ${ }_{5}$ per cent $\mathrm{NaCl}$. RuBENTSCHIK (I928b) related that from the salt lake Ssaky in Crimea he isolated Bacterium cellulosae album and Bacterium cellulosae flavum which digest cellulose.

Cellulose is decomposed primarily to $\mathrm{CO}_{2}$ and water in the presence of oxygen. Under anaerobic conditions appreciable quantities of methane and hydrogen are produced from the decomposition of cellulose. According to several theories of petroleum formation, cellulose may also be converted into higher hydrocarbons. Theoretically, cellulose could be reduced by either hydrogen or hydrogen sulfide to hydrocarbons. In view of the possible significance of the reaction, this question merits thorough investigation.

From marine materials, StANIER (I94I) isolated and described Vibrio fuscus, Pseudomonas iridescens, Cytophaga krzemieniewskae, and Cytophaga diffuens, all being new species which digest cellulose and agar. He also described Vibrio beijerinckii which digests agar but not cellulose. According to Stanier (I94I), Vibrio granii and Pseudomonas droebachense, two species previously named by LUNDESTAD (1928), digest both agar and cellulose. About half of the agar digesters studied by STANIER utilized alginic acid, and most of them attacked starch and simpler carbohydrates.

Agar is the principal carbohydrate constituent of many marine algae, particularly certain Rhodophyceae. Although not attacked by most bacteria, agar is digested by several marine species and a few terrestrial ones. Indicative of the abundance of agar digesters in the sea is the report of BAVENDAMM (r932) that marine muds from the Bahama Islands contain from 50,000 to 200,000 agar digesters per gram. It is estimated that between one and two per cent of the bacteria occurring in the sea are able to digest agar.

Agar-digesting bacteria were more commonly found in the sea than were cellulose decomposers by WAKSMAN et al. (I933a), especially in diatom tows and around larger marine algae or their residues. In $1.0 \mathrm{ml}$. of diatom tow, from 2,100 to 2,500 cells of bacteria capable of liquefying agar were found. Agar digesters made up 5.7 to 6.7 per cent of the total number of colonies developing on plates inoculated with the diatom tow. Starch, cellulose, inulin, galactan, and mannite were decomposed by most of the agar digesters.

GRAN (1902) was the first to isolate a pure culture of agar-digesting bacteria from the sea. His Bacillus gelaticus is now known as Pseudomonas gelatica. In a careful search for agar digesters in sea water off the Norwegian coast, LuNDESTAD (I928) found and described Achromobacter (Vibrio) granii, Flavobacterium rhodomelae, Fl. polysiphoniae, Fl. (Pseudomonas) droebachense, Fl. delesseriae, Fl. boreale, and Fl. ceramicola. Most of the cultures studied by LUNDESTAD were able to grow at $0^{\circ} \mathrm{C}$., although their optimum temperatures ranged from $20^{\circ}$ to $30^{\circ} \mathrm{C}$. Some were killed by prolonged exposure at $3 \mathrm{I}^{\circ} \mathrm{C}$.

VAN DER LEK (I929) demonstrated the occurrence in the sea of Vibrio agarliquefacicns, an organism which is capable of attacking cellulose and agar.

ANGST (1929) found the following new species of agar digesters associated with marine algae: Agarbacterium aurantiacum, A. bufo, A. cyanoides, A. mesentericus, A. reducans, A. viscosum, and seven others which he described but failed to name. 
The decomposition of alginic acid, a polyuronide occurring abundantly in marine algae, was found by WAKSMAN et al. (1934) to be caused largely by certain specific bacteria. Other microorganisms such as fungi were responsible only to a very limited extent. Bacteria which decompose alginic acid occur abundantly in sea water, marine plankton, and in bottom deposits. Three new marine species which decompose alginic acid were described; namely, Bacterium alginicum, Bact. alginovorum, and Bact. fucicola. The last two species also digest agar.

Pseudomonas hypothermis, Ps. marinopersica, Ps. perfectomarimus, Ps. periphytica, and Flavobacterium uliginosum are agar digesters described by ZOBELL and UPIAM (I944). These organisms tend to lose their ability to digest agar after prolonged laboratory cultivation, even on agar slants.

According to KinkEL (I936), cellulose-decomposing bacteria occur abundantly in lake mud. She also found in mud from Lake Mendota several species which fermented pectin.

Cellulose-decomposing microorganisms, as well as those which attack lignin, are instrumental in the destruction of timbers, wooden pilings, ropes, fish nets, and other cellulose- or lignin-containing structures. Such microorganisms may work symbiotically with shipworms or other woodborers. BARGHOORN (I942) reports the occurrence on the North Atlantic coast of marine fungi which cause the deterioration of both hard and soft woods as well as cordage fibres under marine conditions.

Lignin decomposition:- Lignin is a complex, carbohydrate-like substance which constitutes part of the woody structure of plants. According to Sterner and MELoche (I935), from ro to 20 per cent of the organic matter in phytoplankton and from 30 to 48 per cent of the organic residue in lake bottom deposits is lignin. WAKSMAN (I93.3) likewise found a much higher percentage of lignin in marine humus than in marine vegetation. The difference between the lignin content of phytoplankton and bottom deposits is indicative of the relative insusceptibility of lignin to microbial decomposition.

Lignin is slowly oxidized by certain bacteria. BENSON and PARTANSKY (I934) reported that the ligneous materials in sulfite waste liquors discharged by pulp mills are slowly decomposed by bacteria in sea water and marine mud. Sulfite waste liquor is primarily a calcium lignosulfate, or the residue of wood after the hemicelluloses are hydrolyzed by acid treatment and the cellulose is removed as pulp. The lignosulfate consists chiefly of lignin. When inoculated with marine mud, lignosulfate was found to be fermented with the production of $\mathrm{CO}_{2}$, methane, and $\mathrm{H}_{2} \mathrm{~S}$.

ZOBELL and STADLER (I940a) present evidence which indicates that, while lignin is oxidized less readily than are other major organic constituents occurring in lakes, it is slowly decomposed by bacteria found in water and bottom deposits. Several different purified lignins as well as various ligneous products were examined, using oxygen consumption and the disappearance of lignin as criteria of utilization. Most of the strains of Micromonospora found in lake mud by ERIKSON (I94I) attacked lignin.

Marine fungi which attack lignin and cellulose are believed by BARGHOORN and LINDER (I944) to be dominantly responsible for the deterioration of hemp, jute, and sisal cordage as well as pilings and other wooden structures in the sea.

ZoBELL (I940b) found that, provided some oxygen was present, purified lignin and lignoprotein were slowly oxidized by marine bacteria. The 
rate of utilization was relatively independent of the oxygen tension. After the supply of dissolved oxygen was depleted or was reduced to such a low level that oxygen could not be replaced by diffusion as rapidly as it was consumed by respiring bacteria, the oxidation of lignin was retarded. The rate of oxidation of organic matter in sea water, as indicated by oxygen consumption, was found to be independent of the oxygen tension within the examined range of 0.43 to $17.8 \mathrm{mgm} . / \mathrm{L}$.

Proteinaceous compounds:- As a class, marine bacteria are actively proteolytic. They rapidly decompose most simple proteinaceous compounds, and even the most complex compounds are slowly attacked with the liberation of ammonia and $\mathrm{CO}_{2}$. Every one of the 60 pure cultures studied by ZoBELL and UPHAM (I944) liberated ammonia from peptone, 47 of them liquefied gelatin, and half of them hydrolyzed casein. Mixed cultures from mud or sea water break down peptone, gelatin, and casein with the production of $\mathrm{CO}_{2}$ as well as ammonia.

According to TRASK (1934), amino acids and simple proteins constitute a very minor part of the organic content of marine sediments. This is ascribable to the tendency of bacteria to decompose such compounds, which constitute an appreciable part of the protoplasm of plants and animals. Complex nitrogenous compounds are more abundant in sediments than are simple proteins, but neither simple nor complex proteins are proportionately as abundant in sediments as in the organic matter of plant and animal tissues. WAKSMAN (I933) believes that lignoproteins and hemicellulose-protein complexes account for about 75 per cent of the organic nitrogen content of sediments.

Hecht (I934) reports that most simple proteins are completely decomposed in marine sediments even under anaerobic conditions. Decomposition of the bodies of marine invertebrates, birds, and mammals was observed to be most rapid in sea water containing dissolved oxygen. The presence of $\mathrm{H}_{2} \mathrm{~S}$ and reducing conditions inhibited the decomposition of proteins. About 90 per cent of the combined nitrogen content of deeply buried sediments was present in chitin.

The author is aware of no systematic investigations on marine proteolytic bacteria, although many investigators refer to the ability of marine bacteria to liquefy gelatin, utilize peptone, and to decompose fish muscle or the nitrogenous tissues of other marine animals. For example, SCHMIDT-NIELSEN (I9OI) was impressed by the rapidity with which bacteria from Oslo Fjord decomposed proteins with the liberation of ammonia. He remarked that, although pouring sea water over boiled shrimps renders them temporarily more attractive in appearance, the shrimps are soon decomposed subsequently by bacteria from the sea water.

Proteolytic bacteria are primarily responsible for the spoilage of fish, shellfish, crab meat, and other marine food products. Although not based upon quantitative studies, the opinion is rampant that marine fish are more susceptible to spoilage than fresh-water fish. Possibly marine bacteria may be more actively proteolytic than corresponding fresh-water flora; there may be differences in the composition of fish from different environments; marine bacteria may be active at temperatures somewhat lower than fresh-water bacteria as a group, or there may be other explanations to account for this opinion.

Fish and other marine food products soon show signs of spoilage if 
not properly refrigerated. The consistency and color of muscle tissue are altered by bacterial activity, and an odor of ammonia, indol, trimethylamine, or other protein-decomposition products is manifest. Quantitative tests for ammonia, indol, trimethylamine, histamine, tyrosine, and other protein-decomposition products have been proposed by various workers as a means of detecting the early stages of fish spoilage. A common property of the bacteria associated with spoiled fish is their ability to decompose proteins, peptones, peptides, and amino acids (BRADLEY and BAILEY, r940; Hunter, I922; Geiger et al., I944; GrifFiths, I937; Harrison and KENNEDY, I922; SNOW and BEARD, I939; WOOD, I940).

OSTROFF and HENRY (I939) investigated the ability of I 5 representative aerobic bacteria of marine origin to utilize 2 I different nitrogen compounds. Asparagine, aspartic acid, glutamic acid, alanine, propionamide, acetamide, sodium hippurate, urea, and creatinine were commonly utilized either as a source of nitrogen or energy or both. Cystine, betaine, pyridine, and uric acid were utilized by some of the bacteria. Only one culture utilized tyrosine. Guanidine, aniline, and ethylamine were not utilized by any of the organisms.

WAKSMAN and RENN (1936) found that from 2 to $4 \mathrm{mgm} . / \mathrm{L}$. of glycine, alanine, phenylalanine, glutamic acid, tyrosine, and asparagine were almost quantitatively utilized by raw cultures of bacteria in sea water within 2 to 5 days at $20^{\circ} \mathrm{C}$. From these results and others in which they noted the rate of carbohydrate decomposition to be dependent upon an available nitrogen source, they concluded that zooplankton in sea water were decomposed more rapidly than marine algae because of the greater proportion of available nitrogen in the former. WAKSMAN et al. (I933a) noted that marine zooplankton were more susceptible than were marine algae to bacterial decomposition. The green alga, Ulva lactuca, which contains about 2 per cent nitrogen on a dry basis, was decomposed more rapidly than the brown alga, Fucus resiculosis, which contains only half as much nitrogen. The bacterial decomposition of zooplankton proceeded to completion with the liberation of ammonia and $\mathrm{CO}_{2}$, whereas the complete decomposition of Fucus material required the addition of available nitrogen.

Marine diatom plankton, which is relatively rich in proteinaceous material, was observed by WAKSMAN et al. (I937) to undergo rapid oxidation and decomposition by bacteria in sea water. This was measured by oxygen consumption, nitrogen liberation, phosphate regeneration, and bacterial multiplication. Only dead diatoms were attacked by the bacteria.

Chitin decomposition:- Chitin is the chief constituent of the exoskeleton of Crustacea and it occurs in some Mollusca, Coelenterata, and Protozoa. Johnstone (I9o8) estimated that one sub-class of planktonic Crustacea, the Copepoda, produces several million tons of chitin annually. Most of this, as well as the chitin produced by other organisms in the sea, must be decomposed since relatively little accumulates in the marine sediments, and moreover, if it were not decomposed, it would become a serious drain upon carbon and nitrogen in the cycles of these elements. Chitin is generally believed to be a polymer of glucosamine in which each amino group is acetylated, the composition being $\mathrm{C}_{32} \mathrm{H}_{54} \mathrm{O}_{21} \mathrm{~N}_{4}$.

There are few if any animals which can assimilate chitin unaided by microorganisms. Although chitinase has been detected in the alimentary tracts of certain chitin-ingesting animals, it may have been produced by 
chitinoclastic bacteria which commonly occur in great numbers in the alimentary tracts of such animals. One of the best sources of chitinoclastic bacteria is the stomach contents of squid and other cephalopods which ingest chitinous food. Hock (I940) recovered chitinoclastic bacteria from the intestinal contents of seven different genera of marine animals.

BENECKE (I905) isolated Bacillus chitinovorus from the polluted water of Kiel harbor. It is doubtful if this organism, which digests chitin, is a true marine species since it has been found in soil and it grows well in fresh-water media.

Waksman et al. (I933c), Bertel (I935), and ZoBell and ANderson (I936b) have found chitinoclastic bacteria to be widely distributed in marine bottom deposits. From the lesions of live lobsters having a shell disease, HEss (I937) isolated a number of strains of chitinoclastic bacteria. JoHnson (1932) found chitinoclastic bacteria growing on crabs packed in ice. From the shells of crabs in an advanced stage of decomposition, she isolated several kinds of chitin-destroying bacteria.

After finding chitinoclastic bacteria in 8 out of 27 samples of solar salt obtained from Africa, Spain, South America, California, and the West Indies, StUART (1936) concluded that such bacteria are probably widely distributed in the sea. Most of the bacteria were Gram-negative aerobes, morphologically resembling Serratia and Sarcina. STUART expressed the belief that halophilic chitinovors or chitinoclasts may be responsible for damage to skins and hides.

Between O.I and I.o per cent of the marine mud-dwelling bacteria studied by ZoBell and RitTenberG (I938) were able to attack chitin. Some of the bacteria could obtain both their energy and nitrogen requirements from purified chitin, whereas others needed supplementary carbon or nitrogen compounds. Chitinoclastic bacteria were found in nearly all 5-gram samples of bottom deposits. They were most numerous at the mud surface, decreasing in abundance with core depth.

Most of the 3I pure cultures of chitinoclastic bacteria isolated from marine materials by ZoBELL and RITTENBERG were small, Gram-negative rods. Many produced yellow, brown, orange, or pink pigments. One violet pigment producer resembling Chromobacter violaceum was observed. It, like somè of the other chitinoclastic bacteria, had marked attachment propensities, growing almost exclusively tenaciously attached to strips of chitin. None of the chitinoclastic bacteria were able to digest cellulose, and as a class they were feebly saccharolytic. They were active at temperatures as low as $0^{\circ} \mathrm{C}$. Anaerobic as well as aerobic chitinoclastic bacteria occur in the sea.

$\mathrm{CO}_{2}$ and ammonia are end products resulting from the bacterial decomposition of chitin. Acetic acid and reducing sugars have been detected in cultures as intermediate products.

Hock (I940) isolated chitinoclastic bacteria from marine sands, mud, water, decomposing crabs, and the intestinal contents of animals which feed on crustaceans. Shells of Limulus, the horseshoe crab, were decomposed relatively rapidly when buried in beach sand. Hock (I94I) described two new species of marine chitinoclastic bacteria, Bacterium chitinophilum and Bacterium chitinochroma.

Chitinoclastic bacteria were demonstrated in the mud and water of alpine lakes by STEINER (I93I). Chitin was attacked both aerobically and anaerobically by raw cultures. From Lake Mendota mud, Kinkel (1936) isolated I 3 types of chitinoclastic bacteria representing several different 
genera. Most of the strains of Micromonospora isolated from lake mud by ERIKSON (I94I) readily decomposed chitin.

Chitin is attacked more slowly than most other common types of organic matter. It is decomposed less readily anaerobically than aerobically. In spite of the widespread distribution of chitinoclastic bacteria in the sea, chitin persists as one of the principal nitrogenous constituents of marine sediments (HECHT, I934; WAKSMAAN, I933).

Lipolytic bacteria:- Fats and oils of varying degrees of complexity are synthesized as part of the cell substance by most bacteria, yeasts, and molds. However, the amount synthesized is insignificant as compared with the amount which they decompose. The following mean values given by TRASK (r939) show the lipid content of the organic matter of sediments and that of the principal groups of organisms living in the water:

$\begin{array}{lccc} & \text { ETHER } & \text { CRUDE } & \text { CARBOHY- } \\ \text { EXTRACT } & \text { PROTEIN } & \text { DRATES } \\ \text { per cent } & \text { per cent } & \text { per cent } \\ \text { Diatoms } & 8 & 29 & 63 \\ \text { Copepods } & 8 & 65 & 22 \\ \text { Higher invertebrates } & \text { IO } & 70 & 20 \\ \text { Marine sediments } & \mathrm{I} & 40 & 47\end{array}$

The ether extract includes oils, fats, certain pigments, sterols, and waxes. Further examination has revealed that not only is there a great decrease in the ether-extract content of organic matter deposited on the sea floor, but that fats and oils decrease proportionately faster than waxes.

It is difficult to assess the relative importance of animals and bacteria in the decomposition of fats and oils, but it is known that lipolytic bacteria are widely distributed in the sea. Nearly all types of fats and oils seem to be attacked by bacteria in sea water and marine mud. Certain pure cultures, notably anaerobes, hydrolyze tripalmitin, tristearin, and other pure fats with the liberation of fatty acids. Presumably the glycerol which results from the hydrolysis of triglycerides is oxidized as a source of energy.

Some lipolytic bacteria utilize fatty acids under certain conditions. Whether the fatty acids are utilized or left apparently depends partly upon the organisms involved and partly upon the environmental or nutritional conditions. The hydrolysis of fats and the transformation of fatty acids are believed to be of considerable importance in the origin of petroleum. From the formulae of fatty acids, it is evident that the deoxygenation or decarboxylation of fatty acids may result in the formation of petroleum hydrocarbons:

$$
\mathrm{CH}_{3}\left(\mathrm{CH}_{2}\right)_{\mathrm{n}} \mathrm{CH}_{2} \mathrm{COOH}=\mathrm{CH}_{3}\left(\mathrm{CH}_{2}\right)_{\mathrm{n}} \mathrm{CH}_{3}+\mathrm{CO}_{2}
$$

Relationships of microorganisms to the generation of petroleum with particular reference to fats and oils are reviewed by HAMMAR (I934).

In his doctorate dissertation work at the S.I.O., which is concerned with the transformation of lipids by marine anaerobes, W. D. RosENFELD has found lipoclastic anaerobes to be widely and abundantly distributed in recent marine sediments, oil-well brines, tar sands, asphalt deposits, and in paraffin earth samples. Fatty acids are not readily oxidized under anaerobic conditions in the absence of glycerol, an observation which suggests that there is a concomitant oxidation of glycerol and reduction of fatty acid. Binary combinations of fatty acids appear to be assimilated 
more readily by lipoclastic anaerobes than is either fatty acid alone. 'In long-term experiments with mixed cultures of lipoclastic anaerobes growing on lipid-rich algae from Mission Bay, a significant increase in the content of ether-soluble, unsaponifiable material was observed, thereby indicating that lipids may be converted into hydrocarbons or hydrocarbon-like substances. The unsaponifiable material is a waxy substance which gives no colorimetric indications for the presence of sterols.

Working on the hypothesis that petroleum is formed from the fats and oils of diatoms, THAYER (I93I) found that, while marine bacteria may attack various kinds of fats, the only hydrocarbon resulting from the action of mixed cultures of marine anaerobes on fatty acids is methane. Acetic, propionic, butyric, valeric, caproic, heptylic, lauric, palmitic, margaric, and stearic acids were found to be decomposed quantitatively to $\mathrm{CO}_{2}$ and methane by anaerobic organisms occurring in fresh-water and marine muds. The formation of methane from fatty acids has been reported by CoolhaAs (I928), TARVin and Buswell (1934), and others. Most marine aerobes are able to assimilate some of the fatty acids, and all simple fatty acids are utilized by marine bacteria of one species or another.

Ginsburg-Karagitscheva and Rodionowa (I935) noted an abundance of both aerobic and anaerobic lipolytic bacteria in mud from the Black Sea. They found one organism which reduced the iodine number of fats and produced unsaponifiable substances. STURM and ORLOVA (I937) isolated aerobic bacteria from Ala-Kule Lake in Russia which attacked fats and palmitic acid with the production of $\mathrm{CO}_{2}$ and other intermediate products.

ZoBeLL and UPHAM (I944) described I3 species of marine lipolytic bacteria. Pseudomonas enalia, Ps. felthami, Sarcina pelagia, Vibrio algosus, Serratia marinorubra, and Bacillus submarimus were especially active in attacking triglycerides.

The ability of the sulfate reducer to oxidize fats and olive oil was demonstrated by SELIBER (I928). More recent observations (BAARS, I930) suggest that various strains of sulfate reducers can be differentiated upon a basis of their ability to utilize various fatty acids. The marine strain commonly known as Desulfovibrio aestuarii utilizes most of the fatty acids ranging from acetic to stearic. Reports from microbiologists working under the auspices of the American Petroleum Institute at the Scripps Institution of Oceanography indicate that certain strains of $D$. aestuarii produce ceresin wax and other hydrocarbon-like substances from fatty acids (JANKOWSKI and ZoBELL, I944).

HEсHT (I934) buried the bodies of invertebrates, birds, and mammals in perforated celluloid boxes in different sedimentary environments and examined specimens for changes over a period of three years. Fats were found to be far more resistant to attack than proteins, and were still more slowly decomposed in a reducing environment.

Bacterial oxidation of hydrocarbons:- Petroleum consists primarily of hydrocarbons which are believed to have been formed in the sea, probably from the reduction of organic matter in anaerobic bottom deposits. There are many ways in which bacteria may be instrumental in the formation and accumulation of petroleum hydrocarbons. Bacteria also destroy hydrocarbons under certain conditions. Besides their relation to the petroleum problem, hydrocarbon-oxidizing bacteria play an important role in the carbon cycle. 
Many if not all plants including bacteria synthesize waxes and allied hydrocarbons to some extent. BAAS BECKING et al. (I927) found that 9.7 per cent of the organic matter of diatoms, mostly Aulacodiscus kitloni, was extractable by ether, and that 65.7 per cent of the ether extract was unsaponifiable. The unsaponifiable material consisted of hydrocarbons, with lesser amounts of phytosterol and related alcohols. TRASK (I939) reports 8 per cent as the average ether-extractive content of the organic matter in marine diatoms.

ClARKE and MAZUR (I94I) found that from 3 to I4 per cent of the ether extractives of marine diatoms consisted of hydrocarbons, part of which was identified as hentriacontane, $\mathrm{C}_{31} \mathrm{H}_{64}$. After six months incubation in the presence of mud-dwelling microorganisms there was a marked decrease in the organic acid content of diatoms and an increase in hydrocarbons. Hentriacontane occurs commonly in plant tissues, often in considerable abundance as in the candelilla plant, Euphorbia cerifera, for example. Literature on the occurrence of hydrocarbons in the tissues of terrestrial plants has been reviewed by SEYER (I933), CHIBNALL et al. (I934), and SANDERS (I937). Hydrocarbons also occur in animal tissues. Squalene, $\mathrm{C}_{30} \mathrm{H}_{50}$, found in large amounts in the livers of sharks, is a notable example.

In certain environments unfavorable for the activity of hydrocarbonoxidizing bacteria, hydrocarbons may accumulate in bottom deposits, but under other environmental conditions bacteria may oxidize hydrocarbons. According to ZoBell et al. (I943), species of Actinomyces, Micromonospora, Mycobacterium, Pseudomonas, and other genera, which attack aliphatic, aromatic, naphthenic, and olefinic hydrocarbons in the presence of free oxygen, are widely distributed in sea water and marine mud. In general, long chain hydrocarbons are attacked more readily than those of lower molecular weight, and aliphatic compounds are more susceptible to bacterial oxidation than are cyclic or aromatic compounds. Open-chain hydrocarbons having unsaturated bonds are attacked more readily than corresponding saturated compounds. Side-chains appear to be attacked preferentially. $\mathrm{CO}_{2}$, organic acids, bacterial protoplasm, and methane result from the action of bacteria upon complex hydrocarbons. There is some evidence that higher hydrocarbons are converted into simpler homologues besides methane.

Anaerobic sulfate reducers found by TAusson and Alioschina (I932) in lakes, rivers, limans, and the sea were able to utilize saturated aliphatic hydrocarbons containing ten or more carbon atoms per molecule. Naphthenic hydrocarbons were not attacked by sulfate reducers. Upon a basis of thermodynamic considerations, these workers concluded that heavy hydrocarbons may be converted into polymethylene compounds by sulfate reducers.

Desulfovibrio species of marine origin attack waxes and heavy oils with the formation of lighter hydrocarbons, according to NoveluI and ZoBelL (I944). Neither aliphatic hydrocarbons simpler than decane nor aromatic compounds were attacked. Decane was slowly utilized as a sole source of carbon. Tetradecane, cetane, and longer molecules were attacked anaerolsically, progressively more readily as the chain length of the hydrocarbon increased.

Micromonospora species isolated from Lake Mendota mud by ERIKSON (I94I) rapidly oxidized paraffin wax, paraffin oil, toluene, naphthalene, benzene, phenol, resorcinol, $\mathrm{m}$-cresol, and $\beta$-naphthol. From sediments 
of the Dead Sea, ElazARI-VolCANi (I943) obtained enrichment cultures in mineral media containing only kerosene or petroleum as the carbon source.

Rubber, both natural and synthetic, is another type of hydrocarbon which is attacked by microorganisms (ZoBELL and BECKWITH, I944). Although the decomposition of rubber in the sea is of little consequence in the carbon cycle, it is a problem of economic importance.

Marine humus:- There is evidence that more than 99 per cent of the organic matter produced in the sea undergoes complete decomposition or mineralization. The remaining fraction of one per cent is buried to become an integral part of old marine sediments. This fraction, which is highly resistant to decomposition, is known as humus. It consists of the residues of plants, animals, and bacteria which have been subjected to the enzymes of animals and bacteria in the marine environment. Some marine humus originates from terrigenous deposition, but in the open ocean pelagic organisms, primarily plankton, contribute most of the organic residues. Nearer shore, Zostera and sessile algae may be important sources of humus in bottom deposits (JENSEN, I9I 5).

The chemical composition of humus depends primarily upon the organic matter from which it was derived and the transformation of the organic matter during and after its deposition. The relative roles played by autolytic enzymes, animal digestion, and bacterial activity constitute an unsolved problem, but it is generally agreed that bacterial activity is of prime importance. WAKSMAN (I933) states that only a small part of the organic matter built up by marine plants passes through the animal body, and that the major portion is destroyed post mortem through direct bacterial action.

The quality and numbers of transformations caused by bacterial activities depends to a great extent upon the kinds of microorganisms present and the environmental conditions. For example, certain constituents of buried humus in bottom deposits which are relatively stable in an anaerobic environment may be subject to further decomposition by bacteria in the presence of free oxygen. The oxidation-reduction potential and the hydrogen-ion concentration are important factors which influence the state and composition of humus.

WAKSMAN (I933) finds that marine humus consists predominantly of a lignoprotein complex and a hemicellulose-protein complex. Uronic acid, ether-soluble extractives, and alcohol-soluble extractives were also found. The chemical composition as well as relative amounts of the different fractions vary in different mud samples.

Although humus is defined as being organic matter which is resistant to further decomposition by bacteria, there is evidence that humus is not absolutely resistant. Gradual decreases in the organic content of sediments with core depth show that over a period of thousands of years of burial the organic matter is undergoing gradual decomposition, a process which appears to be progressively slower with age.

WAKSMAN (1933) found that, in the presence of sufficient oxygen, marine humus undergoes a process of slow bacterial decomposition, as shown by the continuous liberation of $\mathrm{CO}_{2}$ and ammonia. He points out that humus imparts certain characteristic properties to the marine bottom, making it a more favorable medium for the growth of bacteria and animals. In summary, the composition and amounts of humus both affect and are affected by the activities of marine microflora and fauna. 
By allowing the oxidation of organic matter to proceed for $\mathrm{r}_{5}$ to 30 days, WAKSMAN and Hotchkiss (1937) found that 1.0 mgm. of organic matter in bottoms close to land consumed about o. $\mathrm{I} \mathrm{ml}$. of oxygen under the most favorable conditions. The organic matter in bottom deposits was oxidized to a lesser extent at greater depths than in shallower bottoms nearer to land. Most of these observations were confirmed and extended by ANDERSON (I940).

The activities of bacteria in producing and transforming humus in fresh-water lakes are outlined by WAKSMAN (I94Ia).

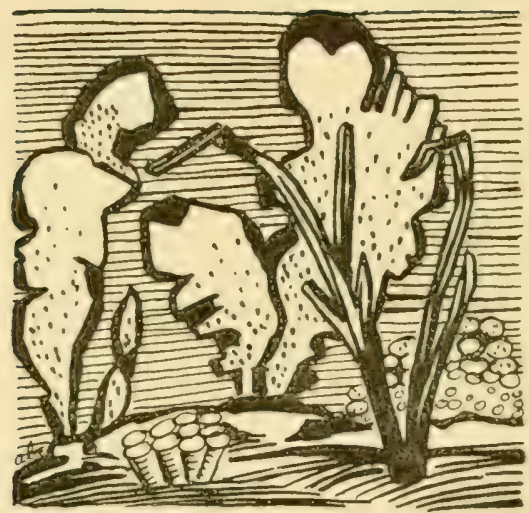




\section{Chapter XI}

\section{THE NITROGEN CYCLE IN THE SEA}

Considerable interest has centered around nitrogen compounds because available nitrogen often limits the productivity of the sea. The origin, mode of formation, and fate of ammonia, nitrite, and nitrate is a time-honored problem, many aspects of which remain unsolved. Some workers believe that most of the fixed nitrogen available for plant nutrition enters the ocean from the atmosphere or from land drainage, whereas others contend that available nitrogen is derived primarily from the decomposition and transformation of nitrogenous compounds in the sea. Only the microbiological aspects of the problem can be reviewed here.

Ammonia production:- Some ammonia is excreted by animals as a disintegration product of nitrogenous materials, but more ammonia is liberated from nitrogenous compounds undergoing bacterial decomposition. The ammonia may be utilized directly by phytoplankton (ZoBELL, I935) or it may be oxidized to nitrite or nitrate. SCHREIBER (I927) found that there was little to choose between ammonia, nitrate, nitrite, and glycine as sources of nitrogen for bacteria-free cultures of Carteria. BRAARUD and FöyN (I93I) noted that cultures of Chlamydomonas could use glycine, alanine, and asparagine, although amino acids were used less efficiently than either ammonia or nitrate. While amino acids may be utilized directly by certain plants, they are readily decomposed with the liberation of ammonia by bacteria.

There is ample evidence from the investigations of WAKSMAN and Renn (I936), Ostroff and Henry (I939), and others that most simple nitrogenous compounds and many complex ones are attacked by marine bacteria. If the nitrogen present exceeds the requirements of the bacteria, ammonia is usually liberated. However, if carbohydrates or other oxidizable non-nitrogenous carbon compounds are present in excess, the nitrogen from decomposing nitrogenous material may be converted directly into bacterial cell substance and thus not appear immediately as free ammonia (WAKSMAN and CAREY, r935 $b$; WAKSMAN and RENN, I936). In such circumstances, the nitrogen will be liberated as ammonia chiefly after the death and decomposition of the bacteria.

Under ordinary conditions, ammonia production accompanies the bacterial decomposition of marine organic matter. The increased bacterial activity which follows the storage of sea water in glass receptacles in the dark results in increased bacterial multiplication and ammonia production (Keys et al., I935; WAKSMAN and CAREY, I935 a ZOBELL and ANDERSON, I936a). Mixed net plankton suspended in sea water was found by VON BRAND et al. (I937) to be decomposed by bacteria in the dark with the evolution of ammonia. The rapid liberation of ammonia from copepods being decomposed by bacteria in sea water was observed by WAKSMAN et al. (I938).

The bacterial fermentation of urea is another important source of ammonia in the sea:

$$
\left(\mathrm{NH}_{2}\right)_{2} \mathrm{CO}+\mathrm{H}_{2} \mathrm{O}=2 \mathrm{NH}_{3}+\mathrm{CO}_{2}
$$


Urea-decomposing bacteria were found by BAVENDAMar (1932) to be widely distributed in water and mud around the Bahama Islands. He believed that the activities of such bacteria promote the precipitation of $\mathrm{CaCO}_{3}$ :

$$
\left(\mathrm{NH}_{2}\right)_{2} \mathrm{CO}+{ }_{2} \mathrm{H}_{2} \mathrm{O}+\mathrm{CaSO}_{4}=\mathrm{CaCO}_{3}+\left(\mathrm{NH}_{4}\right)_{2} \mathrm{SO}_{4}
$$

BERTEL (1935) attributed the high pH values in water immediately overlying the ooze to ammonia produced by urea-decomposing bacteria. RUBENTSCHIK (1925) found urea-decomposing bacteria in all samples taken from the Odessa limans.

Throughout the euphotic zone, which is populated by urea-excreting animals, ZoBELL and FELTHAM (I 935) found from I to Io urea-decomposing bacteria per $\mathrm{ml}$. of sea water. Surface mud, which is also populated by urea-excreting animals, was found to contain from to to rooo ureadecomposing bacteria per gram. Some of these bacteria obtain their nitrogen requirements from urea without decomposing any beyond their needs and others ferment urea with the liberation of excess ammonia. Bacteria in the latter category were able to liberate enough ammonia in sea water enriched with urea to cause a reaction as alkaline as $p \mathrm{H}$ 9.7.

Bacterial oxidation of ammonia:- CoOPER ( $1937 b$ ) points out that the oxidation of ammonia to nitrite is an exothermic reaction which is accompanied by a decrease in thermodynamic potential or free energy of 59,400 gram calories at $25^{\circ} \mathrm{C}$.:

$$
\mathrm{NH}_{4}{ }^{+}+\mathrm{OH}^{-}+3 / 2 \mathrm{O}_{2} \text { (gas) }=\mathrm{H}^{+}+\mathrm{NO}_{2}^{-}+2 \mathrm{H}_{2} \mathrm{O}+59,400 \text { cal. }
$$

This indicates that the reaction will proceed from left to right in the presence of an appropriate catalyst or activator. The energy of activation may be provided by photic, chemical, or biological agents.

A limited amount of photochemical oxidation of ammonia may occur in the topmost few centimeters of sea water but, owing to the rapid absorption of ultraviolet radiations, will be of no importance below a depth of one meter. Purely chemical catalysis of the reaction has not been demonstrated under conditions which exist in the sea. Therefore, it is generally believed that bacteria are primarily responsible for the oxidation of ammonia to nitrite in the sea.

Autotrophic organisms responsible for the oxidation of ammonia to nitrite, namely the Nitrosomonas, have been found in the sea by many investigators. However, failure to find them universally distributed in the sea, and failure to find specific marine Nitrosomonas species, leaves a large gap in our knowledge of the nitrogen cycle. Nitrification appears to be a much more common phenomenon in the sea than can be accounted for by the nitrifying bacteria which have been demonstrated. This discrepancy may be due to the inadequacy of the experimental methods which have been employed to demonstrate nitrifying bacteria.

Most investigators have employed the conventional media employed by soil microbiologists to demonstrate nitrifiers in the soil. Essentially, such media consist of physiologically balanced mineral salts solutions enriched with an ammonium salt and buffered with $\mathrm{CaCO}_{3}$ or $\mathrm{MgCO}_{3}$. Sea water serves as the mineral solution for marine nitrifiers.

VERNON (I898) demonstrated the presence of nitrifying bacteria in the Gulf of Naples. BRANDT (I902) found them in two out of three samples of mud from the Kiel inlet, but he was unable to demonstrate such bac- 
teria in samples of sea water. Using similar methods, GRAN (1903) obtained only negative results with samples of water and mud from Norwegian fjords, except very near shore. Similarly, Nathansohn (Igo6) was unable to demonstrate nitrifiers in the Gulf of Naples beyond the zone which was obviously contaminated by land drainage. GAzERT (I906b) was rarely able to demonstrate nitrifiers in from Io- to 80-ml. samples of sea water collected off the southern coast of Africa or in the Antarctic on the South Polar Expedition of the research vessel Gauss. Negative results were likewise obtained with sea weeds and diatom tows from the Sargasso Sea as well as off Kerguelen Island in the Indian Ocean.

IsSATCHENKo (I9I4) demonstrated the presence of nitrifying bacteria in coastal water of polar Arctic seas and in bottom deposits from off the Murmansk coast. He was unable to find nitrifiers in surface waters of the open ocean. However, he believed that nitrifiers were indigenous to deeper waters and the sea floor. Issatchenko (I926) detected no nitrifiers where $\mathrm{H}_{2} \mathrm{~S}$ was present in the Black Sea. In shallow water such bacteria were found in bottom deposits associated with sand and shells, but only infrequently in clay bottoms. KNIPOWITSCH (1926) reported the presence of nitrifying bacteria in surface water of the Black Sea and the Sea of Azov.

Nitrifying bacteria were demonstrated in all mud samples from Kiel harbor examined by Thomsen (I9IO). He also found them in mud from the Helgoland channel and the Gulf of Naples. Negative results were obtained with samples of sea water collected at considerable distances from land. Likewise THOMSEN found no nitrifiers associated with plankton or sessile algae. The nitrifiers which he isolated from marine mud samples were morphologically and physiologically identical with terrestrial $\mathrm{Ni}$ trosomonas. They grew well in sea water and could be acclimatized to higher or lower salt concentrations. They developed readily at $28^{\circ} \mathrm{C}$.

PIRIE (I9I2) found no nitrifiers while on the Scottish Antarctic Expedition. LIEBERT (I9I5) was unable to isolate nitrifying bacteria from water or bottom deposits of the open ocean. Mud from the North Sea also gave negative results except very near shore. Active nitrifiers were found in the Zuider Zee. BERKELEY's (I9r9) attempts to demonstrate nitrifiers in sea water from off the coast of Vancouver Island were uniformly negative.

After finding no evidence of nitrification in $25^{-}$to $150-\mathrm{ml}$. samples of sea water collected from around American Samoa and Tortugas, Florida, LIPMAN (I922) concluded that nitrifying bacteria were not present in the open sea. However, he obtained good nitrification in samples of bottom deposits from nearly all stations. Similar results were reported by HARVEY (I928).

From their rather extensive investigations, WAKSMAN et al. (r933b) concluded that, beyond the zone of land drainage, surface sea water has either no nitrifying bacteria or only very few. On the other hand, active populations of nitrifying organisms were found in bottom deposits.

Similar conclusions were reached by CAREY (I938) who has reviewed the literature on the occurrence of nitrifying bacteria in the sea. She found active nitrifiers in most samples of bottom deposits and in surface water samples collected near land. Water samples collected far from land, at depths ranging from to to 200 meters, gave negative results. Samples of mud from great depths produced nitrite very slowly and in exceedingly small amounts. Concentrated diatom tows, copepod tows, and 
dinoflagellate plankton from Woods Hole and Vineyard Sound gave rise to nitrite when inoculated into ammoniacal sea-water solutions. Copepod tows which CAREX collected off the Continental Shelf at a depth of roo meters gave rise to ammonia and traces of nitrite. She concluded that nitrifiers occur primarily in bottom deposits, and that, by vertical mixing of water, they may be brought into the plankton layer.

While there is hydrographic evidence that some ammonia and nitrite is produced on the sea floor, data accumulated in recent years suggest that most ammonification occurs in the surface layers of water. RAKESTRAw's (I936) studies on the occurrence of nitrite in the sea indicate that nitrification likewise is primarily a surface phenomenon confined largely to the topmost 200 meters of water. Since nitrifying bacteria are seldom found

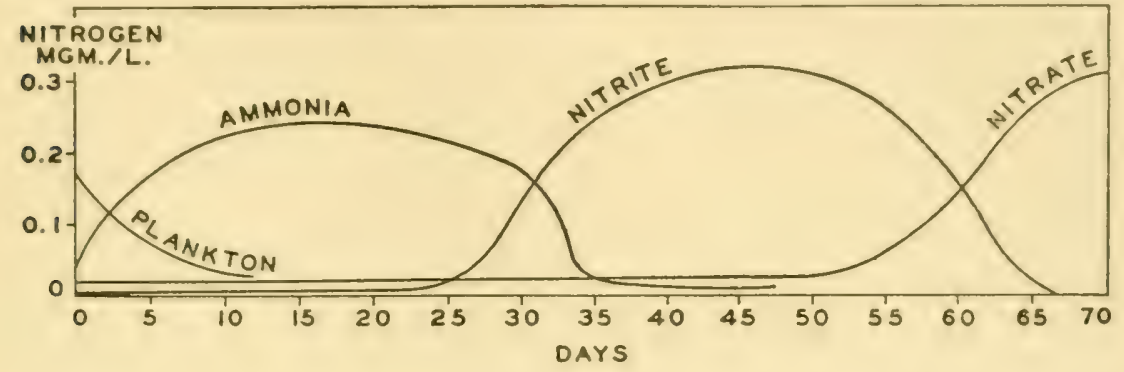

FIG. II. - Changes in the ammonia, nitrite, and nitrate content of sea water enriched with mixed marine plankton (from voN BRAND et al., 1937).

in the open ocean in the topmost 200 meters of water where most of the nitrite appears to be formed, the problem of nitrification in the sea must be regarded as unsolved in spite of the wealth of information on the subject. It is the present author's belief that, besides the soil-like nitrifier which has been commonly found in bottom deposits and near land, there are other marine nitrifying organisms which have escaped detection.

In their experiments on the formation of nitrite and nitrate from ammonia liberated from decomposing plankton (Fig. II), VON BRAND et al. (I937) were unable to isolate nitrifying bacteria. The nitrifiers found in marine materials by vON BRAND et al. (I942) were inhibited by temperatures as low as $5^{\circ} \mathrm{C}$. It will be recalled that over 80 per cent of the sea floor is colder than $5^{\circ} \mathrm{C}$. Although there are many shallow, welloxygenated marine bottoms where nitrifiers analogous to soil Nitrosomonas could be active according to modern concepts of their cultural requirements, in many bottoms where nitrifiers have been demonstrated, the low temperature, low oxygen tension, low oxidation-reduction potential, and relatively high organic content would be expected to retard or inhibit nitrification.

Nitrifying bacteria indistinguishable from the specialized nitriteforming flora of soils are commonly found in fresh-water lakes. Such bacteria were found in mud from Lake Mendota by WrLliAMs and McCoY (I935).

Oxidation of nitrite to nitrate:-According to COOPER (I937b), the oxidation of nitrite to nitrate is accompanied by a decrease of free energy, $\Delta \mathrm{F}^{\circ}{ }_{298}$, of $\mathrm{I} 8,000$ gram calories. Like the oxidation of ammonia, therefore, the reaction requires only activation:

$$
\mathrm{NO}_{2}{ }^{-}+\mathrm{r} / 2 \mathrm{O}_{2} \text { (gas) }=\mathrm{NO}_{3}{ }^{-}+18,000 \mathrm{cal} \text {. }
$$


Suitably equipped bacteria may oxidize nitrite to nitrate as a direct source of energy. Nitrobacter species in the soil are endowed with this ability. Nitrobacter-like organisms have been demonstrated in the sea.

Nitrate-forming bacteria are somewhat more difficult to demonstrate than nitrite-forming bacteria (WAKSMAN et $a l$., I933b). Therefore it is not surprising that nitrate formers have been demonstrated in the sea only infrequently and that the status of our knowledge of them is very fragmentary. Most of the investigators, whose observations on nitrifiers are summarized in the preceding section, looked for nitrate formers as well as nitrite formers, usually with little success. Nitrate-forming organisms have been found near shore and in shallow bottom deposits, but only rarely in the open sea.

CAREY (I938) reports that nitrate production was slower than nitrite production in special media inoculated with various marine materials. In most deep-sea mud cores and plankton tows, no nitrate formers were found, although nitrite formers were usually present. Nitrate formation was observed to follow the formation of ammonia and nitrite in the experiments on the decomposition of marine plankton of VON BRAND et al. (I937), as illustrated by Figure I I on page I53. Attempts to isolate the organisms responsible for nitrate formation were unsuccessful.

Although, in the light of circumstantial evidence, it is tacitly assumed by many oceanographers that nitrate is formed by bacteria at the bottom of the sea, and thence carried into the photosynthetic zone, there is no conclusive evidence bearing on either the mode or place of formation of nitrate in the sea. The problem is complicated by the dynamic nature of the marine environment. In the photosynthetic zone, nitrate may be utilized by plants as fast as it is produced, thereby precluding its accumulation. Elsewhere in the sea, nitrate may be reduced by bacteria.

Reduction of nitrate and nitrite:- The reduction of nitrate or nitrite is an endothermic reaction and therefore is thermodynamically possible only when the required energy is forthcoming from an accompanying exothermic reaction. The sea abounds in bacteria which can obtain the necessary energy for the reduction of nitrate or nitrite from the oxidation of organic matter. However, inasmuch as there is relatively little readily available organic matter in the sea, the extent to which nitrate or nitrite may be reduced is highly problematical. Denitrifiers resembling Thiobacillus denitrificans, which obtains energy for the reduction of nitrate by oxidizing sulfur, have been found in coastal waters by various workers, but evidence of their activity in marine environments is lacking.

Most of the pioneer workers including RUSSELL (I893), FischeR (I894a), VERNON (I898), GAZERT (I906b), and GRÄF (I909) demonstrated the presence in the sea of bacteria capable of reducing nitrate. Impetus was given to investigations by the hypothesis, advanced by BRANDT (I899), that the activity of denitrifying bacteria, or those which reduce nitrate to free nitrogen, destroy nitrate in tropical seas and hence prevent maximum phytoplankton growth. After finding that only near shore, where the organic and nitrate content of the water may be high, is there evidence of denitrification in the sea, GRAN (IgOI) concluded that BRANDT's hypothesis is untenable. The extensive literature on this controversial subject has been reviewed by WAKSMAN et $a l$. (1933b) and BENECKE (I933).

Although he continued to defend his hypothesis for a quarter of a cen- 
tury, BRANDT (I929) finally retracted part of it by attributing the lack of nitrate in surface tropical waters to thermal stratification. However, he maintained that denitrifying bacteria destroy the surplus nitrogen compounds in the ocean, thereby providing the balance in Nature. From their own observations WAKSMAN et al. (I933b) concluded that, although denitrifying bacteria are present in the sea, the activities of such bacteria are so limited under marine conditions as to render them in most instances of little importance in limiting the nitrate supply of the sea. Lack of an available energy source was found to be the chief limiting factor.

The problem of bacterial denitrification in the sea was attacked with renewed vigor after DREW (IOII) credited marine denitrifiers with the ability to promote the precipitation of $\mathrm{CaCO}_{3}$ in tropical seas (page Ioo). According to Bavendam (I932), DRew's (I9I2) Bacterium (Pseudomonas) calcis is closely related to Bact. bauri, Bact. granii, and Bact. feiteli, denitrifiers which PARLANDT (I9II) isolated from the Baltic Sea. It is also related to Bact. balticum and Bact. ornatum, marine denitrifiers studied by FeITEL (IgO3), and to Bact. russelli and Bacl. brandti, marine denitrifiers described by IsSATCHENKo and Rostowzew (IgII). Other marine denitrifiers named as new species include Bact. triviale, Bact. repens, and Bact. henseni isolated by GRAN (I9OI), Bact. actinopelte and Bact. lobatum isolated by BAUR (I9O2), and Bact. helgolanicum isolated by NADSON (1903). Unfortunately none of these denitrifiers is completely described in the available literature.

Molisch (1925) described Pseudomonas calciprecipitans and KaLANTARIAN and PETROSSIAN (I932) described Flavobacterium sewanense, both of which were believed to be marine denitrifiers capable of promoting the precipitation of $\mathrm{CaCO}_{3}$. LLOYD (I93I $b$ ) discussed the mechanism of denitrification and described $B$. (Vibrio) costatus which she isolated from the sea.

About half of the bacteria found in the sea are capable of reducing nitrate to nitrite in sea water enriched with organic matter and nitrate. Thirty-four of the sixty species of marine bacteria studied by ZoBELL and UPHAM (I944) reduced nitrate to nitrite in enrichment media. Most of their Bacillus species, Achromobacter stenohalis, Pseudomonas hypothermis, Ps. aestumarina, Ps. marinopersica, Serratia pelagia, Vibrio hyphalus, and $V$. marinagilis are examples of extremely active nitrate reducers. Pseudomonas azotogena and Ps. perfectomarimus are the only organisms among the sixty species described by ZOBELL and UPHAM which reduced nitrate to free nitrogen.

Although denitrifiers are widely distributed in the sea, particularly in bottom deposits, it is estimated from the aforementioned pure-culture studies, as well as from ecological surveys, that fewer than five per cent of the bacterial species in the sea are endowed with the ability to liberate free nitrogen from nitrate or nitrite in the presence of an abundance of organic matter. Except in certain highly localized environments, there appears to be insufficient organic matter in the sea to provide for the activity of denitrifiers.

GRAN (I $90 \mathrm{I}$ ) classified marine bacteria in four categories according to their action on nitrate and nitrite: ( $I)$ Both nitrate and nitrite reduced to nitrogen, (2) Nitrate reduced to nitrite and ammonia, (3) Nitrite but not nitrate reduced, and (4) Neither nitrate nor nitrite reduced. Several other types of nitrate- and nitrite-reducing bacteria are now recognized. Throughout the foregoing discussion the term denitrification is applied exclusively to the liberation of free nitrogen. 
Nitrogen fixation:- BENECKE (I933) relates that KEUTNER was the first to make an extensive search for nitrogen-fixing bacteria in the sea, this being the subject of his doctorate dissertation at Kiel University. Species of the aerobic nitrogen fixer, Azotobacter chroococcum, and also the anaerobic Clostridium pastorianum were found (BENECKE and KEUTNER, I903). Azotobacter occurred primarily associated with the surface slime of algae, and $\mathrm{Cl}$. pastorianum occurred chiefly in bottom water and ooze. After finding both types of nitrogen-fixers in the Baltic Sea, the North Sea, off the African coast, and in the Malay Archipelago, KeUtNer (I905) concluded that nitrogen-fixing bacteria are normal inhabitants of the sea. Azotobacter chroococcum was found to tolerate up to 8 per cent $\mathrm{NaCl}$.

REINKe (I903), believed Azotobacter to occur as an epiphyte on phytoplankton and larger marine algae, symbiotically obtaining utilizable organic matter therefrom while furnishing fixed nitrogen in return. Several other investigators have noted the occurrence of $A$ zotobacter on marine as well as fresh-water algae, but a definite symbiotic relationship has never been established.

FISCHER (I904) demonstrated that nitrogen fixers may obtain their energy from the hydrolytic products of agar liquefiers. This observation was confirmed by the PRINGSHEIM brothers (I9IO) who inoculated nitrogen-free agar media with cultures of Pseudomonas gelatica and Clostridium pastorianum (also known as Bacillus amylobacter). Good growth of both organisms occurred. Presumably Ps. gelatica broke the agar down into substances which $\mathrm{Cl}$. pastorianum could utilize.

The strains of Azotobacter, which KEDING (I906) found on the surface slime of algae near shore, appeared to be identical with those found in soil. The strains of Azotobacter and Clostridium, which IsSATCHENKo (I 9 I 4, I926) found associated with marine algae, required enough salt for their development to lead him to believe that these nitrogen fixers were specifically adapted to sea water.

According to KORINEK (I932), there are species in the ocean which closely resemble Azotobacter morphologically, but they do not assimilate free nitrogen. He found that Azotobacter chroococcum grew only poorly in sea-water media. He admits that there may be marine strains of Azotobacter which fix nitrogen but he failed to find one. Lloyd (I930) likewise regarded the existence of active marine nitrogen-fixing bacteria as problematical.

Azotobacter cells were only occasionally found by BAVENDAMM (I932) in enrichment cultures of calcareous mud from around the Bahama Islands. $\mathrm{Cl}$. pastoriamum was generally present.

The occurrence in the sea of an abundant population of nitrogenfixing Azotobacter and Clostridium is reported by WAKSMAN et al. (I933b). In the presence of a favorable source of energy, the bacteria were capable of fixing appreciable quantities of nitrogen. However, the extent to which such a process actually takes place in the sea remains to be determined. VON BRAND et al. (I942) concluded that except for the sporadic presence of nitrogen-fixing bacteria, there is no evidence of nitrogen fixation in the sea.

Nitrogen fixation is an endothermic reaction which requires considerable energy. Nitrogen-fixing bacteria obtain this energy from the oxidation of organic matter. Only in the presence of readily available organic matter, therefore, can nitrogen fixers be expected to be functional. With- 
out enrichment with organic matter, filtered sea water does not support the growth of nitrogen-fixing bacteria.

There are numerous accounts of the occurrence of both acrobic and anaerobic nitrogen-fixing bacteria in fresh-water lakes, but whether they are indigenous species which are functional in lakes or are adventitious forms from the soil is another unsolved problem.

It has been definitely established that some species of blue-green algae fix atmospheric nitrogen. Pure cultures of Nostoc punctiforme and Anabaena variabilis isolated by Drewes ( 1928 ) fixed 2 to $3 \mathrm{mgm}$. of nitrogen in 50 days in $250 \mathrm{ml}$. of medium. AlLISON et al. (1937) worked with pure cultures of Nostoc muscormm which fixed as much as $18 \mathrm{mgm}$. of nitrogen per $100 \mathrm{ml}$. of medium in 85 days. In discussing the role of algae in the nitrogen cycle of soil, STOKES (I940) relates that DE demonstrated the ability of Anabaena variabilis, $A$. gelatinosa, and $A$. naviculoides to fix nitrogen. The ability of these blue-green algae from the soil to fix nitrogen suggests the possible importance of algae as nitrogen fixers in the sea.

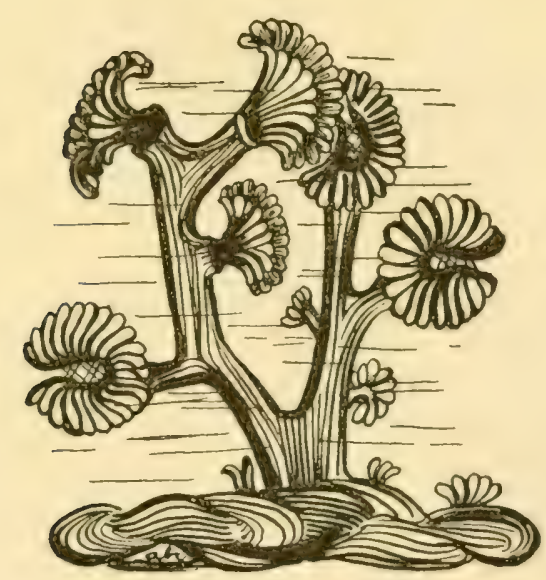




\section{Chapter XII}

\section{BACTERIA WHICH TRANSFORM SULFUR COMPOUNDS}

Sulfur is essential for the growth of plants and is utilized partly as sulfate by most of them. Animals obtain their sulfur requirements largely from plants, other animals, or bacteria. Sulfur is liberated by bacteria, almost exclusively as hydrogen sulfide, from the remains of animals and plants. Specialized bacteria oxidize $\mathrm{H}_{2} \mathrm{~S}$ to elementary sulfur, sulfate, or intermediate compounds of sulfur. Elementary sulfur, thiosulfate, tetrathionate, and other compounds intermediate between sulfur and sulfate may be oxidized by bacteria. Under certain conditions sulfate may be reduced to elementary sulfur or $\mathrm{H}_{2} \mathrm{~S}$ by bacteria. Sulfite, thiosulfate, and other sulfur compounds likewise may be reduced by bacteria and allied microorganisms.

Besides their manifold effects on the sulfur cycle, bacteria which transform sulfur or its compounds may influence the $p \mathrm{H}, \mathrm{E}_{\mathrm{h}}$, color, carbonate content, oxygen tension, and other properties of water or bottom deposits. Bacteria concerned with the sulfur cycle in the sea may render water or mud uninhabitable by other organisms or, on the other hand, they may be growth promoting. Sedimentary sulfur desposits have been ascribed to the activities of sulfate-reducing and sulfur-depositing bacteria. The importance of bacterial activities in the sulfur cycle in marine sediments is outlined by GALLIHER (I933).

Liberation of sulfur from organic compounds:- Most organic sulfur occurs in cystine, cysteine, methionine, or other sulfhydryl amino acids. Lesser quantities are bound in the form of sulfatides, organic sulfates, sulfonates, sulfureted glucosides, etc. The liberation of sulfur from albuminous material is a process which is more or less incidental to its decomposition. While all bacteria are not able to liberate $\mathrm{H}_{2} \mathrm{~S}$ from sulfurcontaining organic matter, those which are endowed with this ability are so widespread in the sea that, except for special compounds, this process can be regarded as universal and non-specific.

In bottom deposits from the Clyde Sea, ElLIS (I932) demonstrated from 10,000 to $3,000,000$ saprophytes per gram, nine-tenths of which liberated $\mathrm{H}_{2} \mathrm{~S}$ from albuminous material. ZoBELL (I938a) found from I0,000 to $\mathrm{I}, 000,000 \mathrm{H}_{2} \mathrm{~S}$-producing bacteria per gram of bottom sediments from the Pacific Ocean off the coast of California.

The bacterial decomposition of animal and plant remains generally results in the liberation of $\mathrm{H}_{2} \mathrm{~S}$. Abundant aeration seems to induce many bacteria, active in the decomposition of proteins, to transform sulfhydryl sulfur directly to sulfate instead of $\mathrm{H}_{2} \mathrm{~S}$. Such bacteria probably produce $\mathrm{H}_{2} \mathrm{~S}$, but under favorable conditions the latter is abiogenically oxidized as fast as it is liberated from the decomposing protein. Under anaerobic conditions organic sulfur is converted almost quantitatively into $\mathrm{H}_{2} \mathrm{~S}$ by raw cultures of saprophytic bacteria. Traces of mercaptans may be produced (BuNKER, I936). 
Little is known concerning the bacterial decomposition of organic sulfates, sulfonates, and related compounds. Under aerobic conditions the sulfur is probably liberated as sulfite or sulfate.

Sulfate reduction:- Bacteria which reduce sulfate are abundantly and widely distributed in the sea. ZoBell ( $1938 a$ ) demonstrated from I000 to 10,000 sulfate reducers per gram of marine mud. RITTENBERG (I94I) found sulfate reducers in each of several hundred samples collected at various stations off the coast of California and in the Gulf of California. They were found at all water depths and core depths from which samples were taken. Sulfate reducers were only rarely present in sea water except near the bottom.

Although earlier workers had postulated that the bacterial reduction of sulfate is responsible for the accumulation of sulfide in marine bottoms, ZELINSKI ( 1893 ) was the first to claim the isolation of sulfate-reducing bacteria. From Black Sea mud he isolated organisms which he designated Vibrio hydrosulfureus and Bacterium hydrosulfureum ponticum which reduced sulfate, sulfite, and thiosulfate to $\mathrm{H}_{2} \mathrm{~S}$. His descriptions of the organisms suggest that he was working with mixed cultures. Actually it is rather difficult to obtain pure cultures of sulfate reducers.

BEIJERINCK (I895) carefully described Spirillum desulfuricans, a sulfate reducer which he isolated from Delft ditch water. He predicted the absence or paucity of sulfate in the deeper layers of soil in Holland due to the activity of the sulfate reducer. A similar organism named Spirillum aestuarii was isolated from North Sea coast water and mud by VAN DELDEN (I904). Sp. aestuarii required sea water or 3 per cent $\mathrm{NaCl}$ for its growth, whereas $S p$. desulfuricans was not active in 3 per cent $\mathrm{NaCl}$ media.

After finding that these two organisms, as well as ElIoN's Spirillum thermodesulfuricans, could be acclimatized to tolerate different salinities and temperatures, BAARS (I930) regarded all three organisms as strains of a single species which he called Vibrio desulfuricans. However, RitTenBERG (I94I) was unable to adapt the strain which he isolated from the sea to grow in fresh water or to grow at temperatures exceeding $40^{\circ}$ to $45^{\circ} \mathrm{C}$. (The optimum temperature for growth of $S p$. thermodesulfuricans is $55^{\circ}$ C.). Likewise the marine sulfate reducer could not be induced to form spores, unlike the organism studied by STARKEY (I938), and no sporogenous marine sulfate reducers have been found.

STARKEY (r938) isolated a sporogenous sulfate reducer from soil which was indistinguishable from Vibrio desulfuricans. He induced an asporogenous strain of the latter to form spores and acclimatized it to grow at from $50^{\circ}$ to $55^{\circ} \mathrm{C}$., whereupon he proposed Sporovibrio as the generic name of the sulfate reducers. In the absence of adequate confirmation of STARKEY's observation and since spore formation does not seem to be a primary or constant characteristic of sulfate reducers, the generic name Desulfovibrio is provisionally applied to previously described species of sulfate reducers in the sixth edition of the BERGEY (I946) Manual. Unquestionably there are sporogenous sulfate reducers, but it has not been established that all sulfate reducers form spores.

The absence of free oxygen, the presence of sulfate, and the presence of organic matter are the chief requirements for the activity of sulfate-reducing bacteria. Apparently there are strains which utilize nearly any kind of organic matter including proteins, sugars, starches, hydrocarbons, fats, 
and fatty acids. Besides playing the key role in the sulfur cycle in the sea, sulfate reducers play an important role in the transformation of organic matter. At least certain strains can utilize elementary hydrogen (see page I09). In marine bottoms the hydrogen for this reaction probably results from the anaerobic decomposition of organic matter. ISSATCHENKO (I9I4) noted the widespread occurrence of Desulfovibrio aestuarii in Arctic Sea bottoms where he believed it was an important biochemical agent.

The ability of sulfate reducers to produce (JANKOWSKI and ZOBELL, I944) and transform hydrocarbons (TAUSSON and ALIOSCHINA, I932), the almost universal presence of such bacteria in marine sediments both recent and ancient (BASTIN, I926), their ability to function over a wide range of environmental conditions, and the decreased sulfate content of oil-well brines strongly suggest that sulfate-reducing bacteria are intimately associated with petroleum genesis. Such bacteria are credited with being responsible for the formation of sulfur of the gypsum type (page I12). The effect of sulfate reducers on iron corrosion is discussed by STARKEY and WIGHT (I943).

BAVENDAMM (I932) noted the presence of large numbers of sulfate reducers in calcareous mud around the Bahama Islands where he believed they were instrumental in the precipitation of $\mathrm{CaCO}_{3}$ under certain conditions:

$$
\mathrm{CaSO}_{4}+8 \mathrm{H}+\mathrm{CO}_{2}=\mathrm{CaCO}_{3}+{ }_{3} \mathrm{H}_{2} \mathrm{O}+\mathrm{H}_{2} \mathrm{~S}
$$

In this reaction, organic matter serves as the hydrogen donor. BAVENDAMM failed to take into account the acid that may result from the oxidation of the organic matter, and that $\mathrm{H}_{2} \mathrm{~S}$ itself is weakly acidic.

The activities of sulfate-reducing bacteria are largely responsible for the occurrence of $\mathrm{H}_{2} \mathrm{~S}$ in stagnant bodies of water. The Black Sea is a classical example of a large body of water in which few if any forms of life except bacterial are possible at depths exceeding a few hundred meters owing to the high concentration of $\mathrm{H}_{2} \mathrm{~S}$. Free oxygen is absent at depths exceeding 200 meters (SVERDRUP et al., I942). ISSATCHENKo (I924) found vigorous sulfate-reducing bacteria in bottom samples from the Black Sea, as did Ravich-Sherbo (r930). Similar conditions occur in Norwegian fjords (StrфM, I939), the Caspian Sea (Butkevich, I938), mud lakes or limans of Odessa (BUNKER, I936), Lake Ritom in Switzerland (DÜGGELI, I924), and many other bodies of water, both salt and fresh, having poor vertical circulation.

COPENHAGEN (I934) described an area approximately 25 by 200 miles in the Atlantic Ocean off Walvis Bay, South Africa, where $\mathrm{H}_{2} \mathrm{~S}$ is periodically liberated from bottom mud in quantities sufficient to be lethal to flora and fauna in the overlying water. Sulfate-reducing bacteria were isolated from the black mud. Incidentally, the mud contained no carbonate, thereby suggesting that in this area sulfate reduction promotes the dissolution rather than the precipitation of $\mathrm{CaCO}_{3}$. The black mud was rich in ferrous sulfide.

BUNKER (I936) attributed the blackening of mud and sand in certain marine and lacustrine localities entirely to the action of sulfate-reducing bacteria. According to Bunker, IsSATCHENko has reported the seasonal production of $\mathrm{H}_{2} \mathrm{~S}$ in the Sea of Azov in sufficient intensity to destroy large numbers of fish and other aquatic animals.

Whether sulfate reduction is a property of only one specific group of bacteria or whether there are several types of organisms endowed with 
this ability is an unsolved problem. Certainly most microorganisms are capable of obtaining their sulfur requirements from sulfate by a process which BEIJERINCK (1895) called "non-specific" sulfate reduction. For such organisms, however, sulfate reduction is not an essential part of their oxidative metabolism as it appears to be for the Desulfovibrio.

Desulfovibrio aestuarii can utilize not only sulfate, but also sulfite, thiosulfate, and sulfur as hydrogen acceptors. Ordinarily $\mathrm{H}_{2} \mathrm{~S}$ is the chief end product, although there is evidence that sulfur may accumulate under certain conditions. Many marine microorganisms are able to reduce sulfite and thiosulfate to $\mathrm{H}_{2} \mathrm{~S}$.

The oxidation of sulfur compounds:- Sulfur bacteria probably depend largely upon the activities of sulfate-reducing bacteria for $\mathrm{H}_{2} \mathrm{~S}$, thiosulfate, and other sulfur compounds which they oxidize. Several physiological types of bacteria, including both autotrophs and saprophytes, which oxidize sulfur or its compounds, occur in the sea. Some of the autotrophs obtain their energy chemosynthetically from the oxidation of $\mathrm{H}_{2} \mathrm{~S}$, sulfur, thiosulfate, or tetrathionate, and some use photic energy.

The photosynthetic autotrophs can oxidize $\mathrm{H}_{2} \mathrm{~S}$ in an anaerobic environment, whereas most of the chemosynthetic autotrophs are strict aerobes or microaerophiles. This greatly restricts the localities in which sulfur bacteria can be functional in the sea. The penetration of sunlight is limited to the topmost hundred or so meters of water, and light penetrates bottom deposits to a negligible extent. The presence of $\mathrm{H}_{2} \mathrm{~S}$ in acrobic environments is limited largely to localities where it is being continuously produced. Several physiological types of sulfur bacteria occur in shallow water where these conditions persist. Such conditions may also occur in growth zones or lamina at greater depths, where $\mathrm{H}_{2} \mathrm{~S}$ from below diffuses upward into overlying oxygenated waters. Such lamina have been reported in the Black Sea, Caspian Sea, Lake Ritom, and elsewhere. The question of the bacterial activity in this thin layer or lamina in the Black Sea is elaborated by RAvich-Sherbo (I930). The term "bacterial plate" or "bacterial fountain" has been applied to localized laminae (ELLIS, I932).

The phylogenetic position of the recognized genera of sulfur-oxidizing bacteria is outlined in Table XXXIV on page I24. They can be grouped for the convenience of this discussion into the following categories according to their pigmentation and sulfur metabolism:

I. Achromic sulfur bacteria, which have neither bacteriopurpurin nor bacterioverdin and consist of $(a)$ the Thiobacillus group, species of which oxidize various sulfur compounds, usually to sulfate, although sulfur may be deposited extracellularly and (b) Leucothiobacteria belonging to genera of Achromatiaceae and Beggiatoaceae, which deposit sulfur intracellularly.

II. Purple sulfur bacteria, or Rhodothiobacteria, which contain bacteriopurpurin and consist of $(a)$ the Thiorhodaceae or Chromotioidaceae, the cells of which contain sulfur granules and $(b)$ the Athiorhodaceae or Rhodobacterioidaceae, which do not deposit sulfur intracellularly. The green sulfur bacteria, or Chlorobacteria, are generally considered in this category, although they contain bacteriochlorin instead of bacteriopurpurin.

The foregoing is not proposed as a new system of classification. It is a hybrid system designed only to expedite the discussion of bacteria which 
oxidize sulfur or its compounds in the sea. In order to facilitate an understanding of the confusing terminology in the literature, an attempt is made to combine the essential features of various classifications proposed by Winogradsky, Molisch, Orla-Jensen, Buchanan, Bavendamm, Ellis, VAN NIEL, and others.

Achromic sulfur bacteria:- Bacteria of the Thiobacillus group oxidize sulfide, elementary sulfur, thiosulfate, or tetrathionate. Some of those which oxidize $\mathrm{H}_{2} \mathrm{~S}$ or other sulfides often deposit sulfur extracellularly, although sulfate is generally the end product of their oxidative metabolism. Several strains of Thiobacillus have been found in water.

Nathansohn (I902) isolated Thiobacillus thioparus from sea water. It grew in sea water enriched with either potassium sulfide or sodium thiosulfate without a source of organic carbon. A little organic matter did not inhibit its development. It failed to grow in the absence of $\mathrm{CO}_{2}$ and carbonate. In the presence of an abundance of sulfide, the latter was oxidized to sulfur and deposited extracellularly. Though able to oxidize elementary sulfur, it prefers sulfide, thiosulfate, or tetrathionate. The form of sulfur oxidized and the end products of oxidation depend upon the concentration of reactants and certain environmental conditions including the $p \mathrm{H}$ and $\mathrm{E}_{\mathrm{h}}$. Thiobacillus thioparus appears to be widely distributed in coastal waters, marine mud, fresh water, and soil (BUNKER, I936).

BEIJERINCK (I904), who found Thiobacillus thioparus in the sea off the Dutch coast, reported that it oxidizes thiosulfate to sulfate and desposits sulfur:

$$
{ }_{2} \mathrm{~S}_{2} \mathrm{O}_{3}^{--}+\mathrm{O}_{2}={ }_{2} \mathrm{SO}_{4}^{--}+2 \mathrm{~S}
$$

Tetrathionate was oxidized less readily to sulfate and free sulfur:

$$
\mathrm{S}_{4} \mathrm{O}_{6}^{--}+\mathrm{O}_{2}={ }_{2} \mathrm{SO}_{4}^{--}+{ }_{2} \mathrm{~S}
$$

RAvich-SHERBo (I930) ascribed the absence of $\mathrm{H}_{2} \mathrm{~S}$ in certain zones in the Black Sea to the activities of Thiobacillus thioparus:

$$
{ }_{2} \mathrm{H}_{2} \mathrm{~S}+{ }_{5} \mathrm{O}_{2}={ }_{2} \mathrm{SO}_{4}^{--}+2 \mathrm{H}_{2} \mathrm{O}
$$

Large numbers of Thiobacillus thioparus were noted in poorly oxygenated laminae or zones of the Black Sea which received $\mathrm{H}_{2} \mathrm{~S}$ produced by sulfate-reducing bacteria.

Thiobacillus denitrificans is often found in mud, water, and soil. IsSATCHENKo (I9I4) noted its occurrence in Arctic Seas along the Murman coast of northern Russia. It is an anaerobe which utilizes nitrate as hydrogen acceptor while oxidizing sulfide or elementary sulfur:

$$
5 \mathrm{H}_{2} \mathrm{~S}+{ }_{2} \mathrm{HNO}_{3}={ }_{5} \mathrm{~S}+\mathrm{N}_{2}+6 \mathrm{H}_{2} \mathrm{O}
$$

Thiobacillus thiooxidans oxidizes elementary sulfur to sulfate:

$$
\mathrm{S}+{ }_{2} \mathrm{O}_{2}=\mathrm{SO}_{4}^{--}
$$

Conditions in the sea do not seem to be conducive to the growth of this organism, although SASLAWSKY (1927) isolated obligately halophilic strains from Russian mud lakes.

According to ELLIS (I932), Thiobacillus thiogenes (Molisch) and Thiobacillus bovista (Molisch) are exclusively marine species. The latter probably belongs to another genus, since its cells contain sulfur granules.

The Achromatiaceae and Beggiatoaceae have been called Leucothio- 
bacteria because they contain sulfur granules and no photosynthetic pigments. Mass cultures often appear white owing to the formation of sulfur. According to ELLIS (I932), the Leucothiobacteria includes all of the colorless sulfur bacteria. He does not regard the Thiobacillus group as "sulfur bacteria" because, unlike the Achromatiaceac and Beggiatoaceae, they do not store sulfur in their cells. Some workers, on the other hand, employ the term "sulfur bacteria" to embrace all classes of bacteria which either oxidize or reduce sulfur or its inorganic compounds, including sulfate reducers and all colorless forms which oxidize sulfur or its compounds, as well as the purple sulfur bacteria, regardless of whether the cells have sulfur granules or not.

There are several marine representatives of the Achromatiaceae and Beggiatoaceae. In fact, most known species grow equally well in salt water and fresh water. They, along with purple sulfur bacteria, are abundant in shallow water where $\mathrm{H}_{2} \mathrm{~S}$ is being produced, particularly in pools among rocks where seaweed is undergoing decomposition.

Achromatium oxaliferum occurs in sea water as well as in fresh water, according to BAVENDAMM (I924) and ElLIS (I932). It oxidizes $\mathrm{H}_{2} \mathrm{~S}$ to sulfur which may be desposited intracellularly along with calcium oxalate granules:

$$
2 \mathrm{H}_{2} \mathrm{~S}+\mathrm{O}_{2}=2 \mathrm{H}_{2} \mathrm{O}+2 \mathrm{~S}
$$

Bavendami also found Achromatium gigas in brackish water. Achromatium miilleri was isolated from sea water off the Danish coast by WARMING (I876).

HINZE (r903) discovered Thiophysa volutans in fine sand in the Gulf of Naples. It oxidizes $\mathrm{H}_{2} \mathrm{~S}$ to free sulfur or sulfate. At low oxygen tensions, cells contain sulfur granules but in the presence of an excess of oxygen, the sulfide is oxidized to sulfate. ELLIS (I932) claims that Thiophysa volutans is confined to marine waters.

Molisch (I9I2) found Thiospira bipunctata growing in the sea. It oxidizes $\mathrm{H}_{2} \mathrm{~S}$ and deposits sulfur granules intracellularly. MoLISCI also found Beggiatoa marina associated with rotting marine algae. The latter, like other species of Beggiatoa, is a filamentous form showing undulatory creeping. It oxidizes $\mathrm{H}_{2} \mathrm{~S}$ to sulfur which is deposited as intracellular granules.

Beggiatoa mirabilis was isolated from sea water by COHN (I865). WARMING (1875) found Beggiatoa minima in the sea. The last two named species, together with Beggiatoa arachnoides, Beggiatoa alba, and Beggiatoa leptomitiformis, were identified in calcareous mud off the Bahama Islands by BAVENDAMM (I932). The occurrence of Beggiatoa species in the sea has been reported by many workers (BAVENDAMM, I924).

Thiothrix anmulata and Thiothrix marina, whose cells contain sulfur granules, were isolated from rotting algae in sea water by MoLIscir ( I 9 I 2). He likewise found Thiothrix nivea and Thiothrix temuis in Trieste harbor sea water and in the Baltic Sea. BAvendamm (I924) and Ellis (I932) have reported the presence of Thiothrix species in the sea.

According to BERGEY et al. (I939), the ocean floor is the habitat of Thioploca schmedlei, a colorless Beggiatoa-like organism which deposits sulfur granules in the cell. BAVENDAMM (1932) expressed surprise at not finding species of Thioploca in calcareous mud around the Bahama Islands. ElLIS (1932) records that Thioploca schmedlei and Thioploca ingrica live in the sea. 
Purple sulfur bacteria:- The purple sulfur bacteria, or Rhodothiobacteria, contain bacteriopurpurin, a photosynthetic pigment. They can utilize radiant energy under suitable conditions, but not all species require sunlight for their activities. Most of them grow best in the presence of $\mathrm{H}_{2} \mathrm{~S}$. Some of the saprophytic and photosynthetic strains live anaerobically, but a little free oxygen is required by the autotrophic strains which obtain their energy from the oxidation of $\mathrm{H}_{2} \mathrm{~S}$.

The purple sulfur bacteria are classified into two categories upon a basis of the deposition of sulfur. The Thiorhodaceae embracing the genera of the family Chromotioidaceae deposit sulfur intracellularly. They are highly cosmopolitan. Representatives of most genera are aquatic. Some species have been found only in marine habitats.

From a survey of the literature, BAVENDAMM (I924) listed the following Thiorhodaceae which have been observed in salt or brackish water: Thiocystis violacea, Thiocystis rufa, Thiocapsa roseopersicina, Thiosarcina rosea, Lamprocystis roseopersicina, Thiopedia rosea, Amoebobacter granulae, Thiothece gelatinosa, Thiodictyon elegans, Thiopolycoccus ruber, Chromatium warmingii, Thiospirillum jenense, Thiospirillum violaceum, Thiospirillum rosenbergii, Rhodacapsa suspensa, and Rhodothece pendens. BAVENDAMM pointed out that these purple sulfur bacteria were found in sunlighted habitats containing $\mathrm{H}_{2} \mathrm{~S}$. The buffering capacity of sea water permits them to grow. Some of them can tolerate relatively wide temperature ranges. Their sulfur metabolism is dependent upon $\mathrm{H}_{2} \mathrm{~S}$ produced by proteolytic saprophytes or sulfate reducers.

In calcareous mud around the Bahama Islands, BAVENDAMM (1932) recognized Chromatium okenii, Chromatium weisii, Chromatium minus, Chromatium vinosum, and others. He described them as being actively motile and coming from the sea bottom generously filled with sulfur granules. They often appeared as red clouds in the sea water covering the mud in cultures. Deep_down into the mud they formed beautiful, characteristic, wine-red pellicles on the glass walls of culture receptacles. He remarked, regarding bottom biocoenoses, that besides numerous sulfur bacteria of all types, there was a large heterotrophic bacterial population, including many sulfate reducers. Closely associated with the sulfur bacteria were many blue-green algae, especially species of Oscillatoria, a few sessile diatoms, and some protozoans. He regarded such an association as being ideal for the activity of the sulfur bacteria. Sulfate reducers provided $\mathrm{H}_{2} \mathrm{~S}$ in the close proximity of algae which, during the hours of daylight, supplied free oxygen.

In marine bottoms off the northern coast of Russia, IsSATCHENKo (I9I4) noted the occurrence of Amoebobacter granulae, Thiopolycoccus ruber, Thiosarcina rosea, Thiothece gelatinosa, Chromatium mimus, Chr. minutissimum, Chr. rosea, Chr.vinosum, Chr. gobii, and Thiodictyon minus. The last two named sulfur bacteria were described by Issatchenko as new species.

In the Dreckee mud swamps along the Danish coast, UtermöHL (I925) found a maximum of 3000 Chromatium cells per $\mathrm{ml}$. along with 2900 Thiopedia cells and several hundred cells of Thiocystis. The combined 6000 to 7000 purple bacteria per $\mathrm{ml}$. of water caused a red coloration. It was from similar shallow "red water" sounds that WARMING (I875) isolated achromic species of sulfur bacteria which were freely mingled with masses of purple bacteria.

Further data on "red water" or so-called "bloody seas" are reported 
by GIetzen (193I). Extensive populations of purple sulfur bacteria along the Holstein coast, growing associated with decomposing plankton including algae, jellyfish, etc., imparted a distinctly red coloration to the sea. The presence of $\mathrm{H}_{2} \mathrm{~S}$, microaerophilic or anaerobic conditions, and sunlight appeared to be requisite for maximum development of the purple bacteria. They grow throughout the entire temperature range of the sea.

The Red Sea and the Vermilion Sea (Gulf of California) were so named because of the frequent red to brownish coloration of the water. According to SVERDRUP et al. (I942), certain algae, particularly Trichodesmium erythraeum, or dinoflagellates are responsible for the color. ALLEN (I933) found Prorocentrum micans, a golden-yellow dinoflagellate, to be responsible for certain occurrences of "red water" off the coast of southern California. Extensive patches of "red water" caused by the ciliate protozoan, Mesodinium rubrum, and the shrimp, Munida cokeri, have been reported by COKER (I938). While these or other organisms may sometimes cause "red water," purple bacteria are often overlooked by oceanographers and hydrographers. It is significant that the hydrographic conditions in "bloody seas" are generally precisely those which would promote the growth of purple sulfur bacteria; namely, the presence of an abundance of decomposing plankton material which provides for $\mathrm{H}_{2} \mathrm{~S}$ production and reduced oxygen tension.

FORTI (I933) found large numbers of Thiopolycoccus ruber, Thiopedia rosea, and Beggiatoa alba in a Sicilian "lake of blood" or "bloody sea." Sulfate reducers in the bottom water provided $\mathrm{H}_{2} \mathrm{~S}$ for the sulfur bacteria.

ELLIS (I932) tells of Rhodothece pendens coloring sea water around Helgoland "as though with rose-red milk of sulfur." Rhabdomonas rosea, Rhodocapsa suspensa, and $A$ moebobacter roseum are other colored bacteria which live in the sea, according to ELLrs.

Thiopedia rosea was the most abundant organism found in fresh-water plankton by UTERMÖHL (I925). There may be as many as I0,000 of these purple bacteria per ml. of plankton tow. KNIPOWITSCH (I926) found microaerophilic Thiopedia rosea down to a depth of 750 meters in the Caspian Sea.

For further information on the ecology and physiology of the purple sulfur bacteria the reader is referred to the treatises of BAVENDAMM (I 924), BaAs Becking (i925), Gietzen (I93I), Ellis (I932), and van Niel (1931, I936).

In the second category of purple sulfur bacteria are the Rhodobacterioides or Athiorhodaceae, which do not show intracellular sulfur granules. They grow best in the presence of $\mathrm{H}_{2} \mathrm{~S}$ and are often found associated with Thiorhodaceae and achromic sulfur bacteria. Apparently the Athiorhodaceae are neither as abundant nor as widespread as other types of sulfur bacteria.

Only one of the seven genera of Rhodobacterioides listed in the BERGEY (I939) Manual is described as having a marine habitat, namely, Rhodobacterium capsulatum which MoLIScH isolated from sea water. However, most of the Rhodobacterioides live in water. A more thorough search of the literature may reveal that most of the genera have marine representatives.

BAAS BECking (I925) recovered a Rhodococcus or Rhodorrhagus from rotting Fucus near Moss Beach on the California coast. According to BAAS BECKING, the sulfur bacteria in brine, brackish water, and fresh- 
water sulfureta are all very much alike. Sulfur bacteria appear to be independent of salinity over a range of 0.05 to 7.5 per cent $\mathrm{NaCl}$. The purple forms prefer diffuse or subdued sunlight and a low oxygen tension. They require $\mathrm{H}_{2} \mathrm{~S}$ which, in sulfureta, is provided largely by sulfate reducers.

BAAS Becking (I925) described a sulfuretum as a natural ecological community of bacteria operative in the sulfur cycle. It is a biocoenosis of sulfate-reducing bacteria and $\mathrm{H}_{2} \mathrm{~S}$-oxidizing bacteria of various kinds along with several other kinds of microorganisms. In the fresh water, brine, and brackish water which he studied, Chromatium and Beggiatoa were commonest, followed by Lamprocystis, Amoebobacter, Thiothrix, Thiopedia, Thiopolycoccus, and Thiospirillum. Protozoans feeding on sulfur bacteria were common. Euglena and Phacus of various types, Oscillatoria, Phormidium, and many diatoms were usually present. The green algae were represented by a Protococcus-like form. Nematodes and a large Spirochaete were observed. BAAS BECKING found green bacteria in brackish water but not in brine.

Chlorobacteria, or green sulfur bacteria, have been found in the sea, especially in brackish water. Although reference has been made to them for more than half a century, agreement concerning their physiology and taxonomic position is still lacking. According to VAN NIEL (I93I), Chlorobium limicola is the only strain which has been obtained in pure culture, although Chlorobacterium, Cyanodictyon, Pelodictyon, and possibly other genera have been named.

NADSON (I9I2) described Chlorobium limicola which he found in brackish water and bottom mud in the Baltic, Black, and Caspian seas, as well as in the salt Lake Weissowo. He thought they were minute algae. BENECKE (I933), who found green bacteria in the Baltic Sea, relates that PAScher designated them as small Protococcales. However, as VAN Niel (I93I) pointed out, bacteriochlorin, the green pigment of Chlorobium limicola, differs from the chlorophyll of algae. Moreover, these bacteria assimilate $\mathrm{H}_{2} \mathrm{~S}$ in subdued sunlight and deposit sulfur extracellularly, therein resembling the purple Athiorhodaceae:

$$
{ }_{2} \mathrm{H}_{2} \mathrm{~S}+\mathrm{CO}_{2}=\left(\mathrm{CH}_{2} \mathrm{O}\right)+\mathrm{H}_{2} \mathrm{O}+{ }_{2} \mathrm{~S}
$$

Transformation of selenium compounds:- The close analogy between the chemical behavior of sulfur and selenium provided the incentive for BRENNER (I9I6) to investigate the effect of bacteria upon selenium compounds. He isolated an organism, Micrococcus selenicus, from marine mud at Kiel which autotrophically oxidized selenide:

$$
{ }_{2} \mathrm{H}_{2} \mathrm{Se}+{ }_{5} \mathrm{O}_{2}={ }_{2} \mathrm{SeO}_{4}^{--}+2 \mathrm{H}_{2} \mathrm{O}
$$

It also oxidized selenite to selenate. When organic matter was added to the medium and oxygen excluded, Micrococcus selenicus reduced selenite and selenate as well as thiosulfate. Thiobacillus thioparus, which BRENNER isolated from the mud, failed to utilize selenium compounds.

Neither selenate nor tellurate was reduced by Desulfovibrio aestuarii studied by RITTENBERG (I94I). 


\section{Chapter XIII}

\section{THE PHOSPHORUS CYCLE}

The phosphorus cycle is relatively simple compared with cycles of nitrogen, sulfur, or carbon. Plants utilize phosphate phosphorus which they convert into organic phosphorus compounds. Animals depend upon plants for their phosphorus requirements. Bacteria fulfill a most important function in the regeneration of phosphate from the remains of animals and plants. The storage of phosphorus in bacterial cells and the effect of bacterial activity on the solubility of phosphate are of secondary importance in the phosphorus cycle in the sea.

Assimilation of phosphate by microorganisms:- Phosphate is essential for the growth of phytoplankton. At times a lack of phosphate may limit the primary productivity of the sea (REDFIELD, I934). ATKINS (I926) discusses certain hydrographic factors which influence the replenishment and utilization of phosphate in the English Channel, where the vigorous growth of phytoplankton often leads to a depletion of phosphate. In such an event, the area has yielded its maximum production until phosphates are regenerated by bacterial activity or replaced by the influx of water from nutrient-rich areas.

The utilization of phosphate and nitrate in the synthesis of organic substances proceeds at approximately parallel rates, according to SVERDRUP et al. (1942). Any deviation from the nitrate-phosphate ratio is believed to be dependent primarily upon factors which influence the rate of nitrification or the bacterial regeneration of phosphate. The ratio of nitrate- $\mathrm{N}$ to phosphate- $\mathrm{P}$ in offshore waters is approximately the same as the ratio of organic- $\mathrm{N}$ to organic-P in marine plankton, namely $7: \mathrm{I}$. This agreement suggests that the composition of the composite animal and plant population of the sea is determined by the rate of available nitrogen to phosphate-P in sea water.

The optimum concentration of phosphate-P for the development of diatoms is about $50 \mathrm{mgm} . / \mathrm{M}^{3}$, according to HARvEY (I933). Water throughout the euphotic zone rarely contains more than $5 \mathrm{mgm} . / \mathrm{M}^{3}$ during the photosynthetic season, and generally less than I mgm./M. ${ }^{3}$ At such times a majority of the total phosphorus content of the water occurs in plant and animal tissues. Upon the death of the organisms, phosphate is rapidly regenerated.

As pointed out by RENN (I937a), bacterial cell substance is notoriously rich in phosphorus. However, it is apparent from their minute size and small numbers that bacteria do not compete effectively for the sea's limited store of this element. There is no evidence that phosphate limits bacterial multiplication in sea water unless the latter is experimentally enriched with organic matter. RENN noted a slight decrease in the phosphate content of sea water incubated in the dark, followed by an increase. He attributed the initial decrease to the assimilation of phosphate by bacteria, and the increase to the liberation of phosphate from organic compounds including autolyzing bacterial cell substance. 
Regeneration of phosphate:- Phosphorus occurs in organisms primarily in the form of phospholipids and nucleoproteins. Animal bones consist largely of tricalcium phosphate. Most organic phosphorus compounds seem to be very susceptible to decomposition by bacteria. Phosphate is liberated very early in the process.

In experiments conducted by SEIWELL and Serwell (I938), about half of the phosphorus content of freshly collected zooplankton was decomposed in 24 hours after the death of the zooplankton, whereas oxygen consumption by bacteria in the experiments indicated that half of the total organic content of the zooplankton was not oxidized for four or five days. In similar experiments conducted by COOPER (I935), about one-fourth to one-third of the phosphorus content of marine zooplankton was liberated as phosphate during the first twelve hours of bacterial activity and nearly all of it in six days. Phosphate was liberated from phytoplankton somewhat less rapidly.

The rapid regeneration of phosphate from dead bacterial cells was observed by RENN (I937a). He reported that after bacterial growth had passed its maximum in sea water enriched with phosphate and glucose, the regeneration of phosphate followed "almost at once - rapid at first, and then leveling off at I4 days toward completion." Phosphate was not liberated from autolyzing, bacteria-free diatoms.

There has been considerable speculation regarding the place of phosphate regeneration. The occurrence of a far greater concentration of phosphate in deep water than near the surface has been interpreted by some oceanographers as indicating that phosphate is regenerated on the sea floor. While unquestionably a certain amount of phosphate is regenerated in bottom deposits, the foregoing observations on the rapidity of phosphate regeneration, together with other considerations, strongly suggest that the majority of the phosphorus cycle is enacted in the euphotic zone. There large quantities of phosphate may be regenerated, but phosphate may not accumulate because it is utilized by phytoplankton or bacteria almost as rapidly as it is regenerated.

From their studies on the rate of sinking of decomposing plankton, Seiwell and Serwell (I938) concluded that due to the low density of the great mass of organic material, most bacterial decomposition must occur in the upper levels of the ocean. Significantly, they found that the minimum concentration of oxygen occurs in the western North Atlantic basin in water which has a density value somewhere near that of the great mass of organic matter, namely, $1.027,232 \pm 0.000,008$. This suggests that most organic decomposition and hence phosphate regeneration takes place above the oxygen minimum layer, roughly 600 to 800 meters. Below this depth only denser, particulate organic matter, which constitutes only a small fraction of the total organic content of the sea, sinks. This is in agreement with the observations of RAKESTRAw (1936), who noted that the zone of maximum accumulation of phosphate roughly parallels that of nitrite.

Similar conclusions were reached by REDFIELD (I942) who believes that the phosphate maximum and oxygen minimum in the North Atlantic are ascribable to the oxidation of organic matter within a few hundred meters of the surface. While part of the phosphate content of South Atlantic water at mid-depths may be derived from the isentropic movement of subsurface layers from higher latitudes, in equatorial and North Atlantic regions, phosphate may be added and oxygen removed by the decomposi- 
tion of sinking organic matter. REDFIELD's argument that some organic matter must sink to depths as great as 600 to 800 meters is a commentary on his belief that the vast majority of the organic matter must undergo complete decomposition nearer the surface.

Whether a specific bacterial flora is involved in the liberation of phosphate from phospholipids and phosphoproteins or whether all lipolytic and proteolytic bacteria are endowed with this ability is not known. Special investigations are needed to answer this question, as well as to elucidate the mechanism of phosphate regeneration. However, bacteria which decompose organic compounds with the liberation of phosphate appear to be abundantly and widely distributed in aquatic environments as well as in soil.

Unless properly preserved, there is nearly always an increase in the phosphate content of either sea water or fresh water stored in the dark (ZoBELL and BROWN, 1944). WAKSMAN et al. (I937) have noted a rapid regeneration of phosphate resulting from the bacterial decomposition of diatoms. WAKSMAN el al. (I938) made similar observations on decomposing copepods and other marine organic matter.

Effect of bacteria on solubility of phosphate:- The solubility of calcium phosphate in sea water is primarily a function of the $p H$. The solubility is increased as a result of the activities of bacteria which produce acidic substances and decreased by metabolites of alkaline character. In localized microspheres where the phosphate content of the water is relatively high, tricalcium phosphate may be precipitated from solution owing to an increased $p \mathrm{H}$ caused by bacteria.

The reverse process, namely the dissolution of tricalcium phosphate, may be of considerable importance in the phosphorus cycle. It is of importance on land where bacterial activities promote the mineralization of rock phosphates. In the sea large quantities of phosphate are bound in the bones of animals in the form of tricalcium phosphate. Part of the latter may be dissolved by the acidic digestive juices of carnivorous animals, and part by bacteria and allied microorganisms. This they do in four different ways recorded in order of importance: (I) Generation of acids. (2) Decomposition of organic matter associated with the bones, thereby mechanically liberating some calcium phosphate, particularly from only partially ossified tissue. (3) Production of ammonium salts and other secondary reaction products which increase the solubility of tricalcium phosphate. To the extent that it increases the $p \mathrm{H}$, microbiologically produced ammonium may decrease the solubility of tricalcium phosphate, but ammonium chloride and ammonium sulfate have a slight solvent action. (4) Conversion of insoluble tricalcium phosphate into cell phosphoproteins or phospholipids by direct assimilation.

Tricalcium phosphate, either in the form of bone or crystals, provides an excellent surface for the attachment of marine bacteria and for the concentration of dissolved organic matter. This would promote increased bacterial activity in the immediate vicinity of the tricalcium phosphate where bacteria in microspheres may produce enough acid to have a solvent action, though surrounded by slightly alkaline water. 


\section{Chapter XIV}

\section{RELATION OF MARINE BACTERIA TO FLORA AND FAUNA}

It is almost axiomatic that the density of the plant and animal population of biotic zones is more or less proportional to the abundance of bacteria and allied microorganisms. This is probably chiefly because bacteria are predominantly heterotrophic, depending largely upon plants and animals for organic nutrients. However, there are other ways in which the flora and fauna are beneficial to bacteria. In turn, most bacteria are beneficial to plants and animals, although in localized regions bacteria may create antibiotic environmental conditions, and some bacteria are parasitic or pathogenic.

Reciprocal relations of bacteria and plants:- It has been definitely established, as outlined in preceding chapters, that bacteria play an important role in the production of plant nutrients including ammonia, nitrite, nitrate, sulfate, and phosphate. It is not known to what extent the ability of bacteria and allied microorganisms to produce these plant nutrients is unique, but certainly it is one of the most important functions of microorganisms. The plant nutrients are produced in considerable quantities and for the most part in the immediate proximity of plants.

Bacteria also produce large quantities of $\mathrm{CO}_{2}$ which is likewise essential for plant growth. Though animals are generally credited with being the principal $\mathrm{CO}_{2}$ producers in the sea, the composite bacterial population of the sea may produce more $\mathrm{CO}_{2}$ than the combined animal population. Based upon oxygen consumption data and considering that bacteria approximate spheres having a mean diameter of $\mathrm{I} .0 \mu$ and a density of 1.028 , ZoBelL (I940b) estimated that bacteria in the sea produce about $30 \mathrm{ml}$. of $\mathrm{CO}_{2}$ per hour per gram of living cells at a mean temperature of $10^{\circ} \mathrm{C}$. This may be contrasted with the value of 0.002 to I.o ml. of $\mathrm{CO}_{2}$ produced per hour per gram of marine animal tissue. Unfortunately, no data are available on the relative mass of bacteria and animals in the oceans of the world, but judging from the data of JUDAY (I942) on the standing crop of plants and animals in lakes, together with information on the bacterial population of these lakes, it is estimated that the ratio of the mass of the standing crop of bacteria to that of animals is about $I: 200$. The fact that bacteria produce $\mathrm{CO}_{2} 30$ to I 5,000 times faster than animals per unit of mass indicates the relative importance of bacteria as $\mathrm{CO}_{2}$ producers.

Plants are the chief source of organic nutrients for saprophytic bacteria. Plants are attacked immediately following their death. The secretions and excretions of living plants also provide food for bacteria associated with them. The secretion of organic matter by growing plants as well as the epiphytic association of bacteria with plants is discussed in the section beginning on page 77. There it is pointed out that bacteria occur primarily attached to phytoplankton or other particulate material which provides both food and solid surface.

Symbiotic nitrogen fixation by bacteria associated with aquatic plants 
is an almost unexplored possibility. The fixation of nitrogen by Azotobacter growing epiphytically on algae (REINkE, I903; KEDING, 1906) is hardly true symbiosis because, while the algae may provide the bacteria with a holdfast and organic nutrients, there is no evidence that the bacteria contribute fixed nitrogen to the algae, at least not until after the death and decomposition of the bacteria.

Marine plant pathogens:- Infections of marine plants by bacteria have been reported. An interesting example is the disease of kelp known as "black rot" which was first noticed off the California coast by BRANDT (I923). It attacked the bladder kelp, Macrocystis pyrifera, the elk kelp, Pelagoplycus porra, and the ribbon kelp, Egregia laceigata. The causative organism was kept in check by the colder water of winter and by proper cutting of the kelp beds.

Brllet $(1888 a, b)$ isolated Bacterinm laminariae and Bact. balbianii from rotting kelp. ScHAUdinN (I903) described Bacillus sporonema, which he isolated from rotting Ulva. LAGERHEn (I900) presented evidence that a fungus-like bacterium, which he named Sarcinastrum urosporae, is responsible for gall formation on red algae.

CANTACUZÈNE (I930) found tumorous growths on Irish moss, Chrondus crispus, which he attributed to infectious bacteria. Tumors or galls on Saccorrhiza bulbosa were likewise found to be infected with bacteria. Healthy plants could be experimentally infected by inoculating them with the bacteria isolated from diseased plants.

Large numbers of bacteria are associated with diseased eel grass, Zostera marina, but they have not been proved to be pathogenic. After finding Labyrinthula species in all specimens exhibiting symptoms, RENN (r936) concluded that these fungi were the etiological agents of the "wasting disease" of eel grass. Halophiobolus species (BARGHOORN and LINDER, I944) may also be involved.

NADSON and BURGWITZ (I93 I) found several varieties of Torula and other yeast-like organisms parasitizing Laminaria, Alaria, Fucus, and other seaweeds. Several species of fungi parasitic on marine algae have been described by KibBE (I9I6), Zeller (I9I8), SpARrow (I934, I936), and others. Some of their observations are detailed in Chapter IX.

Judging from the positive results that have been obtained from the few precursory or exploratory observations made to date, it is believed that pathogenic bacteria, yeasts, and mold fungi may extensively parasitize seaweeds, diatoms, dinoflagellates, and other marine plants. This is a most promising field for further investigation; a field in which the results may contribute to our knowledge of marine microbiology and general hydrobiology.

Although he regards the study of aquatic fungi as still being a virgin field for research, Weston (I94I) writes, "On the plant life of fresh water, fungi are commonly, extensively and often destructively parasitic. Occasional serious epidemics have been reported, chiefly on algae such as diatoms, desmids or other plankton forms significant in aquatic ecology." Weston gives a résumé of the ever-growing literature describing aquatic fungi which have been found to be parasitic on fresh-water algae and higher aquatic plants. The latter appear to be less susceptible to parasitism than the simpler algae. He quotes ZopF to the effect that, "In the household of nature the infectious diseases of the lower organisms play a highly significant part." 
Reciprocal relations of bacteria and animals:- There are several ways in which bacteria and animals are beneficial to each other either directly or indirectly. The bacterial production of plant nutrients, thereby providing for the growth of plants which animals may consume as food, is regarded as an indirect benefit. The part that bacteria play in aiding animals to digest their food is a direct benefit.

The digestive tracts of most animals contain numerous bacteria which as a group are very versatile biochemically, being capable of attacking a wide range of materials. Collectively, these bacteria elaborate a formidable equipment of enzymes which attack many of the substances swallowed by animals for which the consumer itself has no enzyme. The power to break down pectins, hemicelluloses, cellulose, lignin, chitin, and other organic complexes is much more widespread among enteric bacteria than it is among animals which ingest these organic complexes. There are few data on the extent to which commensal bacteria may aid animals in the digestion of food, but with many animal species such bacteria may be virtually indispensable. Certain ship worms and wood borers, which are discussed elsewhere in this volume, are believed to depend upon commensal bacteria which help to digest cellulose and lignin.

The function of bacteria in the pre-digestion or partial digestion of food is not confined to enteric forms. Grazing, filter-feeding, and mudeating animals assimilate much finely particulate food which has been broken down by bacterial activity.

Large numbers of bacteria, along with partially decomposed organic complexes, are ingested and digested by animals. Other bacteria find conditions in the intestinal tracts or on the integuments of the animals conducive to their growth and multiplication. Evidence is forthcoming from analyses which reveals that the intestinal contents of many marine animals contain millions of bacteria per $\mathrm{ml}$. Likewise the slimy integuments of aquatic animals are invested with an extensive bacterial population. From his observations on marine fish, SANBORN (1932) concluded that a more or less definite bacterial flora occurs on the surface of fresh fish.

The integuments or cell walls of virtually all aquatic animals both large and small appear to be veritable bacterial gardens. Illustrative examples are the large bacterial populations associated with copepod tows, the difficulty experienced in attempting to obtain bacteria-free cultures of protozoa, and the bacterial content of fish slime.

Predominating on the surface of halibut freshly taken at depths of 30 to 60 fathoms in the Atlantic Ocean by SANBORN (I932) were Achromobacter pellucidum and Rhodococcus agilis. These, together with Micrococcus varians, $M$. citreus, $M$. candidus, Flavobacterium turcosum, and $F l$. fucatum, were observed by SANBORN on Atlantic halibut and by HARRISON (I929) on Pacific halibut. SANBORN (I932) also noted the presence of Micrococcus nitrificans, $M$. halophilus, Achromobacter geniculatum, A. ambiguum, and Flavobacterium annulatum on halibut. Unlike HARRISON's findings on Pacific halibut, SANBORN noted on Atlantic halibut the presence of Pseudomonas fluorescens, which was very actively proteolytic. SANBORN believed that Ps. fluorescens, along with two other equally active proteolytic marine species, Achromobacter geniculatum and Flavobacterium uc atum, have a direct economic bearing upon the keeping quality of fish. The formation of slimy or viscous growth, which is a common property of bacteria found on the integument of marine fish, is particularly pronounced with $P$ s. fluorescens, Achromobacter pellucidum, and A. viscidum. 
The latter is named by SANBORN as a new species which resembles $A$. litoralis. Of the organisms listed above which were isolated from marine fish, only A. ambiguum, Micrococcus nitrificans, and $M$. halophilus proved to be salt-tolerant. They grew in media containing from to to 20 per cent $\mathrm{NaCl}$.

Species of Acliromobacter predominated in the slime of the 22 haddock examined by STEWART (I932). She also observed species of Micrococcus, Flavobacterium, Pseudomonas, and many unidentified luminescent bacteria in haddock slime. Nearly half of the cultures isolated from the slime of I I species of marine fish by GiBboNs (I934a) were classified as Acliromobacter, with smaller numbers of Flavobacterium, Micrococcus, Pseudomonas, Bacillus, Proteus, and Serratia occurring in abundance in the order listed. Luminescent bacteria have been commonly observed growing on fish and other marine animals. Such bacteria are often associated with the light organs of certain animals (HARvey, I940). Additional data on the kinds of bacteria associated with marine fish are given in Chapter XVI on page I88.

Their predilection for solid surfaces and their organic requirements, both of which are provided by animals, explain why certain bacteria are intimately associated with animals. The secretions and excretions of animals are a source of food for bacteria. The bacterial utilization of urea, uric acid, and other waste products of animals is mutually beneficial to both consumer and producer.

Bacteria as food for animals:- Judging from their chemical composition, bacteria should be highly nutritious and readily digestible. This supposition is substantiated by experimental and field observations which indicate that many kinds of animals ingest bacteria. Certain animals can live almost indefinitely on an exclusive diet of bacteria.

Bacteria constitute an important part of the dietary of nearly all unicellular animals, according to LUCK et al. (I93I). They noted that Euplotes taylori grew better on mixed cultures of bacteria than on any one single strain. Heat-killed bacteria, filtrates, autolyzed bacteria, and phage-lysed bacteria failed to support Euplotes taylori. The failure of certain bacteria to be assimilated by protozoans may be due to toxic metabolic products, unfavorable size or shape, capsular material, or other peculiarities.

The importance of bacteria in the nutrition of pelagic copepods is stressed by the work of EsTERLY (I9I6) who considered the question of the utilization of dissolved organic substances. He concluded that, although unable to utilize dissolved materials directly, copepods may subsist on bacteria which in turn utilize dissolved organic substances. According to KrIZENCKX and PodHRADSKY (I927), one of the most important functions of aquatic bacteria is the conversion of dissolved organic matter into particulate (bacterial cell substance) organic matter which animals can utilize. The ratio of dissolved to particulate organic matter is estimated to range from 7:I to 4000:I in different parts of the ocean. It is the consensus of opinion (KROGH, I93I; Fox and CoE, I943) that, contrary to PÜTTER's theory, organic matter in true solution plays no significant role in the direct nutrition of aquatic animals, but that bacteria serve as intermediary agents of vast importance. Given sufficient time and favorable conditions, including solid surfaces, bacteria utilize the organic content of sea water almost quantitatively (ZoBELL and GRANT, I943), mineralizing roughly 70 per cent of it and converting 30 per cent into bacterial cell substance or intermediate products. 
The experiments of CLARKE and GELLIS (I935) indicate that, while bacteria may be important as food for copepods, there seem to be insufficient bacteria in the sea to provide for the complete nutritional requirements of copepods. According to WAKSMAN and CAREY (I935b), the bacterial population of the sea is kept down to a certain minimum due to the consumption of bacteria by protozoans, copepods, and other marine animals, notably those of the mucous-feeding or filtering classes.

Several kinds of zooplankton organisms were found by VoRosCHILOVA and Dianova (I937) to ingest bacteria. These workers concluded that bacteria nourish zooplankton organisms and that the predatory activities of the latter tend thus to restrict the bacterial population of the Caspian Sea. PACK (I9I9) reported that ciliates in Great Salt Lake feed on bacteria. BAAS BECKING (1925) noted that sulfur bacteria appeared to be the chief food of ciliates in sulfureta.

Mud-dwelling detritus feeders studied by MaCGinitie (I935) utilized bacteria as food. MARE (I942) stressed the importance of bacteria as food for bottom-dwelling animals in marine benthic communities. ZoBELL and FeLtham (I942) estimated that around io grams (dry weight) of bacteria are produced per day per cubic foot of mud in a shallow marine mud flat. The bacterial crop available for the nutrition of the animal population in deeper colder bottoms of the open ocean, where less organic matter reaches the sea floor, is considerably less than ro grams per day.

ZoBell and. Feltham (I938) demonstrated that the sea mussel, Mytilus californianus, ingests and digests bacteria. Specimens were maintained on an exclusive diet of bacteria for several months, during which time the mussels gained in size and weight. Few species of marine bacteria are injurious unless they are present in such great numbers that their metabolic products vitiate the water. Bacteria were also found to sustain the growth of the sand-crab, Emerita analoga, to a limited extent. Emerita is more sensitive to large doses of bacteria than is the mussel and is less efficient in removing bacteria from suspension. The Gephyrean worms, Dendrostroma zostericola and Urechis caupo, were found to eat bacteria and to derive nourishment therefrom.

BAIER (I935) listed several genera of rotifers, copepods, ciliates, and flagellates which may feed directly upon bacteria and small nannoplank ton suspended in water. The larval stages of additional genera are planktonic bacteria feeders. A second group of animals ingest bacteria along with the mud and slime which they swallow promiscuously, digesting the usable portion and ejecting inert materials. Nematodes, mussels, tube worms, and the larvae of midges are in this category. A third group of bacteria feeders discussed by BAIER are animals which graze on solid objects like rocks, aquatic plants, and suspended solids of various kinds. Certain snails, ostracods, copepods, and amoebae are mentioned as examples of animals which feed in this manner. Concerning the latter group, BAIER writes that it is not the decomposing plant substance but rather the bacteria, the cause of the decomposition, which nourish the grazing animals.

That bacteria are ingested and digested by highly diverse fauna is incontrovertible, but quantitative data on their relative importance in the food cycles in the sea are wanting. It is doubtful if bacteria are sufficiently abundant in sea water to constitute an appreciable item in the diet of marine animals, but cumulatively bacteria must play an important role in food cycles by synthesizing cell substances and by converting waste or dissolved organic matter into a particulate form which can be 
utilized as food by animals. In bottom deposits and as a constituent of the slime on solid surfaces, bacteria may be sufficiently abundant to provide for the more or less complete nutrition of certain animals. According to PeARSE ct al. (I942), one of the important functions of bacteria in marine sand beaches is serving as food for nematodes, flatworms, protozoans, amphipods, and other small animals.

Marine animal pathogens:- There is evidence that certain marine animals succumb to bacterial infections. However, conditions in the sea are not conducive to the propagation of microorganisms which cause acute infections of animals, although animal parasites are common. As soon as a pathogen incapacitates its host, the latter almost immediately falls prey to ever-present predators. There is no sanctuary in the sea for the ill or the old where only the fittest survive. Any diseased fish or other animal which can no longer swim quite as fast as his companions may soon be captured and eaten by a larger fish or other predator. Consequently, the pathogen which incapacitates its host may be destroyed also.

Nevertheless, marine animals do have infectious diseases, perhaps much more extensively than indicated by the fragmentary literature on the subject. Animals kept in aquaria, experimental tanks, and elsewhere in captivity are quite susceptible to bacterial and fungus infections. PlehN's (r924) monograph on fish diseases describes many infections of fresh-water fish.

Costly losses to the salmon industry and trout hatcheries have been caused by a generalized bacteremia or epizootic furunculosis, the etiological agent of which is Bacterium salmonicida (DUFF, I932).

Bacillus columnaris is a new species described by DAvIS (1922) which infects the epidermis, gills, and fins of several species of fresh-water fishes. Aronson (I926) described Mycobacterium marimum which causes tuberculosis in certain salt-water fishes. Achromobacter ichthyodermis, the etiological agent of an infectious dermatitis of certain marine fishes, was described by WeLLS and ZoBell (I934). Since it has a polar flagellum, this organism should be designated Pseudomonas ichthyodermis according to the revised key. From the integument of diseased fishes, ZoBELL and UPHAM (I944) isolated Bacterium marinopiscosus, but its pathogenicity was not established.

A "soft shell" disease, which has killed large numbers of lobsters on the West Coast of North America and ruined the commercial value of others, is believed by HESS (I937) to be caused by chitinovorous bacteria. INMAN (I927) described an infectious disease of sand fleas and other crustacea, which was caused by photogenic bacteria. A large number of aquatic animals are infected by photogenic bacteria, according to HARVEY (I940). The problem of the infection of fish and shellfish is discussed in Chapter XVI.

WESTON (I94I) relates that practically all the main groups of freshwater animals, from the simplest protozoan to the most highly developed chordates are attacked, in some phase of development from egg to adult, by various aquatic fungi. He relates that an epizootic caused by the aquatic fungus, A phanomyces astaci, killed millions of commercially valuable crayfish in Europe. Species of Aphanomyces have caused destructive epidemics among protozoans and copepods. TIFFnEy (I939) discusses several species of the water mold, Saprolegnia, which extensively and destructively parasitize fish. Besides attacking a wide range 
of fish species, Saprolegnia parasitica also infects various Amphibia and Reptilia. Saprolegnia ferax and Achlya flagellata are other common aquatic fungi which are pathogenic for animals.

Eggs and larval stages of animals are usually more susceptible to fungus parasitism than are the adult forms. A species of Petersenia, a chytridiaceous fungus parasitic on marine rotifer eggs, was described by SPARROW (1936). Observations on malformed sardine eggs from off the coast of California suggest that fungus infections may contribute to the failure of the sardine crop in certain years.

Antibiotic conditions caused by bacteria:- In the sea as a whole the combined activities of bacteria and allied microorganisms tend to create environmental conditions which are conducive to the growth of plants and animals. However, in localized regions certain types of microbiological activities may be inimical to the well-being of other organisms.

An outstanding example of the antibiotic activities of bacteria is the production of $\mathrm{H}_{2} \mathrm{~S}$ in quantities which are toxic to both animals and plants. Some of the factors which influence $\mathrm{H}_{2} \mathrm{~S}$ production are discussed in Chapter XII.

Likewise in the presence of an abundance of utilizable organic matter, bacteria may reduce the oxygen tension of water below the threshold of tolerance for certain animals. This condition prevails in bottom deposits. The oxygen minimum layer found in the Atlantic and Pacific at a depth ranging from 600 to 900 meters may be ascribable to the consumption of oxygen primarily by bacteria in water masses having a peculiar hydrographic history.

Besides depleting the oxygen content of marine bottoms, bacteria reduce the oxidation-reduction potential of bottom deposits to a level below that which is tolerated by most organisms. Most aquatic animals prefer or require a redox potential ranging from $\mathrm{E}_{\mathrm{h}} \circ$ to +0.2 volt. Bottomdwelling bacteria sometimes create conditions in mud as reducing as $\mathrm{E}_{\mathrm{h}}-0.2$ to -0.5 volt.

Both the sea and its bottom are too well buffered for the $p \mathrm{H}$ to be greatly affected by microbiological activities, except in highly localized regions. There the acidic or basic substances produced by bacteria may have a profound influence on the residents of the small community, as in sulfureta, for example.

Other toxic products besides $\mathrm{H}_{2} \mathrm{~S}$ may be produced by bacteria including various nitrogenous catabolites. Such products can be expected to accumulate in significant quantities only in the immediate vicinity of a decomposing fish, for example, and there only temporarily.

Additional information on the relation of marine bacteria to flora and fauna is given in the sections on Plant and Animal Population in Chapter II, Effect of Other Organisms and the Antagonistic Effects of Microorganisms in Chapter V, Biocoenosis and Bacteria in Bottom Deposits in Chapter VI, Bacteriology of Marine Fish in Chapter XVI, and Fouling of Submerged Surfaces and Bacteria Associated with Wood-borers in Chapter XVII, as well as elsewhere in the text. 


\section{Chapter XV}

\section{MICROORGANISMS IN MARINE AIR}

One of the first problems investigated by pioneer marine microbiologists on oceanographic expeditions was the bacterial content of the atmosphere. Prior to the observations of Certes (I884a), Fischer (I886), and Minervini (I 900), it was tacitly assumed that the air over the ocean at considerable distance from land was sterile. Dating from their investigations, various kinds of microorganisms have been found in the air over the ocean at all stations and elevations where samples have been taken.

Bacteria in marine air:- While on the Talisman Expedition, CERTES (I884a) found bacteria in the air at considerable distances from shore. However, they were present in such small numbers that he felt certain that the aerial transportation of bacteria from land could not possibly account for the presence of bacteria in the sea.

FISCHER (I886) made several hundred analyses of air over the ocean between Kiel and Trinidad while crossing the Atlantic on the S.M.S. Moltke. When the prevailing direction of the wind was onshore, terrigenous bacteria were rarely found in the air at distances exceeding to to 20 miles from land. Only small numbers were carried more than 70 to I 20 miles from land by strong offshore winds. However, he admitted the possibility of bacteria being carried around the world with dust particles. $\mathrm{He}$ stressed the cleansing action of precipitation. Corroborative evidence of the paucity of bacteria in the air over the ocean has been recorded by Levin (i899), Gazert (I902), Ekelöf (I907), Pirie (I9I2), and Hesse (I9I4).

MINERVINI (I900) found air-borne bacteria in all collections taken over the Atlantic Ocean between Gibraltar and New York. Mold fungi and pink yeast were also noted. Rain water collected at sea contained small numbers of microorganisms. There were far fewer bacteria in marine air than in air over the land.

On various Pacific cruises of the Scripps, ZoBell and Mathews (1936) found bacteria in the air over the ocean at all stations where tests were made. In general, the abundance of bacteria decreased progressively with distance from land. The numbers and kinds of microorganisms in the air appeared to depend upon meteorological conditions. At land stations terrigenous microorganisms predominated during offshore winds. During prolonged onshore winds, marine microorganisms predominated. The ability of the microorganisms to develop on fresh-water and sea-water media was considered indicative of their origin. Illustrative data are given in Table XXXVI on page I 78 .

Besides their salinity requirements, other qualitative differences were noted in the microbial content of marine and continental air masses. In air masses known to have a marine history, Gram-negative, pigmented, asporogenous rods generally predominate, with relatively few cocci. GAZERT (I gO6b) and HESSE (I9I4) found virtually no cocci or spore-forming bacteria in marine air. By contrast, large numbers of cocci and Gram- 
TABLE XXXVI. - Average number of bacteria which developed on sea-water and fresh-water mutrient agar exposed to air under comparable conditions during a sustained onshore breeze (from ZoBELL, I942C):-

\begin{tabular}{|c|c|c|c|}
\hline $\begin{array}{l}\text { DISTANCE INLAND } \\
\text { FROM SEA WALL }\end{array}$ & $\begin{array}{l}\text { SEA-WATER } \\
\text { MEDIUM }\end{array}$ & $\begin{array}{c}\text { FRESH-WATER } \\
\text { MEDIUM }\end{array}$ & $\begin{array}{l}\text { Ratio OF } \\
\text { SW:FW }\end{array}$ \\
\hline meters & bacteria & bacteria & \\
\hline$\circ$ & $46 I$ & 43 & 10.70 \\
\hline 100 & 548 & 74 & 7.40 \\
\hline 200 & 263 & 109 & $2.4 I$ \\
\hline 400 & I 74 & I 57 & I. 18 \\
\hline 800 & I 28 & 183 & 0.71 \\
\hline 1600 & 49 & I06 & 0.46 \\
\hline
\end{tabular}

positive, sporogenous rods generally characterize continental air. Only I 5 of the Ioo different cultures of bacteria isolated at random by RITTENBERG (I939) from plates exposed to air over the ocean proved to be terrestrial species.

REITANO and MoRSELLI (I938) found bacteria in the air at all stations where observations were made 2 to 9 kilometers from the coast over the Mediterranean Sea. Their analytical procedures precluded the possibility of differentiating marine from terrestrial bacteria. They failed to take into account meteorological conditions. This also applies to the observations of GIUDICE (I 939) who found from I 2 to 280 bacteria per cubic meter of air in samples collected from 30 stations on the Red Sea and Mediterranean Sea.

The California State Bureau of Sanitary Engineering (I943) presents evidence that Escherichia coli and other enteric organisms may be carried by the wind several miles from sewage outfalls. This observation further emphasizes the ecological and possible sanitary significance of the aerial transport of microorganisms. PROCTOR and PARKER (I942) reported the presence of a great variety of living microorganisms in the air at elevations exceeding 35,000 feet above the earth, which indicates the possibilities of a world-wide distribution by air currents.

Yeasts and mold spores in air:-- Pink yeasts, probably Torula species, have been observed on plates exposed to marine air by many investigators, including Fischer (I894c). MCLEAN (I9I8) recovered two pink yeasts from marine air over Antarctica.

The number of mold spores in air over the ocean generally decreases with distance from land. This is illustrated by the following data from RitTENBERG (I939):

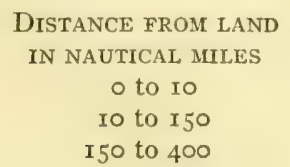

MOLDS DEVELOPING ON
SEA-WATER MEDIUM
I I 5
79
20

Molds DEVELOPING ON
FRESH-WATER MEDIUM
200
69
36

All of the mold fungi isolated from marine air by RITTENBERG proved to be common terrestrial species. The mold spores recovered from air over the ocean by Fischer (I886) were chiefly common varieties of Penicillium, Aspergillus, and Mucor.

The fungus content of air is believed to be an indicator of its origin and history, since few if any mold spores enter the atmosphere from the ocean. 
The comparative freedom of air from contaminating molds is most striling on research vessels and in seaside laboratories favored by prevailing onshore winds. Additional information on air-borne fungus spores is given by DURHAMr (I942).

Microbial content of precipitation:- There has been little additional work done on the microbial content of different forms of precipitation since FRANKLAND and FRANKLAND (1894) reported half a century ago that, "Curiously but few determinations of the number of organisms in rain have been made." According to the FrankLANDS, Miquel found an average of 4.3 bacteria per $\mathrm{ml}$. of rain water collected at Montsouris Observatory outside of Paris, and 19 per $\mathrm{ml}$. in the middle of the city. The average number for three years was 4.3 bacteria and 4.0 molds per ml., which, with an annual rainfall of $60 \mathrm{~cm}$., signified that about 5,000,000 organisms fall annually per square meter in that locality. Other workers have reported the presence of several thousand organisms per $\mathrm{ml}$. of freshly fallen rain water. The FRANKLANDS stated that BUJwID found as many as 2I,000 organisms per $\mathrm{ml}$. of water from hailstones and that FoUTIN found 729 organisms per ml. of hailstone water.

The number and kinds of microorganisms in rain water are influenced by the direction and velocity of the wind, the origin, course, and duration of the storm, and other meteorological conditions. Rain water collected at the Scripps Institution contained from Io to 150 microorganisms per $\mathrm{ml}$. Terrestrial forms, particularly mold spores, predominated in rain water containing the most microorganisms. The largest counts were usually obtained in the first rain. The rain water approached sterility as storms progressed, especially in the absence of local atmospheric turbulence. Rain water collected at considerable distances offshore contained an average of from I to Io bacteria per ml., with few or no mold fungi.

McLEAN (rgr8) recovered cocci, sporogenous rods, and yeasts from falling snow on Adelie Land, Antarctica. He believed that they were carried there from distant continents by air currents.

Significant numbers of bacteria were found by SALIMOvSKaJA-Rodina (I936) in snow from mountains ranging in elevation from 2,050 to $2,8 \mathrm{co}$ meters and also in snow from polar regions. Predominating were colorless rods, although under certain conditions the snow was tinted by the presence of large numbers of pigmented microorganisms. Nineteen different species of yeast fungi colored white, pink, red, or black were isolated from the snow. Two species of red cocci and two yellow rods were found in freshly fallen snow.

Species of Bacillus, Achromobacter, Flaiobacterium, and Micrococcus were found by DARLING and SIPLE (I94I) in freshly fallen snow on Little America and Marie Byrd Land. Only one or two bacteria were found per pint of snow. The same general types of bacteria were found on plates of nutrient media exposed to air. Although they admit the possibility of migrating terns, gulls, or petrels carrying bacteria to this snow-covered region, DARLING and SIPLE were convinced that most of the bacteria were air-borne from the continents. Unfortunately, suitable media were not employed to ascertain if there were any marine bacteria in the air and snow of the Antarctic region.

Pollens in marine air:- ERDTALAN (1938) made a quantitative study of pollens in the atmosphere while crossing the Atlantic Ocean from 
Sweden to New York. He found an average of from 0.7 to I 8 pollen grains per cubic meter of air at different stations. These figures for air over the ocean may be contrasted with the average of 18,000 pollen grains per cubic meter of air near Stockholm. In general, the number of pollen grains in marine air was related to the distance from land, the direction and velocity of the wind, and the flowering time of plants. Pollens of trees, shrubs, grains, and grasses were found several hundred miles from the nearest land.

MEIER and LINDBERgh (I935) found pollens, as well as fungus spores, diatoms, and insect wings, in Arctic air several hundred miles from land and at an elevation exceeding 3000 feet.

Pollen surveys over the ocean at different elevations made by air-lines and other agencies show that, while pollens are widely distributed, their abundance drops off sharply with distance from land and in the face of marine air currents.

Aerial transport of marine bacteria:- There is ample evidence that bacteria, mold spores, and pollens from the land are carried around the world by the wind. Marine microorganisms likewise may be widely disseminated by the movements of the atmosphere, although there are few data on the transportation of marine bacteria inland.

From an onshore wind having a velocity of 5 to 12 miles per hour following a rainstorm, ZoBELL and MATHEws (I936) recovered appreciable numbers of marine bacteria from air on a mountain 80 miles inland. Some marine bacteria probably fall with precipitation, but at inland stations their presence is masked by the preponderance of terrestrial forms.

Microorganisms are introduced into the air over the land by atmospheric disturbances of various kinds, by the movements of animals, and by other agencies. Bacteria are being carried continually from the sea into the air, along with droplets of water. The transfer is most intense along rugged coasts when waves are dashed against rocks or along gently sloping shores where the incoming swell breaks into foam. The transfer is most extensive in the open sea where strong winds often blow spray from crests of waves. Large droplets fall back into the sea almost at once but small ones may be lifted to great elevations by advection and convection currents, and carried away by the wind to regions far removed from the place of origin. The almost universal distribution of sea salt in the air makes this manifest.

TABLE XXXVII. - Rate of fall of water droplets through air and the minimum distance they would be carried by a steady Io mile per hour wind before they fell Ioo meters in the absence of turbulence:-

$\begin{array}{cc}\text { DIAMETER OF } & \text { RATE OF FALL } \\ \text { DROPLET } & \text { OF DROPLET } \\ \text { microns } & \mathrm{cm} . / \mathrm{sec} \\ \text { I } & 0.003 \\ 5 & 0.076 \\ \text { IO } & 0.305 \\ 50 & 7.6 \\ \text { 100 } & 30.5 \\ 500 & 760.0\end{array}$

DISTANCE CARRIED
BY IO M.P.H. WIND
miles
9260.0
366.0
92.0
3.6
0.9
0.036

According to evidence summarized by ZoBELL (I942C), droplets of water exceeding $1.0 \mathrm{~mm}$. in diameter may be conveyed several thousand feet above sea level by convection currents, by orographic uplift, and by vertical motion caused by converging winds (see Fig. I2). In the absence 
of any lifting force whatever, a water particle $0.5 \mathrm{~mm}$. in diameter could be carried about a mile by a steady wind having a velocity of 10 miles per hour before it fell roo meters. Larger droplets would not fall much faster because they break into small ones when they attain a velocity exceeding 800 meters per second, unless frozen solid as in hailstones. The rate of fall of water droplets of different sizes through air as calculated from SToke's law of falling bodies is given in 'Table XXXVII on page I 80. The calculations are based upon a steady state in which there is no turbulence. Since there is nearly always some degree of turbulence which may tend to retard the descent of falling bodies or actually carry them to higher elevations, and since the wind velocity often exceeds ro miles per hour, the physical possibilities for the world-wide aerial transport of bacteria become apparent.
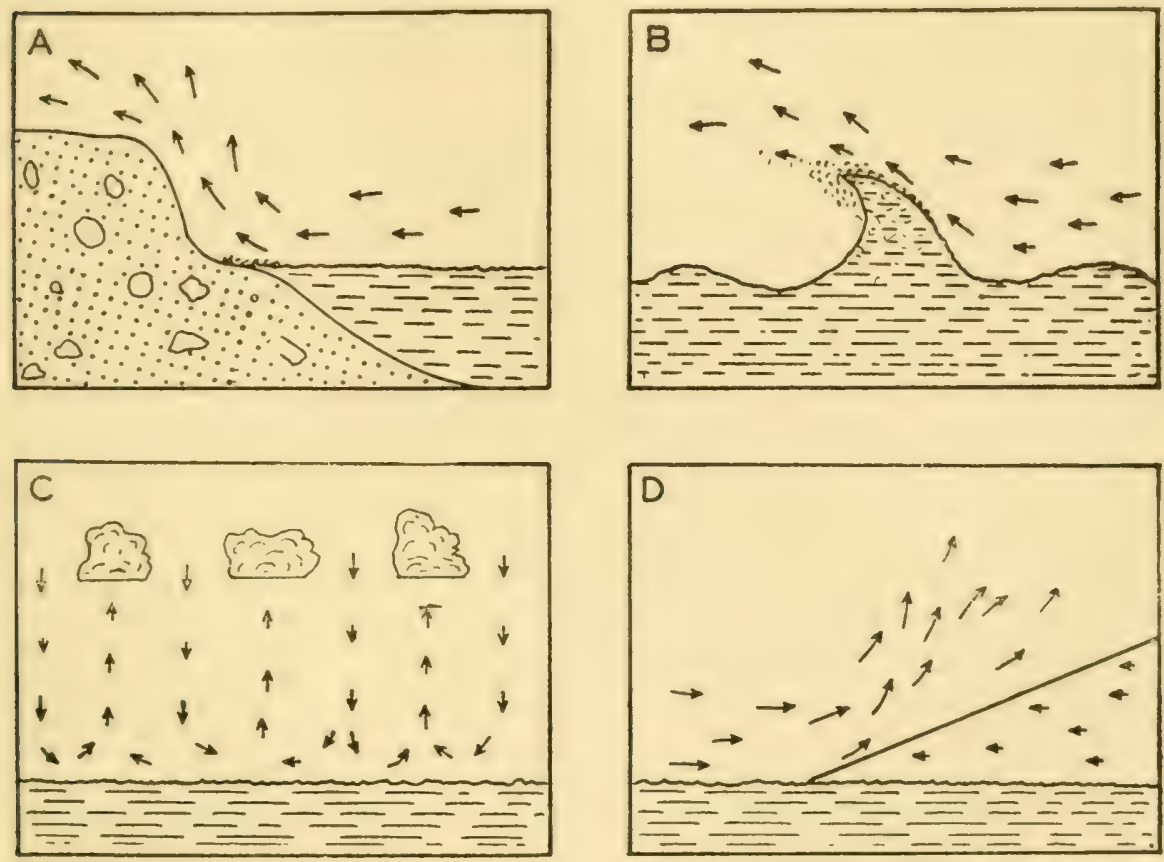

FIG.12. - Principal ways in which bacteria in sea water are carried into the atmosphere: (A) orographic uplift, (B) spray from crests of waves some of which are 20 to 30 feet high, (C) convection, and (D) convergence of light warm air mass and heavy cold air front (taken from ZoBELL, 1942C).

The horizontal distance over which microorganisms can be transported is almost limitless and is largely determined by their ability to survive the atmospheric environment. The presence of microorganism in the atmosphere at great elevations, far removed from their native habitats, shows that certain forms may survive the adversities of the atmospheric environment for long periods of time.

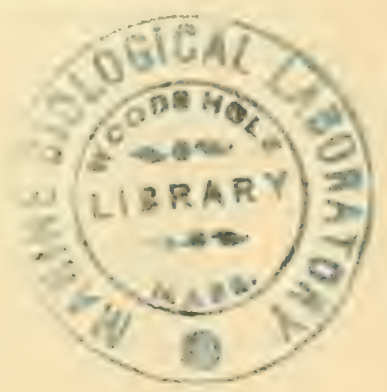




\section{Chapter XVI}

\section{SANITARY ASPECTS OF MARINE MICROBIOLOGY}

Treatises on "water bacteriology" are generally concerned primarily with the study of the sanitary properties of domestic water supplies, swimming pools, and sewage. For various reasons sea water is rarely considered. Nevertheless, the sea does present certain problems of interest to sanitary engineers and students of public health. Outbreaks of oysterborne typhoid and the development of beaches for recreational purposes have focussed attention upon some of these problems in recent years. The problems are of acute interest to those municipalities discharging raw or partially treated wastes into oceans, bays, or estuaries.

Human pathogens in sea water:- It is the consensus of opinion that there are no autochthonous marine bacteria which infect man, but the literature is replete with contradictory accounts of the viability of adventitious pathogens in sea water. Some workers hold that sea water is highly lethal for bacteria from land-dwelling animals while other workers present data which indicate that such bacteria can live almost indefinitely in the sea. A reconciliation of the divergent views requires that several factors which influence the survival of bacteria in sea water be taken into consideration. Artificial, synthetic, diluted, or autoclaved sea water, which has been used for many of the experiments, does not necessarily simulate natural sea water, and the biological properties of the latter may vary greatly.

In his studies on the factors which influence the survival of pathogenic bacteria, DE GIAXA (I889) observed that enteric bacteria perish very soon in the sea. He found more than 100,000 bacteria per $\mathrm{ml}$. of sea water 50 meters from a sewage outfall in the Gulf of Naples, 26,000 at a distance of 350 meters, and fewer than 100 per $\mathrm{ml} .3000$ meters from the sewage outfall. Controlled experiments showed that Bacillus anthracis and Vibrio comma were unable to compete with saprophytes in polluted sea water. The typhoid bacillus and pathogenic species of Stapliylococcus were even less resistant. Vibrio comma lived for several days in heatsterilized sea water, but in untreated sea water it soon disappeared. The period of survival was a function of the organic content and the bacterial population of the water. In grossly polluted water these organisms survived for less than 24 hours.

Experiments of various authors summarized by FRANKLAND and FRANKLAND (1894) show that, in general, human pathogens do not survive as long in sea water as in fresh water, although it is related that Vibrio comma was observed by NICATI and RIETSCH to remain viable in sterilized sea water for as long as $8 \mathrm{I}$ days.

According to SOPER (I 909 ), the virulence of Eberthella typhosa is not reduced by sea water in two or three weeks. The persistence of $E b$. typhosa in refrigerated oysters for 49 days is reported by KRUMWIEDE el al. (1926), who believed that a few typhoid bacilli may live for several months. Repeatedly washing the oysters with fresh sea water materially reduced the number of surviving typhoid bacilli. The occurrence of paratyphoid bacilli and other pathogens in sea water is discussed on page I9I. 
In experiments designed to simulate natural conditions in polluted sea water, BEARD and MEADOWCROFT (1935) noted a rapid diminution in numbers of both Eberthella typhosa and Escherichia coli, although some of each survived for more than a month. Representative findings are summarized in Table XXXVIII. The bacteria were suspended in freshly collected unfiltered water from San Francisco Bay in semipermeable membrane cells which were immersed in the bay. The rate of death of the bacteria was invariably higher in unfiltered water than in similar water which was sterilized by passage through an $\mathrm{L}-3$ Chamberland candle.

TABLE XXXVIII. - Number of enteric bacteria in filtered and unfiltered sea water in scmipermeable cells immersed in the sea (from BEARD and MEADOwCrorT, 1935):-

\begin{tabular}{|c|c|c|c|c|}
\hline \multirow{2}{*}{$\begin{array}{l}\text { Trume } \\
\text { IN } \\
\text { DAYS }\end{array}$} & \multicolumn{2}{|c|}{ Eberthella typhosa PER ML. IN } & \multicolumn{2}{|c|}{ Escherichia coli PER MIL. IN } \\
\hline & $\begin{array}{l}\text { FilTERED } \\
\text { SEA IVATER }\end{array}$ & $\begin{array}{l}\text { UNFILTERED } \\
\text { SEA WATER }\end{array}$ & $\begin{array}{l}\text { Filtered } \\
\text { SEA WATER }\end{array}$ & $\begin{array}{l}\text { UNFILTERED } \\
\text { SEA WATER }\end{array}$ \\
\hline 0 & $300,000, \infty 00$ & $300,000,000$ & $500,000,000$ & $500,000,000$ \\
\hline $\mathbf{I}$ & $84, \infty 00, \infty 00$ & $23,400,000$ & $x 60, \infty 00, \infty 00$ & I $50,000, \infty 00$ \\
\hline 2 & $50,000,000$ & $I_{4}, 100,000$ & $I 44,500,000$ & I $25,000,000$ \\
\hline 4 & $10,800,000$ & $9,000,000$ & $51,500,000$ & $37, \infty 00,000$ \\
\hline 6 & $7,200,000$ & $3, \infty 00,000$ & $30,5 \infty 0,000$ & $23,000,000$ \\
\hline 12 & 270,000 & 60,000 & $12,000,000$ & II $, 000,000$ \\
\hline 20 & $10, \infty 00$ & 2,000 & $3,750,000$ & $2,650,000$ \\
\hline 35 & $\circ$ & $\circ$ & 1,200 & 975 \\
\hline
\end{tabular}

Similar results were obtained by ZoBeLL (1936), who suspended sewage bacteria in different kinds of water in the sea in semipermeable tubes prepared by impregnating porous porcelain filter candles with collodion:

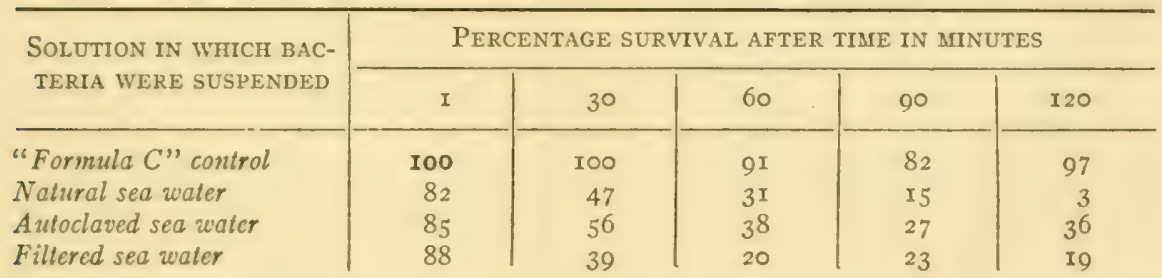

The "natural" sea water was unfiltered and unheated. The "filtered" sea water was passed through a Berkefeld-W candle. A continuation of the experiment summarized above showed that, while 99.9 per cent of the sewage organisms were killed after two days suspension in sea water, a few survived for nearly a month. CARPENTER et al. (I938) found that natural sea water killed 80 per cent of the organisms in sewage within half an hour.

Porcelain or diatomaceous earth filters may remove marine saprophytes with which the terrestrial organisms cannot successfully compete, or may adsorb bactericidal substances from sea water. KIRIBAyAsHI and AIDA (I934) found that Vibrio comma lived much longer in boiled or sterilized sea water than in comparable raw sea water. The average survival time of this organism in harbor water of Kellung, Formosa, was Io days. GELARIE (I9I6) estimated that Vibrio comma could be eliminated by the natural flora and other adverse conditions in New York harbor water within 48 hours.

Water from the Black Sea was found by KRASSILNIKov (I938) to be germicidal for terrestrial bacteria until boiled. Passing the water through 
a Seitz filter rendered Black Sea water less bactericidal for adventitious organisms. KRASSILNIKOV stressed the importance of the organic content of water as a factor which affects the survival of bacteria.

Coliform bacteria surveys:- The sanitary significance of Escherichia coli, Aerobacter aerogenes, and other coliform bacteria in the sea is contingent upon two important considerations. First, do the intestinal tracts of marine animals normally harbor such organisms, and secondly, how long do coliform bacteria of fecal origin survive in the sea?

Large numbers of coliform bacteria are introduced in the sea by land drainage, particularly in raw and partially treated sewage. It is estimated from data given by WARREN and RAWN (I938) that enough coliform bacteria are discharged by sewage effluents along the west coast of the United States each day to give over a hundred for every liter of water in the North Pacific Ocean, if evenly distributed. However, such organisms are found only in tide water, harbors, and bays, which are often badly polluted. Comparable sanitary conditions were found by WESTON (I938) on the east coast of the United States.

Extensive surveys around the Hyperion outfall shows the rapidity with which coliform bacteria succumb in the sea. This outfall carries raw sewage from nearly two million inhabitants of Los Angeles a mile into the ocean. As may be expected, millions of coliform bacteria per $\mathrm{ml}$. are often found near the sewer outlet. The number decreases with distance from the outlet much more rapidly than can be accounted for by dilution. Surveys, summarized by KNOwLTON (I929), indicate that even during onshore winds and currents the count is often less than ro coliform bacteria per ml. in the surf. As many or more Escherichia coli may be introduced by bathers on the beach. Under no conditions were coliform bacteria traced more than a mile or two from sewer outfalls in the open ocean. The effect of air currents, water movements, composition of the sewage, and other factors which influence the distribution of $E$. coli were considered by a commission appointed by the California State Bureau of Sanitary Engineering (I 943). Only in solids or greases were coliform bacteria found to be able to survive for long periods of time in the sea.

Similar observations were made in Europe by DIENERT and GUILLERD (I940) who concluded that, while sea water is neither antiseptic nor inimical to $E$. coli, sewage discharged into the sea is rapidly purified by sedimentation, predatory organisms, and dilution. Lloyd (I930) was impressed by the virtual freedom of Clyde Sea water from coliform bacteria of fecal origin.

ZoBELL ( $194 \mathrm{I} b$ ) failed to find coliform bacteria in any of 96 $\mathrm{I}$ samples of sea water collected at stations remote from possibilities of terrigenous contamination, although large numbers were found in polluted bays and estuaries. Positive presumptive tests were obtained from the intestinal contents of 203 of the 387 marine fishes examined. The coliform bacteria isolated from the fishes were identified as follows using the "IMVIC" tests:

Escherichia coli Aerobacter species Citrobacter species
6 per cent

73 per cent

2 I per cent

Imvic is a mnemonic which fixes in order the four tests commonly used in classifying coliform bacteria: (I) indol formation, (M) methyl-red reac- 
tion, (V) Voges-Proskauer test, and (C) utilization of citrate as a sole carbon source (PARR, I939). E. coli was found only in feedy fishes taken relatively near shore. Aerobacter species were more abundant than $E$. coli in the intestinal tracts of fishes. From the survey it was concluded that $E$. coli or other bacteria which ferment lactose with gas production do not constitute part of the normal intestinal flora of marine fishes, although, if ingested, such bacteria may survive for considerable periods of time.

The absence of $E$. coli from Buzzards Bay and Vineyard Sound near Woods Hole was reported by Browne (I917). E. coli was found in the intestines of only 39.8 per cent of 93 scup which he examined. Clostridium welchii was found in 30.1 per cent of the fishes. The presence of these bacteria in the fishes' intestines seemed to be a function of the amount and type of food present.

After noting that the bacteria in fewer than half of the 72 offshore fishes which he examined produced gas in lactose broth, GibBons ( 1934 ) concluded that $E$. coli and Aerobacter aerogenes are present only in fish from contaminated water. He found $E$. coli in only 6.9 per cent of the positive lactose broth cultures. GRIFFITHS and FULLER (I936) detected only a few $E$. coli in commercial fish, from which they concluded that the $E$. coli content of fish is largely due to handling. Additional literature reviewed by GRIFFITHS (I937) indicates that $E$. coli is not a normal intestinal inhabitant of marine fishes.

The intestinal contents of sea fowls are generally reported to be free from coliform bacteria except in certain cases where there is evidence that the fowls have been feeding in polluted waters. Little is known regarding the intestinal flora of marine mammals. E. coli does not appear to be a normal inhabitant of the intestines of seals in captivity.

The general absence of coliform bacteria in the sea except in areas known to be polluted with sewage confirms the validity of the test for coliform bacteria as an indicator of sewage pollution. It follows that, wherever large numbers of $E$. coli are found in the sea, the possibility exists of typhoid, dysentery, and cholera organisms also being present. Although epidemics of these gastro-intestinal diseases have never been traced to bathing beaches, outbreaks of typhoid have been traced to infected oysters.

Coliform bacteria are commonly present in small inland lakes which are more subject to pollution than the ocean. The coliform bacteria count of the hypolimnion of lakes was found by TAYLOR (I94I) to be very low and relatively constant. More coliform bacteria were found in the epilimnion where the numbers were greatest in summer and autumn, despite less terrestrial pollution during the summer. About 70 per cent of the coliform bacteria isolated from lakes by TAxLOR were $E$. coli types.

Other sanitary problems of hydrobiological interest are reviewed by Whipple (ig27), Prescott and Winslow (r931), Nikitinsky (I938), GATNEY (I939), and SuCKLING (I943).

Bacteriology of shellfish:- Oysters, clams, and mussels are often eaten raw or in a partially cooked condition. As a result, numerous cases of typhoid fever and Asiatic cholera have been traced to the ingestion of contaminated shellfish. Though normally free from dangerous bacteria in clean water, the pollution of bays and estuaries with unpurified sewage renders shellfish a potential source of infection. According to PRESCOTT and WinsLow (I93I) who reviewed the literature on this subject, "In 
practically all of the American epidemics which have been traced to shellfish, it was demonstrated that the oysters which caused the outbreak had been 'floated' or 'fattened' in brackish water near the mouths of polluted streams." Rigorous control measures have done much to lessen the incidence of shellfish-borne diseases during the last two or three decades.

The control of the sanitary conditions under which shellfish are raised and handled is a constant problem for health officials. Although typhoid fever is the disease most often discussed in this connection, such diseases as cholera, diarrhoea, and gastroenteritis also may be transmitted by shellfish (TANNER, I944). Botulism from shellfish is of very rare occurrence. Obviously oysters that have been grown or floated in polluted water are undesirable as articles of human food, regardless of whether or not they contain specific organisms of disease. Several instances of the demonstration of typhoid bacilli in shellfish are related by HuNTER and HARRISON (I928). These workers record evidence for the survival of typhoid bacilli in oysters for from 9 to 42 days and of Escherichia coli for from 7 to $I 7$ days. Shellfish poisoning is discussed on page 199 .

Dodgson (I928) gives experimental evidence that Eberthella typhosa survived in oysters, mussels, and other shellfish in sea water for more than three weeks. He cites several epidemiological instances of the prolonged survival of virulent typhoid bacilli in mussels and oysters.

Large numbers of saprophytic bacteria are ordinarily associated with oysters. These are considered of little sanitary significance except that they promote the decomposition of shellfish. This can be retarded by proper refrigeration, although some marine bacteria slowly multiply at low temperatures. TANIKAWA (I937) reported the slow multiplication of bacteria in oysters at $0^{\circ} \mathrm{C}$. There was little or no multiplication at $-5^{\circ} \mathrm{C}$., as shown by the data in Table XXXIX.

TABLE XXXIX.- Bacterial populations of oyster meats after different periods of storage at different temperatures (from TANIKAWA, I937):-

\begin{tabular}{c|c|c|c}
\hline \multirow{2}{*}{$\begin{array}{c}\text { Storage } \\
\text { PERIoD }\end{array}$} & \multicolumn{2}{|c|}{ BACTERIA PER MI. OF OYSTER MEAT STORED AT } \\
\cline { 2 - 3 } & $5^{\circ} \mathrm{C}$ & $0^{\circ} \mathrm{C}$. & $-5^{\circ} \mathrm{C}$. \\
\hline o days & $\mathrm{I}, 600$ & $\mathrm{I}, 600$ & $\mathrm{I}, 600$ \\
6 days & 6,600 & 3,600 & 3,400 \\
I7 days & 66,500 & 4,100 & 2,700 \\
24 days & $\mathrm{I}, 600,000$ & 8,900 & $\mathrm{I}, 800$
\end{tabular}

Tonney and White (r926) noted a $45^{8}$ per cent increase in the Escherichia coli content of shucked oysters held for I2 days at $5.8^{\circ} \mathrm{C}$. In another lot of oysters the $E$. coli score increased I 490 per cent in II days at $5.8^{\circ} \mathrm{C}$. The $E$. coli content of living oysters did not decrease from the eleventh to the $23 \mathrm{rd}$ day when stored at $5.8^{\circ} \mathrm{C}$. After the 28 th day a consistent decrease was noted, and after the 6oth day the $E$. coli tests were negative.

The Committee on Standard Methods for the Examination of Shellfish of the American Public Health Association has outlined methods for collecting, handling, transporting, and examining oysters for their $E$. coli content. Oyster meats are scored by determining the highest dilution, increasing by powers of $\mathrm{IO}$, in which the presence of $E$. coli is confirmed by the use of appropriate differential media. The results are recorded as the 
numerical value of the greatest dilution in which $E$. coli is found. The sum of five such values is the "score." An illustrative example follows:

\begin{tabular}{|c|c|c|c|c|}
\hline \multirow{2}{*}{$\begin{array}{l}\text { Test } \\
\text { No. }\end{array}$} & \multicolumn{3}{|c|}{ CONFIRMED PRESENCE OF $E$. coli IN } & \multirow{2}{*}{$\begin{array}{l}\text { Numericat } \\
\text { Value }\end{array}$} \\
\hline & I.O ML. & O. I ML. & ०. or ML. & \\
\hline I & + & + & - & 10 \\
\hline 2 & + & - & - & I \\
\hline 3 & + & - & - & I \\
\hline 4 & + & + & - & ro \\
\hline 5 & + & + & - & 10 \\
\hline
\end{tabular}

The necessity of confirming the presence of $E$. coli with dependable tests is emphasized by PERRY (I939) who points out that other types of coliform bacteria associated in large numbers with shellfish may have no sanitary significance. He recommends the Eijkman test in which the differential media are incubated at $46^{\circ} \mathrm{C}$. in order to eliminate Aerogenes, Citrobacter, and other coliform types of bacteria which ferment lactose. PERRY found that only O.I to ro per cent of the coliform organisms in oysters from Chesapeake Bay were $E$. coli. There was no constant relationship between the two groups. Oftentimes no $E$. coli were found in Ioo grams of freshly shucked or market oysters in which several thousand representatives of the coliform group were demonstrated. Experimental results of many investigators show convincingly that $E$. coli is not an inhabitant of normal, unpolluted oysters (HUNTER and HARRISON, I928). Likewise Clostridium welchii, $\mathrm{Cl}$. aerogenes, Aerobacter aerogenes, A. cloacae, and Streptococcus faecalis are not found in normal, unpolluted oysters, although oysters are often contaminated with these organisms. Additional data and many references are given by TANNER (I944) on the significance of oysters in the dissemination of disease, the purification of shellfish, microorganisms in market oysters, the bacteriological examination of shellfish, and other aspects of the microbiology of shellfish.

Oysters themselves may be susceptible to bacterial diseases. The death of a large number in English oyster beds in I920 and I92I was attributed by some investigators to bacterial infection, but doubt is expressed by EYRE (1923). From diseased as well as from healthy oysters, EYrE isolated two new species, Vibrio fuscus and Spirillum ostreae. He also demonstrated the presence of Cladothrix dichotoma, five species of Bacillus, and two micrococci, which he believed to be variants of Micrococcus cimnebareus. None of these organisms appeared to be pathogenic for oysters.

Spirochaetes ostensibly parasitic in the gut of oysters were found in the digestive tract of 9I per cent of the Baltimore, Maryland, market oysters examined by Dimitroff (I926b). He identified Saprospira grandis, S. lepta, S. puncta, Cristospira anodontae, Cr. speculifera, Cr. modialae, $\mathrm{Cr}$. temua, Cr. mina, Cr. balbianii, and Spirillum ostreae. Earlier, DnmtrofF (1926u) described Spirillum airginianum which he found associated with oysters. BERGEY er al. (I939) report that Cristospira interrogationis and $\mathrm{Cr}$. pinnae were isolated from the intestinal canal by the scallop, Pecten jacobaeus.

The spoilage of oysters takes place in three stages, according to ELIOT (1926). First there is a period of rapid increase in acidity due to the bac- 
terial fermentation of glycogen, followed by a period of abundant gas production. Proteolytic bacteria subsequently complete the disintegration of the oyster tissue.

Bacteriology of marine fish:- Woon (I940) deduced, from the absence of coliform bacteria in fish, that the likelihood of marine fish conveying typhoid, dysentery, or other enteric infections to man is very remote except through careless handling. This deduction is in complete harmony with the findings of GRIFFITHS and FULLER (1936) and GIBBONS $(I 934 b)$. From his extensive survey, GibBons (I934b) concluded that representatives of the genera Escherichia and Aerobacter seldom occur in fish taken from waters at considerable distances offshore. "The fecal forms are particularly rare, except in fish taken near shore or in contaminated waters."

Only II of the 4I 2 cultures isolated from the intestines of salmon by FELLERS (I926) proved to be $E$. coli. The kinds of bacteria which he found in fish slime were essentially the same as those in decomposing salmon flesh. Sarcina lutea, Micrococcus varians, and an acid-forming Streptococcus predominated. Fresh salmon slime contained 370 bacteria per $\mathrm{ml}$. After two hours at $16.7^{\circ} \mathrm{C}$. the count increased to 1,950 bacteria per $\mathrm{ml}$, and after 24 hours there were $3,900,000$ bacteria per $\mathrm{ml}$. of slime. FELLERs concluded, as did HunTER (1922), that the organisms responsible for decomposition of marine fish are those whose normal habitat is sea water or fish slime. HunTER isolated $3 r 6$ cultures, including 85 different species, from sea water, decomposing salmon, and salmon canneries. All of them were asporogenous rods except 4 streptococci, 3 sporogenous rods, I actinomyces, and I pink yeast. Four coliform bacteria were identified.

Species of Bacillus predominated among the organisms isolated from mackerel, haddock, halibut, sole, smelt, and butter-fish studied by HARRISON et al. (1926). The tissues of fresh fish were found to be sterile. The gills act as an important source of infection. Puncturing or otherwise damaging fish introduces bacteria from the slime and intestinal contents. Fish decompose more rapidly when the alimentary canal is full of food than when empty. If fish are beheaded, eviscerated, and frozen soon after catching, they may be kept safely for several months. Spoiled fish may contain up to $400,000,000$ bacteria per gram.

Bacteria isolated from the surface slime of haddock were identified by Reed and Spence (I929) as follows: 24 per cent Bacillus, 23 per cent Achromobacter, 22 per cent Pseudomonas, I 8 per cent Proteus, 8 per cent Flavobacterium, and 4 per cent Micrococcus. In the intestinal contents of haddock 7o per cent of the bacteria were Proteus species. Members of the coli-aerogenes group were found in the intestinal contents of haddock only occasionally and never in the integumental slime. Achromobacter-like species predominated in the slime of haddock examined by STEWART (I 932), followed in abundance by Micrococcus, Flavobacterium, and Pseudomonas. Escherichia coli was not found, and very few species of Aerobacter were isolated from haddock.

From the slime and feces of 43 marine fish, representing I I different species, Grbbons (I934a) isolated 80 pure cultures of bacteria, including 3I Achromobacter, I8 Flavobacterium, I 5 Micrococcus, 5 Pseudomonas, 5 Bacillus, 2 Proteus, I Eberthella, and I Scrratia. Taken collectively, the bacterial flora of slime was found to be similar to that of fish feces. Most investi- 
gators agree that the numbers and kinds of bacteria in the intestinal tract of fish are dependent primarily upon the food ingested recently. According to Hunter (I920), Griffitus (1937), and others, the stomach and intestine of fasting fish are frequently bacteria-free.

The flora, which WooD ( 1940 ) isolated from salmon, barracouta, whiting, mullet, and flathead taken from Australian waters, has a great deal in common with that isolated from marine fish in other parts of the world (see Table XL). He found that, if properly handled, fish may be kept for as long as 8 days at $7^{\circ}$ to $8^{\circ} \mathrm{C}$. without becoming too stale to be edible. After finding virtually no coliform bacteria of fecal origin, WooD concluded that there should be little danger of epidemics due to the consumption of fish, provided that a wide berth is given to sewer outfalls by fishermen.

TABLE XL. - The bacterial flora associated with fish and water, expressed as a percentage of the cultures examined (from WOOD, I940):-

\begin{tabular}{|c|c|c|c|c|c|}
\hline GENUS & SEA TVATER & SLIME & GuT & Grlus & TAP WATER \\
\hline & $\%$ & $\%$ & $\%$ & $\%$ & $\%$ \\
\hline Acliromobacter & 26 & I9 & 30 & $3 I$ & 30 \\
\hline Micrococcus & 34 & 48 & $2 I$ & $4 I$ & 4 \\
\hline Pseudomonas & IO & 7 & IO & 7 & 50 \\
\hline Flasobacterium & I8 & 17 & I & 12 & 8 \\
\hline Bacillus & I 2 & 9 & 35 & 9 & 8 \\
\hline
\end{tabular}

From salmon of North Pacific waters, SNow and BEARD (I939) isolated 1838 cultures which they identified as follows:

\begin{tabular}{lc|lc}
\multicolumn{1}{c|}{ GENus } & PER CENT & GENUS & PER CENT \\
Achromobacter & 53.7 & Bacillus & I.5 \\
M icrococcus & I2.6 & Serratia & 0.9 \\
Pseudomonas & 8.4 & Rhodococcus & 0.8 \\
Kurthia & $8 . \mathrm{I}$ & Yeasts & 0.5 \\
Flavobacterium & 4.9 & Aerobacter & 0.4 \\
Proteus & 3.4 & Staphylococcus & 0.3 \\
Lactobacillus & $2 . \mathrm{I}$ & Streptococcus & 0.2 \\
Sarcina & 2.0 & Escherichia & 0.1
\end{tabular}

The last four were found only in Columbia River salmon. Additional information on the kinds of bacteria associated with marine fish is given on page 172 .

The controversial question of the bacterial content of fish flesh is reviewed by GRIFFrTHS (1937). It is generally agreed that the muscles of healthy fish are usually sterile, although some investigators have experienced difficulty in consistently obtaining sterile fish tissue. Infection of the muscle occurs immediately after death, and the bacterial population increases rapidly at a rate which is influenced primarily by the temperature. HunTER (I920) observed an increase in the flesh of salmon from zero at the time of catching to as high as $155,000,000$ per gram after 96 hours' storage at from $10^{\circ}$ to $2 \mathrm{I}^{\circ} \mathrm{C}$. During this period of storage the salmon may be so decomposed as to become unfit for human consumption.

KISER and BECKWITH (I944) found from none to 30,000 bacteria per gram of muscle tissue of freshly caught mackerel and from none to $64,000,000$ per gram of intestinal contents. Predominating were species of Micrococcus, Achromobacter, Pseudomonas, Flavobacterium, Sarcina, Kurthia, Lactobacillus, and Streptococcus in the order named. 
After finding only from 20 to 625 aerobic and from none to 60 anaerobic bacteria per gram of fish tissue, Highlands and Williams (I944) concluded that the chief hazard in the canning of sardines is in the handling and processing and not in the bacterial flora normally associated with fish. The bacterial population increased rapidly during processing preparatory to canning. The increase was related more to the nature of the packing table surface than to any other single factor. Neither thermotolerant nor thermophilic varieties were encountered. Halophilic bacteria were present only in low numbers. Eight per cent salt was required to inhibit bacterial growth for a commercially practicable period of time.

The spoilage of fish may be retarded or prevented by proper handling to minimize infection of the muscle tissue and by refrigeration. While many bacteria associated with marine fish multiply slowly and are otherwise biochemically active at temperatures ranging from $0^{\circ}$ to $-5^{\circ} \mathrm{C}$. (BEDFORD, I933a, $b$; GibBONs, I934c; Hess, r934a, $b$ ), their proteolytic activities are minimized by refrigeration at sub-zero temperatures. Fastfreezing and storage of mackerel at $-28^{\circ} \mathrm{C}$. was found by KISER and BECKWITH (I942) to allay absolutely all bacterial activity. In fact, they observed a decrease in the bacterial flora, including species of Achromobacter and Micrococcus, in I5 days at $-20^{\circ}$ C. HESS (I934a) reported reductions of from 40 to 70 per cent in suspensions of marine bacteria frozen in sea water for eight minutes at $-16^{\circ} \mathrm{C}$., but all organisms were not killed after 44 hours at this temperature. Some of the bacteria were actively proteolytic at $-3^{\circ} \mathrm{C}$.

GRIFFITHS (I937) reports a sharp rise in the bacterial population in haddock flesh stored in ice. After 7 to II days, counts of 100,000 or more bacteria per gram were found to indicate rapid subsequent decomposition. Fish having $I, 000,000$ or more bacteria per gram were not considered to be marketable. GRIFFITHS emphasized the desirability of additional research to establish bacteriological standards for acceptable quality of fish.

Bacteria often affect the marketability of fish by causing discoloration. BecKwith (I9I I) described Diplococcus gadidarum which caused the reddening of cod and allied fishes. KELLERMAN ( 19 I $_{5} b$ ) who called it Micrococcus gadidarum, isolated a similar red organism, Micrococcus litoralis, from salted codfish. KLEBAHN (I grg) found Micrococcus morrhuae, Sarcina morrhuae, and Bacterium halobium rubrum associated with reddened dry cod. GibBons (I937) found 30 species of halophilic bacteria, including two species of Serratia, associated with the reddening of salted fish. A pink yeast, Torula wehmeri, along with Micrococcus albus-translucens, Micrococcus lutulentus, and Bacterium zopfii were isolated from reddened codfish by HANZAWA and TAKEDA (I93I). Clathrocystis roseo-persicina, Oidium pulvunatum, Micrococcus roseus, Serratia salinaria, Vibrio halobicus desulfuricans, and Torula epizoa have been credited with causing the discoloration of codfish, according to TANNER (I944).

The greenish-yellow discoloration of halibut was attributed primarily to Pseudomonas fluorescens by HARRISON (I929), who also isolated from halibut Flavobacterium marinum, $\mathrm{Fl}$. balustinum, $\mathrm{Fl}$. fucatum, $\mathrm{Fl}$. mari, and Achromobacter pellicidum. BEDFORD (I933a) attributed the discoloration and subsequent souring of halibut to the activity of various pink, orange, and yellow marine bacteria, in addition to the fresh-water Ps. fluorescens. All of the bacteria were active at $0^{\circ} \mathrm{C}$., and some developed at $-5^{\circ} \mathrm{C}$. 
Sanitation of sea-water baths:- The dangers from bathing in polluted waters are well known. Gastro-intestinal infections and certain respiratory infections have been traced to infected swimming pools. Some health officers in coastal cities have mistakenly assumed that sea-water pools do not present the same sanitary problems as do fresh-water pools. Though summarized epidemiological data are not at hand, there are fragmentary accounts of communicable diseases having been contracted in sea-water baths. The prolonged survival of pathogenic bacteria in modified sea water is indicative of the public health hazards.

Unless properly treated, sea-water swimming pools may be more menacing than fresh water. Municipal water supplies used as a source of fresh water for swimming pools are usually sanitary, whereas sea water may be pumped directly from polluted bays or beaches. Moreover, the chlorination or chemical treatment of sea water presents unique problems owing to its salt content.

The control of algal growths in sea-water pools exposed to light presents another problem. When enriched with nitrogenous wastes from bathers, both sessile and planktonic algae grow most profusely in sea water.*

Bacteriology of ice:- The bacterial content of sea ice presents no special sanitary problems because there is little likelihood of human pathogens being in the sea, and little sea ice is used for the preservation of foods or for the preparation of drinks. These generalizations, however, do not apply to the large quantities of ice which are harvested from lakes and rivers. From his review of the literature and his own investigations, JENSEN (r943) concluded that, if ice harvested from lakes is handled properly, it is not an important factor in the spread of typhoid or other enteric fevers. It is always a potential source of danger, though, because bacteria, such as the typhoid bacillus, may remain viable for several months in ice.

Frankland and Frankland (I894) described experiments of PrudDEN in which there were I million typhoid organisms per ml. of ice held at from $0^{\circ}$ to $-10^{\circ} \mathrm{C}$. for II days, 72,000 after 77 days, and 7,000 after 103 days. The typhoid bacillus tolerated continuous low temperature in ice better than alternate freezing and thawing. According to the FRANKLANDS, ice from various lakes in the vicinity of Berlin contained from a few to as many as 14,400 bacteria per $\mathrm{ml}$.

JENSEN (I943) found coliform bacteria in only a small percentage of the samples of ice recently harvested from lakes of the upper Mississippi River valley. An average of 22 coliform bacteria per liter were detected

* According to an editorial in Public Health News, of New York State Department of Health, Volume I 2, No. 3, page 402 , polluted harbor waters may be responsible for outbreaks of conjunctivitis, otitis, tonsilitis, rhinitis, sinusitis, sore throat, furuncles, laryngitis, and ringworm, besides various enteric infections. The Second (vaarterly Report of the lew lork State Department o1 Health for 1932 states "from all of the data on hand it is very probable that most of the increase (in typhoid fever) may be charged to bathing in polluted harbor waters condemned by the Department of Health." A higher incidence of typhoid fever was observed in the city blocks bordering waterfronts and tide flats. The California Bureau of Sanitary Engineering (194.3) details the case of a lifeguard who presumably contracted paratyphoid fever from gulping several swallows of surf water while making a rescue near El Segundo, California. In this region both Paratyphoid $\mathrm{A}$ and $\mathrm{B}$ organisms were isolated from water samples taken 200 or 300 feet of the Hyperion outfall. As a result of a sanitary survey of certain beaches around Los Angeles, the Bureau has caused to be posted signs which read, "WT.IR.VIYG: This bearh from high tide line seawarl, incluclins adjacht shore waters, is polluted with sewage and is dangerous to health. The public is excluded from these areas under order of the California State Board of Public Health." Schistosomiasis or swimmer's itch and fungus infections are not uncommonly contracted by sea bathers. 
in $4 \mathrm{I}$ cakes of ice examined in I943. The average aerobic plate count was 4 per ml. at $37^{\circ} \mathrm{C}$. and 7 per ml. at $20^{\circ} \mathrm{C}$. Fifteen samples were sterile or showed fewer than two bacteria per ml. JENSEN asserted that Escherichia coli died off in ice more rapidly at $0^{\circ}$ to $-5^{\circ} \mathrm{C}$., the temperature of natural ice on lakes, than at $-20^{\circ} \mathrm{C}$. or lower. $E$. coli remained viable for long periods when frozen in distilled water at $-16^{\circ},-40^{\circ}$, and $-79^{\circ} \mathrm{C}$. Species of Achromobacter, Aerobacter, Bacillus, Cellulomonas, Chromobacterium, Flavobacterium, Micrococcus, Proteus, Pseudomonas, Serratia, and $S$ pirillum were found in newly harvested lake and river ice. Bacteria were found in polar ice and snow by Gazert (Ig02), McLEAN (I9I8), and DARLING and SiPLE (I94I).

It was directed to the attention of the author by Dr. E. B. FRED of the University of Wisconsin that more bacteria have been found in water immediately under the ice on Lake Mendota than at greater depths. This observation was confirmed by demonstrating the presence of from two to three times as many bacteria in the water adjacent to a $40-\mathrm{cm}$. layer of ice covering Lake Mendota as in water samples collected at depths of from two to five meters beneath the ice. The ice itself generally contained fewer than a hundred bacteria per ml. compared with several thousand bacteria per $\mathrm{ml}$. found in the underlying water. There are several possible explanations, none of which has been established as the cause of the concentration of bacteria next to the ice: $(a)$ Nutrients may be somewhat more concentrated in the water adjacent to ice because as water solidifies, most of the dissolved solids remain in the liquid fraction. (b) Ice may provide a beneficial solid surface for increased bacterial activity or for adsorption of nutrients (see page 84). (c) Trihydrol, a form of water which predominates in ice, may stimulate the growth and activity of bacteria, as suggested by the work of BARNES and JAHN (I934). HARVEY (I933) noted that recently melted ice water seemed to stimulate the growth of diatoms.

While ice cannot be relied upon to prevent the spoilage of fish and other flesh foods, it has a preservative value. According to TARR and SUNDERLAND (I940), ice prepared from water treated with o.I per cent of either benzoic acid or sodium nitrite is relatively effective for preserving fish fillets and other flesh foods. JENSEN (I943) reports that chlorine-water ice, azochloramide ice, katadyn silver ice, sodium propionate ice, and other kinds of germicidal ice show promise for various purposes.

Ice presents special problems where dilution and sedimentation are depended upon to minimize the danger from sewage discharged into rivers or lakes. Unless proper precautions are taken, the warmer, less dense water from sewage effluents may flow over the surface of colder, more dense water, and under certain conditions even over the surface of ice for considerable distance. Such a condition is very noticeable in Great Salt Lake where fresh water flowing over the surface of the denser saline water in mid-winter freezes to form a sheet of ice, over which more fresh water flows farther and farther from land, until higher temperatures or turbulence breaks up the ice sheet.

Bacteria and allied microorganisms preserved in glacial ice may be transported hundreds of miles to sea in icebergs. Icebergs play an important role in the transportation of sedimentary materials at high latitudes. 


\section{Chapter XVII}

\section{ECONOMIC IMPORTANCE OF MARINE MICROORGANISMS}

Marine microorganisms are of economic importance in many ways besides causing diseases and bringing about the decomposition of marine animals and commercial algae. Their indirect effects upon the primary productivity of the sea and their possible role in the origin of oil have already been mentioned. A few additional ways in which bacteria and allied microorganisms are of direct economic concern to man are outlined on the following pages.

Fouling of submerged surfaces:- In nautical parlance fouling is the attachment and growth of a heterogeneous assemblage of plant and animal organisms on ships' bottoms, piles, water conduits, and other submerged structures. Virtually all types of structural materials, whether they be of wood, metal, concrete, glass, or plastic, sooner or later become fouled when submerged in the biotic zone. The assorted organisms are popularly known as "barnacles," "shells," "seaweeds," or "moss." While barnacles or algae are usually the principal offenders, not infrequently a hundred or more different species of organisms have been identified in fouled surfaces, exclusive of bacteria and allied microorganisms. Sometimes nearly a hundred tons of fouling organisms are found on the bottom of a large vessel after it has been in the water for a year. Several pounds of fouling organisms may accumulate on the bottom of a flying boat within a few days.

By increasing the resistance of ships in water, fouling organisms diminish the speed of a vessel, prolong the voyage, increase fuel consumption, and augment wear and tear on the machinery. Fouling organisms necessitate the drydocking of vessels at frequent intervals for cleaning, scraping, and re-painting, costly processes which take the average vessel out of commission for three or four weeks each year. The fouling problem is of gravest concern to the Navy, particularly when operating far from home bases.

Microorganisms are the primary film formers on submerged surfaces. On badly fouled surfaces bacteria may constitute as much as 8 or 9 per cent by volume of the total cumulation. Bacterial attachment to previously cleaned glass surfaces may be detected in less than an hour following immersion in the sea. The numbers increase more or less geometrically with time until their abundance, together with the simultaneous attachment and growth of diatoms, algae, protozoans, suctorians, and various larvae, defeats census attempts. This may be illustrated by data summarized in Table XLI on page I94.

Laboratory as well as field observations (ZoBELL and ALLEN, 1935) suggest that bacteria may play an important role in the fouling of submerged surfaces. This they may do in a variety of ways: $(I)$ By affording the planktonic larval stages of fouling organisms a foothold or otherwise mechanically facilitating their attachment. (2) By discoloring glazed or bright surfaces. Visscier (1927) and others have shown that bright, 
light-reflecting surfaces are fouled less readily than dark or discolored ones. (3) By serving as a source of food. Barnacles, mussels, tunicates, and other fouling organisms are nourished by bacteria (see page I73). (4) By promoting the deposition of the calcareous cements of sessile organisms. (5) By increasing the concentration of plant nutrients, including $\mathrm{CO}_{2}$ and ammonia, which result from the bacterial decomposition of organic matter.

TABLE XLT. - Numbers of different types of fouling organisms found per square inch of glass slide after different periods of submergence in the sea at La Jolla, California (from ZoBELL, I939b):-

\begin{tabular}{|c|c|c|c|}
\hline ORGANISMS & 24 HÓURS & 48 HOURS & 96 HOURS \\
\hline Bacteria & $\mathbf{x}, 876,000$ & $I_{3}, 240,000$ & $78,100,000$ \\
\hline Diatoms & 940 & 3,750 & 8,200 \\
\hline Protozoans & 72 & 290 & $\mathrm{I}, \mathrm{IOO}$ \\
\hline Barnacle larvae & 0.1 & 0.3 & I. 2 \\
\hline Other organisms & 389 & $I, 360$ & 9,700 \\
\hline
\end{tabular}

Under certain conditions the primary film formers may form a protective layer over antifouling paints designed to discourage barnacles, or they may otherwise effectively reduce the toxicity of antifouling paints. Bacteria attack and slowly decompose certain protective surface materials. On the other hand, under certain conditions bacterial films may help to keep surfaces free from larger fouling organisms by the production of antibiotic substances. The interrelationships among the organisms in fouling cumulations are very complex and not well understood. The available information stresses the desirability of taking microorganisms into account in the scientific approach to the preparation of antifouling surfaces (ZoBELL, I938b).

Algae, particularly species of Ectocarpus and Herposiphonia, diatoms, hydroids, barnacles, oysters, bryozoans, and serpulids were the most abundant sedentary organisms observed on submerged surfaces by CoE and AlLEN (I937) during their nine years' study at La Jolla, California. Sixty species of diatoms, I 5 species of algae, and 8 species of foraminifera were commonly recognized on submerged plates, along with a diversity of sponges, hydroids, nemerteans, annelids, bryozoans, mollusks, crustaceans, and ascidians. No record was kept of the presence of bacteria and allied microorganisms.

Bacteria associated with wood-borers:- Wooden structures exposed in the sea are subject to the depredations of several kinds of destructive animals of which the drilling mollusk or "ship-worm," Teredo navalis, and the boring gribble, Limnoria lignorum, are the commonest. Details regarding these and other boring animals and the extent to which they damage pilings, wooden boats, timbers, etc., are given in the literature summarized by CrosthwaIte and REDGrave (I920). Additional information is given by KoFOID (1923) who believes that Limmoria digests the wood which it swallows. Doubt is expressed that Teredo utilizes wood as food.

It is an inadequately explored possibility that these and other woodboring animals depend partly or largely upon bacteria for their nutrition. Plankton organisms have been regarded as the principal food of Teredo navalis, although DORE and MILLER (I923) found that wood loses about 8 o per cent of its cellulose and I 5 to $5^{6}$ per cent of its hemicelluloses during 
passage through the digestive tract of Terelo. The lignin content was decreased only slightly. However, it is still indeterminate whether the cellulases and lignases are elaborated by Teredo or by commensal bacteria. The gut of engorged Teredo as well as its burrows contain large numbers of cellulose- and lignin-digesting bacteria. Conceivably the bacteria convert the cellulose and lignin into products which are more readily assimilated by the wood-borers.

The bacteria themselves are nutritious. The number present at any one time on the wood or in the gut of wood-borers is not enough to provide for the complete requirement of the wood-borers, but the "standing crop" of bacteria is not an adequate criterion. Considering that bacteria reproduce every hour or two under favorable conditions, the standing crop multiplied by ro to 20 would be more representative of the amount of bacteria available per day as food.

Cellulose- and lignin-decomposing microorganisms may help to condition the wood for initial attack by wood-borers. The extensive degradation of wooden structures by fungi in the sea has been reported by BARGHOORN and LINDER (I944), who observed a conspicuous softening in the outer parts of pilings and submerged wood. The activities of such organisms may help to explain why wood becomes increasingly more susceptible to attack by wood-borers as its period of immersion is prolonged. Given a sufficiently extended time, either bacteria or fungi could independently effect the complete deterioration of wooden structures. The rate, though, is far from being commensurate with the rapid destruction of wood by Teredo or Limnoria.

Destruction of cordage and fish nets:- After periods of from three to five weeks' immersion in the sea, textile fibers were found by DORÉE (I920) to be completely rotten. Fabrics had become coated with a bacterial or diatomaceous film within a week after immersion. Cotton was found to be less durable than linen or silk. Wool was the most resistant. The deterioration was shown to be caused by microorganisms and not by abiogenic oxidation, light, or salts.

The deterioration of fish nets in Lake Erie was found by ROBERTSON and Wright (I930) to be due to cellulose-digesting bacteria. Both linen and cotton lines, seines, and nets were attacked. According to RoBERTSON (I93I), the value of fiber seines, nets, traps, and lines used by commercial fishermen in the United States in 1930 was about $\$ 15,000,000$. Such equipment lasts an average of less than two years, its durability being affected primarily by the activities of cellulose-decomposing bacteria. The usefulness of the nets, seines, and lines can be extended by applying copper resinate and other preservatives. The tendency of certain preservatives to decrease the flexibility, impart undesirable colors, or otherwise adversely affect the properties of the fiber equipment complicates the problem.

Manila ropes and cotton nets were found by ATKINS and WARREN (I94I) to be destroyed after I4 months alternate wetting in sea water and drying, as in ordinary use. Preliminary treatment of the fibers with copper naphthenate was found to prolong the useful life of the rope by 40 per cent.

The occurrence of fungi on the North Atlantic coast which infect cordage fibers, including hemp, jute, and sisal, causing deterioration under marine conditions has been reported by BARGHOORN (1942). BARGHOORN 
and LINDER (I944) have investigated the physiology of several such fungi. According to IMSHENETSKY and KoKURINA (I94I), microorganisms cause the destruction of jute coverings on ships.

Bacterial deterioration of cork and rubber:- Cork is a ligno-cellulosesuberin complex filled with air spaces which are responsible for its buoyancy. Large quantities of cork are used for floats on fish nets, fish lines, life preservers, etc. Although relatively resistant to bacterial attack, cork is decomposed by marine microorganisms which slowly destroy its buoyancy by rupturing the cell walls of the cork. Eventually, pieces of cork continuously or periodically exposed to sea water break to pieces.

Rubber is generally regarded as being biologically inert, but highly purified rubber, both natural and synthetic, as well as various rubber products, are susceptible to bacterial oxidation in the presence of minerals and moisture. Even the small areas of rubber gasket exposed to water in citrate of magnesia bottles filled with sea water causes the consumption of oxygen as the rubber is oxidized by bacteria.

According to ZoBELL and BECKWITH (I944), rubber is attacked by many marine bacteria, including species of Actinomyces, Mycobacterium, Micrococcus, Micromonospora, Nocardia, Pseudomonas, and Bacillus. This is not particularly surprising when it is recalled that rubber is an unsaturated hydrocarbon having the composition $\left(\mathrm{C}_{5} \mathrm{H}_{8}\right)_{\mathrm{n}}$. Unsaturated hydrocarbons are quite susceptible to bacterial oxidation. Synthetic rubbers are closely related chemically to natural rubber. Some of the synthetic rubbers are more readily oxidized by bacteria than is natural rubber.

Rubber products are prepared by compounding vulcanizing agents, accelerators of vulcanization, antioxidants, softeners, fillers, etc., with rubber hydrocarbon. Manufacturers have devoted little attention to the development of antimicrobial agents for rubber products, for the obvious reason that they have been more concerned with wearing qualities, heatresistance, tensile strength, elasticity, vulcanizability, and other properties than with biological inertness. Only when it is continuously in contact with moisture does the bacterial deterioration of rubber become a practical problem. Most rubber products, including hoses, bumpers, rubberized products, certain chlorinated rubber paints, bearings, etc., used at sea are either submerged or subject to frequent wetting with sea water. For such rubber products the development of antimicrobial qualities may be desirable.

Halophilic bacteria in solar salt:- Typical marine bacteria are hardly halophilic since very few of them grow well in media containing more than 5 per cent salt. However, a small percentage of the bacteria in the sea are able to grow in saturated salt solutions. Such organisms are particularly abundant in marine salterns where halophilic chromogens often impart a red color to the brine and crude salt. PEIRCE (I9I4) regarded red chromogenic bacteria as being the principal cause of the pink to red coloration of San Francisco Bay salterns, although the algae, Protococcus salinus and Dunaliella salina, may be partly responsible. PEIRCE did not identify the bacteria. They were obligate halophiles, growing in concentrated brine but not in diluted brines. The bacteria grew on salt codfish, giving it a red color.

Unless measures are taken to sterilize re-crystallized and purified solar salt, it may carry halophilic bacteria which are instrumental in the 
spoilage of raw furs, fish, caviar, meat, pickles, and other products on which salt is used as a preservative. According to RAmN (1934), natural rock salt as well as crystallized salt manufactured from rock salt is practically free from bacteria, except such as it may gather up in the process of shipment, storage, and handling. However, salt from marine or solar salterns often carries halophilic bacteria (CLAYTON, I93I). CLAYTON and GIBBS (1027) traced pink halophiles to sea salt which stained salted hides and produced pink blotches on salt fish.

Browne (I922) traced the discoloration of fish to Bacterium halophilicum, which was isolated from sea salt along with Spirochacta halophilica. BAUMrGARTNER (I937) discovered Bacteroides halosmophilus in salted anchovies. The red, brownish, and other spoilage organisms associated with salted food products were traced by PETROWA (I936) to saline lakes from which the salt was reclaimed. Other problems attending the preservation of food with solar salt are discussed by TANNER. (I944).

The cause of the discoloration of salt codfish was shown by HARRISON and KenNedy (I922) to be Pseudomonas salinaria that had been introduced with solar evaporated salt used in curing the codfish. It, like Sarcina litoralis, Bacterium trapanicum, and several other species of halophiles isolated from salt samples and spoiling salt fish by GIBBONs (1937), grew in media containing 20 per cent $\mathrm{NaCl}$. HoF (1935) gives additional information and literature on bacteria which cause the spoilage of various foods in concentrated salt solutions. He points out that halophilic bacteria are widely distributed in salt lakes, limans, salt gardens, soil, and elsewhere in nature.

STUART (1936) detected the presence of proteolytic and chitinoclastic bacteria in nearly all of the 27 samples of solar salt which were examined from different parts of the world. He likewise noted the association of chromogenic halophiles with the reddening of salted fish and hides. STUART believes that halophilic bacteria introduced with salt used for curing may be responsible for damage to skins and hides. Using silica gel media containing I4.5 per cent salt, MOORE (1940) demonstrated the presence of halophilic bacteria in several samples of packing house salt, crude solar evaporated sea salt, tainted steer hides, and tainted sealskins. Before effective control measures were taken, microorganisms damaged large numbers of Alaska sealskins which had been packed with salt as a preservative on the Pribilof Islands preparatory to shipping to the processing plant in the States.

Spoilage of marine food products:- Reference has already been made in preceding chapters to the microorganisms which cause spoilage of oysters and fish. Such microorganisms present special problems to food technologists, because many of the microorganisms are active at the temperature of ice, some grow in concentrated salt solutions, others are both psychrophilic and halophilic, and fish tissues are very susceptible to decomposition. Much progress has been made in recent years in improving the quality of "fresh" marine food products by fast-freezing processes, rapid transit, and more careful handling, but the marine microbiologist is still confronted by numerous unsolved problems in this field.

Typical of the problems confronting the section of the canning industry specializing in sea foods is the blackening of lobsters. The thorough investigations of REED and MACLEOD (1924), revealed that species of Pseudomonas, Flarobacterium, and Bacillus, along with other natural bac- 
terial flora of lobsters, rapidly produced ammonia and $\mathrm{H}_{2} \mathrm{~S}$ after the lobsters were scalded. The $\mathrm{H}_{2} \mathrm{~S}$ reacted with iron in the lobster flesh, resulting in undesirable blackening. Prompt acidification of the prepared meat, followed by immediate sterilization, proved to be remedial. Canneries are confronted by the additional difficulty that the raw material is usually not delivered in as fresh condition as that in which meat, fruit, or vegetables can be procured. No conceivable canning process can correct prior decomposition.

In an effort to determine the cause of the rapid spoilage of fish and its attendant large economic loss to man, LUCKE and SCHWARTZ (I937) made a bacteriological study at various times during the process of catching and marketing fish. The bacterial content of the high seas, about 50 bacteria per $\mathrm{ml}$., was not regarded as the serious source of infection encountered in polluted near-shore water, which in many places contained millions of bacteria per $\mathrm{ml}$. Fishes taken from water having a high bacterial content did not keep well and had an offensive taste. The fish seemed to become infected by handling on board ship, particularly when handled in such a way that the intestinal contents were voided or the skin broken.

The bacteria of polluted sea water, ice, and fish holds were regarded by LUCKE and SCHWARTZ as being secondary sources of infection. They emphasized the importance of proper killing, cleaning, and washing procedures to minimize bacterial spoilage. Bacteria were found to multiply rapidly in infected fish, even in iced holds, resulting in relatively high bacterial counts by the time that the fish were unloaded in port. Consequently the fish were subject to rapid spoilage on shore unless frozen. A mixture of salt and ice instead of ice alone was recommended in order to obtain a temperature sufficiently low to retard effectively the multiplication of spoilage bacteria. Similar observations were made by WOOD (I939) who also stressed the importance of proper handling and refrigeration. The value of benzoates, nitrites, and other preservatives used in conjunction with ice to allay spoilage is discussed by TARR and SUNDERLAND (I940) and by TANNER (I944).

Frozen fish were observed by STEWART (I935) to spoil more rapidly when permitted to thaw than when held at the same temperature without previous freezing. She recommends refrigeration temperatures of from - I $2^{\circ}$ to $-2 \mathrm{I}^{\circ} \mathrm{C}$. for prolonged preservation of marine fish. REAY (I935) confirmed STEWART's observations on the effects of alternate freezing and thawing, but he found that fish could not be kept indefinitely even at $-2 \mathrm{I}^{\circ} \mathrm{C}$. without undergoing undesirable changes in quality.

An appalling quantity of obviously spoiled fish is dumped or processed for fertilizer owing to inadequate control of microbial processes prior to the delivery of the fish to the retailer or cannery. There is a division of opinion among authorities regarding how much decomposition is allowable before the food is no longer fit for human consumption. Fish and other marine foods which are partially pre-digested by certain nonpathogenic bacteria may be entirely wholesome, but those which have been properly preserved are generally more palatable. The solution of this problem presents a challenge to the marine microbiologist and food technologist.

Food inspectors have been guided by one or more of the following properties of commercial fish in passing upon its freshness or eatability: Discoloration, physical consistency, odor, bacterial population, ammonia content, trimethylamine value (BEATty and GiBвons, I937), and tyrosine 
content. Further details of this problem are given by Dyer et al. (I944) who have developed what they believe to be a practicable method for determining the index of spoilage by measuring the $p H$ at the surface of fish or fillets with a glass electrode. The range of fresh fish flesh was found to be from $p \mathrm{H} 6.2$ to 6.8. Between $p \mathrm{H} 6.8$ and 7.5 the fish was found to be in an incipient stage of spoilage, and above $p H 7.5$ the fish is in an advanced stage of decomposition. The test was applied during a two year period to cod, haddock, and flounder with equally satisfactory results.

Histamine produced post mortem in fish muscle as a result of bacterial activity is believed by GEIGER et al. (I944) to be a good criterion of the keeping quality or stage of decomposition of fish. Histamine results from the decarboxylation of histadine, one of the amino acids composing fish flesh.

Many theories have been advanced to account for the occurrence of poison in mussels and other shellfish. Ptomaine or toxin production by putrefactive microorganisms has been regarded as a possible cause. However, it has now been established by the observations of SOMMER and associates at the University of California that the food of shellfish is the source of the poison. The poisonous food has been shown to be a dinoflagellate called Gonyaulax catenella. Gonyaulax digitale, G. polygramma, $G$. spinifera, and $G$. triacontha may be involved also, although most outbreaks of mussel poisoning on the California and Oregon coasts have been associated with an abundance of $G$. catenella in coastal waters. There is some evidence that species of Ceratium, Prorocentrum, Gymnodinium, Noctiluca, and possibly other genera of diatoms or dinoflagellates may contain the toxic principle. The identical poison has been demonstrated in sand crabs. Further information and additional references on shellfish poison are given by SOMMre et al. in Archives of Pathology, Volume 24, pages $537-559$ (I937).

Seaweeds which are used for food, agar, alginates, fibers, insulation, paper pulp, and other purposes are susceptible to decomposition by bacteria during transportation and storage. Unfortunately little is known regarding the microorganisms responsible for the spoilage of seaweeds. Control measures are largely lacking in scientific principles and effectiveness.

Ambergris is a solid, fatty substance produced by the sperm whale. Pure ambergris has a peculiar sweet, earthy odor which makes it invaluable as an ingredient of perfumes, but that found floating in the sea and in the intestines of whales has a disagreeable smell. It has been suggested that the activities of bacteria which slowly decompose crude ambergris are responsible for its foul odor. On the other hand, BEAUREGARD (I897) stated that bacteria tend to purify ambergris by decomposing extraneous material. From concretions of ambergris he isolated an organism which he called Spirillum recti physeteris. 


\section{Chapter XVIII}

\section{MICROBIOLOGY OF INLAND WATERS}

Frequent reference has been made to conditions in inland seas, lakes, and limans in the preceding chapters. The general relationships of organisms to each other and to the environment are much the same in inland bodies of water as in the oceans, although there are certain qualitative and quantitative differences. The latter are probably no greater in magnitude, however, than the differences which exist between different parts of the ocean. Though each environment may have unique features, fundamental observations of conditions in one body of water often help to explain conditions in another. A few of the outstanding microbiological features of certain unique bodies of inland water are outlined on the following pages. A key to the periodical literature is also given.

The Black Sea:- Peculiar hydrographic conditions, coupled with microbiological activities, render nine-tenths of the Black Sea virtually uninhabitable by any form of life except bacteria. Since the influx of fresh water from precipitation and land drainage exceeds evaporation, the density of the surface waters (salinity about $16 \%$ ) is sufficiently less than that of bottom water (salinity up to $23 \%$ ) that there is little vertical mixing. As a result, the oxygen content of the water below the photosynthetic zone is renewed only very slowly.

The oxygen which does penetrate the water is effectively consumed by bacteria either directly or indirectly, so that there is little or no oxygen present at depths exceeding 200 meters. The lower limit of animal life appears to be from I30 to I90 meters. At greater depths, only anaerobic bacteria are active. In the oxygen-poor waters immediately below the photosynthetic zone, bacteria consume oxygen while oxidizing the organic matter which is raining down from the productive surface layers. Sulfur bacteria are also believed to be instrumental in the utilization of oxygen in the zone wherein the overlying oxygenated water merges with deeper $\mathrm{H}_{2} \mathrm{~S}$-containing water. The abiogenic oxidation of $\mathrm{H}_{2} \mathrm{~S}$ likewise helps to deplete the oxygen content of the water.

The $\mathrm{H}_{2} \mathrm{~S}$ results partly from the anaerobic decomposition of albuminous compounds. More is believed to result from the bacterial reduction of sulfate. According to Daniltchenko and Tschigirine (I926), sulfate reduction is most intense on the bottom of the Black Sea where the concentration of $\mathrm{H}_{2} \mathrm{~S}$ sometimes reaches $6000 \mathrm{ml}$./L., calculated at $760 \mathrm{~mm}$. pressure and $0^{\circ} \mathrm{C}$. It was in the Black Sea where sulfate-reducing bacteria were first demonstrated by ZELINSKI (I893). Since that time sulfate reducers have been observed in the Black Sea by numerous investigators. Issatchenko (1924) found vigorous sulfate reducers, presumably Desulfovibrio desulfuricans or D. aestuarii, in all samples examined. Some of the samples were collected from depths as great as 2, I 8 meters. The cultures produced from 0.3 to $0.5 \mathrm{gm}$. of $\mathrm{H}_{2} \mathrm{~S}$ per liter of media in the laboratory.

IsSATCHENKo (I929) asserted that $\mathrm{H}_{2} \mathrm{~S}$-producing bacteria are responsible for the formation of ferrous sulfide in the Black Sea. According to 
him, $\mathrm{H}_{2} \mathrm{~S}$ reacts with iron intracellularly to give black inclusion bodies $0.5 \mu$ in diameter or larger:

$$
\mathrm{H}_{2} \mathrm{~S}+\mathrm{Fe}\left(\mathrm{HCO}_{3}\right)_{2}=\mathrm{FeS}+{ }_{2} \mathrm{H}_{2} \mathrm{CO}_{3}
$$

After the death of the bacteria, crystals of ferrous sulfide are liberated. The Black Sea gets its name from the color caused by ferrous sulfide.

IsSATCHENKO and EgOROVA (1939) were unable to confirm Egounov's celebrated hypothesis that there is a "bacterial plate" (see p. r6I) or zone of sulfur bacteria in the Black Sea where oxygenated surface water merges with $\mathrm{H}_{2} \mathrm{~S}$-containing bottom water. After failing to find sulfur bacteria in samples taken at one meter intervals throughout the boundary layers, it was concluded that $\mathrm{H}_{2} \mathrm{~S}$ must be oxidized abiogenically as it diffuses upward into oxygenated water. However, RAvich-SHerbo (I930) found large numbers of Thiobacillus thioparus in the so-called "thin layer" or "bacterial plate." KNIPOWITSCH (I926) reported the presence of Thiopedia rosea and other sulfur bacteria in the Black Sea as well as in the Caspian Sea and the Sea of Azov.

In the Caspian Sea, where hydrographic and microbiological conditions are akin to those in the Black Sea, Butkevich (I938) found large numbers of sulfate reducers. Near the mouth of the Volga River he found from one to two million bacteria per ml. of water, or the equivalent of a bacterial biomass of about I gram per cubic meter. This compared favorably with the biomass of plankton algae. The bacteria were very active biochemically. Denitrifiers were widely distributed. Both denitrifying and nitrifying bacteria were reported in the Black Sea by KNIPOwiTSCH (I926). As pointed out by Issatchenko (I926), the presence of $\mathrm{H}_{2} \mathrm{~S}$ precludes the possibility of nitrification in deeper water, but nitrifying organisms were abundant in shallow, sandy, or shelly bottoms.

The investigations of POTERIAYEV (1936) on sanitary problems attending the disposal of sewage in the Black Sea are noteworthy. Except in closed basins such as bays or firths, there is generally an intermixing of sea water with sewage, which results in a rapid coagulation and biochemical oxidation of the latter.

Ravich-Sherbo (i936) diagnosed a fatal disease of Amphioxus lanceolatum in the Black Sea as being caused by a red chromogenic bacterium which he described briefly, but did not identify.

Bacteriology of Russian limans:- The shallow salt lakes bordering the Black Sea have been the subject of extensive and intensive study by microbiologists. Unique conditions exist here where the salinity ranges from a few parts per thousand (when flooding rivers overflow into the mud lakes or limans) to concentrated salt solutions following prolonged periods of drought and evaporation. Especially noteworthy are the voluminous contributions of RUBENTSCHIK and associates on the limans or mud lakes around Odessa.

Representative of the work of RUBENTSCHIK (1925) are his observations on urea-splitting and proteolytic bacteria which are active in saline media at $0^{\circ}$ to $-2^{\circ} \mathrm{C}$. He isolated and described Sarcina psychrocarteria and Bacillus psychrocartericus, both of which attacked urea at $-2.5^{\circ} \mathrm{C}$.

From the Kilyalnizki Liman, RUBENTSCHuK (I928a) isolated sulfate reducers which used the decomposition products of cellulose as an energy source but not cellulose itself. The sulfate reducers were able to grow in media containing from 0 to 20 per cent $\mathrm{NaCl}$. In nature, the bacterial 
destruction of cellulose probably provides the energy source for sulfate reduction. Both aerobic and anaerobic cellulose decomposers are widely distributed in the limans, according to RUBENTSCHIK (I933). He (I928b) isolated Actinomyces melanogenes and several other aerobic cellulose decomposers from liman mud and water. A good review of the microbiology of liman mud is given by RuBENTSCHIK and Goicherman (I935), who show that nitrifiers which oxidize ammonia to nitrite are active in concentrated salt solutions. Azotobacter-like organisms were found in the liman mud but there was no evidence reported that they fixed nitrogen in the limans.

The freshening of certain limans in the Odessa region from 1932 to I934 owing to floods from increased precipitation was found by RUBENTSCHIK and GoICHERMAN (I936) to be responsible for an appreciable increase in the bacterial content. In terms of separate physiological groups the increases were as follows:

Sulfur bacteria
Sulfate reducers
Putrefying bacteria
Nitrifying bacteria
Denitrifying bacteria
Urea splitters
Cellulose anaerobes
Cellulose aerobes

$$
\begin{aligned}
& \text { I00 to } 10,000 \text { times } \\
& \text { I0 to } 1,000 \text { times } \\
& \text { 10 to } 1,000 \text { times } \\
& \text { I0 to } \text { 100 times } \\
& \text { 100 to } 10,000 \text { times } \\
& \text { 100 to } 10,000 \text { times } \\
& \text { 10 to } \text { 100 times } \\
& \text { 10 to } 1,000 \text { times }
\end{aligned}
$$

The salt optimum of halophilic sulfate reducers isolated from the limans was observed to decrease from an average value of from 5 to 8 per cent $\mathrm{NaCl}$ in 1932 to an average of from 2 to 4 per cent in I934 after the freshening of the limans.

Most of the bacteria occurring in the mud were reported by RUBENTSCHIK et al. (I936) to be adsorbed on the sediment particles. Adsorbed bacteria may survive in mud for long periods without undergoing detectable changes. Nitrification is diminished and sulfate reduction is increased when the bacteria responsible for these processes are adsorbed on mud particles.

In limans near Odessa containing $256 \%$ of salt, BARANIK-PIKOWSKY ( 1927 ) demonstrated the presence of denitrifiers, $\mathrm{H}_{2} \mathrm{~S}$-producers, and other physiological types of bacteria. He described several new species to which he applied numbers but no names. BERGEY et al. (I939) have assigned names to his numbered species as follows:

$$
\begin{aligned}
& \text { No. I9 Micrococcus halophilus } \\
& \text { No. } 22 \text { Micrococcus pikowskyi } \\
& \text { No. } 25 \text { Achromobacter pikowskyi }
\end{aligned}
$$

No. 27 Achromobacter galophilum

No. 30 Flavobacterium halophilum

No. 36 Achromobacter halophilum

The extensive literature on the microbiology of liman mud has been summarized by ISSATCHENKO (I938).

Great Salt Lake:- This extremely saline body of water, now covering an area of I,I 20 square miles in northern Utah, is the remnant of Lake Bonneville, an old fresh-water lake 19,000 square miles in area. At the present time it is saturated with $\mathrm{NaCl}, \mathrm{Na}_{2} \mathrm{SO}_{4}$, and probably $\mathrm{CaCO}_{3}$, the water containing about 335 grams of salt per liter, or about ten times as much as normal sea water. PACK (I9I9) reported that one crustacean, four protozoans, nine algae, two fly larvae, and several bacterial species live in Great Salt Lake. Two ciliates inhabiting the lake were found to 
feed on bacteria, small plants, and small protozoans. The brine shrimp, Artemia gracilis, which abounds in the lake, was shown by JENSEN (Ig18) to be an obligate halophile. Lake water diluted to a specific gravity of I.044 to 1.027 was found to be most favorable for the development of Arlemia. The specific gravity of undiluted lake water is about I.I 5 .

In his review of the literature on life in Great Salt Lake, EARDLEY (1938) lists the brine shrimp, 3 flies, 5 protozoans, and I3 species of algae. He relates that at times the brine shrimps "congregate in such numbers as to tint the water over wide areas." During certain years the puparia of the fly Ephydra were reported to drift upon the shore in long windrows, and countless swarms of the adult flies were observed over the water, in which they drop their eggs freely. The extensive calcareous bioherms along the exposed lake shores were believed by EARDIEY to consist principally of deposits of the alga, A phanothece packardii, although the possible importance of bacterial activity in the precipitation of the carbonate deposits was not overlooked.

The occurrence of small algae in the lake has been reported by various investigators. However, the extent to which they are growing in the undiluted brine is problematical. According to PATRICK (1936), who identified 24 genera and 62 species of diatoms from lake bottom samples, no diatom flora is found living in the lake proper today. PATRICK avers that the living forms reported from the lake have been found, no doubt, in the surrounding brackish marshes and river estuaries which have a much lower salt concentration. FLOWERS (I934) stated that the lake water proper harbors six species of algae, including four Myxophyceae and two Chlorophyceae. Numerous additional species were found in surrounding brackish water.

An abundant bacterial flora representing several genera was observed on glass slides submerged in the lake by Smith and ZoBell (1937). The development of micro-colonies on the submerged slides established that the bacteria multiplied in the brine and were not merely passive inhabitants. DAINES (I9I7) demonstrated the presence of from 200 to 625 bacteria per $\mathrm{ml}$. of lake water by plate count procedures. Pigmented rods predominated.

The decomposition of organic matter in the lake was regarded as evidence of bacterial activity. ZoBELL et al. (I937) found an average number of 167 bacteria per ml. which formed colonies on nutrient lake-water agar. Most of the organisms proved to be obligate halophiles whose growth required 6 to 5 per cent $\mathrm{NaCl}$. Sea water was found to be little better than fresh water for the cultivation of lake bacteria. Conversely, very few marine, soil, and sewage bacteria were able to grow in media prepared with undiluted water from Great Salt Lake. This is illustrated by the data in Table XLH.

TABLE XLII. - Relative numbers of bacteria from different sources which developed on nutrient agar prepared with warious dilutions of Great Sall Lake water (L.W.), fresh water, and sea water:-

\begin{tabular}{|c|c|c|c|c|c|c|}
\hline SOURCE OF SAMPLE & $\begin{array}{l}75 \% \\
\text { L.W. }\end{array}$ & $\begin{array}{l}50 \% \\
\text { L.W. }\end{array}$ & $\begin{array}{l}25 \% \\
\text { L. W. }\end{array}$ & $\begin{array}{l}10 \% \\
\text { L.WV. }\end{array}$ & $\begin{array}{l}\text { FrESH } \\
\text { WATER }\end{array}$ & $\begin{array}{c}\text { SEA } \\
\text { WATER }\end{array}$ \\
\hline Sewage & 0.0 & 0.0 & 6.7 & I $8 . \mathrm{I}$ & 100.0 & $9 \cdot 5$ \\
\hline Soil & 0.0 & 0.8 & 12.6 & 29.8 & 100.0 & 13.7 \\
\hline Pacific Ocean & 0.2 & 0.6 & 10.4 & $64 \cdot 3$ & 6.2 & 100.0 \\
\hline Great Sall Lake & 100.0 & 96.4 & 51.2 & II. 3 & 3.8 & $4 \cdot I$ \\
\hline
\end{tabular}


When suspended in brine from the lake, most sewage or fresh-water bacteria were killed within a few minutes.

The Dead Sea:- The salt composition of Dead Sea water is distinguished from that of other naturally occurring brines by the predominance of magnesium chloride and the relative abundance of bromides. The total salt content ranges from 227 to 330 grams per liter. Although this body of water has the popular reputation of being lifeless, ELAzARIVOLCANI (I940) found numerous bacteria in water and mud samples. He reports the presence of several species of algae, including genera of Chlorophyceae, Diatomeae, and Cyanophyceae.

ELAZARI-VolCANI isolated organisms similar to Micrococcus morrhuae, Bacterium trapanicum, Bacterium halobium, Pseudomonas indigofera, and Sarcina morrhuae from the Dead Sea. Flavobacterium maris-mortui, Chromobacterium maris-mortui, Pseudomonas halestorgus, and Flavobacterium halmephilum were described as new species. The organisms thrived in media containing from 3 to 30 per cent salt. Organisms carried into the Dead Sea by inflowing streams failed to grow in the saline waters, but certain terrigenous spore formers exhibited remarkable salt resistance.

In bottom sediments of the Dead Sea, Elazari-Volcani (I943) demonstrated the presence of cellulose decomposers, hydrocarbon oxidizers, denitrifiers, and sulfur bacteria. He found both aerobes and anaerobes in stratified cores. Some of the latter were $170 \mathrm{~cm}$. long and were collected from water depths of 70 to 330 meters. The bacteria developed in enrichment media containing 25 per cent salt.

Fresh-water lakes:- The factors which influence the distribution and activities of bacteria in fresh-water lakes have been discussed in the preceding chapters. The parts played by bacteria and allied microorganisms in lakes as producers of plant nutrients, in the cycle of elements, as geological agents, in the food cycles of animals, as agents which influence physico-chemical conditions, as parasites, and in their relations to higher organisms are analogous to those features of marine bacteria, to which frequent references have already been made.

Although most hydrobiologists and limnologists recognize that bacteria play an important part in the economy of lakes; hydrobacteriology of lakes, like that of the sea, has lagged considerably behind other biological sciences in participating in the study of lake metabolism and ecology. Whereas zoologists and botanists have classified their organisms as to species, habitat, and activity, bacteriologists have only the most general ideas regarding the characteristics, distribution, and activities of bacteria which live normally in lake water and bottom deposits. Until a decade ago the emphasis had been placed upon the occurrence of bacteria of sanitary significance in lakes (MINDER, I920).

The fragmentary literature on the subject suggests that the microflora of lakes differs qualitatively from that of the surrounding soil and inflowing streams. For example, SNow and FRED (I926) noted that nearly half of the bacteria isolated from Lake Mendota, Wisconsin, were brilliantly pigmented, whereas fewer than ten per cent of the known species of soil bacteria are chromogenic. Regarding the characteristics of bacteria in Lake Mendota, they write:

"The bacteria of lake water, taken far out from shore, show certain well defined characteristics. The kind of microorganisms present in the 
water is more or less constant. These indigenous forms are present at all seasons and at all depths. As compared with other organisms commonly studied, the majority of them grow slowly on ordinary culture media, and on plate cultures appear as punctiform colonies. About $10^{\circ}$ to $25^{\circ} \mathrm{C}$. is the optimum for their growth. In general they do not form acid or gas from sugars. They do not curdle milk and the majority of the true lake forms liquefy gelatin slowly. A considerable proportion are chromogenic, but long incubation at comparatively low temperatures is necessary to bring out the deep color. It is in respect to pigment production that the typical water flora of Lake Mendota is most easily recognized. A large number of pure cultures were selected from well isolated colonies on plates poured during the winter, when the true water bacteria were more prevalent."

Data summarized in Table XXXI on page Ir4 show that TAYLOR (1942) found nearly three times as many Gram-negative rods in English lakes as in soil, and twelve times as many Gram-positive rods in soil as in lake water. There were five times as many cocci in soil as in lake water. The chances for transplantation are so great that virtually any soil microorganism may be found in lakes, but apparently only certain types find conditions suitable for their multiplication or prolonged survival in lakes.

BAIER (I935) compared the bacterial species found in three shallow lakes around Kiel, Germany, where each body of water was found to have a more or less distinctive microflora. No attempt was made to isolate new species, but he recognized many common soil forms and several sulfur bacteria. BAIER was especially impressed by the differences in the fungous flora of soil, lake water, and bottom deposits. He concluded that the failure of soil fungi spores to germinate in aquatic environments is due to their inability to compete with bacteria for the limited supply of oxygen and organic matter.

The total number of bacteria found in any given lake depends upon the distance from land, depth, season, type of lake, and other factors, many of which are only poorly understood. After reviewing the literature on the subject, Henrici (I939) declared that data are as yet too incomplete to warrant any general conclusions regarding the distribution of bacteria in different types of lakes. The largest bacterial populations usually occur in eutrophic lakes, which are richer in organic nutrients than are oligotrophic lakes. Dystrophic lakes, which are rich in humus, occupy an intermediate position, although the microflora in many dystrophic lakes differs more in quality than in quantity from that of other types of lakes. The eutrophication or dystrophication of lakes (WELCH, I935) is influenced by bacterial activities and the latter are in turn modified by other factors. This chain of causes and effects further emphasizes the necessity of having detailed information on microbiological activities when attempting to explain the metabolism of lakes.

One of the distinguishing characteristics of oligotrophic lakes is the disappearance of oxygen in the hypolimnion during the period of stagnation. Kusnetzow and Karzinkin (i93I), Miyadi (i934), Kusnetzow $\left(1935^{b}\right)$, and others have shown that bacterial activity in deeper water or in lake bottoms is primarily responsible for the depletion of oxygen. Combining field and laboratory observations, LiAGiNA and KusNETzow (I937) calculated that the decrease in the oxygen content of the waters of Lake Glubokoje in Russia could be accounted for by the respiration of bacteria. Similar conclusions were reached by ZOBELL (I940a), who investigated 
the factors which influence oxygen consumption by bacteria in Lake Mendota.

Other things being equal, bacteria are generally more abundant in the epilimnion than in the hypolimnion of fairly deep, well stratified lakes. The differences are not marked. Differences in the abundance of bacteria at different depths disappear entirely during overturns and are nonexistent in shallow lakes. Only slight or no differences in the vertical distribution of bacteria were observed by FRED et al. (I924) in Lake Mendota and by GraHam and Young (I 934) in Flathead Lake, Montana. Progressive decreases were found by KUSNETzow and KARZINKIN (I93I) in Lake Glubokoje and in various lakes in northeastern Wisconsin by BERE (I933).

Additional observations by KLEIBER (I894), Minder (I920, I927), Pfenniger (I902), Düggeli (I924), Fred el al. (I924), Ruttner (I932), ZIH (I932), and others on the factors influencing the distribution of bacteria in lakes are recorded in Chapter $\mathrm{V}$.

The densest bacterial populations are almost invariably found in bottom deposits. HENRICI and MCCOY (I938) counted from a few thousand to $500,000,000$ aerobes per $\mathrm{ml}$. of lake mud (see Table XXVII on page 92). According to HENRICI (I939), the bacterial content of the overlying water is no criterion of the number or kinds of bacteria in bottom deposits. The observations of Williams and McCoy (I935), Kusnetzow (I935b), RubentschiK and Gorcherman (I935), Düggeli (I936), and CARPENTER (1939) on the numbers, kinds, and activities of bacteria in lake deposits are noteworthy (see Chapter VI).

The seasonal distribution of bacteria in lakes is influenced by changing water temperatures, plankton pulses, overturn, runoff, etc. As in the sea, the abundance of bacteria in lakes responds more quickly to changes in organic content than to any other environmental factor. Therefore most seasonal fluctuations can be traced either directly or indirectly to factors which influence the quantity and quality of organic matter. In about half of the lakes examined by BERE (I 933) the bacterial content was quantitatively proportional to the organic and inorganic nutrients in the water, and in about one-third of the lakes the bacterial content was proportional to the organic content alone. The relation of bacteria to the cycle of organic matter in lakes has been reviewed by WAKSMAN (I94ra).

Some of the ways in which aquatic fungi influence the transformation of organic matter are outlined by WESTON (I94I). The activities of parasitic and pathogenic fungi are of considerable importance in aquatic biology. Bacteria are also known to infect fresh-water organisms, some of which are of economic significance.

The studies of KLEIN and STEINER (I929) and DÜGGELI (I924, I934) on Swiss lakes, those of FRED et al. (I924) on Wisconsin lakes, those of Kusnetzow (I935b, I939) on Russian lakes, and those of BAIER (1935) on German lakes are illustrative examples of the results which may be expected to accrue from intensive hydrobacteriological investigations of particular bodies of water. After making a survey of the numbers of various physiological types of bacteria throughout the lake in question, these workers undertook to estimate bacterial activity in situ. This was achieved either by controlled experiments in which concentrations, temperature, and other environmental conditions were designed to simulate the natural environment, by comparing the abundance of various physiological types of bacteria present from time to time with the chemical composition of the water. or by a combination of both methods. 
DÜGGELI (I924) was one of the first to make extensive use of selective media specifically designed to estimate the relative abundance of various physiological types of bacteria in Lake Ritom in Switzerland. He was particularly concerned with the factors which influence the removal of oxygen and the occurrence of $\mathrm{H}_{2} \mathrm{~S}$. The formation of the latter was shown to be due to the activities of Desulfovibrio desulfuricans. The $\mathrm{H}_{2} \mathrm{~S}$ was oxidized either abiogenically or by certain sulfur bacieria, thereby depleting the oxygen. Chromatium species occurred in sufficient abundance in the boundary zone between the overlying oxygenated water and the deeper, $\mathrm{H}_{2} \mathrm{~S}$-containing water to cause a rosy red color. In the bottom water of Lake Ritom, DÜGGELI found up to $30 \mathrm{mgm}$./L. of $\mathrm{H}_{2} \mathrm{~S}$, a concentration which was toxic for nearly all forms of life, including most bacteria except those that produced $\mathrm{H}_{2} \mathrm{~S}$ by reducing sulfates.

KLEIN and STEINER (I929) made quantitative studies on ammonification, nitrification, nitrogen fixation, nitrate reduction, and sulfate reduction in Lake Lunz. Their comprehensive activity determinations gave new impetus to the study of hydrobacteriology.

Seasonal fluctuations in the ammonia, nitrate, and oxygen content of Lake Mendota were found by Domogalla et al. (1926) to be due almost entirely to bacterial activity. Increases in bacterial numbers were generally accompanied by increases in ammonia. An increase in nitrification followed the production of ammonia except in waters deficient in oxygen. From 800 to 3800 bacteria per $\mathrm{ml}$. of water were found, with little evidence of seasonal or vertical variations.

BAIER (I935) noted a close correlation between chemical, physicochemical, biological, and bacteriological conditions in five shallow lakes around Kiel. The foul odor emanating from the Little Kiel, a black, brackish backwater within the city limits of Kiel, was shown to be due to the activities of sulfate reducers. Several factors which influence the numbers, kinds, and activities of microorganisms in inland waters were examined with the help of much relevant literature and original research. BAIER stressed the importance of microorganisms as biochemical agents and as a food source for aquatic animals.

More intensive and extensive studies on the activities, distribution, and characteristics of aquatic microorganisms are needed in order to gain a complete understanding of the productivity, metabolism, and ecology of bodies of water. While hydrobacteriological research can contribute much to the pure science of bacteriology, its chief objective should be an elucidation of general hydrobiology, biochemical and geological processes in bottom deposits, and other practical problems. The importance of hydrobacteriological research was emphasized by THIENEMANN (1927) in a ten-year progress report of the Hydrobiological Institute Plön of the Kaiser Wilhelm Society. A literal translation of his statement follows:

"The greatest need of limnology, the satisfaction of which would be of benefit to many associated departments, is bacteriological information. It may be momentarily surprising if I insist that hydrobacteriology as such is virtually non-existent. It is true that there have been investigations regarding bacteria living in water, but for the most part they have had reference primarily to practical hygienic problems. It is well known that bacteria play an extremely important part in the cycle of lifematerials; it may even be the most important part, if we are justified in assigning degrees of importance. No matter how detailed may be our methods in water chemistry, even the most intensive delving into purely 
chemical processes is not going to solve for us the mystery of the metamorphosis of matter, if we neglect bacterial action.... What has been said here about the importance of bacteriological research to hydrobiology and limnology applies also to fisheries and biology in general. Wherever we encounter the difficult problems of the cycle of substances on this earth, we also encounter the necessity of considering bacteria."

Sufficient progress has been made by hydrobacteriologists during the last decade to substantiate the views of THIENEMANN expressed above, but the solution of most of the problems to which he refers is still woefully wanting. For the microbiologist with adequate training in chemistry, biochemistry, physical chemistry, general biology, and hydrography, the field of hydrobacteriology or marine microbiology is most promising, being almost virgin, for research in pure and applied science.

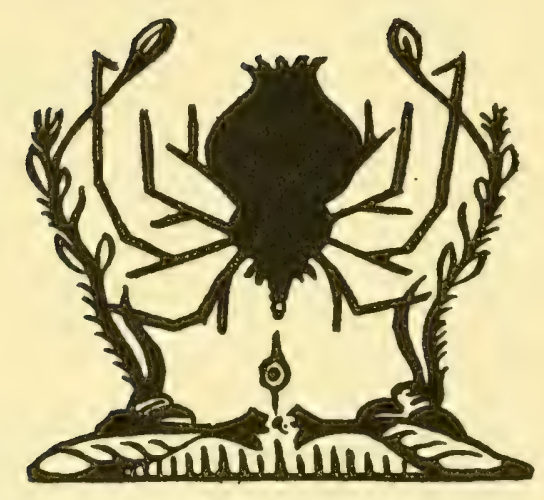




\section{BIBLIOGRAPHY}

Аввотт, A. C., I921: The Principles of Bacteriology (Lea \& Febiger, New York, roth Ed., 686 pp.).

ALLEN, W. E., 1921: A brief study of the range of error in micro-enumeration (Trans. Amer. Micro. Soc., 40:14-25).

__ - 1933: "Red water" in La Jolla Bay in r933 (Science, 78:12-13).

_- 1937: Plankton diatoms of the Gulf of California obtained by the G. Allan Hancock Expedition of 1936 (Hancock Pacific Expeditions, Univ. South. Calif. Press, Los Angeles, Calif., 3:47-59).

___ I _ I 194: 'Twenty years' statistical studies of marine plankton dinoflagellates of Southern California (Amer. Midland Naturalist, 26:603-635; 25 ref.).

Allgeier, R. J., HAFFORD, B. C., and JUdAY, C., I94I: Oxidation-reduction potentials and $p H$ of lake waters and of lake sediments (Trans. Wisconsin Acad. Sci., 33:I I5-I33; II ref.).

Allgeier, R. J., Peterson, IV. H., Juday, C., and Birge, E. A., I932: The anaerobic fermentation of lake deposits (Internat. Rev. d. ges. Hydrobiol. u. Hydrogr., 26:444-46 I; 2 I ref.).

Allison, F. E., Hoover, S. R., and Morris, H. J., I937: Physiological studies with the nitrogen-fixing alga, Nostoc muscorım (Botan. Gaz., 98:433-463; 35 ref.).

Amann, J., I9II: Die direkte Zählung der Wasserbakterien mittels des Ultramikroskops (Centralbl. f. Bakt., II Abt., 29:38I-384).

American Public Health Association, 1936: Standard Methods for the Examination of Water and Sewage (Amer. Pub. Health Assoc., New York, 8th Ed., 309 pp.; many ref.).

ANDERSON, D. Q., I940: Distribution of organic matter in marine sediments and its availability to further decomposition (Jour, Mar. Res., 2:225-235).

Angst, E. C., 1929: Some new agar-digesting bacteria (Publ. Puget Sound Biol. Sta., Univ. IVash., 7:49-63;4 ref.).

Aronson, J. D., I926: Spontaneous tuberculosis in salt water fish (Jour. Infect. Dis., 39:315320; I5 ref.).

ATKINS, IV. R. G., 1923: The phosphate content of fresh and salt waters in its relationship to the growth of the algal plankton (Jour. Mar. Biol. Assoc., I3:1 19-150; 26 ref.).

- 1926 : A quantitative consideration of some factors concerned in plant growth in water (Jour. du Conseil Perm. Internat. p. l'explor. de la Mer, I:99-126; 197-226; 55 ref.).

- I 1932 : Solar radiation and its transmission through air and water (Jour. du Conseil Perm. Internat. p. l'explor. de la Mer, 7:171-21I; 5I ref.).

AtKins, W. R. G., and WARREN, F. J., I94I: The preservation of fishing nets, trawl twines and fibre ropes for use in sea water (Jour. Mar. Biol. Assoc., 25:97-107; 4 ref.).

BAARS, J. K., I930: Over Sulfaatreductie door Bacteriën (Dissertation, Delft, I64 pp.; 9 I ref.).

BAAs Becking, L. M. G., I925: Studies on the sulfur bacteria (Ann. Botany, 39:613-650; 68 ref.).

BaAs Becking, L. [Becking], Tolman, C. F., McMillin, H. C., Field, J., and Hashinoto, T., 1927: Preliminary statement regarding the diatom "epidemics" at Copalis Beach, Washington, and an analysis of diatom oil (Econ. Geol., 22:356-368; i 7 ref.).

BAIER, C. R., I935: Studien zur Hydrobakteriologie stehender Binnengewässer (Arch. f. Hydrobiol., 29:183-264; 157 ref.).

_- I937a: Die Bedeutung der Bakterien für den Kalktransport in den Gewässern (Geol. d. Meere u. Binnengewässer, $1: 75-105 ;$ I 29 ref.).

- $1937 b$ : Die Bedeutung der Bakterien für die Bildung oxydischer Eisen- und Manganerze (Geol. d. Meere u. Binnengewässer, I:325-348; 87 ref.).

Bancel, C., and Husson, C., i879: Sur la phosphorescence de la viande de homard (Compt. rend. Acad. Sci., 88:I9I-192).

Baranik-PIkowsky, M. A., 1927: Ueber den Einfluss hoher Salzkonzentrationen auf die Limanbakterien (Centralbl. f. Bakt., II Abt., 70:373-383; I3 ref.).

BARGHOORN, E. S., I942: The occurrence and significance of marine cellulose-destroying fungi (Science, 96:358-359).

BARgIOORN, E. S., and LINDER, D. H., I944: Marine fungi: their taxonomy and biology (Farlowia, $\mathbf{1}: 395-467 ; 45$ ref.).

BARKER, H. A., I936a: On the biochemistry of the methane fermentation (Arch. f. Mikrobiol., 7:404-4I9; 30 ref.).

-1 , 1936b: Studies upon the methane-producing bacteria (Arch. f. Mikrobiol., 7:420 $438 ; 2$ r ref.). 
Barnes, T. C., and JAHN, T. L., I934: Properties of water of biological interest (Quart. Rev. Biol., 9:292-34I; 206 ref.).

Basset, J., Gratia, A., Macheboeuf, M., and Manil, P., 1938: Action of high pressures on plant viruses (Proc. Soc. Exper. Biol. Med., 38:248-25I; 26 ref.).

Basset, J., and Macheboeur, M., I932: Etude sur les effets biologiques des ultra-pressions (Compt. rend. Acad. Sci., I95:I43 I-I433).

BAstin, E. S., I926: The problem of the natural reduction of sulphates (Bull. Amer. Assoc. Petrol. Geol., 10:1 270-1299; 20 ref.).

Bastin, E. S., and Greer, F. E., I930: Additional data on sulphate-reducing bacteria in soils and waters of Illinois oil fields (Bull. Amer. Assoc. Petrol. Geol., I4:153-159).

Baumgartner, J. G., I937: The salt limits and thermal stability of a new species of anaerobic halophile (Food Res., 2:32I-329; I9 ref.).

BAUR, E., I902: Ueber zwei denitrificirende Bakterien aus der Ostsee (Wiss. Meeresunters., Abt. Kiel, N.F., 6:9-22).

BAvEnDAMM, W., I924: Die farblosen und roten Schwefelbakterien des Süss- und Salzwassers (G. Fischer, Jena, I 59 pp.; 295 ref.).

deut. botan. Ges., 49:282-287; xi ref.).

- — - I932: Die mikrobiologische Kalkfällung in der tropischen See (Arch.f. Mikrobiol., $3: 205-276 ;$ I 43 ref.).

BEARd, P. J., and MEAdowcroft, N. F., I935: Survival and rate of death of intestinal bacteria in sea water (Amer. Jour. Pub. Health, $25: 1023-1026$; 10 ref.).

Beatty, S. A., and Gibbons, N. E., 1937: The measurement of spoilage in fish (Jour. Bicl. Bd. Canada, 3:77-91; 25 ref.).

Beauregard, H., 1897: Étude bactériologique de l'ambre gris (Compt. rend. Acad. Sci., I25: 254-256).

BECKWITH, T. D., I9II: The bacteriological cause of the reddening of cod and other allied fish (Centralbl. f. Bakt., I Abt., 60:35 I-354; I5 ref.).

BEDFORD, R. H., I93I: The bactericidal effect of the "Prince Rupert" sea water sampling bottle (Contr. Canad. Biol. Fish., N.S., 6:423-426).

- I 1933a: The discolouration of halibut by marine chromogenic bacteria at $0^{\circ} \mathrm{C}$. (Contr. Canad. Biol. Fish., N.S., 7:425-430; 4 ref.).

- $1933 b$ : Marine bacteria of the northern Pacific Ocean. The temperature range of growth (Contr. Canad. Biol. Fish., N.S., $7: 43 I-438 ; 5$ ref.).

Beijerinck, M. W., i889: Le Photobacterium luminosum, bactérie lumineuse de la mer du nord (Arch. néerlandaises sci. exactes naturelles, 23:40I-4I5).

- 1 1895: Ueber Spirillum desulfuricans als Ursache von Sulfatreduction (Centralbl. f. Bakt., II Abt., I:I-9; 49-59; I04-II4; 20 ref.).

- I - I904: Ueber die Bakterien, welche sich im Dunkeln mit Kohlensäure als Kohlenstoffquelle ernähren können (Centralbl. f. Bakt., II Abt., II:593-599; 4 ref.).

BeNeCKE, W., I905: Ueber Bacillus chitinovorus, einen Chitin zersetzenden Spaltpilz (Botan. Zeitung, I Abt., 63:227-242; 20 ref.).

_- 1933: Bakteriologie des Meeres (Abderhalden's Handb. d. biol. Arbeitsmethoden, IX Abt., T. 5:7r $7-854 ; 600$ ref.).

Benecke, W., and KeUtner, J., I903: Ueber stickstoffbindende Bakterien aus der Ostsee (Ber. deut. botan. Ges., 2 I :333-345; I4 ref.).

Benson, H. K., and Partansky, A. M., I934: The rate and extent of anaerobic decomposition of sulfite waste liquor by bacteria of sea water mud (Proc. Nat. Acad. Sci., 20:542-55x; I 8 ref.).

BERE, RUBY, I933: Numbers of bacteria in inland lakes of Wisconsin as shown by the direct microscopic method (Internat. Rev. d. ges. Hydrobiol. u. Hydrogr., 29:248-263; I 7 ref.).

Bergey, D. H., et al., r939: Manual of Determinative Bacteriology (Williams \& Wilkins Co., Baltimore, 5th Ed., 1032 pp.).

_- 1946: Manual of Determinative Bacteriology (Williams \& Wilkins Co., Baltimore, 6th Ed.; in press).

Berkeley, C., I9r9: A study of marine bacteria, Straits of Georgia, B.C. (Trans. Roy. Soc. Canada, Ser. 3, Sec. 5, I3:15-43; 8 ref.).

Bertel, Lilly, i936: Sur quelques avantages remarquables dans la culture des bactéries marines (Bull. Inst. Océanogr., Monaco, No. 688:I-5).

Bertel, R., I9II: Ein einfacher Apparat zur Wasserentnahme aus beliebigen Meerestiefen für bakteriologische Untersuchungen (Biol. Centralbl., 3r:58-6r).

- - 1912: Sur la distribution quantitative des bactéries planctoniques des cóes de Monaco (Bull. Inst. Océanogr., Monaco, No. 224:I-12; I 5 ref.).

- - I935: Les bactéries marines et leur influence sur la circulation de la matière dans la mer (Bull. Inst. Océanogr., Monaco, No. 672:I-I2, 4 ref.). 
Brgelow, H. B., I03I: Ocennography (Houghton Minlin Co., Boston, 263 pp.).

Bigelow, H. B., and Sears, MARY, r939: Studies of the waters of the continental shelf, Cape Cod to Chesapeake Bay, II. A volumetric study of the zooplankton (Mcm. Mus. Comp. Zoöl. Harvard College, $54: 189-378 ; 84$ ref.).

Brllet, A., I888a: Sur le cycle évolutif et les variations morphologiques d'une nouvelle Bactériacée marine, Bacterium laminariae (Compt. rend. Acad. Sci., 106: 293-295).

- - 1888b: Sur le cycle évolutif d'une nouvelle Bactériacée chromogène et marine, Bacterium balbianii (Compt. rend. Acad. Sci., ro7: 423-425).

Bokova, E., Borsook, V., Verjbinskaya, N., Kreps, E., and Lukyanowa, V., i936: Enzymes in sea water (Arkh. biol. nauk, 43(ser, 2-3) :353-364; Russian with English summary; IS ref.).

BraARUd, T., and Föyn, B., I93I: Beiträge zur Kenntnis des Stoffwechsels im Meere (Avhandl. Norske Videnskaps-Akad. i Oslo, 1. Matem.-Naturv. Klasse, 1930, No. I4:I-24; 24 ref.).

Bradley, H. C., and BAILEY, B. E., 1940: Estimation of decomposition of fish muscle (Food Res., 5-487-493; 8 ref.).

Brandt, K., I899: Ueber den Stoffwecksel im Meere (IViss. Meeresunters., Abt. Kiel, N.F., $4: 213^{-230}$; 50 ref.).

- I902: Ueber den Stoffwechsel im Meere, II. Abhandlung (Wiss. Meeresunters., Abt. Kiel, N.F., 6:23-79; $3^{8}$ ref.).

_ 1929: Phosphate und Stickstoffverbindungen als Minimumstoffe für die Produktion im Meere (Rapp. et Proc.-Verb. Conseil Perm. Internat. p. l'explor. de la Mer, 53:5-35; 75 ref.),

BRANDT, R. P., I923: Potash from kelp. Early development and growth of the giant kelp, Macrocyst is pyrifera (U.S. Dept. Agric., Bull. No. I I9I:I-40; 10 ref.).

BREED, R. S., and BREw, J. D., IgI6: Counting bacteria by means of the microscope (N.Y. Agric. Exper. Sta., Tech. Bull. No. 49:I-3I; 35 ref.).

Breed, R. S., Murray, E. G. D., and Hitchens, A. P., i944: The outline classification used in the Bergey Manual of Determinative Bacteriology (Bact. Rev., 8:255-260; 24 ref.).

$-1-1945$ : The new system of classification used in the Bergey Manual of Determinative Bacteriology (Jour. Bact., 49: In press).

BRENNER, IV., I9I6: Züchtungsversuche einiger in Schlamm lebenden Bakterien auf selenhaltigem Nährboden (Jahrb. f. wiss. Botan., $57: 95^{-128} ; 22$ ref.).

Brown, C. J. D., and BALL, R. C., 1940: A rowboat crane for hauling limnological apparatus (Limnol. Soc. Amer., Special Publ. No. 3:I-3).

BRowne, W. W., I9I 7: The presence of the B. coli and B. welchii groups in the intestinal tract of fish (Stenomus chrysops) (Jour. Bact., $2: 417-422 ;$ i 2 ref.).

- - I922: Halophilic bacteria (Proc. Soc. Exper. Biol. Med., I9:32I-322).

BRUjevicz, S. IV., I937: Oxidation-reduction potentials and $p \mathrm{H}$ of sea bottom deposits (Verhandl. d. internat. Vereinigung f. theor. u. angew. Limnologie, 8:35-49).

- , I938: Oxidation-reduction potential and the $p \mathrm{H}$ of sediments of Barentz and Kara Seas (Compt. rend. Acad. Sci., URSS, I9:637-640; 8 ref.).

BRUTSAERT, P., I924: Les Bactériophages et les microbes dans le bouillon hypersale (Compt. rend. Soc. biol., 90:646-648; 5 ref.).

Buchanan, R. E., and Fulmer, E. I., I928: Physiology and Biochemistry of Bacteria (WVilliams \& Wilkins Co., Baltimore, Vol. I, 516 pp.; 672 ref.).

_ _ - I930: Physiology and Biochemistry of Bacteria (Williams \& Wilkins Co., Baltimore, Vol. II, 709 pp.; 2237 ref.).

Becher, W. H., 1921: Logan's explanation of the origin of Indiana's kaolin (Econ. Geol., I6:48I-492; 9 ref.).

BuCnNer, H., I 893: Ueber den Einfluss des Lichtes auf Bakterien und über die Selbstreinigung der Flüsse (Arch. f. Hyg., I $7: 179-204 ; 5$ ref.).

BUNker, H. J., I936: A review of the physiology and biochemistry of the sulphur bacteria (His Majesty's Stationery Office, London, 48 pp.; I60 ref.).

Buswell, A. M., 1936: Anaerobic fermentations (Illinois State Water Survey, Bull. 32, I93 pp.; 394 ref.).

ButkevicH, V. S., I928: Die Bildung der Eisenmangan-Ablagerungen am Meeresboden und die daran beteiligten Mikroorganismen (Ber. d. wiss. Meeresinst., Moscow, 3(3):5-8I ; Russian with German summary; 86 ref.).

- - 1932a: Ein neuer Apparat zur Entnahme von Wasserproben für mikrobiologische Untersuchungen (Mikrobiologiia, $\mathbf{1}: 280-283$; Russian with German summary).

- - 1932b: Zur Methodik der bakteriologischen Meeresuntersuchungen und einige Angaben über die Verteilung der Bakterien im Wasser und in den Böden des Barents Meeres (Trans. Oceanogr. Inst. Moscow, 2:5-39; Russian with German summary).

- 1938 : On the bacterial population of the Caspian and Azov seas (Mikrobiologiia, 7:1005-1021; Russian with English summary; 9 ref.). 
Butterfield, C. T., I932: The selection of a dilution water for bacteriological examinations (Jour. Bact., 23:355-368; 7 ref.).

- 1933a: Observations on changes in numbers of bacteria in polluted water (Sewage Works Jour., 5:600-622; 4 ref.).

- _ - I933b: Comparison of enumeration of bacteria by means of solid and liquid media (U.S. Pub. Health Reports, 48:1292-1297).

California State Bureau of Sanitary Engineering, 1943: Report on a pollution survey of Santa Monica Bay beaches in 1942 (Calif. State Printing Office, Sacramento, 69 pp.).

Calkins, G. N., I926: The Biology of the Protozoa (Lea \& Febiger, Philadelphia, 623 pp.; 460 ref.).

Cantacuzène, A., I930: Contribution à l'étude des tumeurs bactériennes chez les Algues marines (Thèse Universitaire Paris. Abstract in Bibliographia Oceanographia, 3:236, I932).

CAREy, CORnelia L., r938: The occurrence and distribution of nitrifying bacteria in the sea (Jour. Mar. Res., I:29I-304; 25 ref.).

CAREY, CoRnelia L., and Waksman, S. A., I934: The presence of nitrifying bacteria in deep seas (Science, 79:349-350).

Carpenter, L. V., Setter, L. R., and Weinberg, M., i938: Chloramine treatment of sea water (Amer. Jour. Pub. Health, 28:929-934; 5 ref.).

CARPenter, P. L., I 939: Bacterial counts in the muds of Crystal Lake - an oligotrophic lake of Northern Wisconsin (Jour. Sediment. Petrology, $9: 3-7 ; 7$ ref.).

Cassedebat, P. A., I894: De l'action de l'eau de mer sur les microbes (Rev. d'hyg. et de police san., I6:IO4-II8).

Cattell, M., I936: The physiological effects of pressure (Biol. Rev., II :44I-476; I2I ref.).

Certes, A., I884a: Sur la culture, à l'abri des germes atmosphériques, des eaux et des sédiments rapportés par les expéditions du Travailleur et du Talisman; I882-1883 (Compt. rend. Acad. Sci., 98:690-693).

- I $1884 b$ : De l'action des hautes pressions sur les phénomènes de la putréfaction et sur la vitalité des micro-organismes d'eau douce et d'eau de mer (Compt. rend. Acad. Sci., $99: 385-388$ ).

Chibnall, A. C., et al., I934: The constitution of the primary alcohols, fatty acids and paraffins present in plant and insect waxes (Biochem. Jour., 28:2189-2208; 59 ref.).

Chlopin, G. W., and Tammann, G., r9o3: Ueber den Einfluss hoher Drucke auf Mikroorganismen (Zeitschr. f. Hyg., 45:I 7I-204; 9 ref.).

Cholodny, N., I926: Die Eisenbakterien (G. Fischer, Jena, I7I pp.; 67 ref.).

__ - I929: Zur Methodik der quantitativen Erforschung des bakteriellen Planktons (Centralbl. f. Bakt., II Abt., 77:I79-I93; 6 ref.).

- - I930: Ueber eine neue Methode zur Untersuchung der Bodenmikroflora (Arch. $\mathrm{f}$. Mikrobiol., I:620-652; 4 ref.).

Clarke, F. W., r924: The data of geochemistry (U. S. Geol. Survey, Bull. 770, 84I pp.).

Clakke, G. L., I933: Diurnal migration of plankton in the Gulf of Maine and its correlation with changes in submarine irradiation (Biol. Bull., 65:402-436; 29 ref.).

Clarke, G. L., I936: Light penetration in the Western North Atlantic and its application to biological problems (Rapp. et Proc.-Verb. Conseil Perm. Internat. p. l'explor. de la Mer, IOI:I-I4; 27 ref.).

ClaRke, G. L., and GELLIS, S. S., I935: The nutrition of copepods in relation to the food-cycle of the sea (Biol. Bull., 68:23I-246; 3 I ref.).

Clarke, G. L., and Oster, R. H., I934: The penetration of the blue and red components of daylight into Atlantic coastal waters and its relation to phytoplankton metabolism (Biol. Bull., 67:59-75; 99 ref.).

Clarke, H. T., and Mazur, A., I94I: The lipids of diatoms (Jour. Biol. Chem, I4I:283-289; 9 ref.).

Clayton, W., r93r: The bacteriology of common salt (Food Manufacture, 6:133 and 257).

Clayton, W., and GrbBs, W. E., I927: Examination for halophilic micro-organisms (Analyst, $52: 395-397 ; 7$ ref.).

COE, W. R., and ALLEN, W. E., 1937: Growth of sedentary marine organisms on experimental blocks and plates for nine successive years (Bull. Scripps Inst. Oceanogr., Tech. Ser., 4:IoI136; 9 ref.).

Comn, F., I865: Zwei neue Beggiatoen (Hedwigia, 4:81-84).

Coker, R. E., I938: Life in the sea (Scient. Monthly, 46:299-322, 4I6-432; I 2 ref.).

Committee on Oceanography, 1932: Physics of the Earth - V. Oceanography (Bull. Nat. Res. Council, 85:I-581; many ref.).

Conn, H. J., 1918: The microscopic study of bacteria and fungi in soil (N. Y. Agric. Exper. Sta., Tech. Bull. No. 64:3-20; II ref.).

Coolhas, C., I928: Zur Kenntnis der Dissimilation fettsaurer Salze und Kohlenhydrate durch thermophile Bakterien (Centralbl. f. Bakt., II Abt., 75:I6I-170). 
Cooper, L. H. N., 1935: The rate of liberation of phosphate in sea water by the breakdown of plankton organisms (Jour. Mar. Biol. Assoc., 20:197-200; 6 ref.).

$-\ldots, 1937 a$ : Oxidation-reduction potential in sea water (Jour. Mar. Biol. Assoc., 22:167I 76 ; I ref.).

_ - 1937 b: The nitrogen cycle in the sea (Jour. Mar. Biol. Assoc., 22:183-204; 76 ref.).

COPENHAGEN, W. J., I934: Occurrence of sulphides in certain areas of the sea bottom on the South African coast (Union So. Africa Fish Mar. Biol. Survey, Report No. 3:3-18).

Coupin, H., I915: Sur le pouvoir fermentaire des Bactéries marines (Compt. rend. Acad. Sci., $161: 597-600)$.

Crostiwate, P. M., and Redgrave, G. R., 1920: The Deterioration of Structures in Sea Water (His Majesty's Stationery Office, London, 301 pp.; 56 ref.).

Cupp, Easter E., 1943: Marine plankton diatoms of the west coast of North America (Bull. Scripps Inst. Oceanogr., $5: 1-238 ; 234$ ref.).

CURR.1x, H. R., I93I: Influence of osmotic pressure upon spore germination (Jour. Bact., 21:197-209; 7 ref.).

Cutler, D. IV., and Cruarp, L. M., 1929: Carbon dioxide production in sands and soils in the presence and absence of amoebae (Ann. Appl. Biol., I6:472-482; 16 ref.).

- $-1, \ldots 35$ : Problems in Soil Microbiology (Longmans, Green and Co., London, ro4 pp.; 50 ref.).

DAHLGREN, U., I915: The production of light by animals (Jour. Franklin Inst., 180:5 13-537; $7 \mathrm{II}-727)$

Daines [nec Dantels], L. L., I917: On the flora of Great Salt Lake (Amer. Naturalist, 51 :499$506 ; 4$ ref.)

Danitchenko, P., and Tschurinine, N., I926: Sur l'origine de l'hydrosulfure dans la mer Noire (Trav. du Lab. zool. et de la Sta. biol. de Sébastopol, Ser. 2, No. 10:I4I-19I; Russian with French summary; 27 ref.).

Darling, C. A., and Siple, P. A., r94I: Bacteria of Antarctica (Jour. Bact., 42:83-98; 8 ref.).

DAvis, B. L., 1933: An investigation into the bacterial pollution of swimming baths, III Results of an investigation to determine the presence of bacteriophage in ordinary tap-water, sea-water and the water from sea-water bathing pools after use (Jour. Roy. Army Med. Corps., 6r:18-25; 4 ref.).

Davis, H. S., I922: A new bacterial disease of fresh-water fishes (Bull. U. S. Bur. Fish., $38: 26 \mathrm{I}-280$ ).

D'Herelle, F., 1926: The Bacteriophage and Its Behavior (Translated by G. H. SMTH; Williams \& Wilkins Co., Baltimore, 629 pp.; 647 ref.).

Dienert, F., and Guillerd, A., i940: Etude de la pollution de l'eau de mer par le déversement des eaux d'égouts (Ann. d'hyg. pub., ser. 5, r8:209-2I7).

Dnmtroff, V. T., I926a: Spirillum virginianum nov. spec. (Jour. Bact., I2:19-49; 32 ref.).

- - I926b: Spirochaetes in Baltimore market oysters (Jour. Bact., I2:135-177; I6 ref.).

Dodgson, R. W., I928: Report on Mussel Purification (His Majesty's Stationery Office, London, 535 pp.; I 26 ref.).

Domogalla, B. P., Fred, E. B., and Peterson, W. H., I926: Seasonal variations in the ammonia and nitrate content of lake waters (Jour. Amer. Water Works Assoc., I 5:369-385; x 7 ref.).

Dore, W. H., and Mrller, R. C., r923: The digestion of wood by Teredo navalis (Univ. Calif. Publ. in Zool., 22:383-400; 25 ref.).

DoRfE, C., 1920: The action of sea water on cotton and other textile fibers (Biochem. Jour., 14:709-714; 3 ref.).

DorfF, P., 1935: Die Eisenorganismen, II. Biologie des Eisen- und Mangankreislaufs (Verlagsgesellschaft für Ackerbau, ro6 pp.; 305 ref.).

DREW, G. H., IgII: The action of some denitrifying bacteria in tropical and temperate seas, and the bacterial precipitation of calcium carbonate in the sea (Jour. Mar. Biol. Assoc., 9:142-155).

- I912: Report of investigations on marine bacteria carried on at Andros Island, Bahamas, British West Indies, in May, I9I 2 (Yearbook Carnegie Inst. Wash., No. I1:136I44).

_- , r913: On the precipitation of calcium carbonate in the sea by marine bacteria, and on the action of denitrifying bacteria in tropical and temperate seas (Jour. Mar. Biol. Assoc., 9:479-524; 17 ref.).

- I914: On the precipitation of calcium carbonate in the sea by marine bacteria, and on the action of denitrifying bacteria in tropical and temperate seas (Papers from Tortugas Lab., Carnegie Inst. Wash., 5:7-45; 17 ref.).

DrEwes, K., I928: Ueber die Assimilation des Luftstickstoff durch Blaualgen (Centralbl. f. Bakt., II Abt., 76:88-IoI; 24 ref.).

DufF, D. C. B., 1932: Furunculosis on the Pacific coast (Trans. Amer. Fish. Soc., 62:249-255; 7 ref.). 
DÜGGELI, M., I924: Bakteriologische Untersuchungen am Ritomsee (Zeitschr. f. Hydrol. (Rev. d'Hydrol.), 2:65-206; 7 ref.).

- I I934: Bakteriologische Studien am Wasser des Rotsees (Zeitschr. f. Hydrol. (Rev. d'Hydrol.), 6:2 I6-440; 4 ref.).

- I936: Die Bakterienflora in Schlamm der Rotsee (Zeitschr. f. Hydrol. (Rev. d'Hydrol.), $7: 205-363$; I ref.).

Durham, O. C., I942: Air-borne fungus spores as allergens (Aerobiology, Amer. Assoc. Adv. Sci., Washington, D. C., Publ. No. I 7:32-47; 58 ref.).

Dyer, W. J., Sigurosson, G. J., and Wood, A. J., I944: A rapid test for detection of spoilage in sea fish (Food Res., 9:183-r87; 8 ref.).

EARdley, A. J., r938: Sediments of Great Salt Lake, Utah (Bull. Amer. Assoc. Petrol. Geol., $22: 1305^{-I} 4$ II ; IOO ref.).

EHRENBERG, C. G., I838: Die Infusionsthierchen als vollkommene Organismen. Ein Blick in das tiefere organische Leben der Natur (Folio, Leipzig, 547 pp.).

EkelöF, E., I907: Studien über den Bakteriengehalt der Luft und des Erdbodens der antarktischen Gegenden, ausgeführt während der schwedischen Südpolar-Expedition 1901-1904 (Zeitschr. f. Hyg., 56:344-370).

Ekman, S., I935: Tiergeographie des Meeres (Akad. Verlagsgesellschaft M.B.H., Leipzig, 542 pp.; 660 ref.).

Elazari-Volcani, B., I940: Studies on the microflora of the Dead Sea (Dissertation, Hebrew University, Jerusalem, I I9 pp.; Hebrew with English summary; 85 ref.).

- I 1943 : Bacteria in the bottom sediments of the Dead Sea (Nature, $152: 274-275 ; 4$ ref.).

Elema, B., I932: De Bepaling van de Oxydatie-Reductiepotentiaal in Bacteriëncultures en hare Beteekenis voor de Stofwisseling (Thesis, W. D. Meinema, Delft, I9I pp.; Dutch with English summary; 130 ref.).

Elema, B., Kluyver, A. J., and van Dalfsen, J. W., I934: Ueber die Beziehungen zwischen den Stoffwechselvorgängen der Mikroorganismen und dem Oxydo-reduktionspotential im Medium, I. Versuche mit denitrifizierenden Bakterien (Biochem. Zeitschr., 270:3I $7-340$; 22 ref.).

Eliot, C., I926: Bacterial flora of the market oyster (Amer. Jour. Hyg., 6:755-776; 31 ref.).

Ellrotr, Jessie S., I930: The soil fungi of the Dovey Salt Marshes (Ann. Appl. Biol., I 7:284$305 ; 2$ I ref.).

Eltis, B. F., and Messina, A. R., I940: A Catalogue of Foraminifera (Amer. Mus. Nat. Hist., New York, 30,000 pp. in 30 volumes).

Ellis, C., Wells, A. A., and Boehmer, N., r925: The Chemical Action of Ultraviolet Rays (Chem. Cat. Co., New York, 362 pp.; many ref.).

Elis, D., I9I9: Iron Bacteria (Frederick A. Stokes Co., New York, I79 pp.; 53 ref.).

- 1932: Sulphur Bacteria. A Monograph (Longmans, Green and Co., New York, 26 I pp.; 335 ref.).

EMERY, K. O., and Dietz, R. S., I94I: Gravity coring instrument and mechanics of sediment coring (Bull. Geol. Soc. Amer., 52:1685-1714; 10 ref.).

ENEvoldsen, V., I927: Ueber vielleicht durch Bakterienwachtum verursachte Änderungen in der Wasserstoffionenkonzentration natürlicher Wässer (Biochem. Zeitschr., I8I:25 I-266; 4 ref.).

ERdtMan, G., I938: Pollen grains recovered from the atmosphere over the Atlantic (Medd. Göteborgs Botan. Trädgård, I2:185-196; 8 ref.).

ERIKSON, D., I94I: Studies on some lake-mud strains of Micromonospora (Jour. Bact., 41:277300; 18 ref.).

Esterly, C. O., rgr6: The feeding habits and food of pelagic copepods and the question of nutrition by organic substances in solution in water (Univ. Calif. Publ. in Zool., 16:17 $1-184$; 18 ref.).

Eyre, J. W. H., I923: Some notes on the bacteriology of the oyster (including description of two new species) (Jour. Roy. Micro. Soc., 43:385-394).

——, 1930: Bacteriological Technique (Wm. Wood \& Co., New York, 3rd ed., 6r 7 pp.).

FARRell, M. A., and Turner, H. G., I932: Bacteria in anthracite coal (Jour. Bact., 23 :I55I62; 12 ref.).

Feitel, R., r903: Beiträge zur Kenntnis denitrifizirender Meeresbakterien (Wiss. Meeresunters., Abt. Kiel, N.F., 7:89-II0; 7 ref.).

FEJGIN, B., I926: Études sur les microbes marins, II. Etude sur la forme imperceptible des bactéries dans l'eau de mer (Bull. Inst. Océanogr., Monaco, No. 484:I-7; 20 ref.).

Fellers, C. R., I926: Bacteriological investigations on raw salmon spoilage (Univ. Wash. Publ. Fish., I:I $57-188$; 54 ref.).

Fernand, A., Sempe, and Chavanne, r925: Propriétés antimicrobiennes de diverses eaux fluviales ou marines. Pouvoir bactériophagique (Bull. Acad. de méd., 93:184-187). 
Fiscrer, B., I886: Bacteriologische Untersuchungen auf einer Reise nach Westindien (Zeitschr. f. Hyg., I:42I-464; 3 ref.).

- I I857: Bacteriologische Untersuchungen auf einer Reise nach Westindien, II. Ueber einen lichtentwickelnden, im Meerswasser gefundenen Spaltpilz (Zeitschr. f. Hyg., $2: 54-95 ; 7$ ref.).

- I 1889 : Ueber einen neuen lichtentwickelnden Bacillus (Centralbl. f. Bakt., 3 :105108; I37-141).

_- IS88b: Berichte über Bakterienwachsthum bei $0^{\circ} \mathrm{C}$ sowie über das Photographiren von Kulturen leuchtender Bakterien in ihrem eigenen Lichte (Centralbl. f. Bakt., 4:89-92; 4 ref.).

4 I 1803: Ueber das Grundwasser von Kiel mit besonderer Berücksichtegung seines Eisengehaltes und über Versuche zur Entfernung des Eisens aus demselben (Zeitschr. f. Hyg., 13:251-335; 27 ref.).

___- I 894a: Die Bakterien des Meeres nach den Untersuchungen der Plankton-Expedition unter gleichzeitiger Berücksichtigung einiger älterer und neuerer Untersuchungen (Ergebnisse der Plankton-Expedition der Humboldt-Stiftung, 4:I-83; 22 ref.).

_ - ISo4 $b$ : Die Bakterien des Meeres nach den Untersuchungen der Planktonexpedition unter gleichzeitiger Berücksichtigung einiger älterer und neuerer Untersuchungen (Centralbl. f. Bakt., I5:657-666).

- - I894c: Ergebnisse einiger auf der Planktonexpedition ausgeführten bakteriologischen Untersuchungen der Luft über dem Meere (Zeitschr. f. Hyg., I $7: 185-194 ; 4$ ref.).

Fischer, B., and BREBECK, C., I894: Zur Morphologie, Biologie und Systematik der Kahmpilze, der Monilia candida Hansen und des Soorerregers (G. Fischer, Jena, 52 pp.; 3 I ref.).

Fiscier, H., I904: Ueber Symbiose von Azotobacter mit Oscillarien (Centralbl. f. Bakt., II Abt., 12:267-268; 5 ref.).

FLowers, S., I934: Vegetation of the Great Salt Lake Region (Botan. Gaz., 95:353-4I8; II ref.).

Forster, J., 1887: Ueber eininge Eigenschaften leuchtender Bakterien (Centralbl. f. Bakt., $2: 337-340$ ).

__ I 892 : Ueber die Entwickelung von Bakterien bei niederen Temperaturen (Centralbl. f. Bakt., I2:431-436; 9 ref.).

ForTr, A., r933: Il fenomeno del "lago di sangue" nello stagno di Pergusa in Sicilia alla metà di settembre 1932 (Nuovo giorn. botan. ital., 40:76-78).

Fortunato, L., I928: Il fenomeno litico del d'Herelle in rapporto alla flora batterica delle acque di mare (Ann. d'igiene, Rome, 38:544-549; 12 ref.).

Fowler, G. H., and Allen, E. J., I928: Science of the Sea (Clarendon Press, Oxford, 502 pp.; 55 ref.).

Fox, D. L., I934: Emulsin in certain marine invertebrates and micro-organisms (Biochem. Jour., 28:1674-I677; I2 ref.).

Fox, D. L., and CoE, IV. R., 1943: Biology of the California sea-mussel (Mytilus Californianus), II. Nutrition, metabolism, growth and calcium deposition (Jour. Exper. Zool., 93:205$249 ; 28$ ref.).

Fox, D. L., Sverdrup, H. U., and Cunningham, J. P., I937: The rate of water propulsion by the California mussel (Biol. Bull., $72: 4$ r $7-438 ; 23$ ref.).

Föyn, B., and Gran, H. H., I928: Ueber oxydation von organischen Stoffen im Meerwasser durch Bakterien (Avhandl. Norske Videnskaps-Akad. i Oslo, x. Matem.-Naturv. Klasse, No. $3: 1-16$; 12 ref.).

Frankland, E., and Burgess, W. T., 1897: Sea water microbes in high latitudes (Chem. News, $75: 1-2)$.

Frankland, P., and Frankland, Mrs. P., i894: Micro-organisms in Water (Longmans, Green, and Co., London, 532 pp.; many ref.).

Fred, E. B., WILSON, F. C., and DAVENPORT, AUdrey, I924: The distribution and significance of bacteria in Lake Mendota (Ecology, 5:322-339; 10 ref.).

GAARDER, T., and Gran, H. H., I927: Investigations of the production of plankton in the Oslo Fjord (Rapp. et Proc.-Verb. Conseil Perm. Internat. p. l'explor. de la Mer, 42:I-48; 37 ref.)

GAARDER, T., and SPÄRCK, R., I931: Biochemical and biological investigations of the variations in the productivity of the West Norwegian oyster pools (Rapp. et Proc.-Verb. Conseil Perm. Internat. p. l'explor. de la Mer, 75:47-58).

Gairl, R., and Anderson, B., I928: Sulphate reducing bacteria in California oil waters (Centralbl. f. Bakt., II Abt., 73:33I-338; 7 ref.).

Ganey, P. L., 1939: Microbiology of Water and Servage (Burgess Publishing Co., Minneapolis, 283 pp.; 4 ref.).

Galmimer, E. W., x933: The sulfur cycle in sediments (Jour. Sediment. Petrology, 3:51-63; 37 ref.).

GAZERT, H., I902: Bakteriologische Untersuchungen (Die Deutsche Südpolar-Expedition) (Veröff. Inst. Meeresk., Berlin, I:53-55). 
GAzERT, H., Igo6a: Bedeutung der Bakterien im Haushalt des Meeres (Deutsche Rev., 32 :236244).

- - I I $-606 b$ : Untersuchungen über Meersbakterien und ihren Einfluss auf den Stoffwechsel im Meere (Deutsche Südpolar-Expedition, I90r-03, Berlin, 7:235-296).

GEE, A. H., 1929: Research in marine bacteriology (Proc. 4th Pacific Sci. Congress, Java, I p.). _- I $3: 19 I-200 ; 13$ ref.).

- I932b: Lime deposition and the bacteria, I. Estimate of bacterial activity at the Florida Keys (Papers from Tortugas Lab., Carnegie Inst. Wash., 28:67-82; 20 ref.).

_- _ I932C: Mechanical spinner for Esmarch cultures (Jour. Bact., 24:35-4I).

- I I $-132 d$ : Scope and function of marine bacteriology (Final Report as Bacteriologist, Scripps Inst. Oceanogr., La Jolla, Calif., I 25 pp.; 420 ref.).

Geiger, E., Courtney, G., and Schnakenberg, G., 1944: The content and formation of histamine in fish muscle (Arch. Biochem., 3:3I I-3I9; I5 ref.).

Gelarie, A. J., I916: Vitality of cholera vibrio in the water of New York Bay (Medical Record, 89:236-239).

DE GraXA, I889: Ueber das Verbalten einiger pathogener Mikroorganismen im Meerwasser (Zeitschr. f. Hyg., 6:162-225; 4 ref.).

Gibbons, N. E., r934a: The slime and intestinal flora of some marine fishes (Contr. Canad. Biol. Fish., N.S., 8:275-290; 23 ref.).

- I I934 $b$ : Lactose-fermenting bacteria from the intestinal contents of marine fish (Contr. Canad. Biol. Fish., N.S., 8:291-300; 3 I ref.).

- I934C: A bacteriological study of "ice fillets" (Contr. Canad. Biol. Fish., N.S., 8:301-310; 6 ref.).

_ - I937: Studies on salt fish, I. Bacteria associated with the reddening of salt fish (Jour. Biol. Bd. Canada, 3:70-76; I7 ref.).

Gietzen, Johanna, I93I: Untersuchungen über marine Thiorhodaceen (Centralbl. f. Bakt., II Abt., 83:183-218; 97 ref.).

Gildemeister, E., and Watanabe, H., I93I: Untersuchungen über das Vorkommen von Bakteriophagen in Oberflächenwasser (Centralbl. f. Bakt., I Abt., I22:556-575; I9 ref.).

Ginsburg-KaRagitscheva, T. L., I933: Microflora of oil waters and oil-bearing formations and biochemical processes caused by it (Bull. Amer. Assoc. Petrol. Geol., I 7:52-65; I8 ref.).

Ginsburg-Karagitscheva, T., and Rodionowa, K., 1935: Beitrag zur Kenntnis der im Tiefseeschlamm stattfindenden biochemischen Prozesse (Biochem. Zeitschr., 275:396-404; 8 ref.).

Ginter, R. L., I930: Causative agents of sulphate reduction in oil-well waters (Bull. Amer. Assoc. Petrol. Geol., I4:I39-I52; 23 ref.).

Giudice, A., I939: Esame batteriologico dell'aria sul Mediterraneo e sul Mar Rosso (Ann, di med. navale e coloniale, 45:520-523).

GLock, W. S., I923: Algae as limestone makers and climatic indicators (Amer. Jour. Sci., $6: 377-408 ; 48$ ref.).

GRÄF, Dr., I909: Forschungsreise S. M. S. "Planet" 1906/o7 (Herausgegeben vom ReichsMarine-Amt. Berlin, Verlag von Karl Siegismund, 4:I-I98; I8 ref.).

Gratam, V. E., and Young, R. T., 1934: A bacteriological study of Flathead Lake, Montana (Ecology, I5:IOI-IO9; 9 ref.).

Gran, H. H., Igor: Studien über Meeresbakterien, I. Reduction von Nitraten und Nitriten (Bergens Museums Aarbog, No. IO:I-23; 8 ref.).

- 1902 : Studien über Meeresbakterien, II. Ueber die Hydrolyse des Agar-Agars durch ein neues Enzym, die Gelase (Bergens Museums Aarbog, No. 2:I-16; 7 ref.).

- - I I903: Havets Bakterier og deres Stofskifte (Naturen, Bergen, 27:33-40; 72-84).

- 1933 : Studies on the biology and chemistry of the Gulf of Maine, II. Distribution of phytoplankton in August, I932 (Biol. Bull., 64:I59-I82; 13 ref.).

Gran, H. H., and RuUd, B., I926: Untersuchungen über die im Meerwasser gelösten organischen Stoffe und ihr Verhältnis zur Planktonproduktion (Avhandl. Norske VidenskapsAkad. i Oslo, I. Matem.-Naturv. Klasse, No. 6:I-I4; I6 ref.).

Griffiths, F. P., I937: A review of the bacteriology of fresh marine-fishery products (Food Res., 2:I $2 \mathrm{I}-\mathrm{I} 34 ; 62$ ref.).

Griffithis, F. P., and Fuller, J. E., I936: Detection and significance of Escherichia coli in commercial fish and fillets (Amer. Jour. Pub. Health, 26:259-264; 13 ref.).

HALL, I. C., 1929: A review of the development and application of physical and chemical principles in the cultivation of obligately anaerobic bacteria (Jour. Bact., I 7:255-301; 247 ref.).

Halvorson, H. O, and Ziegler, N. R., I933a: Application of statistics to problems in bacteriology, I. A means of determining bacterial population by the dilution method (Jour. Bact., 25:IOI-I 2I; 30 ref.). 
- 1933b: Application of statistics to problems in bacteriology, III. A consideration of the accuracy of dilution data obtained by using several dilutions (Jour. Bact., 26:559-567; 5 ref.).

Hamar, H. E., I934: Relation of micro-organisms to generation of petroleum (Problems of Petroleum Geology, Amer. Assoc. Petrol. Geol., Tulsa, Okla., pp. 35-49; 8 I ref.).

Hanks, J. H., and IVentraub, R. L., 1936: The preparation of silicic acid jellies for bacteriological media (Jour. Bact., 32:639-670; ro ref.).

HanzawA, J., and TakedA, S., 1931: On the reddening of boned codfish (Arch. f. Mikrobiol., $2: \mathrm{I}-22 ; 48$ ref.).

HARDER, E. C., I9I9: Iron-depositing bacteria and their geologic relations (U.S. Geol. Survey, Prof. Paper II $3: 1-89 ; 65$ ref.).

Hardian, Yvette, and Henrici, A. T., I939: Studies of freshwater bacteria, V. The distribution of Sidcrocapsa treubii in some lakes and streams (Jour. Bact., 37:97-105; I3 ref.).

Harrison, F. C., I929: The discoloration of halibut (Canad. Jour. Res., I:214-239; 7 ref.).

Harrison, F. C., and Kennedy, MARgaret E., I922: 'The red discolouration of cured codfish (Trans. Roy. Soc. Canada, Ser. 3, Sec. 5, I6:I0I-152; 36 ref.).

Harrison, F. C., Perry, H. Margaret, and Suuth, P. W. P., I926: The bacteriology of certain sea fish (Nat. Res. Council, Canada, Report No. I9:I-48; Io ref.).

HaRTUlari, E. M., I939: Bacteriological and chemical researches of a number of lakes in the neighbourhood of Moskow in connection with the problem of mud decomposition with gas formation (Proc. Kossino Limnolog. Sta., 22:115-127; Russian with English summary; 5 ref.).

Harvey, E. N., 1940: Living Light (Princeton Univ. Press, Princeton, 328 pp.; 535 ref.).

HARvey, H. W., I926: Nitrate in the sea (Jour. Mar. Biol. Assoc., I4:71-88; I6 ref. Also I5:I83-I90, I928).

- I - I928: Biological Chemistry and Physics of Sea Water (Cambridge Univ. Press, London, I94 pp.; I3I ref.).

- - I I933: On the rate of diatom growth (Jour. Mar. Biol. Assoc., 19:253-276; I5 ref.).

Hauduroy, P., I923: I. Recherches sur le bactériophage de d'Hérelle (Présence du principe dans l'eau de mer) (Bull. Inst. Océanogr., Monaco, No. 433:I-12).

Hеснт, F., 1934: Die chemische Zersetzung der tierischen Substanz während der Einbettung in marine Sedimente (Kali, 28:209-215).

HenricI, A. T., I933: Studies of freshwater bacteria, I. A direct microscopic technique (Jour. Bact., 25:277-287; I2 ref.).

_ - I936: Studies of freshwater bacteria, III. Quantitative aspects of the direct microscopic method (Jour. Bact., 32:265-280; 7 ref.).

- - I 2 I938: Studies of freshwater bacteria, IV. Seasonal fluctuations of lake bacteria in relation to plankton production (Jour. Bact., 35:129-139; 10 ref.).

- - 1939: The distribution of bacteria in lakes (Problems of Lake Biology, Amer. Assoc. Adv. Sci., Washington, D. C., Publ. No. I0:39-64; 60 ref.).

Henrici, A. T., and Johnson, Delia E., I935: Studies of freshwater bacteria, II. Stalked bacteria, a new order of Schizomycetes (Jour: Bact., 30:6r-93; 25 ref.).

Henrici, A. T., and MCCOY, ElIZABETH, I938: The distribution of heterotrophic bacteria in the bottom deposits of some lakes (Trans. Wisconsin Acad. Sci., 31:323-36r; 34 ref.).

HEss, E., 1932: The influence of low temperatures above freezing upon the rate of autolytic and bacterial decomposition of haddock muscle (Contr. Canad. Biol. Fish., N.S., 7:147-163; 20 ref.).

-1 , I934a: Cultural characteristics of marine bacteria in relation to low temperatures and freezing (Contr. Canad. Biol. Fish., N.S., 8:459-474; 40 ref.).

- $1934 b$ : Effects of low temperatures on the growth of marine bacteria (Contr Canad. Biol. Fish., N.S., 8:489-505; 33 ref.).

- 1937: A shell disease in lobsters (Homarus americanus) caused by chitinovorous bacteria (Jour. Biol. Bd. Canada, 3:358-362; 2 ref.).

Hesse, E., I9I4: Bakteriologische Untersuchungen auf einer Fahrt nach Island Spitzbergen und Norwegen im Juli I9I3 (Centralbl. f. Bakt., I Abt., 72:454-477; 28 ref.).

HeUkelekian, H., I933: Effect of dilution of sewage on bacterial numbers (Sewage Works Jour., $5: 774-787 ; 7$ ref.).

Heukelekian, H., and Heller, A., 1940: Relation between food concentration and surface for bacterial growth (Jour. Bact., 40:547-558; 7 ref.).

HewsT, L. F., I936: Oxidation-Reduction Potentials in Bacteriology and Biochemistry (London County Council, 4th Ed., ror pp.; 377 ref.).

Heydenreich, L., 1899: Einige Neuerungen in der bakteriologischen Technik (Zeitschr. f. wiss. Mikroskopie, I6:145-179; 1 I ref.).

Highlands, M. E., and Williaws, O. B., r944: A bacteriological survey of sardine canning in Maine (Food Res., 9:34-4I). 
HILEN, Ethel J., I923: Report on a bacteriological study of ocean slime (Report Bureau Construction and Repair, U. S. Navy Department, Washington, D. C.).

Hinze, G., I903: Thiophysa volutans, eine neue Schwefelbakterie (Ber. deut. botan. Ges., 2I:309-3I6; 7 ref.).

Hitchens, A. P., I92I: Advantages of culture mediums containing small percentages of agar (Jour. Infect. Dis., 29:390-407; 26 ref.).

Hite, H., Giddings, N. J., and Weakley, C. E., I9I4: The effect of pressure on certain microorganisms encountered in the preservation of fruits and vegetables (West Virginia Univ. Agric. Exper. Sta., Bull. 146:I-67).

HJoRT, J., and RuUd, J. T., I938: I. Deep-sea prawn fisheries and their problems. II. A bottom-sampler for the mud-line (Norske Videnskaps-Akad. i Oslo, Hvalrådets Skrifter, No. I 7:I-I5I; 37 ref.).

Hock, C. W., I940: Decomposition of chitin by marine bacteria (Biol. Bull., 79:199-206; I.7 ref.).

- - I94I: Marine chitin-decomposing bacteria (Jour. Mar. Res., 4:99-ro6; II ref.).

HoF, T., I935: Investigations concerning bacterial life in strong brines (Rec. d. Trav. botan. néerlandais, $32: 92-173$; 10 r ref.).

Horowitz-Wlassowa, L. M., and Grinberg, L. D., I933: Zur Frage über psychrophile

1. Mikroben (Centralbl. f. Bakt., II Abt., 89:54-62; 20 ref.).

Hotchkiss, M., and Waksman, S. A., I936: Correlative studies of microscopic and plate

( methods for evaluating the bacterial population of the sea (Jour. Bact., 32:423-432; 9 ref.).

Houston, A. C., I904: Results of a number of separate bacteriological observations bearing on the general question of the pollution of estuarial waters and shell-fish (Roy. Comm. Sewage Disposal Report No. 4, 3:19I-309).

Huber-Pestalozzi, G., I938: Das Phytoplankton des Süsswassers (Die Binnengewässer, I6( $\mathrm{x}): \mathrm{x}-342 ; 63$ ref.).

Hulburt, E. O., I928: The penetration of ultra-violet light into pure water and sea water (Jour. Opt. Soc. Amer., I7:I5-22).

Hunr, W. F., I9I5: The origin of the sulphur deposits of Sicily (Econ. Geol., ro:543-579; 54 ref.).

Hunter, A. C., I920a: Bacterial groups in decomposing salmon (Jour. Bact., 5:543-552; I I ref.).

Hunter, A. C.. I920b: A pink yeast causing spoilage in oysters (U. S. Dept. Agric., Bull. No. $819: 1-24 ; 28$ ref.).

- - - and HARRISON, C. W., 1928: Bacteriology and chemistry of oysters, with special reference to regulatory control of production, handling, and shipment (U. S. Dept. Agric., Tech. Bull. No. 64:I-75; I06 ref.).

- I I 22: The sources and characteristics of the bacteria in decomposing salmon (Jour. Bact., $7: 85$-ro9; 8 ref.).

Hưtchinson, G. E., Deevey, E. S., and Wollack, Anne, I939: The oxidation-reduction potentials of lake waters and their ecological significance (Proc. Nat. Acad. Sci., 25:87-90; 9 ref.).

Imshenetsky, A. A., and Kokurina, N. A., I94I: Destruction of jute coverings on ships by microorganisms (Microbiologiia, I0:739-75I; in Russian).

INMAN, O. L., 1927: A pathogenic luminescent bacterium (Biol. Bull., 53:197-200; 3 ref.).

Issatschenko, B. L., I9I2: Ueber die Ablagerung von schwefligem Eisen in den Bakterien (Bull.d. Jard. impér. Botan. d. St. Pétersbourg, I $2:$ I 34-1 39; Russian with German summary).

- - I9I4: Investigations on the bacteria of the glacial Arctic Ocean. (Monograph, Petrograd, 300 pp.; in Russian; 420 ref.).

- 1924: Sur la fermentation sulfhydrique dans la Mer Noire (Compt. rend. Acad. Sci., 178:2204-2206).

- - 1926: Sur la nitrification dans les mers (Compt. rend. Acad. Sci., 182:185-186).

- - 1 1 29: Zur Frage der biogenischen Bildung des Pyrits (Internat. Rev. d. ges. hydrobiol. u. Hydrogr., $22: 99-$ Ior; 5 ref.).

- - 1937: A microbiological characteristic of the bottom and the waters of the Kara Sea (Trans. Arctic Inst., Leningrad, 82:7-46; Russian with English summary; 45 ref.).

- 1938 : Review of works on the microbiology of muds and mineral springs (r9r 71937) (Mikrobiologiia, 7:385-410; in Russian).

- I940: On the microörganisms of the lower limits of the biosphere (Jour. Bact., 40: $379-381 ; 4$ ref.).

Issatchienko, B., and Egorova, A., r939: On the "bacterial plate" in the Black Sea (Vol. in Honor of Scient. Activity of N. M. KNIPovicr, Moscow, pp. 47-58; Russian with English summary; I7 ref.).

Issatchenko, B., and Rostowzew, S., I9I I: Denitrificierende Bakterien aus dem Schwarzen Meere (Bull. d. Jard. impér. Botan. d. St. Pétersbourg, Ir:9I-96; Russian with German summary). 
JACKson, D. D., rgo2: A new species of Crenothrix (C. manganifcra) (Trans. Amer. Micro. Soc., 23:3 I-39; 7 ref.).

JANkowski, G. J., and ZoBell, C. E., I944: Hydrocarbon production by sulfate-reducing bacteria (Jour. Bact., $47: 447$ ).

Jensen, A. C., rgr8: Some observations on Arlemia gracilis, the brine shrimp of Great Salt Lake (Biol. Bull., 34:18-33; 7 ref.).

JENSEN, L. B., ro43: Bacteriology of ice (Food Res., 8:265-272; 30 ref.).

JENSEN, P. B., I915: Studies concerning the organic matter of the sea bottom (Report Danish Biol. Sta., 1914, 22:3-39;27 ref.).

Jepps, Margaret W., I931: Note on a marine Labyrinthula (Jour. Mar. Biol. Assoc., 17:833$838 ; 5$ ref.).

Jomnson, Delia E., 1932: Some observations on chitin-destroying bacteria (Jour. Bact., $24: 335-340 ; 4$ ref.).

Jorinson, F. H., 1936: The oxygen uptake of marine bacteria (Jour. Bact., 31:547-556; 15 ref.).

Jonnson, F. H., and HARvey, E. N., r938: Bacterial luminescence, respiration and viability in relation to osmotic pressure and specific salts of sea water (Jour. Cellular Comp. Physiol., I I : 2 I $3-232$; 2 ref.).

Johnson, F. H., and SHonk, I. V., I936: An interesting new species of luminous bacteria (Jour. Bact., 3I:585-593; 22 ref.).

Jornston, WV., x892: On the collection of samples of water for bacteriological analysis (Canad. Rec. Sci., 5:19-28).

Jomnstone, J., I908: Conditions of Life in the Sea (Cambridge Univ. Press, 332 pp.; 25 ref.). - - I928: An Introduction to Oceanography (Liverpool Univ. Press, 2nd Ed., 368 pp.; I4 ref.).

JORDAN, E. O., I900: Some observations upon the bacterial self-purification of streams (Jour. Exper. Med., 5:27I-3I4; I6 ref.).

JUDAY, C., I942: The summer standing crop of plants and animals in four Wisconsin lakes (Trans. Wisconsin Acad. Sci., 34:103-I35; 28 ref.).

Kalantarian, P., and Petrossian, A., I932: Ueber ein neues kalkfällendes Bakterium aus dem Sewan-See (Goktschasee), Bact. Sewanense spec. nov. (Centralbl. f. Bakt., II Abt., $85: 43$ I-436; 3 ref.).

KANEI, E. S., I94I: The oxidation-reduction potential of bacterial cultures; review of literature (Mikrobiologiia, Io:595-620; in Russian; 32 ref.).

Karzinkin, G. S., I934: Zum Studium des bacterialen Periphytons (Proc. Kossino Limnolog. Sta., $17: 2 \mathrm{I}-48$ ),

Katz, O., I891: Zur Kenntniss der Leuchtbakterien (Centralbl. f. Bakt., 9:1 57-163; 199-204; 229-234; 258-264; 31I-316; 343-350; I7 ref.).

Kedisc, M., I906: Weitere Untersuchungen über stickstoffbindende Bakterien (Wiss. Meersunters., Abt. Kiel, N.F., 9:273-309; I4 ref.).

Kellerdax, K. F., IgI5a: Relation of bacteria to deposition of calcium carbonate. (Bull. Geol. Soc. Amer., 26:58).

II Abt., 42:398-402; I3 ref.).

Kellerman, K. F., and Smith, N. R., I9i4: Bacterial precipitation of calcium carbonate (Jour. Wash. Acad. Sci., 4:400-402).

- $1916:$ Halophytic and lime precipitating bacteria (Centralbl. f. Bakt., II Abt., $45: 37$ I).

KeUTNER, J., I905: Ueber das Vorkommen und die Verbreitung stickstoffbindender Bakterien im Meere (Wiss. Meersunters, Abt. Kiel, N.F., 8:27-55).

Keys, A., Curistensen, E. H., and KroGH, A., I935: The organic metabolism of sea-water with special reference to the ultimate food cycle in the sea (Jour. Mar. Biol. Assoc., 20:18II96; 23 ref.).

Kibbe, Alice L., r916: Chylridium alarium on Alaria fistulosa (Publ. Puget Sound Biol. Sta., Univ. Wash., I:22 I-226; I3 ref.).

KINKEL, DOROTHY E., I 936: A study of chitin-, pectin- and cellulose-destroying bacteria from lake mud (Master's Thesis, Univ. Wisconsin, 35 pp.; 70 ref.).

Kirubayasm, S., and AIDA, T., I934: Fate of cholera vibrio in the sea water of Keclung Port, Formosa (U. S. Pub. Health Eng. Abstracts, I4:6I).

KISER, J. S., 1944: Effects of temperatures approximating $0^{\circ} \mathrm{C}$. upon growth and biochemical activities of bacteria isolated from mackerel (Food Res., 9:257-267;28 ref.).

Kiser, J. S., and BEckwith, T. D., I942: Effect of fast-freezing upon bacterial flora of mackerel (Food Res., $7: 255^{-2} 59$; 13 ref.).

$-\frac{}{-}, 1944:$ A study of the bacterial flora of mackerel (Food Res., 9:250-256; 25 ref.). 
KцевAнN, H., г9i9: Die Schädlinge des Klippfisches. Ein Beitrag zur Kenntnis der salzliebenden Organismen (Mitt. a. d. Inst. f. allg. Botan., Hamburg, 4:I I-69; many ref.).

KLEIBER, A., I894: Qualitative und quantitative bacteriologische Untersuchungen des Zürichseewassers (Dissertation, Zürich, 57 pp.).

KleIN, G., and Steiner, M., I929: Bakteriologisch-chemische Untersuchungen am Lunzer Untersee, I. Die bakteriellen Grundlagen des Stickstoff- und Schwefelumsatzes im See (Österr. botan. Zeitschr., 78:289-324, 32 ref.).

KLigler, I. J., and GuggenherM, K., I938: The influence of vitamin C on the growth of anaerobes in the presence of air, with special reference to the relative significance of $\mathrm{E}_{\mathrm{h}}$ and $\mathrm{O}_{2}$ in the growth of anaerobes (Jour. Bact., 35:I4I-I 56;25 ref.).

KNIPOwitsch, N. M., 1926: Zur Hydrologie und Hydrobiologie des Schwarzen und des Asowschen Meeres (Internat. Rev. d. ges. Hydrobiol. u. Hydrogr., r6:8I-102; 8 ref.).

Knowlton, W. T., I929: B. coli surveys, Los Angeles ocean outfall (Calif. Sewage Works

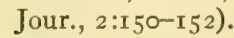

Knudsen, M., I90I: Hydrographische Tabellen (G. E. C. Gad, Kopenhagen, 63 pp.).

Koford, C. A., 1923: Report on the San Francisco Bay Marine Piling Survey (S. F. Bay Marine Piling Committee, San Francisco, 401 pp.; 60 ref.).

KoRINEK, J., I926: Ueber Süsswasserbakterien im Meere (Centralbl. f. Bakt., II Abt., 66:500$505 ; 6$ ref.).

- - 1927: Ein Beitrag zur Mikrobiologie des Meeres (Centralbl. f. Bakt., II Abt., 7 1:73-79; I9 ref.).

- I932: Ueber oligonitrophile Mikroben im Meere (Centralbl. f. Bakt., II Abt., 86: 20I-206; 1 I ref.).

Korochkina, O. I., I936: The oxidation-reduction regime of denitrification (Mikrobiologiia, 5:645-656; Russian with English summary; I9 ref.).

KRASSILNIKov, N. A., I938: The bactericidal action of sea water (Mikrobiologiia, 7:329-334; Russian with English summary).

KREPS, E., I934: Organic catalysts or enzymes in sea water (James Johnstone Memorial Volume, Liverpool Univ. Press, pp. I93-202; I5 ref.).

Krizencky, J., and PodhradSky, I927: Studien über die Funktion der im Wasser gelösten Nährsubstanzen im Stoffwechsel der Wassertiere, XI. Ist die Bakterienflora der Vermittler zwischen den Tieren und den aufgelösten Nährsubstanzen? (Zeitschr. vergl. Physiol., $6: 43 \mathrm{I}-452 ; 34$ ref.).

KroGH, A., I93I: Dissolved substances as food for aquatic organisms (Biol. Rev., 6:4I2-442; 78 ref.).

- - I934: Conditions of life in the ocean (Ecol. Monogr., 4:42I-439).

Krumwiede, C., Park, W. H., Cooper, G., Grund, M., Tyler, C. H., and Rosenstein, C., 1926: Effect of storage and changing sea water on contaminated oysters (Amer. Jour. Pub. Health, $16: 263-268 ; 5$ ref.).

KrUSE, I908: Beiträge zur Hygiene des Wassers (Zeitschr. f. Hyg., 59:6-94).

Kusnetzow, S. I., I93I: The dependence of the oxidizing fermentations from the oxidation reduction potential of the external medium (Centralbl. f. Bakt., II Abt., 83:37-52; 3 ref.).

, I935a: Das Oxydoreduktionspotential in den Seen und die Methode seiner kolorimetrischen Bestimmung (Proc. Kossino Limnolog. Sta., 20:55-65; Russian with German summary; I 2 ref.).

- $1935 b$ : Microbiological researches in the study of the oxygenous regimen of lakes (Verhandl. d. internat. Vereinigung f. theor. u. angew. Limnologie, $7: 562-582 ; 23$ ref.).

- I939: Determination of the intensity of oxygen-absorption in the lake water, caused by bacteriological processes (Proc. Kossino Limnolog. Sta., 22:53-74; Russian with English summary; I 7 ref.).

Kusnetzow, S. I., and Karzinkin, G. S., r93I: Direct method for the quantitative study of bacteria in water and some considerations on the causes which produce a zone of oxygenminimum in Lake Glubokoje (Centralbl. f. Bakt., II Abt., 83:169-174; 8 ref.).

Kusnetzowa, Z. I., I937: Methode der Ausscheidung der Plankton- und Periphytonbakterien und ihre Anwendung zum Studium der Dynamik der bakteriologischen Prozesse im Wasserbecken (Proc. Kossino Limnolog. Sta., 21:89-104; Russian with German summary; I 8 ref.).

LACkEY, J. B., 1936: Occurrence and distribution of the marine protozoan species in the Woods Hole area (Biol. Bull., 70:264-278; 3 I ref.).

LAGERHEIM, G., I900: Mykologische Studien, III. Beiträge zur Kenntniss der parasitischen Bacterien und der bacterioiden Pilze (Med. fr. Stockholms Högskola, No. 204. Bihang till K. Svenska Vetenskaps-Akad. Handlingar Bd. 26, Afd. III, No. 4:I-2I; 3 I ref.).

Larsen, W. P., Hartzell, T. B., and DiemL, H. S., I9r 8: The effect of high pressures on bacteria (Jour. Infect. Dis., 22:27I-279; Io ref.).

Lebour, Marie V., I9I7: The microplankton of Plymouth Sound from the region beyond the breakwater (Jour. Mar. Biol. Assoc., II:I33-182; I3 ref.). 
Levin, 1809: Les microbes dans les régions arctiques (Ann. Inst. Pasteur, I 3:558-567; 4 ref.).

LEwIS, I. M., 1929: Bacterial antagonism with special reference to the effect of $P$ seudomonas fluorescens on spore forming bacteria of soils (Jour. 13act., 17:89-ro3; 20 ref.).

LIAGINA, N. M., and KUZNETZOW, S. I., 1937: 'The determination of the intensity of respiration of some species of water bacteria at various temperatures under laboratory conditions (Mikrobiologiia, 6:21-27; Russian with English summary; 5 ref.).

LIEBERT, F., 1015: Ueber mikrobiologische Nitrit- und Nitratbildung im Meere (Rapp. Verhandel. Rijksinst. Visscherijonderz, $\mathrm{I}: 3$ ).

Lieske, R., and Hofaran, E., I920: Untersuchungen über den Bakteriengehalt der Erde in grossen Tiefen (Centralbl. f. Bakt., II. Abt., 77:305-309; 3 ref.).

LipMan, C. 13., I920: Studies on sea-water bacteria and other subjects in the South Seas (Yearbook Carnegie Inst. Wash., No. 19:196-197).

- - 1922: Does nitrification occur in sea water (Science, 56:501-503; 7 ref.).

_- I I 24: A critical and experimental study of DREw's bacterial hypothesis on $\mathrm{CaCO}_{3}$ precipitation in the sea (Dept. Mar. Biol., Carnegie Inst. Wash., 19:179-19I; I I ref.).

- - 1926: The concentration of sea-water as affecting its bacterial population (Jour. Bact., I2:3II-3I3).

- 1929: Further studies on marine bacteria with special reference to the Drew hypothesis on $\mathrm{CaCO}_{3}$ precipitation in the sea (Papers from Tortugus Lab., Carnegie Inst. Wash., 26:23I-248; 7 ref.).

—— I931: Living microörganisms in ancient rocks (Jour. Bact., 22:183-198).

Lloyd, Blodwen, 1930: Bacteria of the Clyde Sea Area: A quantitative investigation (Jour. Mar. Biol. Assoc., 16:879-907; 24 ref.).

- - I93 Ia: Muds of the Clyde Sea Area, II. Bacterial content (Jour. Mar. Biol. Assoc., I 7:75I-765; I6 ref.).

_- _ I93 $\mathrm{I} b$ : A marine denitrifying organism (Jour. Bact., 21:89-96; 5 ref.).

-, 1937: Bacteria in stored water (Jour. Roy. Tech. College, Glasgow, 4:I 73-177i 4 ret.).

Lommann, H., I922: Zentrifugenplankton und Hochseeströmung (Internat. Rev. d. ges. Hydrobiol. u. Hydrogr., Io:603-682; 3 ref.).

Lovering, T. S., I927: Organic precipitation of metallic copper (U. S. Geol. Survey, Bull. 795 C: $45-52$; I4 ref.).

Luck, J. M., Sheets, Grace, and Thowas, J. O., I93I: The rôle of bacteria in the nutrition of protozoa (Quart. Rev. Biol., 6:46-58; 45 ref.).

Lucke, F., and Schwartz, W., I937: Mikrobiologische Untersuchungen an Seefischen (Arch. f. Mikrobiol., 8:207-230).

Lundestad, J., I928: Ueber einige an der norwegischen Küste isolierte Agar-spaltende Arten von Meerbakterien (Centralbl. f. Bakt., II Abt., 75:321-344; I9 ref.).

Lyman, J., and Fleming, R. H., I940: Composition of sea water (Jour. Mar. Res., 3 :I34-I46; 23 ref.).

MACGinitie, G. E., I935: Ecological aspects of a California marine estuary (Amer. Midland Naturalist, $16: 629-765 ; 247$ ref.).

Mare, Molly F., I942: A study of a marine benthic community with special reference to the micro-organisms (Jour. Mar. Biol. Assoc., 25:51 7-554; 73 ref.).

Marmer, H. A., I932: Tides and tidal currents. (Physics of the Earth-V Oceanography, Bull. Nat. Res. Council, 85:220-309; 7 ref.).

Marsiall, S. M., and ORR, A. P., 1930: A study of the spring diatom increase in Loch Striven (Jour. Mar. Biol. Assoc., I6: 853-878).

MARTIN, J. P., and WAKsman, S. A., I940: Influence of microorganisms on soil aggregation and erosion (Soil Sci., 50:29-47; 30 ref.).

Mathews, D. J., I9r3: A deep-sea bacteriological water-bottle (Jour. Mar. Biol. Assoc., 9:525-529).

MAtudaira, T., 1939: The physiological property of sea water considered from the effect upon the growth of diatom, with special reference to its vertical and seasonal change (Bull. Jap. Soc. Sci. Fish., 8:187-193; in Japanese; 3 ref.).

McCready, R. M., Owens, H. S., and MaClay, W. D., 1943: The use of fibrous sodium pectate as a substitute for agar in bacteriological gels (Science, 97:428).

McLean, A. L., r918: Bacteria of ice and snow in Antarctica (Nature, ro2:35-39; 6 ref.).

Mears, E. G., 1943: The Callao Painter (Scient. Monthly, 57:33I-336).

Meier, F. C., and Lindbergh, C. A., I935: Collecting micro-organisms from the Arctic atmosphere (Scient. Monthly, 40:5-20; 9 ref.).

Meiklejohn, JANE, 1930: The relation between the numbers of a soil bacterium and the ammonia produced by it in peptone solutions; with some reference to the effect on this process of the presence of amoebae (Ann. Appl. Biol., r 7:6 r4-637; 22 ref.).

MrNdeR, L., I920: Zur Hydrophysik des Zürich- und Walensees, nebst Beitrag zur Hydrochemie und Hydrobakteriologic des Zürichsees (Arch. f. Hydrobiol., 12:122-194; 39 ref.). 
Minder L., I927: Ueber den Bakteriengehalt des Zürichsees (Vierteljahrsschrift naturf. Ges. Zürich, 72:354-366; 7 ref.).

Minervini, R., I900: Einige bakteriologische Untersuchungen über Luft und Wasser inmitten des Nord-Atlantischen Oceans (Zeitschr. f. Hyg., 35:165-194; 38 ref.).

Mryad, D., I934: Oxygen absorption of the lake deposit (Proc. Imper. Acad., Kyoto Imper. Univ., I0:236-239).

Moberg, E. G., Fleming, R. H., Heusner, K., and Revelle, R. R. D., I937: The organic nitrogen content of marine sediments off the west coast of North America (Proc.-Verb. Assoc. Océanogr. Phys., No. 2:I54).

Moberg, E. G., Greenberg, D. M., Revelle, R., and Allen, Ester C., I934: The buffer mechanism of sea water (Bull. Scripps Inst. Oceanogr., Tech. Ser., 3:23I-278; 77 ref.).

Molısch, H., I9ıо: Die Eisenbakterien (G. Fischer, Jena, 83 pp.).

- — , I9 2: Neue farblose Schwefelbakterien (Centralbl. f. Bakt., II Abt., 33:55-62; I 2 ref.).

_ _ I925: Ueber Kalkbakterien und andere kalkfällende Pilze (Centralbl. f. Bakt., II Abt., 65:130-139; 4 ref.).

Moore, Helen N., I940: The use of silica gels for the cultivation of halophilic organisms (Jour. Bact., 40:409-4I3).

Müller, P. T., I9I2a: Ueber eine neue, rasch arbeitende Methode der bakteriologischen Wasseruntersuchungen und ihre Anwendung auf die Prüfung von Brunnen und Filterwirken (Arch. f. Hyg., 75:189-223; I3 ref.).

- $1912 b$ : Ueber die Rolle der Protozen bei der Selbstreinigung stehenden Wassers (Arch. f. Hyg., 75:321-352; I9 ref.).

Murray, A. N., and Love, W. W., r929: Action of organic acids upon limestone (Bull. Amer. Assoc. Petrol. Geol., I3:1467-1475; 6 ref.).

Murray, J., and HJort, J., I9i2: The Depths of the Ocean (Macmillan and Co., London, 82 I pp.).

MURRAY, J., and IRvine, R., r889: On coral reefs and other carbonate of lime formations in modern seas (Proc. Roy. Soc. Edinburgh, I7:79-109; 6 ref.).

NAdson, G. A., I9I2: Mikrobiologische Studien, I. Chlorobium limicola Nads., ein grüner Mikroorganismus mit inaktivem Chlorophyll; II. Ueber die Farbe und die Farbstoffe der Purpurbakterien (Bull. d. Jard. impér. Botan. d. St. Pétersbourg, I2:83-89).

- - , 1928: Beitrag zur Kenntnis der bakteriogenen Kalkablagerungen (Arch. f. Hydrobiol., I9:I 54-164; 9 ref.).

Nadson, G., and Burgwitz, G., I93I: Hefen des Nördlichen Eismeeres (Compt. rend. Acad. Sci., URSS, pp. I03-II0; 6 ref.).

NAdson, S., I903: Die Mikroorganismen als geologische Faktoren, I. Ueber die Schwefelwasserstoffgährung im Weissowo-Salzsee und über die Betheiligung der Mikroorganismen bei der Bildung des schwarzen Schlammes (Heilschlammes) (Aus den Arbeiten der Commission für die Erforschung der Mineralseen bei Slawjansk, St. Petersburg, 1903. Abstract in Botan. Centralbl., 96:591-593, I904).

Nathansohn, A., I902: Ueber eine neue Gruppe von Schwefelbacterien und ihren Stoffwechsel (Mitt. zool. Sta. Neapel, 15:655-680; 23 ref.).

_ - I906: Ueber die Bedeutung vertikaler Wasserbewegungen für die produktion des Planktons im Meere (Abhandl. math.-phys. Klasse K. sächs. Ges. Wiss., 29:335-44 I; 94 ref.).

Naumann, E., 1925: Wasserwerkbiologie (Abderhalden's Handb. d. biol. Arbeitsmethoden, IX Abt., T. 2(I):229-232; 3 ref.).

- - I930: Einführung in die Bodenkunde der Seen (ThienEmann's Die Binnengewässer, $9: I-I 26 ;$ I8 3 ref.).

Newton, Dorothx, I924: Marine sporeforming bacteria (Contr. Canad. Biol. Fish., N.S., I:377-400; II ref.).

Nikitinsky, J. J., I938: Some research results in the field of sanitary and technical hydrobiology (Mikrobiologiia, 7:3-35; in Russian; г7 1 ref.).

Novel.r, G. D., and ZoBeli, C. E., 1944: Assimilation of petroleum hydrocarbons by sulfatereducing bacteria (Jour. Bact., 47: 447-448).

Omeliansky, V. L., I9I7: Bacteriological investigations of the mud of lakes Bieloie and Poloruno (Zhurn. Mikrobiologii, 4:186-195; in Russian).

OrR, A. P., I926: The nitrite content of sea-water (Jour. Mar. Biol. Assoc., I4:55-6r; 8 ref.).

Ostroff, Rose, and Henry, B. S., I939: The utilization of various nitrogen compounds by marine bacteria (Jour. Cellular Comp. Physiol., I3:353-371; 22 ref.).

Otro, M., and Neumann, R. O., I904: Ueber einige bacteriologische Wasseruntersuchungen im Atlanlischen Ozean (Centralbl. f. Bakt., II Abt., I3:48I-489; r 2 ref.).

PACk, D. A., r919: Two ciliata of Great Salt Lake (Biol. Bull., 36:273-282; 13 ref.).

Parlandt, D., rgri: Ueber einige denitrificierende Bakterien aus dem Baltischen Meere (Bull. d. Jard. impér. Botan. d. St. Pétersbourg, I I:97-105). 
PARR, L. W., 1939: Coliform bacteria (Bact. Rev., 3:1-48; 188 ref.).

Parsons, P. B., rgr I: Apparat zur Entnahme von Wasser aus grösserer 'Tiefe (Centralbl. f. Bakt., II Abt., $32: 197$ ).

Patrick, Ruth, 1936: Some diatoms of Great Salt Lake (Bull. Torrey Botan. Club, 63:157I66; 3 ref.).

Patton, R. S., and Mararer, H. A., 1932: 'The waves of the sea. (Physics of the Earth-V. Oceanography, Bull. Nat. Res. Council, $85: 207-228 ; 38$ ref.).

Pearsali, W. H., and Mortimer, C. H., 1939: Oxidation-reduction potentials in water-logged soils, natural waters and muds (Jour. Ecol., 27:483-50r; 44 ref.).

Pearse, A. S., Huma, H. J., and Wharton, G. W., I9 42 : Ecology of sand beaches at Beaufort, North Carolina (Ecol. Monogr., 12:135-190; 223 ref.).

Peele, T. C., I936: Adsorption of bacteria by soils (Cornell Univ. Agric. Exper. Sta., Mem. 197:I-r8; I3 ref.).

PeIRCE, G. J., I9I4: The behavior of certain micro-organisms in brine ('The Salton Sea, Carnegie Inst. Wash., Publ. No. 193:49-69; 1 I ref.).

PERRY, C. A., I939: A summary of studies on pollution in shellfish (Food Res., 4:381-395; I4 ref.).

Petersen, H. E., I905: Contributions à la connaissance des Phycomycètes marins (Chytridineae Fischer) (Oversigt $\mathrm{K}$. Danske Videnskaps Selskabs Forhandl., 5:439-488).

Petrowa, E. K., 1936: Salt water from saline lakes, as a source of sowing microorganisms on the salt products (Arkh. biol. nauk, 43(ser. 2-3):201-207; Russian with English summary; 2 I ref.).

Pettersson, H., Höglund, H., and Landberg, S., I934: Submarine daylight and the photosynthesis of phyto-plankton (Göteborgs K. Vetenskaps- o. Vitterh.-Samh. Handl., 5 Följden, Ser. B. $4(5): I-17$; ro ref.).

Pfenniger, A., I902: Beiträge zur Biologie des Zürichersees (Zeitschr.f. Gewässerkunde, $4($ Heft 6):32I-38I).

PFlÜger, E., I875: Beiträge zur Lehre von der Respiration, I. Ucber die physiologische Verbrennung in den lebendigen Organismen (Arch. f. d. ges. Physiol., 10:251-367).

Prrie, J. H. H., I9I2: Notes on Antarctic bacteriology. Scottish National Antarctic Expedition report on the scientific results of the voyage of S. Y. "Scotia" during the years I902, 1903 and 1904 (Scottish Oceanogr. Lab., Edinburgh, Botany, 3(10):I37-148; 3 ref.).

PlenN, M., I924: Praktikum der Fischkrankheiten (E. Schweizerbart'sche, Stuttgart, I79 pp.; I 88 ref.).

Portier, P., and Richard, J., I906: Sur une méthode de prélèvement de l'eau de mer destinée aux études bactériologiques (Compt. rend. Acad. Sci., I42:IIog-IIII).

Poteriayev, E. A., 1936: A review of the sanitary-biological investigations in the Black Sea (Works of the V. M. Arnoldi Biol. Sta., Novorossiysk, 2:I3I-I48; Russian with English summary; 7 ref.).

Prescotr, S. C., and Winslow, C.-E. A., r931: Elements of Water Bacteriology (John Wiley \& Sons, New York, 5 th Ed., 219 pp.; 563 ref.).

Pringsheim, H., and E., I9I0: Ueber die Verwendung von Agar-agar als Energiequelle zur Assimilation des Luftstickstofis (Centralbl. f. Bakt., II Abt., 26:227-23I; I6 ref.).

Proctor, B. E., and PARker, B. IV., r942: Microorganisms in the upper air (Aerobiology, Amer. Assoc. Adv. Sci., Washington, D. C., Publ. No. 17:48-54; 61 ref.).

Purdy, IV. C., and Butterfield, C. T., I9I8: The effect of plankton animals upon bacterial death-rates (Amer. Jour. Pub. Health, 8:499-505).

PÜTTER, A., I926: Atmung und Assimilation im Canarenstrom (Arch. f. Hydrobiol., I7:597$627 ; 6$ ref.).

Rami, Otro, r934: Salt. A study of its bacterial content (Nat. Provisioner, 2 pp.).

Rakestraw, N. W., 1936: The occurrence and significance of nitrite in the sea (Biol. Bull., $71: 133-167 ; 28$ ref.).

RAvicir-Sherbo, J., 1930: To the question of bacterial thin layer in the Black Sea according to the hypothesis of Prof. Egounoff (Trav. de la Sta. biol. de Sébastopol, 2:127-I41; Russian with English summary; 17 ref.).

__- 1936: De l'origine bactérienne du pigment rouge de l'Amplioxus lanceolatum, cause de sa mort et destruction (Trav. de la Sta. biol. de Sébastopol, 5:287-296; Russian with French summary; 4 ref.).

REAY, G. A., I935: The preservation of fresh and thawed fish in ice (Jour. Soc. Chem. Ind., 54:96T-9ST; 4 ref.).

REDFIELD, A. C., I934: On the proportions of organic derivatives in sea water and their relation to the composition of plankton (JAMes JoInstone Memorial Volume, Liverpool Univ. Press, pp. I76-192; ir ref.).

- 1942 : The processes determining the concentration of oxygen, phosphate and other organic derivatives within the depths of the Atlantic Ocean (Papers in Physical Oceanogr. Meteorol., Cambridge, Mass., 9:22 pp.; I9 ref.). 
ReDfield, A. C., and Keys, A. B., I938: The distribution of ammonia in the waters of the Gulf of Maine (Biol. Bull., 74:83-92; ro ref.).

REED, G. B., and MACLEOD, D. J., I924: A bacteriological and chemical study of certain problems in lobster canning (Contr. Canad. Biol. Fish., N.S., 2:I-30; 10 ref.).

REED, G. B., and ORR, J. H., I943: Cultivation of anaerobes and oxidation-reduction potentials (Jour. Bact., 45:309-320; I I ref.).

ReEd, G. B., and Spence, C. M., I929: The intestinal and slime flora of the haddock. A preliminary report (Contr. Canad. Biol. Fish., N.S., 4:257-264; 7 ref.).

ReINke, J., I903: Symbiose von Volvox und Azotobacter (Ber. deut. botan. Ges., 2 I :48I-483; 3 ref.).

Reitano, U., and Morselli, G., I938: Ricerche sui germi dell'aria marina a diversa distanza dalla costa (Ann. di med. navale e coloniale, 44:530-534).

RENN, C. E., I936: The wasting disease of Zostera marina, I. A phytological investigation of the diseased plant (Biol. Bull., 70:148-158; I9 ref.).

- 1 - 1937a: Bacteria and the phosphorus cycle in the sea (Biol. Bull., 72 :190-195; 8 ref.). _ $1937 b$ : Conditions controlling the marine bacterial population and its activity in the sea (Jour. Bact., 33:86-87).

Reuszer, H. W., I933: Marine bacteria and their rôle in the cycle of life in the sea, III. The distribution of bacteria in the ocean waters and muds about Cape Cod (Biol. Bull., 65:48o$497 ; 33$ ref.).

REYNIERS, J. A., I932: Apparatus for taking water samples from different levels (Science, $75: 83-84)$.

RrLey, G. A., I94 : Plankton studies, III. Long Island Sound (Bull. Bingham Oceanogr. Coll., $7: I-93 ; 32$ ref.).

Rittenberg, S. C., I939: Investigations on the microbiology of marine air (Jour. Mar. Res., 2:208-2I7; I5 ref.).

- - I940: Bacteriological analysis of some long cores of marine sediments (Jour. Mar. Res., 3:I9x-20I; 20 ref.).

- I941: Studies on marine sulphate-reducing bacteria (Dissertation, Univ. Calif., II 5 pp.; 93 ref.).

Rittenberg, S. C., Anderson, D. Q., and ZoBell, C. E., 1937: Studies on the enumeration of marine anaërobic bacteria (Proc. Soc. Exper. Biol. Med., 35:652-653; 6 ref.).

Roberg, M., I930: Ein Beitrag zur Stoffwechselphysiologie der Grünalgen (Jahrb. f. wiss. Botan., 72:369-384; I3 ref.).

Robertson, A. C., I93I: Preservation of textile fish nets (Ind. Eng. Chem., 23:1093-1098; II ref.).

Robertson, A. C., and Wright, W. H., I930: Investigations upon the deterioration of nets in Lake Erie (U. S. Bur. Fish., Document 1083:149-176).

Rolı, H., I939: Zur Terminologie des Periphytons (Arch. f. Hydrobiol., 35:59-69; 27 ref.).

RosenthaL, L., I937: "Chromium-sulphuric acid" method for anaerobic cultures (Jour. Bact., $34: 317-320$ ).

Rossi, G., I936: Direct microscopic and bacteriological examination of the soil (Soil Sci., $4 \mathrm{I}: 53-66$; 14 ref.).

Rubentschik, L., I925: Ueber die Lebenstätigkeit der Urobakterien bei einer Temperature unter $0^{\circ}$ C. (Centralbl. f. Bakt., II Abt., 64:166-174; 26 ref.).

$\ldots$ - I928a: Ueber Sulfatreduktion durch Bakterien bei Zellulosegarungs-produkten als Energiequelle (Centralbl. f. Bakt., II Abt., 73:483-496; I3 ref.).

- - I928b: Zur Frage der aeroben Zelluloserzertsung bei hohen Salzkonzentration (Centralb). f. Bakt., II Abt., 76:305-3I4; 8 ref.).

- - 1933: Zur anaeroben Zellulosezersetzung in Salzeen (Centralbl. f. Bakt., II Abt., $88: 182-186 ; 6$ ref.).

Rubentschik, L., and Chait, S. S., i937: Etude sur la vitalité des microbes (Ann. Inst. Pasteur, 58:446-458; 33 ref.).

Rubentschik, L., and Goicherman, D. G., I935: On the microbiology of mud salt lakes, I. Investigation of the Kujalnizki liman (Mikrobiologiia, 4:403-420; Russian with English summary; 23 ref.).

- _ _ _ 1936 : The influence of a decrease in salt-content in limans on the microflora of medicinal muds (Arkh. biol. nauk, 43(ser.2-3):217-227; Russian with English summary; 17 ref:).

Rubentschik, L., Roisin, M. B., and Bieljansky, F. M., I936: Adsorption of bacteria in salt lakes (Jour. Bact., $32: \mathbf{I} \mathbf{I}-3 \mathbf{I} ; 25$ ref.).

Russel., F. S., 1936: Submarine illumination in relation to animal life (Rapp. et Proc.-Verb. Conseil Perm. Internat. p. l'explor. de la Mer, ror:I-8; 34 ref.).

Russeli, H. L., I89I: Untersuchungen über im Golf von Neapel lebende Bakterien (Zeitschr. f. Hyg., II:I65-206; 20 ref.). 
RUSSELL, H. L., 1 892: Bacterial investigation of the sea and its floor (Botan. Gaz., 17:3x 2-32x).

- 1893: The bacterial flora of the Atlantic Ocean in the vicinity of Woods Hole,

; Mass. (Botan. Gaz., 18:383-395; 411-417; 439-447).

RUTTNER, F., r932: Bericht über ältere, bisher unveröffentlichte bakteriologische Untersuchungen an den Lunzer Seen (Internat. Rev. d. ges. Hydrobiol. u. Hydrogr., 26:438-443; 9 ref.).

Salimovskaja-Rodina, A. G., r936: Ueber die Mikroflora des farbigen Schnees (Arkh. biol. nauk, 43(ser. 2-3):220-238; Russian with German summary; I4 ref.).

SANBORN, J. R., I930: Certain relationships of marine bacteria to the decomposition of fish (Jour. Bact., 19:375-382; 5 ref.).

- 1932: Marine bacteria commonly found on fresh fish (Jour. Bact., 23:349-351).

SANDERS, J. M., r937: The microscopical examination of crude petroleum (Jour. Inst. Petrol. Tech., 23:525-573; 5 I ref.).

SANFElice, F., 1889: Ricerche batteriologische delle acque del mare in vicanza dello sbocco delle fognature ed in lontananza da questa (Boll. Soc. nat. Napoli, 3:32-37).

Saslawsky, A. S., 1927: Ueber eine obligat halophile Thionsäurebakterie (Centralbl. f. Bakt., II Abt., 72:236-242; 5 ref.).

ScrAcr, H., 1938: Ein Apparat zur Entnahme von Meerwasserproben aus der Tiefe für bakteriologische Untersuchungen (Jour. du Conseil Perm. Internat. p. l'explor. de la Mer, 13:349-356; 5 ref.).

SchAUDINN, F., 1903: Beiträge zur Kenntnis der Bakterien und verwandter Organismen, II. Bacillus sporonema n. sp. (Arch. f. Protistenk., 2:42 I-444; ref.).

Schumd-Nielsen, S., rgor: Beitrag zur Biologie der marinen Bakterien (Biol. Centralbl., $21: 65-71 ; 8$ ref.).

SCHREIBER, E., I927: Die Reinkultur von marinem Phytoplankton und deren Bedeutung für die Erforschung der Produktionsfähigkeit des Meerwassers (IViss. Meeresunters., Abt. Helgoland, N.F., I6, No. I0:I-34; 16 ref.).

Serwelt, H. R., I93I: Observations on the ammonia content of sea water (Ecology, I $2: 485-$ 488).

- - I935: The cycle of phosphorus in the western basin of the North Atlantic, I. Phosphate phosphorus (Papers in Physical Oceanogr. Meteorol., Cambridge, Mass., 3:1-56; 46 ref.).

Serweli, H. R., and Seiwell, Gladys E., I938: The sinking of decomposing plank ton in sea water and its relationship to oxygen consumption and phosphorus liberation (Proc. Amer. Phil. Soc., 78:465-48r; 8 ref.).

Seliber, G., I928: La réduction des sulphates par des microorganismes en présence des graisses (Compt. rend. Soc. biol., 99:544-546; 8 ref.).

SEYER, W. F., I933: Conversion of fatty and waxy substances into petroleum hydrocarbons (Bull. Amer. Assoc. Petrol. Geol., I 7:125I-1267; 24 ref.).

Sмлтн, B. W., I940: The World Under the Sea (D. Appleton-Century Co., New York, 230 pp.).

Sмтн, N. R., I926: Report on a bacteriological examination of "chalky mud" and sea-water from the Bahama Banks (Dept. Mar. Biol., Carnegie Inst. Wash., 23:67-72).

Simtr, IV. W., and ZoBell, C. E., 1937: Direct microscopic evidence of an autochthonous bacterial flora in Great Salt Lake (Ecology, I8:453-458; I 2 ref.).

SNow, JANE E., and BEARD, P. J., I939: Studies on bacterial flora of North Pacific salmon (Food Res., 4:563-585; 29 ref.).

Snow, LAetitia M., and Fred, E. B., I926: Some characteristics of the bacteria of Lake Mendota (Trans. Wisconsin Acad. Sci., 22:I43-154; I6 ref.).

Sörngen, N. L., rgro: Sur le rôle du méthane dans la vie organique (Rec. de trav. chim.. $29: 238-274 ; 8$ ref.).

Soper, G. A., rgog: The discharge of sewage into tidal waters (Jour. Amer. Med. Assoc., $52: 1221-1224)$.

SPARRow, F. K., 1934: Observations on marine Phycomycetes collected in Denmark (Dansk botan. Ark., 8(6):I-33; 15 ref.).

-, 1936: Biological observations on the marine fungi of Woods Hole waters (Biol. Bull., 70:236-263; 12 ref.).

- _ - 1937: The occurrence of saprophytic fungi in marine muds (Biol. Bull., $73: 242-248$; 4 ref.).

4 1943: Aquatic Phycomycetes (Exclusive of the Saprolegniaceae and Pylhium) (Univ. Mich. Press, Ann Arbor, 785 pp.; 736 ref.).

SpITtA, O., I903: Weitere Untersuchungen über Flussverunreingung (Arch. f. Hyg., 46:64I $20 ; 23$ ref.).

SPOONER, G. M., I933: Observations on the reactions of marine plankton to light (Jour. Mar. Biol. Assoc., 19:385-438; 46 ref.).

SPRAY, R. S., 1936: Semisolid media for cultivation and identification of the sporulating anaerobes (Jour. Bact., 32:135-155; 14 ref.). 
StAnbury, F. A., I93I: The effect of light of different intensities, reduced selectively and non-selectively, upon the rate of growth of Nitzschia closterium (Jour. Mar. Biol. Assoc., I $7: 633-653 ; 26$ ref.).

Stanier, R. Y., I94I: Studies on marine agar-digesting bacteria (Jour. Bact., 42:527-559; 32 ref.).

Stark, W. H., Stadler, Janice, and McCoy, Elizabeth, 1938: Some factors affecting the bacterial population of freshwater lakes (Jour. Bact., 36:653-654).

StARKEY, R. L., 1938: A study of spore formation and other morphological characteristics of Vibrio desulfuricans (Arch. f. Mikrobiol., 9:268-304; 4I ref.).

Starkey, R. L., and Halvorson, H. O., I927: Studies on the transformations of iron in nature, II. Concerning the importance of microorganisms in the solution and precipitation of iron (Soil Sci., 24:38I-402; 42 ref.).

Starkey, R. L., and Wight, K. M., I943: Soil areas corrosive to metallic iron through activity of anaerobic sulfate-reducing bacteria (Amer. Gas Assoc. Monthly, 25:223-228; 29 ref.).

Steiner, J. F., and Meloche, V. W., I935: A study of ligneous substances in lacustrine materials (Trans. Wisconsin. Acad. Sci., 29:389-402; 23 ref.).

Sterner, M., I93I: Beiträge zur Kenntnis der Zellulose- und Chitinabbaues durch Mikroorganismen in stehenden Binnengewässern (75 Jahre Stella Matutina, Festschrift, Feldkirch, 2:367-402. Abstract in Biol. Abstracts, 8:316; 1934).

Stephenson, Marjory, and Stickland, L. H., i93i: Hydrogenase, II. The reduction of sulphate to sulphide by molecular hydrogen (Biochem. Jour., 25:215-220; 7 ref.).

StEWART, MARY M., 1932: The bacterial flora of the slime and intestinal contents of the haddock (Gadus aeglefinus) (Jour. Mar. Biol. Assoc., I8:35-50; I2 ref.).

- - I934: Effect of exposure to low temperatures on the number of bacteria in fish's muscle (Jour. Soc, Chem. Ind., 53:273T-278T; I5 ref.).

- 1 1935: The keeping quality of haddock from cold storage (Jour. Soc. Chem. Ind., $54: 92 \mathrm{~T}-96 \mathrm{~T})$.

Stokes, J. L., I940: The role of algae in the nitrogen cycle of the soil (Soil Sci., 49:265-275; 24 ref.).

Stone, H. W., I936: The use of chromous sulfate in the removal of oxygen from a stream of gas. A comparison with other oxygen absorbents (Jour. Amer. Chem. Soc., 58:2591-2595; 7 ref.).

SтRøM, K. M., I939: Land-locked waters and the deposition of black muds (Recent Marine Sediments, Amer. Assoc. Petrol. Geol., Tulsa, Okla., pp. 356-372; 75 ref.).

Stuart, L. S., I936: A note of halophilic chitinovorous bacteria (Jour. Amer. Leather Chem. Assoc., 3I:II9-I20; 5 ref.).

Sturm, L. D., and OrLova, S. I., 1937: On the transformation of fat, paraffin, and palmitinic acid under the influence of microorganisms from the Ala-Kule Lake (Mikrobiologiia, 6:754772; Russian with English summary; 13 ref.).

Suckling, E. V., I943: The Examination of Waters and Water Supplies (Blakiston Co., Philadelphia, 5 th ed., 849 pp.).

Sugawara, K., Shintani, S., and Oyama, T., I937: Dissolved gases in some Japanese lakes and their significance in lake metabolism (Jour. Chem. Soc. Japan, 58:890-9I9).

Sutherland, G. K., I9I5a: New marine fungi on Pelvetia (New Phytologist, I4:33-42; I3 ref.).

- - I9I 5b: Additional notes on marine Pyrenomycetes (New Phytologist, 14:183-193; 5 ref.).

Sverdrup, H. U., Johnson, M. W., and Fleming, R. H., I942: The Oceans (Prentice-Hall, New York, I087 pp.; many ref.).

TANIKAWA, E., I937: Recherches baktériologiques sur les chairs d'huîtres réfrigérées aux basses températures (Centralbl. f. Bakt., II Abt., $97:$ I33-r47; 8 ref.).

TAnner, F. W., r944: Microbiology of fish and shellfish (The Microbiology of Foods, 2nd ed., Garrard Press, Champaign, Illinois, pp. 780-837; 243 ref.).

TAnner, F. W., and Houston, C. W., I940: Survival of microorganisms in physiological sodium chloride solutions and in distilled water (Centralbl. f. Bakt., II Abt., I02:353-36I; 20 ref.).

TAnner, F. W., and Schneider, Doris L., I935: Effect of temperature of storage on bacteria in water samples (Proc. Soc. Exper. Biol. Med., $32: 960-965 ; 8$ ref.).

TARR, H. L. A., 194I: A direct method for counting bacteria in fish flesh (Pacific Fish. Exper. Sta., 49:8-ro).

TARR, H. L. A., and Sunderland, P. A., I940: The comparative value of preservatives for fresh fillets (Jour. Fish. Res. Bd. Canada, 5:I48-163; 48 ref.).

TARVin, D., and BuSwell, A. M., I934: The methane fermentation of organic acids and carbohydrates (Jour. Amer. Chem. Soc., 56:1751-1755; 9 ref.).

Tausson, W. O., and Alioschina, W. A., I932: Ueber die bakterielle Sulfatreduktion bei 
Anwesenheit der Kohlenwasserstoffe (Mikrobiologiia, 1:229-261; Russian with German summary; 75 ref.).

TAYloR, C. B., I940: Bacteriology of fresh water, I. Distribution of bacteria in English lakes (Jour. Hyg., 40:616-6.40; 20 ref.).

- , 1941: Bacteriology of fresh water, П. The distribution and types of coliform bacteria in lakes and streams (Jour. Hyg., 4r:I $7-38$; 19 ref.).

- - - I942: Bacteriology of fresh water, III. The types of bacteria present in lakes and streams and their relationship to the bacterial flora of soil (Jour. Hyg., 42:284-296; 16 ref.).

TAYLOR, C. B., and LOCHHEAD, A. G., 1938: Qualitative studies of soil micro-organisms, II. A survey of the bacterial Alora of soils differing in fertility (Canad. Jour. Res., Sec. C, 16:162173; 15 ref.).

Trayer, L. A., r931: Bacterial genesis of hydrocarbons from fatty acids (Bull. Amer. Assoc. Petrol. Geol., I5:44I-453; 15 ref.).

Tmel, G. A., I925: Manganese precipitated by microorganisms (Econ. Geol., 20:301-310; 9 ref.).

_- I928: A summary of the activities of bacterial agencies in sedimentation (Nat. Res. Council, Reprint \& Circular Ser. No. 85:6I-77; 37 ref.).

Tuienemans, A., 1927: Zehn Jahre Hydrobiologische Anstalt Plön der Kaiser WilhelmGesellschaft (Dic Naturwissenschaften, 15:753-760).

Trompson, T. G., r932: The physical properties of sea water (Physics of the Earth - V. Oceanography, Bull. Nat. Res. Council, 85:63-94; 60 ref.).

Thompson, T. G., and Robinson, R. J., I932: Chemistry of the sea (Physics of the Earth - V. Oceanography, Bull. Nat. Res. Council, 85:95-203; 181 ref.).

Thousen, P., rgro: Ueber das Vorkommen von Nitrobakterien im Meere (Wiss. Meeresunters., Abt. Kiel, N.F., II:I-27; I4 ref.).

Thornton, H. G., and Gray, P. H. H., 1934: The numbers of bacterial cells in field soils, as estimated by the ratio method (Proc. Roy. Soc. London, II 5:522-543; 13 ref.).

TrFfney, W. N., I939: The identity of certain species of the Saprolegniaceae parasitic to fish (Jour. Elisha Mitchell Sci. Soc., 55:I34-I5I; 36 ref.).

Tonney, F. O., and White, J. L., I926: B. coli in market oysters (Amer. Jour. Pub. Health, I6:597-602).

ToppIng, Lucy E., 1937: The predominant micro-organisms in soils, I. Description and classification of the organisms (Centralbl. f. Bakt., II Abt., 97:289-304; 45 ref.).

Trask, P. D., I932: Origin and Environment of Source Sediments of Petroleum (Gulf Publ. Co., Houston, Texas, 323 pp.; I9 ref.).

- 1934: Deposition of organic matter in recent sediments (Problems of Petroleum Geology, Amer. Assoc. Petrol. Geol., Tulsa, Okla., pp. 27-33; 7 ref.)

- 1 1939: Recent Marine Sediments (Amer. Assoc. Petrol. Geol., Tulsa, Okla., 736 pp.; many ref.).

Trask, P. D., and Patnode, H. W., r942: Source Beds of Petroleum (Amer. Assoc. Petrol. Geol., Tulsa, Okla., 566 pp.; 22 ref.).

Tutrs, T. G., I934: The fungus on Zosiera marina (Nature, I34:573; 3 ref.).

Uteriönl, H., r925: Limnologische Phytoplanktonstudien (Arch. f. Hydrobiol., Suppl. $5: 1-527 ; 3$ I 3 ref.).

- - I931: Neue Wege in der quantitativen Erfassung des Planktons, mit besonderer Berücksichtigung des Ultraplanktons (Verhandl. d. internat. Vereinigung f. theor. u. angew. Limnologie, 5:567-596).

UTterback, C. L., I936: Spectral bands of submarine solar radiation in the North Pacific and adjacent inshore waters (Rapp. et Proc.-Verb. Conseil Perm. Internat. p. l'explor. de la Mer, ror:I-I5; 6 ref.).

vaN Delden, A., I904: Beitrag zur Kenntnis der Sulfatreduktion durch Bakterien (Centralbl. f. Bakt., II Abt., I I:8I-94; II3-II9; I4 ref.).

VAN DER LEK, J. B., 1929: Vibrio agarliquefaciens Gray (Nederl. Tijdschr. Hyg., 3:276-280; 8 ref.).

VAN NiEL, C. B., I93I: On the morphology and physiology of the purple and green sulphur bacteria (Arch. f. Mikrobiol., 3:1-112; I22 ref.).

- 1936: On the metabolism of the Thiorhodaceae (Arch. f. Mikrobiol, 7:323-358; 17 ref.).

VAUGHAN, T. W., I924: Oceanography in its relations to other earth sciences (Jour. Wash. Acad. Sci., I4:307-333; 22 ref.).

VERNON, H. M., I898: The relations between marine animal and vegetable life (Mitt. zool. Sta. Neapel, $13: 34 \mathrm{I}-425 ; 34$ ref.).

Visscrer, J. P., I927: Nature and extent of fouling on ships' bottoms (Bull. U. S. Bur. Fish., Part II, 43:193-252; 55 ref.).

von BRAND, T., RAKESTRAw, N. W., and RENN, C. E., I937: The experimental decomposition 
and regeneration of nitrogenous organic matter in sea water (Biol. Bull, ,72:165-I75; I6 ref.). von Brand, T., Rakestraw, N. W., and Zabor, J. W., I942: Decomposition and regeneration of nitrogenous organic matter in sea water, V. Factors influencing the length of the cycle; observations upon the gaseous and dissolved organic nitrogen (Biol. Bull., 83:273-282; 7 ref.).

von WOLZOGEN KüHR, C. A. H., I922: On the occurrence of sulphate-reduction in the deeper layers of the earth (Proc. K. Acad. v. Wetenschappen Amsterdam, 25:188-198; 10 ref.).

Voroschilova, A., and Dianova, E., r937: The role of plancton in the multiplication of bacteria in isolated samples of sea-water (Mikrobiologiia, 6:741-753; Russian with English summary; 12 ref.).

WAKSMAN, S. A., I933: On the distribution of organic matter in the sea bottom and the chemical nature and origin of marine humus (Soil Sci., 36:125-I47; 22 ref.).

—_ - 1934: The rôle of bacteria in the cycle of life in the sea (Scient. Monthly, 38:35-49; 33 ref.).

- - I937: Associative and antagonistic effects of microorganisms: I. Historical review of antagonistic relationships (Soil Sci., 43:5 I-68; 107 ref.).

- I94I $a$ : Aquatic bacteria in relation to the cycle of organic matter in lakes (A Symposium on Hydrobiology, Univ. Wisconsin Press, Madison, pp. 86-ro5; 58 ref.).

- - I94 $b$ : Antagonistic relations of microörganisms (Bact. Rev., 5:23I-29I; 373 ref.).

Waksman, S. A., and Carey, Cornelia L., I935a: Decomposition of organic matter in sea water by bacteria, I. Bacterial multiplication in stored sea water (Jour. Bact., 29:53I-543; 2 I ref.).

— — - - 1935b: Decomposition of organic matter in sea water by bacteria, II. Influence of addition of organic substances upon bacterial activities (Jour. Bact., 29:545$56 \mathrm{r} ; 4$ ref.).

Waksman, S. A., Carey, Cornelia L., and Allen, M. C., I934: Bacteria decomposing alginic acid (Jour. Bact., 28:2I $3-220 ; 3$ ref.).

Waksman, S. A., Carey, Cornelia L., and Reuszer, H. W., i933a: Marine bacteria and their rôle in the cycle of life in the sea, I. Decomposition of marine plant and animal residues by bacteria (Biol. Bull., 65:57-79; 26 ref.).

WAksman, S. A., and Hotchisiss, MARgaret, I937: Viability of bacteria in sea water (Jour. Bact., 33:389-400; ro ref.).

- $-1,1938$ : On the oxidation of organic matter in marine sediments by bacteria (Jour. Mar. Res., I:IOI-II8; I5 ref.).

Waksman, S. A., Hotchisiss, Margaret, and Carey, Cornelia L., i933b: Marine bacteria and their rôle in the cycle of life in the sea, II. Bacteria concerned in the cycle of nitrogen in the sea (Biol. Bull., 65:I37-167; 5 I ref.).

Waksman, S. A., Hotchisiss, Margaret, Carey, Cornelya L., and Hardman, Yvette, 1938: Decomposition of nitrogenous substances in sea water by bacteria (Jour. Bact., $35: 477-486$; 5 ref.).

Waksman, S. A., and RenN, C. E., I936: Decomposition of organic matter in sea water by bacteria, III. Factors influencing the rate of decomposition (Biol. Bull, $70: 472-483 ; 8$ ref.).

Waksman, S. A., Reuszer, H. W., Carey, Cornelia L., Hotchkiss, Margaret, and Renn, C. E., I933c: Studies on the biology and chemistry of the Gulf of Maine, III. Bacteriological investigations of the sea water and marine bottoms (Biol. Bull., 64:I83-205; 6 ref.).

Waksman, S. A., and Stevens, K. R., 1929: Contribution to the chemical composition of peat: V. The rôle of microörganisms in peat formation and decomposition (Soil Sci., 28:315$340 ; 47$ ref.).

Waksman, S. A., Stokes, J. L., and Butler, Margaret, R., r937: Relation of bacteria to diatoms in sea water (Jour. Mar. Biol. Assoc., 22:359-373; 9 ref.).

WAKSMAN, S. A., and VARTIOvaARA, U., I938: The adsorption of bacteria by marine bottom (Biol. Bull., 74:56-63; II ref.).

WALKer, A. W., and DAY, A. A., I943: The use of a substance extracted from Irish moss as a substitute for agar for bacteriological purposes (Jour. Bact., 45:20).

WARMing, E., I875: Om nogle ved Danmarks Kyster levende Bakterien (Medd. naturhist. For. Kjöbenhavn, $7: 356-376)$.

—_ - I876: Om nogle ved Danmarks Kyster levende Bakterien (Medd. naturhist. For. Kjöbenhavn, 8:2I-42).

WARren, A. K., and RAwn, A. M., r938: Disposal of sewage into the Pacific Ocean (Modern Sewage Disposal, Federation of Sewage Works Assoc., New York, pp. 202-208).

Welch, P. S., 1935: Limnology (McGraw-Hill Book Co., New York, 47 I pp.; many ref.).

Wells, N. A., and ZoBell, C. E., 1934: Achromobacter ichthyodermis, n. sp., the etiological agent of an infectious dermatitis of certain marine fishes (Proc. Nat. Acad. Sci., 20:I23-I26; 6 ref.).

Weston, A. D., I938: Disposal of sewage into the Atlantic Ocean (Modern Sewage Disposal, Federation of Sewage Works Assoc., New York, pp. 209-218; 7 ref.). 
WEstoN, W. H., I04I: 'The role of the aquatic fungi in hydrobiology (A Symposium on Hydrobiology, Univ. Wisconsin Press, Madison, pp. 120-151; 50 ref.).

IVhrple, G. C., r9or: Changes that take place in the bacterial content of waters during transportation (Tech. Quart., I4:2I-29).

—_- 1927: The Microscopy of Drinking Water (John Wiley \& Sons, New York, 586 pp.; 400 ref.).

Wrlumas, F. T., and McCoy, ElrzABETH, I934: On the role of microorganisms in the precipitation of calcium carbonate in the deposits of fresh water lakes (Jour. Sediment. Petrology, $4: 1 x_{3}-126 ; 15$ ref.).

ment. Petrology, 5:31-36; i I ref.).

Wrilson, F. C., I920: Description of an apparatus for obtaining samples of water at different depths for bacteriological analysis (Jour. Bact., 5:103-108; 13 ref.).

Wilson, P. W., and Kullmann, Etrel D., I93I: A statistical inquiry into methods for estimating numbers of Rhizobia (Jour. Bact., $22: 71 \sim 90$; 5 ref.).

WINOGRADSKY, S., I928: The direct method in soil microbiology and its application to the study of nitrogen fixation (Soil Sci., 25:37-43).

WOoD, E. J. F., 1939: Studies on the marketing of fresh fish in eastern Australia, Part I. Field observations and quantitative bacterial results (Australia Council Sci. Ind. Res., Melbourne, Pamphlet No. 93:I-24).

- - I940: Studies on the marketing of fresh fish in eastern Australia, Part 2. - 'The bacteriology of spoilage of marine fish (Australia Council Sci. Ind. Res., Melbourne, Pamphlet No. I00:I-92; 23 ref.).

IVulfF, A., I926: Nannoplankton-Untersuchungen in der Nordsee. Mit Bemerkungen über die Methode des Zentrifugierens (Wiss. Meersunters., Abt. Helgoland, N.F., I 5(3):I-44; 28 ref.).

Young, O. C., Finn, D. B., and Bedford, R. H., I93I: A deep sea bacteriological water bottle (Contr. Canad. Biol. Fish., N.S., 6:417-422; 2 ref.).

Zapffe, C., r931: Deposition of Manganese (Econ. Geol., 26:799-832; 50 ref.).

ZeLINSKI, N. D., I893: On hydrogen sulfide fermentation in the Black Sea and the Odessa estuaries (Proc. Russ. Phys. Chem. Soc., 25: 298-303).

Zelier, S. M., r9r8: Fungi found on Codium mucronatum (Publ. Puget Sound Biol. Sta., Univ. Wash., 2:I2I-I25; 5 ref.).

ZIH, A., I932: Beiträge zur Bakteriologie der Lunzer Seen (Internat. Rev. d. ges. Hydrobiol. u. Hydrogr., 26:431-438).

ZILLIG, A. M., I929: Bacteriological studies of Lake Erie (Bull. Buffalo Soc. Nat. Sci., I4(3): $5 \mathrm{I}-58)$.

ZoBELL, C. E., I934: Microbiological activities at low temperatures with particular reference to marine bacteria (Quart. Rev. Biol., 9:460-466; 38 ref.).

- 1935: The assimilation of ammonium nitrogen by Nitsschia closterizm and other marine phytoplankton (Proc. Nat. Acad. Sci., 21:517-522; I3 ref.).

- - 1936: Bactericidal action of sea-water (Proc. Soc. Exper. Biol. Med., 34:1 I3-1 16: 8 ref.).

- $1938 a$ : Studies on the bacterial flora of marine bottom sediments (Jour. Sediment. Petrology, 8:10-18; i9 ref.).

- I938b: The sequence of events in the fouling of submerged surfaces (Official Digest Fed. Paint Varnish Production Clubs, $178: 379-385$ ).

- 1939a: Occurrence and activity of bacteria in marine sediments (Recent Marine Sediments, Amer. Assoc. Petrol. Geol., Tulsa, Okla., pp. 416-427; 58 ref.).

- $1939 b$ : The biological approach to the preparation of antifouling paints (Proc. Scient. Sect. Nat. Paint, Varnish Lacquer Assoc., Circular 588:149-163; 20 ref.).

- I940a: Some factors which influence oxygen consumption by bacteria in lake water (Biol. Bull., 78:388-402; 42 ref.).

I940b: The effect of oxygen tension on the rate of oxidation of organic matter in sea water by bacteria (Jour. Mar. Res., $3: 21 \mathrm{I}-223 ; 29$ ref.).

- - I 194 I $a$ : Studies on marine bacteria, I. The cultural requirements of heterotrophic aerobes (Jour, Mar. Res., 4:42-75; 66 ref.).

- $194 \mathrm{x} b$ : The occurrence of coliform bacteria in oceanic water (Jour. Bact., 42:284).

_ _ I _ I I $C$ : Apparatus for collecting water samples from different depths for bacteriological analysis (Jour. Mar. Res., 4:173-188; 28 ref.).

- - I942a: Bacteria of the marine world (Scient. Monthly, 55:320-330; 7 ref.).

- $1942 b$ : Changes produced by microorganisms in sediments after deposition (Jour. Sediment. Petrology, 12:127-136; 50 ref.).

- - I942c: Microorganisms in marine air (Aerobiology, Amer. Assoc. Adv. Sci., Washington, D.C., Publ. No. 17:55-68; 59 ref.). 


\section{(Petroleum World, 40:30-43; 42 ref.).}

$-1943 b$ : The effect of solid surfaces upon bacterial activity (Jour. Bact., 46:39-56; 50 ref.).

ZoBell, C. E., and Allen, Esther C., r933: Attachment of marine bacteria to submerged slides (Proc. Soc. Exper. Biol. Med., 30:1409-I4I I; 6 ref.).

$--1-1$, I935: The significance of marine bacteria in the fouling of submerged surfaces (Jour. Bact., 29:239-25I; I5 ref.).

ZoBell, C. E., and ANderson, D. Q., 1936a: Observations on the multiplication of bacteria in different volumes of stored sea water and the influence of oxygen tension and solid surfaces (Biol. Bull., 7 r:324-342; 25 ref.). Amer. Assoc. Petrol. Geol., 20:258-269;20 ref.).

ZoBelt, C. E., Anderson, D. Q., and Smith, W. W., I937: The bacteriostatic and bactericidal action of Great Salt Lake water (Jour. Bact., 33:253-262; 13 ref.).

ZoBel., C. E., and BeCKWITH, JosePHINE D., I944: The deterioration of rubber products by micro-organisms (Jour. Amer. Water Works Assoc., 36:439-453; 30 ref.).

ZoBell, C. E., and Brown, BARBARA F., I944: Studies on the chemical preservation of water samples (Jour. Mar. Res., 5:I 78-184; 17 ref.).

ZoBELL, C. E., and CONN, JEAN E., I940: Studies on the thermal sensitivity of marine bacteria (Jour. Bact., 40:223-238; 26 ref.).

ZoBeli, C. E., and Feltham, Catharine B., i934: Preliminary studies on the distribution and characteristics of marine bacteria (Bull. Scripps Inst. Oceanogr., Tech. Ser., 3:279-296; 33 ref.). (Science, $8 \mathrm{r}: 234^{-236} ; 5$ ref.).

- - - , - 1938: Bacteria as food for certain marine invertebrates (Jour. Mar. Res., I:3 $2-327 ; 39$ ref.).

$-1-1,1942$ : The bacterial flora of a marine mud flat as an ecological factor (Ecology, 23:69-78; 30 ref.).

ZoBell, C. E., and GRANT, C. W., I943: Bacterial utilization of low concentrations of organic matter (Jour. Bact., 45:555-564; 23 ref.).

ZoBell, C. E., Grant, C. W., and HaAs, H. F., I943: Marine microörganisms which oxidize petroleum hydrocarbons (Bull. Amer. Assoc. Petrol. Geol., 27:II 75-I I93; 83 ref.).

ZoBell, C. E., and LANdon, Winifred A., 1937: Bacterial nutrition of the California mussel (Proc. Soc. Exper. Biol. Med., 36:607-609; 5 ref.).

ZoBell, C. E., and Mathews, Helen M., I936: A qualitative study of the bacterial flora of sea and land breezes (Proc. Nat. Acad. Sci., 22:567-572; 9 ref.).

ZoBeLl, C. E., and McEwen, G. F., r935: The lethal action of sunlight upon bacteria in sea water (Biol. Bull., 68:93-106; 36 ref.).

ZoBeli, C. E., and Michener, H. D., I938: A paradox in the adaptation of marine bacteria to hypotonic solutions (Science, $87: 328-329 ; 5$ ref.).

ZoBell, C. E., and Rittenberg, S. C., I938: The occurrence and characteristics of chitinoclastic bacteria in the sea (Jour. Bact., $35: 275^{-28} 7$; I 8 ref.).

ZoBell, C. E., and Stadler, Janice, rg40a: The oxidation of lignin by lake bacteria (Arch. $f$. Hydrobiol., $37: 163-171 ; 24$ ref.).

$-1,-1940 b$ : The effect of oxygen tension on the oxygen uptake of lake bacteria (Jour. Bact., 39:307-322; 29 ref.).

ZoBell, C. E., and UphaM, H. C., r944: A list of marine bacteria including descriptions of sixty new species (Bull. Scripps Inst. Oceanogr., 5:239-292; I60 ref.).

Zuelzer, MARgarete, I928: Zur Hydrobiologie der Spirochaeta icterogenes syn. biflexa in den Tropen, IV. Mitteilung (Centralbl. f. Bakt., I Abt.; 105:384-393). 


\section{AU'THOR INDEX}

AввотT, 26, 200

Aida, $47,81,183,280$

Alioschina, Ix $2,147,160,226$

Allen, Esther C. $56,57,230$

- (in Moberg el al.), $19,20,100$, 222

Allen, E. J. 3I, 285

Allen, M. C. (in Wiksman et al.), I I I, 328

Allen, WV. E., $60,76,77,85,165,193$, 200,212

Allgcier, 95, 99, 105, 106, 108, 200

Allison, 157,200

Alfison, 157,200

Amderson, B., 02, III, 2 I5

Anderson, B., 02, III, 215 $93,95,107,110,144,149,150$, 200,230

(is Rittenberg et al.), 50, 224 (in ZoBell el al.), 203, 230

Angst, $121,127,140,200$

Aronson, 175, 200

Atkins, 13, 19, 167, 195, 209

BAARS, I 46, I59, 200

Baas Becking, $147,165,166,174$,

Baier, $9,79,80,87,96, x 03,104,110$, I 74, 205, 207,209

Bailey, 143,2 II

Ball, 40, 2 II

Bancel, 3, 209

Baranik-Pikowsky, 202, 200

Barghoorn, I32, I34, I35, I39, I4I, I7 I, I I95, 200

Barker, 108, 109, III, 209

Barnes, 192, 210

Basset, 60, 210

Bastin, 92, II I, 160,210

Baumgartner, 107, 210

Baur, 101, 155, 2 I0

Bavendamm, 42, 90, 99, 102, II 4 , I1 $8,139,140,151,155,156,160$, $162,163,164,165,210$

Beard, $143,183,189,210,225$

Beatty, 198, 210

Beauregard, 199, 2 10

Becking (see Baas Becking)

Beckwith. J. D. 128, 148, 196, 230

Beckwith, T. D., I24, I89, 190, 210 , 219

Bedford, $0,114,116,122,190,210$

(is Young el al.), 27, 31, 229

Beijerinck, $118,159,16 \mathrm{r}, 162,210$

Benecke, 9, 54,56, 99, I1 $4,144,154$, $156,166,210$

Benson, 99, 141, 2 10

Bere, 51, 53, 206, 210

Bergey, 2, 5, II7, II9, I 24, I27, I59, $163,165,187,202,210$

Berkeley, 42, 44, 10I, I18, I20, 121 I52, 210

Bertel, L., 44, 2 IO

Bertel, R., 7, 27, 31, 64, 66, I44, I5I,

Bieljansky (in Rubentschik el al.), $87,91, x 13,202,224$

Bigelow, 9, 19, 2 II

Billet, I7I, 21 I

Birge (in Allgeier el al.), 95, 99, 108,

Boebmer (in Ellis el al.), 7x, 2x4

Bokova, I13, $21 \mathrm{I}$
Borsook (in Bokova el al.), II3, $2 \mathrm{II}$

Braarud, 78, 150, 21 I

Braarud, 78, 150, 2

Bradley, I 43,211 .

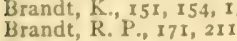

Brebeck, 129,215

Breed, 52, 127,211

Brenner, 99, 166, 211

Brew, 52, 2 II
Brown, B. F., I69, 230

Brown, C. J.'D., 40, 2 II

Browne, $185,107,211$

Brujevicz, 106, 21 I

Brujevicz, I06, 211

Buchanan, 71, 105, 162, 211
Bucher, x0.4, 2 I I

Buchner, 73, 2 II

Bunker, $158,160,162,211$

Burgess, 5, 215

Burcwitz, I30, 171, 222

Buswell, 108, 109, $146,211,226$

Butkevich, 9, 28, 49, 91, 97, 98, 99 ,

$103,109,160,201,21$

Butler (in Waksman el al.), 78, 143. $\mathrm{I} 69,228$

Butterfield, 36, 47, 48, 79, 212, 223

Calkins, 24, 212

Cantacuzene, 171,212

Carey, $9,19,36,83,87,88,98,118$, $138,139,150,152,153,154,174$,

212 (in Waksman et al.), 51, 52,77, $78,79,85,91,140,141,143,144$. $155,156,169,228$

Carpenter, L. V., I83, 212

Carpenter, P. L., 92, 99, 206, $2 \times 2$

Cassedebat, $60,65,212$

Cattell, 69, 2 I

Certes, 2, 3,69, 90, 177, 212

hait, 98,224

Chavanne (in Fernand et al.), 83 . 2 I 4

Chibnall, 147, 212

Chlopin, 69, 212

Cholodny, 54, 55, 103, 2 I 2

Christensen (in Keys el al.), 83, 87

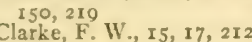

Clarke, G. L., I2, I3, 24, 65, 73, 174。

212

Clarke, H. T., r47, 212

Clayton, 197, 212

Coe, $79,173,212,215$

Cohn, $2,163,212$

Coker, 23, I65, 212

Conn, H.J., 52, 55, 212

Conn, J. E., 38, 45, 46, I2I, I22, 123,230

Coolhaas, I46, 21

Cooper, 9, 98, 106, 15 1, 153, 168, 213

Copenhagen, 109, 160, 213

Coupin, 118,213

Courtney (in Geiger el al.), 143, 199. 216

Crosthwaite, 194, 213

Crump, 79, 80, 213

Cunningham (in Fox et al.), 79, 215

Cupp, 23, 213

Curran, 88, 213

Cutler, $79,80,213$

DAHLGREN, II $9,2 \mathrm{I} 3$

Daines, 203, 213

Daniltchenko, 200, $2 \mathbf{I}_{3}$

Darling, I79, 192, 213

Davenport (in Fred el al.), 36, 63.

$70,74,206,215$

Davis, B. L., $83,2 \mathrm{I}_{3}$

Davis, H. S., 175, 213

Day, 45,228

Deevey (in Hutchinson et al.), 106, $2 \mathrm{r} 8$

d'Herelle, 82,2 I 3

Diehl (in Larsen el al.), 33, 69, 220

Dienert, 184,213

Dietz, 34 35, 92, 214

Dimitroff, 187, 21 3

Dodgson, 79, 186, 21

Domogalla, 207, $2 \mathrm{x}_{3}$

Dore, $194,2 \times 3$

Dorke, I95, 213

Dorff, 103, ro $4,2 \mathrm{I}_{3}$

Drew, $7,27,31,42,67,90$, I01, т1 8 ,

I. $21,155,213$

Drewes, 157,213

Duff, 175,213

Düggeli, $43,68,70,9 \mathrm{r}, 99,108,160$, $206,207,214$

Durbam, 179,214

Dyer, 199,214
EARDLEY, 203, 2I 4

Gyorova, 20I, 218

Ehrenberg, 2, 128, 314

Ekeloff, $6,177,214$

Ekman, $17,74,23,284$

Elazari-Volcani, 9, 9r, 99, 148, 204 .

214

Elema, 106, 214

Eliot, 187,2 I 4

Elliott, 99, 214

Ellis, B. F., 24, 214

Ellis, C., 7 1,214

Ellis, D., $103,158,161,162,163$, 165,284

Emery, 34, 35, 02, 214

Enevoldsen, $105,139,2 \times 4$

Erdtman, 179, 214

Erikson, 99, I41 $, 145,147,214$

Esterly, I73, 214

Eyre, 26, 187,214

FARRELL, 93, 214

Feitel, IOr, I55, 214

Fejgin, $83,2 r_{4}$

Fellers, 188,214

Feltham, 28, 37, 55, 59, 6x, 62, 63,

$64,70,9 \mathrm{r}, 95,96,108,116,130$, I $51,174,230$

Field (in Baas Becking et al.), r47, Field

Finn (in Young el al.) , 27, 31, 229

Fischer, $1,2,3,4,6,7,27,31,42$, $60,64,65,70,114, x 18,123, x 27$ I $29,130,131,154,177,178,215$ Fischer, H., 156, 215

Fleming (in Moberg et al.), I10, 222 - (in Sverdrup et al.), 9, 10, 12, I $4,15,17,21,22,33,160,165$, $167,22 \pi, 226$

Flowers, 203, 255

Forster, 4, I 21, 123, 285

orti, 165,215

Fortunato, 83,215

Fowler, 2I, 2x

Fox, 79, 139, 173, 215

Föyn, 66, 78, 150, 211,215

Frankland, E., 5, 215

Frankland, P., 70, 85, x22, 179, 182, I 92,215

Fred, 9, 36, 43, 53, 54, 63, 70, 74, II7, 20.4, 206, 215, 225

Fuller, $185,188,216$

Fulmer, 7I, 78, 105, 2 I I

GAARDER, 70, 78, 215

$\mathrm{Gahl}, 92$, III, 2 IS

Gainey, $86,185,215$

Galliher, 158,215

Gazert, 6, 27, 3I, 38, 43, 60, 6r, 152, $154,177,102,215,216$

Gee, 8, 9, 28, 29, 32, 37, 39, 43, 54, $62,83,90,116,118,216$

Geiger, 143, 199, 216

Gelarie, 183,216

Gellis, 24, 174,212

de Giaxa, $8 \mathrm{r}, 182,2 \mathrm{r} 6$

Gibbons, 9, $123,173,185,188,190$, $197,198,210,216$

Gibbs, 197, 212

Giddings (in Hite et al.), 69, 218

Gietzen, 165,216

Gildemeister, 83,216

Ginsburg-Karagitscheva, 92, 146 , 216

Ginter, $92,2 \times 6$

Giudice, I78, 216

Glock, 100, 216

Goicherman, 202, 206, 224

Grïf, 7, 61, 154, 216

Graham, 206, 216

Gran, $19,66,77,78$, 101, 118,140 . $152,154,155,215,216$

Grant, 36, 88, 107, $117,118,138$, 173 (in ZoBcll et al.) , 99, 112,128 , 147,230 
Gratia (in Basset et al.), 69, 210

Gray, 55, 227

Greenberg (in Moberg et al.), I9, 20, I00, 222

Greer, 92, III, 210

Griffiths, $143,185,188,189,190,216$

Grinberg, I 24, 218

Guggenheim, 49, 50, 220

Guillerd, 184,213

HAAS (in ZoBell et al.), 99, II2, I28,

I47, 230
Hafford (in Allgeier et al.), I05, 106, 209

Hall, 49,216

Halvorson, 48, 103, 104, 216, 226

Hammar, 145, 217

Hanks, 45, 2 I 7

Hanzawa, 190, 217

Harder, 103,217

Hardman, I04, 217,228 228 (in Waksman et al.), 150, 169,

Harrison, C. W., 186, I87, 218

Harrison, F. C., 9, 143, 172, I88, I90, 197, 217

Hartulari, 9I, 2 I7

Hartzell (in Larsen et al.) , 33, 69, 220 Harvey, E. N., II9, 217,219

Harvey, H. W., $14,18, x_{9}, 1_{52}, 167$

I73, I75, I92, 217
Hashimoto (in Baas Becking et al.), 147,209

Hauduroy, 83, 217

Hecht, I42, I 45, I46, 217

Heller, 84, 2 I 7

Henrici, $9,35,40,43,56,57,58,68$, $74,78,85,86,9 x, 92,93,96,104$, $205,206,217$

Henry, 88, I43, I50, 222

Hess, 9, I 23, I 44, I75, I90, 217

Hesse, 8, I77, 217

Heukelekian, 36, 84, 217

Heusner (in Moberg el al.), 110, 221

Hewitt, 49, 105, 106, 217

Heydenreich, 26, 217

Highlands, I90, 217

Hilen, 56,2 I 8

Hilen, 56,218
Hinze, 163,218

Hinze, 163,218
Hitchens, 51,218

Hitchens, 5I, 218 (in Breed et. $), 127,21$

Hite, 69,218

Hjort, 22, 34, 218, 222

Hock, I44, 218

Hof, I $21,197,2$ I 8

Hofmann, 02,221

Höglund (in Pettersson et al.), 73,

Hoover (in Allison et al.), I 57, 209

Hoover (in Alison el al.), 15

Hotchkiss, 9, 57, 82, 85, 94, 108, 110 , I 49, 218,228

149 (in Waksman et al.), 5I, 52,77,

$78,79,85,91,144,150,152,1_{54}$, $\mathbf{1 5 5}, 156,169$

Houston, A. C., 218

Houston, C. W., 48,226

Huber-Pestalozzi, 25,218

Hulburt, 71, 72, 218

Humm (in Pearse et al.), 95, I75, 223

Hunt, I I 2, 2 I 8

Hunter, $130,143,186,187,188,189$, 218

Husson, 3, 200

Hutchinson, 106, 218

IMSHENETSKY, I $96,2 \times 8$

Inman, 175,218

Irvin,

Irvin, roo, 222 $, 28,20,91,03,99$ $I_{03} I_{14}, I_{30}, I_{52}, I_{54}, I_{55}, I_{56}$, $160,162,164,200,201,202,218$

JACKSON, IO4, 219

Jahn, 192, 2 10

Jankowski, III, I46, I60, 219

Jensen, A. C., 203, 219

Jensen, L. B., 102, 210

Jensen, P. B., 148, 219

Jepps, 133, 219

Johnson, F. H., 107, 118, 119, 160,

Johnson, M. W. (in Sverdrup et al.), $9,10,12,14,15,17,21,22,33$. $160,165,167,226$
Johnston, 26, 219
Johnstone, I4, I43, 219

Jordan, $72,85,219$

Juday, $136,137, x_{3} 8, \mathbf{1} 70,2$ I 9 (in Allgel

KALANTARIAN, I03, I55, 219

Kanel, I06, 210

Karzinkin, 53, 57, 108, 205, 206, 219, 220

Katz, II9, 2 I9

Keding, 156, 171,219

Kellerman, Ior, 118 , 190 219

Kennedy, I43, 197, 217

Keutner, $156,210,217$

Keys, $18,83,87,150,217,224$

Kibbe, I 34, I7I, 219

Kinkel, I4I, I44, 2 I

Kiribayashi, $47,81,183,219$

Kiser, $123,124,189,190,219$

Klebahn, I90, 220

Kleiber, $63,68,86,206,220$

Klein, 206, 207, 220

Kligler, 49, 50, 220

Kluyver (in Elema et al.), I06, 214

Knipowitsch, I52, I65, 201, 220

Knowlton, 184,220

Knudsen, 15, I6, 220

Kofoid, 194, 220

Kokurina, I96, 2 I 8

Korinek, 44, 48, I 20, I2I; I56, 220

Korochkina, ro6, 220

Krassilnikov, 81, $183,184,220$

Kreps, 113,220

(in Bokova et al.), II 3, 2 I I

Krizencky, 173,220

Krogh, 19, 33, 78, 87, 173, 220

(in Keys et al. $), 83,87,150,219$

Krumwiede, 182,220

Kruse, 28, 220

Kullmann, 52, 229

Kusnetzow, S. I., 9, 53, 105, 106, $107,108,109,205,206,220,221$

Kusnetzowa, Z I., 85,220

LACKEY, 24, 220

Lagerheim, I 7 I, 220

Landberg (in Pettersson et al.), 73, 223

Landon, 79, 230

Larsen, $33,69,220$

Lebour, 24, 53, 220

Levin, 5, 6, 177, 22 I

Lewis, 80, 221

Liagina, 107, 205, 221

Liebert, I52, 221

Lieske, $92,22 \mathrm{I}$

Lindberg, 180,22 I

Linder, I32, I34, I35, 139, I41, I 7 1, 195,209

Lipman, 4I, 42, 44, 61, 92, 101, I02, I $8,120,152,221$

Lloyd, $9,36,42,52,63,64,67,68$, $70,74,84,85,87,90,91,97,121$, I 55, I $56,184,22$ I

Lochhead, II 4, 227

Lohmann, 24, 53, 22

Love, I02, 222

Lovering, I04, 107, 22 $\mathrm{x}$

Luck, 24, I73, 22 I

Lucke, I98, 221 . Lukyano

Lundestad, r40, 22 I

Lyman, 21, 221

MacGinitie, 95, 96, 174, 221 Macheboeuf, 69, 210

- (in Basset ef al.), 60, 210

Maclay (in McCready et al.), 45, 22 I

MacLeod, 197,224

Manil (in Basset et al.), 69, 210

Mare, 79, 95, 96, 97, 174, 22I

Marmer, I 4, 221, 223

Marshall, 78,221

Martin, II3, 22

Mathews, D. J., 27, 22 I

Mathews, H. M., 177, 180, 221, 230

Matudaira, 44, 22 I

Mazur, 147,212

McCoy, 9, 35, 40, 43, 91, 92, 93, 96, 99, I02, 103, 153,206, 217,229

(in Stark et al.), 84, 226

McCready, 45, 221

Mickwen, 66, 70, 230

Iclean, I 78, 179, 102, 221

McMillin (in Baas Becking el al.) 147, 209
Meadowcroft, 183,210

Mears, I10, 221

Meier, I 80,221

Meiklejohn, 80, 221

Meloche, I4I, 226

Messina, 24, 214

Michener, 120,230

Miller, I94, 2 r 3

Minder, 68, 70, 74, 204, 206, 22r, 222

Minervini, 6, 26, 177, 222

Miyadi, 105, 108, 205, 222

Moberg, $19,20,100,110,22$

Molisch, ro2, $103,118,155,162$, 163,222

Moore, 45, I07, 222

Morris (in Allison et al.), 157, 209

Morselli, $\mathrm{x} 77,224$

Mortimer, 107,223

Müller, 53, 79, 222

Murray, A. N., 102, 222

Murray, E. G. D. (in Breed et al.), I 27,2 I 1

I 27, 2I I
Murray, J., 22, 100, 222

NADSON, G., I00, IOI, I29, I66, I7I, 222

adson, S., I00, I55, 222

Nathansohn, 152, 162, 222

Naumann, 33, 56, 222

Neumann, 7, 27, 31, 61, 65, 67, 222

Newton, II $5,122,222$

Nikitinsky, 185,222

Novelli, 147,222

OMELIANSKY, 99, 222

Orlova, 146, 226

Orr, A. P., 18, 78, 221, 222

Orr, J. H., 49, 50, 51, 105, 224

Oster, 13,212

Ostroff, 88, 143, 150, 222

Otto, 7, 27, 31, 61, 65, 67, 222

Owens (in McCready et al.), 45, 221

Oyama (in Sugawara et al.), 109, 226

PACK, 174, 202, 222

Parker, I78, 223

Parlandt, ror, I55, 222

Parr, I85, 223

Parsons, 28, 223

Partansky, 99, I4I, 210

Patnode, II 2, 227

Patrick, 203, 223

Patton, 14, 223

Pearsall, 107,223

Pearse, 95, I75, 223

Peele, II 3,223

Peirce, 116, 196, 223

Perry, C. A., I87, 223

Perry, H. M. (in Harrison et al.), I 88, 217

Peterson (in Domogalla et al.), 207, 213 (in Allgeier et al.), 95, 99, 108, 209

Petrossian, 103, 155, 219

Petrowa, 197, 223

Pettersson, 73, 223

Pfenniger, 70, 74, 206, 223

Pflüger, 3,223

Pirie, 7, 152, 177, 223

Plehn, 175,223

Podhradsky, 173,220

Portier, 28, 223

Poteriayev, 20r, 223

Prescott, 72, 79, 8r, 85, 87, I85, 223

Pringsheim, 156,223

Proctor, 178,223

Purdy, 79, 223

Pütter, 78, 173, 223

RATN, 197, 223

Rakestraw, I 8, I53, 168, 223

- (in von Brand et al.), 150,154 , I $56,227,228$

Ravich-Sherbo, $160,161,162,20 \pi$, 223

Rawn, 184, 228

Reay, 198, 223

Redfield, I8, I67, I68, 223, 224

Redgrave, r94, 213

Reed, 49, 50, 51, 105, 188, x97, 224

Reinke, I56, I 7 I, 224

Reitano, 178,224

Renn, 9, 19, 28, 85, 87, 88, I33, I34, $143,150,167,168,171,224$ 
- (in von Brand el al.), 150, 153, 154227

(in Waksman et al.), 51, 52, 77 $78,79,85,91,844,228$

Reuszer, $9,42,59,61,70,91,93,94$,

96,224 inaksman el al.), 51, 52, 77, $78,79,85,91,139,140,143,144$, 228

Revelle (in Moberg ef al.), 19, 20, roo, 110,222

Reyniers, 28,224

Richard, 28,223

Riley, 136,224

Rittenberg, 50, 91, 101, 144, 159. $166,178,224,230$

Robers, 78, 224

Robertson, 105,224

Robinson, 18,227

Robinson, 18,227

Rodionowa, 146,216

$91,113,202,224$

Roll, 57,224

Rosenfeld, 145

Rosenthal, 51, 224

Rossi, 55, 224

Rostowzew, $\times 55,218$

Rubentschil:, 9, 87, 91, 98, 113,139 , I 40,15 I, 20I, 202, 206, 224

Russell, F. S., 13, 73, 224

Russell, H. L., 2, 4, 5, 28, 29, 60, 65, $86,90,93,97,114,154,224,225$

Ruttner, 74, 206, 22

Ruud, 19, 34, 78, 216, 218

SALIMOVSKAJA-RODINA, I79, 225

Samborn, 123, 172, 225

Sanders, 147,225

Sanfelice, 60, 225

Saslawsky, 162,225

Schach, 29, 225

Schach, 29, 225

Schaudinn, 171, 225 65idt-Nielsen, 6, 66, 70, 142,

Schnakenberg (in Geiger el al.), I43, 199,216

Schneider, 37, 226

Schreiber, 150,225

Schwartz, 108,221

Sears, 19, 2 II

Seiwell, I8, 19, 168, 225

Seliber, 146,225

Sempé (in Fernand et al.) 83,214 Sempé (in Fernand el al.) $, 83,214$
Setter (in Carpenter el al.), 183,212

Seyer, I 47,225
Sheets (in Luck et al.) , 24, I73, 22 I

Shintani (in Sugawara el al.), Iog, 226

Shunk, II8, II9, 2 I0

Sigurdsson (in Dyer ef al.), 199, 214

Siple, I79, I02, 213

Smith, B.' I. 14,225

Smith, N. R, 90, 101, 102, II8, 2 19,

Smith, P. W. P. (in Harrison et al.), I88, 217

Smith, W. W., 58, 85, 203, 225

- (in ZoBell el al. $), 203,230$

Snow, Jane E., 143, 189, 225

Snow, Laetitia M., 43, 53, 54, I17. 204,225

Söhngen, rog, 225

Sommer, 199

Soper, 182, 225

Spärck, 70, 215

Sparrow, I3I, 132, 133, 134, I35.

Sparrow, I3I, 132
$171,176,225$
Spence, IS8, 224

Spitta, 86, 225

Spooner, 73, 235

Spray, 51,225

Stadler, 36, 00, 107, I4 I, 230

- (in Stark el al.) , 84, 220

Stanbury, 73,226

Stanier, 840,226

Stark, $8 \$, 226$

Starkey, $103,104, x 09,159,160,226$

Steiner, J. F., 141, 226

Steiner, M., 144, 206, 207, 226

Stephenson, 109, 226

Stevens, 92, 228

Stervart, 123, 173, 188, 198, 226

Stickland, $x 00,226$

Stokes, 157,226

(in W'aksman el al.), 78,143 ,

169,228

tone, 50, 226

Strom, 95, 160, 226

Stuart, 144, 197, 226

Sturm, 146, 220

Suckling, $x 85,226$

Sugawara, xo9, 226

Sunderland, 102, 108, 226

Sutherland, I3I, 226

Sverdrup, $9,10,12,14,15,17,21$,

$22,33,160,165,167,226$ (in Fox el al. $), 79,215$

TAKEDA, 190, 217

Tammann, 60, 212

Tanikawa, 186, 226

Tanner, $37,48,186,187,190,197$, 198,226

Tarr, $9,52,192, x 98,226$

Tarvin, I46, 226

Tausson, II2, 147, I60, 226

Taylor, $9,60,63,72,74,82,87$, I 14 $185,205,227$

Thayer, 146,227

Thiel, 99, 103, 104, 227

Thienemann, 207, 208, 227

Thomas (in Luck of al.), 24, I 73, 221

Thompson, 15, 18, 227

Thomsen, I 52,227

Thornton, 55, 227

Tiffney, $x 75,227$

Tolman (in Bass Becking et al.), I.47, 209

Tonney, 186, 227

Topping, Ix 4,227

Trask, 9, 19, 22,33. 34, 94, ro5, I 10

III, II 2, I 42, I 45, I47, 227

Tschigirine, 200, 21 3

Turner, 93, 2I4

Tutin, 134,227

UPHAM, 5, 85, 99, I $14,115,116,117$, I1 $8,1_{2} 1, I_{24}, 1_{2} 8,139, I_{4} 1, I_{42}$, $146,155,175,230$

Utermöht, $53,54,164,165,227$

Utterback, I2, 13, 227

VAN DALFSEN (in Elema $e l a l$.), ro6, $2 \mathrm{I} 4$

van Delden, 159,227

Van der Lek, 140,227

van Niel, $162,165,166,227$

Vartiovaara, 55, 85, 9I, II 3,228

Vaughan, 100, 227

Verjbinskaya (in Bokova el al.), II3, 2 II

Vernon, 151, 154, 227

Visscher, 193,227 von Brand, 9, $150,153,154,856$, 227,228

von Wolzogen Kuhr, 02, 238

Voroschilova, 174,228

WAKSAMAN, $9,19,36,51,52,55,57$.

$77,78,79,80,81,82,83,85,87$.

$88,91,92,94,08,108,110,113$,

$114,115,118,831,138,139,140$, I.41, I $42,143,1.44,145,1.48, x .40$, $150,152,154,155,156,169,174$, $206,218,221,228$

Walker, 45, 228

Warming, $2, x 63,164,228$

Warren, A. K., 184, 223

Warren, F. J., I05, 200

Watanabe, 83,216

Weakley (in Hite ol al.), 60, 218

Weinberg (in Carpenter el al.), I83,

$W^{212}$ eintraub, 45, 217

Welch, 9, 25, 66, 74, 205, 228

Wells, A A. (in Ellis et al.), 71, 214

Wells, N. A., 175, 228

Weston, A. D., I84, 228

Weston, W. H., 135, I 7 x, 175, 206,

Wharton (in Pearse el al.), 95, 175. 223

Whipple, 26, 36, 84, 133, 185, 229

White, 186,227

Wight, $100,160,226$

IVilliams, F. T., 9, 91, 99, 102, 103

I53,206, 220

Williams, O. B., I90, 217

Vilson, F. C., $28,29,220$

- (in Fred el al.), 36, 63, 70, 74, 206,215

Wilson, P. W., 52, 229

Winogradsky, 55, 162, 220

Winslow, 72, 79, 8x, 85, 87, 185, 223

Wollack (in Hutchinson el al.), 106, 218

Wood, A. J. (in Dyer et al.), 199, 214

Wlood, E. J. F., 143, 188, 189, 198, 229

Wright, 195, 224

Wulff, 24,229

Younc, O. C., 27, 3I, 229

Young, R. T., 206, 216

ZABOR (in von Brand el al.), r53, I56, 228

Zapffe, 104, 220

Zelinski, 159, 200, 229

Zeller, 13I, 17 1, 229

Ziegler, 48,216

Zib, 70, 206, 229

Zillig, 26,229

ZoBell, 5, 9, 18, 28, 29, 30, 3r, 36, $37,38,41,42,43,45,46,48,51,55$, $56,57,58,59,61,62,63,64,66$, $67,70,75,79,81,82,84,85,88$, $90,91,93,94,95,96,93,99$, 105, $106,107,108, I I 1,112, I 13, I 14$, I15, I16, I17, I18, I1 $9,120,121$, $I_{22}, x_{23}, I_{24}, x_{2} 8, x_{30}, x_{3} 8, x_{39}$, I4 I, I 42, I44, I46, I $47,148,150$, I5I, I55, I58, I59, I60, I60, I70, I73, I 74, I75, 177, I78, I80, I8I, $183,184,103,104,106,203,205$, $183,184,193,194,196,203,205$ $219,222,224,225,228,229,230$

Zuelzer, 128,230 


\section{GENERAL INDEX}

Abyss, I

Achlyogeton salinum, I34

Achromatiaceae, $\mathrm{I}_{62}, \mathrm{I} 63$

Achromatium, 127

- gigas, 163

- mulleri, 2, 163

Achromobacter, 97, II 5, I23, 125 ,

173, $188,189,190$

173, I88, 189, 190
- ambigum, 172,173

- aquamarinus, 124

二 fischeri, Iro

- Jalophilum, 202

- gericulatum, 172

- granii, $\mathrm{I}_{40}$

- halophilum, 202

- harveyi, II9

-ichthyodermis, 175

- litorale, 5

- litoralis, 173

- luminosum, II

- pellucidum, 172,190

- phosphorewm, IIg

- phosphoricum, IIg

- pikowskyi, 202

- stationis, I 24

- stenohalis, I55

- viscidum, 172

Achyla flagellata, I76

Actinomyces, 57, 99, 102, 115, 126, $\mathrm{r} 28, \mathrm{r}_{47}$

- albus, 100

- halotrichis, I28, I30

- marinolimosus, 128,13

- melanogenes, 139, 202

Actinomycetales in sea, $126, \mathbf{1} 28$

Adsorption of bacteria, $83-87,91$, 202

Aerial transport of microbes, 178 , I80, I8I

Aerobacter, 125, 185, 188, 180

- aerogenes, $184,185,187$

- cloacae, 187

Aerobes, 68

- and $\mathrm{E}_{\mathrm{t},} 49$

- in mud, $90-99,107,117$

Agar, as solidifying agent, 44

- plating temperature, $x 21,122$

- substitutes, 45

Agarbacterium, 127

- aurantiacum.

- bufo, r 40

- cyanoides, 140

- mesentericus, 140

- meducans, 140

- viscosum 140

Agar-digesting bacteria, 44, 77, 116 , I 40

- in muds, 99

— relation to $\mathrm{N}$-fixers, 156

- species of, 140, I4I

Aged sea water, 44,58

Aggregation of particles, $\mathrm{II}_{2}, \mathrm{II}_{3}$

Air, bacteria in, $3,5,7, x 77^{-1} 81$

- pollens in, 179, 180

- yeasts and molds in, 178,179

Ala-Kule Lake, 146

Algae, blue-green, 23, 164

- brown, 134 cause of red water, 165

- decomposition, 143

- film-forming, 193, 194

- green, 23, I43

- in Dead Sea, 204

-in Great Salt Lake, 202, 203

- in mud, 99

-in sea, 22, 23

- molds associated with, $131-135$

- N-fixation by, 157

- nitrogen content, 143

- parasitism of, 13 I -135, I 7 I

- red, $\mathrm{x}_{40}, \mathrm{I71}$

- relation to $\mathrm{N}$-fixers, 156,157

Alginic acid, 140, $14 \mathrm{I}$

Alternaria, $3 \mathrm{I}$

- maritima, 132

Aluminum ppt., 104

Ambergris, 199
American Petroleum Institute, $x_{46}$

Amino acid utilization, 88, I43

- by plants, 150

- effect on $\mathrm{CaCO}_{3}$ ppt., 100-103

Ammonia, oxidation, 15I-I53

- production, $102,142,150,151$

- utilization by plants, 150

Ammonia-N, in sea water, 18

- microbial utilization, 88,150

Ammonifiers, 8, 98, 102, 142, 150 , I5I, 207

A moebobacter, 124, 166

granulae, 16

Amphisphaeria maritima, $\mathbf{I}_{32}$

Amygdalin decomposition, 139

Amyloclastic bacteria, 98, I18, 139

Anaerobes, and $\mathrm{E}_{\mathrm{k},} 49$

- enumeration, $49^{-5 I}$

- in mud, 93, 97, 98, 107

- isolation of, $5 \mathrm{I}$

- jars, 50, 51

Analysis of samples, at sea, 39, 40

- direct counts, $5 \mathrm{I}-58$

- plate count media, $4 \mathrm{I}-44$

- successive dilution method, 48,

Andro

I, 90

Animals, bacterial flora, 5, 6, 7, 172,

- bacterial nutrition, $79,80,96$, I37, I 72-1 75

- effect on bacteria, 78-80, 96, 97,

—injured by $\mathrm{H}_{2} \mathrm{~S}, \mathrm{I} 60$

- in sea, 23-25, 77-80

- light organs, 173

Antagonism, microbial, 80-82, 176

Antarctic Ocean, bacteria in, 7,60

Antibiosis, 80,176

A phanomyces astaci, 175

A phanothece packardii, 203

Aphotic zone, II

Aquatic yeasts and molds, $129-135$. I7I

Arctic Ocean, 8, 130

- seas, $5,6,8,152,160,162$

Artemia gracilis, 203

Artificial sea water, 2I, 47, 48, I2I

Ascomycetes, I29, I35

Ascorbic acid for anaerobes, 50

Aspergillus, 131, I78

Atlantic Ocean, 3-8, 60, 61, 64, 67

Attachment, count, 57,58

- organisms, 56-58, 85, I 24, I93, 194

- propensities of chitinoclasts, 144

Autotrophic bacteria, 95, 103, 104, I $6 \mathrm{I}-\mathrm{I} 66$

Azores Islands, I29, 130

Azolobacter, 125, 156, 202

- chroococcum, 156

Bacillus, 5, 93, II 5, I21, I26, 155 ,

173, 187, 188, 189

$\begin{aligned} & 173,187,188, \\ - & a b y s s e u s,\end{aligned}$

二 amylobacter, 156

- amylobacter, 156

- argenteo-phosphorescens, II 9

- borborokoites, 115

- cereus, 5

- chitinovorus, 144

- cirroflagellosus, II5

- columnaris, 175

- cyaneo-phosphorescens, II9

- epiphylicus, I15, 124

- filicolonicus, II5

- gelaticiss, 140

- granulosis, 5

- halophilus, 5

- immomarinus, IIs

- kildini, 8

- limicola, 5

- limosus, 5

- litoralis, 5

- maritimus, 5

- mycoides, 5, 100

- pelagicus, 5
- phosphorescens gelidus, Irg - psychrocartericus, 201

- salinus, 100

- sphaericus, 5

- sporonema, I7I

- submarinus, 115,146

- subtilis, 69,82

- thalassokoiles, Ir $_{5}$

- Ihalassophilus, 5

- tumescens, 5

Bacteria, as chemical agents, tooI 13

- as food, 24, 79, 80, 96, I72-I75,

- as geological agents, roo- $\mathbf{I r}_{3}$

-importance of, $1,8,9,100-113$, I $50-176, x_{93}-199$

- in sea, 2-8, 38, 59-68, 75, 90-99, I 24-127

Bacterial, genera in sea, $124^{-127}$

- growth near $0^{\circ} \mathrm{C} ., 3-8,45,98$.

I $22,123,144,190,201$

- periphyton, $57,85,124,193$

- plate, I6r, 201

- stratification, 68, 16r, $20 \mathrm{I}$

Bactericidal action, of metal, 31,32

- of sea water, $47,81,182,183$

Bacteriochlorin, 166

Bacteriological samplers, $26-33$

Bacteriophage, $82,8_{3}$

Bacteriopurpurin, $\mathrm{r}_{4}$

water, 47,8 I

Bacterium, 8, II 5,126

- actinopelie, 155

- albo-luteum, 100

- alginicum, I4I

- alginovorum, I4I

- amforeti, 8

- arcticum, 8

- balticum, 55

- barentsianum, 8

- bauri, 155

- beijerincki, 8

- brandti, 155

一 breitfussi, 8

- calcis, I01, 155

- cellulosae album, I40

- cellulosae flavum, 140

- chitinochroma, I44

- chitinophilum, I44

- fausseki, 8

- feiteli, 155

- flavum, 8

- fucicola, I4

- giardi, II9

- granii, I55

-halobium, 204

- halobium rubrum, 190

- halophilicum, 197

- halophilum, 5

- helgolanicum, 155

- henseni, 155

- hydrosulfureum ponticum, 150

- immotum, 124

- knipowilchi, 8

- laminariae, 17

- linkoe, 8

- lobatum, 155

- marinopiscosus, 175

- marinum, 8

- ornalum, 155

- papillare, 8

- repens, 155

- russelli, 155

- salmonicida, 17

- sepientrionale,

- sewanense, I0

- smaragdinophosphorescens, II9

- sociovivum, 124

- spirale, 8

- Irapanicum, 197, 204

- triviale, 155

- zopfii, $x 90$

Bacteroides, 125

- halosmophilus, 197 
Bahama Jslands, 7, $90,840,15 x, 156$, $\pm 60, x 63, x 64$

Baltic Se2, 3, 155, 856, x66

Bank, Ix

Barents Sea, 8, 106

Barnacles, r93, 194

Basin, ro

Beaches, ecology of, 175

- pollution of, zor

Beggialoa, 127, 163, 166

- alba, 103,105

- arachosdes, 163

- marina, 163

- minimo, 2, 163

- mirabilis, 2, I63

Beggiatoaceae, $127,162,163$

Benthic organisms, II

Benthos, II

Biloculing, 24

Binding action of microbes, $I_{12}, I_{3}$

Biococoosis, 95, 164, 166

Bioluminescence, 3, 4, $118,119,173$

Biomass, 97, 201

Biosphere, lower limits of, 92, 93

Biotic zones, II

Black rot of kelp, 17 I

Black Sea, $8 \mathrm{r}, 95,200,20 \mathrm{r}$

- anaerobic conditions, 68, 109, 200

- bacterial stratification, 68, 16 $\mathbf{I}_{\text {, }}$ 201

- iron bacteria, 103

- lipoclasts, 146

- nitrifiers, 152

- salinity, 15, 200

- sulfate reducers, 159,200

- sulfur bacteria, 162, 166, 20

- water germicidal, $8 \mathrm{I}, \mathrm{x} 83$

Blastoderma salmonicolor, 120

"Bloody seas," I64, I65

Boat laboratory, 39

B.O.D. of mud, $108,110,149$

Boring gribble, 194

Bolryophialophora marina, 132

Bottom deposits, bacteria in, 2, 3, 6, $7,67,86,90-99$

- bacterial activity in, 100-1I3

- biocoenosis in, 95-97, 164, 166

- chitinoclasts in, 144

- collection of, 33-36

- Eb of, 105 , 106

- enumerating organisms in, 54-56

- enzymes in, II3

- factors influencing microbes, 9397

- neritic, 22

-oceanic, 22

- of lakes, 9r, 206

- organic content, I0

- organisms in, 21, 22, 93-97, 100-

- oxygen consumption in, 107, 108,

I10, 149

- $\mathrm{pH}$ of, 104,105

- terrigenous, 22

Brandt's hypothesis, $154, \mathbf{I} 5$

Breed and Brew method, 52

Brine, discoloration, 116,196

- shrimp, 203

Buffers in sea water, 19

"Calcium bacteria," 102

Calcium carbonate ppt., 100-103,

- effect of sulfate reducers, 160

- role of denitrifiers, I55

Calcium phosphate, 169

"Calloa Painter," Iro

Canyon, submarine, xo

Capacity, poising, 106

Cape Cod region, 6r, 65, 70

Capillary tube water samplers, 28-

Carbohydrate, assimilation, 117 , II $8,138-145$

- content of organisms, 145

- relation to nitrogen, $\mathbf{3} 38, \mathbf{1} 39$

Carbonates, in sea water, 19, 20

- precipitation, 100-103. 15 I, I55. 160

Carbon cycle in sea, $136-149$

Carbon dioxide, in sea water, 19,20

- production, 108, 137, 170

Caribbean Sea, 65

Carrier for submerged slides, 57

Caseinate, for plate counts, 43
Caspian Sen, bacterial stratification, 68, 108

- bacteria in mud, 98

- biomass 97

- gas produced in, 100

- $\mathrm{H}_{3} \mathrm{~S}$ in, 160

- sulfate reducers, 201

- sulfur bacteria, 165,166

Caulobacter, 124, 126

Cellfalcicula, $\times 25,139$

Cell morphology, 114, I 55

Cellulose, decomposers, $98,99, x_{39}$, 140, 195

- decomposed by fungi, 135

Cellibiorio, $\times 25,139$

Centrifuge plankton, 24

Cephalosporium, $13 \mathrm{I}$

Ceralium, rog

Ceralophyllum, 96

Ceriosporopsis halima, 132

Chaelomium, 131

Chalky mud, ro2

Channel Jsland region, 90, ro5

Chara, 96

Characteristics of marine bacteria, I $14-128$

- attachment propensities, 56-58,

I 24,193

12

- physiological, II 7-II9

- Salinity requirements, II9-I 2 I

- temperature tolerance, $12 \mathrm{I}-124$

Chemical composition of sea water

I $7-2 \mathrm{I}$

Chitin decomposition, 98, 143-145

Chitinoclastic bacteria, in muds, 144 .

- as parasites, I 44, I 75

Chlamydobacteriales, I 26, 127

Chlorinity of sea water, 15,16

Chlorobacierium, 16I, I66

Chlorobium limicola, 166

Cholodny, direct counts, 55

Chromatium, $126,164,165,20$

- gobii, 8, 164

- minus, 164

- minutissimum, I65

- okenii, I6.4

- rosea, 164

- vinosum, I64

Chromobaclerium, 97, 125

Chromobaclerium, 97,

Chromogens, I 16, II 7, I64, I66, I90, I.96

- in lakes, 20

Chromous sulfate for anaerobes, 50

Chroococcus turgidis, 135

Chytridiaceous fungi, 132, 133

Chytridiales, 133

Chylridium, $\mathbf{x}_{3} \mathbf{1}-\mathrm{r}_{34}$

- alarium, 134

- codicola, I3I

- megastomum, I32

- polysiphoniae, 132, I34

Citrate of magnesia bottles, 29, 30

- effect of pressure on, 32

Cilrobacter, 184,187

Cladosporium, $\mathrm{I}_{3} \mathrm{I}$

Cladolhrix, 103

- dichotoma, 18

- intricala, 5

Clathrocystis roseo-persicina, 100

Clay particle size, 22, 94

Clonolhrix, 103, 126

Clostridium, 126,156

- aerogenes, 187

- paslorianum, 156

- welchii, 185,187

Clyde Sea, bacteria in mud, 90,158

- coliform bacteria, 184

- distribution of bacteria, 67, 68, $70,74,75,87$

ducers in, 158

- tides and bacteria, 63

- "water bacteria" in, 97

Coal, bacteria in, 92,93

Coccolith ooze, 22

Codfish, 190, 10,

Coliform bacteria in, fish, 184,185

-ice, $19 \mathrm{I}$

- sea water, 184,185

- shellfish, 186,187

Collection of, mud samples, 33-36

- water samples, 26-33

Compensation point 13

Concentrating water for counts, 53

Conn direct count, 55
Copepods, bacteria as food for, 173. 17.

- decomposition, 150

- in sea, 2.4

- lipid and protein content, 145

Copper precipitation, 10.4

Cordage tiber decomposition, $\mathbf{8 3 5}$.

143,105

Coring devices for mud, 33-36

Cork decomposition, 196

Counts, dilution method, 48,49

- direct microscopic, $5 \mathrm{x}-58$

- media for, 4I-45

- water blanks for, 46,48

Crabs, chitinoclasts on, 144

Crenothrix, 103, 127

- manganifera, 104

- ochracea, 104

- polyspora, 104

Crislospira, 127,128

- anodonlae, 18

- balbianii, 187

- interrogationis, 187

- mina, 187

- modialae, 187

- pinnae, 187

- speculifera, 187

- tenua, 187

Cultural characteristics, $I 16,127$

Cyanodiclyon, 166

Cylophaga, 127, I39

- diffuens, 140

- krzemieniewskae, 140

Dead Sea, 9, I48, 204

Decomposition of, carbohydrates, I3 8 -I 4 I

- chitin, 98, 143-\$45

- cordage fibers, 135, I4 I, I95

- cork, 196

- fish, Ix $6,123,142,190,197,198$

- fish nets, I4I, 195

- hydrocarbons, 90, I46-148, 196

- lignin, 99, I35, 141, 142, 195

- lipids, 98, 99, 145, 146

- plankton, 143, 150, 153

- rubber, 148 , 196

- wood, I35, I4I, I94, I95

Deep, 10

Deep sea, bacteria in, $2-4$, -

Dematium, 130

Denitrification, IOI, 154, I55

Denitrifiers, 154,155

- effect on $\mathrm{CaCO}_{3}$ ppt., IOI

- in sea, $7,8,98,118,155,201$

Density of sea water, $15, x$

- of marine bacteria, 53

Depth of sea, Io

- effect on bacteria, 3, 4, 7, 65-70, 206

Desulforibrio, I25, 147, I59, x6 1

- aesluarii, $146,160,161,166,200$

- desulfuricans, 200, 207

Dextrose fermentation

Diagenesis of sediments, $100-1 \times 3$

Diatomaceous earth, 22

Diatom ooze, 22

Diatoms, decomposition, $\mathbf{I}_{43}$

- ether extract, $\times 45,147$

- film-forming, 193, 194

- fungus infections, $133,134,135$

- in Dead Sea, 20.

- in Great Salt Lake, 203

- in mud, 97,99

- in sea, 22,67,73

- relation to bacteria, $77,78,140$

- shellfish poison, 109

Didymosphoeria, fucicola, I3I

- pelreliana, I3I

Dilution, method counts, 48,49

- water blanks, 40, 46-48, 88

Dinoflagellates, 22

- cause of red water, 165

- parasitized by fungi, I34

- shellfish poison, 199

Diplococcus, 125

- gadidarum, 190

Diplodia orae-maris, 132

Direct microscopic counts, $5 \mathbf{I}-58$, 9I

- compared with plate counts, 5 I,

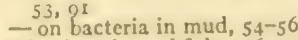

Discoloration, of fish, I16, I17, 190

- submerged suríaces, 193

Disease, amphioxus, 201

- contracted in sea water, ror

- kelp, 871 
- lobsters, I $44, \mathbf{I} 75$

- oysters, 187

- typhoid bacillus, $182,183,186$, Ior

Disinfectants for water samplers, 27 Distance from land, $60-63,86,93$

Distilled water for blanks, $46-48$

Distribution of bacteria in sea, $3 \rightarrow 7$. $59-89$

- effect of depth, 3, 4, 7, 65-69

- factors influencing, 59-89

- fluctuations in, $59,60,74$

- seasonal, 74-77

- solid surfaces and, 36, 56-58, 78, $83-85$

Diurnal variations, 64

Dothidella laminariae, $\mathrm{I}_{34}$

Dunaliella salina, 166,106

Dysphotic zone, I 2

Eberthella typhosa, $182, \mathrm{I} 83, \mathrm{I} 86$

Economic problems, 9, 193-199

Ectrogella perforans, I3I, I32, I34

Eel grass, 23

Egounov's hypothesis, 2 or

$\mathrm{E}_{\mathrm{b}}$, anaerobiosis and, 49

- effect on iron ppt., 103

- effect on microbial activity, 106

- of bottom deposits, 105, 106

- of sea water, ro6

Elodea, 96

Emerita analoga, I74

Emery-Dietz coring device, 34, 35

Endomyces vernalis, I 30

Enumerating marine bacteria, 4I-58

Environment, marine, IO-25

Enzymes in mud, $\mathrm{II}_{3}$

Epilimnion, 68, 206

Epiphytic fungi, I34

Epiplankton, 25

Escherichia, 125,188

- coli, 5,82 , I 78, 183-188

Esmarch cultures, 30

Ether extract, from lipoclasts, 146

- in marine humus, 148

- of decomposing diatoms, 147

- of organisms, 145

Eubacteriales in sea, $124-126$

Euglena, I66

Euphausiids, 24

Euphotic zone, II, 66

Euploles taylori, 173

Eurychasma dicksonii, $\mathrm{I}_{32}$

Eurychasmidium tumefaciens, $\mathbf{1} 3$

Euryhaline organisms, I6, I 20

Examination of samples at sea, 39,40

Expedition, Moltke, 3, I30, I 77

- Nathorst, 5

- Planet, 7

- Plankton, 3

- Scottish Ántarctic, 7

- Solar Eclipse, 5

- South Polar, 6

- Talisman

Extracts for nutrient media, 42

Fabric deterioration, I95

Fat hydrolysis, 98,99, I 45, I46

Fatty acid utilization, I43, I 46

Fauna, effect on bacteria, 78-80, 96 , $97,172,173$

Fermentative power, II 8

Ferric salts for media, 42

Film-formers, $56-58,85,193,194$

Film-formers, $56-58,85,193,194$
Filtration, effect on sea water,

Fish, bacteriology of, 4, I72, I 73 , r $88-190$

- coliform bacteria, 184,185

- decomposition, I23, $142,197,198$

- discoloration, 116, I17, I90, I97

- diseases, 133,175

- effect on bacteria, 60, 75

- extract media, 42

- net deterioration, I4I, I95

- parasitized by fungi, 133

- spoilage, 143, 190, 197, 198

Flathead Lake, 206

Flavobacterium, $115,123, \times 25,173$. I 88,189

- amoconlactum, 124

- annulatum, 172

- balustinum,

- boreale, 140

- ceramicola, 140

- delesseriae, 40

- droebachense, 140
- fucatum, 172, 190

- halmephilum, 204

- halohydrium, I30

- halophilum, 202

- marinotypicum, II6

- marinovirosum, II6

- marinum, 100

- maris, I9o

- maris-mortui, 204

- neptunium, $\mathbf{1} 39$

- okenokoites, Ir6

- rhodomelae, I40

- sewanense, I 55

- turcosum, 72

\section{- uliginosum, $\mathbf{I}$}

Fluctuations in bacteria, 50, 74

Food spoilage, 142, 144, 197-199

Foraminifera, 22, 24, 194

Formula C dilution water, $47,8 \mathrm{I}$

Fouling organisms, 56, I93, 194

Freezing point of sea water, 13,16 ,

I 23

Fresh-water bacteria, I I 4, I I 5, 204

- on submerged slides, 56

- salt requirements, 43,48 , II9-I2I

- thermal sensitivity, I22

Fresh-water media, for bacteria, 43,

- for fungi, I 32

Fungi, classification, $\mathbf{x} 20$

- imperfecti, I 29, I3 1 -I 35

- in air, 178

- infect kelp, 134

- in lakes, $135,17 \mathrm{r}$

- in sea, $13 \mathrm{I}-135$, 19

- lignoclastic, 14

- parasitic, I3I-135, I7 I, I75, I76

Fur spoilage, 197

Fusarium, 135

Gallionella, ז24, I26

- ferruginea, 103

- reticulosa, 103

- turtuosa, 103

Gases, in mud, ro8-rio

- in sea water, 10

Gas producers, 1 r 8

Gee-Esmarch tubes, 39

Gee water sampler, 20

Gelatin, liquefaction, II8

- media, 44, 1 22

- plating temperature, 122

Genera of bacteria in sea, $124-\mathbf{2} 28$

Geological activities of bacteria IOO-IO4

German S. Polar Expedition, 6

Glass-bulb water sampler, 28-30

Glass-disk anaerobe plate, 50

Globigerina, 24

Globigerina ooze, 22

Gonyaulax, catenella, 190

- digitale, ro

- polyeramma, $\mathbf{1 9 9}$

- spinifera, 199

- tricantha, 199

Gram character, of marine bacteria, I 4

- of soil bacteria, II

Grazing animals, 137

Great Salt Lake, 15, 58, I74 I92, 202,203

- water bacteriostatic, 203

Green Lake, I 36

Green sulfur bacteria, I 66

Guignardia, alaskana, 134

-irrilans, 134

-ulvae, $\mathrm{r} 34$

Gulf, of Bothnia, I5

- of California, $64,105,159,165$

- of Maine, 130

- of Naples, $4,60,65,86,90,93,97$.

I $5 \mathrm{I}, \mathrm{I} 52, \mathrm{I} 63, \mathrm{I} 8$

Gymnodinium, 190

Haddock, bacteria of, I73, 188

Halibacterium, 4, 127

- aurantiacum, 4

- liquefaciens, 4

- pellucidum, 4,180

- polymor phum, 4

- purpureum. 4

- roseum, 4

- rubrofuscum, 4

Halibut bacteria on, $172, \mathbf{1} 88,100$

Halophiles, $121,196,197$

- chitinoclastic, 144

- in Great Salt Lake, 202, 203

- in limans, 201, 202
Halophiobolus, I34, I 7 I

- cylindricus, $\mathrm{I}_{32}$

- halimus, I32, I34

- maritimus, 132,134

- medusa, $\mathrm{I} 32$

- longirosiris, $\mathrm{I}_{32}$

- opacus, 132

salinus, I32, 134

Halosphaeria appendicula $a$, I32

Harbor water, bacteria in, 6o, $6 \mathrm{r}$

Heat sensitivity of marine bacteria,

38,46

Helgoland, 152,165

Helicoma, maritimum, I 32

- salinum, $\mathbf{3 2}$

Hemicellulose decomposition, 130

Henrici-McCoy mud sampler, 35

Henrici submerged slides, 56

Hentriacontane, 147

Hides spoilage, 144,197

$\mathrm{H}$-ion conc., effect of organisms on, I9, 10I, IO4, IO5

- effect on $\mathrm{CaCO}_{3}$ ppt., IOI

- effect on plate counts, 42,43

- effect on $\mathrm{PO}_{4}$ solubility, 169

$\rightarrow$ of sea water, 19

Histamine, 143

Humboldt Plankton Expedition, 4

Humus, lignin in, I4I

- marine, 94, 148, 149

Hydrobacteriology, importance of, I, 2, 207, 208

Hydrocarbons, assimilation, 99 , $146-148$

- bacterial oxidation, $\mathrm{x}_{4} 6-\mathrm{x} 48$, I96

- fats as progenitor, I45

- from cellulose, I40

- synthesis, I47

Hydrogen, effect on $\mathrm{SO}_{4}$ reduction, I09

- for anaerobes, 49-5

- from cellulose, 140

- HC formation, I00, III

- produced in mud, 108,100

Hydrogen sulfide, effect on iron ppt., I03

- effect on oxygen tension, I09, 207

- from organic matter, 158

- from sulfate, $160,16 \mathbf{I}, 207$

- in "bacterial plate," 201

- oxidation, $162-166$

- produced in mud, 108-110

- toxic to animals, 200, 207

Hydrostatic pressure of sea water, 3 ,

- effect on organisms, $16,32,33,69$

- effect on water samplers, 29,32

Hyperion sewage outfall, 184, I9I

Hypoderma laminariae, $\mathbf{I}_{3} \mathbf{I}$

Hypolimnion, 68,206

Ice, bacteria in, I9I, 192

Impression smears, 55

IMVIC test, r84

Incubation temperature, 45,46

Indian Ocean, 82, 152

Indol, indicator of fish spoilage, $\mathbf{r}_{43}$

- production, 118,184

Infections from sea water, I 91

Inland waters, (see Lakes), 200-208

- coliform bacteria in, 185

- fungi in, 135

Intertidal zone, $\mathbf{r}, 14,63$

Inverted microscope, 53,54

Iron, bacteria, 56, 99, 103, 104

- effect on plate counts, 42

- precipitation, 103,104

J-Z water sampler, 29-31

Kara Sea, 9r, 106

Kelp disease, I34, I7

Kerosene oxidation, $\mathbf{I} 48$

Kiel Harbor, 3, I44, I51, 152, 166

Kurthic, 126, 189

Laboratory work at sea, 39

Labyrinthula, 132-134, 171

- challoni, I32

- macrocystis, 133

Lactobaciulus, I25, I 80

Lactose fermenters, II 8

Lagenidiales, $\mathrm{x} 33$

Lake, Ala-Kule, 146

- Alexander, $74,78,06$

- Bonneville, 202 
- Glubokoje, 107-109, 205, 206

- Lunz, 70, 207

- Mendota, 63, 70, 74, 102, 107 $117,130,141,144,147,153,892$, $204,205,207$

- Ritom, 68, 160, 161, 207

- Sewan, 103

- Ssaky, I10

- Veissowo, 100, 166

- llindermere, $62,72,82$

- Zürich, 63, 68, 70, 74, 86

Lakes, aquatic plants in, 96,131

- bacteria in mud, $91,99,201,202$. 206

- bacterial population, $60,62,63$, $68,86,114$

- cellulose decomposers in, 1.48

- chitinoclasts in, 144

- Eb of mud, 106

- lluctuations in bacteria, 60

- nitrifiers in, 153

- organic matter in, 136, 137, 141

- oxycen consumed in, 108

- $\mathrm{pH}$ of mud, 105

- yeasts in, 13

Lamprocystis, 1 26, 166

- roseopersicina, 164

Land drainage, $6 x-63,74,75,86$,

I 50, I 52

Land, effect on bacteria in sea, 7 60-63

Lerlescospora submaring, $\mathrm{r}_{32}$

Leplosphaeria orae-maris, $\mathrm{I}_{3}$

Leptospira, 127

Leplothrix, $57, \mathbf{1 2}$

- crassa, 10.4

- longissima, 103

- ochracea, 103

Leucothiobacteria, $16 \mathrm{x}, 163$

Light, as ecological factor, $\mathbf{r}_{3}, 64$, 69,76

- germicidal action, $70-72$

- penetration, 12, 13,67

- producing bacteria, 3,4 , I1 8, II9, 173

Lignin digestion, 99, 141, I42, 195

- by fungi, 135

Limans, bacteria in mud, 91, 99, 202

- bacteriology of, $20 \mathrm{r}_{3} 202$

- cellulose digesters in, r39, 20r, 202

- sulfate reducers in, $I 47,160,201$

- urea decomposers in, I5I, 201

Limnoria, x94, I05

- lignorum,

Lipids, decomposition, 98, 99, I45, 146

- in organic matter, 14

Lipoclastic organisms, $98, \mathbf{1 4 5}, \mathbf{1 4} 6$

Little Kiel, 207

Littoral zone, I I

Lobsters, bacteria on, 3,144

- blackening of, 197,198

- shell disease, 144, 175

Luminescent bacteria, $3,4,118,110$ 173

Mackerel, bacteria of, 188

Macrobenthos, 96, 97

Macroplankton, 24

Macrosporium pelretiae, 131

Manganese ppt., 99, I03, I04

Mannite utilization, 130

Marine bacteria, characteristics of, II $4-128$

- genera of in sea, $124-127$

- media for, $4 \mathrm{I}-45$

- physiological characteristics, I17II 9

- sessile habits of, $51,52,56-58,85$. I 24, 193

- specific gravity of, 53

- temperature optima, 45, 46

- thermal sensitivity, $121-124$

Marine Biological Association, 9

Marine environment, $10-25$

Media, for anaerobes, $49-51$

- for plate counts, $4 \mathrm{I}-45$

- for plate counts, $4 \mathrm{I}-45$

- sea-water vs.

- solidifying agents for, 44,45

Mediterranean Sea, $7,64,178$

Medium $2216,41,42$

Meiobenthos, 06, 07

Mesodinium rubrum, 165
Metal cylinders, bactericidal effect, $3 x, 32$

- for samples, 27,28

Methane, from cellulose, $x_{40}$

- from fatty acids, $\mathbf{x} 45$

- produced in mud, x08, yog

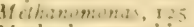

Method, anaerobiosis, 49-5I

- Breed and Brew, 52

- collecting mud, 33-36

- collecting water, $26-3$

- concentrating water, 53

- direct microsconic, $5 \mathrm{I}-58$

- of enumerating bacteria, $4 \mathbf{x}-58$

- Petroff-Hausser, 52

- successive dilution, 48, 49

Methylene blue, 50

Microaerophiles, 49
Microbenthos, 96,07

Nicrobial antagonism, $80-82$

I icrococcus, I 21, 123, 125, 173, 188 ,

$\begin{aligned} & 80 \\ - & \text { albus-translucens, } 100\end{aligned}$

- aquiritus, $12 \mathrm{I}$

- boreus, 8

- condidus, 172

- calharinensis, 8

- centropunctatus, 8

- cinnebareus, 187

- cilreus, I72

- euryhalis, I2I

- gadidarum, roo

- gelatinosus, 8

- halophilus, 172, I73, 202

- infimus, 12

- Ittoralis, I90

- marinus, 8

- maripuniceus, $\mathrm{T} 2 \mathrm{I}$

- minulissimus, 8

- morrinuce, 190,204

- nitrificans, 172, 173

- pflugeri, I I0

- phosphoreus, II9

- pikowskyi, 202

- roseus, rgo

- sedimentarius, 124

- sedimenteus, 124

- selenicus, 99, 166

-varians, 172,188

Micro-colonies, 58

Ificromonospora, 99, I26, I28, I45. 147

Microplankton, 24

Microspira murmanensis, 8

Mindanoa Deep, ro

Mission Bay, 62, 64, 108, I19, I49

Molds, importance of, 133,134

- in air, 178 , 179

-in lakes, 135

- in mud, 99

-in sea, $4,130-135$

- iron ppt., 103

- marine, $13 \mathrm{I}, \mathrm{I}_{33}$

- on submerged surfaces, 56

Moltke Expedition, 3, 130, I77

Morphology of marine bacteria, I I4 II 5

Mouth microflora, Ixo

Movements of sea water, 14, r5

Mucor, 178

Mud, agar digesters in, 140

- bacterial activity in, $100-113$

- biocoenosis, 95-97, x64, 166

- B.O.D. of, 108, тro

- chitinoclasts in, $\mathbf{r} 44$

- direct microscopic counts, 54-56

- effect of storing samples, 37,38

- enzymes in, II3

- factors influencing bacteria in, 93-97

.

- kinds of microbes in, $97-09$

- lake, 91, 99, 20r, 202, 206

- microorganisms in, 4, 90-99

- mold fungi in, 13

- nitrifiers in, 152,153

- nitrogen fixers in, 156

- oxyren consumption in, 108

- profile series, ox-93

- sample collection, 33-36

- water content, 00

Mundi cokeri, 165

Murman coast, $8,113,152,162$

Mussels, 79, 174,185

- poisonous, 199

M ycobacterium, $99,126,128,147$

- marinum, 875
Aycoderma, $20, \mathbf{3 0}$

If ycosphaerella peloetioe, I3I

II yriophyllum, of

If yilitus colifornianus, 174

11 yxomyceles, 132,133

Nahrstoff lieyden media, 43

Naias, 00

Nannoplankton, 24, 82

Nansen bottles, $3 \mathrm{I}$

Nathorst Expedition, 5

Nebish Lake, I36

Neritic, bottom deposits, 22

-zone, I 1

Net plankton, 24

Nets, deterioration of, I4I, 195

Neuston, 25, 66

Nitrate, in media, 43

- in sea water, 18

-reduction, 98, 154, 155

Nitrification, $158-154$

Nitrifiers, 8, 98, $15 x-154,201$

Nitrite, in sea water, 18

- oxidation, I53, I54

Nitrobacter, 124,154

Nitrogen, content of mud, 94

- content of sea water, 18,20, 21

- cycle in the sea, 150-157

- fixers in sea, 8, 98, 90. 156,157

- limits carbon utilization, 138,139

- produced in mud, 108

- requirements of bacteria, 88,143

Nitrosomonas, 24, 151, I52, 153

Nocardia, 99, $126, x_{2} 8$

Noctiluca, 199

North Sea, 3, 4, 65, 129, 152, 156,

I 59

Norwegian coast, $140,152,160$

Ocean, depth and size, ro

Oceanic, deposits, 22

- organisms, II

zones, II

Oidium, I30

- pulounatum, 190

Oil-well brines, bacteria in, 92

- lipoclasts in, I45

Olpidium, 131, 134

- aggregatum, 134

- bryopsidis, 134

- enlosphaericum, 134

- laguncula, I3I

- lauderiae, I34

- plumulae, I34

- sphacellarum, I32, 134

- tumefaciens, 134

Ophiobolus, halimus, 134

- salinus, 134

Orbimyces speclabilis, I 32

Orcedia pelveliana, I $3 \mathrm{I}$

Organic matter, I9, 137, 168, 173

- anaerobic fermentation, 99

- as protopetroleum, II

- content of sea water, 18, 87,88

- content of sediments, 19,94 , I10, I I I

- density of, 168

- dissolved, $19,138,168,173$

- effect on bacteria, $36,77,87-89$,

206

- in aged sea water, 58

- in lakes, 136, 137, 206

- humus formation, 148,149

- Low concentration, $84,85,87-89$, I38

- microbial utilization, 87,118 ,

135,138

- oxygen consumed by, 107, 108, 138

- phosphorus from, I08

- required by bacteria, 88

- secreted by plankton, 78

- sulfur liberated from, $158, \mathbf{x} 59$

$\mathrm{O} / \mathrm{R}$ potential, for anaerobes, 49

- of sediments, 105-107

- petroleum, $\mathbf{1}$ r

Oscillatoria, 164

Oslo Fjord, I42

Osmotic pressure of sea water, 15

- effect on bacteria, 48

Oval tubes for anaerobes, $50,5 \mathrm{I}$

Oxygen, absorbed by muds, 107

- consumption, 84, $107,108,140$.

205

- content of sea water, 20

- effect on bacteria, $36,84,95,107$. 142 
- minimum layer, 20, I68

- relation to $\mathrm{Eh}, 49$

Oysters, bacteriology of, $185-188$

- "score," I87

- spoilage by yeasts, $x_{30}$

- typhoid bacillus in, 182, 186

Pacific Ocean, 61, 62, 64, 98, 184

Parasitic fungi, I3 1 -1 35

Particle-binding action, I I 2, II 3

Particle size of sediments, 94

Particulate material, r9, 84-87, 168,

I73
Pathogens, animal, I75, I76

- cholera vibrio in sea, 81, 182, 183

- for lobsters, 144 , I75

- in sea water, $182,183,191$

- paratyphoids in sea, I9I

- plant, 13 I-I35, I 7 I

- survival in shellfish, 18

- typhoid bacillus in sea, 182,183 ,

I86, r 91
Peat, bacteria in, 92

Pectin fermenters, 99, I4I

Pelagic, zone, in

- bottom deposits, 22

Pelodictyon, I66

Penicillium, 131, 135, 778

- notatum, 80

Periphytic bacteria, 57, 84, 193

Peritrichospora, integra, 132

- lacera, 132

Peronosporales, I33

Pelersenia, $131-\mathrm{r} 33,176$

- andreei, 132

- lobata, I3I, I32

- pollagaster, I3 I, I32

Petroff-Hausser counter, 52

Petroleum, assimilation, 99

- bacterial oxidation, 99, 146-148

- effect of hydrogen on, $r 00$

- fats as progenitor, 145

- from cellulose, r40

- relation to sulfate reducers, I60

Petschora Sea, IO3

$\mathrm{pH}$ (see $\mathrm{H}$-ion conc.)

-indicative of fish spoilage, 190

- optima for marine molds, 133

Phacus, 166

Pharcidia pelvetiae, I3 I

Phialophorophoma litoralis, 132

Phormidium, I66

Phosphate, assimilation, 167

- in sea water, $18,167,160$

- regeneration, 168

Phosphorus, cycle, $167-169$

- in sediments, III

Photobacterium, I 27

- annulare, 4

- balticum, Iro

- caraibicum, 4

- coronatum, 4

- cyoneum, II9

- degenerans. 4

- delagadense 4

- delasadense, 4

- fischeri, II 8

- girtinosum,

- indicum, 3,118

- javanense, Irg

- luminosum, 118

- papillare, 4

- pfiügeri, IIg

- phosphorescens, II8

- plymouthii, Irg

- iuberosum, 4

Photogenic bacteria, 3,4, I 8 , II9. 173

Phycomycetes, I29, I31-I35

Phyllospadix, 23

Physiological characteristics, II7I 9

Phytoplankton, 24, 73

- effect on bacteria, 60, 67, 75, 77, 78,96

- in lakes, 136

- molds associated with, I3I

- nitrogen requirements, 88 , I50

- vertical distribution, 67

Pigment production, x16, х17, 164 106

- by sulfur bacteria, 164,166

- in fish, $116,117,190$

Pink yeasts, $102,130,178,188,190$

Planet Expedition,

Plankton, 24, 25, 77

- bacteria associated with, 52,67, $\mathbf{7 7}, \mathbf{7 8 , 8 7}$
- decomposition, $150, \mathbf{I}_{53}$

Plants, effect on bacteria, $77,78,95$, 96, 170

- marine, 22, 23

Plasmodiophorales, 133

Plate counts, deviation, 59, 60

- effect of temperature, I II-I 23

- media for, 4I-45

- vs. dilution method counts, 48, 49

Plating temperature, I2I, 122

Pleospora pelvetiae, I3I

Pleotrachelus, I3I

- inhabilis, 13

- minutus, I3I

- olpidium, 132

- paradoxus, I3I

- rosenvingin, I3I, 132

Poising capacity of mud, 106

Poison of shellfish, rog

Pollens in air, 179,180

Pollution, of sea water, 184 , 191

- terrigenous, $6 \mathbf{r}$

Pontisma lagenidioides, 131,132

Pools, swimming, rgI

Potamogeton, 23, 96

Precipitation, microbes in, 179

Prescription bottles, for plate

counts, 39, 40

for water blanks, 40

Pressure-cooker anaerobe jar, 50

Pressure, hydrostatic, 16, 32, 33, 69

- osmotic, 15, I6, 48

Primary productivity, $136,137,167$

Prince Rupert water sampler, 3

Proactinomyces, 128

Prorocentrum, 199

- micans, 164

Proteus, I 25, 173, I88, I80

- vulgaris, 100

Protococcales, 166

Protococcus, I 66

- salimus, II6, 196

Protozoans, effect on bacteria, 78-80

- importance of, 24

- ingest bacteria, 24, 36, 79, 173

- in Great Salt Lake, 202,203

- in sea, 23, 24, 13

in sediments, $97,99,164$

Pseudomonas, 99, 115, 121, 125, 147. I73, I88, I89

- aestumarina, I55

- azotogena, I55

- calciphilia, I02

- calcipraecipilans, 102, I55

- calcis, 101, I02, I55

- coenobios, I 24

- droebachense, 140

- enalia, ${ }_{4} 6$

- felthami, 140

- fluorescens, 80, I72, 190

- gelatica, 140, 156

- hypothermis, I4I, I5I

- ichthyodermis, 175

- indigofera, 204

- iridescens, 130

- marinoglutinosus, I24

- marinopersica, 141,155

- membranoformis, 124

- membranula, 124

- neritica, II6

- obscura, II 6

- oceanica, 1 r6

- perfectomarinus, I4I, I55

- periphyta, 124, I4I

- phosphorescens, 3

- pierantonii

- pleomorpha, 139

- salinaria, 197

- sessilis, 124

- stereotropis, 124

—vadosa, II6

- xanthochrus, II6

Psychrophiles, 3-8, 45, 98, I22, I 23,

144, I90, 201

Public health problems, 182,183 ,

I85, r 88 , r $91,197, \mathbf{1 9 0}$

Purple bacteria, I6I, I64-I66

- cause of red water, 165

Puitter's theory, 173

Pyrenomycetes, I3I

Pyrrhosorus marinus, 133

Pythium marinum 132

Radiations, $12,13,64,67,69-73,76$

Radiolaria, 22, 24

Radiolarian ooze, 22, 24
Rain, microbes in, 179

Rainfall, effect on bacteria, 60,6

Ratio method of counting bacteria, Red clay, 22

Red Lake, 99, 108

Redox potential of muds, 106

Red Sea, I 5, I65, I78

Red water, 164, I65, 207

Reef, II

Remispora maritima, $\mathbf{I} 32$

Renn mud sampler, 33

Reuszer's medium, 42

Reynier's water sampler, 28

Rhabdomonas, 126

-rosea, I65

Rhizophydium, I3I

- agile, 135

- codicola $\mathbf{1 3 I}$

- dicksonii, 134

- discinclum, I3I, I32

- gelatinosum, 134

- globosum, I32

- marinum, 134

Rhizopus, 131

Rhodobacterioides, 165,166

Rhodobacterium capsulatum, $16_{5}$

Rhodocapsa, I 26

Rhodococcus, I65, I89

$\longrightarrow$ agilis, 172

Rhodorrhagus, I26, 165

Rhodothece, I 26

- pendens, 164,165

Rhodothiobacterium, I6I, I64-I66

Ridge, ro

Rise, ro

River water, bacteriophage in, 82

- chemical composition, I7

- thermal sensitivity of bacteria, 122

Rope deterioration, I35, I4I, I95

Rossi direct counts, 55

Rotifer eggs parasitized, 133, I 76

Rotted sea water, 58

Rowboat crane, 40

Rozella marina, $\mathrm{I}_{32}, 134$

Rubber-bottle water sampler, 29-35

Rubber deterioration, I48, I96

Saccharolytic activities, II7, II8, I38, 139

Saccharomyces, 130

- cerevisiae, 130

- ellipsoidus, 130

- olexudans, IO2

Salinity, of sea water, $\mathbf{I}_{5}, \mathbf{I}$

- requirements of bacteria, 42-44, 119-1 21

- requirements of fungi, I32, I33

Salmon, bacterial flora of, 188,189

Salt, bacteria in, 196,197

- chitinoclasts in, I4

- lakes, $15,58,140$

- tolerance, $42-44$, I I9-I 2 I

Salterns, 116

Samarosporella pelagica, $\mathbf{1 3 2}$

Samplers, mud, $33-36$

- water, $3,6,26-33$

Samples, effect of storage, 36,37

- examination at sea, $2,39,40$

- temperature of, 38

San Diego Bay, 62, 63, I19

Sand, bacterial content, 94

- crabs, 174, I99

- particle size, 22, 94

San Francisco Bay, 106

Sanitary problems, 182-192, I97, I99, 201

Saprolegnia, 133, 175

- ferax, 175

- parasilica, I76

Sapropel, marine, II

Saprospira, 127, 128

- grandis, 187

- lepla, 187

puncta, 187

- litoralis, 187

- lulea 188

- Ialea

- morrace, 190, 20.

- pelagia, I 21, I46

- psychrocarleria, 20

Sarcinastrum urosporae, 171

Sardines, bacteria of, 133,190

- eggs parasitized, 133

Sargasso Sea, $12,13,60,152$

Schistosomiasis, 191 
Schizomycetes in sea, $124-126$

Scottish Antarctic Expedition, 7 Is 2

Scripps Institution, 9, 4x, 6x, 64, 75, $83, x \times 6, x 46, x 70$

Sea-cock water sampler, 26,27

Sea, depth and extent, ro

Sea fowls, 185

Sealskins, spoilage, 197

Sea of Azov, ro3, $152,160,201$

Seasonal distribution, 74

Sea water, aged, $58^{\circ}$

- bacteria in, 2-9,62

- chemical

- dilution water blanks, \$6-48

- for media, $4,5,8,42-44$, I 1 9-121

- organic content, $19,87,88$

- properties of , 13-20

- required by yeasts, 130

- synthetic or artificial, $31,47,48$, 121

Seaweeds, 6, 22, 60, 130, 152, I71, 109

Sedimentation, $85-87$

Sediments (see mud or bottom deposits)

Selenium oxidation, $x 66$

Semi-solid media, $5 x$

Serratia, 125, 173, 188, 190

- marinorubra, 12I, I46

- pelagia, I55

Sessilc

193,104
Sewage, bacteria, 119,183

- outfalls, $182,184,191,201$

Shelf, II

Shell disease of lobsters, $\mathbf{1} 44, \mathbf{1} 75$

Shellifish, bacteriology of, 185-188

- poison, r99

Ship laboratory, 39

Ships, fouling of, 193, 194

Ship-worms, 194

Shrimp spoilage, I 42

Siderocapsa, 104, 124, 126

- major, 104

Sideromon, 104

$124, \mathbf{2} 6$

Silica gel media, 45

Sill, ro

Silt, bacterial content, 94

- particle size, 22, 9

Sirolpidium bryopsidis, 131, 132

Skins, damaged by bacteria, I4

Slime, molds, $133,{ }^{3} 4$

- on submerged surfaces, 56

Slope, II

Snow, microbes in, I 79

Soil bacteria, 44, II4, II

Solid surface, $35,56-58,78,83-85$.

124

South Seas, 6

Specific gravity, of bacteria, 53

- of sea water, 15, 10

Specificity of marine bacteria, 82

Speira pelagica, I 32

Spermatophytes in sea, 23

Sphaerotilus, I26

Sphaerulina orae-maris, $x_{32}$

Spirillum, I25

- eestuarii, 159

- desulfuricans, I50

- levocolelaenum, 103

- marinum,

- ostreae, 187

- recti physeleris, 199

- thermodesulfuricans, 159

- virginionum, 187

Spirochaeta, 127

- eurystrepla, 128

- halophilicum, 197

- marina, 128

- marma, 128

Spirochaetales in sea, 127,128

Spoilage of fish, 143,19

- criteria of, 198 , 190

Spoilage of oysters, 187

spore formers, $3,4,115$

Sporocylophaga, I27

Sporotibrio, 150

Squalene, 146

Standing crop in lakes, $x_{3} 6,137$

Staphylococcus, 182,180

- albus, 82

- eureus, 8r, 8

Starch hydrolysis, $98,118,139$

Siemplisylium codii, 13

Stenohaline organisms, 16
Stigmalea pelcetiae, 138

Stinking putrefaction, 110

Storage, of fish, 189,190

- of oysters, i 86

Co samples, $36-38,82-85,150$

Stratification, bactcrial, $6,65-68,70$

- in mud, $9 \bar{x}-93$

Sireptococcus, 125, 188, I89

- faecalis, 187

Successive dilution method, 48,49

Sugar utilization, $117,118,138,139$

- limited by nitrogen, 138,139

Sulfate reducers, deposit sulfur, II2

- effect on $\mathrm{CaCO}_{3} \mathrm{ppt}$., ro

- effect on hydrogen, 100

- from limans, 201, 202

- in oil-well brines, 92

- in sea, 6, 68, $159,160,200$

- in sediments, $02,98,99,160,166$

- liberate adsorbed oil, $1 x^{2}$

- oxidize hydrocarbons, I47

- produce hydrocirbons, II

- utilize lipids, 146

Sulfate reduction, $159-16$

- in Black Sea, 200

Sulfite waste liquor, r4

Sulfur, bacteria, $68,99,161-166$

- "bacterial plate," I6I, 20r

- cycle in sea, r58-166

- deposition, II2

Sulfureta, 166

Sulfur-oxidizing bacteria, $161-166$

- cause of red water, 165

Sunlight, effect on bacteria, $3,7,64$. $60 \rightarrow 74,76$

- penetration of water by, 12

Surface, solid, $36,56-58,78,8_{3}-85$, 94,124

Surface water, bacteria in, 6,66

Survival of bacteria in sea, $18_{2}-18_{4}$,

191

Swimming pools, I9I

Symbiosis, 80

Synthetic sea water, 2 I, I2I

- for water blanks, 47,48

Talisman Expedition, 2, 90, I77

Tap water, bacteria in, II0

- for water blanks, 47

Temperature, as ecological factor. I $3, \mathbf{1} 4,73,74$

- effect on bacterial respiration, 107

- for marine molds, 133

- growth at low, 3-8, 45, 98, I22,

I 23, I $44, \times 90,201$

- incubation, $45,46,122-124$

- of ocean, $r_{3}, I_{4}, 67$

- of storing samples, 37-39

- range of growth, 3-8, 38, 45, I22-

124

- tolerance of bacteria, 4,12 I-I 24

- vertical distribution of, 67

Teredo, I94, I95

- navalis, 194

Thermal sensitivity, 38 , 46, I 2 I-124

Thermocline, 14,68

Thiobacillus, 124, I61, 162, 163

- bovista, 162

- denitrificans, 154,162

- thiogenes, 162

- thiooxidans, 162

- thioparus, 162, 166, 200

Thiocapsa, I26

roseopersicina, 164

Thiocysitis, 126,164

- rusa, $\mathrm{x}_{4}$

- riolacea, 164

Thiodictyon, 126

- elegans, 16.4

- minus, 8, I64

Thiopedia, 126,166

- rosea, $164,165,200$

Thiophysa, 127

Thioploca, 127, 163

- ingrica, 163

- schmedlei, 163

Thiopolycoccus, 126, 166

Truber, 164, 165

Thiosarcina, 126

- rosea, 164

Thiospira, 125

- bipunciala, 163

Thiospirillum, $126, \mathbf{2} 66$

- jenense, I64

- jenense, 164 .

- violaceum, 3,164
Thiosu fate, oxidation, 162

- reduction, 159,161

Thothece, 126

Thiolhrix, 127, 163, 166

- ennulata, 163

- marina, 163

- nivea, 103

- Iensis, 163

Thraustochylrium proliferum, 132

Tides, It

- effect on bacteria, 63,6 .

Tintinnids, 24

Topography of sea floor, 10, $x \mathbf{x}$

Tortugas, 37, 120,152

Torula, 129, 130, 171,178

- epizoa, 190

- wehmeri, 190

Toxic products in water, 81

Transparency of sea water, $\mathrm{I}^{2}$

Trench, ro

Treponema, 127

Tricalcium phosphate, 169

Tricoderma, I3I

Trimethylamine, 143,198

Trough, ro

Turnover in lakes, 68

Typhoid bacillus, $182, x 83,186$, 19

- in ice, 191

Tyrosine, 143,198

Ultrafiltration method, 54

Ultraplankton, 24

Ultraviolet radiations, effect on bacteria, 70

- penetration in water, $12,64,71$ 72

Urea fermenters, in mud, $98,99, \mathbf{I} 5 \mathrm{I}$

Valley, submarine, $\mathbf{I}$

Vanadium ppt., I04

Vancouver Island, 152

Vegetation in sea, 23, 96

Vermillion Sea, 165

Vertical distribution, in lakes, 206

- in mud, 9 I-93

- of bacteria in water, $3,6,65-68$

- of phytoplankton, 67

Vibrio, 115, I2 I, I25

- adaplalus, 116 , I18

- agarliquefaciens, 140

- algosus, 146

- beijerinckii, 140

- comma, $81,182,183$

- costatus, 155

- desulfuricans, I59

- fuscus, 130, 187

- granii, 140

- halobicus desulfuricans, 590

- halnplanklis, 124

- hydrosulfureus, 159

- hyphalus, 155

- marinagilis, 155

- marinoflarus, II6

- marinofulvus, 118

- marinopraesens, 130

- marinovulgaris, II6

- marinus, 5

- phyloplanktis, I24

- pierantonii, 159

- ponticus, I30

Volume of water and bacteria, 36

Walvis Bay, 110,160

Wasting disease, I3 I, I34, 17 I

Water, blanks, 40, 46-48

- molds, 133

- samplers, 26-33

- samples storage, 36-38

Waves, $\mathrm{I}_{4}$

Weber Lake, 136

West Indies, 3, 7, 67

White Sea, 8, 103

IVilson water sampler, 20

Wind transport of microbes, 178 , I 80,181

Wood, borers, r94, I95

- destruction by fungi, 135, 14I,

194, 105

, $5,9,28,42,90,93$, ros

I3I, I32, I85.

- ship, x04

Yeasts, aquatic, 129-13x

- $\mathrm{CaCO}_{3}$ ppt. by, 102

- importance in sea, 133,134

- in air, $\leq 78$ 
- in lakes, I3I

- in sediments, 90

- enormis, 134

ZoBell Medium 22I6, 4r, 42

ZoBell water sampler, 20-3I

Zones, biotic, II

- on submerged surfaces, 56

- pink, 102, 130, 178, 188, I90

Zignoella, calospora, I34

- decomposition of, I43

- ingest bacteria, I74

- in lakes, $x_{3} 6$

content, 168

- relation to bacteria, 78-80, I74

Zostera marina, 23, I34 I48, I7I

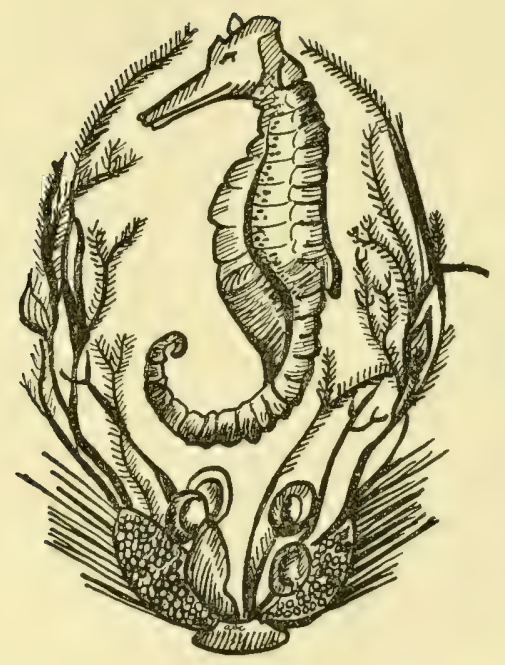




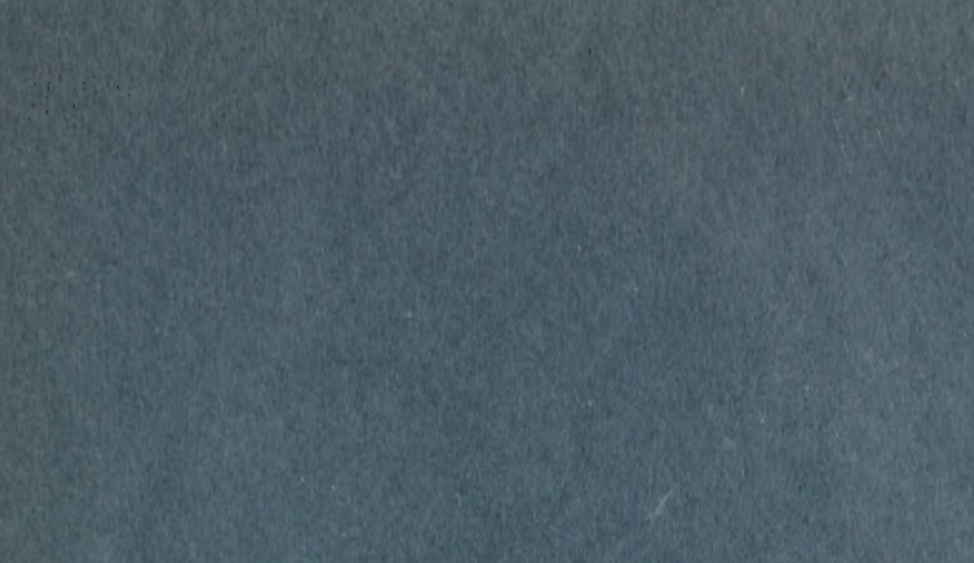

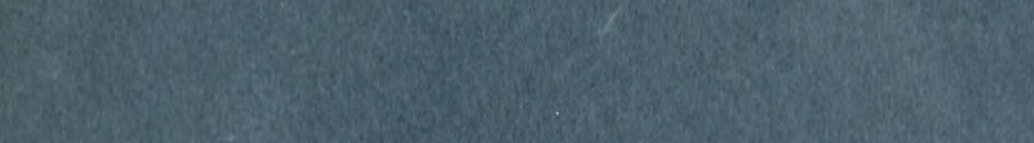
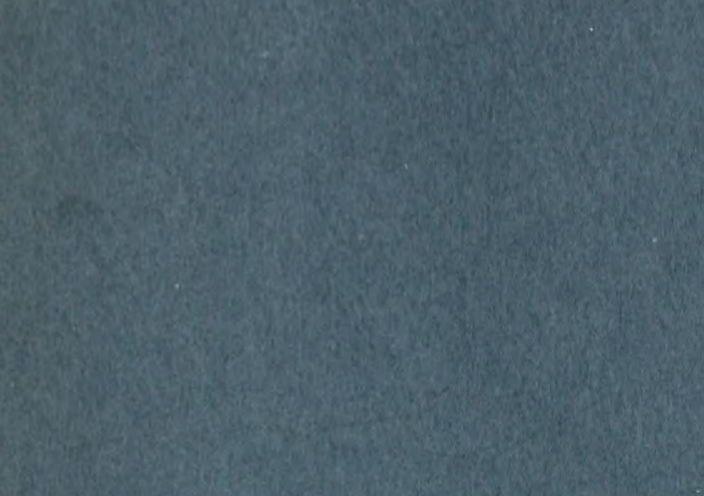

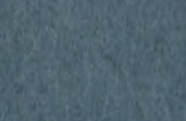

ing

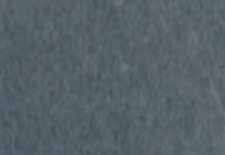

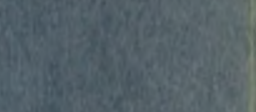




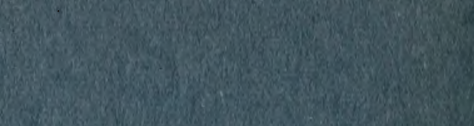

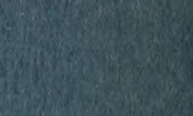

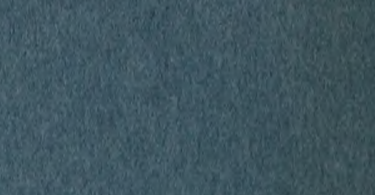
Siche

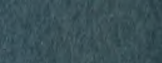

forstes 16.

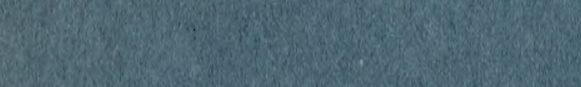

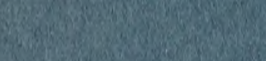

$3^{2} x^{2}$ 


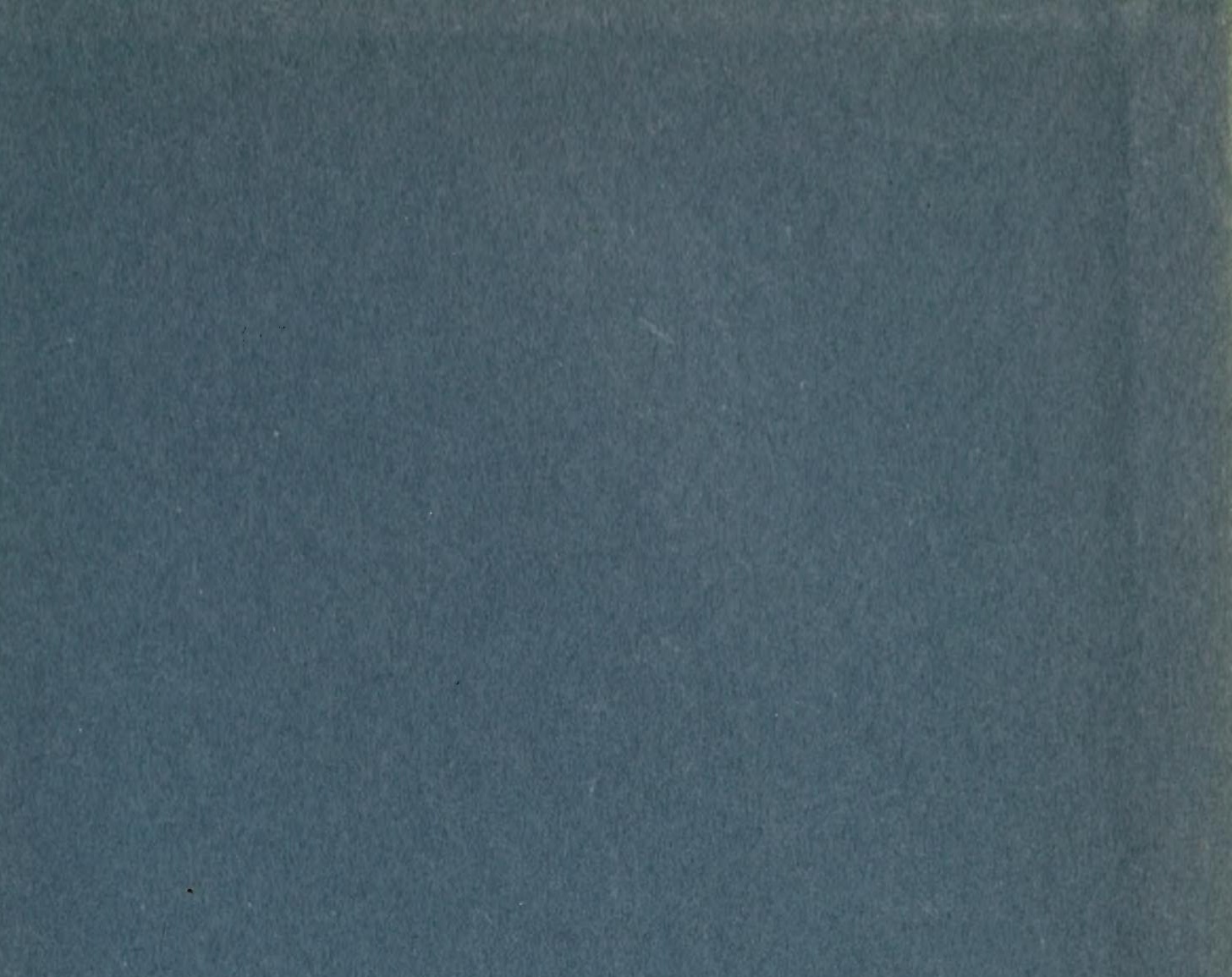


